\title{
A Hydrostratigraphic Model and Alternatives for the Groundwater Flow and Contaminant Transport Model of Corrective Action Unit 97: Yucca Flat-Climax Mine, Lincoln and Nye Counties, Nevada
}

\author{
Prepared for \\ U.S. Department of Energy \\ National Nuclear Security Administration \\ Nevada Site Office \\ Las Vegas, Nevada
}

Prepared by

Geotechnical Sciences Group

Bechtel Nevada

Las Vegas, Nevada

January 2006 


\title{
DISCLAIMER STATEMENT
}

Reference herein to any specific commercial product, process, or service by trade name, trademark, manufacturer, or otherwise, does not necessarily constitute or

imply its endorsement, recommendation, or favoring by the U.S. Government or any agency thereof or its contractors or subcontractors.

\section{AVAILABILITY STATEMENT}

Available to the public, in paper from-

\author{
U.S. Department of Commerce \\ National Technical Information Service \\ 5285 Port Royal Road \\ Springfield, VA, 22161-0002 \\ Telephone: 800.553.6847 \\ Fax: 703.605.6900 \\ E-mail: orders@ntis.gov \\ Online ordering: http://www.ntis.gov/ordering.htm
}

Available electronically at http://www.osti.gov/bridge

Available for a processing fee to U.S. Department of Energy and its contractors, in paper, from-

U.S. Department of Energy

Office of Scientific and Technical Information

P.O. Box 62

Oak Ridge, TN, 37831-0062

Telephone: 865.576 .8401

Fax: 865.576.5728

E-mail: reports@adonis.osti.gov 


\section{A Hydrostratigraphic Model and Alternatives for the Groundwater Flow and Contaminant Transport Model of Corrective Action Unit 97: Yucca Flat-Climax Mine, Lincoln and Nye Counties, Nevada}

Approved by:

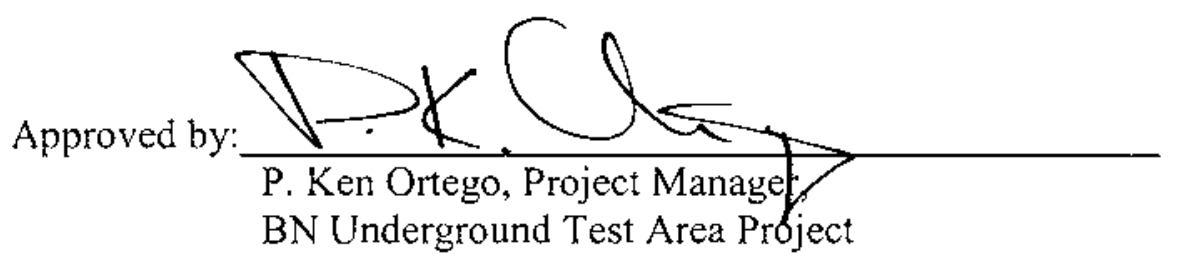

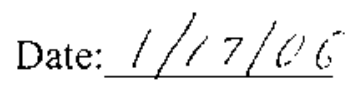

Date: $0 / 17 / 06$ 
This page intentionally left blank. 


\title{
A Hydrostratigraphic Model and Alternatives for the Groundwater Flow and Contaminant Transport Model of Corrective Action Unit 97: Yucca Flat-Climax Mine, Lincoln and Nye Counties, Nevada
}

\author{
DOE/NV/11718--1119
}

\begin{abstract}
A new three-dimensional hydrostratigraphic framework model for the Yucca Flat-Climax Mine Corrective Action Unit was completed in 2005. The model area includes Yucca Flat and Climax Mine, former nuclear testing areas at the Nevada Test Site, and proximal areas. The model area is approximately 1,250 square kilometers in size and is geologically complex.
\end{abstract}

Yucca Flat is a topographically closed basin typical of many valleys in the Basin and Range province. Faulted and tilted blocks of Tertiary-age volcanic rocks and underlying Proterozoic and Paleozoic sedimentary rocks form low ranges around the structural basin. During the Cretaceous Period a granitic intrusive was emplaced at the north end of Yucca Flat.

A diverse set of geological and geophysical data collected over the past 50 years was used to develop a structural model and hydrostratigraphic system for the basin. These were integrated using EarthVision ${ }^{\circledR}$ software to develop the 3-dimensional hydrostratigraphic framework model. Fifty-six stratigraphic units in the model area were grouped into 25 hydrostratigraphic units based on each unit's propensity toward aquifer or aquitard characteristics. The authors organized the alluvial section into 3 hydrostratigraphic units including 2 aquifers and 1 confining unit. The volcanic units in the model area are organized into 13 hydrostratigraphic units that include 8 aquifers and 5 confining units. The underlying pre-Tertiary rocks are divided into 7 hydrostratigraphic units, including 3 aquifers and 4 confining units. Other units include 1 Tertiary-age sedimentary confining unit and 1 Mesozoic-age granitic confining unit. The model depicts the thickness, extent, and geometric relationships of these hydrostratigraphic units ("layers" in the model) along with the major structural features (i.e., faults). The model incorporates 178 high-angle normal faults of Tertiary age and 2 low-angle thrust faults of Mesozoic age.

The complexity of the model area and the non-uniqueness of some of the interpretations incorporated into the base model made it necessary to formulate alternative interpretations for some of the major features in the model. Five of these alternatives were developed so they could be modeled in the same fashion as the base model.

This work was done for the U.S. Department of Energy, National Nuclear Security Administration Nevada Site Office in support of the Underground Test Area subproject of the Environmental Restoration Project. 
This page intentionally left blank. 


\section{Table of Contents}

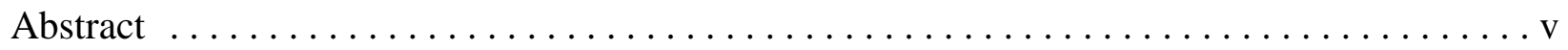

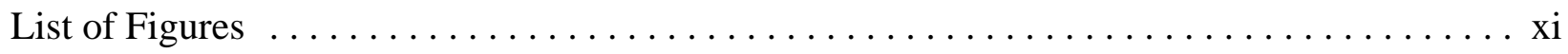

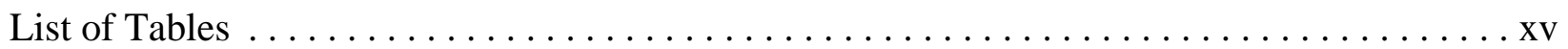

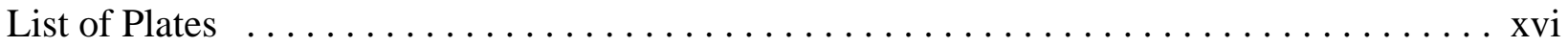

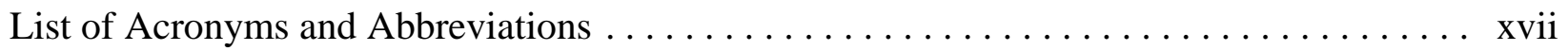

$1.0 \quad$ INTRODUCTION $\ldots \ldots \ldots \ldots \ldots \ldots \ldots \ldots \ldots \ldots \ldots \ldots \ldots \ldots \ldots \ldots \ldots \ldots .1-1$

1.1 Background Information for the Hydrostratigraphic Framework Model Task . 1-1

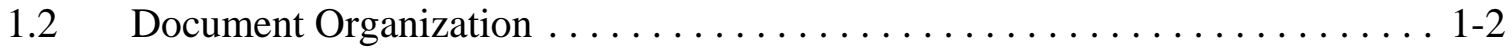

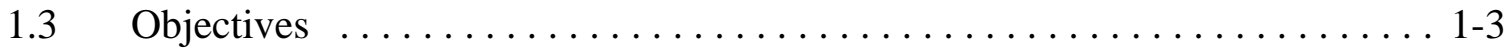

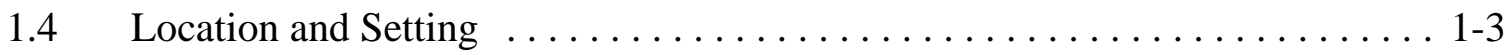

1.4.1 Underground Nuclear Tests in Yucca Flat and Climax Test Areas .... 1-4

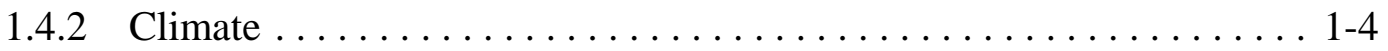

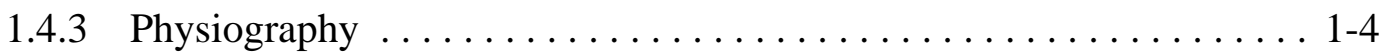

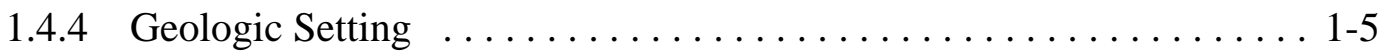

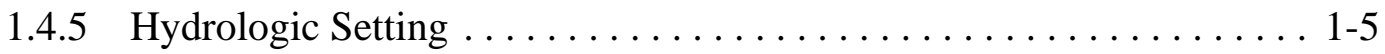

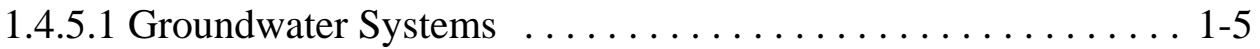

1.4.5.2 Static Water Levels $\ldots \ldots \ldots \ldots \ldots \ldots \ldots \ldots \ldots . \ldots \ldots$

1.5 Previous Work ................................. 1-7

$1.6 \quad$ Framework Model...$\ldots \ldots \ldots \ldots \ldots \ldots \ldots \ldots \ldots \ldots \ldots \ldots \ldots$. $1-7$

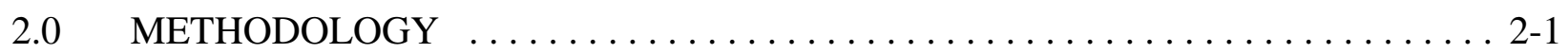

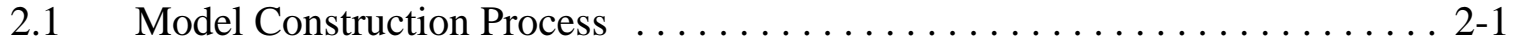

2.2 Determination of Model Area Boundaries ................... 2-3

2.3 Data, Interpretive Products, and Other Information Used in

Model Construction ............................... 2-3

2.3.1 Existing Geological and Geophysical Maps $\ldots \ldots \ldots \ldots \ldots \ldots . . \ldots 2-7$

2.3 .2 Drill Hole Data ............................. 2-8

2.3.3 UGTA Phase I Well Drilling Initiative $\ldots \ldots \ldots \ldots \ldots \ldots \ldots \ldots . \ldots \ldots$

2.3.3.1 Well ER-2-1 . ........................... 2-8

2.3.3.2 Well ER-3-1 ............................ 2-9

2.3.3.3 Well ER-3-2 ......................... 2-9

2.3.3.4 Well Cluster ER-6-1 . . . . . . . . . . . . . . . . . . . . 2 2-9

2.3.3.5 Well Cluster ER-6-2 $\ldots \ldots \ldots \ldots \ldots \ldots \ldots \ldots \ldots . .2-10$

2.3.3.6 Well ER-7-1 ........................... 2-10

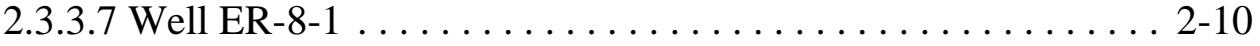

2.3.3.8 Well ER-12-2 ........................ 2-11

2.3.3.9 Other UGTA Drilling and Completion Activities ........ 2-11 


\section{Table of Contents, continued}

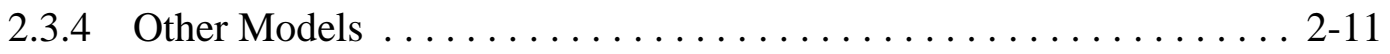

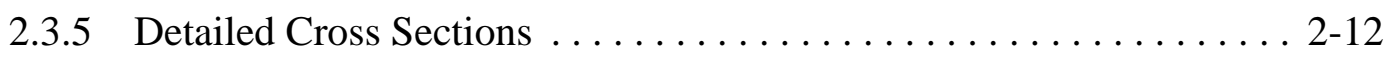

2.3.6 Surface Effects from Underground Nuclear Explosions .......... 2-12

2.3.7 Geophysical Investigations $\ldots \ldots \ldots \ldots \ldots \ldots \ldots \ldots \ldots \ldots . \ldots \ldots$

2.3.7.1 Gravity Data ........................ 2-13

2.3.7.2 Ground Magnetic Data ........................ 2-14

2.3.7.3 Aeromagnetic Data ....................... 2-14

2.3.7.4 Natural Source Magnetotelluric Survey ............ 2-15

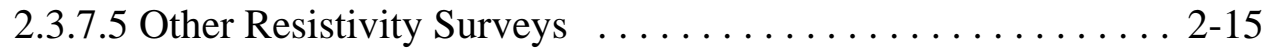

2.3.7.6 Seismic Half-Refraction Surveys ............... 2-16

2.3.7.7 2-D Seismic Reflection Surveys ................ 2-16

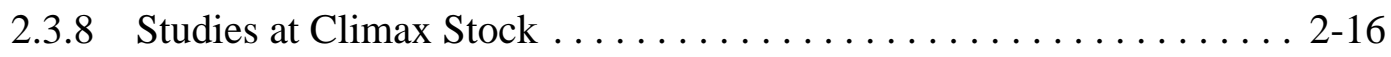

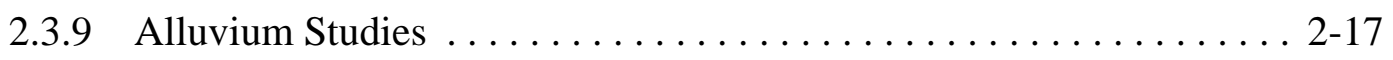

2.3.9.1 Carbonate Content ........................ 2-18

2.3.9.2 U-1 Complex ......................... 2-18

2.3.9.3 Other Studies ......................... 2-18

2.3.10 Mineralogic Studies of Volcanic Rocks ................. 2-18

2.3.10.1 Tuff Confining Unit Study $\ldots \ldots \ldots \ldots \ldots \ldots \ldots .2-19$

2.3.10.2 Reactive Mineral Characterization of Volcanic and

Sedimentary Rocks ..................... 2-20

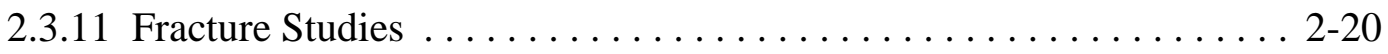

2.4 Pre-emptive Review . . . . . . . . . . . . . . . . . . . . . . . . . . . 2-21

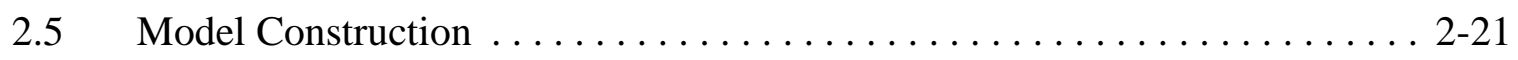

2.5.1 Use of Computer Software to Construct the Model ............ 2-22

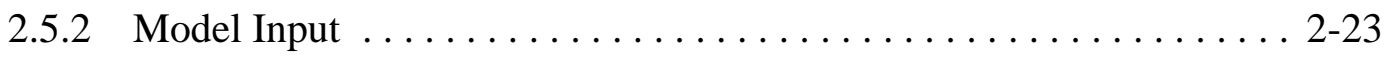

2.5.3 Quality Control and Model Review .................. 2-23

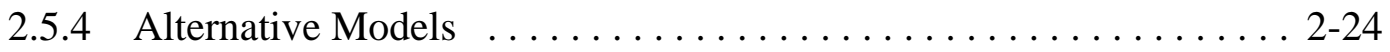

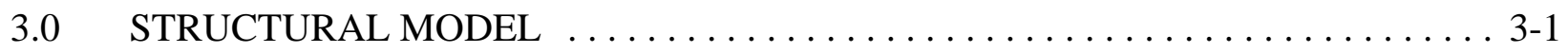

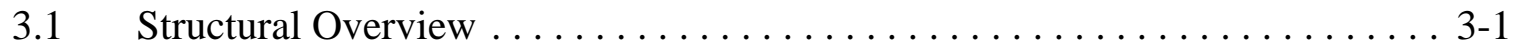

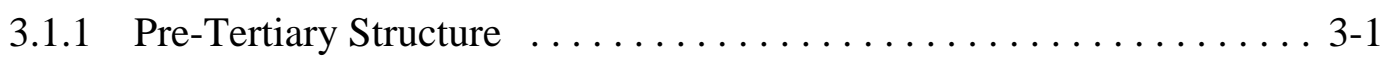

3.1.2 Development of Yucca Flat Basin ................... 3-3

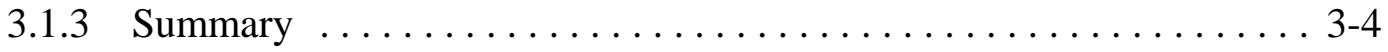

3.2 Structural Elements in the Model $\ldots \ldots \ldots \ldots \ldots \ldots \ldots \ldots \ldots \ldots \ldots \ldots \ldots$

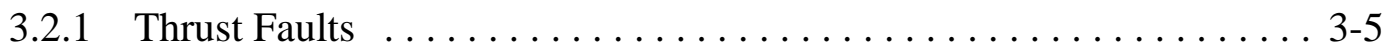

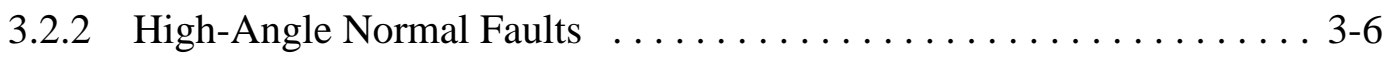

3.2 .3 Folds . . . . . . . . . . . . . . . . . . . . . . . . 3-7

3.3 Hydrologic Characteristics of Faults $\ldots \ldots \ldots \ldots \ldots \ldots \ldots \ldots \ldots \ldots \ldots \ldots$ 


\section{Table of Contents, continued}

4.0 HYDROSTRATIGRAPHY $\ldots \ldots \ldots \ldots \ldots \ldots \ldots \ldots \ldots \ldots \ldots \ldots \ldots \ldots .4 .1$

4.1 Development of the Hydrostratigraphic Classification System . . . . . . . . . 4 4-1

4.2 Stratigraphy of the Yucca Flat-Climax Mine Model Area $\ldots \ldots \ldots \ldots \ldots .4-2$

4.3 Unit Thickness ............................. 4-5

4.4 Hydrogeologic Units of the Yucca Flat Model Area . . . . . . . . . . . 4-5

4.4 .1 Alluvial HGUs ............................ 4 4

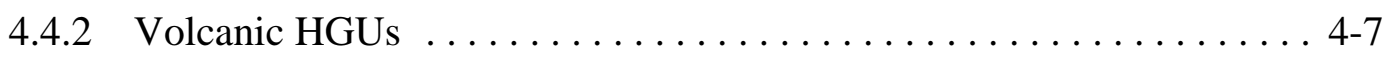

4.4 .3 Pre-Tertiary HGUs $\ldots \ldots \ldots \ldots \ldots \ldots \ldots \ldots \ldots \ldots \ldots \ldots .4 .7$

4.5 Hydrostratigraphic Units of the Yucca Flat-climax Mine Model Area . . . . . . 4-7

4.5.1 Alluvial Aquifer (AA, AA3, AA2, AA1) $\ldots \ldots \ldots \ldots \ldots \ldots .4-15$

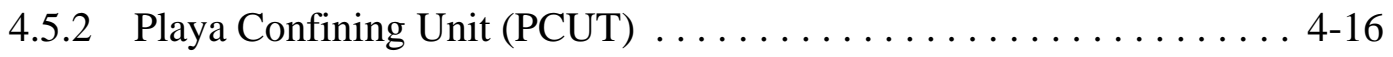

4.5.3 Basalt Lava-Flow Aquifer (BLFA) $\ldots \ldots \ldots \ldots \ldots \ldots \ldots \ldots \ldots .4 .16$

4.5.4 Timber Mountain Hydrostratigraphic Units . . . . . . . . . . . . . 4-16

4.5.4.1 Timber Mountain Upper Vitric-Tuff Aquifer (TM-UVTA) . 4-17

4.5.4.2 Timber Mountain Welded-Tuff Aquifer (TM-WTA) ...... 4-18

4.5.4.3 Timber Mountain Lower Vitric-Tuff Aquifer (TM-LVTA) . 4-18

4.5.5 Upper Tuff Confining Unit (UTCU) $\ldots \ldots \ldots \ldots \ldots \ldots \ldots \ldots .4 .19$

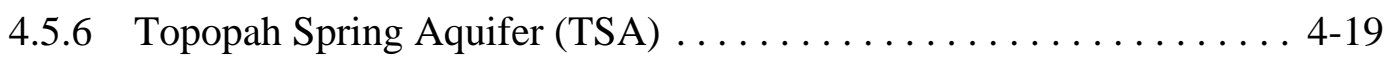

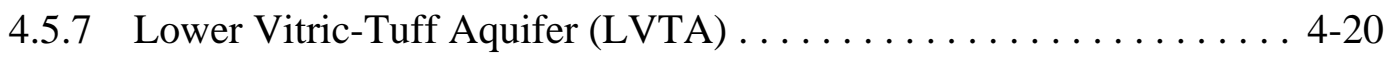

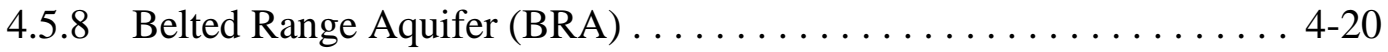

4.5.9 Belted Range Confining Unit (BRCU) $\ldots \ldots \ldots \ldots \ldots \ldots \ldots \ldots \ldots \ldots$

4.5.10 Pre-Grouse Canyon Tuff Lava-Flow Aquifer

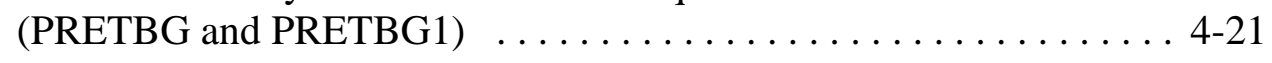

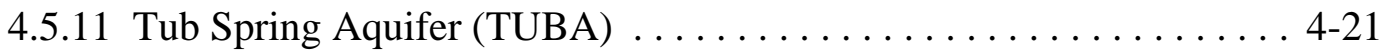

4.5.12 Lower Tuff Confining Unit (LTCU) $\ldots \ldots \ldots \ldots \ldots \ldots \ldots \ldots .4 .21$

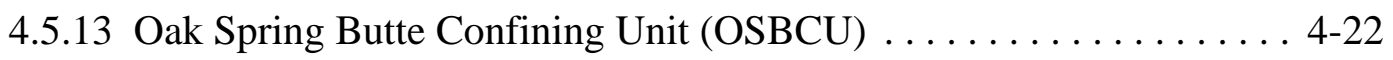

4.5.14 Argillic Tuff Confining Unit (ATCU) $\ldots \ldots \ldots \ldots \ldots \ldots \ldots \ldots .4 .22$

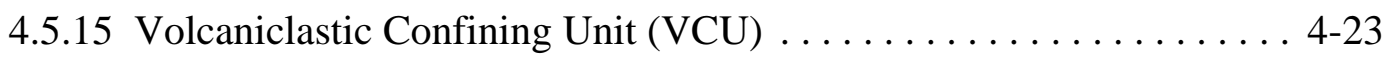

4.5.16 Mesozoic Granitic Confining Unit (MGCU) ................ 4-23

4.5.17 Lower Clastic Confining Unit 1 - Thrust Plate (LCCU1) ......... 4-24

4.5.18 Lower Carbonate Aquifer - Thrust Plate (LCA3) ............. 4-24

4.5.19 Lower Clastic Confining Unit 2 - Thrust Plate (LCCU2) . ........ 4-25

4.5.20 Upper Carbonate Aquifer (UCA) . . . . . . . . . . . . . . . 4 4-25

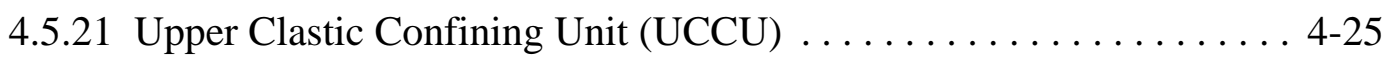

4.5.22 Lower Carbonate Aquifer (LCA) . ................... 4-26

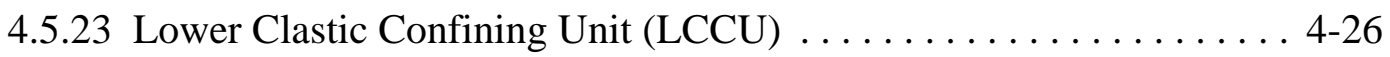

4.6 Relationship of Hydrostratigraphic Units and the Water Table . . . . . . . 4-27 


\section{Table of Contents, continued}

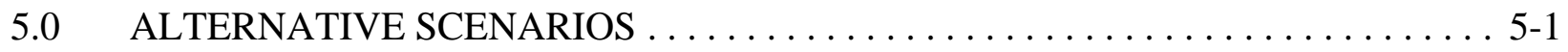

5.1 Process of Addressing Alternatives to the Base Model . . . . . . . . . . . 5-1

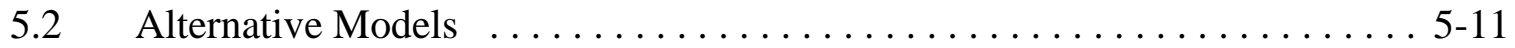

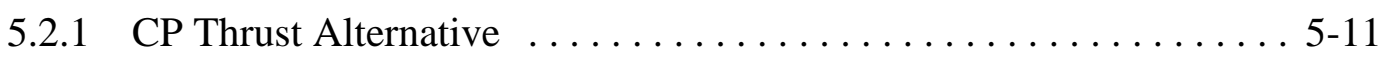

5.2.2 Hydrologic Barrier in Northern Yucca Flat .............. 5-11

5.2.3 Contiguous UCCU in Southwestern Yucca Flat ............... 5-12

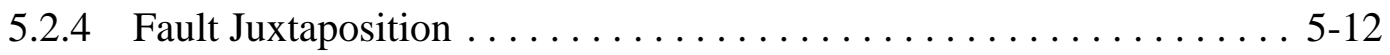

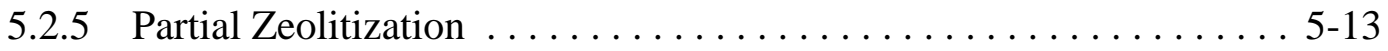

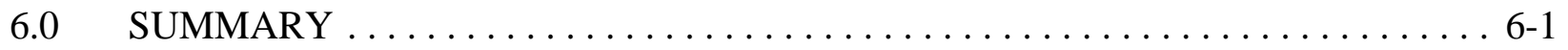

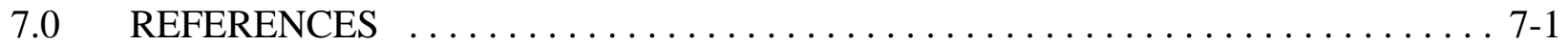

\section{DISTRIBUTION LIST}

\section{APPENDICES}

A Hydrostratigraphic Drill Hole Database for the Yucca Flat - Climax Mine Model Area

B Graphical Presentations for Selected UGTA Wells in the Yucca Flat - Climax Mine Model Area Showing Stratigraphy, Lithology, Alteration, and Hydrogeologic Units

C Hydrostratigraphic Profiles through the Yucca Flat - Climax Mine Model Area

D Magnetotelluric Survey Conducted in the Yucca Flat - Climax Mine Model Area 


\section{List of Figures}

\section{NOTE: Figures are located at the end of each section.}

Number

1-1 Map Showing Location of All UGTA Model Areas

1-2 Satellite Image of the Yucca Flat-Climax Mine Model Area Showing Physiographic Features and Locations of Underground Nuclear Tests

1-3 Color Relief Map Showing Locations of the Basin and Range Physiographic and Great Basin Hydrographic Provinces

1-4 Generalized Geologic Map of the Yucca Flat-Climax Mine Region

1-5 Natural Springs and Seeps on the Nevada Test Site

1-6 Groundwater Subbasins of the Nevada Test Site and Vicinity

1-7 Locations of the Northern and Eastern Extensions of the Yucca Flat-Climax Mine Model Boundary

2-1 3-D Display from EarthVision of the Yucca Flat-Climax Mine Model Volume

2-2 Example of a Detailed Geologic Cross Section (SD2) through East-Central Yucca Flat

2-3 Locations of Detailed Cross Sections Constructed for the UGTA Yucca Flat-Climax Mine Model

2-4 Map Showing Location of Surface Effects from Underground Nuclear Tests in EastCentral Yucca Flat

2-5 Magnetotelluric (MT) Stations in the Yucca Flat-Climax Mine Model Area

2-6 Comparison of Calculated Predicted Elevation Values from the Yucca Flat-Climax Mine Model versus Well-Pick Data

2-7 Histogram of Differences in Elevation between the Yucca Flat-Climax Mine Model and Well-Pick Data for the Timber Mountain Lower Vitric-Tuff Aquifer

3-1 Pre-Tertiary Structure of the Yucca Flat-Climax Mine Model Area

3-2 Color Elevation Relief Map of the Pre-Tertiary Surface Beneath Yucca Flat Based on Gravity Data

3-3 Tilt Domain Map of the NTS and Vicinity

3-4 Structure Contour Map of the Pre-Tertiary Rocks

4-1 Simplified Stratigraphic Section of Yucca Flat

4-2 Correlation of Stratigraphic and Hydrostratigraphic Units of the Yucca Flat-Climax Mine Model Area

4-3 Block Model View Showing Hydrostratigraphic Units at the Surface within the Yucca Flat-Climax Mine Model Area

4-4 Schematic Cross Section through Southern Yucca Flat Showing Relationships Among the Alluvial Aquifers, Playa Confining Unit, and the Basalt Lava-Flow Aquifer 


\section{List of Figures, continued}

4-5 Block Model View Showing Extent of the Alluvial Aquifer (AA) within the Yucca FlatClimax Mine Model Area

4-6 Block Model View Showing Extent of the Playa Confining Unit (PCUT) and the Basalt Lava-Flow Aquifer (BLFA) within the Yucca Flat-Climax Mine Model Area

4-7 Schematic West-East Cross Section across Yucca Flat Showing Variability in Hydrogeologic Character of the Timber Mountain Hydrostratigraphic Units

4-8 Block Model View Showing Extent of the Timber Mountain Upper Vitric-Tuff Aquifer (TM-UVTA) within the Yucca Flat-Climax Mine Model Area

4-9 Depth to the Timber Mountain Upper Vitric-Tuff Aquifer (TM-UVTA) in the Yucca Flat-Climax Mine Hydrostratigraphic Framework Model

4-10 Block Model View Showing Extent of the Timber Mountain Welded-Tuff Aquifer (TM-WTA) within the Yucca Flat-Climax Mine Model Area

4-11 Schematic West-East Hydrostratigraphic Cross Section through the Eastern Extension of the Yucca Flat Model

4-12 Schematic South-North Hydrostratigraphic Cross Section through the Eastern Extension of the Yucca Flat Model Area

4-13 Depth to the Timber Mountain Welded-Tuff Aquifer (TM-WTA) in the Yucca FlatClimax Mine Hydrostratigraphic Framework Model

4-14 Block Model View Showing Extent of the Timber Mountain Lower Vitric-Tuff Aquifer (TM-LVTA) within the Yucca Flat-Climax Mine Model Area

4-15 Depth to the Timber Mountain Lower Vitric-Tuff Aquifer (TM-LVTA) in the Yucca Flat-Climax Mine Hydrostratigraphic Framework Model

4-16 Block Model View Showing Extent of the Upper Tuff Confining Unit (UTCU) within the Yucca Flat-Climax Mine Model Area

4-17 Schematic West-East Cross Section through Southern Yucca Flat Showing Relationships Among the Tuff Confining Units and the Topopah Spring Aquifer

4-18 Block Model View Showing Extent of the Topopah Spring Aquifer (TSA) within the Yucca Flat-Climax Mine Model Area

4-19 Depth to the Topopah Spring Aquifer (TSA) in the Yucca Flat-Climax Mine Hydrostratigraphic Framework Model

4-20 Block Model View Showing Extent of the Lower Vitric-Tuff Aquifer (LVTA) within the Yucca Flat-Climax Mine Model Area

4-21 Depth to the Lower Vitric-Tuff Aquifer (LVTA) in the Yucca Flat-Climax Mine Hydrostratigraphic Framework Model

4-22 Block Model View Showing Extent of the Belted Range Aquifer (BRA) within the Yucca Flat-Climax Mine Model Area

4-23 Schematic West-East Cross Section in Northern Yucca Flat Showing Relationships Among the Belted Range and Older Volcanic Hydrostratigraphic Units 


\section{List of Figures, continued}

4-24 Depth to the Belted Range Aquifer (BRA) in the Yucca Flat-Climax Mine Hydrostratigraphic Framework Model

4-25 Block Model View Showing Extent of the Belted Range Confining Unit (BRCU) within the Yucca Flat-Climax Mine Model Area

4-26 Block Model View of the Pre-Grouse Canyon Tuff Lava-Flow Aquifer (PRETBG and PRETBG1) within the Yucca Flat-Climax Mine Model Area

4-27 Block Model View Showing Extent of the Tub Spring Aquifer (TUBA) within the Yucca Flat-Climax Mine Model Area

4-28 Depth to the Tub Spring Aquifer (TUBA) in the Yucca Flat-Climax Mine Hydrostratigraphic Framework Model

4-29 Block Model View Showing Extent of the Lower Tuff Confining Unit (LTCU) within the Yucca Flat-Climax Mine Model Area

4-30 Block Model View Showing Extent of the Oak Spring Butte Confining Unit (OSBCU) within the Yucca Flat-Climax Mine Model Area

4-31 Block Model View Showing Extent of the Argillic Tuff Confining Unit (ATCU) within the Yucca Flat-Climax Mine Model Area

4-32 Block Model View Showing Extent of the Upper Clastic Confining Unit (UCCU) and the Volcaniclastic Confining Unit (VCU) within the Yucca Flat-Climax Mine Model Area

4-33 Schematic West-East Cross Section Showing the Climax Stock Granitic Intrusive

4-34 Block Model View Showing Extent of the Mesozoic Granitic Confining Unit (MGCU) within the Yucca Flat-Climax Mine Model Area

4-35 Block Model View Showing Extent of the Lower Clastic Confining Unit 1 (LCCU1) within the Yucca Flat-Climax Mine Model Area

4-36 Block Model View Showing the Extent of the Lower Carbonate Aquifer-Thrust Plate (LCA3) within the Yucca Flat-Climax Mine Model Area

4-37 Depth to the Lower Carbonate Aquifer-Thrust Plate (LCA3) in the Yucca Flat-Climax Mine Hydrostratigraphic Framework Model

4-38 Block Model View Showing Extent of the Lower Clastic Confining Unit 2 (LCCU2) within the Yucca Flat-Climax Mine Model Area

4-39 Block Model View Showing Extent of the Upper Carbonate Aquifer (UCA) within the Yucca Flat-Climax Mine Model Area

4-40 Depth to the Upper Carbonate Aquifer (UCA) in the Yucca Flat-Climax Mine Hydrostratigraphic Framework Model

4-41 Block Model View Showing Extent of the Lower Carbonate Aquifer (LCA) within the Yucca Flat-Climax Mine Model Area

4-42 Depth to the Lower Carbonate Aquifer (LCA) in the Yucca Flat-Climax Mine Hydrostratigraphic Framework Model

4-43 Block Model View Showing Extent of the Lower Clastic Confining Unit (LCCU) within the Yucca Flat-Climax Mine Model Area 


\section{List of Figures, continued}

5-1 Comparison of the UCCU Extent and CP Thrust Location in the Base Model with the CP Thrust Alternative

5-2 West-East Profiles through Northern Yucca Flat Comparing the Base Model with the CP Thrust Alternative

5-3 Comparison of the LCCU Geometry in the Base Model with the Hydrologic Barrier Alternative

5-4 West-East Profiles through Climax Stock Comparing the Base Model with the Hydrologic Barrier Alternative

5-5 Comparison of the UCCU Extent in the Base Model with the Contiguous UCCU Alternative

5-6 West-East Profile through the Southwestern Corner of the Yucca Flat Model Comparing the Base Model with the Contiguous UCCU Alternative

5-7 West-East Profiles through Central Yucca Flat Comparing the Base Model with the Fault Juxtaposition Alternative

5-8 View of the Yucca Flat Base Model Showing Area Affected in the Partial Zeolitization Alternative

B-1 Graphical Presentation Showing Stratigraphy, Lithology, Alteration, and Hydrogeologic Units for UGTA Well ER-2-1

B-2 Graphical Presentation Showing Stratigraphy, Lithology, Alteration, and Hydrogeologic Units for UGTA Well Cluster ER-6-1

B-3 Graphical Presentation Showing Stratigraphy, Lithology, Alteration, and Hydrogeologic Units for UGTA Well ER-7-1

B-4 Graphical Presentation Showing Stratigraphy, Lithology, Alteration, and Hydrogeologic Units for UGTA Well ER-8-1

B-5 Graphical Presentation Showing Stratigraphy, Lithology, Alteration, and Hydrogeologic Units for UGTA Well ER-12-2

D-1 Magnetotelluric (MT) Stations in the Yucca Flat-Climax Mine Model Area

D-2 Legend for Stratigraphic Units Depicted on Geological Maps 


\section{List of Tables}

Number

1-1 Boundaries of the Yucca Flat-Climax Mine Model Area $\ldots \ldots \ldots \ldots \ldots \ldots \ldots$ 1-3

2-1 Geologic Quadrangle Maps (Scale 1:24,000) Used in Construction of the Yucca FlatClimax Mine Hydrostratigraphic Framework Model $\ldots . \ldots \ldots \ldots \ldots . . . . .2-5$

2-2 Special Purpose Geologic Maps Used in Construction of the Yucca Flat-Climax Mine

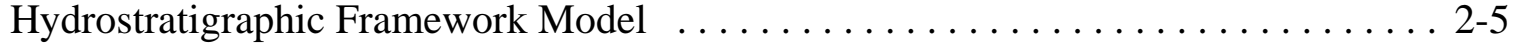

2-3 Miscellaneous Special Purpose Maps and Geophysical Studies Used in the Construction of the Yucca Flat-Climax Mine Hydrostratigraphic Framework Model . . . . . . . . . 2-6

2-4 Examples of Maps, Detailed Cross Sections, and Other Geologic Information Originally Prepared for WTP Projects and Early UGTA Modeling Efforts . . . . . . . . . . 2-7

4-1 Quaternary, Tertiary, and Mesozoic Stratigraphic Units of the Yucca Flat-Climax Mine

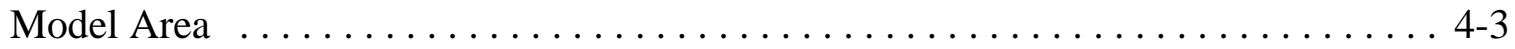

4-2 Proterozoic and Paleozoic Stratigraphic Units of the Yucca Flat-Climax Mine

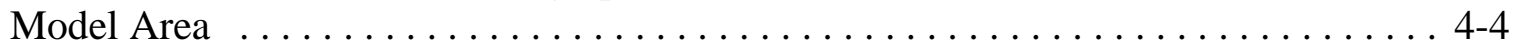

4-3 Hydrogeologic Units of the Yucca Flat-Climax Mine Model $\ldots \ldots \ldots \ldots \ldots \ldots$ 4-6

4-4 Hydrostratigraphic Units of the Yucca Flat-Climax Mine Hydrostratigraphic Framework Model $\ldots \ldots \ldots \ldots \ldots \ldots \ldots \ldots \ldots \ldots \ldots \ldots \ldots \ldots, \ldots, \ldots$

4-5 Correlation of Hydrostratigraphic Units of the Yucca Flat-Climax Mine Model and Earlier Models ........................................ 4-13

5-1 Abridged List of Alternative Scenarios for the Yucca Flat-Climax Mine Hydrostratigraphic Framework Model 


\section{List of Plates}

Plate 1 Surface Geologic Map of the Yucca Flat - Climax Mine Model Area

Plate 2 Hydrostratigraphic Units at the Water Table in the Yucca Flat - Climax Mine Hydrostratigraphic Framework Model

Plate 3 Figure Showing All Drill Holes Used in the Yucca Flat - Climax Mine Hydrostratigraphic Model 


\section{List of Acronyms and Abbreviations}

3-D

AA

AA1

AA2

AA3

ARG

ATCU

BLFA

BN

BRA

BRCU

CAU

$\mathrm{CC}$

DEM

DMP

DMR

DOE

ERMA ${ }^{\circledR}$

FFACO

$\mathrm{EV}$

$\mathrm{ft}$

HGU

HSU

IT

$\mathrm{km}$

LANL

LCA

LCA3

LCCU

LCCU1

LCCU2

LFA

LLNL

LTCU

LVTA

$\mathrm{m}$

$\mathrm{Ma}$

mi three-dimensional

alluvial aquifer; valley fill aquifer

alluvial aquifer 1

alluvial aquifer 2

alluvial aquifer 3

argillic reactive mineral category

argillic tuff confining unit

basalt lava-flow aquifer

Bechtel Nevada

Belted Range aquifer

Belted Range confining unit

Corrective Action Unit

calcic reactive mineral category

digital elevation model

devitrified mafic-poor reactive mineral category

devitrified mafic-rich reactive mineral category

U.S. Department of Energy

Environmental Resources Management Applications System

Federal Facility Agreement and Consent Order

Earth Vision ${ }^{\circledR}$

feet (foot)

hydrogeologic unit

hydrostratigraphic unit

International Technologies Corporation (also IT Corp.)

kilometer(s)

Los Alamos National Laboratory

lower carbonate aquifer

lower carbonate aquifer - thrust plate

lower clastic confining unit

lower clastic confining unit 1-thrust plate

lower clastic confining unit 2-thrust plate

lava-flow aquifer

Lawrence Livermore National Laboratory

lower tuff confining unit

lower vitric-tuff aquifer

meter(s)

Mega anna (i.e., million years ago)

mile(s) 


\section{List of Acronyms and Abbreviations (continued)}

MT

NAD

NNSA/NSO

NTS

OSBCU

PCU

PCUT

PRETBG

PRETBG1

$\mathrm{RMC}$

RWMS

SAIC

SC

SME

SNJV

SWL

TCU

TD

TMA

TM-UVTA

TM-WTA

TM-LVTA

TSA

TWG

TUBA

UCA

UCCU

UGT

UGTA

USGS

UTCU

UTM

VCU

VMP

VMR

VOIA

VTA magnetotelluric

North American Datum

U.S. Department of Energy, National Nuclear Security Administration Nevada Site Office

Nevada Test Site

Oak Spring Butte confining unit

playa confining unit (HGU)

playa confining unit (HSU)

pre-Grouse Canyon Tuff lava-flow aquifer

pre-Grouse Canyon Tuff lava-flow aquifer 1

reactive mineral category

Radioactive Waste Management Site

Science Applications International Corporation

silicic reactive mineral category

subject matter expert

Stoller-Navarro Joint Venture

static water level

tuff confining unit

total depth

Timber Mountain aquifer

Timber Mountain upper vitric-tuff aquifer

Timber Mountain welded-tuff aquifer

Timber Mountain lower vitric-tuff aquifer

Topopah Spring aquifer

Technical Working Group

Tub Spring aquifer

upper carbonate aquifer

upper clastic confining unit

underground nuclear test

Underground Test Area

U.S. Geological Survey

upper tuff confining unit

Universal Transverse Mercator

volcaniclastic confining unit

vitric mafic-poor reactive mineral category

vitric mafic-rich reactive mineral category

Value of Information Analysis

vitric-tuff aquifer 


\section{List of Acronyms and Abbreviations (continued)}

WTA welded-tuff aquifer

WTP

weapons testing program

YMP

Yucca Mountain Project

ZEOL

zeolitic reactive mineral category 
This page intentionally left blank. 


\subsection{INTRODUCTION}

The Environmental Restoration Project of the U.S. Department of Energy (DOE), National Nuclear Security Administration Nevada Site Office (NNSA/NSO) initiated the Underground Test Area (UGTA) subproject to investigate the extent of groundwater contamination at the Nevada Test Site (NTS) and surrounding areas due to past underground nuclear testing. The UGTA investigation focuses on the geology and hydrology of the NTS to estimate the direction and rate contaminants are transported by groundwater flow. This report describes the Phase I hydrostratigraphic framework model constructed for the Yucca Flat-Climax Mine area. This model will be used to develop groundwater flow and contaminant transport models for the underground nuclear testing areas in the Yucca Flat/Climax Mine area.

\subsection{Background Information for the Hydrostratigraphic Framework Model Task}

A regional three-dimensional (3-D) computer groundwater model (International Technologies Corporation [IT], 1996a) was developed in the initial stages of the UGTA project to identify any immediate risk, and to provide a basis for developing more detailed models of specific nuclear testing areas designated as Corrective Action Units or CAUs. The CAU-specific models, of which four are planned, geographically cover each of the six former NTS underground nuclear testing areas (Figure 1-1). CAU-specific groundwater-flow and contaminant-transport models will be used to determine contaminant boundaries based on the maximum extent of contaminant migration at specified regulatory limits. The models will also be used to refine a monitoring network to ensure public health and safety.

Construction of CAU-specific groundwater-flow and contaminant-transport models requires a hydrostratigraphic framework that depicts the character and extent of hydrostratigraphic units in three dimensions. CAU-specific framework model will give modelers the ability to test a range of potential groundwater flow and contamination scenarios by allowing them to apply flow and transport algorithms and vary parameters for each hydrostratigraphic unit.

This report provides information about how the hydrostratigraphic framework model for the Yucca Flat-Climax Mine CAU was developed, presents a description of the model, and provides documentation of data sources used to produce the model. This document addresses only the hydrostratigraphic framework model; separate data documentation packages containing detailed descriptions of the hydrologic modeling process and other pertinent flow and transport information, will be prepared after such efforts are complete. 
The Yucca Flat-Climax Mine testing area was originally defined as two separate CAUs in the Federal Facilities Agreement and Consent Order (FFACO, 1996) because the geologic settings of the two areas are distinctly different. In Yucca Flat (CAU 97), underground nuclear tests (UGTs) were conducted in alluvial, volcanic, and carbonate rocks, whereas in the Climax Mine area (CAU 100) in northern Yucca Flat, tests were conducted in an igneous intrusion, usually referred to as the Climax stock. However, particle-tracking simulations performed during the regional evaluation (IT, 1996d) indicated that the local Climax groundwater flow system merges into the much larger Yucca Flat groundwater flow system during the 1,000-year time period of interest; therefore, the two areas were joined into the single CAU 97.

The Yucca Flat-Climax Mine hydrostratigraphic framework model was developed by a multidisciplinary team of scientists of the Bechtel Nevada (BN) Geotechnical Sciences group and of the joint venture of IT, Science Applications International Corporation (SAIC), and GeoTrans, Incorporated; later replaced by Shaw Environmental, Incorporated, successor to IT; and now replaced by Stoller-Navarro Joint Venture (SNJV). The team also received valuable input from scientists at Los Alamos National Laboratory (LANL), Lawrence Livermore National Laboratory (LLNL), and the U.S. Geological Survey (USGS), and guidance from the NNSA/NSO, and the NNSA/NSO UGTA Technical Working Group (TWG).

The model presented here consists of a base model and several alternatives. Because of the geologic complexity of the model area and non-unique interpretations incorporated into the base model, different geologic interpretations were developed for some features in the model area. These alternative interpretations can be tested to determine if they produce an impact on the hydrology at the site or on the fate and transport of possible contaminants.

\subsection{Document Organization}

This section contains background information for the development of the Yucca Flat hydrostratigraphic framework model, including location, setting, and previous work. Section 2.0 provides descriptions of the processes, methods, and data used to construct the model, including discussions of data obtained within the last five years specifically to support the development of the Yucca Flat UGTA model. Section 3.0 presents a discussion of the structural elements of the model, and Section 4.0 describes all the hydrostratigraphic units included in the model.

Alternative models are described in Section 5.0. Section 6.0 presents a document summary, and relevant references are listed in Section 7.0. 


\subsection{Objectives}

The primary objective of the Yucca Flat-Climax Mine hydrostratigraphic modeling effort was to produce a 3-D hydrostratigraphic framework model that depicts the geometric relationships of hydrostratigraphic units (HSUs) and structural features in the Yucca Flat-Climax Mine model area. This also included development of alternative scenarios for some of the non-unique interpretations. The Yucca Flat-Climax Mine hydrostratigraphic framework model and alternative scenarios will be used to model groundwater flow and contaminant transport for the Yucca Flat-Climax Mine CAU.

\subsection{Location and Setting}

The hydrostratigraphic framework model for the Yucca Flat-Climax Mine area encompasses more than 1,250 square kilometers (483 square miles) in the northeastern part of the NTS (Figure 1-1). The model area is located approximately 130 kilometers (km) (80 miles [mi]) northwest of Las Vegas, Nevada, and includes lands managed by the U.S. Air Force (Nevada Test and Training Range) and a co-use area of the Desert National Wildlife Refuge and Nevada Test and Training Range, in addition to the northeastern portion of the NTS. The model area lies mostly in southern Nye County, Nevada, but also includes a portion of southwestern Lincoln County, Nevada. The model area also encompasses a buffer area surrounding the CAU that includes important rock outcrop and drill-hole control that help constrain geologic interpretations. The model area includes the Yucca Flat topographic basin and portions of the adjacent highlands. The model area also includes portions of Emigrant Valley and Mid Valley located northwest and southwest of Yucca Flat, respectively (Figure 1-2). The model has a north-south dimension of $44.7 \mathrm{~km}$ (27.8 mi) and an east-west dimension of $29.2 \mathrm{~km}$ (18.1 mi), and includes geologic units as deep as $5.1 \mathrm{~km}$ (3.2 mi) below mean sea level. Boundaries for the Yucca Flat-Climax Mine model area are listed in Table 1-1.

Table 1-1

Boundaries of the Yucca Flat-Climax Mine Model Area

\begin{tabular}{||l|c|c||}
\hline & $\begin{array}{c}\text { Central Nevada State Planar } \\
\text { Coordinates } \\
\text { (NAD 27; feet) }{ }^{\mathrm{a}, \mathrm{b}}\end{array}$ & $\begin{array}{c}\text { Universal Transverse } \\
\text { Mercator (Zone 11) } \\
\text { (NAD 27; meters) }\end{array}$ \\
\hline \hline Northern Boundary, Along Northing & $\mathrm{N} \mathrm{933,000}$ & $\mathrm{N} \mathrm{4,129,828}$ \\
\hline Southern Boundary, Along Northing & $\mathrm{N} \mathrm{787,000}$ & $\mathrm{N} \mathrm{4,085,141}$ \\
\hline Western Boundary, Along Easting & $\mathrm{E} \mathrm{650,000}$ & $\mathrm{E} \mathrm{575,165}$ \\
\hline Eastern Boundary, Along Easting & $\mathrm{E} \mathrm{742,227}$ & $\mathrm{E} \mathrm{603,500}$ \\
\hline
\end{tabular}

a NAD $27=1927$ North American Datum

b $\mathrm{N}=$ North; $\mathrm{E}=\mathrm{East}$ 


\subsubsection{Underground Nuclear Tests in Yucca Flat and Climax Test Areas}

Between 1951 and 1992, 659 UGTs (747 detonations) were conducted in Yucca Flat; 3 tests were detonated in the Climax stock in 1962, 1965, and 1966 (Allen et al., 1997). All underground nuclear tests conducted in the Yucca Flat-Climax Mine area are listed in DOE (2000a).

Most of the UGTs in Yucca Flat were detonated in vertical shafts. Two of the 415 tests conducted in the alluvial deposits of Yucca Flat were conducted below the water table, and 26 others were conducted within 100 meters (m) (328 feet [ft]) of the water table. Of the 325 UGTs conducted in the Tertiary-age volcanic rocks in Yucca Flat, 74 were conducted below the water table and 64 were near the water table (Allen et al., 1997). Of the four tests conducted in the carbonate units of Yucca Flat, three were conducted at depths above the regional water table, and one was conducted near the water table.

All three UGTs conducted at Climax were detonated in intrusive granitic rock, one in a vertical shaft and the other two in tunnels. Two of the Climax stock tests were conducted below the elevation of the regional water table in the area (Allen et al., 1997).

\subsubsection{Climate}

The NTS is located in the high desert, with annual precipitation totals averaging approximately 10 centimeters (4 inches) in the lower valleys, such as Yucca Flat, and 25 centimeters (10 inches) in the higher mountain ranges (DOE, 1996, 1998). Precipitation in the area is sporadic, typically falling as small amounts of rain or snow during isolated, short-duration winter and summer storms. Severe weather can occur in the region, usually in the form of summer thunderstorms with intense lightning, strong winds and, localized heavy rainfall. Daily temperatures vary with elevation, with extremes ranging from minus 15 to 45 degrees Celsius (5 to 113 degrees Fahrenheit) (DOE, 1998).

\subsubsection{Physiography}

Yucca Flat is an intermontane valley in the northern portion of the Basin and Range physiographic providence (Figure 1-3). Yucca Flat is a topographically closed basin with a playa (a seasonally dry lake) at its southern end (Figure 1-4). The basin is bounded by the Halfpint Range on the east; by Rainier Mesa and the Belted Range on the north; by the Eleana Range and Mine Mountain on the west; and by the CP Hills and Massachusetts Mountain on the south (Figures 1-2 and 1-4). Ground elevation in Yucca Flat ranges from about 1,195 m (3,920 ft) above mean sea level at Yucca Lake (playa) in the southern portion to about 1,463 m $(4,800 \mathrm{ft})$ in the northern portion of the valley. 


\subsubsection{Geologic Setting}

Yucca Flat is a Cenozoic basin formed in response to basin-and-range extension. Rocks exposed in the highlands around the margins of Yucca Flat include late Precambrian (Proterozoic) and Paleozoic sedimentary rocks, Mesozoic intrusive rocks, and Cenozoic volcanic and tuffaceous sedimentary rocks.

The oldest rocks exposed in the area consist of Proterozoic carbonate and siliciclastic rocks that outcrop in the northern portion of the Halfpint Range. Paleozoic sedimentary rocks are exposed along the margins of Yucca Flat (Figure 1-4 and Plate 1), and consist mostly of carbonate rocks ranging in age from Cambrian to Mississippian. The Paleozoic rocks show contractional deformation most likely related to both east- and west-directed thrusting during the Mesozoic (e.g., Belted Range and CP thrust faults). However, contractional deformation has been overprinted by extensive extensional deformation related to basin-and-range extension during the late Cenozoic (Caskey and Schweickert, 1992; Cole and Cashman, 1999). During the middle Late Cretaceous, granitic bodies (including the Climax stock in northern Yucca Flat) intruded these deformed rocks (Maldonado, 1977; Houser and Poole, 1960).

Volcanic rock exposures include Miocene tuffs of generally rhyolitic composition erupted from large calderas and associated vents located $30 \mathrm{~km}(22 \mathrm{mi})$ west of Yucca Flat. These rocks dominate much of the highlands surrounding Yucca Flat. The volcanic rocks include ash-flow tuff, ash-fall tuff, and reworked tuff. The thickness and extent of these units vary partly due to the irregularity of the underlying depositional surface, and partly due to the paleotopography (e.g., barriers to ash flows) between Yucca Flat and the source areas to the west. The volcanic and sedimentary rocks are covered in many areas by a variety of late Tertiary-age and Quaternary-age surficial deposits. These deposits consist of alluvium, colluvium, eolian deposits, basalt lavas, and playa deposits.

\subsubsection{Hydrologic Setting}

\subsubsection{Groundwater Systems}

Yucca Flat is located within the Great Basin hydrographic province (see Figure 1-3). The Great Basin is characterized by internal drainage, and consists of numerous hydrographically closed topographic basins, including Frenchman Flat and Yucca Flat (Harrill et al., 1988). Streams in the Yucca Flat vicinity are ephemeral, flowing only in response to precipitation events. Runoff is conveyed through normally dry washes toward the topographically lowest areas of the basin, and collects on the Yucca Flat playa. The water may stand for a few weeks on the playa before evaporating, however, the playa is dry most of the year. Springs that emanate from the local 
perched groundwater systems are the only natural sources of perennial surface water in the region. There are 24 known springs or seeps on the NTS (Hansen et al., 1997) (Figure 1-5). The springs are important sources of water for wildlife, but they are too small to be used as a public water supply source. Five springs or seeps are present within the boundaries of the Yucca FlatClimax Mine model area.

The NTS, including the Yucca Flat-Climax Mine model area, is located within the Death Valley regional groundwater flow system, one of the major hydrologic subdivisions of the southern Great Basin (Waddell et al., 1984; Laczniak et al., 1996). Groundwater in the NTS region is conveyed within several groundwater flow-system sub-basins within the Death Valley regional flow system (Figure 1-6). The Yucca Flat-Climax Mine model area is located within the Ash Meadows sub-basin. Recharge areas for the Death Valley groundwater system are the higher mountain ranges of central and southern Nevada, where there can be significant precipitation and snow-melt. Groundwater flow is generally from these upland areas to natural discharge areas. Existing data and interpretations from the regional groundwater flow model (IT, 1996b, d) indicate that the overall groundwater flow direction in the Yucca Flat area is to the south and southwest. Groundwater ultimately discharges at Franklin Lake Playa to the south and Death Valley to the southwest.

Two water supply wells within the Yucca Flat model area provide both potable and non-potable water to the NTS. These are Water Well 2 in north-central Yucca Flat and Well TWC6 at the southern end of Yucca Flat.

\subsubsection{Static Water Levels}

The static water level (SWL) in the Yucca Flat basin is relatively deep, ranging in depth from $153.6 \mathrm{~m}$ (504 ft) (elevation of 1,204.9 m [3,953 ft]) at drill hole UE-1L in extreme western Yucca Flat to more than $580 \mathrm{~m}(1,900 \mathrm{ft}$ ) (elevation of $734 \mathrm{~m}$ [2,410 ft]) in north-central Yucca Flat (Fenelon, 2005). Throughout much of the Yucca Flat area, the SWL typically is located within the lower portion of the volcanic section, in the lower tuff confining unit. In the extreme northern, eastern, and western portions of the model area, the SWL can be within the Paleozoic units, while in the deeper structural sub-basins of Yucca Flat proper, the Tertiary volcanic rocks and the lower portion of the alluvium are also saturated.

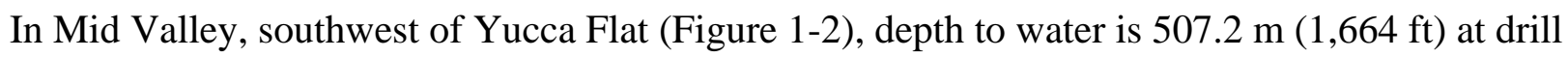
hole UE-14b (Fenelon, 2005; Reiner et al., 1995). With a ground level elevation of 1,326.8 m $(4,353 \mathrm{ft})$, this equates to an elevation of $819.6 \mathrm{~m}$ (2,689 ft). At this central Mid Valley location the SWL is within the volcanic aquifer (Rainier Mesa Tuff). 
Immediately south of Yucca Flat, in CP Basin, groundwater occurs at $256.6 \mathrm{~m}(842 \mathrm{ft})$ below ground surface at Water Well 4A. With a ground level of 1,099.1 m (3,606 ft), this corresponds to an elevation of $842.5 \mathrm{~m}$ (2,764 ft). The water level in eastern CP Basin is within the upper volcanic aquifers, the Ammonia Tanks and Rainier Mesa Tuffs.

To the north, in West Emigrant Valley, the groundwater table is relatively shallow and within the alluvium, resulting in a steep groundwater gradient southward into Yucca Flat. In the northeast

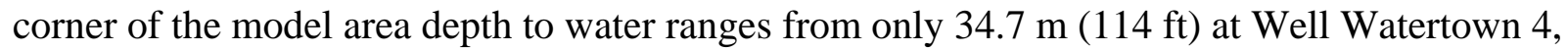
to $80.2 \mathrm{~m}$ (263 ft) at Well Stewart 1 (Thordarson and Robinson, 1971). These depths correspond to $1,320.7 \mathrm{~m}(4,333 \mathrm{ft})$ and $1,332.3 \mathrm{~m}(4,371 \mathrm{ft})$ elevation respectively.

\subsection{Previous Work}

The draft hydrostratigraphic framework model for Yucca Flat (Gonzales et al., 1998; Gonzales and Drellack, 1999) and interpretive products produced in support of the UGTA Phase I regional model (IT, 1996a) were the starting point for the development of the Phase I Yucca Flat-Climax Mine CAU-scale model. Other data for the adjacent Frenchman Flat hydrostratigraphic model were also available (BN, 2005a), as well as published maps and geologic reports, and unpublished geologic and geophysical data originally collected in support of other NTS programs (e.g., DOE weapons testing program [WTP], Yucca Mountain Project [YMP], and Area 3 Radioactive Waste Management Site [RWMS]).

\subsection{Framework Model}

The Yucca Flat-Climax Mine hydrostratigraphic framework model described in this document is based largely on the hydrologic framework described by Winograd and Thordarson (1975) for the NTS area. This early work was further developed by Laczniak et al. (1996), by the UGTA Phase I hydrostratigraphic regional modeling team (IT, 1996a, b, c), and by the initial Yucca Flat modeling team (Gonzales et al., 1998).

The study area was expanded northward in fiscal year (FY) 1999 to investigate the cause of a steep groundwater potentiometric gradient north of Yucca Flat. An eastward extension of the model area, completed in FY 2004, was needed to include the groundwater flow-path from the nuclear test BOURBON (U-7n) in eastern Yucca Flat, conducted in the regional carbonate aquifer in 1967. Boundaries for the northern and eastern extensions, along with the original Yucca Flat model area, are shown in Figure 1-7. 
The process used to construct the northern and eastern extensions to the Yucca Flat study area was similar to that conducted for the initial Yucca Flat model in 1998, and included a rigorous evaluation of the geology and hydrology of the area. 


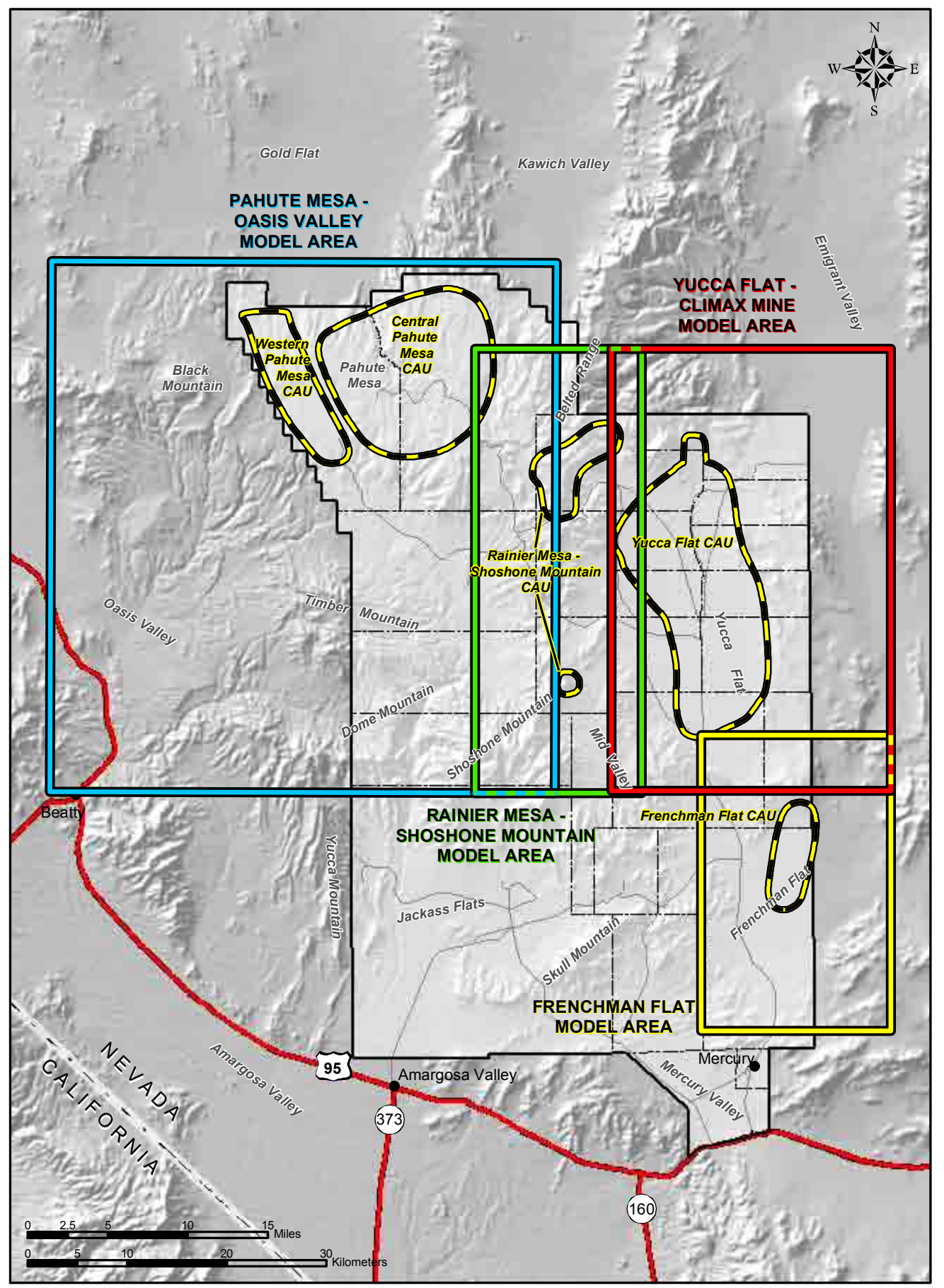

Figure 1-1

Map Showing Location of All UGTA Model Areas 


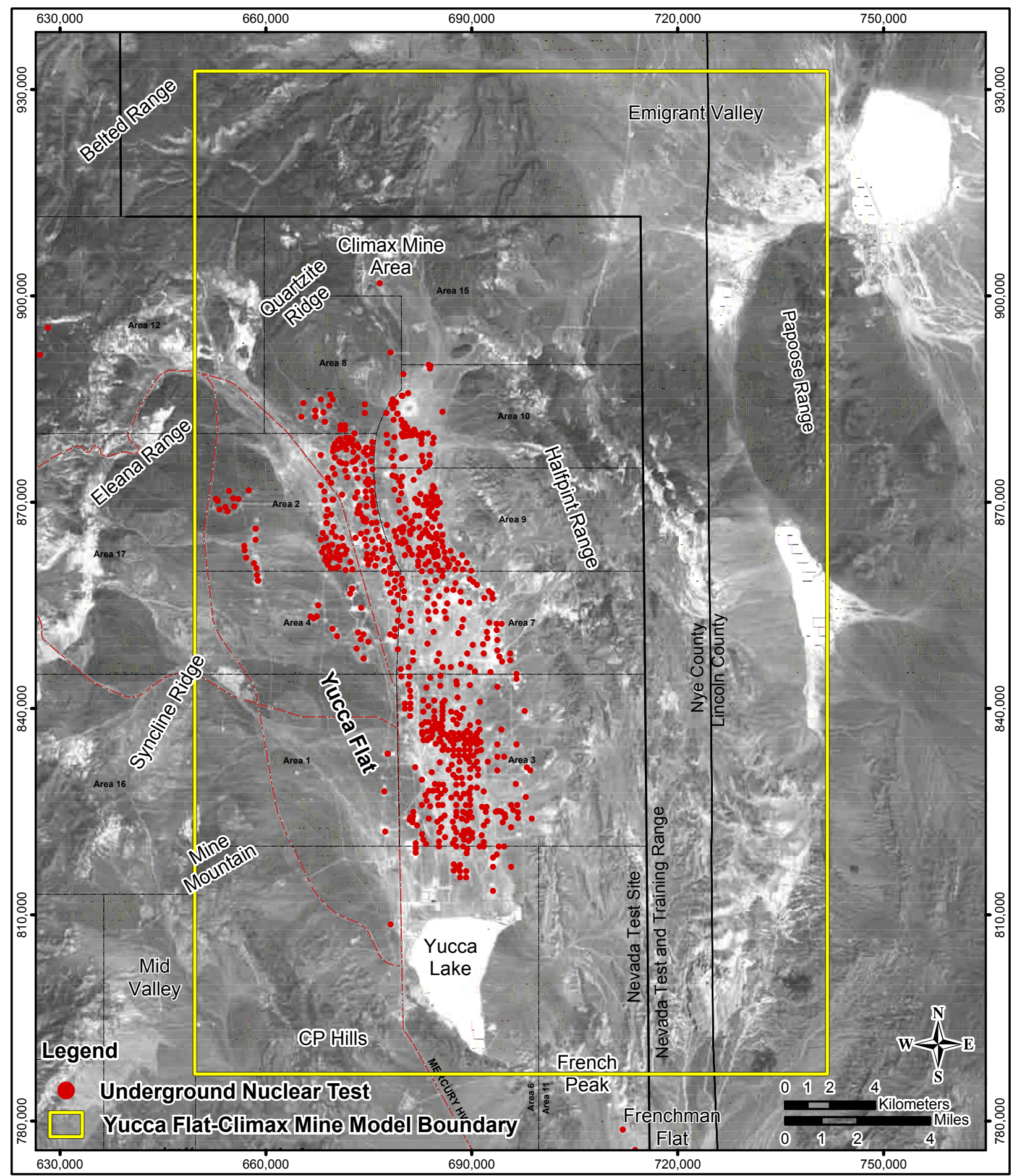

Figure 1-2

Satellite Image of the Yucca Flat-Climax Mine Area Showing Physiographic Features and Locations of Underground Nuclear Tests 


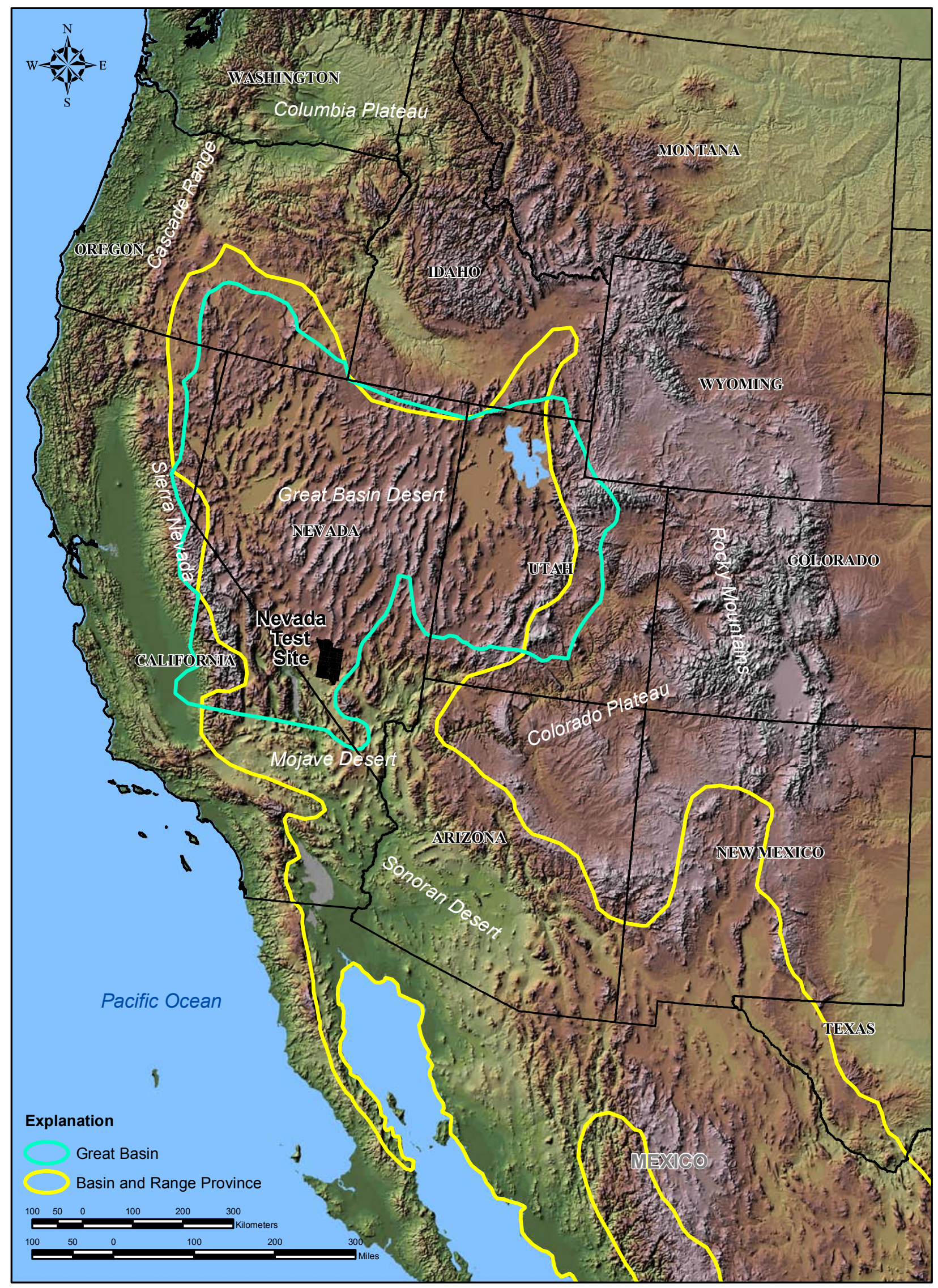

Figure 1-3

Color Relief Map Showing Locations of the Basin and Range Physiographic and Great Basin Hydrographic Provinces 


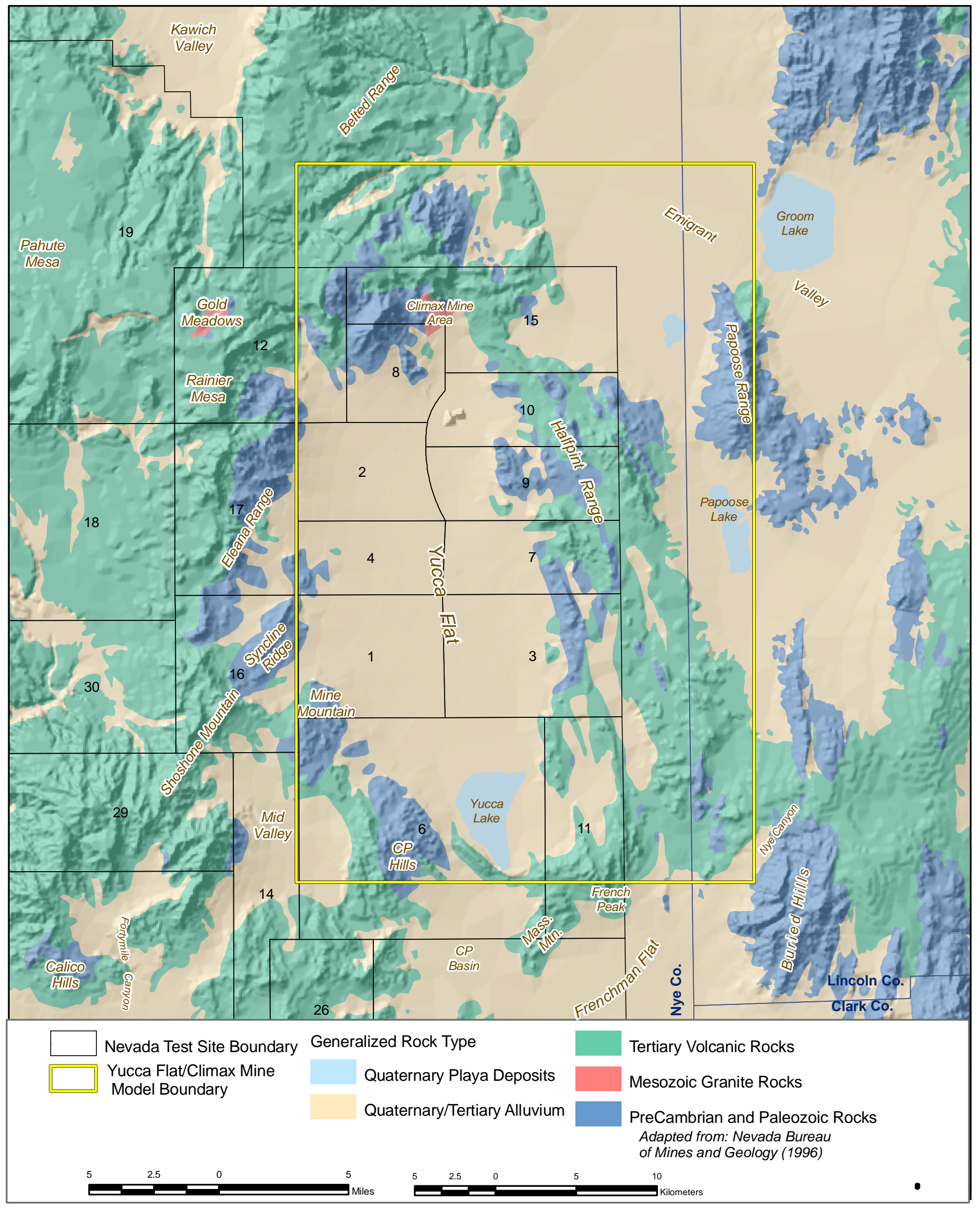

Figure 1-4 Generalized Geologic Map of the Yucca Flat/Climax Mine Region 


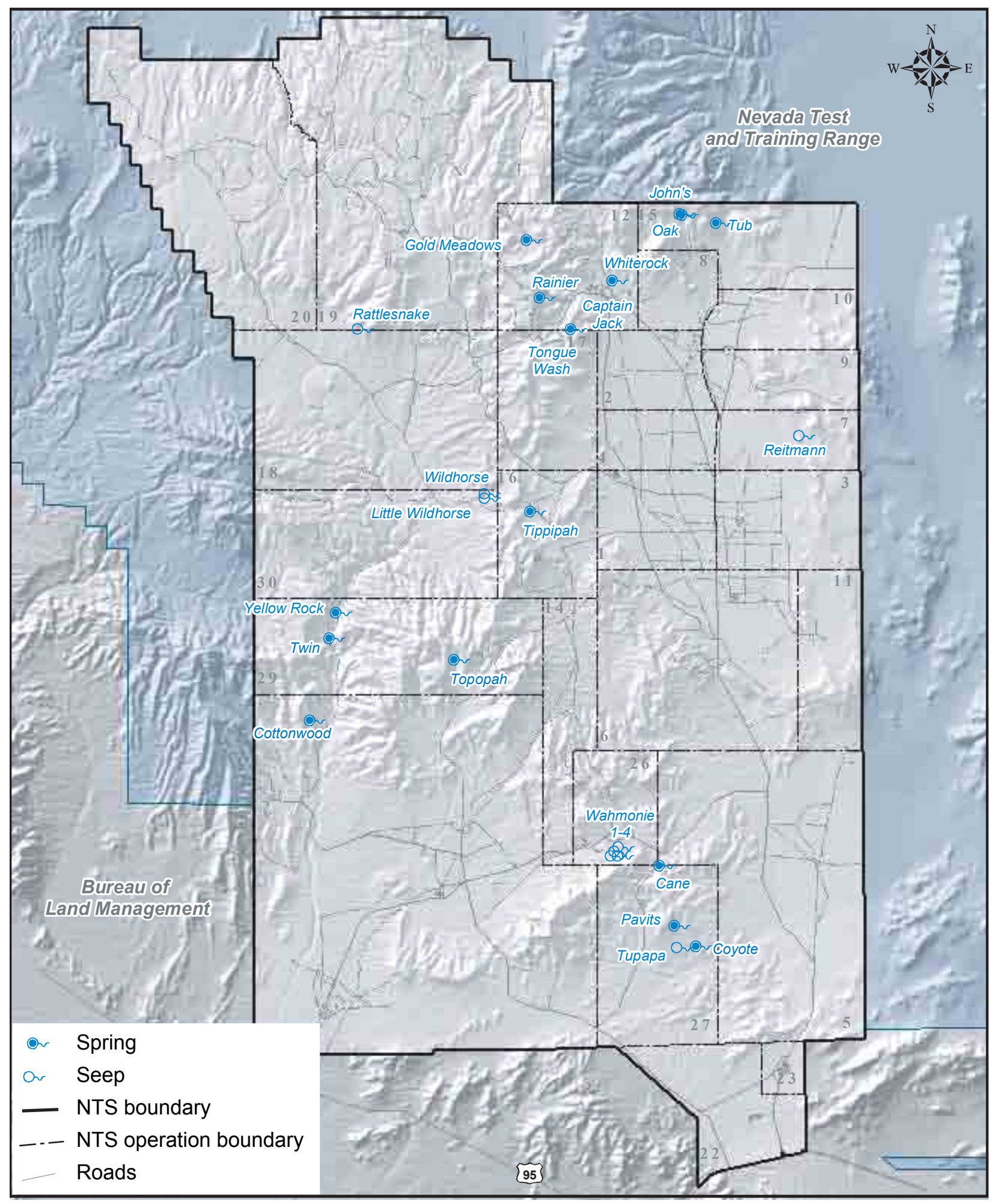

Figure 1-5

Natural Springs and Seeps on the Nevada Test Site

(After Hansen et al., 1997) 


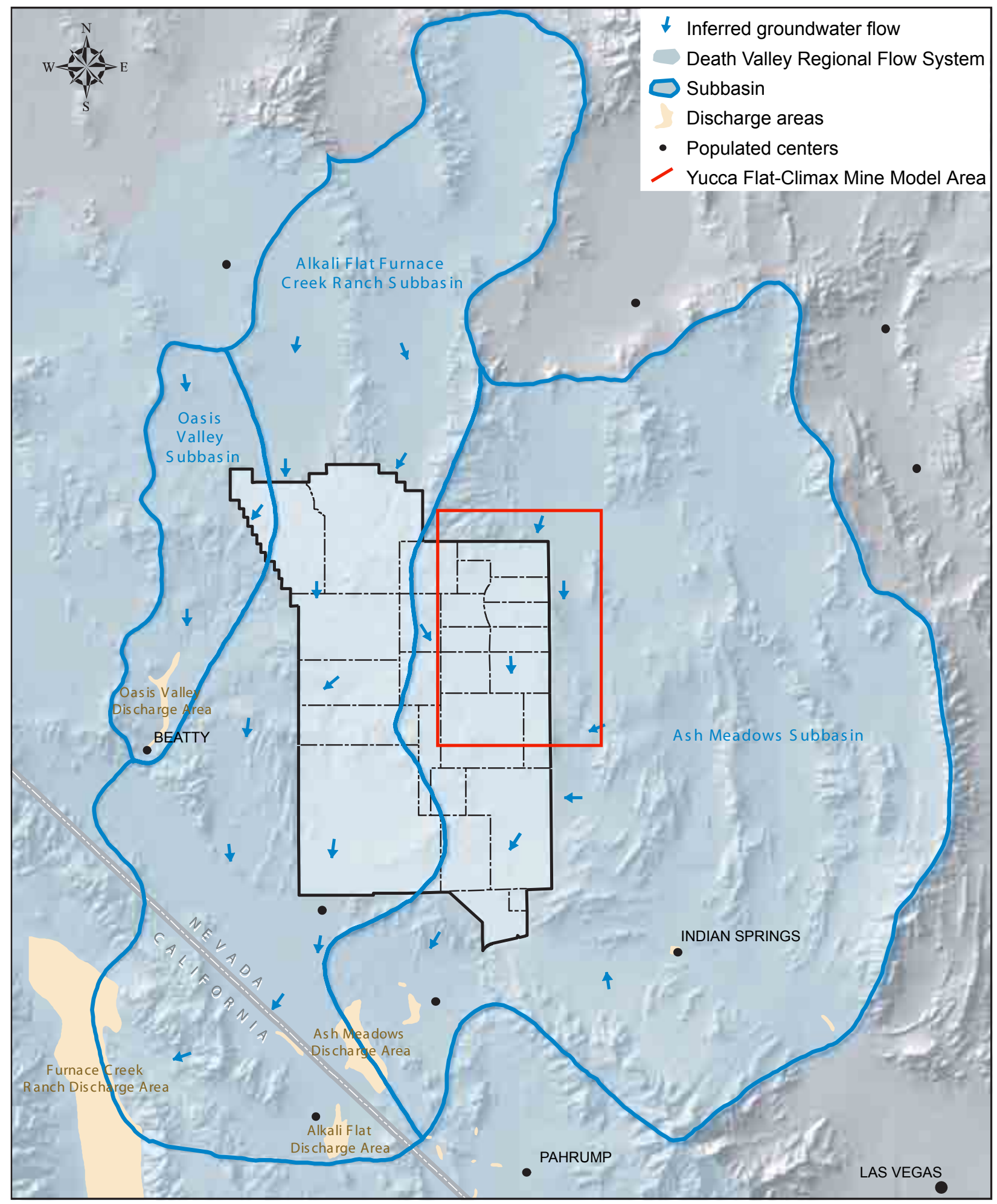

Figure 1-6

Groundwater Subbasins of the Nevada Test Site and Vicinity (Modified from Waddell et al., 1984, and Laczniak et al., 1996) 


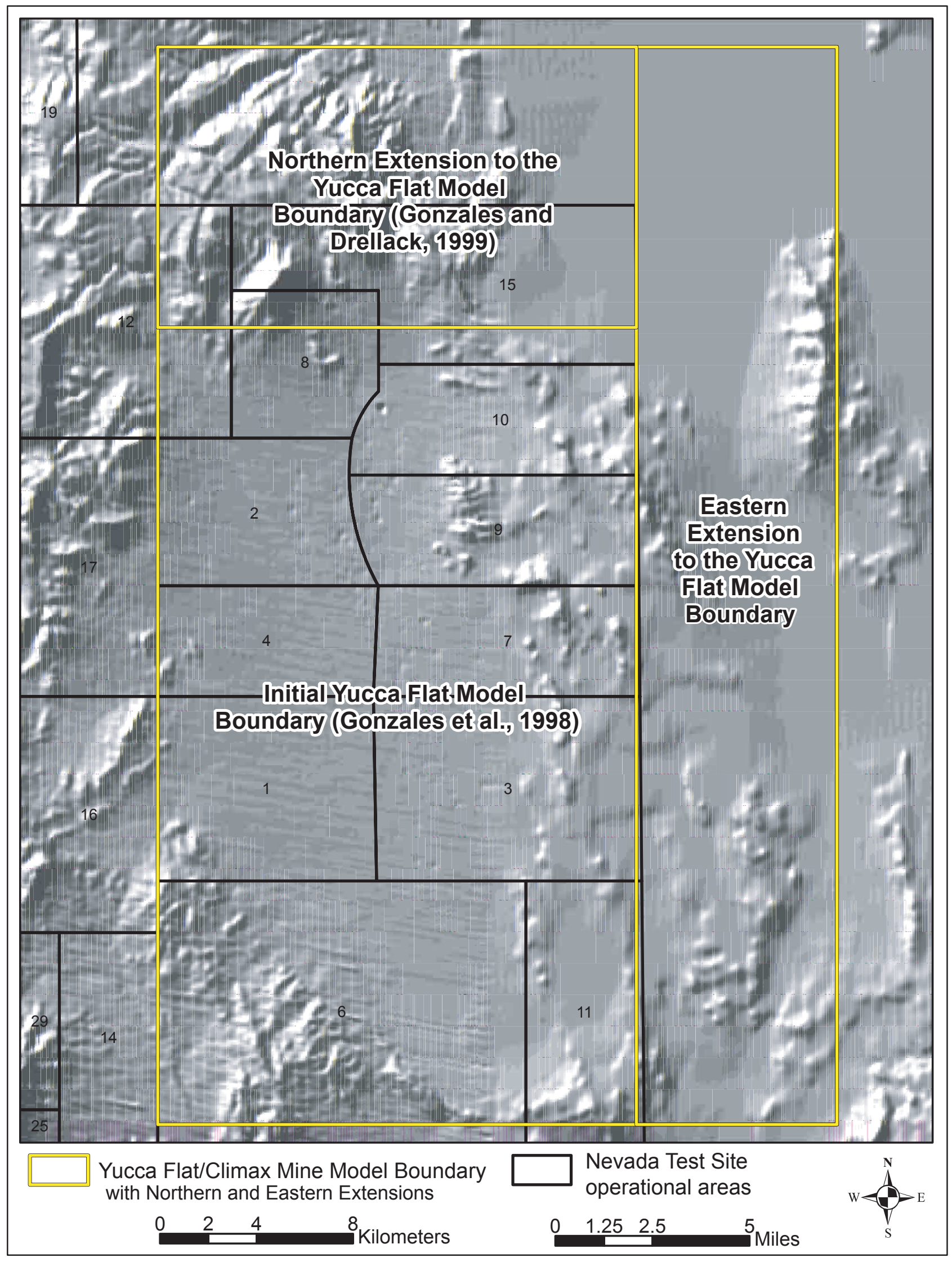

Figure 1-7

Locations of the Northern and Eastern Extensions of the Yucca Flat-Climax Mine Model Boundary 


\subsection{METHODOLOGY}

This section describes the process, methods, and data utilized to construct the Yucca Flat-Climax Mine hydrostratigraphic framework model.

\subsection{Model Construction Process}

A summary of the general work-flow for model construction is provided below. The summary lists in general chronological order individual tasks accomplished to build the final framework model.

\section{FY 1998: Produced a draft hydrostratigraphic framework model of Yucca Flat}

- Established and defined the boundaries of the model area.

- Assembled stratigraphic, lithologic, and alteration data for all drill holes within the area.

- Assembled other existing geologic data and interpretive products including geologic maps and cross sections, and geophysical investigations:

» Relevant hydrostratigraphic cross sections originally prepared during the UGTA Phase I regional effort

» Special-purpose maps, cross sections, and other data originally prepared in support of the DOE WTP

- Developed a hydrostratigraphic system for the Yucca Flat model using stratigraphic, lithologic, and alteration data; hydrologic well data; and information from earlier hydrologic investigations (e.g., Winograd and Thordarson, 1975).

- Built upon existing stratigraphic databases to create an expanded database for the Yucca Flat model.

- Integrated data from geophysical studies.

- Refined the structural model as necessary for the study area.

- Constructed interpretive geologic cross sections, pseudo drill holes/control points, and structure-contour maps for selected HSUs.

- Input hard data and interpretive products into Environmental Resources Management Applications System ${ }^{\circledR}\left(\right.$ ERMA $\left.^{\circledR}\right)$ modeling software.

- Resolved relational problems and modified the hydrostratigraphic framework model as necessary.

- Documented the data used, their sources, interpretative approach, methods, etc. (Gonzales et al., 1998)

- Submitted model and documentation for internal and external (UGTA and DOE community) reviews. 


\section{FY 1999: Produced a draft model of the Northern Extension}

- Used EarthVision ${ }^{\circledR}$ modeling platform, which replaced ERMA®.

- Established and defined the boundaries of the northern extension model area.

- Assembled existing surface data, geologic quadrangle maps, and cross sections, as modified for the 1998 effort.

» Relevant hydrostratigraphic cross sections originally prepared during the UGTA Phase I regional effort

" Special-purpose maps, cross sections, and other data originally prepared in support of the WTP

- Developed a hydrostratigraphic system for the Yucca Flat Northern Extension model using stratigraphic, lithologic, and alteration data.

- Built upon existing stratigraphic database to create an expanded database for the Yucca Flat model.

- Integrated data from recent geophysical studies.

- Refined the structural model as necessary for the study area.

- Constructed interpretive geologic cross sections, pseudo drill holes/control points, and structure-contour maps for selected HSUs.

- Resolved relational problems and modify the hydrostratigraphic framework model as necessary.

- Blended this new extended area with the existing Yucca Flat model (Gonzales et al., 1998), adjusting for edge effects as necessary.

- Documented the data used, their sources, interpretative approach, methods, etc. (Gonzales and Drellack, 1999).

\section{FY 2002: Converted initial Yucca Flat model (1998) to EarthVision ${ }^{\circledR}$.}

- Resolved relational problems and modified the framework model as necessary.

- Performed quality assurance/quality control evaluation of drill hole database.

\section{FY 2003: Gathered new data}

- Drilled five new drill holes.

- Conducted natural-source magnetotelluric (MT) survey.

\section{FY 2004: Produced a draft model of the Eastern Extension}

- Extended the Yucca Flat hydrostratigraphic model eastward (“eastern extension”) using the same work process as described above for the original Yucca Flat and northern extension models.

- Joined all three draft model areas, adjusting for edge effects as necessary.

- Integrated MT, gravity, and drill hole data, including fracture study using image log data.

- Conducted mineralogical study of tuff confining unit (TCU).

- Conducted pre-emptive review meeting (Section 2.4). 


\section{FY 2005: Produced base and alternative models for expanded model area}

- Conducted alternative scenario elicitation meeting.

- Built alternative models.

- Compiled draft documentation package.

- Conducted internal review of draft base model.

- Revised draft base model and documentation package.

- Submitted model and draft documentation package to NNSA/NSO and UGTA community for review.

\section{FY 2006: Produced final data documentation package (this document)}

- Addressed technical comments from ten reviewers.

- Produced and distributed final document.

\subsection{Determination of Model Area Boundaries}

The model boundaries were constrained by the needs of the hydrologic modelers and by the limitations and benefits of using computer modeling software. The model area had to be large enough to encompass all potential regulatory boundaries and any subsequent, or derivative flow and transport models. However, the area covered by the Yucca Flat 3-D hydrostratigraphic framework model may not necessarily be the same as that covered in the final flow and transport model. The hydrostratigraphic framework model area encompasses all of the underground testing locations (i.e., source areas) in the Yucca Flat and Climax test areas. The model includes all relevant geologic features, including known and inferred geologic structures. It also encompasses plausible flow paths from the source areas, based on the regional flow model (DOE, 1997) and on known hydrologic features.

Geographic coordinates that define the boundaries for the Yucca Flat-Climax Mine model area are given in Table 1-1. Vertically, the model extends from the ground surface to $5.1 \mathrm{~km}$ (3.2 mi) below mean sea level. The base of the model is below the top of the Proterozoic sedimentary rocks that underlie the regional aquifer. This deep confining unit is referred to as the "hydrologic basement” (“LCCU” in Figure 2-1).

\subsection{Data, Interpretive Products, and Other Information Used in Model Construction}

Despite the numerous drill holes in portions of the model area (Drellack and Thompson, 1990; Wagoner and Richardson, 1986) subsurface information in some parts of the model area is sparse, particularly around the margins of the model area (outside of the WTP-use areas). However, geoscientists have been working in the NTS region for more than 50 years (Byers et al., 1989), and many sources of geologic and geophysical information and data relevant to the 
Yucca Flat area are available. For example, most of the geologic units in the model are exposed at the surface within the NTS region, allowing direct observation of rock properties and characteristics. Drill hole and surface geophysical data are also available for these units. Numerous studies of similar geologic terrains have been conducted in other parts of the NTS and Nevada, and serve as analogs for some parts of the model area. Data collected as part of the Phase I data acquisition also added to the quality of subsurface data available for the model area.

The draft hydrostratigraphic framework model for Yucca Flat (Gonzales et al., 1998; Gonzales and Drellack, 1999) and interpretive products produced in support of the UGTA Phase I regional model (IT, 1996a) were the starting point for the development of the Phase I Yucca Flat-Climax Mine model. Data for the adjacent Frenchman Flat CAU area were also available (BN, 2005a), as well as published maps and geologic reports, and unpublished geologic and geophysical data originally collected in support of other NTS programs (e.g., WTP, YMP, and Area 3 RWMS). Data also became available from five new boreholes and several recent geophysical studies conducted in the study area. Surface elevations for the alluvium and bedrock (uppermost HSUs) were imported from a digital elevation model (DEM) data set. This DEM was compiled from 10-m DEM data derived from NTS-specific aerial photography reconnaissance in 1998 by the Remote Sensing Laboratory (BN, 2002b). Surface and near-surface geologic information was derived from the USGS geologic maps of the study area. The most important sources of data used to develop the subsurface interpretation presented in this model are listed below and discussed in more detail in following paragraphs. Individual data sources are identified where appropriate in Sections 3.0, 4.0, and 5.0 of this report. A complete list of references is provided in Section 7.0.

Geologic data for the Yucca Flat-Climax Mine area were compiled from existing data sets and from studies conducted specifically for this task. The subsurface interpretation is based on a variety of information sources, including the following:

- $\quad$ Twelve USGS geologic quadrangle maps (Table 2-1)

- Other geologic maps (Table 2-2)

- $\quad$ Surface gravity and aeromagnetic investigations (Table 2-3)

- High-resolution 10-m DEM data (BN, 2002b)

- Various USGS reports (e.g., Cole and Cashman, 1997, 1999; Cole et al., 1997)

- Seismic surveys conducted for WTP by LLNL and LANL

- Drill hole data (USGS, 1974; Fernald et al., 1975; Maldonado et al., 1979; Drellack and Thompson, 1990; Wagoner and Richardson, 1986; Gonzales and Drellack, 1999)

- Maps, detailed cross sections, and other information originally prepared for WTP projects and early UGTA modeling efforts (examples in Table 2-4) 
Table 2-1

Geologic Quadrangle Maps (Scale 1:24,000) Used in Construction of the Yucca Flat-Climax Mine Hydrostratigraphic Framework Model

\begin{tabular}{||l|l||}
\hline \multicolumn{1}{|c||}{ Quadrangle Name } & \multicolumn{1}{c|}{ Authors $^{\text {a }}$} \\
\hline \hline Oak Spring & Barnes et al., 1963 \\
\hline Jangle Ridge & Barnes et al., 1965 \\
\hline Paiute Ridge & Byers and Barnes, 1967 \\
\hline Yucca Flat & Colton and McKay, 1966 \\
\hline Groom Mine & Colton and Nobel, 1967 \\
\hline Rainier Mesa & Gibbons et al., 1963 \\
\hline Plutonium Valley & Hinrichs and McKay, 1965 \\
\hline Yucca Lake & McKeown et al., 1976 \\
\hline Tippipah Spring & Orkild, 1963 \\
\hline Mine Mountain & Orkild, 1968 \\
\hline Oak Spring Butte & Rogers and Noble, 1969 \\
\hline Quartet Dome & Sargent et al., 1966 \\
\hline
\end{tabular}

a See full citations in Section 7.0

Table 2-2

Special Purpose Geologic Maps Used in Construction of the Yucca Flat-Climax Mine Hydrostratigraphic Framework Model

\begin{tabular}{||l|l||}
\hline \multicolumn{1}{|c|}{ Map Title and Scale } & \multicolumn{1}{|c||}{ Authors $^{\text {a }}$} \\
\hline \hline Geologic Map of the Nevada Test Site (1:100,000) & Frizzell and Shulters, 1990 \\
\hline $\begin{array}{l}\text { Preliminary Digital Geologic Map Database of the Nevada Test Site Area, } \\
\text { Nevada }\end{array}$ & Sawyer et al., 1994 \\
\hline Geologic Map of Nevada (1:500,000) & Stewart and Carlson, 1978 \\
\hline $\begin{array}{l}\text { Digital Geologic Map of the Nevada Test Site and Vicinity, Nye, Lincoln, and } \\
\text { Clark Counties, Nevada and Inyo County, California (1:120,000) }\end{array}$ & Slate et al., 1999 \\
\hline \begin{tabular}{l} 
County Digital Geologic Maps (1:250,000) \\
\hline $\begin{array}{l}\text { Geologic Map of the Death Valley Groundwater Basin and Surrounding Areas, } \\
\text { Nevada and California (1:250,000) }\end{array}$
\end{tabular} & $\begin{array}{l}\text { Nevada Bureau of Mines and } \\
\text { Geology, 1996 }\end{array}$ \\
\hline $\begin{array}{l}\text { Tectonic Map of the Death Valley Groundwater Model Area, Nevada and } \\
\text { California (1:250,000) }\end{array}$ & Workman et al., 2002b \\
\hline $\begin{array}{l}\text { Subcrop Geologic Map of the Pre-Tertiary Rocks in the Yucca Flat and Northern } \\
\text { Frenchman Flat Areas, Nevada Test Site, Southern Nevada }\end{array}$ & Cole et al., 1997 \\
\hline $\begin{array}{l}\text { Geologic Map of the Wheelbarrow Peak-Rainier Mesa Area, Nye County, } \\
\text { Nevada (1:48,000) }\end{array}$ & Sargent and Orkild, 1973 \\
\hline $\begin{array}{l}\text { Geology and Mineral Deposits of Lincoln County, Nevada, Recently Dated as } \\
\text { Miocene }\end{array}$ & Tschanz and Pampeyen, 1970 \\
\hline \hline
\end{tabular}

a See full citations in Section 7.0 
Table 2-3

Miscellaneous Special Purpose Maps and Geophysical Studies Used in the Construction of the Yucca Flat-Climax Mine Hydrostratigraphic Framework Model

\begin{tabular}{|c|c|}
\hline Map or Study Title and Scale & Authors $^{a}$ \\
\hline $\begin{array}{l}\text { Geologic Surface Effects of Underground Nuclear Testing, Buckboard } \\
\text { Mesa, Climax Stock, Dome Mountain, Frenchman Flat, Rainier/Aqueduct } \\
\text { Mesa, and Shoshone Mountain, Nevada Test Site, Nevada }\end{array}$ & Grasso, 2003 \\
\hline $\begin{array}{l}\text { GIS Surface Effects Archive of Underground Nuclear Detonations } \\
\text { Conducted at Yucca Flat and Pahute Mesa, Nevada Test Site, Nevada }\end{array}$ & Grasso, 2001 \\
\hline $\begin{array}{l}\text { Preliminary Aeromagnetic Map of the Nevada Test Site and Vicinity, } \\
\text { Nevada }\end{array}$ & Kirchoff-Stein et al., 1989 \\
\hline $\begin{array}{l}\text { Digital Aeromagnetic Map of the Nevada Test Site Area, Nye, Lincoln, } \\
\text { and Clark Counties, Nevada, and Inyo County, California }(1: 100,000)\end{array}$ & Ponce, 1999 \\
\hline $\begin{array}{l}\text { Complete Bouguer Gravity Map of the Nevada Test Site and Vicinity, } \\
\text { Nevada }\end{array}$ & Healey et al., 1987 \\
\hline Isostatic Gravity Map of the Nevada Test Site and Vicinity, Nevada & Ponce et al., 1988 \\
\hline $\begin{array}{l}\text { Digital Isostatic Gravity Map of the Nevada Test Site Area, Nye, Lincoln, } \\
\text { and Clark Counties, Nevada, and Inyo County, California }(1: 100,000)\end{array}$ & Ponce et al., 1999 \\
\hline $\begin{array}{l}\text { Maps of the Thickness of Cenozoic Deposits and the Isostatic Residual } \\
\text { Gravity over Basement for Nevada }\end{array}$ & Jachens and Moring, 1990 \\
\hline $\begin{array}{l}\text { Aeromagnetic and Gravity Anomaly Maps of the Southwestern Nevada } \\
\text { Volcanic Field, Nevada and California }(1: 250,000)\end{array}$ & $\begin{array}{l}\text { McCafferty and Grauch, } \\
1997\end{array}$ \\
\hline $\begin{array}{l}\text { Paleomagnetic Data Bearing on the Origin of Arcuate Structures in the } \\
\text { French Peak-Massachusetts Mountain Area of Southern Nevada }\end{array}$ & Hudson, 1992 \\
\hline $\begin{array}{l}\text { Structural Geology of the French Peak Accommodation Zone, Nevada } \\
\text { Test Site, Southwestern Nevada }\end{array}$ & Hudson, 1997 \\
\hline $\begin{array}{l}\text { High-Angle Faults in the Basement of Yucca Flat, Nevada Test Site, } \\
\text { Nevada, Based on the Analysis of a Constrained Gravity Inversion } \\
\text { Surface }\end{array}$ & Phelps and McKee, 1999 \\
\hline Geophysical Study of the Subsurface Distribution of the Climax stock & Jachens, 1999 \\
\hline $\begin{array}{l}\text { Thickness of Cenozoic Deposits of Yucca Flat Inferred from Gravity Data, } \\
\text { Nevada Test Site, Nevada }\end{array}$ & Phelps et al., 1999 \\
\hline $\begin{array}{l}\text { Preliminary Model of the Pre-Tertiary Basement Rocks Beneath Yucca } \\
\text { Flat, Nevada Test Site, Nevada, Based on Analysis of Gravity and } \\
\text { Magnetic Data. }\end{array}$ & Phelps et al., 2000 \\
\hline $\begin{array}{l}\text { Modeling of Climax Stock and Related Plutons Based on the Inversion of } \\
\text { Magnetic Data, Southwest Nevada }\end{array}$ & Phelps et al., 2004 \\
\hline $\begin{array}{l}\text { A Preliminary Investigation of the Structure of Southern Yucca Flat, } \\
\text { Massachusetts Mountain, and CP Basin, Nevada Test Site, Nevada, } \\
\text { Based on Geophysical Modeling }\end{array}$ & Phelps et al., 2005 \\
\hline
\end{tabular}

a See full citations in Section 7.0 
Table 2-4

Examples of Maps, Detailed Cross Sections, and Other Geologic Information Originally Prepared for WTP Projects and Early UGTA Modeling Efforts

\begin{tabular}{||l|l||}
\hline \multicolumn{1}{|c|}{ Investigation Title } & \multicolumn{1}{|c||}{ Authors } \\
\hline \hline $\begin{array}{l}\text { Tuff Pile I - A Justification for the Projection of Material Properties within a } \\
\text { Portion of Los Alamos Test Areas 1, 3, 4, and 7, Nevada Test Site. }\end{array}$ & App and Marusak, 1997 \\
\hline $\begin{array}{l}\text { Lithologic Logs and Stratigraphic Identification of Exploratory and } \\
\text { Emplacement Drill Holes in Area 3, Nevada Test Site }\end{array}$ & Dixon et al., 1973 \\
\hline $\begin{array}{l}\text { Supplementary Lithologic Logs and Stratigraphic Identifications for } \\
\text { Exploratory and Emplacement Drill Holes in Areas 3, 4, and 7, Nevada } \\
\text { Test Site }\end{array}$ & Dixon et al., 1975 \\
\hline Sloughing Sand Lens Map & Drellack, 1992 \\
\hline Fault-Naming Protocols & Drellack, 1994a \\
\hline Subsurface Geologic Maps of Southern Yucca Flat & Drellack, 1994b \\
\hline Descriptive Narrative for Cross Sections SD1, SD2, SD3, and MS1 & Drellack, 1995a \\
\hline Fault Inventory for Yucca Flat, NTS & Drellack, 1995b \\
\hline Structure Contour Map of the Pre-Tertiary Surface in Southern Yucca Flat & Drellack, 1995c \\
\hline $\begin{array}{l}\text { Lithologic Logs of Three Exploration Core Holes, U15b Area, Climax } \\
\text { Stock, Nevada Test Site, Nye County, Nevada }\end{array}$ & Houser, 1961 \\
\hline $\begin{array}{l}\text { Supplementary Lithologic Logs of Selected Vertical Drill Holes in Area 12, } \\
\text { Nevada Test Site }\end{array}$ & Maldonado et al., 1979 \\
\hline $\begin{array}{l}\text { Lithologic Logs and Stratigraphic Identification for Vertical Drill Holes in } \\
\text { Area 12, Nevada Test Site. }\end{array}$ & Miller, 1970 \\
\hline $\begin{array}{l}\text { A Petrographical, Geochemical and Geophysical Database and } \\
\text { Framework for the Southwestern Nevada Volcanic Field }\end{array}$ & Warren et al., 2003 \\
\hline
\end{tabular}

- UGTA wells in Yucca Flat:

» Well Cluster ER-6-1 and Wells ER-2-1, ER-7-1, ER-8-1, and ER-12-2 (DOE, 2004a, b, c, d, e; WoldeGabriel et al., 2004)

» Wells ER-6-2 (IT, 1997), ER-3-1 (DOE, 1995a), and ER-3-2 (DOE, 1995b)

- Magnetotelluric survey (Appendix D, this report)

- Various studies conducted to characterize the site of the Area 3 RWMS (BN, 1998, 1999, 2005b; Levitt and Yucel, 2002)

\subsubsection{Existing Geological and Geophysical Maps}

Geologists working for the USGS have been mapping in the NTS area since the 1950s, and have produced numerous geologic quadrangle maps at a scale of 1:24,000. Table 2-1 lists the 12 USGS maps that include portions of the Yucca Flat-Climax Mine model area. Other surface geologic maps at larger scales were also utilized (Table 2-2). Table 2-3 lists some of the special- 
purpose geological maps and geophysical studies that were considered during model construction.

\subsubsection{Drill Hole Data}

Nearly 2,900 holes have been drilled in and near the Yucca Flat area for various purposes, including construction of water wells and monitoring wells, emplacement holes and post-shot holes for UGTs, and exploratory holes (RSN, 1990). Hundreds of holes relevant to the Yucca Flat-Climax Mine model were drilled by the DOE in support of NTS programs, but data from most of these were held primarily in NTS agency files. During development of the UGTA Phase I regional model and the initial Phase I Yucca Flat model, these data were compiled, analyzed, and organized into databases for import into modeling software applications. Boreholes providing input for the Yucca Flat framework model are listed in Appendix A and shown on Plate 3. The boreholes provide information on the geologic and hydrologic character and distribution of subsurface units.

Although much of the drill-hole information provided in Appendix A is typically referred to as data, it should be remembered that such information is a result of a rigorous interpretive process based on an integrated analysis of drill cuttings, rock core, geophysical logs, and nearby surface exposures. Results from laboratory analyses such as petrography, X-ray diffraction, and X-ray fluorescence (WoldeGabriel et al., 2004; Warren et al., 2003) were also integrated into the stratigraphic interpretation when available.

\subsubsection{UGTA Phase I Well Drilling Initiative}

Eight wells were drilled and completed as part of the Phase I data acquisition initiative for the Yucca Flat-Climax Mine CAU, and provide important information and constraints for the framework model. The wells were intended to provide confirmatory information for the Yucca Flat-Climax Mine hydrogeologic model, and new, detailed information about the geology, hydrogeology, and water chemistry in the immediate vicinity of the underground nuclear testing areas within Yucca Flat. The purpose and expectations of the FY 2003 drilling initiative are spelled out in the Yucca Flat Hydrogeologic Investigation Wells Drilling and Completion Criteria (IT, 2002). Objectives of the wells drilled before 2003 (Wells ER-3-1, ER-3-2, and ER-6-2) are described in separate drilling and completion criteria reports (IT, 1992, 1993, 1994a, 1994b). Each of these UGTA wells is described briefly in the following paragraphs.

\subsubsection{Well ER-2-1}

Well ER-2-1 is located in north-central Yucca Flat within Area 2 (Plate 3) and was drilled to a total depth (TD) of $792.5 \mathrm{~m}$ (2,600 ft) in 2003 (DOE, 2004b). The primary purpose of 
constructing Well ER-2-1 was to characterize the radiological and physical environment near UGTs conducted in a saturated volcanic aquifer setting, where the local groundwater flow direction is uncertain. Information from the completion, sampling, and later hydraulic testing at Well ER-2-1 helped to establish the physical characteristics, hydrologic source-term, and hydraulic parameters for the near-field environment, providing a means of investigating possible contaminant migration in saturated volcanic aquifers.

\subsubsection{Well ER-3-1}

Well ER-3-1 is located in the Halfpint Range in the eastern part of Area 3 (Plate 3) and was drilled to a TD of $855.5 \mathrm{~m}$ (2,807 ft) in 1994 (DOE, 1995a). The purpose of drilling this well was to provide potentiometric data from the saturated lower carbonate aquifer (LCA) underlying the alluvium and volcanic rocks east of Yucca Flat. This well also provided information about the stratigraphy and structure of the area.

\subsubsection{Well ER-3-2}

Well ER-3-2 is located in south-central Yucca Flat within Area 3 (Plate 3) and was drilled to a TD of $914.4 \mathrm{~m}$ (3,000 ft) in 1994 (DOE, 1995b). The purpose of this well was to provide hydrogeologic data to increase the understanding of a postulated hydraulic sink in this portion of Yucca Flat. The location of this well was also chosen because it is hydraulically down-gradient from expended nuclear tests in an area where no drill holes had penetrated the full thickness of the alluvial section.

\subsubsection{Well Cluster ER-6-1}

Well Cluster ER-6-1 is located in southeastern Yucca Flat (Plate 3). The goal of constructing, sampling, and hydrologic testing at Well Cluster ER-6-1 was to collect subsurface geologic and hydrologic data that would help characterize the hydrogeology of southeastern Yucca Flat. Data from these wells will allow for more accurate modeling of the groundwater flow and radionuclide migration in the region. A multi-well tracer test was run at the well cluster in 2003, and additional hydrologic tests were conducted at the site in 2005.

The cluster consists of 3 boreholes drilled on the same drill pad (DOE, 2004a). Well ER-6-1 was initially drilled to a temporary TD of $648.9 \mathrm{~m}(2,129 \mathrm{ft})$ in 1992. In 1994, the borehole was deepened to a TD of $977.3 \mathrm{~m}$ (3,206 ft). Well ER-6-1 Satellite Hole \#1 is located about $15.2 \mathrm{~m}$ $(50 \mathrm{ft})$ south-southeast of Well ER-6-1. This well was drilled to a TD of $635.5 \mathrm{~m}(2,085 \mathrm{ft})$ in July 1993. Well ER-6-1\#2 was drilled to a TD of 975.4 m (3,200 ft) in October 2002, and served as the pumping well for a multi-well tracer test. 


\subsubsection{Well Cluster ER-6-2}

Well ER-6-2 is located in the southwestern portion of Yucca Flat in the central part of the NTS Area 6 (Plate 3). This location was selected to investigate geologic and hydrologic conditions of the LCA in southern Yucca Flat. The site is located in a potentially down-gradient position from expended UGTs in northern and central Yucca Flat. In addition, Well Cluster ER-6-1 and recompletion wells TW-B and UE-6e are positioned such that data from the wells have been used to establish an east-west hydrogeologic transect across southern Yucca Flat.

Well ER-6-2 and its satellite hole Well ER-6-2 \#1 were drilled on the same pad approximately $15.2 \mathrm{~m}$ (50 ft) apart in 1992 and 1994 (IT, 1997). Well ER-6-2\#1 was intended as an observation well in conjunction with hydrologic tests at Well ER-6-2; however, it was abandoned at $399 \mathrm{~m}$ (1,309 ft) due to stuck drill pipe and was cemented to the surface.

\subsubsection{Well ER-7-1}

Well ER-7-1 is located in eastern Yucca Flat within south-central NTS Area 7 (Plate 3) and was drilled to a TD of $756.4 \mathrm{~m}(2,481.7 \mathrm{ft})$ in 2003 (DOE, 2004c). The primary purpose for constructing Well ER-7-1 was to evaluate the LCA down-gradient from a UGT conducted close to the LCA. The well is located within a cluster of UGTs, some of which were conducted near (and therefore, potentially connected hydraulically) the LCA. Of particular interest was the determination of whether there are permeable, near-vertical pathways (faults) along which radionuclides could migrate from individual UGT locations to the underlying regional aquifer.

\subsubsection{Well ER-8-1}

Well ER-8-1, located in the northeast corner of NTS in Area 8 (Plate 3), was drilled to a TD of $1,066.8 \mathrm{~m}$ (3,500 ft) in 2002 (DOE, 2004d). This well was intended to provide information on the steep potentiometric gradient at the north end of Yucca Flat, and to provide modeling constraints on groundwater flux into Yucca Flat from the north. Geologic data obtained from Well ER-8-1, especially the tag on the Climax stock granitic intrusive, were used to enhance the hydrogeologic framework model, and hydrologic data from the well will provide the necessary hydraulic parameters for later flow and transport modeling for the Yucca Flat-Climax Mine CAU.

The construction of this well also addressed comments by the peer reviewers of the draft Corrective Action Investigation Plan for Yucca Flat and the Climax area (DOE, 2000b) concerning the need for adequately characterizing the former Climax Mine test area. Note that the Climax Mine and the Yucca Flat underground testing areas, originally defined as two separate CAUs in the original FFACO (1996), are now combined into a single CAU. 


\subsubsection{Well ER-12-2}

Well ER-12-2 is located in the southeastern corner of the NTS Area 12 in the northwestern portion of Yucca Flat (Plate 3) and was drilled to a TD of 2,097.9 m (6,883 ft) in 2003 (DOE, 2004e). The borehole was intended to provide information that would enhance the understanding of the hydrogeology of northwestern Yucca Flat including; the extent and thickness of pre-Tertiary HSUs, the lower carbonate aquifer - upper thrust plate (LCA3) and the upper clastic confining unit (UCCU), and the characterization of structural features such as the CP thrust fault (IT, 2002).

Some of these objectives were based on the assumption that Well ER-12-2 would penetrate completely through the UCCU and into the underlying LCA. Well ER-12-2 reached TD in UCCU, never reaching the LCA. Therefore, some of the scientific objectives were not met as anticipated.

\subsubsection{Other UGTA Drilling and Completion Activities}

In addition to drilling and completion of the specific hydrogeologic investigation wells described above, the UGTA project has installed, deepened and/or otherwise re-completed several miscellaneous-use holes in the Yucca Flat model area. These include the deepening and completion of exploratory holes UE-1q, UE-6e, and UE-10j, and of Well TW-B; installation of two new post-shot holes, U-2gg PS\#3A and U-7ba PS\#1AA; installation of two subsidence recharge study holes, U-10i \#1 and \#2; recompletion of existing boreholes U-3cn\#5 and U-3cn PS\#2; and assumption of ownership of sampling wells UE-2ce, UE-3e\#4, U-4t PS\#3A, U-4u PS\#2A, and UE-7nS. These endeavors and resultant data have been documented in either stand-alone UGTA reports and/or were incorporated into larger UGTA documentation reports.

\subsubsection{Other Models}

Several organizations have produced, or are in the process of producing, geologic and hydrologic models of various sizes and degrees of complexity for areas that adjoin or include portions of the UGTA Yucca Flat area. The UGTA models that served as a starting point for the Yucca Flat model have already been mentioned: the UGTA Phase I Regional Model (IT, 1996a) and the initial Yucca Flat 3-D hydrostratigraphic framework model (Gonzalez, et al., 1998). The Death Valley regional groundwater flow model (D’Agnese et al., 1997; Workman et al., 2002a, b; Sweetkind et al., 2001; Faunt, 1998; Faunt et al., 1999) was developed by the USGS at the request of a multi-organizational consortium which includes the National Park Service, the Bureau of Land Management, the State of Nevada, and NNSA/NSO for the YMP. The developers of the Yucca Flat 3-D hydrostratigraphic framework model benefitted from access to these other models, and incorporated data and working concepts from them as necessary. 


\subsubsection{Detailed Cross Sections}

Construction of geologic cross sections is a necessary and important step in the process of understanding subsurface geology. Detailed geologic cross sections for the Yucca Flat area were constructed for the Phase I regional geologic model (IT, 1996a) at a scale of 1:12,000. This unusual level of detail was possible because of the abundant data (e.g., drill holes) and the information accumulated for the WTP. A portion of one of these detailed cross sections is reproduced in Figure 2-2. Drill hole data, surface geology, surface effects produced by UGTs, age dates for Paleozoic carbonate rocks, and geophysical data were integrated in the construction of these detailed cross sections.

The locations for the detailed cross sections (Figure 2-3) were chosen to ensure that geologic and hydrologic information would be developed in a cost-effective way for as much of the Yucca Flat CAU as possible, with enhanced coverage in the testing areas. Smaller working cross sections, which served as intermediate interpretive tools, were constructed through some areas to help solve relationships of specific stratigraphic units or structural problems. Each detailed geologic cross section was then simplified to depict only HSUs and larger (potentially hydrologically significant) structures. Additional information regarding the method of construction for UGTA cross sections is provided in Gonzales et al. (1998) and BN (2002a).

The simplified hydrostratigraphic cross sections served as direct input to the model and were an intermediate step in the creation of other interpretive products (e.g., structure contour maps representing the tops of selected HSUs).

\subsubsection{Surface Effects from Underground Nuclear Explosions}

The confirmation and locations of some of the faults in the Yucca Flat model are based on surface effects produced by UGTs. Surface cracks and collapse craters were the dominant features, however, other effects such as pressure ridges, faults (i.e., cracks displaying vertical displacement), fluffed ground, and block chatter were also documented (Allen, et al., 1997). These features were routinely mapped after each test and provide a unique source of geologic information. Cracks may be randomly oriented, but usually trend along certain preferred directions or patterns relative to the surface ground zero that can be categorized as linear, concentric or circumferential, or radial. It was not uncommon for all three types of cracks to form as a result of a UGT. Figure 2-4 shows a representative portion of a composite crack map for Yucca Flat (after Grasso, 2001).

Cracks produced by UGTs commonly formed preferentially along pre-existing zones of weakness, such as faults, joints or lineaments. Cracks also formed preferentially on or along 
man-made or "prepared” surfaces such as roads or on drill pads, and along topographic features such as drainage ways and mesa rims. The type and intensity of test-related surface effects is a result of a complex interaction of factors including yield of the explosion, depth of burial, strength of surface strata, existing geologic structure, the ambient stress field, etc.

Preferential alignment of cracks is often thought to be a manifestation of the presence, movement, and/or differential compaction along some subsurface structure, such as a buried scarp or fault (Allen et al., 1997). Correlation of surface effects with faults is made stronger if there is drill hole evidence (e.g., abrupt variations in the depth to a formation (as may be defined in structure contour maps and detailed cross sections, as shown in Figure 2-2), or actual fault intercepts (based on missing stratigraphic intervals). Several sets of relatively long linear trends of post-test surface cracks that represent the surface traces of buried faults are depicted in Figure 2-4 (e.g., the 7r, 7s, and 7y faults, the Area 3 fault).

\subsubsection{Geophysical Investigations}

Numerous geophysical investigations have been conducted in Yucca Flat since the 1960s and include seismic, resistivity, magnetic, and gravity. The USGS made an analysis of existing gravity data in Yucca Flat using 3-D inversion (Phelps and McKee, 1999 and Phelps et al., 1999; 2000), and collected additional gravity data in FY 2003 in the southern portion of the model area including CP Basin and Massachusetts Mountain (Phelps et al., 2005). An MT survey was also conducted in the Yucca Flat vicinity in 2003 as part of the Phase I data acquisition initiative for Yucca Flat.

Data and results of geophysical investigations conducted in Yucca Flat were reviewed during model construction and, where appropriate, integrated into the hydrostratigraphic framework model. Information from geophysical investigations was integrated with surface geology and drill hole data to develop a structural model of the basin and determine the distribution of hydrostratigraphic units. The geophysical data were also utilized during development of alternative scenarios. Each of the geophysical methods conducted in Yucca Flat and utilized during model construction are discussed below.

\subsubsection{Gravity Data}

Since 1962 geologists have used gravity data from the Yucca Flat area in the effort to define the overall shape of the basin, determine approximate locations of major faults, and estimate the depth to pre-Cenozoic rocks (Healey, 1968; Healey et al., 1987; Ferguson et al., 1988; Phelps and McKee, 1999; Phelps et al., 1999, 2000, 2005). These studies indicated that Yucca Flat is a 
north-south oriented, elongate basin dominated by north-south striking normal faults. The major basin-forming faults dip eastward.

Additional gravity measurements were made in the southwest portion of the model area, including CP Basin and Massachusetts Mountain, by the USGS in 2003 (Phelps et al., 2005). These data showed that the CP Basin is deepest on its eastern side adjacent to the Cane Spring fault, but did not indicate substantial vertical offset along the fault. The new data also indicated that the substantial negative gravity anomaly at Massachusetts Mountain (an area with few controlling data points [Wahl, 1995; Phelps and Graham, 2002]) was not as pronounced when the new data points from this survey were taken into consideration.

The various gravity investigations conducted in and around Yucca Flat provided valuable information for constructing the Yucca Flat-Climax Mine hydrostratigraphic model. The overall shape of the basin observed in the gravity data conforms to the detailed drill hole tags. Gravity data played a more important role in developing a structural model for the eastern extension of the Yucca Flat model. Areas with strong gravity gradients provided information on the approximate locations of major basin-forming faults. Gravity data also provided useful information for estimating the depth to pre-Cenozoic rocks in areas of little or no subsurface control.

\subsubsection{Ground Magnetic Data}

Ground magnetic surveys were conducted during special geologic and geophysical studies of northern Yucca Flat, including the Climax stock area, mainly in support of the WTP. Some of these surveys were used to determine the configuration of the Climax stock (Bath et al., 1983). Others were conducted in support of individual UGTs, for example, to help locate faults in areas with less alluvial cover.

\subsubsection{Aeromagnetic Data}

Numerous aeromagnetic surveys were flown over the Yucca Flat vicinity in support of the WTP (Bath, 1968). The USGS collected additional aeromagnetic data in the southern portion of the model area in 2003 (Phelps et al., 2005). This area included CP Basin, the southern end of Yucca Flat, and the extreme northwest portion of Frenchman Flat.

Aeromagnetic data were the least useful of all the geophysical data utilized to interpret the subsurface geology of the Yucca Flat-Climax Mine area. This is due mostly to the great thickness of alluvium within the basin and the presence of both normally and reversely magnetized units (e.g., the Ammonia Tanks and Rainier Mesa Tuffs) among the volcanic rocks 
of the area. However, a new method of inversion modeling of magnetic data was used to reexamine the shape and depth of the Climax stock (Phelps et al., 2004) in northern Yucca Flat. The shape hypothesized as a result of this process forms the basis for the Climax intrusion in the Yucca Flat hydrostratigraphic framework model.

\subsubsection{Natural Source Magnetotelluric Survey}

An MT survey was conducted in the Yucca Flat vicinity in 2003 to better characterize preTertiary stratigraphy and structure beneath Yucca Flat, particularly the 3-D distribution of Mississippian siliciclastic rocks that form the upper clastic confining unit (UCCU). The survey was conducted by personnel from the USGS, and consisted of 51 stations spaced approximately 2 to $3 \mathrm{~km}$ (1.2 to $1.9 \mathrm{mi}$ ) apart along 7 generally east-west oriented lines across the basin (Figure 2-5). Data were collected with both high and low frequency MT systems (Asch et.al., 2005). USGS personnel processed the MT data and provided two-dimensional (2-D) inverted resistivity model profiles along each line to $\mathrm{BN}$ geologists for interpretation and integration into the Yucca Flat hydrostratigraphic framework model (Rodriguez 2004a). USGS personnel also performed 2-D forward modeling of the data to address questions presented by BN geologists (Rodriguez, 2004b). Forward modeling mostly involved determining the maximum and minimum possible thickness and maximum eastward extent of the UCCU. The interpreted profiles are provided in Appendix D of this report.

The MT method proved very successful in providing important constraints on the general thickness and lateral extent of the UCCU beneath Yucca Flat. The data indicate that the UCCU is confined to the western portions of the basin, and thus is not present beneath the central and eastern portions of Yucca Flat. The data also indicate that the UCCU has a maximum thickness of between 2,000 and 3,000 $\mathrm{m}$ (6,600 and 9,800 ft) beneath the western portion of the basin.

\subsubsection{Other Resistivity Surveys}

Electrical resistivity surveys were conducted around the Yucca Lake playa in 1979 (Zohdy and Bisdorf, 1979). Information from these early resistivity surveys was used during model construction to help determine the thickness of the Yucca Flat playa deposit and the depth to the underlying volcanic units in the vicinity of the Yucca playa. Data from the resistivity surveys indicate that the depth to higher resistivity units such as welded volcanic rocks and Paleozoic sedimentary rocks is more than $328 \mathrm{~m}(1,000 \mathrm{ft})$ which, with respect to the Paleozoic rocks, is consistent with gravity data (Phelps et al., 2005). The data also indicate that the playa deposits are greater than $183 \mathrm{~m} \mathrm{(600} \mathrm{ft)} \mathrm{thick,} \mathrm{which} \mathrm{is} \mathrm{consistent} \mathrm{with} \mathrm{nearby} \mathrm{drill} \mathrm{hole} \mathrm{data.}$ 


\subsubsection{Seismic Half-Refraction Surveys}

Half-refraction surveys were conducted in Yucca Flat for the WTP in an attempt to map the preTertiary surface near select UGT locations (e.g., U-7bh). In a half-refraction survey a drill hole that penetrated the contact between Tertiary and Paleozoic rocks was instrumented with a geophone package set near the top of the Paleozoic section. The seismic sources were located at the ground surface and various offset distances from the borehole. The associated travel times were recorded but only the head wave (refracted ray) was used to map the Paleozoic rocks (highvelocity layer). Modeling techniques applied to the survey data showed that the half-refraction method was successful for mapping the Paleozoic surface in the vicinity (App, 1981).

\subsubsection{2-D Seismic Reflection Surveys}

Two-dimensional seismic reflection data have been acquired along approximately $225 \mathrm{~km}$ (140 mi) of lines in Yucca Flat. Most of these data were acquired between 1970 and 1985 in support of the WTP at the NTS (App, 1981; Burkhard, 1981; Burkhard and McArthur, 1985). Seismic reflection surveys in Yucca Flat were successfully used to image the general geology above the pre-Tertiary surface, including the contact between the alluvium and underlying volcanic rocks, the distribution of welded volcanic rocks, and the major faults that offset these units. Due to a variety of geologic and geophysical factors seismic reflection method has been mostly unsuccessful imaging pre-Tertiary stratigraphy and structure beneath the basin (Burkhard, 1981).

Although of limited success, information from seismic reflection surveys in Yucca Flat forms a component of the geologic knowledge base for Yucca Flat that was incorporated into the framework model.

\subsubsection{Studies at Climax Stock}

The following paragraphs present a history of investigations by USGS personnel at Climax stock, toward determining the size and shape of the intrusive body.

The Climax stock was investigated using potential field methods by Healey (1983) and Bath et al. (1983). Healey (1983) used the gravitational anomaly to model the shape of the stock. Unfortunately, the Climax stock has a density similar to the surrounding pre-Tertiary rocks it intrudes, and so cannot be distinguished from these rocks. Therefore the entire shape of the stock cannot be modeled using gravity data. The rocks separating the Climax stock from the rocks filling Yucca Flat basin southeast of the stock, however, are different in density. Therefore, an estimate of the depth to the Climax stock in the vicinity of Well ER-8-1 can be made using gravity data. While the report by Healey (1983) does not specifically address this 
question, depths obtained from cross-sections published in the report indicate the predicted depth would be roughly $250 \mathrm{~m}(829 \mathrm{ft})$.

Bath et al. (1983) modeled the shape of the Climax stock using the magnetic properties of the stock. The Climax stock is strongly magnetic, unlike the rocks surrounding it, and this property is used to characterize its shape. Bath et al. (1983) developed a modified 5-prism model of the Climax stock based on data they collected for the study. The 5-prism model assumes an increasing magnetization with depth. The shapes of the prisms are simple polygons with vertical sides, with each of the deeper prisms larger than the previous, shallower prism. The two deepest prisms have depths of 694 and 2,379 $\mathrm{m}$ (2,277 and 7,805 ft). Well ER-8-1 is situated at the edge of these two prisms, so the estimated depth of the Climax stock is between 694 and 2,379 m $(2,277$ and $7,805 \mathrm{ft})$.

Subsequent modeling by Phelps et al. (2004) uses more recently compiled magnetic data (McCafferty and Grauch, 1997) to model the Climax stock based on its magnetic properties, using a new inversion technique derived from the pseudo-gravity anomaly (Baranov, 1957). Two models were generated, one that modeled the stock as a single body and used an average value for its magnetic properties, and a second that modeled the stock as a two-layer body with variable magnetic properties. The second model used existing magnetic data and new physical property and lithologic data collected at Well ER-8-1 to improve the characterization of the magnetization within the stock. A two-layer model was generated based on a conceptual model of the spatial structure of the magnetic mineralogy of the stock. Neither model was able to match the intercept in Well ER-8-1: the first model predicted the depth to be 1,100 m (3,609 ft) and the second predicted the depth to be $1,350 \mathrm{~m}(4,429 \mathrm{ft})$. While the magnetic data collected from Well ER-8-1 improved the understanding of the magnetic character of the stock, the modeling of the Climax stock based upon its magnetization was not accurate enough to successfully predict the location of the stock at depth. The data at Well ER-8-1 were essential for providing a data point with which to pin the model in the subsurface.

\subsubsection{Alluvium Studies}

The alluvial deposits that fill the Yucca Flat basin form an important HSU because the deposits are fairly thick, and many of the UGTs in Yucca Flat were conducted within the alluvium. Though generally unsaturated, the alluvium is saturated in the deeper sub-basins, particularly in south-central Yucca Flat. Extensive studies of the alluvium in Yucca Flat have been conducted on behalf of several NTS programs, including the WTP and the Area 3 RWMS. A detailed study of the layering and mineral distributions for the alluvium in northern Frenchman Flat (Warren et al., 2002) was reviewed for this Yucca Flat modeling effort. Information from 
Warren et al. (2002) was considered prior to subdividing the alluvium in Yucca Flat and in developing the "Partial Zeolitization" alternative discussed in Section 5.2.5 of this report. Information from these sources, described below, along with the extensive drill hole and sample database, was incorporated into the Yucca Flat framework model.

\subsubsection{Carbonate Content}

An underground nuclear explosion produces noncondensable carbon dioxide gas from naturally occurring carbonate material (e.g., limestone and dolomite detritus, and secondary calcite cement) in the alluvium. Generation of carbon dioxide in UGTs was linked to a significant percentage of containment failures, so the carbonate content of the alluvium was one of the concerns for site characterization for a UGT. The alluvium in southern Yucca Flat was characterized by Rayburn et al. (1989), and the alluvium in northern Yucca Flat was characterized by Wagoner and McKague (1984).

\subsubsection{U-1a Complex}

The U-1a complex, located in south-central Yucca Flat, comprises two vertical shafts, several large-diameter cable access holes, and several kilometers of horizontal drifts mined within alluvium, $292.6 \mathrm{~m}$ (960 ft) below the surface. Geologic mapping and related work at the U-1a Complex afford a unique opportunity to observe and evaluate the characteristics of alluvium in the subsurface of Yucca Flat, and to compare the results with alluvium data from surface and drill hole studies. The U-1a efforts are well documented in Allen (1995) and Drellack et al. (1989).

\subsubsection{Other Studies}

The surficial alluvial deposits have been studied, mapped and correlated by USGS personnel and are documented by Hoover, et al. (1981) and Fernald et al. (1968). The shallow sediments have been well characterized for the Area 3 RWMS and documented in several reports including BN (1998, 1999, 2005b) and Levitt and Yucel (2002).

\subsubsection{Mineralogic Studies of Volcanic Rocks}

Hydrologic source-term modeling has shown that radionuclide transport is highly sensitive to the abundance and availability of certain reactive minerals (Pawloski et al., 2000; Tompson et al., 1999; Zavarin et al., 2004). Although a thorough mineralogic assessment of the rocks in the Yucca Flat model area was beyond the scope of this modeling effort, mineralogic characteristics did factor into the process of defining HSUs. As described in more detail in Section 4.1, the altered volcanic rocks tend to be confining units and unaltered volcanic rocks tend to be aquifers. The final mineralogy of the formations can be further modified by devitrification of the original 
glass, and various minerals can be deposited by groundwater solutions in the matrix or in fractures.

The lowermost volcanic units in the Yucca Flat area tend to be zeolitic and are classified hydrologically as a tuff confining unit (see Section 4.1 for a discussion about hydrogeologic units). The basal TCU in Yucca Flat was subdivided into three mineralogic zones HSUs based on relative abundances of major mineral assemblages by Prothro (2005a), as summarized in Section 2.3.10.1.

New and existing mineralogic data for NTS rocks were assembled for a variety of UGTA tasks, including for the Yucca Flat CAU, specifically. The application of this mineralogic dataset to the construction of the Yucca Flat hydrostratigraphic model and to subsequent endeavors to create frameworks based on reactive mineral content are briefly discussed in Section 2.3.10.2.

\subsubsection{Tuff Confining Unit Study}

Altered volcanic rocks that form the TCU hydrogeologic unit beneath Yucca Flat consist mainly of 3 major mineral assemblages: zeolite, felsic minerals, and clay minerals (Prothro, 2005a). Based on these 3 mineral assemblages, the TCU can be subdivided into 3 zones representing differences in the abundance of these mineral assemblages. This 3-layer model includes:

- An upper zone which comprises both the upper and lower tuff confining units (UTCU and LTCU; see Sections 4.5.5 and 4.5.12), HSUs that are characterized by the abundance of the zeolite mineral clinoptilolite with lesser amounts of felsic and clay minerals

- A middle zone which correlates to the Oak Spring Butte confining unit (OSBCU; Section 4.5.13), an HSU with felsic minerals dominant over clinoptilolite and clay minerals

- A basal argillic zone which correlates to the argillic tuff confining unit (ATCU; Section 4.5.14), with clay minerals dominant over felsic minerals and clinoptilolite

Mineralogic data (x-ray diffraction) from 17 holes, along with lithologic, stratigraphic, and geophysical log data from approximately 500 drill holes, were interpreted to develop a 3-layer mineralogic model for the TCU, which shows that all 3 zones are extensive beneath the eastern half of Yucca Flat within the Yucca Flat basin proper. Only the basal argillic zone occurs beneath western Yucca Flat within the western sub-basin. All 3 zones appear to be absent along the buried ridge that separates Yucca Flat basin proper from the western sub-basin. The LTCU is, on average, the thickest of the 3 zones, averaging $213 \mathrm{~m}(700 \mathrm{ft})$, followed by the OSBCU at $126 \mathrm{~m}$ (413 ft), and finally the ATCU at $27 \mathrm{~m}$ (89 ft). 
The identification of the type, quantity, and distribution of alteration minerals within each TCU layer will permit modelers to better predict the spatial distribution and extent of contaminant transport from UGTs in Yucca Flat, at the scale of both the hydrologic source term and the CAU.

\subsubsection{Reactive Mineral Characterization of Volcanic and Sedimentary Rocks}

Zeolitic and argillic alteration is commonly observed in the volcanic rocks at the NTS. Zeolitic alteration generally results in the formation of clinoptilolite, with lesser amounts of other zeolite minerals such as analcime and mordenite. Argillic alteration commonly is characterized by the presence of the clays smectite and illite. In addition to decreasing the hydraulic conductivity of the rock, these secondary alteration minerals are reactive with respect to radionuclide transport. Clinoptilolite and smectite, for example, have a strong sorptive affinity for certain radionuclides (Zavarin et al., 2004). The confining unit HSUs in the Yucca Flat model (e.g., the UTCU and LTCU) contain a significant amount of zeolite minerals (typically more than 30 percent). The ATCU contains a significant percentage of clays (generally more than 30 percent). In addition to the zeolite and clay minerals mentioned above, the list of reactive minerals for radionuclide transport includes iron oxides (hematite), certain mafic minerals such as biotite, and calcite. These reactive minerals are found in the rock matrix, in lithic fragments, as phenocrysts, or in the fracture fill/coatings.

After relating these reactive minerals to geologic processes relevant to the rocks at the NTS, several natural categories emerge. The reactive mineral categories (RMCs) for NTS volcanic rocks are vitric mafic-poor (VMP), vitric mafic-rich (VMR), devitrified mafic-poor (DMP), devitrified mafic-rich (DMR), zeolitic (ZEOL), and argillic (ARG). The RMCs for Paleozoic sedimentary rocks are calcic (CC) for the carbonate rocks and silicic (SC) for the siliciclastic rocks. In general, the volcanic confining units relate to the ZEOL RMC, the welded-tuff aquifers relate to the DMR or DMP, the vitric-tuff aquifers relate to VMR or VMP, and the argillic tuff confining unit relates to the ARG RMC. The carbonate aquifers relate to the CC and the siliciclastic confining units relate to the SC if mostly quartzite or the ARG if mostly shale.

The contaminant-transport modeling team may build upon the Yucca Flat-Climax Mine hydrostratigraphic framework model, incorporating RMC information to establish an initial geometry for the distribution of reactive minerals. These derivative reactive-mineral models will, in turn, better constrain contaminant transport models of the Yucca Flat CAU.

\subsubsection{Fracture Studies}

Numerous fracture studies have been conducted at the NTS, including studies specific to Yucca Flat. Winograd and Thordarson (1975) describe fractures and their role in groundwater flow in 
the NTS region, including fracture characteristics of hydrogeologic units. Studies specific to Yucca Flat include fracture studies for the UGTA project based on borehole image logs (SNJV, 2005) and conventional core holes (Prothro, 1998). These studies emphasized hydrologic properties of fractures. Other UGTA fracture studies include a detailed study of fractures in volcanic rocks beneath Pahute Mesa (Drellack et al., 1997). Fracture data from these and other studies in the NTS region are compiled in SNJV (2004). Hydrogeologic designations in the Yucca Flat-Climax Mine framework model are based to a large degree on the fracture characteristics described in these reports.

\subsection{Pre-emptive Review}

Before the Yucca Flat-Climax Mine hydrostratigraphic model was constructed, the UGTA TWG initiated a pre-emptive review process. The purpose of this review was to provide a forum for the TWG to evaluate the model and the model-building process at various stages during construction of the Phase I model. The pre-emptive review subcommittee consisted of scientists from BN, LANL, LLNL, SNJV, and the USGS. Pre-emptive reviews for the Yucca Flat model were conducted on June 16, 2004; December 14, 2004; and May 3, 2005. The subcommittee assessed the data sets, the current status of the model, alternative interpretations, and the path forward from both technical and programmatic perspectives. Comments and suggestions from the subcommittee members were addressed as appropriate. Many of the subcommittee’s findings are discussed in Section 5.0, Alternative Scenarios.

\subsection{Model Construction}

Prior to the actual digital construction of the 3-D framework model, 2 important tasks had to be completed. First, a structural model of the area was developed that included the locations and orientations of all the relevant faults in the model area. Fault information was imported into EarthVision $^{\circledR}$, a 3-D computer modeling program, to form a fault-tree model that depicts all the model faults in 3-D space. The fault-tree model formed the framework on which the hydrostratigraphic model was built. A detailed discussion of the structural model is provided in Section 3.0 of this report.

Although the framework of Yucca Flat hydrostratigraphic model is the fault-tree, the foundation of the model is the hydrostratigraphic classification system. The second important step was to develop a hydrostratigraphic system through a rigorous analysis of stratigraphic and lithologic data in and around Yucca Flat. The Yucca Flat hydrostratigraphic system consists of 25 HSUs that form volumes in the model. A detailed description of the hydrostratigraphic classification system developed for the Yucca Flat model is provided in Section 4.0 of this report. 
Alternative models created to explore the effects of other possible geologic interpretations in some areas of the model with non-unique solutions are discussed in Section 5.0 of this report.

\subsubsection{Use of Computer Software to Construct the Model}

Computer software designed to handle large data sets and numerous interpretive products is used to present the hydrostratigraphic framework for the use of the flow-and-transport modelers. The size of the study area, the large amount of data to be manipulated, and the complexity of the geologic setting of the NTS and vicinity demand sophisticated algorithms for production of realistic interpretations. As the field of computer modeling rapidly grows, new software becomes available which improves the efficiency and the results of the modeling process. Thus, though the UGTA hydrostratigraphic modeling efforts for Yucca Flat were initiated in 1998 using ERMA ${ }^{\circledR}$ software, the data were migrated in 2002 to EarthVision ${ }^{\circledR}$, an improved system, for continuation of the modeling process. See Gonzales et al. (1998) and IT (1996a) for descriptions of modeling done with ERMA ${ }^{\circledR}$ software.

EarthVision ${ }^{\circledR}$ software (Version 7.5, by Dynamic Graphics) accepts spatially located data such as the elevation of the tops of stratigraphic units in boreholes, outcrop traces, locations and orientations of faults, and other data such as seismic profiles or other geophysically derived surfaces. The software then applies geology-based geometric "rules" to determine the most likely 3-D interpretation of the geology in the model area that honors the input data. After the data and interpretive products are input, the computer's interpretation can be adjusted to suit the geologist's concept, to incorporate additional information, or to test alternate hypotheses. It is possible to easily and thoroughly evaluate a geologic model built in EarthVision ${ }^{\circledR}$ and examine relationships of the individual elements. Because the interpretive rules are geology-based, the model automatically satisfies many fundamental geometric requirements for geologic structure, so the geologist spends less time checking and adjusting interpretations than with the previously used modeling software. EarthVision ${ }^{\circledR}$ can be used to produce maps and profiles that illustrate the structure and distribution of HSUs for any portion of the model.

The final expanded hydrostratigraphic model will be provided in digital form to the UGTA flowand-transport modelers who will use this framework to model groundwater flow and contaminant movement within the Yucca Flat-Climax Mine area. The figures (plates, maps, and profiles) included with this documentation report are intended to provide only general illustrations of the physical framework, structure, and distributions of the HSUs to aid the reader. The flow-and-transport modelers will receive the complete digital, 3-D model (Figure 2-1). 


\subsubsection{Model Input}

As mentioned previously, the draft Yucca Flat models (Yucca Flat proper and northern extension) were used as the initial starting point for the Phase I model. Details regarding the construction of the draft models were reported in Gonzales et al., (1998) and Gonzales and Drellack, (1999). Input to the model consisted of interpretive products produced in support of the UGTA Regional Geologic Model Data Documentation Package (IT, 1996c) and "hard" data (DEM, drill-hole data, surface geologic maps, etc.). Soft data, such as interpretations of the top of the pre-Tertiary surfaces from inversion of gravity-data (see Subsection 2.3.7.1), were input to use as guides. After the initial 3-D framework model was created (Gonzales et al., 1998) this preliminary model was checked and modified as necessary in an iterative fashion by the authors.

Interpretive products produced to serve as input to the model include a drill hole database of HSUs (Appendix A); surface (i.e., outcrop; Plate 1) HSU maps derived from USGS geologic quadrangle maps (Table 2-1); unit extent maps for each HSU (see Figure 4-3 for an example); hydrostratigraphic cross sections; and traces of surface faults. The fault traces and unit extent and outcrop maps were digitized by personnel of HSI/GeoTrans, IT, and Shaw. These new interim interpretive products were developed by $\mathrm{BN}$ geologists from a variety of sources (see Section 2.3).

\subsubsection{Quality Control and Model Review}

The Phase I model was checked and modified as necessary by the SNJV and BN team members during model construction. This was an iterative process utilizing the capabilities of EarthVision ${ }^{\circledR}$ to cut profiles anywhere through the model. The geologists then interactively viewed individual or groups of HSUs in 3-D, and visually compared various data sets such as drill hole tops and surface-grid points with HSU layers in the model. Traditional 2-D products such as structure contour maps and thickness maps were also produced from the model, and these were used to further evaluate the model. Modifications were made to address geometric conflicts, assure that geologic conventions were honored, assure conformation to drill hole, outcrop, and geophysical data, and incorporate geologic interpretations in areas of limited data. The various versions of the model produced during this process are electronically archived at the offices of SNJV in Las Vegas, Nevada. The final Yucca Flat-Climax Mine "base” model, including five alterative scenarios and electronic data sets, resides on workstations and electronic archival media at the offices of SNJV in Las Vegas, Nevada.

Several quality control processes were performed to ensure that model surfaces honor available data. These included a total-depth check, a horizon-grid back-interpolation, and a fault-pick back-interpolation. These assessments indicated that the computer-generated HSU surfaces tie 
well with the drill hole data (Figure 2-6), with associated errors typically less than $5 \mathrm{~m}$ (16.4 ft).

Figure 2-7 is an example of a histogram showing the difference between the EarthVision ${ }^{\circledR}$ model surface and the drill-hole data input for the Timber Mountain lower vitric-tuff aquifer. In this case, the interpolation algorithm honors the drill hole data to within a few meters. Error associated with outcrop data is greater due to the complexity of the topographic surface, but is still considered to be relatively small.

Quality control for the alternative models followed the same process as used for the base model. Additionally, the alternative models were compared against the base model and differences were mapped. This process ensured that the changes associated with the alternative models are restricted to appropriate areas.

Review of the model and alternatives was conducted within the UGTA pre-emptive review process as described in Section 2.4.

\subsubsection{Alternative Models}

As briefly summarized in Section 1.4.4 and discussed in more detail in Sections 3.0 and 4.0, the Yucca Flat-Climax Mine model area is geologically very complex. Many of the major features within the valley are buried, and subsurface data are scarce in some areas. Portions of the model are thus necessarily simplified, and represent non-unique solutions to the 3-D distribution of HSUs.

To address non-unique aspects of different interpretations within the base model, alternative interpretations were developed for portions of the base model. Ideas for alternative scenarios were conceived and evaluated during construction of the base model. The alternative models were constructed after the base model was completed, generally using the same model construction techniques. Each alternative model is equally bound by all the data and interpretation methods used for development of the base model. However, each alternative scenario is of limited geographic extent, and thus affects only a portion of the base model. The alternatives are fully functional replicas of the base model that can be used to test whether the alternative interpretations affect flow and transport.

The TWG pre-emptive review subcommittee also participated in the development of alternative scenarios. This working group was also tasked with defining what constitutes an alternative scenario, compiling a list of alternatives, establishing criteria and guidelines for prioritizing the scenarios, and grouping and prioritizing the viable scenarios. Three types of hydrogeologic scenarios were developed: recommended changes to the base model; viable alternative 
scenarios, to be modeled separately; and proposed alternatives that might be better addressed during the hydrologic modeling phase, rather than in the hydrostratigraphic framework model. The pre-emptive review subcommittee also served as peer reviewers of the draft model presented to them for development of alternative scenarios, as some of their suggestions were incorporated directly into the base model.

An electronic copy of the base model was used in developing each alternative, and only those areas of the base model affected by the alternative interpretation were modified to produce the alternative model. Ultimately, five scenarios were selected for further development as alternative models, and one scenario was identified that might be better addressed later during hydrologic modeling. The UGTA pre-emptive review subcommittee participated in the development of alterative interpretations by reviewing the interpretations throughout the model construction process, including the final alternative interpretations. The process for addressing alternative interpretations is described in more detail, along with the interpretations themselves, in Section 5.0. 
This page intentionally left blank. 


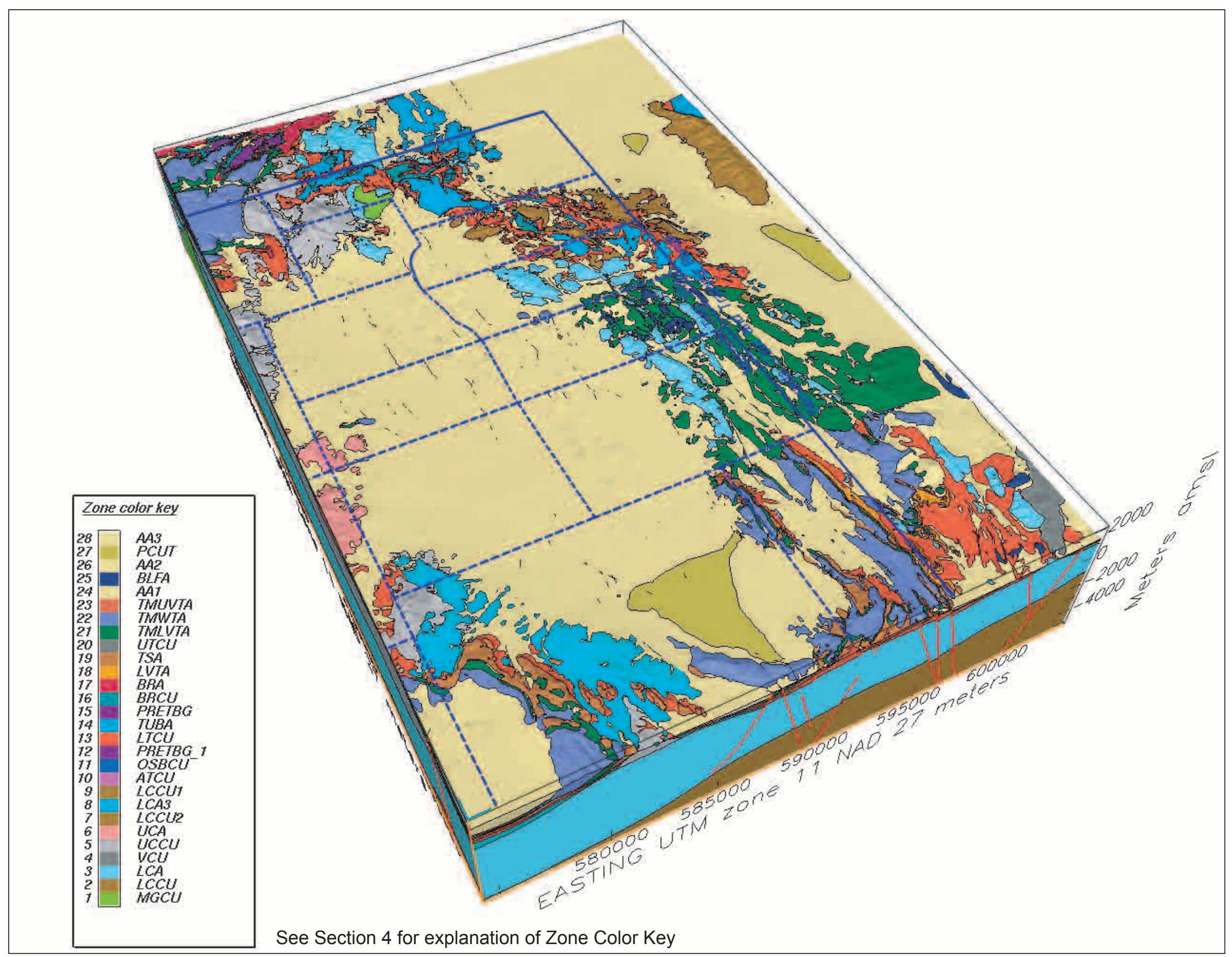

Figure 2-1

3-D Display from EarthVision of the Yucca Flat-Climax Mine Model Volume 


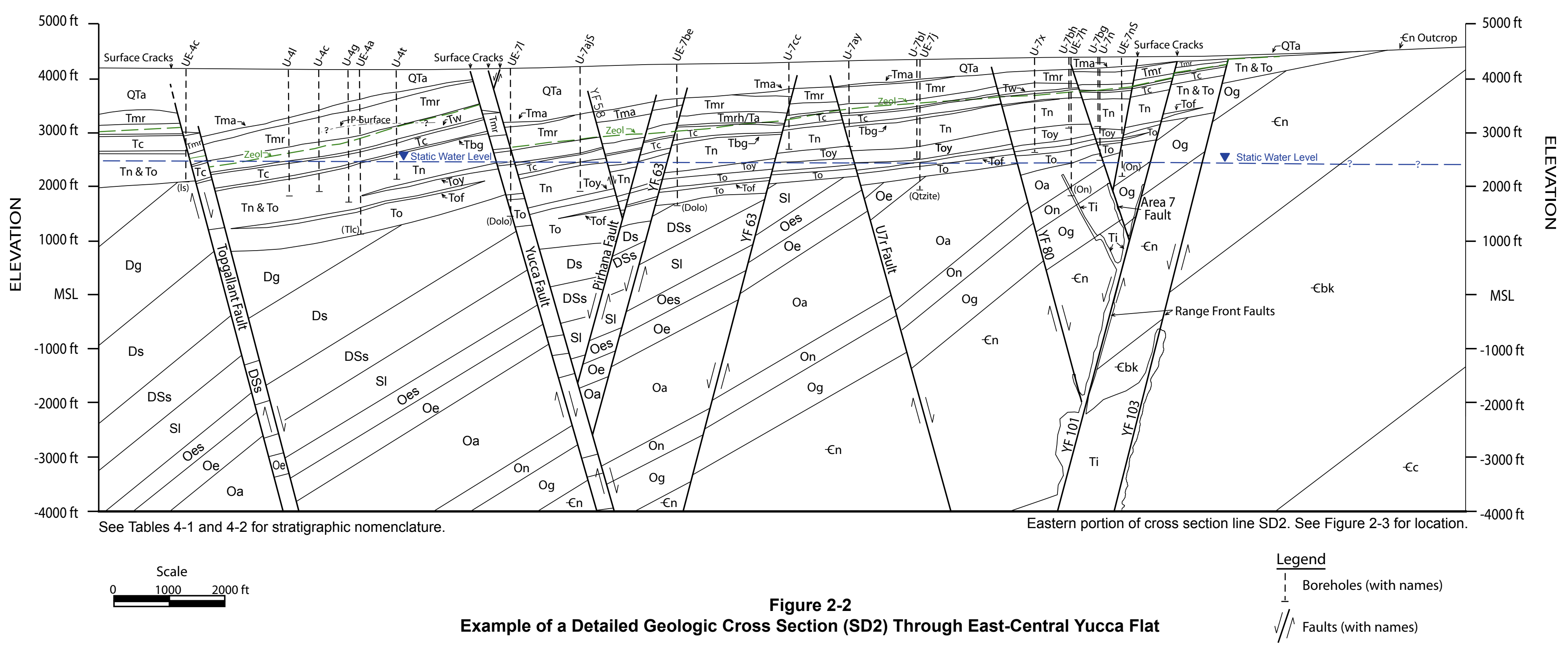




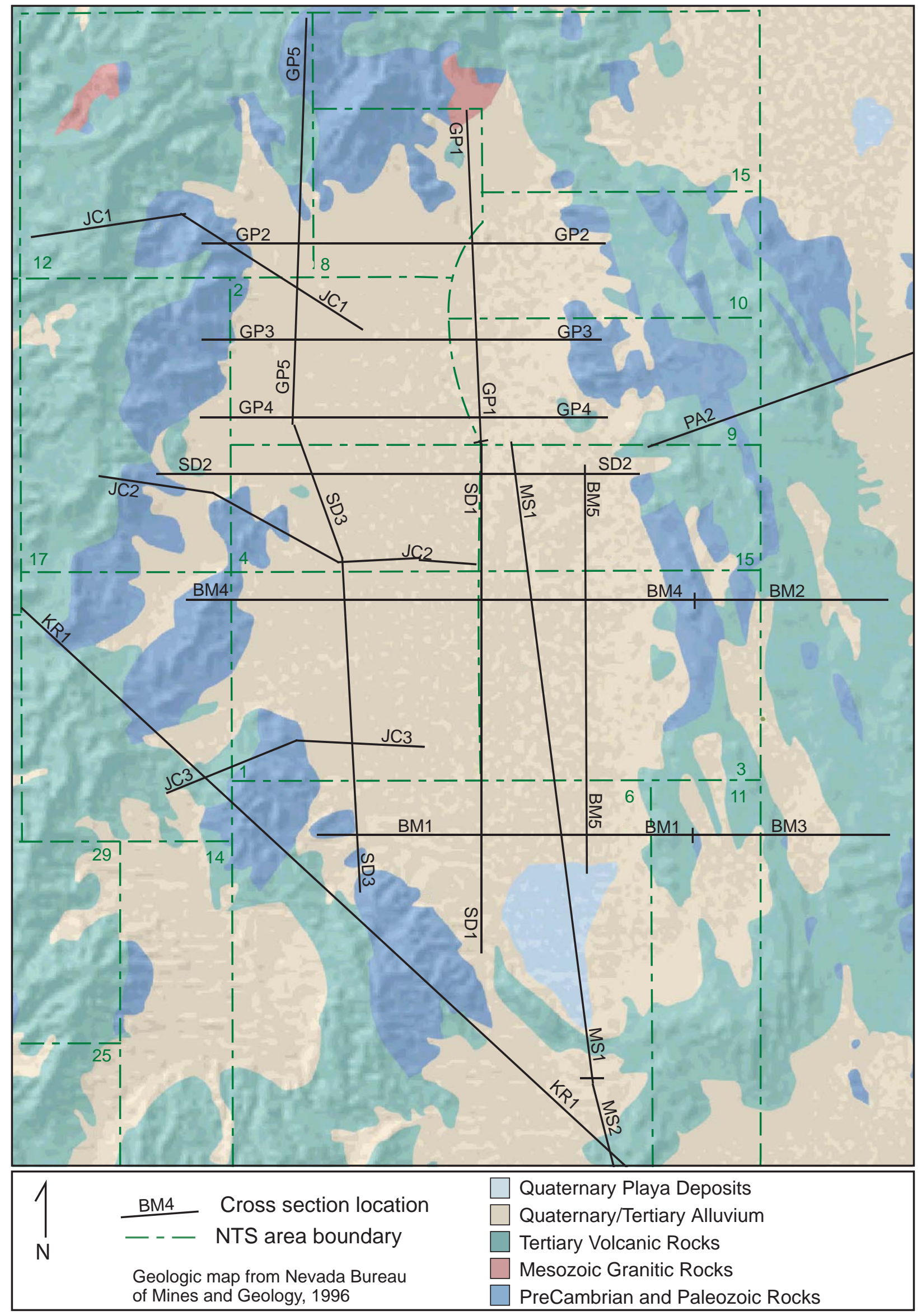

Figure 2-3

Locations of Detailed Cross Sections Constructed for the UGTA Yucca Flat-Climax Mine Model 


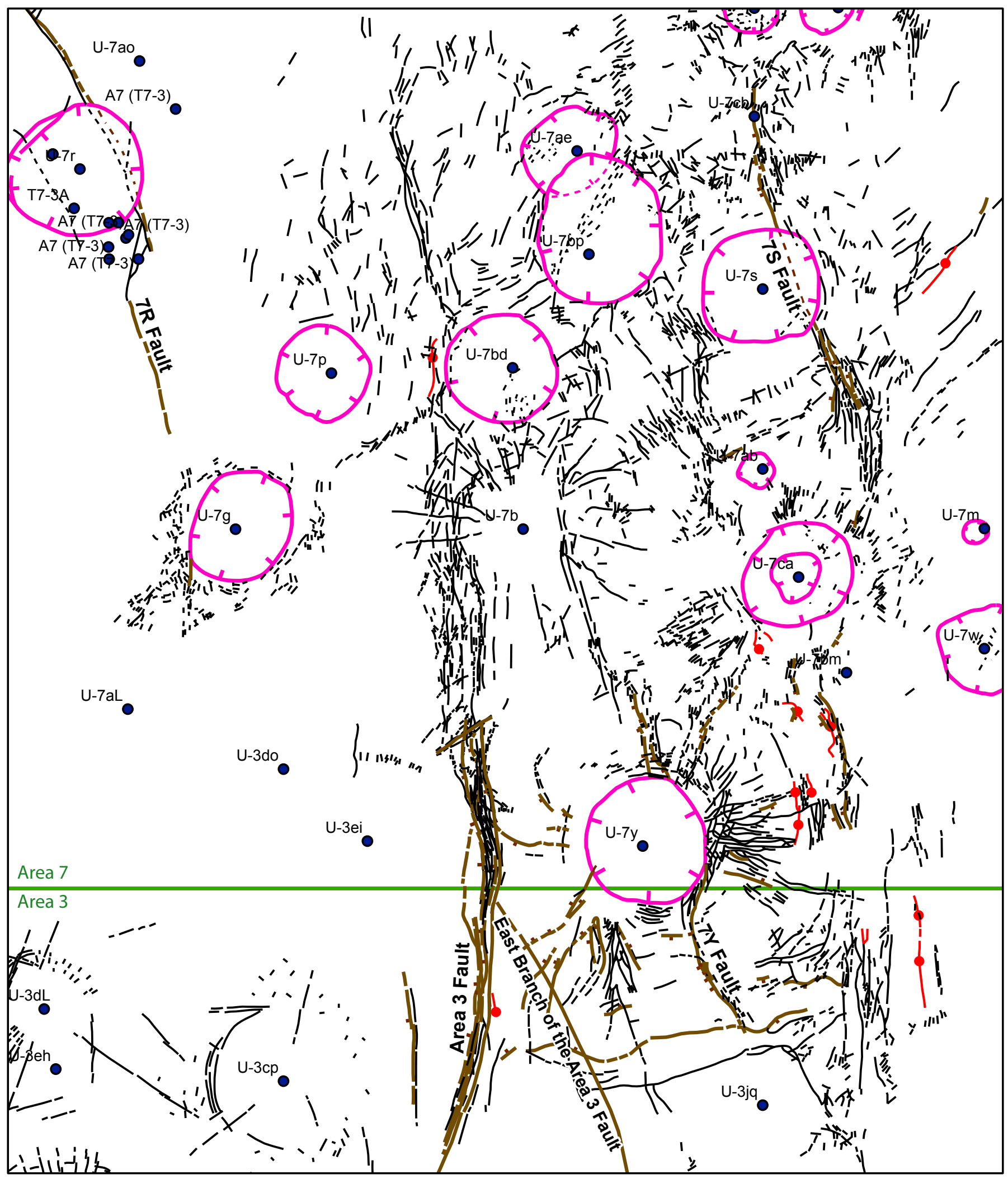

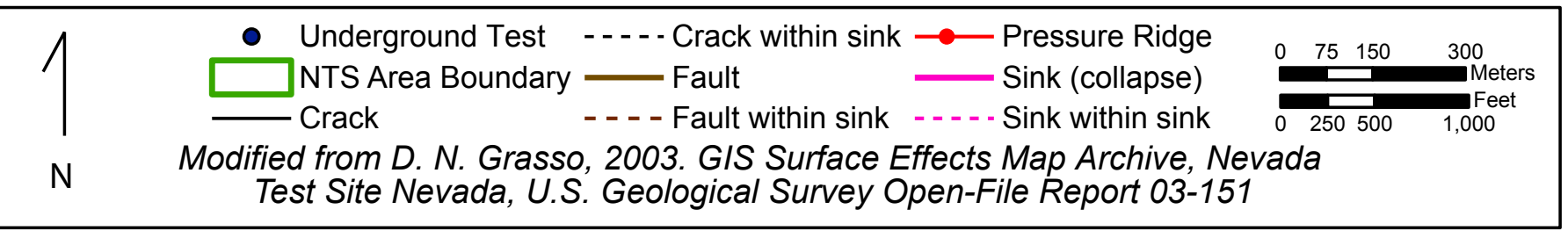




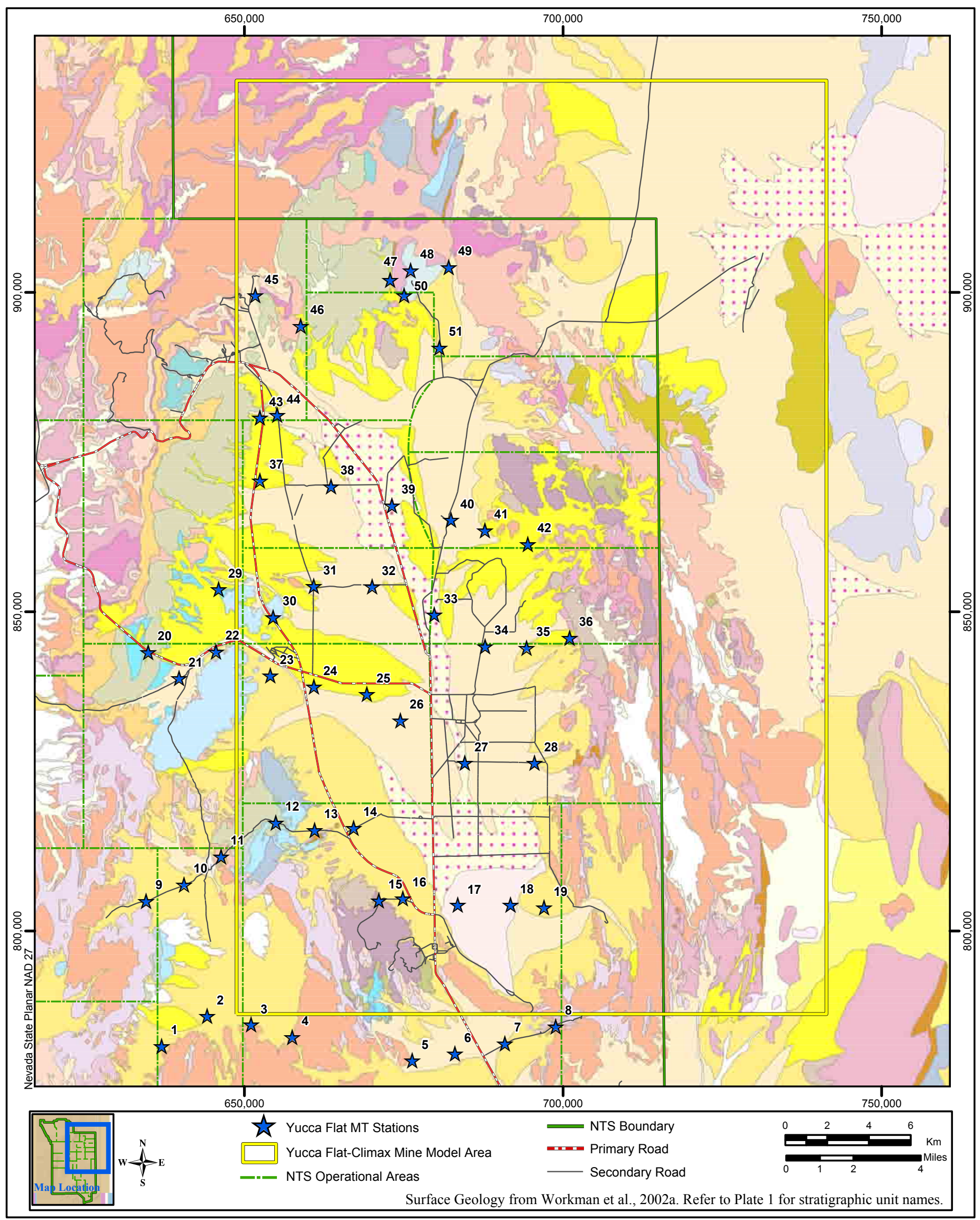

Figure 2-5

Magnetotelluric (MT) Stations in the Yucca Flat-Climax Mine Model Area 
YUCCA FLAT HSU MODEL CALCULATED VALUES VS WELL PICK DATA

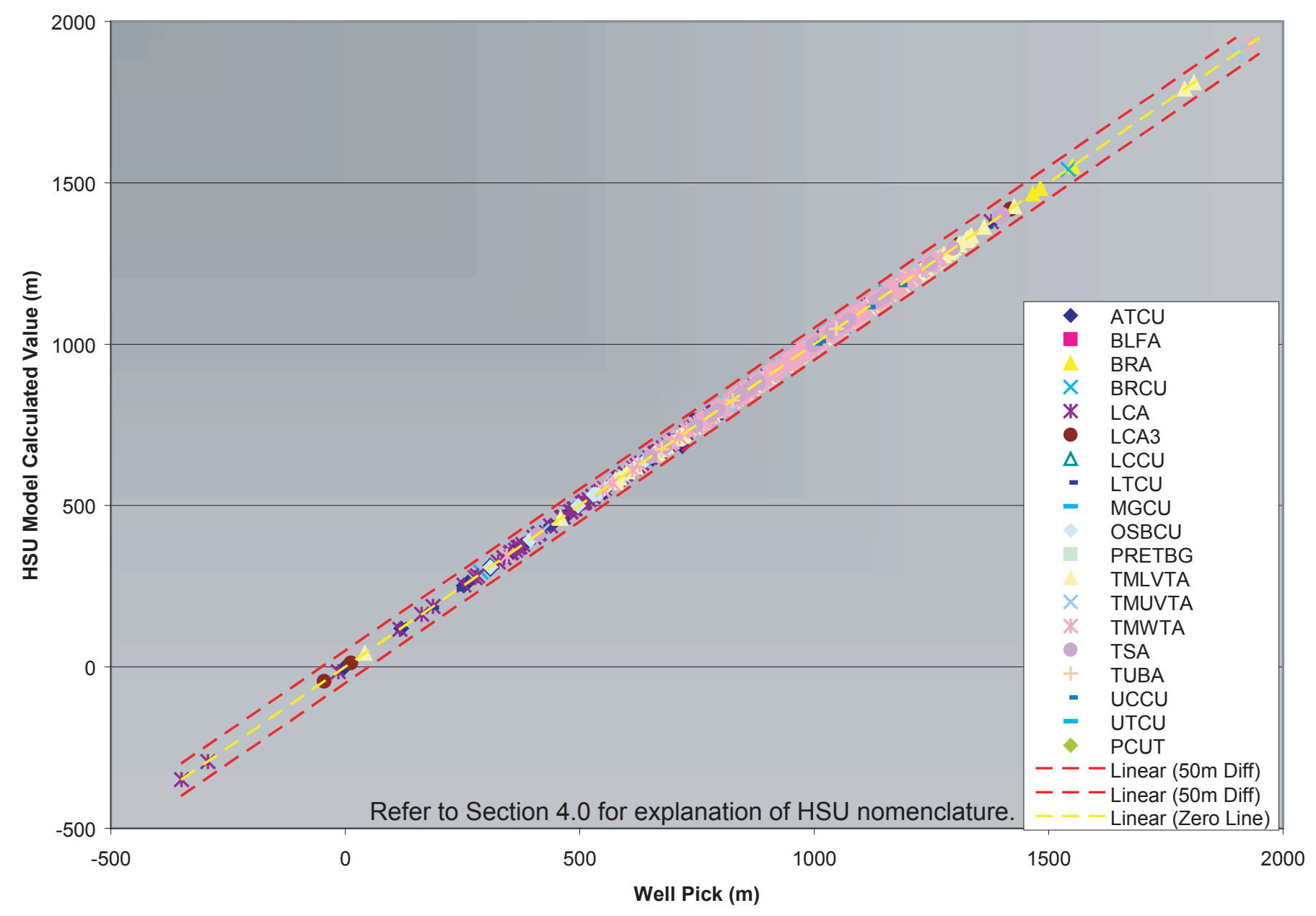

Figure 2-6

Comparison of Caculated Predicted Elevation from the Yucca

Flat-Climax Mine Model versus Well-Pick Data 


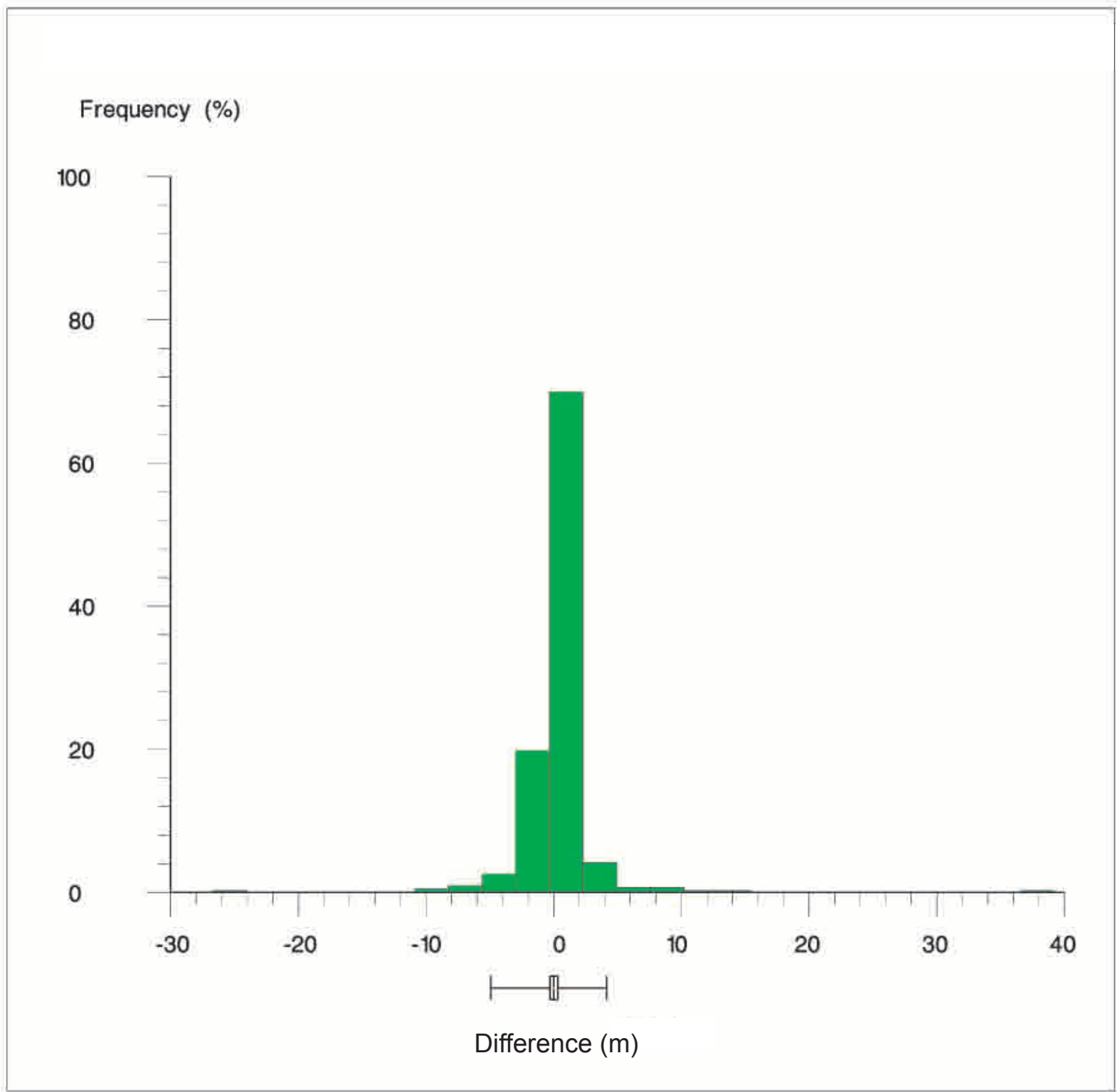

Figure 2-7

Histogram of Differences in Elevation Between the Yucca Flat-Climax Mine Model and Well-Pick Data for the Timber Mountain Lower Vitric-Tuff Aquifer 


\subsection{STRUCTURAL MODEL}

Structures define the geometric configuration of the Yucca Flat-Climax Mine model area, including the distribution, thickness, and orientation of units, and thus are an important part of the hydrogeologic regime of the area. Basin-forming structures had a strong influence on depositional patterns of alluvial deposits and the extent, thickness, and structural elevation of volcanic deposits. Some faults place units with different hydrologic properties in juxtaposition, which may have significant hydrogeologic consequences. Also, the structures may themselves act as either conduits of groundwater flow, if characterized by open fractures, or barriers to flow, if associated with fine-grained gouge or increased alteration of nearby rocks. This section describes the structural elements of the model area, and includes discussions of how they were identified and spatially defined for the model.

\subsection{Structural Overview}

The interpretation of the structural geology in the Yucca Flat vicinity is difficult because complex pre-Tertiary contractional deformation was overprinted by more recent extensional deformation. In addition, most of the major structural features are buried by thick deposits of volcanic rocks and alluvium. Fortunately, a large and robust data set is available for Yucca Flat that includes surface geologic exposures, drill hole data, and a variety of geophysical data. Recently acquired data from deep drilling and geophysical surveys proved valuable in better constraining the structural model of the basin.

\subsubsection{Pre-Tertiary Structure}

Pre-Tertiary structural features in the Yucca Flat vicinity are mainly the result of east-westdirected contractional deformation related to the Cordilleran Orogeny (Barnes et al., 1968; Caskey, 1991; Cole and Cashman, 1999). Exposures of pre-Tertiary rocks in the highlands surrounding Yucca Flat, particularly along the western margin of the basin in the CP Hills, Mine Mountain, Syncline Ridge, Eleana Range, and Quartzite Ridge, show complex contractional deformation in the form of both east- and west-vergent thrusting and associated over-folding (Figure 3-1). Exposures of pre-Tertiary rocks east of Yucca Flat show considerably less intense contractional deformation than do pre-Tertiary exposures to the west.

East-vergent contractional deformation in the Yucca Flat area is the result of movements along the Belted Range thrust fault and associated foreland imbricate faults (Gibbons et al., 1963; Barnes et al., 1968; Cole and Cashman, 1999) (Figure 3-1). Although the trace of the Belted Range thrust fault is not exposed, the location of the fault is fairly well constrained northwest of Yucca Flat by exposed stratigraphic relationships and data from deep drill holes in the vicinity of 
Gold Meadows and Rainier Mesa, where the fault places Proterozoic to Cambrian siliciclastic rocks over Devonian carbonate and Mississippian siliciclastic rocks (Gibbons et al., 1963). Foreland imbricate faults associated with the Belted Range thrust fault are exposed in the Eleana Range and Mine Mountain (Gibbons et al., 1963; Orkild, 1963; Orkild, 1968; Cole and Cashman, 1999) and have been penetrated in UGTA Well ER-12-1 (Russell et al., 1996). These imbricate faults form a complex series of stacked thrust slices involving mostly Devonian carbonate and Mississippian siliciclastic rocks within the footwall of the Belted Range thrust fault.

West-vergent contractional deformation is observed near the south end of Yucca Flat in the CP Hills as well as at the northern end of the basin east of Quartzite Ridge (McKeown et al., 1976; Caskey, 1991; Cole and Cashman, 1999). This deformation is associated with the CP thrust fault which is exposed only in the CP Hills where a small window in the hanging wall shows Cambrian and Proterozoic rocks emplaced over rocks as young as Mississippian and Pennsylvanian (McKeown et al., 1976; Caskey, 1991). The fault, however, can be traced (based on stratigraphic relationships from deep drill holes [Cole et al., 1997]) beneath the western portion of Yucca Flat, where it appears to dip moderately to the east. The fault appears to steepen rapidly eastward beneath central Yucca Flat, where it likely forms a ramp structure that is coincident with the location of the east-dipping Carpetbag-Topgallant normal fault system. The CP thrust fault was penetrated in UGTA Well ER-6-2 in the southwestern portion of Yucca Flat (IT, 1997), where Cambrian Bonanza King Formation is thrust over overturned Devonian Guilmette Formation and Late Devonian to Mississippian Chainman Shale. The CP thrust fault and related contractional deformation are slightly younger than the Belted Range thrust fault (Cole and Cashman, 1999).

Pre-Tertiary exposures at the north end of Yucca Flat show particularly complex structural relationships (Barnes et al., 1963; Sargent and Orkild, 1973). The pre-Tertiary structural geology in this area is further complicated by Mesozoic intrusive activity and younger basinand-range normal faulting. Stratigraphic relationships indicate large amounts of vertical and possibly horizontal (Cole and Cashman, 1999) offset along several north-striking high-angle faults including the Tippinip, Butte, and Area 13 faults.

Pre-Tertiary rocks exposed in the Halfpint Range east of Yucca Flat show a marked difference in style and degree of contractional deformation compared to rocks exposed along the west side of the basin (Figure 3-1). East of Yucca Flat, tight folds and over-turned beds are rarely observed and no large thrust faults have been identified (Barnes et al., 1965; Cole and Cashman, 1999). 
The timing of contractional deformation in the NTS region is poorly constrained. Deformation must have occurred after the Pennsylvanian because rocks of this age (about 280 million years old [Ma]) are deformed within the footwall of a thrust fault in the CP Hills (McKeown et al., 1976; Caskey, 1991 and Cole and Cashman, 1999) and folded into a broad syncline at Syncline Ridge. Contractional deformation in the region is probably older than Middle Cretaceous because approximately 100-Ma granite intrudes hanging wall rocks of the Belted Range thrust fault in the northern portion of the NTS (Barnes et al., 1963; Gibbons et al., 1963; and Naeser and Maldonado, 1981).

\subsubsection{Development of Yucca Flat Basin}

Structurally, Yucca Flat is composed of two structural basins separated by a narrow structural ridge (Figure 3-2). These structural features formed in response to basin-and-range extension; however, pre-existing structural features related to pre-Tertiary contractional deformation, such as the CP thrust fault, may have had a significant influence on basin formation. The main Yucca Flat structural basin lies beneath central and eastern Yucca Flat east of the Carpetbag-Topgallant fault system. This basin consists of two main west-tilted half-grabens formed by dip-slip movement along the north-striking and east-dipping Carpetbag-Topgallant and Yucca fault systems. Movements along many antithetic and synthetic faults have created smaller sub-basins, resulting in several parallel, north-striking sub-basins beneath the eastern half of Yucca Flat (Figures 2-2 and 3-4).

The Carpetbag-Topgallant fault system forms the eastern flank of a narrow structural ridge that separates the main Yucca Flat basin from a smaller structural basin beneath the western portion of Yucca Flat (Figure 3-2). This western basin is narrower, and generally shallower, than the main basin to the east. Drill hole and seismic data indicate that the western sub-basin is a full graben bounded on the east and west by normal faults. Cenozoic rocks within the western subbasin appear to be less tilted than Cenozoic rocks within the main basin to the east.

The common locations and orientations of the CP thrust ramp and the Carpetbag-Topgallant fault system suggest that the Carpetbag-Topgallant fault system, and consequently the formation of Yucca Flat basin, may be related to the reactivation of the pre-Tertiary CP thrust ramp during basin-and-range extension. Extension-related reactivation of thrust faults in the Yucca Flat vicinity is not unprecedented. Cole and Cashman (1999) describe thrust surfaces at Mine Mountain that have been reactivated as a result of extension. Additional evidence for reactivation of the $\mathrm{CP}$ thrust ramp may include the observation that Cenozoic rocks within the main Yucca Flat structural basin east of the Carpetbag-Topgallant fault system, as well as 
Cenozoic rocks exposed in the Halfpint Range east of Yucca Flat, dip west into the main eastdipping basin-forming faults (e.g., Carpetbag-Topgallant and Yucca faults).

As Figure 3-3 shows, however, most basins and many of the Cenozoic rocks in the region surrounding Yucca Flat are tilted to the east as a result of movement along large west-dipping basin-forming faults. The basin structure and stratal tilt shown on Figure 3-3 are based on the analysis of stratigraphic relationships at the margins of basins and orientations of Cenozoic rocks depicted on published geologic maps of the Yucca Flat region (see Tables 2-1 and 2-2 this report); regional gravity investigations (Blakely and Ponce, 2001; Ponce et al., 2001); seismic surveys (BN, 2005a, Appendix D); and satellite images. Tilt orientations of Cenozoic rocks and basins shown in Figure 3-3 are generally consistent with more regional investigations (Chuang et al., 2003, Sheets 13 and 15; and Faulds and Stewart, 1998, Plate 1). This localized reversal of Cenozoic stratal tilt orientation in the Yucca Flat vicinity could be the result of dip-slip displacement and basin formation along the pre-existing east-dipping CP thrust ramp.

The beginning of the main period of basin development for Yucca Flat is fairly well constrained. No predominantly sedimentary units are recognized within the volcanic section between the Redrock Valley Tuff (15.25 Ma) and Ammonia Tanks Tuff (11.45 Ma). In addition, extensive drill hole data show no stratigraphic relationships within the volcanic section that are characteristic of growth-faulting (e.g., increasing dip magnitudes with depth and depositional thickening of volcanic units towards basin-forming faults). Thus, basin development must have begun after the eruption of the Ammonia Tanks Tuff, 11.45 Ma. Basalt intercalated within alluvium in drill hole UE-1j has been dated at 8.1 Ma (Marvin et al., 1989), indicating that basin development had begun before approximately 8 Ma in southern Yucca Flat. These stratigraphic relationships constrain the onset of major basin development to some time after the eruption of the Ammonia Tanks Tuff 11.45 Ma and before the eruption of basalt in the area. This is consistent with the onset of basin development for Frenchman Flat (BN, 2005a). The surface expression of the Yucca Fault within Quaternary alluvium prior to underground nuclear testing (Barnes et al., 1963; Colton and McKay, 1966) indicates basin development continued into the Quaternary (1.8 Ma).

\subsubsection{Summary}

In summary, east- to southeast-directed thrusting along the Belted Range thrust fault between 280 and 100 Ma resulted in complex contractional deformation within pre-Tertiary rocks along the present western margin of Yucca Flat. Proterozoic to Cambrian siliciclastic rocks were placed over Devonian carbonate and Mississippian siliciclastic rocks along the Belted Range thrust fault northwest of Yucca Flat. Imbricate thrusting in front of the advancing Belted Range 
thrust sheet created a complex stack of thrust slices of the Belted Range footwall rocks that involve Devonian carbonate rocks and Mississippian siliciclastic rocks. Shortly after the initiation of Belted Range thrusting, a west-vergent thrust fault, the CP thrust fault, formed foreland (east) of the Belted Range thrust system along an east-dipping high-angle ramp structure in what is now the central portion of Yucca Flat. The CP thrust placed Cambrian and Ordovician carbonate rocks over Mississippian siliciclastic and Devonian carbonate rocks. Between approximately 15 and $10 \mathrm{Ma}$ in the NTS region, generally east-west directed extension resulted in the formation of basins such as Frenchman Flat, Emigrant Valley, and Kawich Valley by displacement along west-dipping high-angle normal faults located along the eastern margins of the developing basins. This also resulted in an eastward tilt to stratigraphic units. In Yucca Flat, however, reactivation of the east-dipping high-angle ramp structure of the CP thrust fault resulted in the formation of the east-dipping Carpetbag-Topgallant fault system near the center of the present Yucca Flat topographic basin and the formation of the west-tilted Yucca Flat structural basin.

\subsection{Structural Elements in the Model}

The primary structural elements within the Yucca Flat-Climax Mine model are high-angle normal faults, thrust faults, and folds. Each of these structural elements is described in the following subsections.

\subsubsection{Thrust Faults}

Although the Belted Range thrust fault is not within the boundaries of the Yucca Flat model, a foreland imbricate thrust fault related to the main thrust fault is present in the northwest corner of the model area. This fault places Devonian and Silurian carbonate rocks over Mississippian siliciclastic rocks (Gibbons et al., 1963; Cole and Cashman, 1999) and was included in the hydrostratigraphic framework model. The hanging wall rocks of this imbricate thrust fault are designated the Dolomite Hill plate by Cole and Cashman (1999). Just east of the Dolomite Hill plate and directly below it structurally, Cole and Cashman (1999) designated another imbricate thrust sheet the Grouse Canyon plate. According to Cole and Cashman (1999), this imbricate thrust sheet is floored by a thrust fault beneath the Eleana Range, and places Mississippian siliciclastic rocks over rocks of similar age and composition. Because the fault likely juxtaposes rocks of similar hydrogeologic character, it was not included in the model. In addition, data from Well ER-12-2 drilled east of the Eleana Range in northwestern Yucca Flat provide

evidence that no major structural disruption occurs between the Mississippian rocks of the Eleana Range and those penetrated in Well ER-12-2 (Prothro, 2005b). 
The west-vergent CP thrust fault is likely the most hydrologically significant pre-Tertiary structure within the model area, and thus is included in the framework model. The thrust fault is located in the western portion of the model area, where it places carbonate rocks over siliciclastic rocks. The sinuous trace of the $\mathrm{CP}$ thrust fault indicates that it is a relatively lowangle fault beneath the western portion of Yucca Flat where it cuts through the less competent and highly bedded Mississippian siliciclastic rocks of the Chainman Shale and Eleana Formation. The fault plane, however, appears to steepen rapidly eastward beneath central Yucca Flat, based on MT data (Asch et al. (2005), and thus forms a ramp structure beneath the central portion of the basin (Profile 2, Appendix D, this report). As discussed previously, the location of the CP thrust ramp appears to be coincident with the location of the east-dipping CarpetbagTopgallant normal fault system, a major basin-forming fault system which bounds the deep Yucca Flat structural basin on the west. Thus, the Carpetbag-Topgallant normal fault system may represent a reactivation of the pre-existing $\mathrm{CP}$ thrust ramp. Additional evidence for coupling of the $\mathrm{CP}$ thrust ramp and the Carpetbag-Topgallant fault system is that Mississippian rocks within the footwall of the $\mathrm{CP}$ thrust fault beneath the western portion of Yucca Flat are not observed in the MT data east of the Carpetbag-Topgallant fault system, nor do they crop out in the hills bordering Yucca Flat on the east. This suggests that Mississippian rocks within the hanging wall of the $\mathrm{CP}$ thrust fault were eroded off of the hanging wall as a result of being thrust upward along a high-angle ramp structure located beneath central Yucca Flat. In the Yucca Flat hydrostratigraphic framework model the $\mathrm{CP}$ thrust fault is modeled as merging downward and eastward into the Carpetbag-Topgallant fault system.

\subsubsection{High-Angle Normal Faults}

The most common structural feature in the model are high-angle normal faults related to basinand-range extension and basin formation. Approximately 178 high-angle faults are included in the framework model (Figure 3-4). Faults are typically modeled with a 75-degree dip based on measured dips of faults exposed around Yucca Flat (which range from 50 to 85 degrees), and the stratal tilt (i.e., generally less than 15 degrees) of the Rainier Mesa and Ammonia Tanks Tuff within and along the eastern margin of the basin (Barnes et al., 1965; Byers and Barnes, 1967; and Hinrichs and McKay, 1965). Each fault typically is modeled as a single fault plane that extends to the base of the model. Some faults, however, terminate against other faults. Because the main basin-forming faults dip to the east in Yucca Flat, west-dipping faults in the model were typically terminated against east-dipping faults. Almost all of the high-angle faults are modeled with a component of dip-slip displacement, and most are probably best classified as normal faults. 
The locations of the high-angle faults were based on mapped surface traces, drill hole data, mapped surface effects from UGTs, and geophysical evidence. The traces of surface faults were digitized from surface geology maps (USGS geologic quadrangle maps listed in Table-2-1, and Workman et al., 2002a). Only the main surface faults were included in the framework model. These faults typically have offsets greater than $61 \mathrm{~m}$ (200 ft) and appear to provide the main control on the structural fabric and outcrop patterns in the highlands bordering Yucca Flat.

\subsubsection{Folds}

Pre-Tertiary contractional deformation in the Yucca Flat vicinity resulted in the folding of preTertiary rocks within the model area. Because of the scale of the framework model, only the larger folds are expressed in the model. These include the Halfpint Range anticline, Syncline Ridge syncline, Yucca Flat syncline, and Quartzite Ridge anticline.

The pre-Tertiary rocks in the Halfpint Range generally dip moderately to the southwest and west toward Yucca Flat, forming the southwest limb of the broad northwest-trending Halfpint Range anticline, the axis of which crosses the northern portion of the range (Figure 3-1). Proterozoic siliciclastic rocks form the core of the Halfpint Range anticline, and pre-Tertiary rocks become progressively younger to the south within the range away from the anticline (Barnes et al., 1965; Hinrichs and McKay, 1965; and Byers and Barnes, 1967).

Pre-Tertiary rocks within the Halfpint Range also form the northeast limb of the broad synclinal form beneath the eastern portion of Yucca Flat. This synclinal form is expressed by stratigraphic relationships of the pre-Tertiary subcrop surface beneath the eastern portion of Yucca Flat based on deep drill hole data (Cole et al., 1997). This synclinal form likely represents a hanging-wall syncline associated with the CP thrust fault. Designated the Yucca Flat syncline, it has been severely overprinted by later extensive normal faulting related to basin-and-range extension and basin formation.

Another syncline is present along the western edge of the model area. This structural feature is the northeast continuation of the Syncline Ridge syncline which is exposed at Syncline Ridge just west of the model area. Syncline Ridge is composed of Pennsylvanian and Permian carbonate rocks that have been broadly folded into a northeast trending syncline. The Syncline Ridge syncline trends northeast beneath the northwest portion of Yucca Flat where it composes the footwall of the CP thrust fault. It is overridden by and eventually terminates against the CP thrust fault beneath the northern portion of Yucca Flat. 
The Mississippian siliciclastic rocks exposed on Quartzite Ridge in the northwestern portion of the model area have been folded into a north-northeast-trending anticline that appears to continue southwestward into the Eleana Range, located west of the model area. The Quartzite Ridge anticline and Syncline Ridge syncline are modeled as adjacent fold pairs within the footwall rocks between the converging Belted Range and CP thrust faults.

\subsection{Hydrologic Characteristics of Faults}

It is typical for rocks to be more fractured near faults, and thus a rock's properties tend to be different near and adjacent to faults. However, thrust faulting (including the $\mathrm{CP}$ thrust) and associated fracturing are older than approximately 100 million year at the NTS. Therefore, fractures associated with thrusting are more likely to be healed/filled than fractures associated with more recent basin-and-range normal faulting which began in the Yucca Flat area approximately 10 million years ago and probably continues today. Reactivation of the older thrust structures during basin-and-range extension, such as that described for the CP thrust fault and documented at Mine Mountain (Cole and Cashman, 1999), likely created new fractures and could have reopened preexisting fractures associated with the old thrust structures. However, it is difficult to predict if (and where) an older thrust fault may have undergone reactivation due to later structural activity, particularly if the thrust fault is poorly exposed or unexposed.

Regarding the CP thrust fault and how it is modeled in the EarthVision ${ }^{\circledR}$ framework model, the steeper portion (i.e., ramp) that is coincident with the Carpetbag-Topgallant fault should be considered reactivated, resulting in a possible increase in transmissivity along and near the fault where it cuts through brittle rocks such as the LCA. 


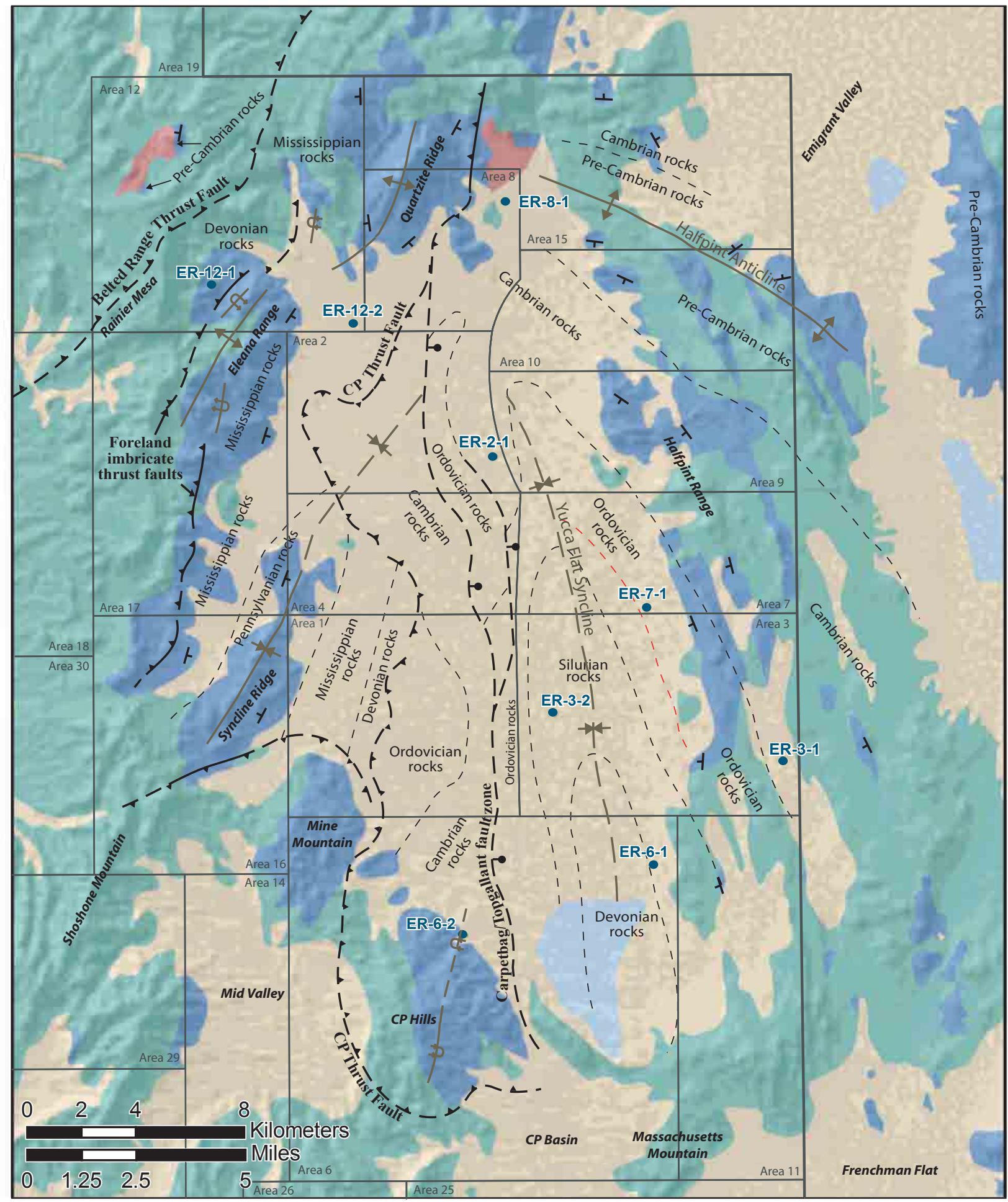

* Syncline; dashed where buried

Anticline

\$ Overturned syncline

$\propto$ Overturned anticline

ـ Thrust fault; teeth on hanging wall; dashed where buried

I Normal fault; ball and bar on downthrown side (reactivated CP thrust fault); dashed where buried

- - Pre-Tertiary subcrop stratigraphic contact

_. - Eureka Quartzite (Ordovician)
- UGTA Well

$\dashv$ Strike and dip of Pre-Tertiary rocks

- NTS Boundary

Quaternary Playa Deposits

Quaternary/Tertiary Alluvium

Tertiary Volcanic Rocks

Mesozoic Granitic Rocks

Pre-Cambrian and Paleozoic Rocks

Structural elements modified from Cole, 1997

Geologic map from Nevada Bureau of Mines and Geology, 1996 


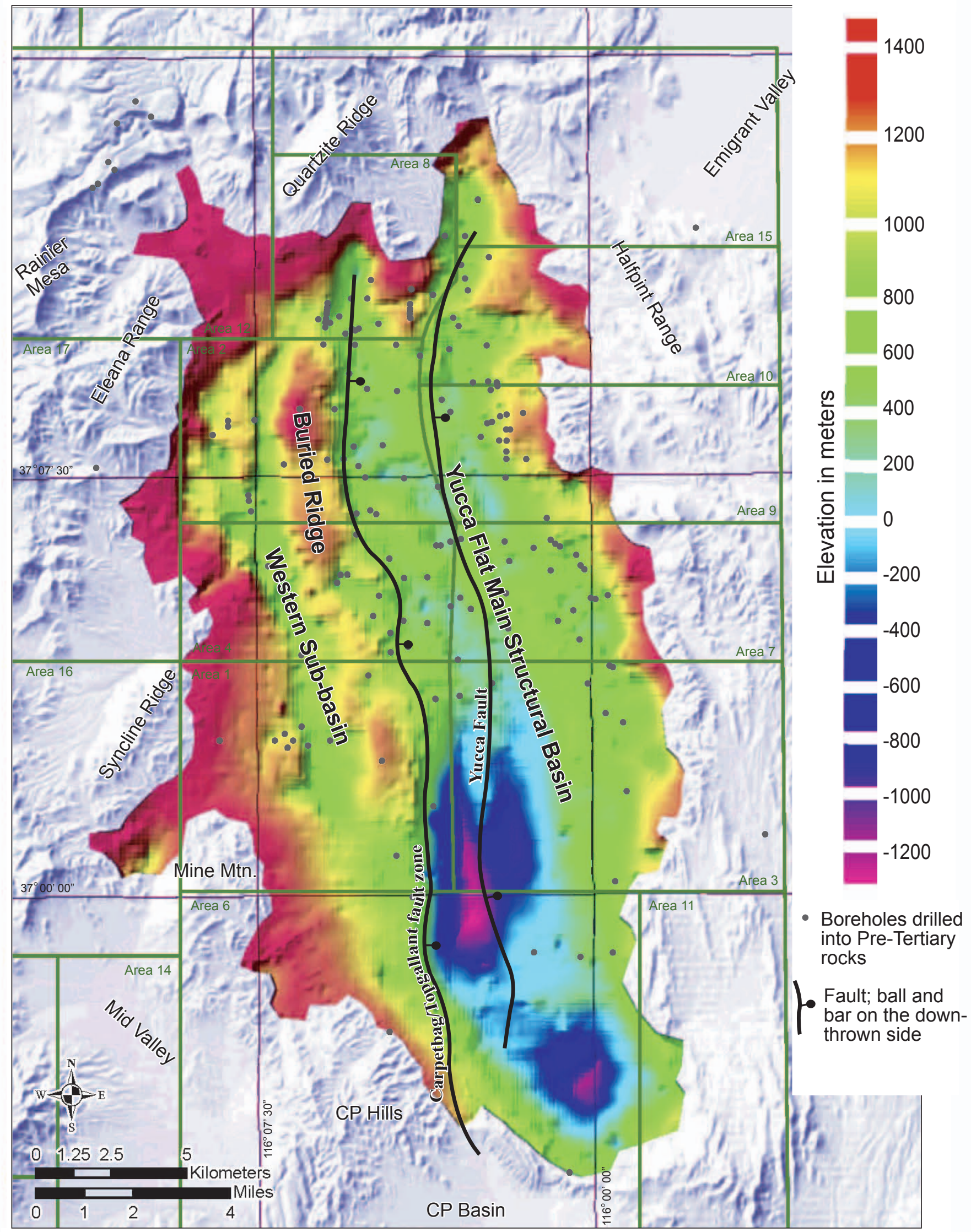

Figure 3-2

Color Elevation Relief Map of the Pre-Tertiary Surface Beneath Yucca Flat Based on Gravity Data

(Modified from Phelps et al., 1999a) 


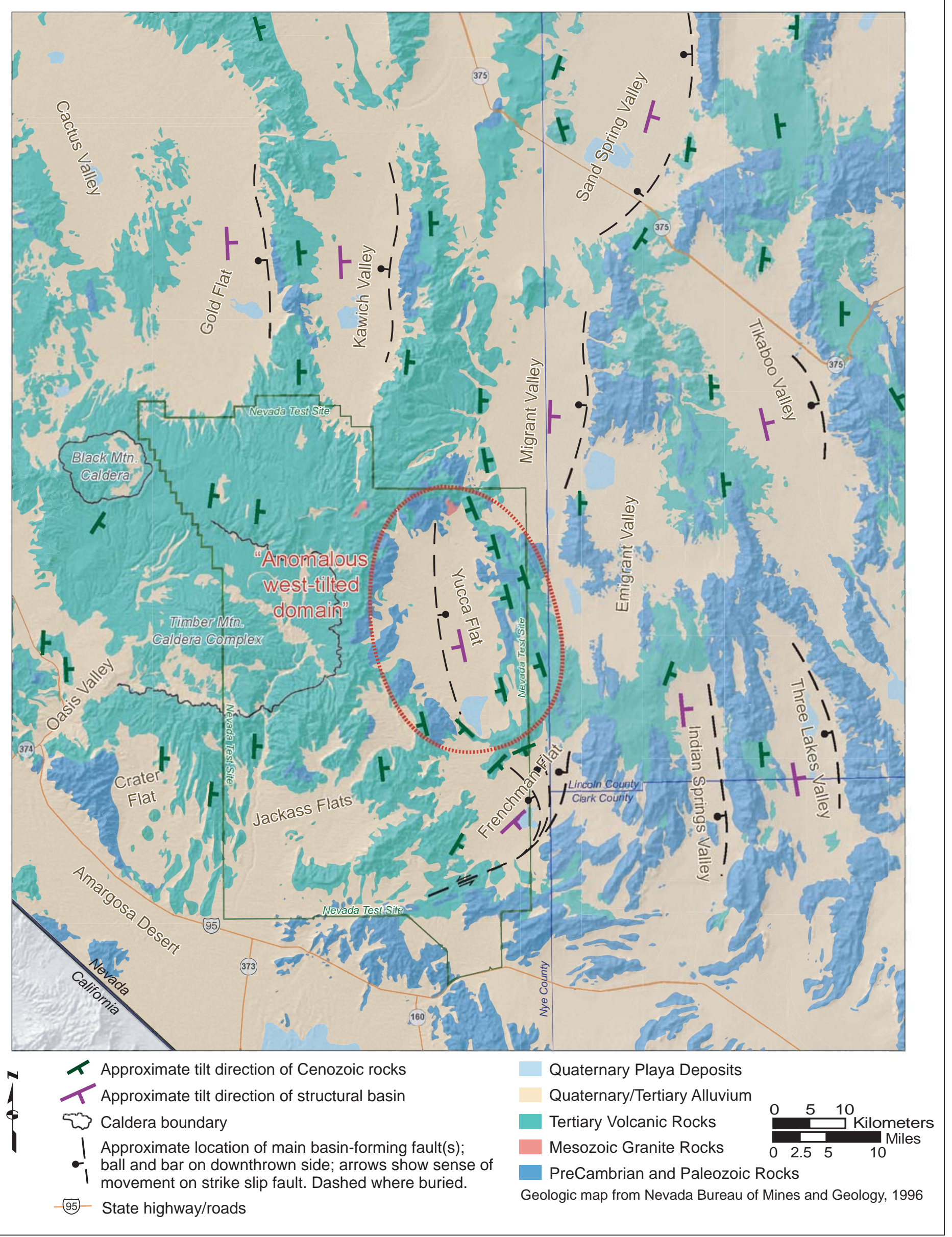

Figure 3-3

Tilt Domain Map of the NTS and Vicinity 


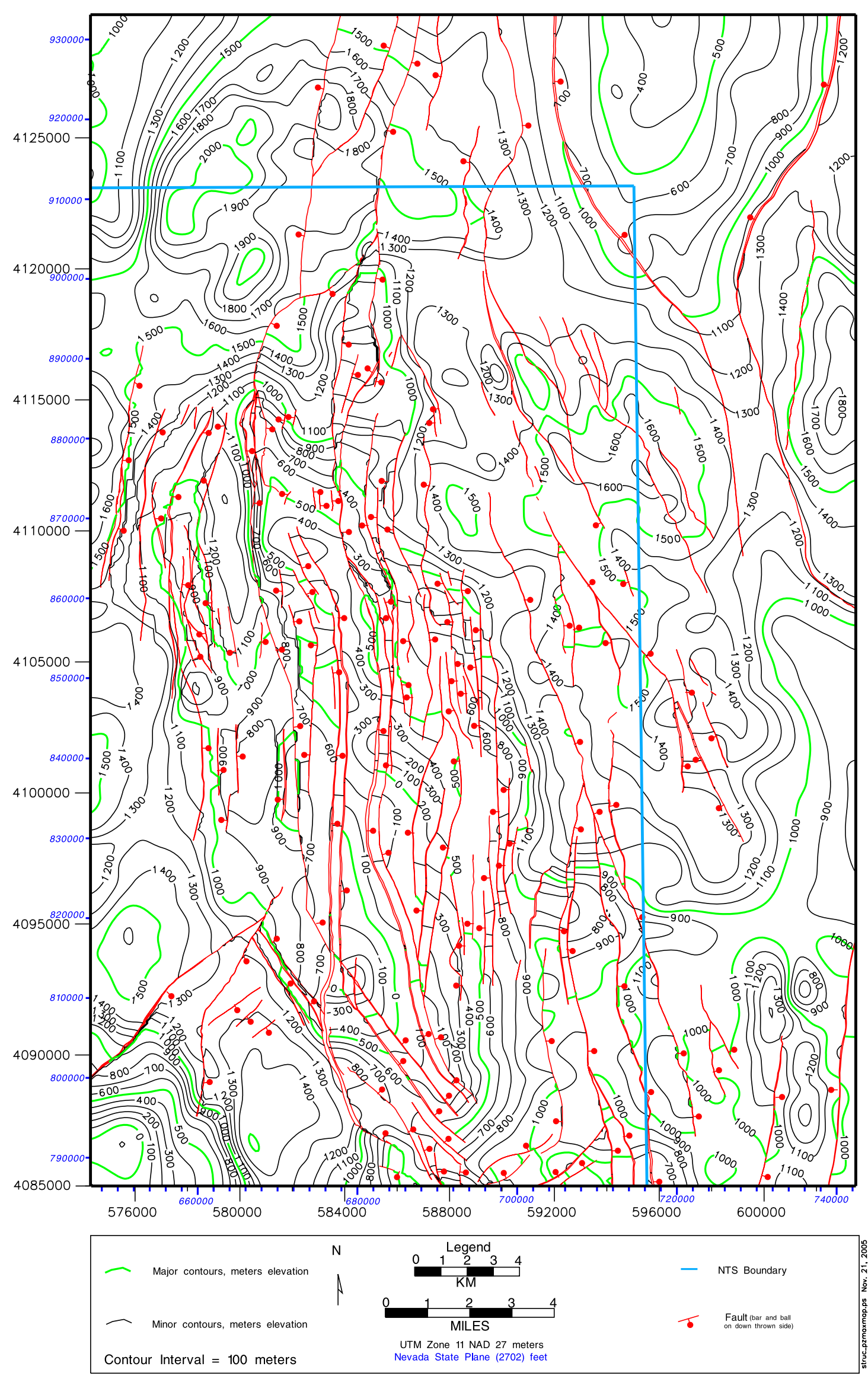

Figure 3-4

Structure Map on Top of the Pre-Tertiary Surface

Generated from the EarthVision ${ }^{\circledR}$ Model 


\subsection{HYDROSTRATIGRAPHY}

As introduced in Section 2.5, a hydrostratigraphic classification system for depicting the hydrologic character of complexly inter-fingering rocks of a wide range of lithologic and hydrologic characteristics had to be developed for use in the digital framework model. The hydrogeologic framework for Yucca Flat and vicinity established by Winograd and Thordarson (1975) provided the foundation for most subsequent hydrogeologic studies in the area. As described in this section, the rocks of the NTS have been classified for hydrologic modeling using a two-level classification scheme, in which HGUs are grouped to form HSUs (IT, 1996a; BN, 2002a).

\subsection{Development of the Hydrostratigraphic Classification System}

The development of the hydrostratigraphic classification system for the Yucca Flat model area involved a three-step process. The first step was acquiring a thorough understanding of the character and three-dimensional distribution of the rocks, both lithologically and stratigraphically, within the model area. This critical first step was accomplished through a rigorous analysis of published surface geologic maps and descriptions, and drill hole and geophysical data.

In the second step, rocks in the Yucca Flat area were classified as one of nine HGUs based on the rock's ability to transmit groundwater, which is mainly a function of a rock's primary lithology, type and degree of post-depositional alteration, and propensity to fracture (Winograd and Thordarson, 1975). The most important factor affecting how groundwater flows through a body of rock is the rock's original primary lithology, which exerts a strong influence on the other two important processes, post-depositional alteration and fracturing. Hard, dense, brittle rocks such as welded tuff, lava, and carbonate generally have low primary porosity and matrix permeability, but tend to fracture readily in response to tectonic forces and, as in the case of welded tuffs and lavas, also as a result of contraction during cooling. In addition, the low primary porosity and matrix permeability of these rocks tend to inhibit significant secondary alteration such as zeolitization which typically changes the hydrologic character of the rocks. These rocks are considered aquifers and have been shown to be prolific water producers at the NTS. Less dense rocks such as alluvium and bedded and nonwelded tuff, typically do not support extensive fracture systems and thus usually have low fracture-related effective porosity. However, some low density rocks such as nonwelded tuff and alluvium can have relatively high primary effective porosity and these units are also considered aquifers where they are unaltered. The high primary effective porosity of these rocks, particularly nonwelded tuff, makes them susceptible to post-depositional alteration processes such as zeolitization, which can significantly 
reduce the effective porosity of altered rocks. Nonwelded tuff units that have undergone zeolitic alteration are considered confining units because of their very low effective porosity.

The third step in the development of the Yucca Flat hydrostratigraphic classification system was to group individual HGUs of similar character into larger HSUs to facilitate mapping and 3-D model construction. A critical component of this step was the careful integration of Yucca Flat stratigraphy. The integration of stratigraphic concepts is important to assure that individual HGUs grouped within HSUs, and the HSUs themselves, properly correlate within the model. Therefore, HSUs can be thought of as groupings of contiguous stratigraphic units that have a particular hydrogeologic character, such as aquifer or confining unit. For the Yucca Flat model, HSUs generally consist of a single HGU (e.g., the Timber Mountain lower vitric-tuff aquifer essentially is 100 percent vitric-tuff aquifer). There are four exceptions: the Timber Mountain upper vitric-tuff aquifer, the Timber Mountain welded-tuff aquifer, the Topopah Spring aquifer, and the volcaniclastic confining unit. These HSUs may consist of several HGUs, but are defined so that a single general type of HGU dominates (e.g., mostly welded-tuff aquifer). These exceptions are noted in the "Dominant HGU" column of Table 4-4 and in the appropriate paragraphs of Section 4.5 below. This definition generally follows those of Maxey (1964) and Seaber (1988). HSUs serve as 3-D bodies that are represented in the finite element mesh for the UGTA groundwater modeling process (IT, 1996c).

Sections 4.2, 4.3, and 4.4 describe the stratigraphy, unit thicknesses, and the HGUs of the Yucca Flat area. Each of the 25 HSUs in the Yucca Flat hydrostratigraphic framework model is described in Section 4.5.

\subsection{Stratigraphy of the Yucca Flat-Climax Mine Model Area}

To define appropriate HSUs to serve as layers in the framework model, the modelers had to start from a well understood stratigraphic system. Refinement of the stratigraphy of the area was a continuous process during the decades in which geoscientists associated with the WTP worked to understand the complex volcanic setting (Byers et al., 1976, 1989). The need to develop detailed geologic models in support of the UGTA program intensified this process, and the recognition of smaller and smaller distinct volcanic units permitted a greater understanding of the 3-D configuration of the various types of rocks, which has been incorporated into the model via the hydrostratigraphic framework. Efforts to understand the structure and stratigraphy of the non-volcanic rocks (pre-Tertiary) have also continued to a lesser degree. The most widespread and significant Quaternary- and Tertiary-age (mainly volcanic) units of the Yucca Flat-Climax Mine model area are listed in Table 4-1. Refer to Table 4-2 for a list of Paleozoic and 
Table 4-1

Quaternary, Tertiary, and Mesozoic Stratigraphic Units of the Yucca Flat-Climax Mine Model Area

\begin{tabular}{|c|c|}
\hline Stratigraphic Assemblages and Major Units ${ }^{\text {a, }}$ & Volcanic Sources $^{c}$ \\
\hline $\begin{array}{l}\text { Quaternary and Tertiary Sediments } \\
\text { Young playa deposits (Qp) } \\
\text { Young alluvium (Qay) } \\
\text { Quaternary - Tertiary colluvium (QTc) } \\
\text { Intermediate alluvium (Qai) } \\
\text { Quaternary-Tertiary alluvium (QTa) } \\
\text { Pliocene Basalts (Tyby) } \\
\text { Tertiary alluvium (QTa) }\end{array}$ & Not applicable \\
\hline $\begin{array}{l}\text { Timber Mountain Group (Tm) } \\
\text { Ammonia Tanks Tuff (Tma) } \\
\text { bedded Ammonia Tanks Tuff (Tmab) } \\
\text { Rainier Mesa Tuff (Tmr) } \\
\text { tuff of Holmes Road (Tmrh) }\end{array}$ & $\begin{array}{l}\text { Timber Mountain Caldera Complex } \\
\text { Ammonia Tanks Caldera } \\
\text { Rainier Mesa Caldera }\end{array}$ \\
\hline $\begin{array}{l}\text { Paintbrush Group (Tp) } \\
\text { Tiva Canyon Tuff (Tpc) } \\
\text { Topopah Spring Tuff (Tpt) }\end{array}$ & $\begin{array}{c}\text { Claim Canyon Caldera } \\
\text { Unknown }\end{array}$ \\
\hline Calico Hills Formation (Th; formerly Tac) & Unknown \\
\hline $\begin{array}{l}\text { Wahmonie Formation (Tw) } \\
\text { tuff of Wahmonie Flat (Twlb) }\end{array}$ & Wahmonie Volcanic Center \\
\hline $\begin{array}{l}\text { Crater Flat Group (Tc) } \\
\text { Prow Pass Tuff (Tcp) } \\
\text { Bullfrog Tuff (Tcb) } \\
\text { Tram Tuff (Tct) } \\
\text { Belted Range Group (Tb) } \\
\text { Grouse Canyon Tuff (Tbg) } \\
\text { Comendite of Quartet Dome (Tbq) }\end{array}$ & $\begin{array}{l}\text { Silent Canyon Caldera Complex } \\
\text { Area } 20 \text { Caldera } \\
\text { Grouse Canyon Caldera }\end{array}$ \\
\hline $\begin{array}{l}\text { Tunnel Formation (Tn) } \\
\text { Tunnel bed } 4 \text { member, undivided (Tn4) } \\
\text { Tunnel bed } 3 \text { member, undivided (Tn3) }\end{array}$ & Unknown \\
\hline $\begin{array}{l}\text { Volcanics of Big Dome (Tu) } \\
\text { Comendite of Ocher Ridge (Tuo) } \\
\text { Tub Spring Tuff (Tub) } \\
\text { Comendite of Emigrant Valley (Tue) }\end{array}$ & Unknown \\
\hline $\begin{array}{l}\text { Volcanics of Oak Spring Butte (To) } \\
\text { Tunnel bed } 2 \text { (Ton2) } \\
\text { Yucca Flat Tuff (Toy) } \\
\text { Tunnel bed } 1 \text { (Ton1) } \\
\text { Redrock Valley Tuff (Tor) } \\
\text { tuff of Twin Peaks (Tot) } \\
\text { Older Volcanics, undivided (To) }\end{array}$ & Unknown \\
\hline $\begin{array}{l}\text { Older Tuffaceous Sedimentary Rocks } \\
\text { Rocks of Pavits Spring (Tgp) } \\
\text { Rocks of Winapi Wash (Tgw) }\end{array}$ & $\begin{array}{l}\text { Unknown } \\
\text { Not applicable }\end{array}$ \\
\hline
\end{tabular}


Table 4-1

Quaternary, Tertiary, and Mesozoic Stratigraphic Units of the Yucca Flat-Climax Mine Model Area (continued)

\begin{tabular}{||l|c||}
\hline \multicolumn{1}{|c|}{ Stratigraphic Assemblages and Major Units ${ }^{\text {a, b }}$} & Volcanic Sources $^{\mathbf{c}}$ \\
\hline \hline $\begin{array}{l}\text { Paleocolluvium (TI) } \\
\text { Paleocolluvium, undivided }\end{array}$ & Not applicable \\
\hline $\begin{array}{l}\text { Plutonic Rocks (Kg) } \\
\text { Climax stock (Kgc) } \\
\text { Gold Meadows stock (Kgg) }\end{array}$ & Not applicable \\
\hline
\end{tabular}

a Compiled from Slate et al. (1999) and Ferguson et al. (1994).

b Letters in parentheses are stratigraphic unit map symbols.

c Sources, where known, from Sawyer et al. (1994)

d Prothro and Drellack, 1997a

e Proposed symbol: Tg after Wahl et al., 1996

$f$ Informal unit, after Yount (1996). Formerly the Horse Spring Formation

Refer to Table 4-2 for lists of Paleozoic and Proterozoic sedimentary rock formations.

Table 4-2

Proterozoic and Paleozoic Stratigraphic Units of the Yucca Flat-Climax Mine Model Area

(Stratigraphic and lithologic units adapted from Cole, 1992)

\begin{tabular}{|c|c|c|c|c|}
\hline Map Unit & $\begin{array}{c}\text { Stratigraphic } \\
\text { Unit Map } \\
\text { Symbol } \\
\end{array}$ & $\begin{array}{r}\text { Strati } \\
\text { Thic } \\
\text { Feet }\end{array}$ & $\begin{array}{l}\text { raphic } \\
\text { ness } \\
\text { Meters }\end{array}$ & Dominant Lithology \\
\hline $\begin{array}{l}\text { Chainman Shale } \\
\text { Eleana Formation }\end{array}$ & $\begin{array}{l}\text { Mc } \\
\text { MDe }\end{array}$ & $7,700^{a}$ & $2,350^{a}$ & Shale, Argillite, and Quartzite \\
\hline Guilmette Formation & $\mathrm{Dg}$ & 1,400 & 430 & Limestone \\
\hline Simonson Dolomite & Ds & 1,100 & 330 & Dolomite \\
\hline Sevy Dolomite & DSs & 690 & 210 & Dolomite \\
\hline Laketown Dolomite & $\mathrm{SI}$ & 650 & 200 & Dolomite \\
\hline Ely Springs Dolomite & Oes & 340 & 105 & Dolomite \\
\hline Eureka Quartzite & Oe & 400 & 125 & Quartzite \\
\hline Antelope Valley Limestone & $\mathrm{Oa}$ & 1,530 & 466 & Limestone \\
\hline Ninemile Formation & On & 335 & 102 & Limestone \\
\hline Goodwin Limestone & Og & 685 & 209 & Limestone \\
\hline Nopah Formation & $\mathrm{Cn}$ & 2,050 & 620 & Limestone \\
\hline Bonanza King Formation & $\mathrm{Cb}$ & 4,350 & 1,330 & Limestone/Dolomite \\
\hline Carrara Formation & Cc & 925 & 280 & Limestone/Shale/Siltstone \\
\hline Zabriskie Quartzite & $\mathrm{Cz}$ & 200 & 60 & Quartzite \\
\hline Wood Canyon Formation & $C Z w$ & 2,300 & 700 & Micaceous Quartzite \\
\hline Stirling Quartzite & Zs & 2,900 & 890 & Quartzite \\
\hline Johnnie Formation & $\mathrm{Zj}$ & 3,000 & 914 & Quartzite/Siltstone/Limestone \\
\hline
\end{tabular}

a Estimates of combined thickness range from 2,350 meters (Poole et al., 1961) to 1,300 meters (Cole and Cashman, 1999) 
Proterozoic (sedimentary) units. Figure 4-1 illustrates the stratigraphy of rocks in the Yucca Flat area.

The stratigraphic section for the Yucca Flat-Climax Mine area consists of Proterozoic and Paleozoic siliciclastic and carbonate rocks, Mesozoic intrusive rocks, Tertiary-age fluvial deposits, Tertiary-age volcanic rocks, and Tertiary- and Quaternary-age alluvium (Figure 4-1). Throughout most of Yucca Flat, middle to upper Miocene volcanic rocks that originated from vents located to the west and northwest of the basin unconformably overlie pre-Tertiary carbonate and siliciclastic rocks (Orkild, 1983a).

\subsection{Unit Thickness}

The alluvial fill of the Yucca Flat basin ranges in thickness from a thin veneer along the valley edges to over $914 \mathrm{~m}$ (3,000 ft) in south-central Yucca Flat. The volcanic units are interpreted to be up to $792 \mathrm{~m}(2,600 \mathrm{ft})$ thick in the central part of the Yucca Flat basin, as determined from outcrops and drill holes (Drellack and Thompson, 1990; Wagoner and Richardson, 1986). The thicknesses of the pre-Tertiary units (Table 4-2) were derived from estimates given by Cole (1992). Data for these units from the USGS geologic quadrangle maps, particularly Plutonium Valley, Paiute Ridge, Jangle Ridge, Oak Spring, Tippipah Spring, and Mine Mountain (Hinrichs and McKay, 1965; Byers and Barnes, 1967; Barnes et al., 1965; Barnes et al., 1963; Orkild, 1963; and Orkild, 1968) and from drill holes, were also incorporated.

\subsection{Hydrogeologic Units of the Yucca Flat Model Area}

All the rocks of the Yucca Flat-Climax Mine model area are classified as one of the following nine HGUs: playa confining unit, alluvial aquifer, welded-tuff aquifer, vitric-tuff aquifer, lavaflow aquifer, tuff confining unit, granitic confining unit, clastic confining unit, and carbonate aquifer (Table 4-3).

\subsubsection{Alluvial HGUs}

Two alluvial HGUs are present in the Yucca Flat-Climax Mine model area: the alluvial aquifer (AA; also an HSU) and the playa confining unit (PCU). The AA consists mainly of gravelly sand and sandy gravel eroded from the surrounding mountains during basin development, and deposited on alluvial fans by debris flow and sheetflood processes. Deposits of finer-grained eolian sand are intercalated within the coarser alluvial deposits. The PCU consists of finegrained sand, silt, and clay deposited as playa lake sediments in the topographic low point of the basin. Descriptions for these HGUs are included in the subsections for the similarly named HSUs. 
Table 4-3

Hydrogeologic Units of the Yucca Flat-Climax Mine Model

(Adapted from Winograd and Thordarson (1975); IT (1996a); and Laczniak et al. (1996)

\begin{tabular}{|c|c|c|}
\hline Hydrogeologic Unit & Typical Lithologies & Hydrologic Significance \\
\hline $\begin{array}{l}\text { Playa confining unit } \\
\text { (PCU) }\end{array}$ & Clayey-silt, sandy-silt & $\begin{array}{l}\text { Surface and near-surface confining unit at } \\
\text { Yucca Lake. May also limit, or redirect, } \\
\text { recharge where present at surface. }\end{array}$ \\
\hline $\begin{array}{l}\text { Alluvial aquifer } \\
\text { (AA) } \\
\text { (AA is also an HSU } \\
\text { in the Yucca Flat } \\
\text { hydrogeologic model.) }\end{array}$ & $\begin{array}{l}\text { Unconsolidated to partially } \\
\text { consolidated gravelly sand, } \\
\text { eolian sand, and colluvium }\end{array}$ & $\begin{array}{l}\text { Has characteristics of a highly conductive } \\
\text { aquifer, but less so where lenses of clay-rich } \\
\text { paleocolluvium, zeolitic alteration, or playa } \\
\text { deposits are present. }\end{array}$ \\
\hline $\begin{array}{l}\text { Welded-tuff aquifer } \\
\text { (WTA) }\end{array}$ & $\begin{array}{l}\text { Welded ash-flow tuff; vitric } \\
\text { to devitrified }\end{array}$ & $\begin{array}{l}\text { Degree of welding greatly affects interstitial } \\
\text { porosity (i.e., less porosity as degree of } \\
\text { welding increases) and permeability (i.e., } \\
\text { greater fracture permeability as degree of } \\
\text { welding increases). }\end{array}$ \\
\hline $\begin{array}{l}\text { Vitric-tuff aquifer } \\
\text { (VTA) }\end{array}$ & $\begin{array}{l}\text { Bedded tuff; ash-fall and } \\
\text { reworked tuff; vitric }\end{array}$ & $\begin{array}{l}\text { Constitutes a volumetrically minor HGU. } \\
\text { Generally does not extend far below the static } \\
\text { water level due to tendency of tuffs to become } \\
\text { zeolitic under saturated conditions, which } \\
\text { drastically reduces permeability. Significant } \\
\text { interstitial porosity (i.e., } 20 \text { to } 40 \text { percent). } \\
\text { Generally insignificant fracture permeability. }\end{array}$ \\
\hline $\begin{array}{l}\text { Lava-flow aquifer } \\
\text { (LFA) }\end{array}$ & $\begin{array}{l}\text { Rhyolite, basalt and dacite } \\
\text { lava flows; includes flow } \\
\text { breccia (commonly at base) }\end{array}$ & $\begin{array}{l}\text { Generally occurs as small, moderately thick } \\
\text { (rhyolite) to thin (basalt) local flows. } \\
\text { Hydrologically complex, showing a wide range } \\
\text { of transmissivity values; fracture density and } \\
\text { interstitial porosity differ with lithologic } \\
\text { variations. }\end{array}$ \\
\hline $\begin{array}{l}\text { Tuff confining unit } \\
\text { (TCU) }\end{array}$ & $\begin{array}{l}\text { Zeolitic bedded tuff with } \\
\text { interbedded, but less } \\
\text { significant, zeolitic, } \\
\text { nonwelded to partially } \\
\text { welded ash-flow tuff }\end{array}$ & $\begin{array}{l}\text { May be saturated but measured } \\
\text { transmissivities are very low. May cause semi- } \\
\text { perched conditions. }\end{array}$ \\
\hline $\begin{array}{l}\text { Granite confining unit } \\
\text { (GCU) }\end{array}$ & $\begin{array}{l}\text { Granodiorite and quartz } \\
\text { monzonite }\end{array}$ & $\begin{array}{l}\text { Saturated at depth but because of low } \\
\text { intergranular porosity and permeability, plus } \\
\text { the lack of inter-connecting fractures, is } \\
\text { considered a confining unit. }\end{array}$ \\
\hline $\begin{array}{l}\text { Clastic confining unit } \\
\text { (CCU) }\end{array}$ & Argillite, siltstone, quartzite & $\begin{array}{l}\text { Siliciclastic rocks are relatively impermeable; } \\
\text { coarser-grained siliciclastic rocks are fractured, } \\
\text { but with fracture porosity generally sealed due } \\
\text { to secondary mineralization. }\end{array}$ \\
\hline $\begin{array}{l}\text { Carbonate aquifer } \\
\text { (CA) }\end{array}$ & Dolomite, limestone & $\begin{array}{l}\text { Transmissivity values differ greatly and are } \\
\text { directly dependent on fracture frequency. }\end{array}$ \\
\hline
\end{tabular}




\subsubsection{Volcanic HGUs}

The volcanic rocks within the study area are categorized into four HGUs based on primary lithologic properties, degree of fracturing, and secondary mineral alteration. In general, the altered volcanic rocks, which are typically zeolitized and support few fractures (Prothro, 1998), act as confining units, and the unaltered rocks form aquifers. The aquifer units are further divided into welded-tuff and vitric-tuff aquifers, depending on degree of welding, and lava-flow aquifers. Denser rocks, such as welded ash-flow tuff and lava flows, tend to fracture more readily, and therefore have relatively high permeability (Blankennagel and Weir, 1973; Winograd and Thordarson, 1975; Laczniak et al., 1996; IT, 1996a; Prothro and Drellack, 1997b).

\subsubsection{Pre-Tertiary HGUs}

The hydrogeology of the pre-Tertiary sedimentary rocks at the NTS follows the framework developed by Winograd and Thordarson (1975), and used in the Phase I regional modeling effort (IT, 1996a, b, c) and subsequent CAU-scale models (BN, 2002a, 2005a; Gonzales et al., 1998). Within the study area, pre-Tertiary rocks are categorized as aquifer or confining unit HGUs based on lithology. The siliciclastic rocks, such as quartzite, siltstone, and shale, are classified as clastic confining units. The granitic intrusive rocks are classified as confining units. Carbonate rocks, such as limestone and dolomite, are classified as carbonate aquifers (Winograd and Thordarson, 1975; Laczniak et al., 1996).

\subsection{Hydrostratigraphic Units of the Yucca Flat-Climax Mine Model}

The following sections describe all the HSUs in the Yucca Flat-Climax Mine hydrostratigraphic framework model. They are generally listed in descending order from the top of the model to the bottom, though some are laterally rather than vertically contiguous, and not all units are present in all parts of the model area. Summaries of the characteristics of each of the 25 HSUs of the Yucca Flat-Climax Mine model are given in Table 4-4. Table 4-5 shows the correlation of Yucca Flat-Climax Mine HSUs with HSUs of other hydrostratigraphic framework models of the NTS region.

The geometric configuration of the HSUs as defined in the model is represented in 3-D perspective views and 2-D plan maps and profiles in various figures throughout this report. Contour maps depicting depth to aquifer HSUs are introduced as necessary to aid in the description of the HSUs. The correlation of stratigraphic units and hydrostratigraphic units of 
Table 4-4

Hydrostratigraphic Units of the Yucca Flat-Climax Mine Hydrostratigraphic Framework Model

\begin{tabular}{|c|c|c|c|c|}
\hline $\begin{array}{c}\text { Hydrostratigraphic } \\
\text { Unit }\end{array}$ & $\begin{array}{c}\text { Dominant } \\
\text { Hydrogeologic } \\
\text { Units }^{\text {a }}\end{array}$ & Typical Lithologies & $\begin{array}{l}\text { Stratigraphic } \\
\text { Unit Map } \\
\text { Symbol(s) }\end{array}$ & Hydrologic Significance \\
\hline $\begin{array}{l}\text { alluvial aquifer } \\
\text { (AA) }\end{array}$ & AA & $\begin{array}{l}\text { Alluvium: Gravelly sand; } \\
\text { also includes one or more } \\
\text { thin basalt flows, playa } \\
\text { deposits (differentiated as } \\
\text { separate HSUs), and } \\
\text { eolian sands }\end{array}$ & $\begin{array}{c}\text { Qay, QTc, Qai, } \\
\text { QTa }\end{array}$ & Generally unsaturated except in deepest basins. \\
\hline $\begin{array}{l}\text { playa confining unit } \\
\text { (PCUT) }\end{array}$ & $\mathrm{PCU}$ & Clayey silt and sandy silt. & Qp & $\begin{array}{l}\text { Playa units occur well above local water table, but could } \\
\text { impede downward recharge, or could intermittently } \\
\text { concentrate local recharge through large surface } \\
\text { cracks. Forms surface and near-surface playas at } \\
\text { Yucca Lake and Papoose Lake, and southern West } \\
\text { Emigrant Valley. }\end{array}$ \\
\hline $\begin{array}{l}\text { basalt lava-flow } \\
\text { aquifer } \\
\text { (BFLA) }\end{array}$ & LFA & Basalt lava flows & Tyby, Ttb & $\begin{array}{l}\text { Several (possibly dissected) basalt flows recognized in } \\
\text { the middle of the alluvial section of southwestern Yucca } \\
\text { Flat, at the surface as dikes and sills in the Halfpint } \\
\text { Range, and as a dike in the subsurface of eastern } \\
\text { Yucca Flat, at drill hole UE-7h. Generally unsaturated, } \\
\text { but deep feeder dikes could possibly affect groundwater } \\
\text { flow. }\end{array}$ \\
\hline $\begin{array}{l}\text { Timber Mountain } \\
\text { upper vitric-tuff } \\
\text { aquifer } \\
\text { (TM-UVTA) }\end{array}$ & $\begin{array}{l}\text { VTA } \\
\text { minor }(<15 \%) \\
\text { WTA }\end{array}$ & $\begin{array}{l}\text { Includes vitric nonwelded } \\
\text { to partially welded ash- } \\
\text { flow and bedded tuff }\end{array}$ & Tma, Tmab & $\begin{array}{l}\text { Typically saturated only in the deepest structural } \\
\text { basins. This HSU comprises only the Ammonia Tanks } \\
\text { Tuff, which stratigraphically overlies the TM-WTA. }\end{array}$ \\
\hline $\begin{array}{l}\text { Timber Mountain } \\
\text { welded-tuff aquifer } \\
\text { (TM-WTA) }\end{array}$ & $\begin{array}{l}\text { WTA } \\
\text { minor }(<20 \%) \\
\text { VTA }\end{array}$ & $\begin{array}{l}\text { Partially to densely } \\
\text { welded ash-flow tuff; vitric } \\
\text { to devitrified }\end{array}$ & $\begin{array}{l}\text { Tma, Tmab, } \\
\text { Tmr }\end{array}$ & $\begin{array}{l}\text { Typically saturated only in deep structural basins. } \\
\text { Strongly welded zones typically sandwiched between } \\
\text { less welded zones. }\end{array}$ \\
\hline
\end{tabular}


Table 4-4

Hydrostratigraphic Units of the Yucca Flat-Climax Mine Hydrostratigraphic Framework Model (continued)

\begin{tabular}{|c|c|c|c|c|}
\hline $\begin{array}{l}\text { Hydrostratigraphic } \\
\text { Unit }\end{array}$ & $\begin{array}{c}\text { Dominant } \\
\text { Hydrogeologic } \\
\text { Units }^{\text {a }}\end{array}$ & Typical Lithologies & $\begin{array}{l}\text { Stratigraphic } \\
\text { Unit Map } \\
\text { Symbol(s) }\end{array}$ & Hydrologic Significance \\
\hline $\begin{array}{l}\text { Timber Mountain } \\
\text { lower vitric-tuff aquifer } \\
\text { (TM-LVTA) }\end{array}$ & VTA & $\begin{array}{l}\text { Nonwelded ash-flow and } \\
\text { bedded tuff; vitric }\end{array}$ & $\begin{array}{l}\text { Tma, Tmab, } \\
\text { Tmr, Tmrh, Tp, } \\
\text { Th, Tw, Tc } \\
\text { (in N. Yucca } \\
\text { Flat may also } \\
\text { include Tbgb, } \\
\quad \text { and Tn) }\end{array}$ & $\begin{array}{l}\text { Typically includes the nonzeolitized, nonwelded lower } \\
\text { portion of the Rainier Mesa Tuff. However, this HSU } \\
\text { can encompass all nonzeolitized, nonwelded and } \\
\text { bedded units below the welded Rainier Mesa Tuff and } \\
\text { above the level of pervasive zeolitization. Unaltered } \\
\text { nonwelded and ash-fall tuffs generally not found at } \\
\text { depths much below the static water level due to } \\
\text { tendency to become zeolitized (which drastically } \\
\text { reduces permeability) under saturated conditions. }\end{array}$ \\
\hline $\begin{array}{l}\text { upper } \\
\text { tuff confining unit } \\
\text { (UTCU) }\end{array}$ & TCU & Zeolitized bedded tuff & $\begin{array}{l}\text { Tmr (lower } \\
\text { most), Tmrh, } \\
\text { Tp }\end{array}$ & $\begin{array}{l}\text { Defined to encompass the zeolitized bedded tuffs that } \\
\text { stratigraphically overlie the Topopah Spring aquifer } \\
\text { (TSA). Although some geologic units of the UTCU are } \\
\text { laterally continuous with those of the LTCU, the UTCU } \\
\text { is limited areally to extreme southern Yucca Flat, where } \\
\text { the welded Topopah Spring Tuff is an important aquifer } \\
\text { present between the two tuff confining units (UTCU and } \\
\text { LTCU). }\end{array}$ \\
\hline $\begin{array}{l}\text { Topopah Spring } \\
\text { aquifer } \\
\text { (TSA) }\end{array}$ & $\begin{array}{l}\text { WTA } \\
\text { minor }(<15 \%) \\
\text { VTA }\end{array}$ & Welded ash-flow tuff & Tpt & $\begin{array}{l}\text { Distribution in Yucca Flat is limited to the extreme } \\
\text { southern portion, south of the N } 828,000 \text { (NTS) grid } \\
\text { line. Hydrogeologic properties are similar to those of } \\
\text { the TM-WTA. }\end{array}$ \\
\hline $\begin{array}{l}\text { lower vitric tuff aquifer } \\
\text { (LVTA) }\end{array}$ & VTA & $\begin{array}{l}\text { Nonwelded and bedded } \\
\text { ash-flow tuff; vitric }\end{array}$ & Th & $\begin{array}{l}\text { Relatively thin VTA unit below the TSA. Grouped with } \\
\text { the TM-LVTA where TSA is not present. }\end{array}$ \\
\hline $\begin{array}{l}\text { Belted Range aquifer } \\
\text { (BRA) }\end{array}$ & WTA & Welded ash-flow tuff & Tbg & $\begin{array}{l}\text { Typically saturated (perched water) only in the Rainier } \\
\text { Mesa area. This HSU includes only welded Grouse } \\
\text { Canyon Tuff and is limited to the northern portion of the } \\
\text { Yucca Flat model area. }\end{array}$ \\
\hline $\begin{array}{l}\text { Belted Range } \\
\text { confining unit } \\
\text { (BRCU) }\end{array}$ & TCU & Zeolitized bedded tuff & Tn, Tn4, Tn3 & $\begin{array}{l}\text { Generally includes all zeolitized tuffs between the } \\
\text { (welded) Grouse Canyon Tuff and the (welded) Tub } \\
\text { Spring Tuff. Limited to the northern Yucca Flat } \\
\text { extension area. }\end{array}$ \\
\hline
\end{tabular}


Table 4-4

Hydrostratigraphic Units of the Yucca Flat-Climax Mine Hydrostratigraphic Framework Model (continued)

\begin{tabular}{|c|c|c|c|c|}
\hline $\begin{array}{l}\text { Hydrostratigraphic } \\
\text { Unit }\end{array}$ & $\begin{array}{c}\text { Dominant } \\
\text { Hydrogeologic } \\
\text { Units }^{\text {a }}\end{array}$ & Typical Lithologies & $\begin{array}{l}\text { Stratigraphic } \\
\text { Unit Map } \\
\text { Symbol(s) }\end{array}$ & Hydrologic Significance \\
\hline $\begin{array}{l}\text { pre-Grouse Canyon } \\
\text { Tuff lava-flow aquifer } \\
\text { (PRETBG) }\end{array}$ & LFA & Lava flow & Tbq, Tuo & $\begin{array}{l}\text { Defined to include all the comendite lava flows } \\
\text { emplaced before the Grouse Canyon Tuff but after the } \\
\text { Tub Spring Tuff. Limited to the northern Yucca Flat } \\
\text { extension area. }\end{array}$ \\
\hline $\begin{array}{l}\text { Tub Spring aquifer } \\
\text { (TUBA) }\end{array}$ & WTA & Welded ash-flow tuff & Tub & $\begin{array}{l}\text { Comprises only the welded Tub Spring Tuff and is thus } \\
\text { limited to the northern Yucca Flat extension area. }\end{array}$ \\
\hline $\begin{array}{l}\text { pre-Grouse Canyon } \\
\text { Tuff lava-flow } \\
\text { aquifer } 1 \\
\text { (PRETBG1) }\end{array}$ & LFA & Lava flow & Tue & $\begin{array}{l}\text { Defined to include all the comendite lava flows } \\
\text { emplaced before the Tub Spring Tuff but after the older } \\
\text { Tunnel beds. Limited to the northern Yucca Flat } \\
\text { extension area. Hydrogeologically equivalent to the } \\
\text { PRETBG. }\end{array}$ \\
\hline $\begin{array}{l}\text { lower } \\
\text { tuff confining unit } \\
(\text { LTCU) }\end{array}$ & TCU & $\begin{array}{l}\text { Zeolitized bedded tuff with } \\
\text { interbedded but less } \\
\text { significant zeolitized, } \\
\text { nonwelded to partially } \\
\text { welded ash-flow tuff }\end{array}$ & $\begin{array}{l}\text { Tmrh, Tp, Th, } \\
\text { Tw, Tc, Tn, } \\
\text { Tub, Ton2, To, } \\
\text { Tlt }\end{array}$ & $\begin{array}{l}\text { Generally includes all zeolitized tuff in the Yucca Flat } \\
\text { area. Stratigraphically the LTCU may include all units } \\
\text { from the base of the Rainier Mesa Tuff to the top of the } \\
\text { Paleozoic rocks. The strongly argillized older tuffs and } \\
\text { paleocolluvium that immediately overlie the pre-Tertiary } \\
\text { rocks may also be included. The uppermost zeolitized } \\
\text { bedded tuffs overlying the TSA in southern Yucca Flat } \\
\text { form a separate HSU (the UTCU). Subdivided in the } \\
\text { Yucca Flat basin (see below). }\end{array}$ \\
\hline $\begin{array}{l}\text { Oak Spring Butte } \\
\text { confining unit } \\
\text { (OSBCU) }\end{array}$ & TCU & $\begin{array}{l}\text { Devitrified to zeolitic non- } \\
\text { to partially welded tuffs } \\
\text { and intervening bedded } \\
\text { tuffs }\end{array}$ & $\begin{array}{l}\text { Ton, To, Toy, } \\
\text { Tor, Tot }\end{array}$ & $\begin{array}{l}\text { Includes altered older ash-flow tuff units and Tunnel } \\
\text { beds } 1 \text { and } 2 \text {. Welding in the older ash flow units may } \\
\text { increase overall hydraulic conductivity. Devitrification of } \\
\text { the ash flow units may have limited zeolitization. } \\
\text { Differentiated in the Yucca Flat basin. }\end{array}$ \\
\hline $\begin{array}{l}\text { argillic tuff } \\
\text { confining unit } \\
\text { (ATCU) }\end{array}$ & TCU & $\begin{array}{l}\text { Argillic bedded tuff, minor } \\
\text { paleocolluvium }\end{array}$ & To, Tlt & $\begin{array}{l}\text { Includes the argillic, lowermost Tertiary volcanic units } \\
\text { and paleocolluvium that immediately overlie the pre- } \\
\text { Tertiary rocks. Differentiated in the Yucca flat basin. }\end{array}$ \\
\hline
\end{tabular}


Table 4-4

Hydrostratigraphic Units of the Yucca Flat-Climax Mine Hydrostratigraphic Framework Model (continued)

\begin{tabular}{|c|c|c|c|c|}
\hline $\begin{array}{c}\text { Hydrostratigraphic } \\
\text { Unit }\end{array}$ & $\begin{array}{c}\text { Dominant } \\
\text { Hydrogeologic } \\
\text { Units }^{\text {a }} \\
\end{array}$ & Typical Lithologies & $\begin{array}{l}\text { Stratigraphic } \\
\text { Unit Map } \\
\text { Symbol(s) } \\
\end{array}$ & Hydrologic Significance \\
\hline $\begin{array}{l}\text { volcaniclastic } \\
\text { confining unit } \\
\text { (VCU) }\end{array}$ & $\begin{array}{l}\text { In Yucca Flat } \\
\text { model: } \\
80 \% \text { AA } \\
20 \% \text { TCU }\end{array}$ & $\begin{array}{l}\text { Sandy gravel, siltstone, } \\
\text { and tuffaceous sandstone }\end{array}$ & Tgp, Tgw & $\begin{array}{l}\text { Older Tertiary-age sedimentary rocks of variable } \\
\text { lithologies. Present in the southeastern corner of the } \\
\text { Yucca Flat model area, but is a significant HSU in the } \\
\text { Frenchman Flat model area (BN, 2005a). Similar to AA } \\
\text { in the Yucca Flat model, but name retained to correlate } \\
\text { with the Frenchman Flat model in the area of overlap. }\end{array}$ \\
\hline $\begin{array}{l}\text { lower clastic } \\
\text { confining unit - Yucca } \\
\text { Flat upper plate } \\
\text { (LCCU1 and 2) }\end{array}$ & $\mathrm{CCU}$ & Quartzite and siltstone & $\begin{array}{l}\text { Lower Cc, Cz, } \\
\text { CZw, Zs, Zj }\end{array}$ & $\begin{array}{l}\text { Includes Proterozoic through lower Cambrian units that } \\
\text { have been thrust over younger units. }\end{array}$ \\
\hline $\begin{array}{l}\text { upper } \\
\text { carbonate aquifer } \\
\text { (UCA) }\end{array}$ & CA & Limestone & PPt & $\begin{array}{l}\text { Includes the Tippipah Limestone (correlative with the } \\
\text { Bird Spring Formation) which stratigraphically overlies } \\
\text { the Chainman Shale at Syncline Ridge and thus may } \\
\text { contain perched water. }\end{array}$ \\
\hline $\begin{array}{l}\text { upper clastic } \\
\text { confining unit } \\
\text { (UCCU) }\end{array}$ & $\mathrm{CCU}$ & Argillite and quartzite & Mc, MDe & $\begin{array}{l}\text { As much as } 2,745 \mathrm{~m}(9,000 \mathrm{ft}) \text { thick. Typically forms } \\
\text { foot walls of Mesozoic thrust faults in NTS region. } \\
\text { Limited areal extent (western Yucca Flat and portions of } \\
\text { CP Basin). }\end{array}$ \\
\hline
\end{tabular}


Table 4-4

Hydrostratigraphic Units of the Yucca Flat-Climax Mine Hydrostratigraphic Framework Model (continued)

\begin{tabular}{||c|c|c|c|c||}
\hline $\begin{array}{c}\text { Hydrostratigraphic } \\
\text { Unit }\end{array}$ & $\begin{array}{c}\text { Dominant } \\
\text { Hydrogeologic } \\
\text { Units }^{\text {a }}\end{array}$ & Typical Lithologies & $\begin{array}{c}\text { Stratigraphic } \\
\text { Unit Map } \\
\text { Symbol(s) }\end{array}$ & Hydrologic Significance \\
\hline \hline $\begin{array}{c}\text { lower carbonate } \\
\text { aquifer (LCA) }\end{array}$ & $\mathrm{CA}$ & Dolomite and limestone & $\begin{array}{c}\text { Dg through } \\
\text { upper Cc }\end{array}$ & $\begin{array}{l}\text { Important regional aquifer underlying most of southern } \\
\text { Nevada. Composite thickness up to 4,430 m } \\
\text { (14,500 ft). Transmissivity values differ greatly and are } \\
\text { directly dependent on fracture and fault frequency. }\end{array}$ \\
\hline $\begin{array}{c}\text { lower clastic confining } \\
\text { unit } \\
(\mathrm{LCCU})\end{array}$ & $\mathrm{CCU}$ & Quartzite and siltstone & $\begin{array}{c}\text { Lower Cc, Cz, } \\
\text { CZw, Zs, Zj }\end{array}$ & $\begin{array}{l}\text { Significant regional confining unit. Composite thickness } \\
\text { about 2,870 m (9,400 ft). May present barrier to deep } \\
\text { regional groundwater flow where structurally high. } \\
\text { (e.g., northeastern Yucca Flat). }\end{array}$ \\
\hline
\end{tabular}

a See Table 4-3 for definitions of hydrogeologic units.

$\stackrel{f}{\stackrel{b}{a}}$ b See Tables 4-1 and 4-2 for definitions of stratigraphic unit map symbols. 
Table 4-5

Correlation of Hydrostratigraphic Units of the Yucca Flat-Climax Mine Model and Earlier Models

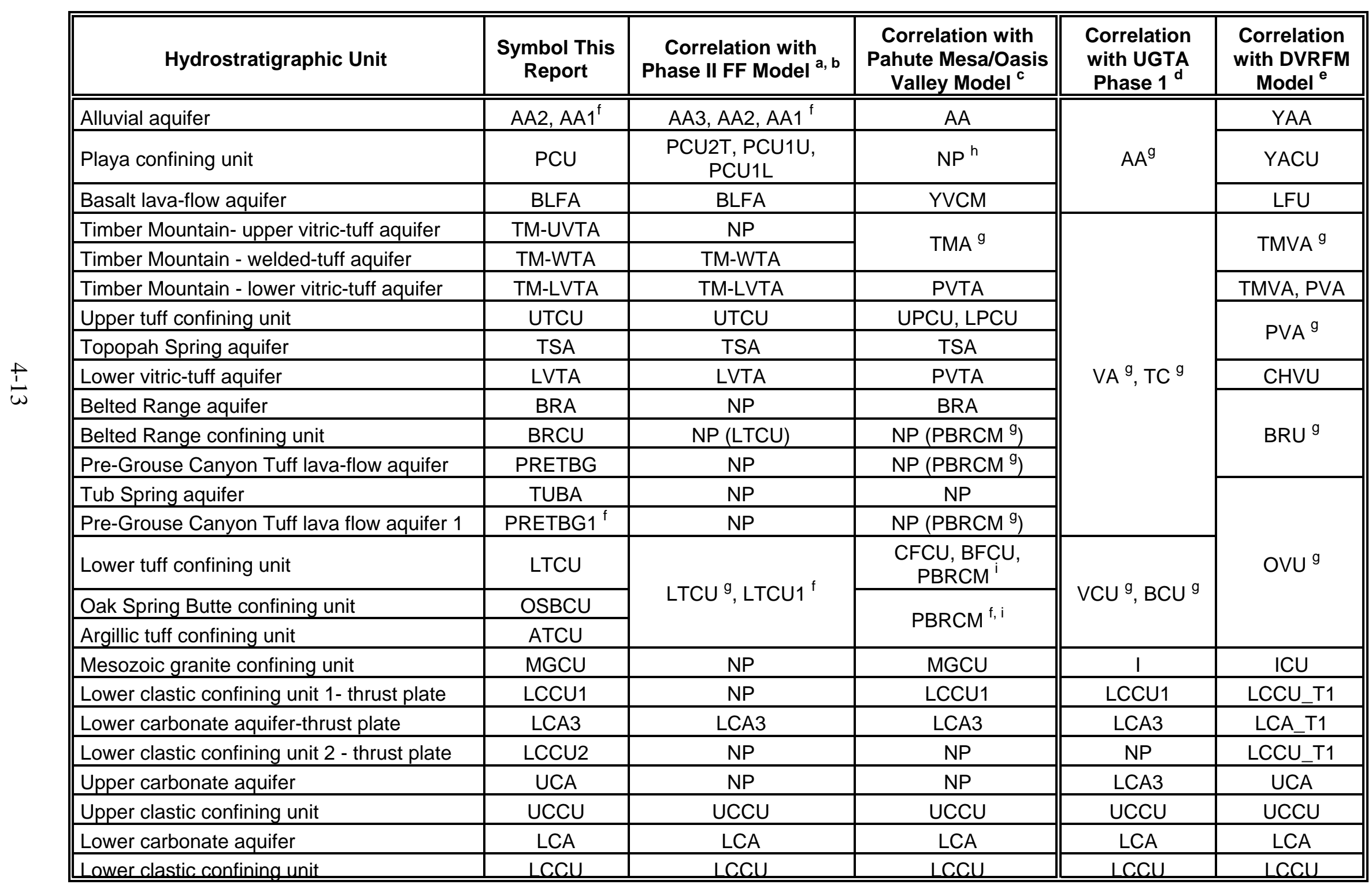




\section{Table 4-5}

Correlation of Hydrostratigraphic Units of the Yucca Flat-Climax Mine Model and Earlier Models (continued)

\section{Explanation}

a If correlative to more than one HSU, all HSUs are listed.

b See BN (2005) for explanation of Frenchman Flat HSU nomenclature.

c See BN (2002a) for explanation of Pahute Mesa/Oasis Valley HSU nomenclature.

d See IT (1996a) for explanation of the UGTA Phase I HSU nomenclature.

e See Belcher (2004) for explanation of the Death Valley Regional Flow Model nomenclature.

f Subdivisions, though hydrogeologically equivalent, are necessary to satisfy operational requirements of the EarthVision ${ }^{\circledR}$ modeling software.

g Not subdivided.

h Not present.

i PBRCM may included minor embedded ash-flow tuffs. 
the Yucca Flat-Climax Mine model area is depicted graphically in Figure 4-2. Figure 4-3 is a HSU surface map (see also Plate 2, the same map produced at a larger scale). Profiles A-A' through E-E', which illustrate the relationships of the HSUs and structures in various vertical planes, can be found in Appendix C. The locations of these profile lines are shown on Plate 2 and on the "depth to" maps at the end of this section.

\subsubsection{Alluvial Aquifer (AA, AA3, AA2, AA1)}

This HSU consists of Quaternary- and Tertiary-age basin-filling alluvium such as that mapped at the surface in the central portions of Yucca Flat (Qay, Qa, and QTa in Slate et al., 1999)

(Figure 1-4; Plate 1 and Figure 4-3). Although the AA is considered the highest (i.e., youngest) HSU in the model, stratigraphically, it consists of alluvial debris as young as recent alluvium found in active drainages, and as old as tuffaceous gravels that may correlate timestratigraphically with the volcanic units of the Thirsty Canyon Group, approximately 9 Ma (Sawyer et al., 1994).

The alluvium in Yucca Flat is a friable to moderately consolidated, poorly sorted mixture of detritus derived from volcanic and Paleozoic sedimentary rocks, ranging in particle size from clay to boulders. Sediment deposition is largely in the form of alluvial fans which coalesce to form discontinuous, gradational, and poorly sorted deposits. Eolian sand, basalt lava flows, and playa deposits are also present within the alluvium section. Basalt lava flows and playa deposits have been designated as separate HSUs in the Yucca Flat-Climax Mine base model and are discussed in following subsections.

The alluvial aquifer is an important aquifer in Yucca Flat because many of the UGTs were conducted in this unit, and it is thick and extensive within much of the model area. In the central portion of the model area significant sections of the AA are saturated (Profiles D-D' and E-E'). Where saturated, the unit is considered an aquifer due to its relatively high hydraulic conductivity. High hydraulic conductivity and specific capacity values have been measured in NTS wells completed within the AA (e.g., Water Wells 5a, 5b, and 5c in Frenchman Flat [Claassen, 1973; IT, 1996b]; Well A, Well 3 [IT, 1996b], and Well ER-3-2 in Yucca Flat [DOE, 1995b]). However, the more tuffaceous intervals within the AA may have zeolitic alteration that could locally reduce the unit's ability to transmit water. The AA is $1,161 \mathrm{~m}(3,810 \mathrm{ft})$ thick at borehole UE-6d (Drellack and Thompson, 1990) on the down-thrown side of the Topgallant fault in south-central Yucca Flat. On the east side of the Yucca fault, the thickest alluvium is about

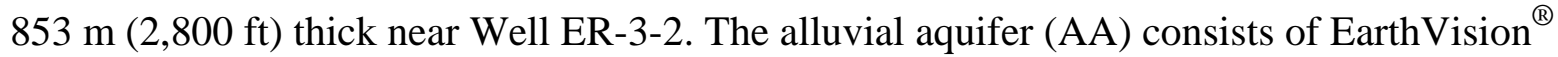
model layers AA1, AA2, and AA3. These layers are equivalent hydrogeologically except for position relative to other HSUs imbedded within the alluvial section (Figure 4-4). Such 
subdivisions are necessary to satisfy operational requirements of the EarthVision ${ }^{\circledR}$ software. The extent of the combined alluvial aquifers is shown in Figure 4-5.

\subsubsection{Playa Confining Unit (PCUT)}

There are three playas within the model area: Yucca Lake, Papoose Lake and an unnamed playa in south-eastern West Emigrant Valley (Plate 1). Yucca Lake is a prominent playa in the southern portion of Yucca Flat. The playa deposits are mainly clayey silt, but may also contain interbeds of sand and pumice. The playa deposits behave as an aquitard due to the abundance of silt and clay (Winograd and Thordarson, 1975). These playa deposits are designated PCUT in the hydrostratigraphic framework model. The Yucca Lake PCUT is the thickest, at approximately $244 \mathrm{~m}(800 \mathrm{ft})$. The relationship of the PCUT with the alluvial aquifer is shown in Figure 4-4. The extent of the PCUT is shown in Figure 4-6.

\subsubsection{Basalt Lava-Flow Aquifer (BLFA)}

Basalt was encountered within the alluvial section beneath the western portion of Yucca Flat in drill holes UE-1h and UE-1j (Drellack and Thompson, 1990). Basalt lava flows, sills, and dikes are also present in the northern portion of the Halfpint Range, along the eastern side of Yucca Flat (Byers and Barnes, 1967). The flows at these outcrops and in the Yucca Flat subsurface are unsaturated but are included in the model for completeness.

Because dense volcanic rocks like basalt tend to be highly fractured at the NTS, the basalt beneath Yucca Flat likely has hydraulic properties considerably different than that of the surrounding alluvium. Therefore, the basalt was modeled as a separate HSU called the basalt lava-flow aquifer (BLFA). This HSU includes all of the basalt occurrences beneath Yucca Flat. Figure 4-6 shows the distribution of the BLFA, and the relationship of the BLFA with the various alluvial aquifers is shown in Figure 4-4.

\subsubsection{Timber Mountain Hydrostratigraphic Units}

The Timber Mountain HSUs consists largely of rocks that are stratigraphically assigned to the Rainier Mesa Tuff and the younger Ammonia Tanks Tuff, both formations of the Timber Mountain Group (Figure 4-2). These rocks were erupted from the Rainier Mesa and Ammonia Tanks calderas, and deposited as outflow sheets and ash-fall deposits in areas outside of the margins of the calderas. For hydrostratigraphic purposes the unaltered bedded tuffs immediately underlying the Timber Mountain Group units are included with the Timber Mountain HSUs. Lithologically, the Timber Mountain HSUs consist mostly of welded ash-flow tuff and lesser amounts of vitric (i.e., unaltered) nonwelded ash-flow tuff and bedded tuff. 
The hydrology of this part of the geologic section is complicated by the presence of one or more ash-flow tuff units that are quite variable in properties both vertically and laterally. The unaltered volcanic rocks of the Timber Mountain Group within the Yucca Flat-Climax Mine model area are divided into three HSUs to help address this complexity. The Timber Mountain Group includes ash-flow tuffs that might be either welded-tuff aquifers or vitric-tuff aquifers, depending on the degree of welding. Where the Rainier Mesa Tuff is less than about $76 \mathrm{~m}$ $(250 \mathrm{ft})$ thick the formation is typically poorly welded, and the entire unit is classified as the Timber Mountain lower vitric-tuff aquifer (TM-LVTA). In locations where the Rainier Mesa

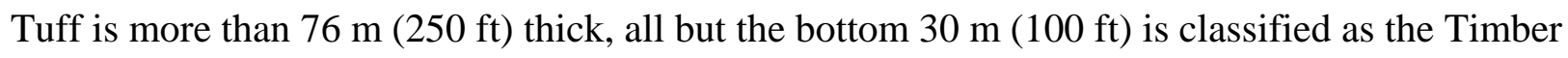
Mountain welded-tuff aquifer (TM-WTA), and the bottom $30 \mathrm{~m}$ (100 ft) of nonwelded ash-flow tuff is generally included in the TM-LVTA. The overlying Ammonia Tanks Tuff is included with the TM-WTA when either Ammonia Tanks Tuff or Rainier Mesa Tuff is sufficiently thick to be welded. Where the Ammonia Tanks Tuff is not welded and the Rainier Mesa Tuff is welded (i.e., TM-WTA), the Ammonia Tanks Tuff is considered to be a vitric-tuff aquifer, and is designated as the TM-UVTA. The relationship of these HSUs is depicted in Figure 4-7.

The thicknesses of the TM-UVTA, TM-WTA, and TM-LVTA in the central portion of the model area are well constrained where numerous drill holes penetrate them. In this area the Timber Mountain volcanic aquifers are as much as $260 \mathrm{~m}(850 \mathrm{ft})$ thick.

The designation of the these units as aquifers is based on the predominance of welded tuff (which is assumed to be fractured and transmissive) and unaltered, nonwelded and bedded tuff. This designation is consistent with water production data from Water Wells 4 and 4a in CP Basin (Reiner, 2002). Other hydrologic data from outflow sheets of welded Ammonia Tanks and Rainier Mesa Tuff outside of the model area but near Yucca Flat (e.g., in Well ER-5-3\#2 located in northern Frenchman Flat [DOE, 2005]) indicate these units are significant aquifers where saturated (IT, 1996c and BN, 2005a).

\subsubsection{Timber Mountain Upper Vitric-Tuff Aquifer (TM-UVTA)}

The TM-UVTA is defined to include the non- to partially welded, nonzeolitized ash-flow and bedded tuffs of the Ammonia Tanks Tuff, which lie above the TM-WTA. The TM-UVTA may include up to 15 percent welded-tuff aquifer in parts, if the welded portions of the Ammonia Tanks ash-flow tuff are inconsistent, thin, or otherwise not mappable. Where the Ammonia Tanks Tuff is consistently welded, it is included with the underlying TM-WTA. These rocks are included in the laterally more extensive TM-LVTA when the TM-WTA is not present, i.e., where the Rainier Mesa Tuff is less than 76 m (250 ft) thick (and thus no welded horizon formed). The upper and lower Timber Mountain vitric-tuff aquifers may be laterally continuous

at the distal nonwelded edges of the Ammonia Tanks Tuff where Timber Mountain Group rocks 
are not welded (see Figure 4-7 for an example of this configuration). It is saturated only in the deeper sub-basins of south-central Yucca Flat (i.e., against the Topgallant fault [Plate 2]). Based on observed lithologic characteristics, its hydraulic properties are probably similar to those of the TM-LVTA. The distribution of the TM-UVTA is shown in Figure 4-8. Figure 4-9 is a contour map showing the depth to this aquifer.

\subsubsection{Timber Mountain Welded-Tuff Aquifer (TM-WTA)}

The TM-WTA also is not an extensive HSU, being generally confined to the central and southcentral portions of Yucca Flat, east of the basin-forming faults. Additionally, in Yucca Flat the Ammonia Tanks and Rainier Mesa Tuffs are saturated only in the deeper portions of the basin. The distribution of the TM-WTA is shown in Figure 4-10. The relationship of the TM-WTA with other Timber Mountain HSUs is depicted in Figure 4-7, and its relationship with other volcanic HSUs in the eastern portion of the model is shown in Figure 4-11 and Figure 4-12. Note that the TM-WTA may contain up to 20 percent vitric-tuff aquifer. This is to accommodate the nonwelded top of the Rainier Mesa Tuff, which is typically thin and not easily mapped for a CAU-scale model. In cases where the overlying Ammonia Tanks Tuff is welded, and therefore included in the TM-WTA (see Section 4.5.4.1), some intervening nonwelded tuff and bedded tuff (the bedded Ammonia Tanks Tuff; see Table 4-1 and Figure 4-1) are necessarily incorporated into the TM-WTA. A contour map showing the depth to the TM-WTA is presented in Figure 4-13.

The extent of the TM-WTA is fairly well constrained (Figure 4-10). Extensive outcrops and numerous drill-hole penetrations in Yucca Flat provide unambiguous information as to its location and hydrogeologic character in the model area. This HSU is a fracture-controlled aquifer, and wells completed in the TM-WTA are highly productive (e.g., Water Wells 4 and 4a in CP Basin and Well ER-5-3 in northern Frenchman Flat [DOE, 2005]).

\subsubsection{Timber Mountain Lower Vitric-Tuff Aquifer (TM-LVTA)}

The TM-LVTA includes all unaltered bedded, ash-fall, reworked tuff, and nonwelded ash-flow tuff units present above the level of pervasive zeolitization in Frenchman and Yucca Flats. However, where welded Topopah Spring Tuff (Paintbrush Group), which forms the Topopah Spring aquifer (TSA), is present, unaltered nonwelded tuffs below the TSA are grouped within a separate HSU called the lower vitric-tuff aquifer (LVTA) (Section 4.5.7). Welded tuffs of the Timber Mountain Group are included in the TM-WTA (Section 4.5.4.2). Stratigraphically, the TM-LVTA typically includes formations of the Timber Mountain Group and Paintbrush Group, but may also include unaltered units within the Calico Hills Formation, Wahmonie Formation, and Crater Flat Group. Older units are generally zeolitized, and are therefore categorized as confining units and placed with the LTCU. 
The TM-LVTA has a larger distribution than the TM-WTA. The distribution of the TM-LVTA is shown in Figure 4-14. The relationship of the TM-LVTA with other volcanic HSUs is shown in Figures 4-7, 4-11, and 4-12. Figure 4-15 is a contour map showing the depth to this aquifer.

In Yucca Flat the TM-LVTA units are saturated only in the deep south-central portion of the basin (Plate 2). The TM-LVTA exhibits significant interstitial porosity, ranging from about 20 to 40 percent. However, because these lithologies tend to be poorly to moderately indurated, fractures are not common. So even though interstitial porosity may be high, transmissivity is not great.

\subsubsection{Upper Tuff Confining Unit (UTCU)}

The zeolitized nonwelded tuffs that overlie the TSA welded-tuff aquifer (Section 4.5.6) in southern Yucca Flat and northern Frenchman Flat are designated as the UTCU.

Stratigraphically, the UTCU includes units from the base of the welded Rainier Mesa Tuff (i.e., TM-WTA) to the top of welded Topopah Spring Tuff (i.e., TSA). The areal extent of the UTCU is therefore the same as for the TSA, and the UTCU is confined to southern Yucca Flat east of the Topgallant fault. The rocks in this HSU are equivalent stratigraphically and hydrogeologically to the upper portion of the LTCU outside the extent of the underlying TSA (see Figure 4-17). This subdivision is necessary to satisfy operational requirements of the EarthVision ${ }^{\circledR}$ software. The distribution of the UTCU in the Yucca Flat-Climax Mine Flat model area is shown in Figure 4-16. The relationship of the UTCU with other volcanic HSUs is shown in Figure 4-17.

In Yucca Flat, the UTCU is mostly saturated except for a narrow area around the basin perimeter. The hydrologic properties of the two tuff confining units (the UTCU and the LTCU; see Section 4.5.12 below) are considered to be essentially identical. The UTCU at Well ER-5-3\#2 in northern Frenchman Flat produced only a few liters of water per minute and behaved as an aquitard separating the overlying TM-WTA and the underlying TSA, both of which produced abundant water (DOE, 2005).

\subsubsection{Topopah Spring Aquifer (TSA)}

The TSA consists of a single welded-tuff aquifer composed of welded ash-flow tuff of the Yucca/Frenchman Flat lobe of the Topopah Spring Tuff, a formation of the Paintbrush Group (Figure 4-2). The TSA may also contain up to 15 percent vitric-tuff aquifer, which represents the nonwelded top and base of this generally welded ash-flow tuff. The unit is saturated and has a distribution limited to extreme southern Yucca Flat east of the Topgallant fault, and Mid Valley. The relationship of the TSA with other volcanic HSUs is shown in Figure 4-17. The 
distribution of the TSA is shown in Figure 4-18. Figure 4-19 is a contour map showing the depth to this aquifer.

The TSA is typically well fractured and therefore highly transmissive. Overall, the hydraulic properties of the TSA are similar to those of the TM-WTA (see Section 4.5.4.2).

\subsubsection{Lower Vitric-Tuff Aquifer (LVTA)}

The LVTA includes all unaltered bedded, ash-fall, reworked tuff, and nonwelded ash-flow tuff units below the TSA and above the level of pervasive zeolitization in Yucca Flat. The LVTA is only differentiated where the TSA is present; these rocks would otherwise be included in the TM-LVTA (Figure 4-2). Overlying welded tuffs are included in the TSA welded-tuff aquifer (Section 4.5.6). Stratigraphically, the LVTA may include members of the Calico Hills and Wahmonie Formations, and formations of the Crater Flat Group. Older units are generally zeolitized, and are therefore categorized as confining units and assigned to the LTCU.

The relationship of the LVTA with other HSUs is shown in Figure 4-12. The distribution of the LVTA is shown in Figure 4-20. Figure 4-21 is a contour map showing the depth to this aquifer.

The LVTA exhibits significant interstitial porosity, ranging from about 20 to 40 percent. However, because these lithologies tend to be poorly to moderately indurated, fractures are not common. So, even though interstitial porosity may be high, transmissivity is not great. The LVTA is not saturated in the Yucca Flat-Climax Mine model area.

\subsubsection{Belted Range Aquifer (BRA)}

The Belted Range aquifer (BRA) consists of a single welded-tuff aquifer composed of peralkaline, welded ash-flow tuff of the Grouse Canyon Tuff formation. Within Yucca Flat the Grouse Canyon Tuff is an ash-fall tuff. Where it is vitric (typically northern Yucca Flat) it is included in the overlying TM-LVTA. Where it is zeolitized (typically southern Yucca Flat) it is included with the underlying LTCU. However, the welded ash-flow tuff lithofacies of the Grouse Canyon Tuff is present in the northern extension area (in the Belted Range just north of Yucca Flat [Figure 4-22]), and the BRA was established to address this mappable HGU. The relationship of the BRA with other units in shown in Figure 4-23. Figure 4-24 is a contour map showing the depth to this aquifer. The unit is typically unsaturated.

\subsubsection{Belted Range Confining Unit (BRCU)}

The Belted Range confining unit (BRCU) generally consists of zeolitized bedded and nonwelded tuffs that occur between the welded ash-flow tuff lithofacies of the Grouse Canyon Tuff (BRA) above and the Tub Spring Tuff (TUBA) below, or above the pre-Grouse Canyon Tuff 
lava-flow aquifer (PRETBG; Section 4.5.10) where the Tub Spring Tuff is absent. The upper part of this unit is locally vitric, but the unit is usually unsaturated. Hydrologically, this tuff confining unit would behave similarly to the UTCU (Section 4.5.5) and the LTCU (Section 4.5.12). Figure 4-25 shows the distribution of the BRCU. The relationship of the BRCU with other HSUs is shown in Figure 4-23.

\subsubsection{Pre-Grouse Canyon Tuff Lava-Flow Aquifer (PRETBG and PRETBG1)}

The PRETBG and PRETBG1 consist of peralkaline lava flows erupted in the area north of Yucca Flat before the Grouse Canyon Tuff. This is not an extensive HSU, consisting of several separate local lava flows (Figure 4-26). It is generally confined to the northwestern portion of the model area. Stratigraphically, the PRETBG is between the Grouse Canyon Tuff and the Tub Spring Tuff. The PRETBG1 is below the Tub Spring Tuff (Figure 4-2). Based on lithologic characteristics, these units are believed to be equivalent hydrogeologically except for position relative to the other HSUs. These subdivisions are necessary to satisfy operation requirements of the EarthVision ${ }^{\circledR}$ software. Figure 4-23 illustrates the discontinuous nature of this HSU.

Only a small portion of the this HSU is saturated, along the northern boundary of the Yucca FlatClimax Mine model area (Plate 2).

\subsubsection{Tub Spring Aquifer (TUBA)}

The TUBA consists only of the welded portion of the Tub Spring Tuff, and is limited to the northern Yucca Flat extension area, where it can be up to 90 meters (300 ft) thick. The TUBA is a fairly extensive HSU in West Emigrant Valley and in the northwestern corner of the model area (Figure 4-27 and Profile B-B'), but it is saturated only in the deeper basins of the area (Plate 2). Its hydraulic properties are similar to those of the BRA and the TM-WTA. A contour map showing the depth to the TUBA is presented in Figure 4-28.

\subsubsection{Lower Tuff Confining Unit (LTCU)}

The LTCU is an important hydrogeologic layer over much of the NTS because it separates the volcanic aquifer units from the underlying regional LCA. Almost all zeolitized tuff units in Yucca Flat and Frenchman Flat are grouped within the LTCU, which comprises mainly zeolitized nonwelded tuff. Stratigraphically, the LTCU may include all the Tertiary volcanic strata from the top of the pre-Tertiary rocks to the base of the Rainier Mesa Tuff (Figure 4-2). However, in the Yucca Flat basin the zeolitized tuffs are divided into three separate HSUs, based on their mineralogy (Section 2.3.10.1). These include the LTCU, the OSBCU (Section 4.5.13), and the ATCU (Section 4.5.14). The OSBCU and ATCU are not differentiated as separate HSUs in the surrounding highlands, where they are included in the LTCU. 
The LTCU is not present on the buried ridge beneath the western portion of Yucca Flat or in the western sub-basin, mainly because of the scarcity of volcanic rocks in those areas as well as the lack of zeolitic alteration due to the relatively high structural elevation. The distribution of the LTCU is shown in Figure 4-29. The relationship of the LTCU, OSBCU, and the ATCU is shown in Figure 4-17.

The LTCU is saturated in much of Yucca Flat, however, measured transmissivities are very low (Hawkins et al., 1989).

\subsubsection{Oak Spring Butte Confining Unit (OSBCU)}

The OSBCU consists of zeolitic tuffs and tuffaceous sediments that occur stratigraphically below the Tub Spring Tuff beneath Yucca Flat. Most of the units composing the OSBCU are stratigraphically assigned to the Volcanics of Oak Spring Butte (Table 4-1 and Figure 4-2), and include such formations as Tunnel beds 1 and 2, Yucca Flat Tuff, Redrock Valley Tuff, and Tuff of Twin Peaks. Although the OSBCU can include all stratigraphic units from the top of the Volcanics of Oak Spring Butte (base of the Tub Spring Tuff) to the top of pre-Tertiary rocks, the basal portion of the Tertiary section beneath Yucca Flat is commonly argillized, and these argillic rocks are assigned hydrostratigraphically to the ATCU (Section 4.5.14).

Lithologically, the OSBCU includes zeolitic bedded tuff, ash-flow tuff, tuffaceous sandstone, and tuffaceous paleocolluvium. The relatively diverse lithologic composition of the OSBCU, particularly the presence of devitrified ash-flow tuff, may result in hydrologic properties somewhat different than those for the more lithologically homogeneous confining HSUs such as the LTCU. In addition, the lithologic diversity of the OSBCU results in a more diverse mineralogy that may have important ramifications with regard to retarding radionuclides via sorption and ion exchange processes (Prothro, 2005a).

The OSBCU is modeled only within the main Yucca Flat basin beneath the eastern half of Yucca Flat (Figure 4-30 and Plate 2). Within the main Yucca Flat basin, where numerous drill holes penetrate the unit, the OSBCU is thick and extensive, commonly attaining thicknesses greater than $200 \mathrm{~m}$ (650 ft). Also, within the main basin the unit is typically saturated. Equivalent rocks that occur outside of the main Yucca Flat basin are included within the LTCU where the rocks are altered and within the TM-LVTA where they are unaltered.

\subsubsection{Argillic Tuff Confining Unit (ATCU)}

Volcanic rocks and tuffaceous sediments that occur at the base of the Tertiary section beneath Yucca Flat are commonly argillized (Prothro, 2005a), and are assigned to the ATCU. The ATCU typically includes the oldest Tertiary-age units that lie directly on top of pre-Tertiary 
rocks beneath Yucca Flat. Lithologically, the ATCU includes highly argillized bedded tuff, ashflow tuff, tuffaceous sediments, and paleocolluvium.

The ATCU is modeled only within the main Yucca Flat basin and the western sub-basin (Figure 4-31). The unit is typically saturated and laterally extensive in both basins where it is generally less than $100 \mathrm{~m}$ (328 ft) thick. Equivalent argillized rocks that occur outside of Yucca Flat are included within the LTCU.

\subsubsection{Volcaniclastic Confining Unit (VCU)}

The older Tertiary sedimentary rocks that are exposed in southern Frenchman Flat and in the southeastern portion of the Yucca Flat model area are divided into two formations: Rocks of Winapi Wash (Yount, 1996) and the younger, more extensive, Rocks of Pavits Spring (Prothro and Drellack, 1997a). These units consist of a diverse assemblage of interbedded volcanic and sedimentary rocks deposited primarily in lacustrine and fluvial environments. Specific lithologies include ash-flow tuff, ash-fall tuff, and reworked tuff; shale; tuffaceous sandstone and argillaceous sandstone; siltstone and mudstone; conglomerate; and lesser limestone (Hinrichs, 1968; Barnes et al., 1982; Bohanon, 1984).

The Tertiary sedimentary rocks as a whole are believed to behave as a confining unit because of their tuffaceous character, which has a tendency to become zeolitized below the water table, and the abundance of fine-grained clastic rocks (Prothro and Drellack, 1997a). However, the presence of rocks that tend to act as aquifers such as limestone and coarser clastic rocks, might justify their classification as a "leaky” confining unit. Winograd and Thordarson (1975) included these rocks with their "tuff aquitard.” For this UGTA Yucca Flat-Climax Mine CAU work, the Tertiary sedimentary rocks are grouped into a distinct HSU, the VCU. The VCU potentially is a significant HSU in the Frenchman Flat model (BN, 2005a) because of its intervening position between overlying saturated rocks and the LCA. However, these older sediments in the southeastern portion of the Yucca Flat model are unsaturated and therefore are less likely to become zeolitized. The relative proportion of gravels increases to the northeast. Consequently, the hydraulic properties of these rocks in the Yucca Flat model are may be more towards the aquifer category. The VCU name is retained for continuity with the contiguous Frenchman Flat model to the south. The distribution of the VCU in Yucca Flat is shown in Figure 4-32.

\subsubsection{Mesozoic Granite Confining Unit (MGCU)}

The Mesozoic era is represented at the NTS only by intrusive igneous rocks. Cretaceous granitic rocks exposed at the north end of Yucca Flat area are commonly referred to as the Climax stock. This intrusive body, along with the Gold Meadows stock, which lies $12.9 \mathrm{~km}$ (8 mi) west of the 
Climax stock, are probably related in both source and time and, may be connected at depth (Barnes et al., 1963; Snyder, 1977; Bath and Jahren, 1980; Jachens, 1999; Phelps et al., 2004). The Gold Meadows intrusive body consists principally of quartz monzonite

(Houser et al., 1961). However, the Climax stock is a composite granitic intrusive comprising an older medium-grained equigranular granodiorite and a younger fine- to medium-grained, coarsely porphyritic quartz monzonite (Orkild, 1983b; Orkild et al., 1983). Recent re-analyses of magnetic data by Jachens (1999) and Phelps et al. (2004) reaffirm the general geometry and connection at depth of the Climax and Gold Meadows stocks. However, Jachens (1999) states that the very small magnetic anomaly associated with the Twinridge Hill rocks (formerly believed to be a third occurrence of granite at the NTS) suggests that this granitic body is of negligible size in the subsurface. The Yucca Flat-Climax Mine hydrostratigraphic framework model follows this interpretation. The Climax and Gold Meadows intrusives are grouped into the MGCU HSU. The MGCU is saturated at depth but because of low intergranular porosity and permeability, and lack of inter-connecting fractures (Walker, 1962) the MGCU HSU is considered a confining unit.

Figure 4-33 is a schematic west-east cross section showing the Climax granitic intrusive. Figure 4-34 shows the distribution of the MGCU in northern Yucca Flat.

\subsubsection{Lower Clastic Confining Unit 1 - Thrust Plate (LCCU1)}

Northwest of Yucca Flat deformation related to the east-vergent Belted Range thrust fault has placed Proterozoic siliciclastic strata (LCCU) over Devonian and Silurian carbonate rocks (LCA) that in turn have been thrust over Mississippian (UCCU) strata (Cole and Cashman, 1998). Although the upper plate includes some of the same units as the regional clastic confining unit (i.e., LCCU), its position above younger HSUs requires that it be distinguished from the LCCU. Therefore, this HSU is designated LCCU1 and its very limited extent is shown in Figure 4-35.

Fractures in these older siliciclastic sedimentary rocks tend to be healed/sealed with secondary silica. The LCCU rocks, including the over-thrust components, are classified as confining units in UGTA hydrostratigraphic models.

\subsubsection{Lower Carbonate Aquifer - Thrust Plate (LCA3)}

Cambrian through Devonian, mostly carbonate, rocks that form the hanging wall of the CP thrust fault are assigned to the LCA3. Deformation related to the west-vergent CP and east-vergent Belted Range thrust faults has placed these older LCA rocks over younger rocks of the UCCU, and over stratigraphically equivalent LCA rocks (Figure 3-4). Thus, the rocks of LCA3 are stratigraphically equivalent, and probably hydrogeologically similar to the LCA, but are 
structurally separated from the LCA by the CP thrust fault (Section 3.2.1; Profiles B-B' through E-E'). The position of these rocks above the UCCU requires that they be distinguishable in the model from the regional aquifer (LCA). The interpreted extent of the LCA3 in the Yucca Flat model area is shown in Figure 4-36. A contour map showing the depth to the LCA3 is presented in Figure 4-37.

Subsurface control for the LCA3 is poor, with only a few drill holes penetrating this HSU (Appendix A) and even fewer holes penetrating the thrust fault structures. Remnants of thrust plates are mapped in the Carbonate Wash area (Rogers and Noble, 1969), in the Eleana Range (Orkild, 1963), Mine Mountain (Orkild, 1968) and CP Hills (McKeown et al., 1976).

\subsubsection{Lower Clastic Confining Unit 2 - Thrust Plate (LCCU2)}

Along a north-south corridor in western Yucca Flat deformation related to the west-vergent CP thrust fault has placed Proterozoic siliciclastic strata (LCCU) over younger Paleozoic carbonate rocks (LCA) that in turn have been thrust over Mississippian (UCCU) strata (Cole and Cashman, 1998). Although the upper plate includes some of the same units as the regional clastic confining unit, its position above younger HSUs requires that it be distinguished from the LCCU. Therefore, this HSU is designated LCCU2. The three lower clastic confining units (LCCU1, LCCU2, and LCCU) are expected to be hydrologically similar. The north-south configuration of the LCCU2 may affect deep interbasin flow (refer to Profiles C-C' and D-D'). The extent of the LCCU2 is shown in Figure 4-38.

\subsubsection{Upper Carbonate Aquifer (UCA)}

The Tippipah Limestone (believed to be correlative with the Bird Spring Formation of southern Nevada) is the only unit at the NTS known to represent deposition during late Pennsylvanian to Permian time. This unit is found at the surface only at Syncline Ridge (Figure 1-2), though it is believed to underlie a slightly larger area in the subsurface of the western part of Yucca Flat. This unit consists of thick limestone layers interbedded with mudstone and siltstone beds. Surface exposures are highly deformed and fractured. The upper carbonate aquifer (UCA) is present only in areas where the Tippipah Limestone is present. Figure 4-39 shows the distribution of the UCA. A contour map showing the depth to the UCA is presented in Figure 4-40. Perched groundwater is produced from the UCA at Water Well UE-16d, located just west of the model area (Gillespie et al., 1996), averaging approximately 100 acre-feet per year (Fenelon, 2005).

\subsubsection{Upper Clastic Confining Unit (UCCU)}

Late Devonian and Mississippian siliciclastic rocks in the NTS vicinity are assigned to the

Eleana Formation and the Chainman Shale (Cashman and Trexler, 1991; Cashman et al., 2001; 
Trexler et al., 1996). The Eleana Formation as originally defined by Poole et al. (1961) was partitioned by Cashman and Trexler (1991) on the basis of lithofacies variations and sediment source. The shaley lithofacies in the Yucca Flat-Climax Mine model area are now generally grouped in the Chainman Shale, while the section bearing the non-shaley quartzite, sandstone, and conglomeratic lithofacies, retains the original formation name. The Mississippian and Devonian Eleana Formation and the Mississippian Chainman Shale form the UCCU (Figure 4-2) the extent of which is shown on Figure 4-32. The subsurface control for this HSU is also poor, with no drill holes fully penetrating UCCU within the model area. Well ER-12-2 reached TD in the UCCU after penetrating 1,912 m (6,273 ft) of this HSU (DOE, 2004e), and approximately $1,566 \mathrm{~m}(5,139 \mathrm{ft})$ of UCCU was penetrated at Well UE-1d (Fernald et al. 1975). The most recent MT data (Section 2.3.7.4; Appendix D) helped define where this relatively thick and electrically conductive unit is present or absent. The subsurface configuration of this unit and its relation to neraby HSUs are depicted in Profiles B-B' through E-E'.

Hydrologically, the UCCU is very tight, and though saturated in parts of western Yucca Flat, it yields very little water, as found at Well ER-12-2 (DOE, 2004e).

\subsubsection{Lower Carbonate Aquifer (LCA)}

The LCA consists of thick sequences of Middle Cambrian through Upper Devonian carbonate rocks (Figure 4-2). This HSU serves as the regional aquifer for most of southern Nevada, and locally may be as thick as 5,000 m (16,400 ft) (Winograd and Thordarson, 1975; Cole, 1992). The unit consists mostly of dolomite and interbedded limestone but contains thin shale, quartzite, and calcareous clastic units (Burchfiel, 1964; see also Table 4-2). The LCA is exposed in the Halfpint Range on the east side of Yucca Flat (Plate 1). Its extent is shown in Figure 4-41, and a structure contour map showing the depth to the LCA is presented in Figure 4-42.

Measured transmissivity in LCA rocks differs from place to place, apparently reflecting the observed differences in fracture and fault densities and characteristics (Winograd and Thordarson, 1975).

\subsubsection{Lower Clastic Confining Unit (LCCU)}

Proterozoic to Middle Cambrian rocks in the NTS region are largely quartzite and silicacemented siltstone (Barnes et al., 1965; Byers and Barnes, 1967; Barnes, 1962). This section includes the Johnnie Formation, Stirling Quartzite, Wood Canyon Formation, Zabriskie Quartzite, and the lower half of the Carrara Formation (Winograd and Thordarson, 1975). These units make up the LCCU, which is considered to be the regional hydrologic basement (Winograd and Thordarson, 1975; Laczniak et al., 1996; IT, 1996a). The base of the Yucca Flat-Climax Mine model terminates within the LCCU. The composite thickness of the LCCU is about 
2,870 $\mathrm{m}(9,400 \mathrm{ft})$. Although these rocks are brittle and commonly fractured, secondary mineralization seems to have greatly reduced formation permeability (Winograd and Thordarson, 1975). Where it is in a structurally high position, the LCCU may act as a barrier to deep regional groundwater flow. The present structural interpretation for the Yucca Flat-Climax Mine model depicts the LCCU at great depth throughout the model area except in the Halfpint Range anticline. (Profile C-C'). The interpreted extent of the LCCU is shown in Figure 4-43.

\subsection{Relationship of Hydrostratigraphic Units and the Water Table}

The EarthVision ${ }^{\circledR}$ base framework model was electronically "sliced" along a surface that represents the water table (IT, 1996a) to reveal the distribution of HSUs at the water table (Plate 2). Within much of the model area where the LCA is structurally high, such as in the northern, eastern, and northwestern portions, the water table is within the LCA. In scattered areas throughout the central portion of the model area the water table is within the LTCU. Within much of the Yucca Flat basin, the water table is within the volcanic aquifers except in the deepest portion of the basin (south-central Yucca Flat) and in West Emigrant Valley, where it is within the AA. The water table within the UCA along the western edge of the model is considered to be perched above the UCCU. 
This page intentionally left blank. 


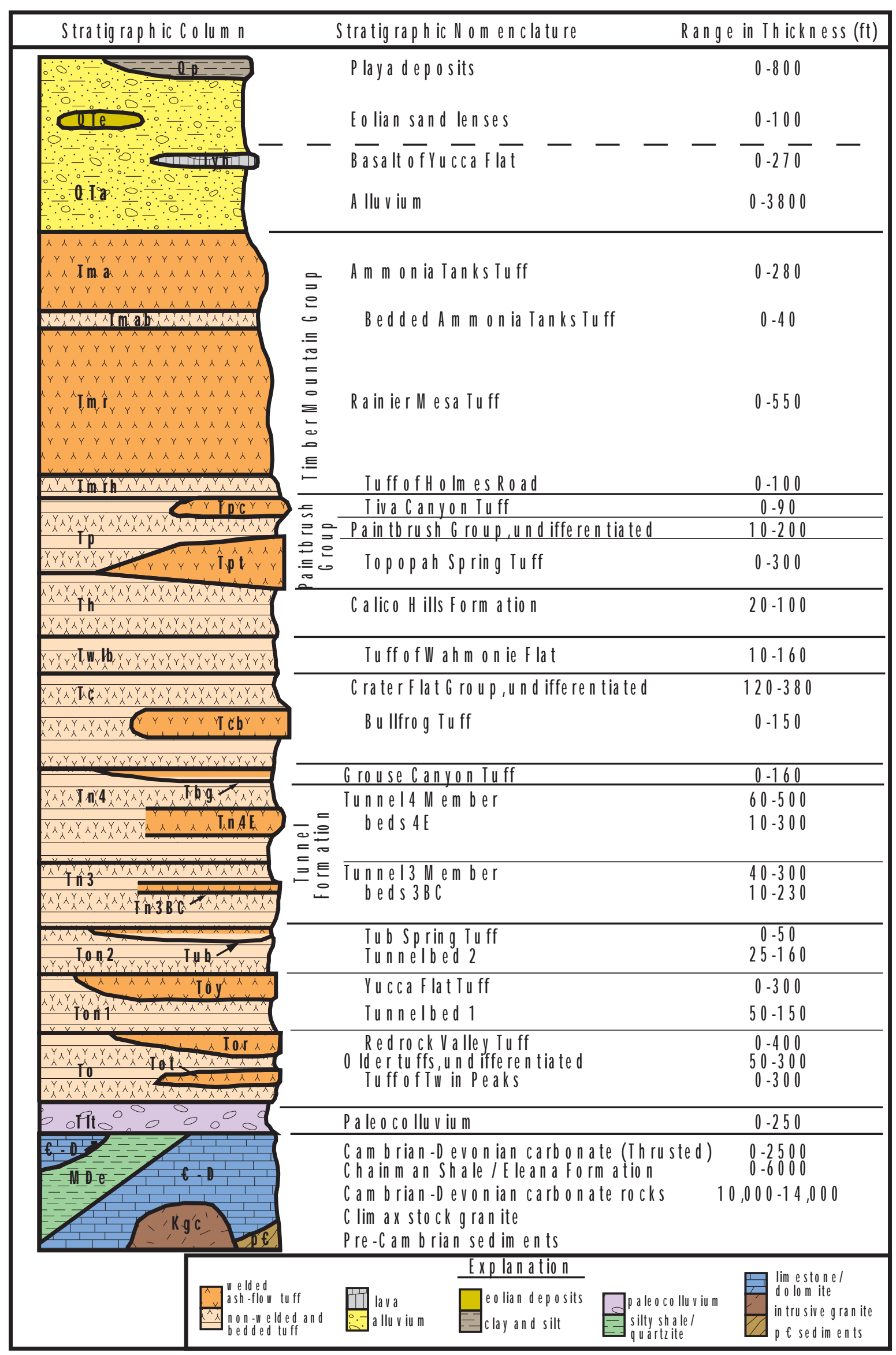

Figure 4-1 


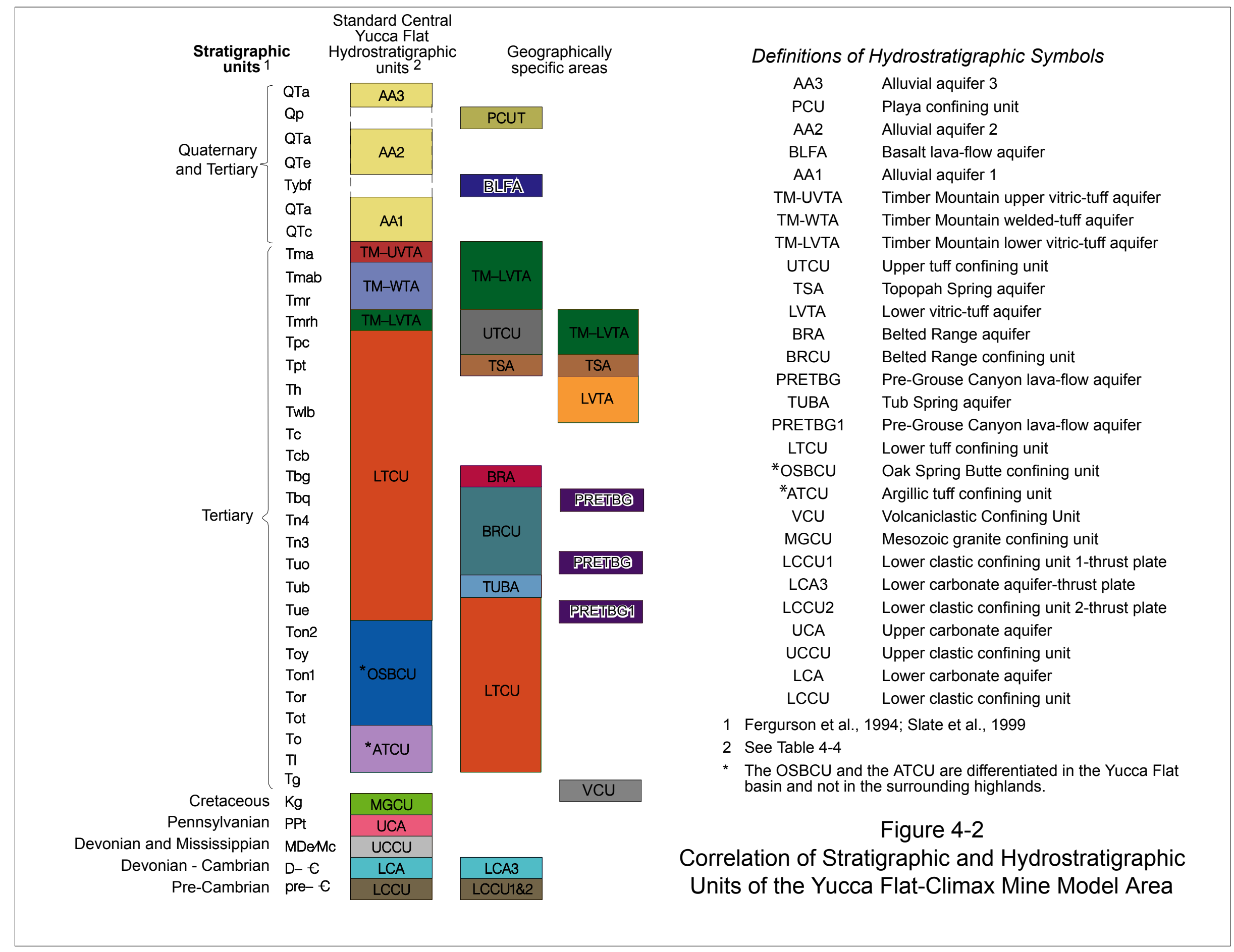




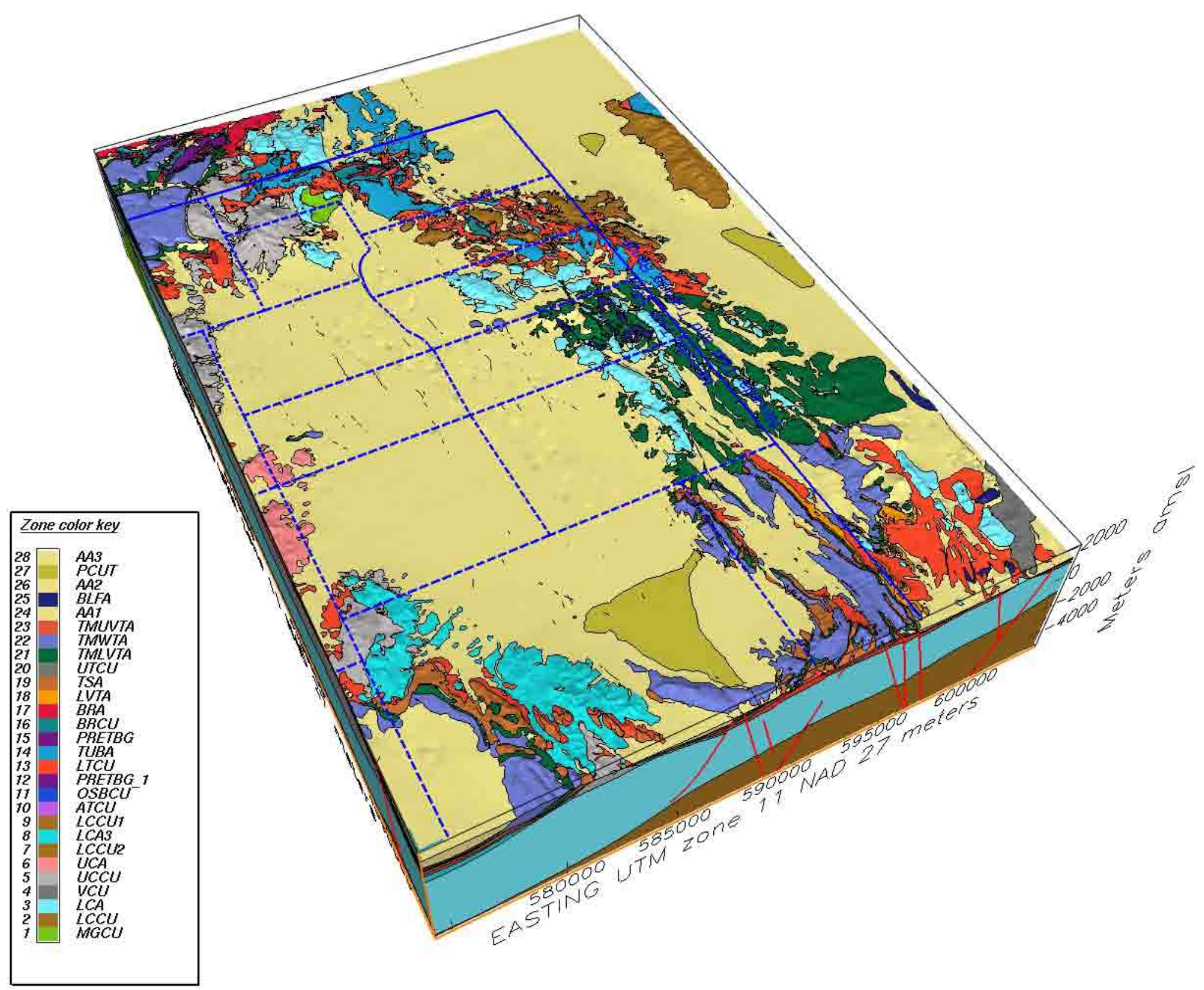

Figure 4-3

Block Model View Showing Hydrostratigraphic Units at the Surface within the Yucca Flat-Climax Mine Model Area 


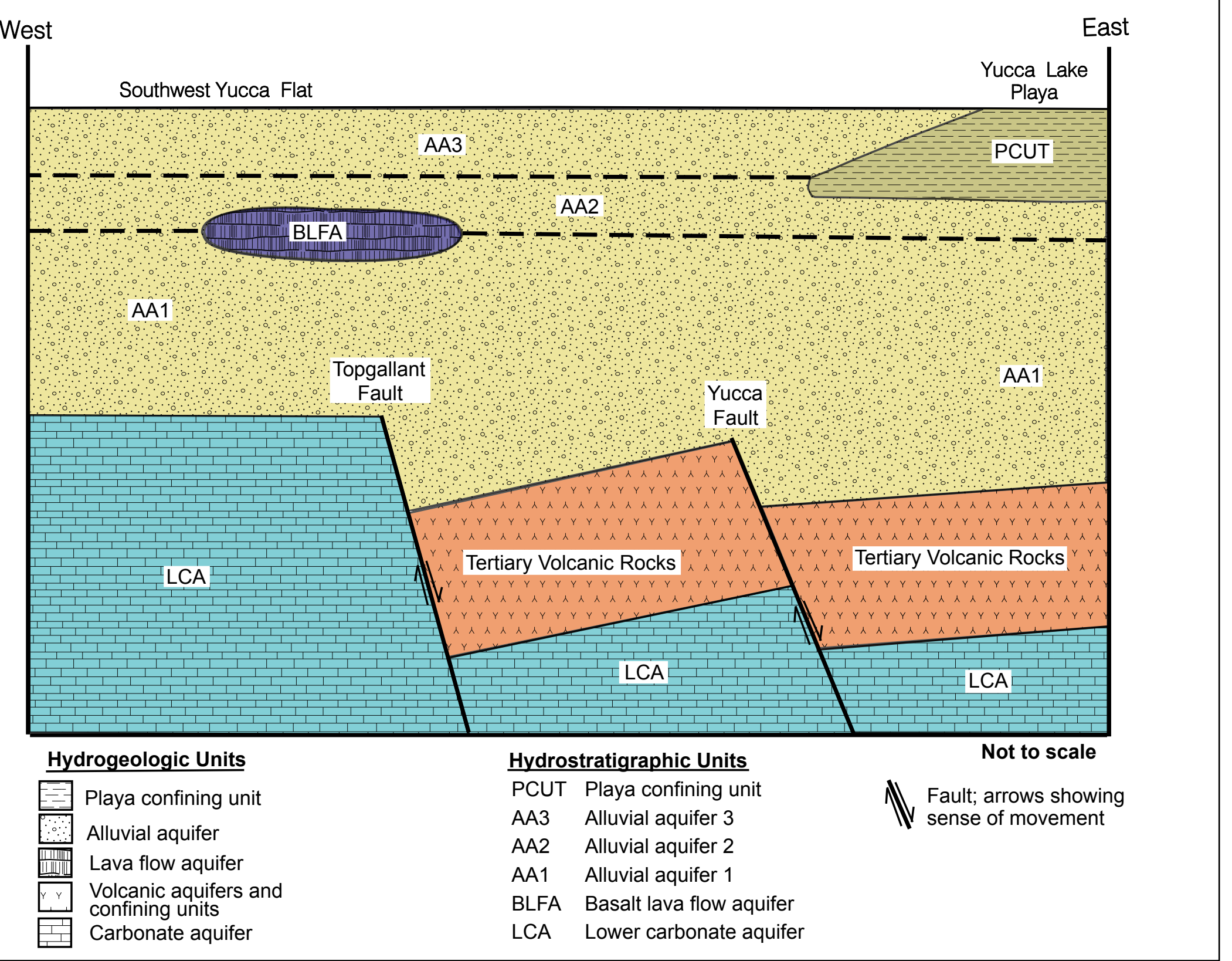

Figure 4-4

Schematic Cross Section through Southern Yucca Flat Showing Relationships Among the Alluvial Aquifers, Playa Confining Unit, and the Basalt Lava Flow Aquifer 


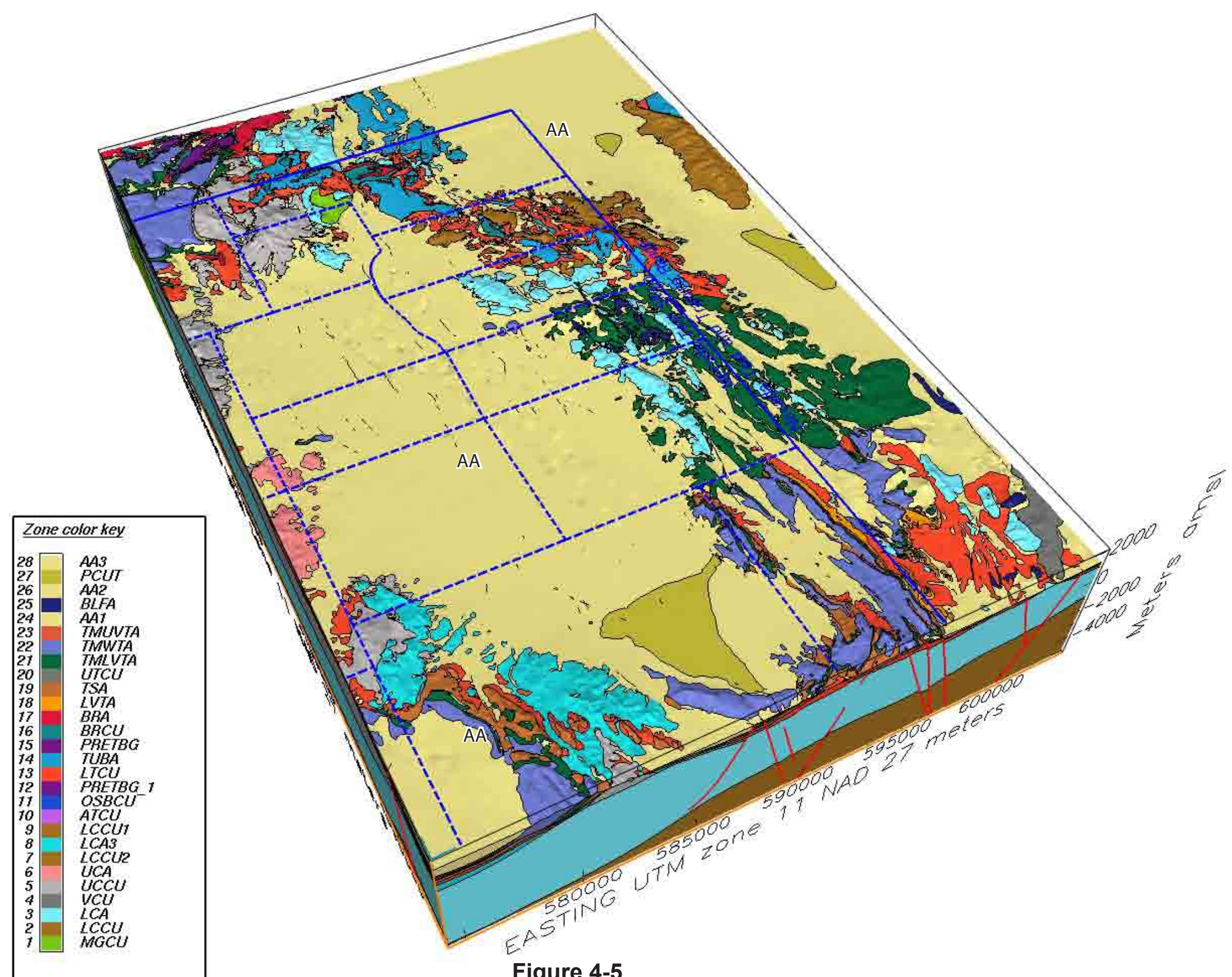

Figure 4-5

Block Model View Showing Extent of the Alluvial Aquifer (AA)

within the Yucca Flat-Climax Mine Model Area 


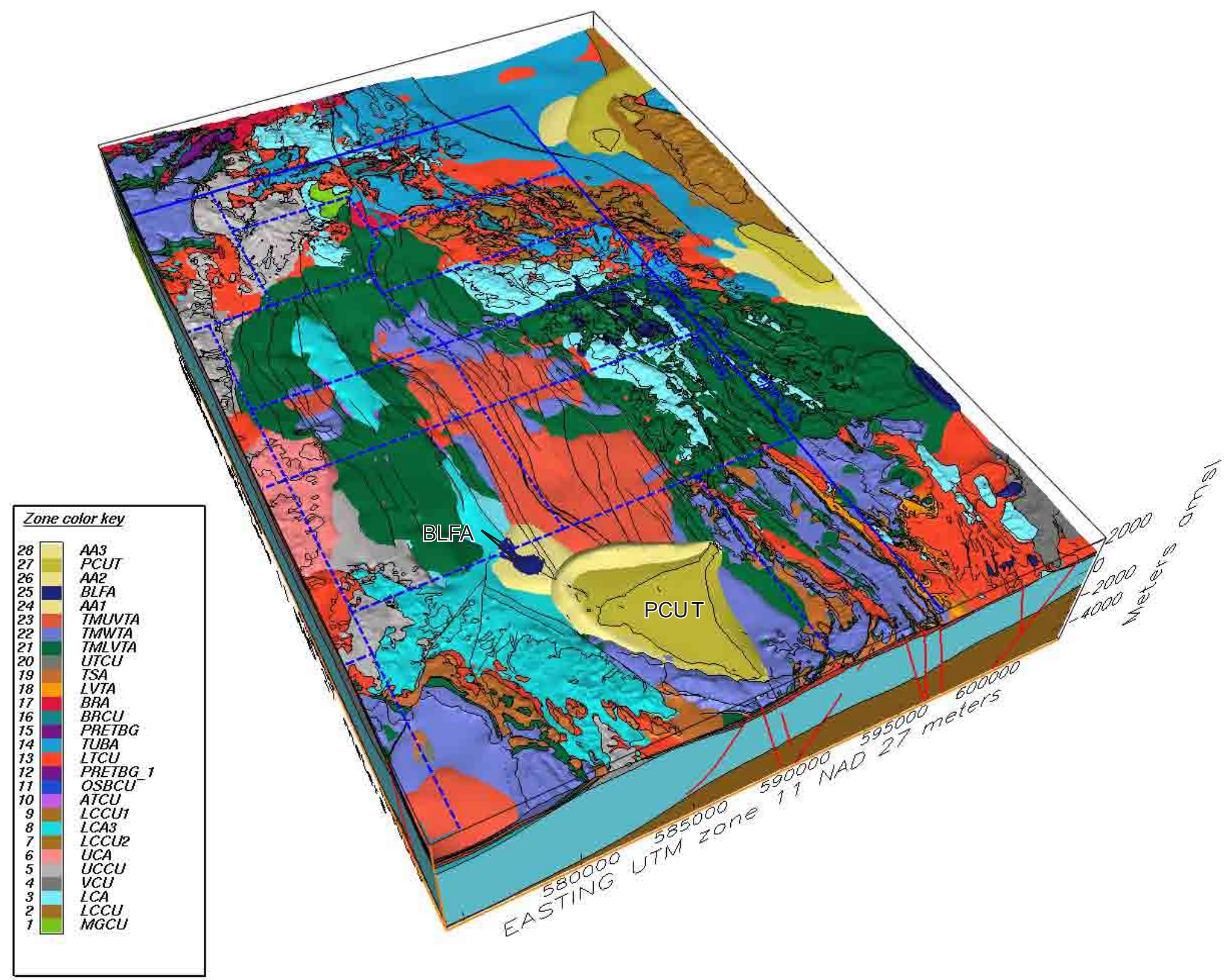

Figure 4-6

Block Model View Showing Extent of the Playa Confining Unit (PCUT) and the Basalt Lava Flow Aquifer (BLFA) within the Yucca Flat/Climax Mine Model Area 


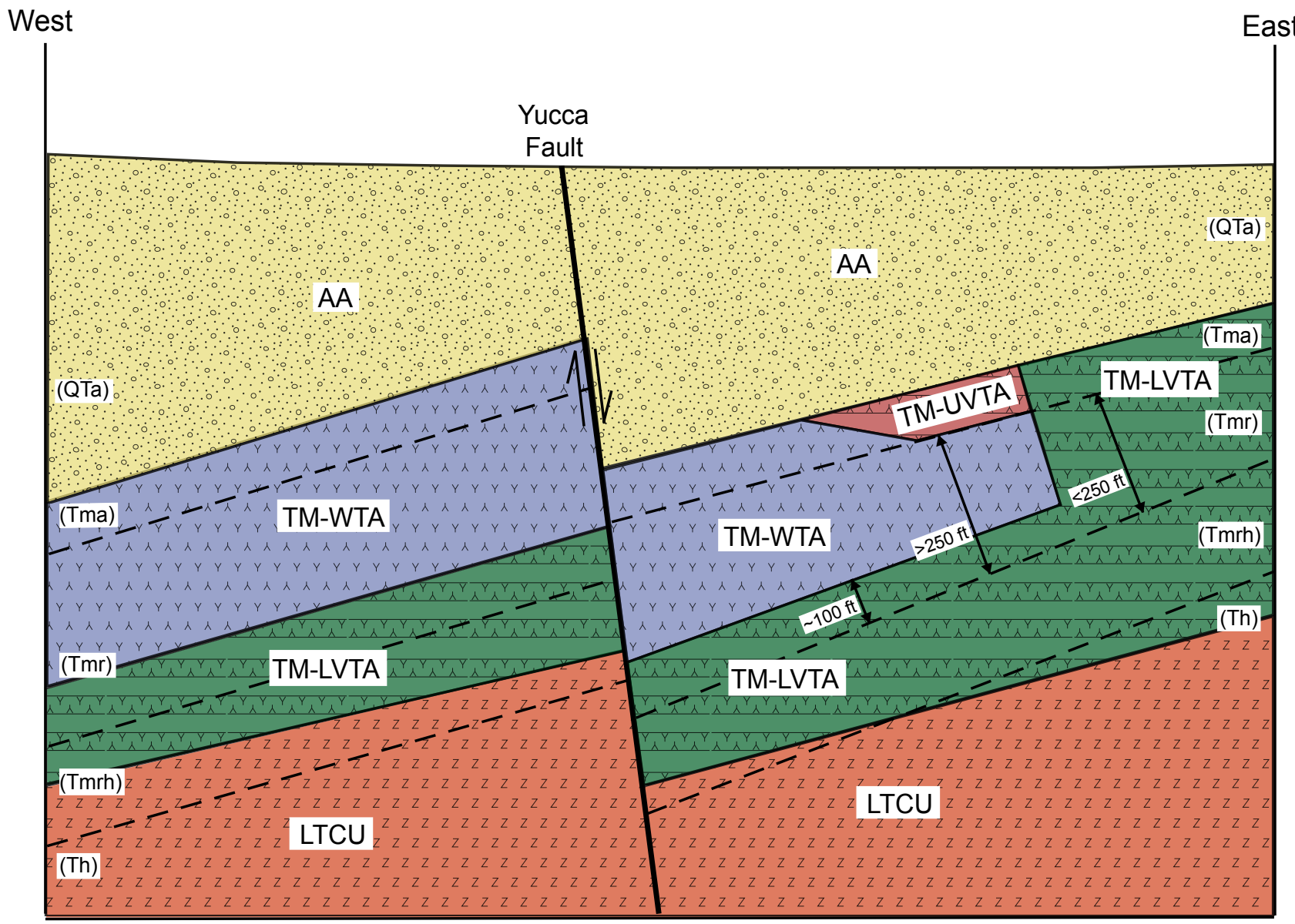

\section{Not to scale}

Hydrogeologic Units

Alluvial aquifer

$\therefore \wedge$ Welded-tuff aquifer

Vitric-tuff aquifer

$\left.\begin{array}{ll}2 & z \\ z & \end{array}\right]$ Tuff confining unit

MV Fault; arrows showing sense of movement

/ Stratigraphic contact

Hydrostratigraphic contact $\underline{\text { Hydrostratigraphic Units }}$

AA Alluvial aquifer

TM-UVTA Timber Mountain upper vitric-tuff aquifer

TM-WTA Timber Mountain welded-tuff aquifer

TM-LVTA Timber Mountain lower vitric-tuff aquifer

LTCU Lower tuff confining unit

Stratigraphic Units

(QTa) Alluvium

(Tma) Ammonia Tanks Tuff

(Tmab) Bedded Ammonia Tanks Tuff

(Tmr) Rainier Mesa Tuff

(Tmrh) Tuff of Holmes Road

(Th) Calico Hills Formation

Figure 4-7

Schematic West-East Cross Section across Yucca Flat Showing Variability in Hydrogeologic Character of the Timber Mountain Hydrostratigraphic Units 


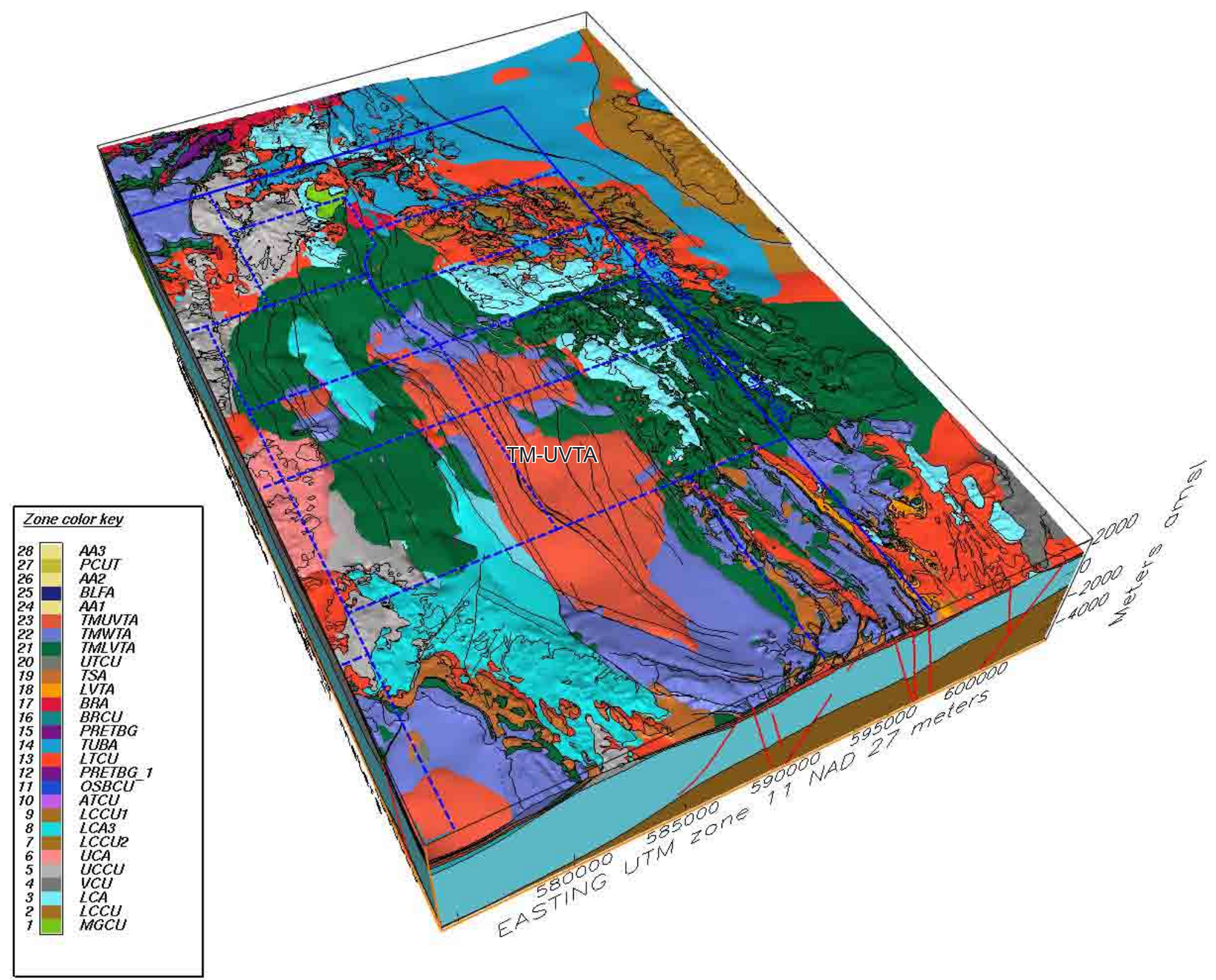

Figure 4-8

Block Model View Showing Extent of the Timber Mountain Upper Vitric-Tuff Aquifer (TM-UVTA) within the Yucca Flat-Climax Mine Model Area 


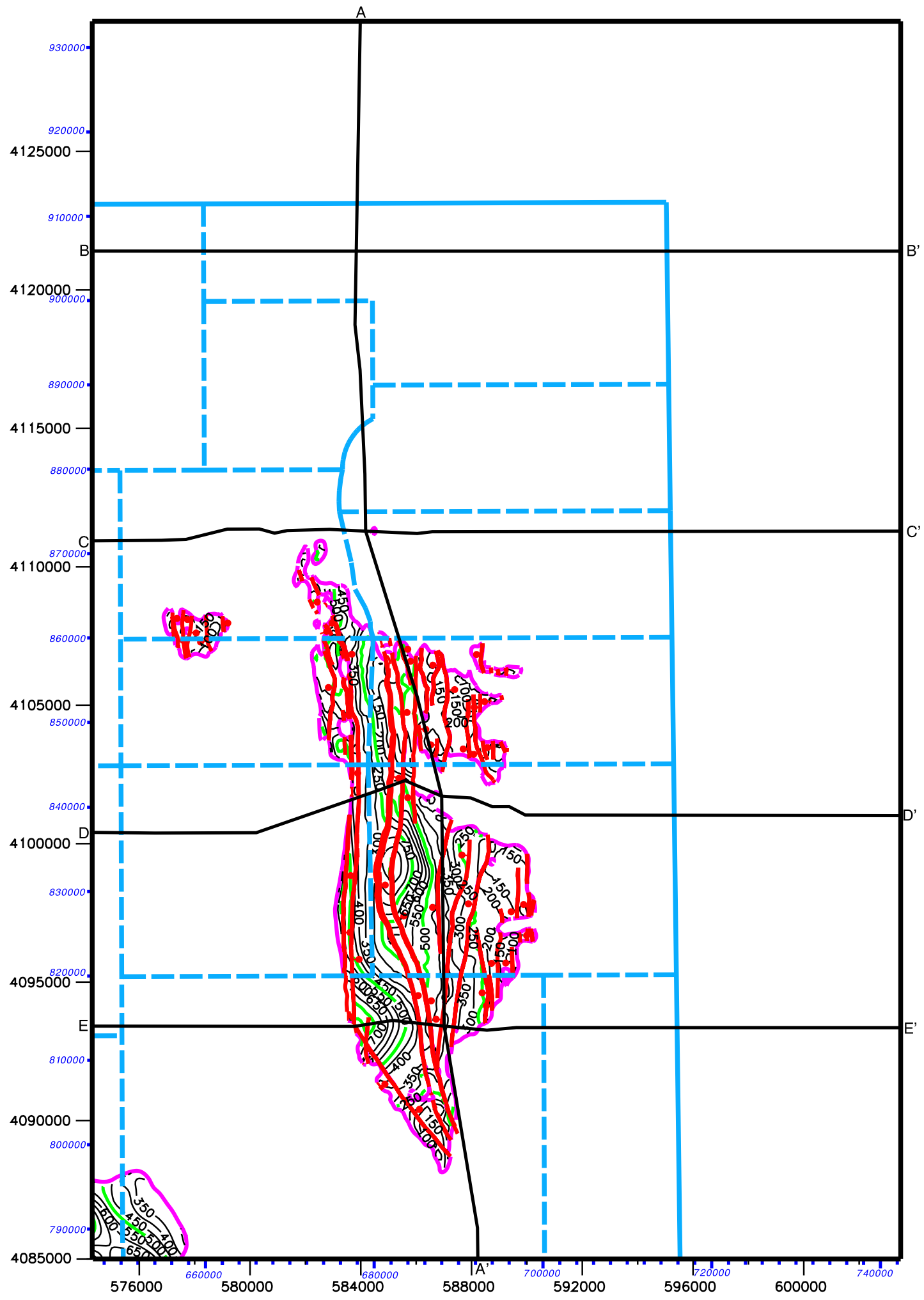

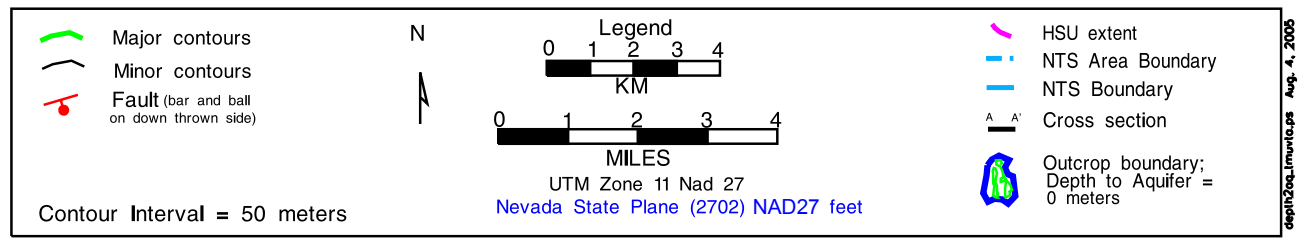

Figure 4-9

Depth to the Timber Mountain Upper Vitric-Tuff Aquifer (TM-UVTA) in the Yucca Flat-Climax Mine Hydrostratigraphic Framework Model 


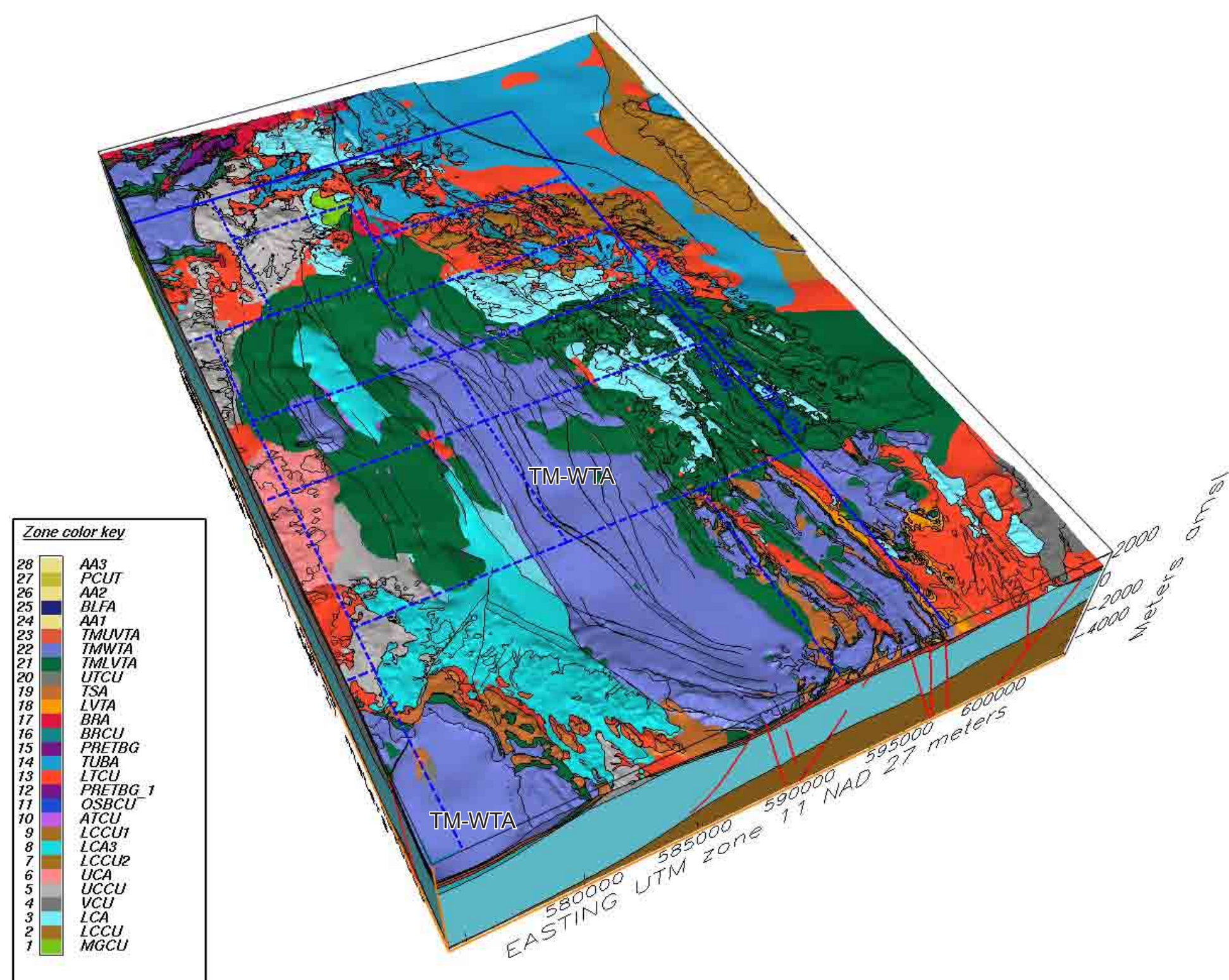

Figure 4-10

Block Model View Showing Extent of the Timber Mountain Welded-Tuff Aquifer (TM-WTA) within the Yucca Flat-Climax Mine Model Area 


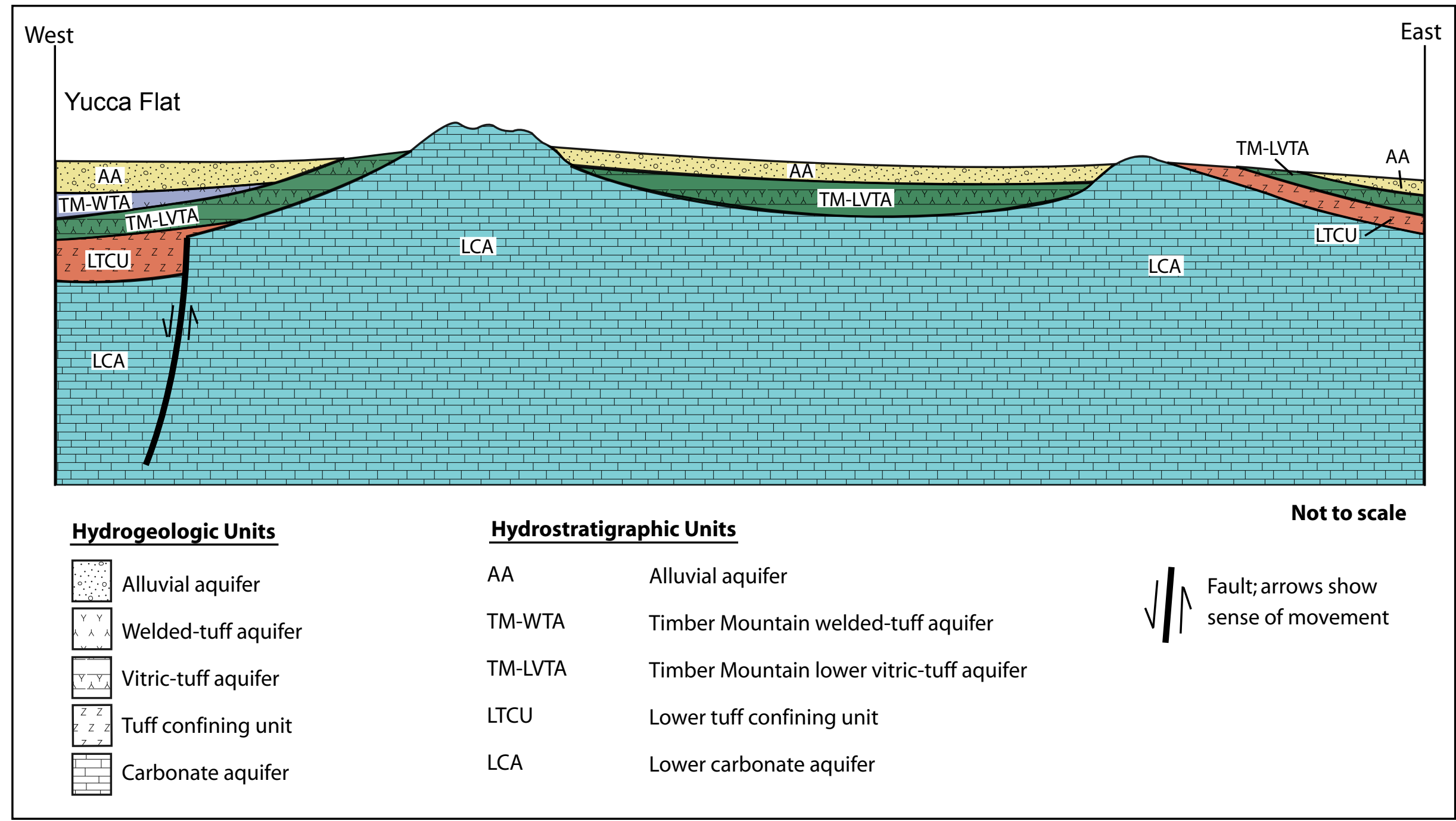

Figure 4-11

Schematic West-East Hydrostratigraphic Cross Section through the Eastern Extension of the Yucca Flat Model 


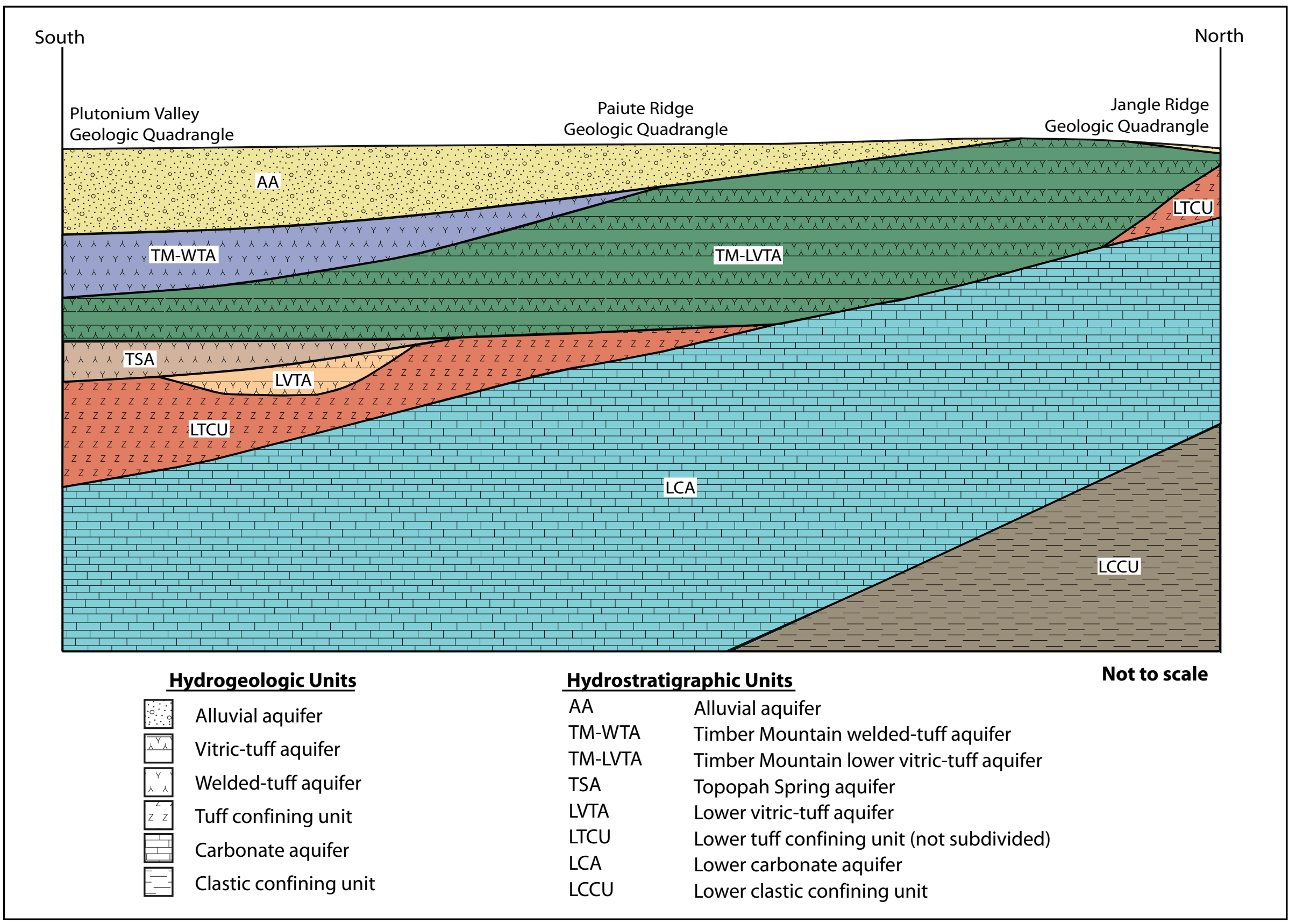

Figure 4-12

Schematic South-North Hydrostratigraphic Cross Section through the Eastern Extension of the Yucca Flat Model Area 


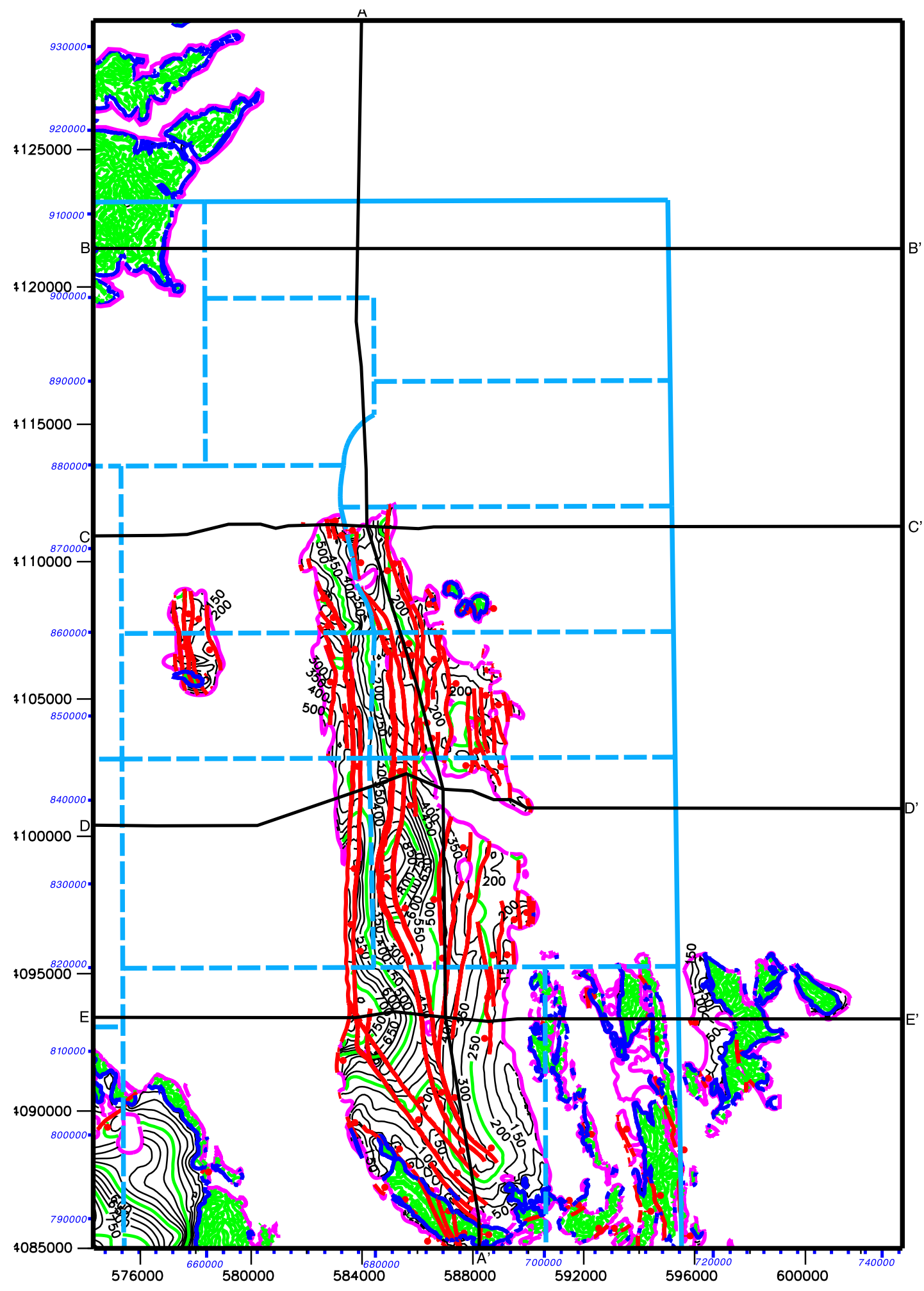

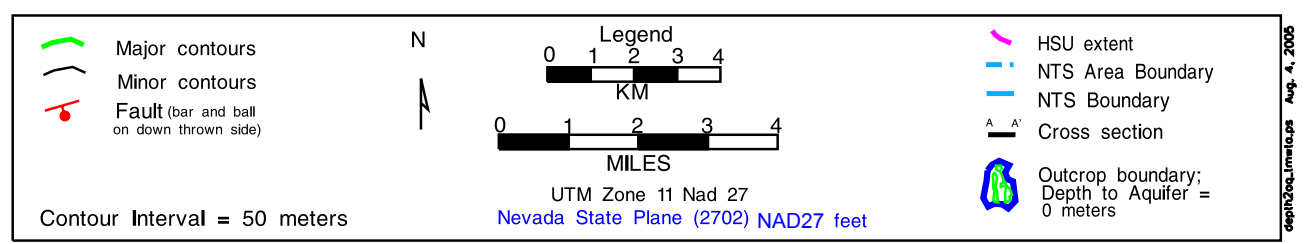

Figure 4-13

Depth to the Timber Mountain Welded-Tuff Aquifer (TM-WTA) in the Yucca Flat-Climax Mine Hydrostratigraphic Framework Model 


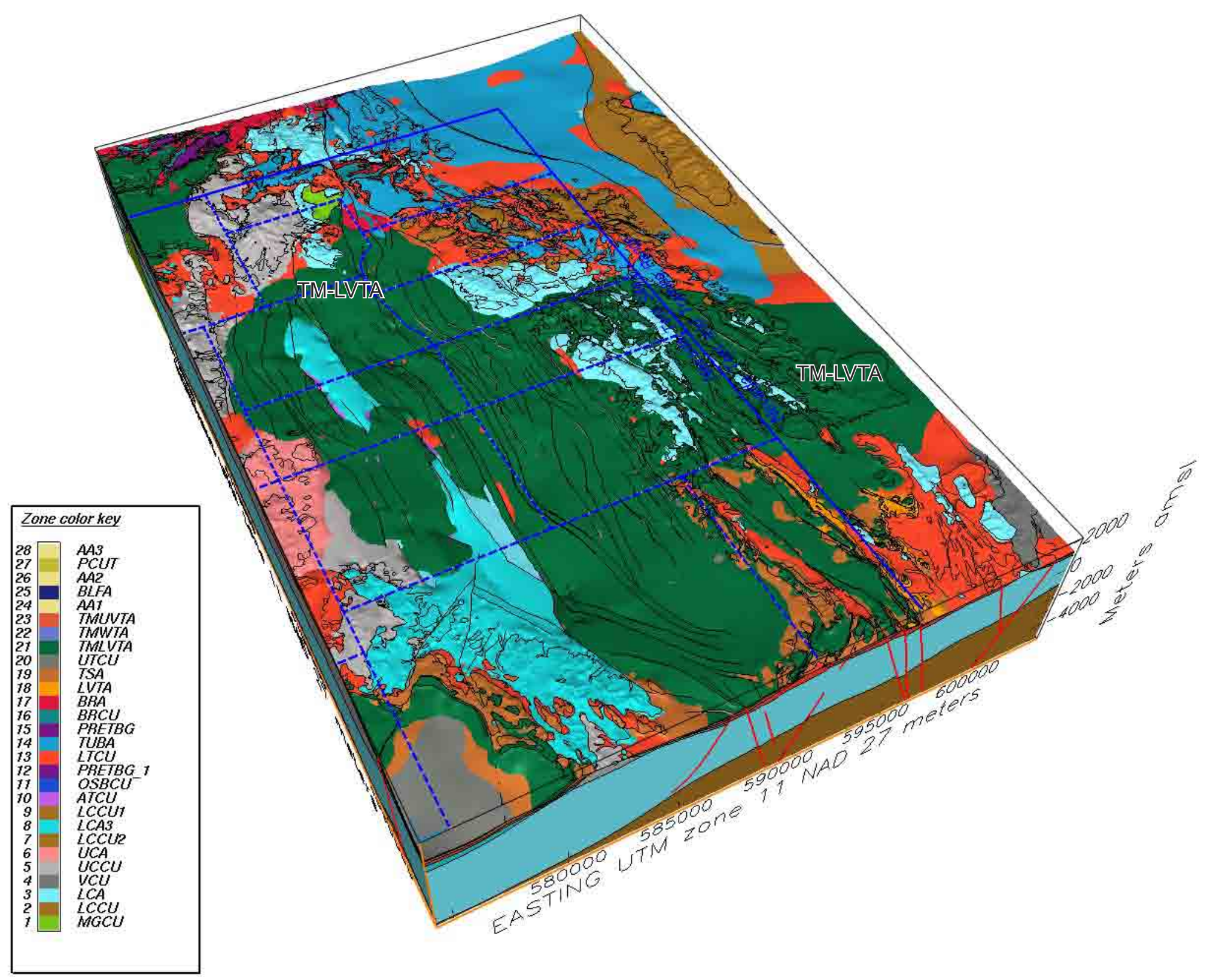

Figure 4-14

Block Model View Showing Extent of the Timber Mountain Lower Vitric-Tuff Aquifer (TM-LVTA) within the Yucca Flat-Climax Mine Model Area 


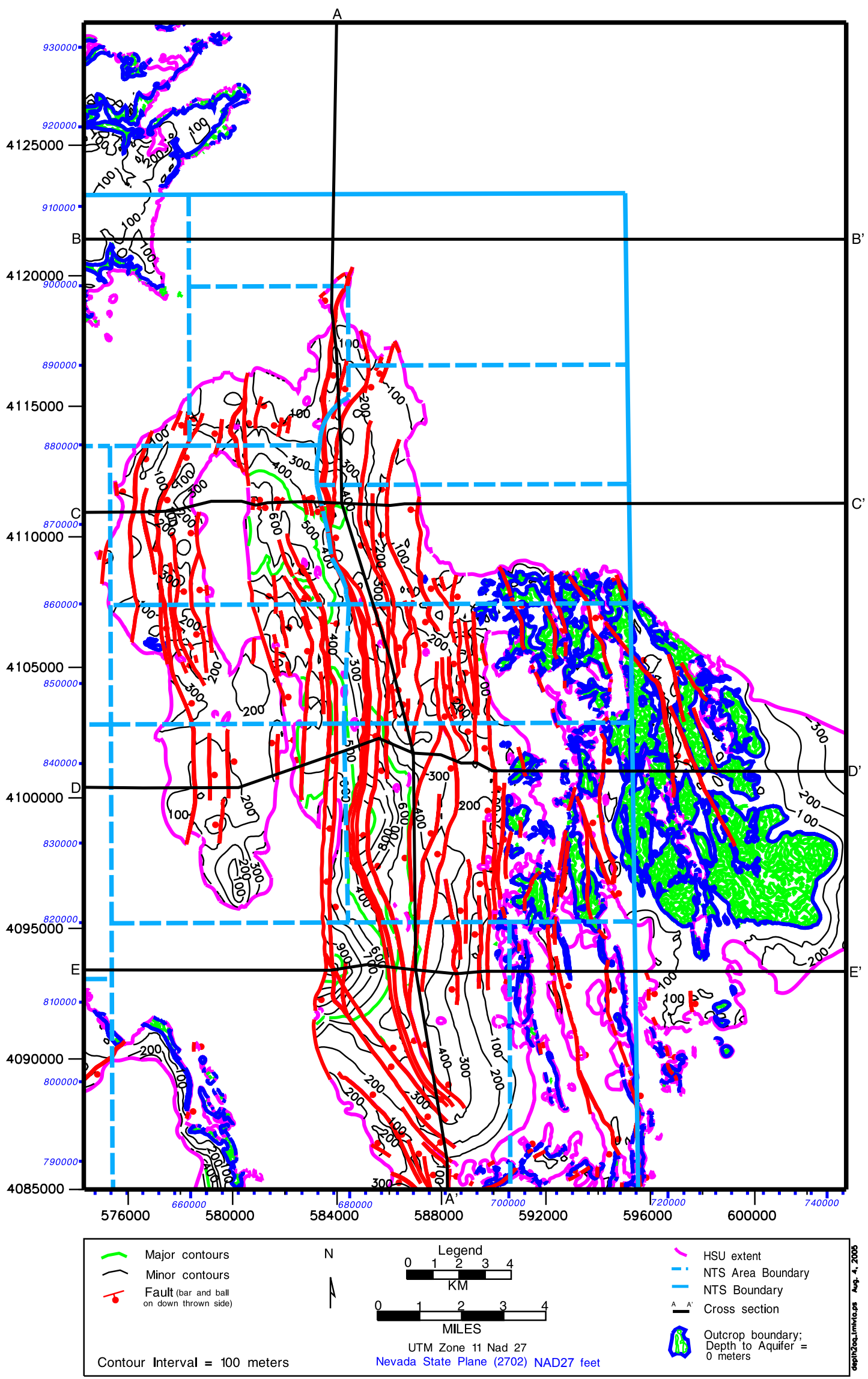

Figure 4-15

Depth to the Timber Mountain Lower Vitric-Tuff Aquifer (TM-LVTA) in the Yucca Flat-Climax Mine Hydrostratigraphic Framework Model 


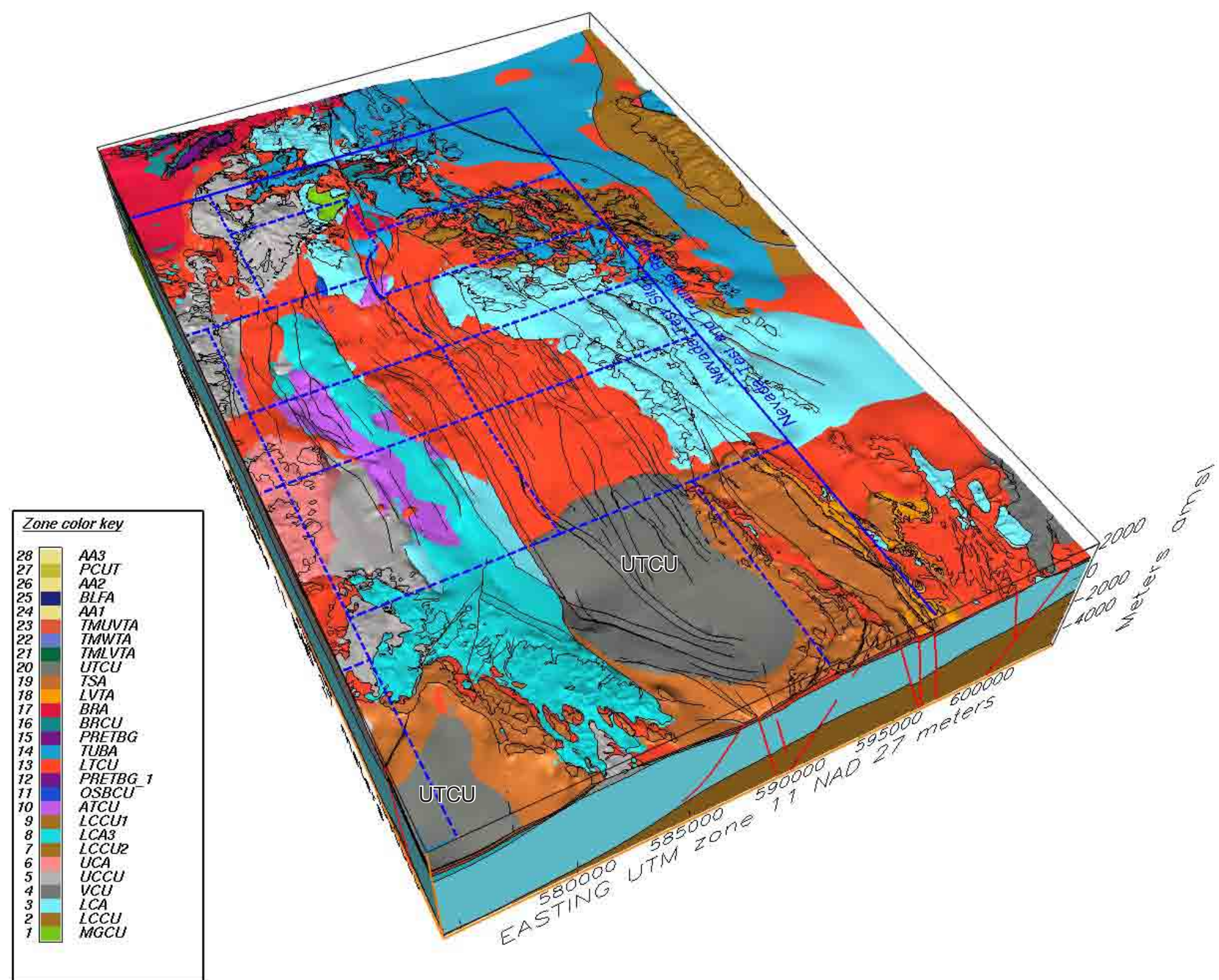

Figure 4-16

Block Model View Showing Extent of the Upper Tuff Confining Unit (UTCU) within the Yucca Flat-Climax Mine Model Area 


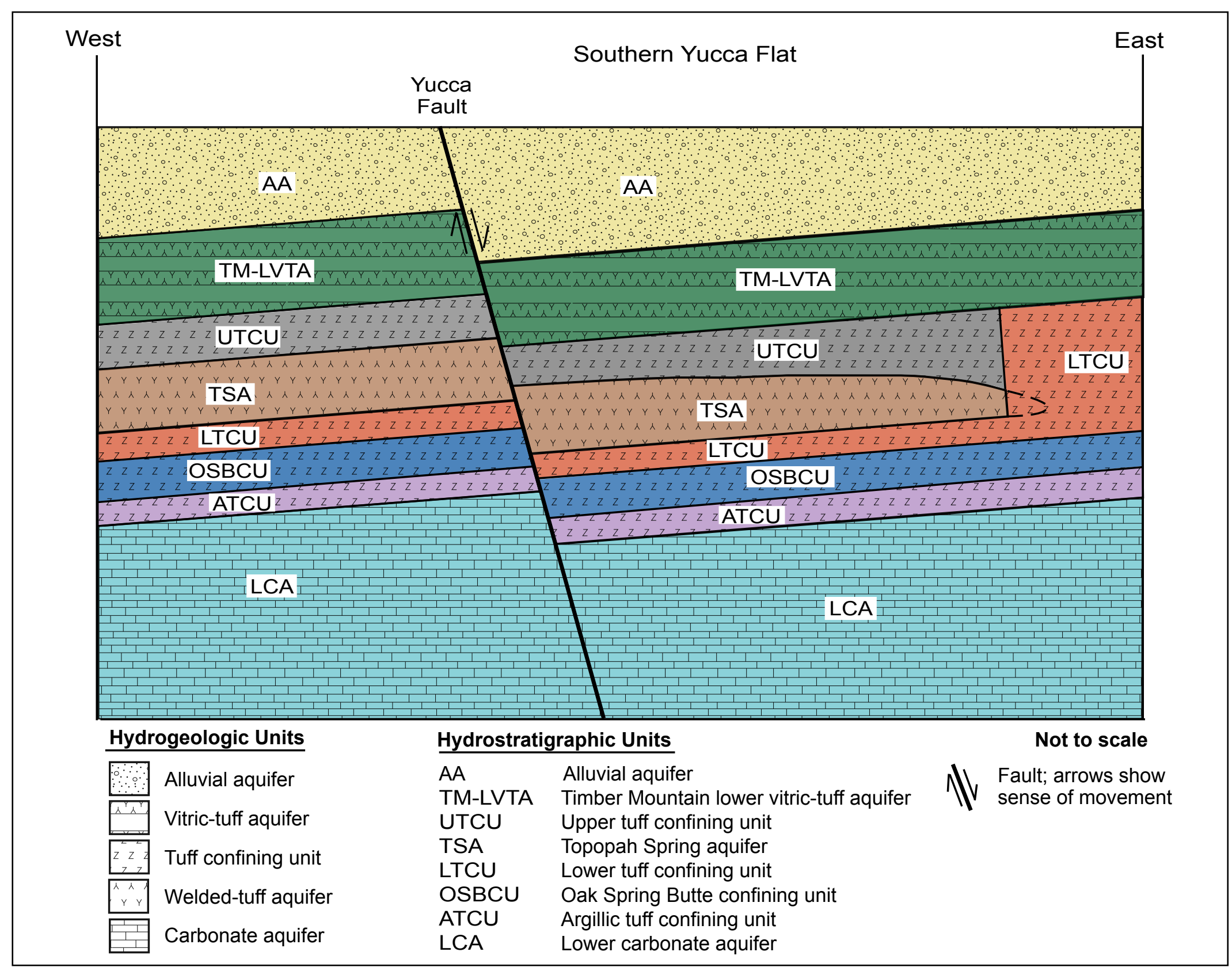

Figure 4-17

Schematic West-East Cross Section through Southern Yucca Flat Showing Relationships Among the Tuff Confining Units and the Topopah Spring Aquifer 


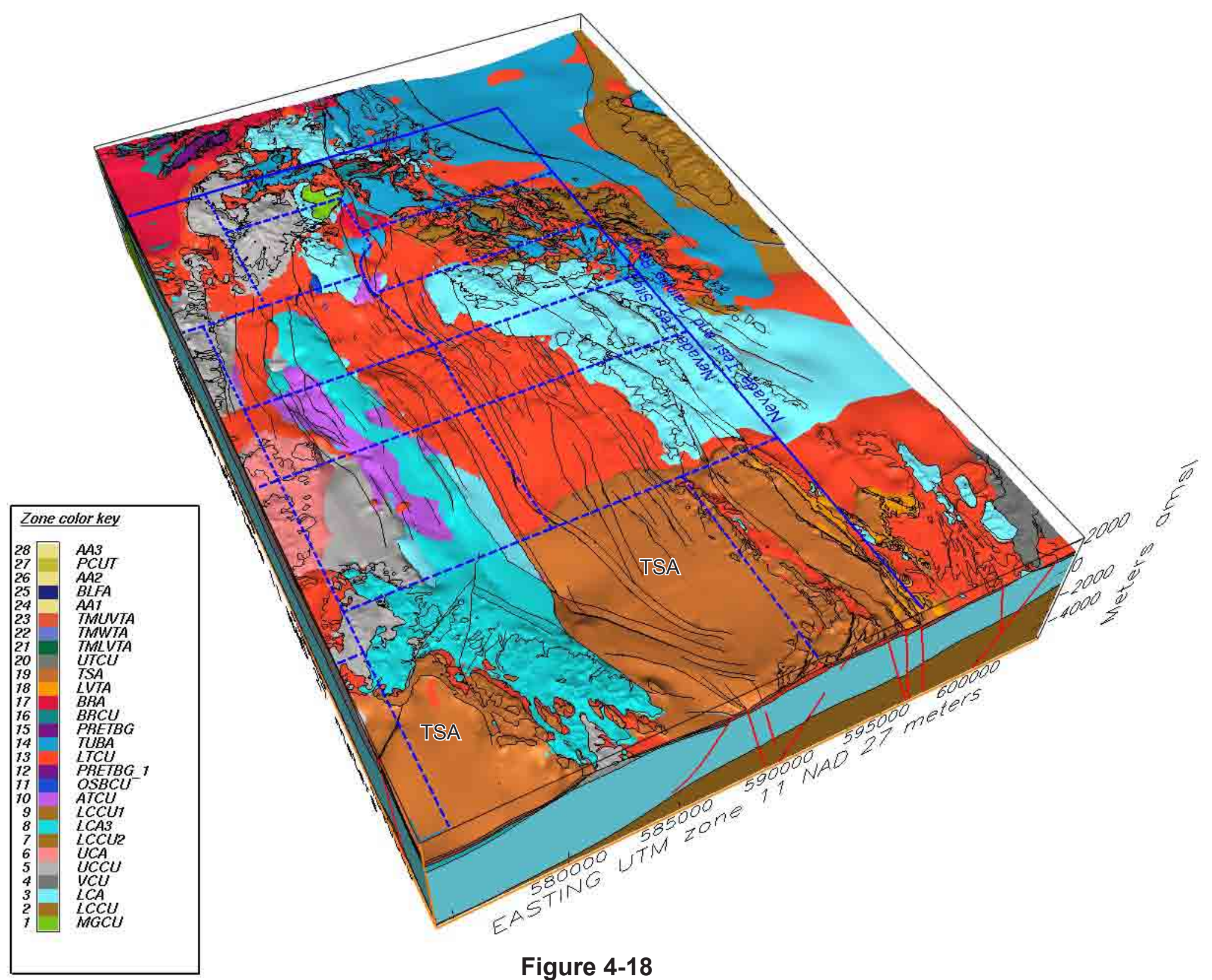

Block Model View Showing Extent of the Topopah Spring Aquifer (TSA)

within the Yucca Flat-Climax Mine Model Area 

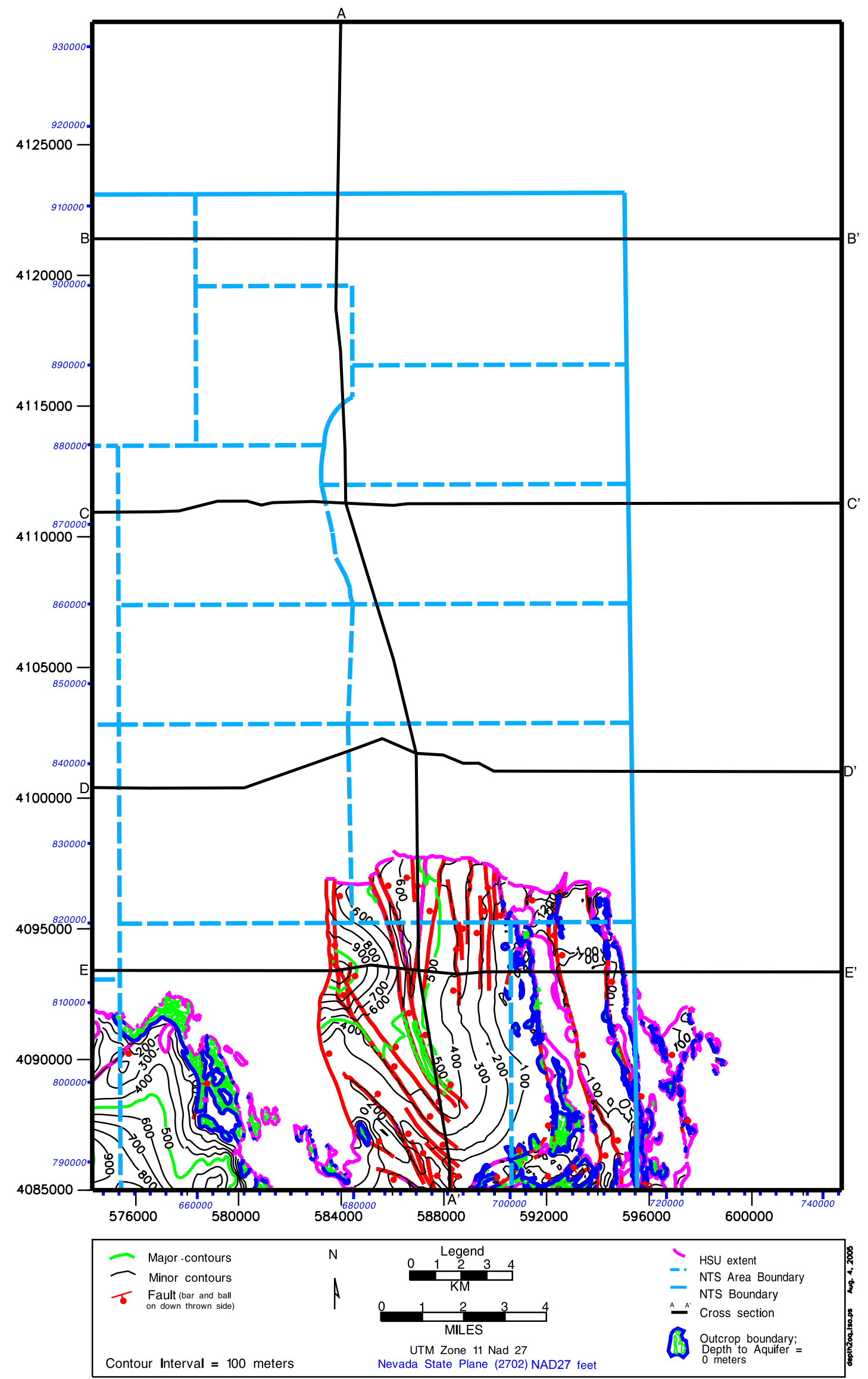

Figure 4-19

Depth to the Topopah Spring Aquifer (TSA) in the Yucca Flat-Climax Mine Hydrostratigraphic Framework Model 


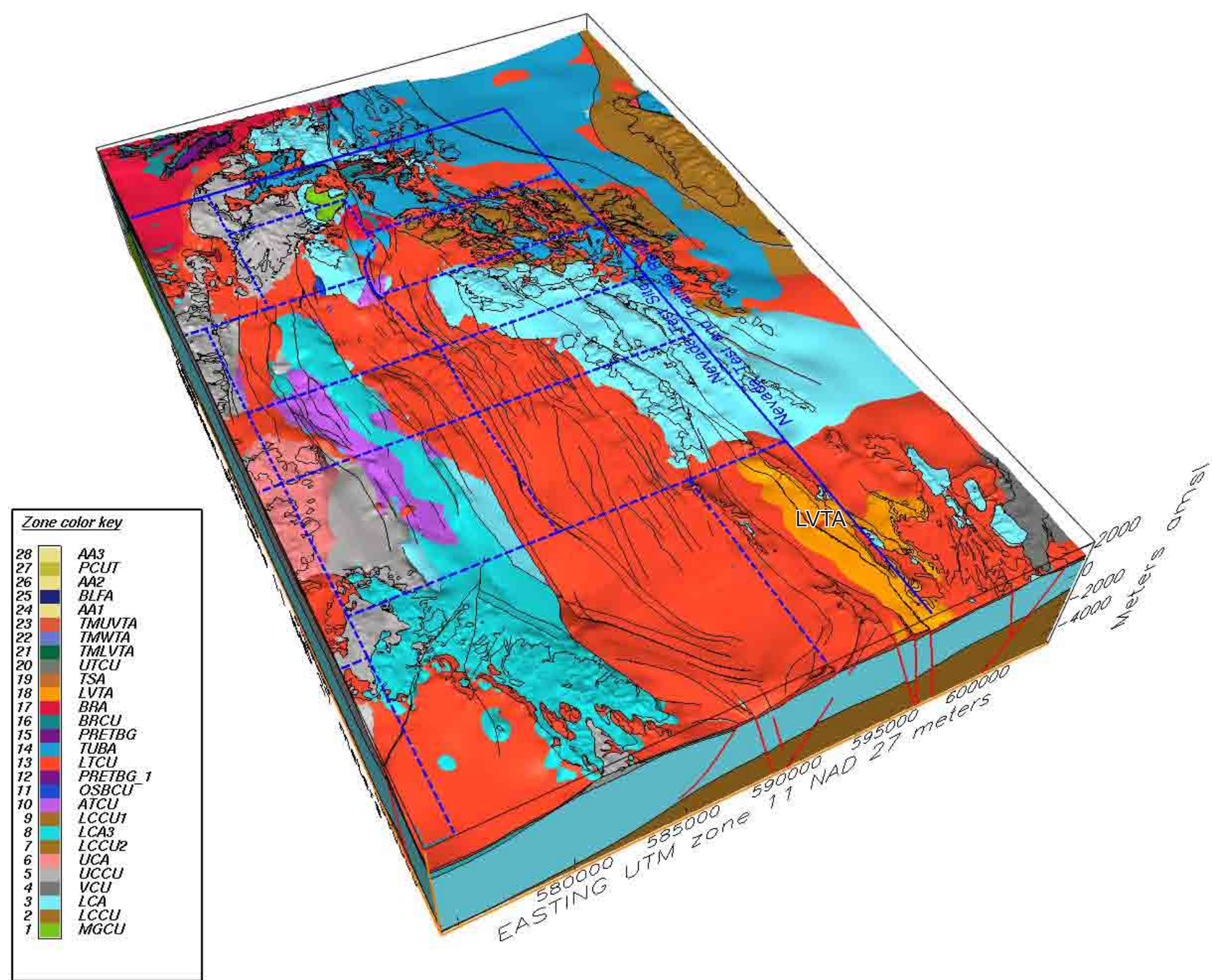

Figure 4-20

Block Model View Showing Extent of the Lower Vitric-Tuff Aquifer (LVTA) within the Yucca Flat-Climax Mine Model Area 


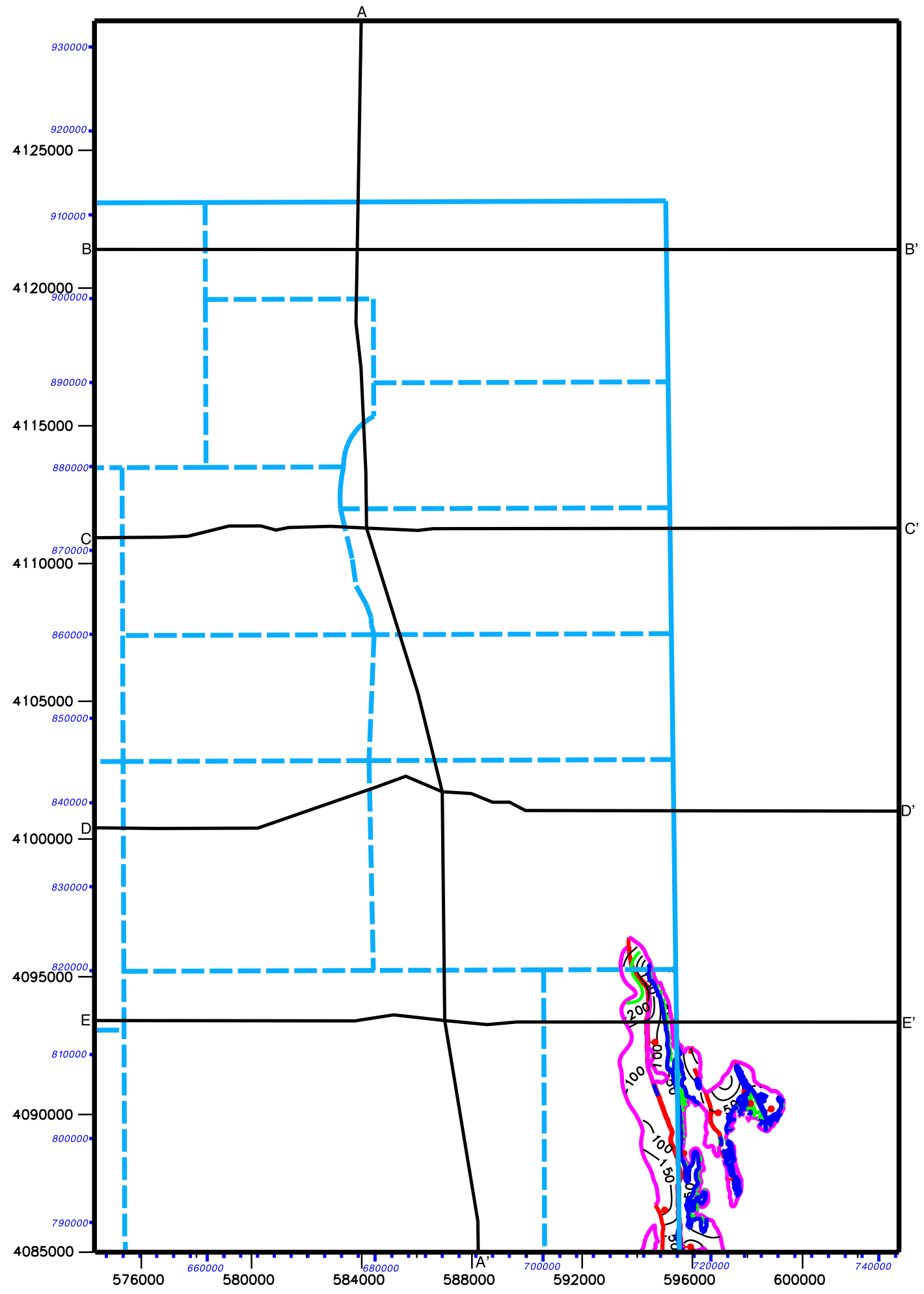

$\begin{array}{llll}\text { Major contours } \\ \begin{array}{l}\text { Minor contours } \\ \begin{array}{l}\text { Fault (bar and ball } \\ \text { on down thrown side) }\end{array}\end{array} \\ \text { Contour Interval }=50 \text { meters } & \mathrm{N} & \text { Legend } \\ \text { NTM Zone 11 Nad 27 } \\ \text { Nevada State Plane (2702) NAD27 feet }\end{array}$

Figure 4-21

Depth to the Lower Vitric-Tuff Aquifer (LVTA) in the Yucca Flat-Climax Mine Hydrostratigraphic Framework Model 


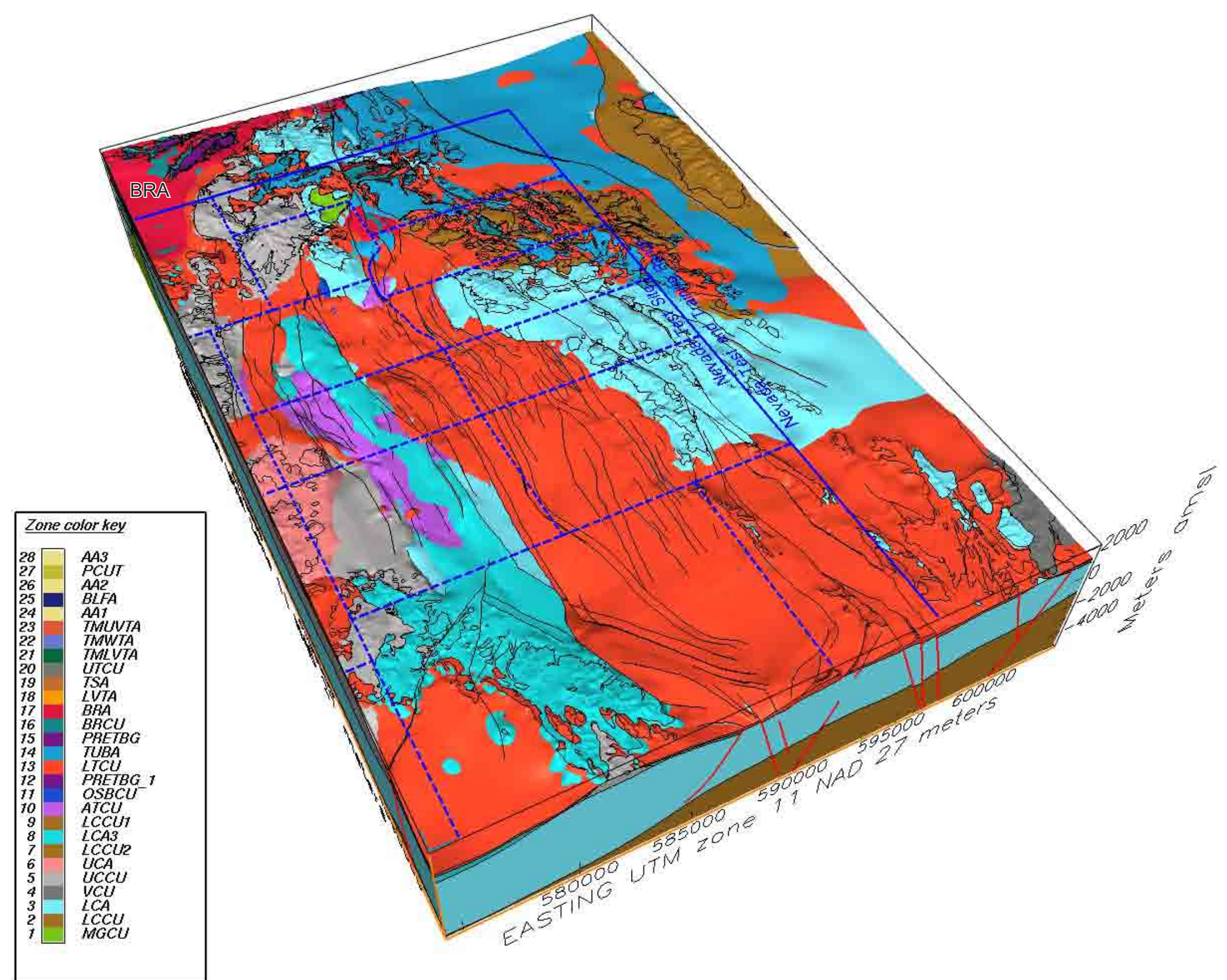

Figure 4-22

Block Model View Showing Extent of the Belted Range Aquifer (BRA)

within the Yucca Flat-Climax Mine Model Area 


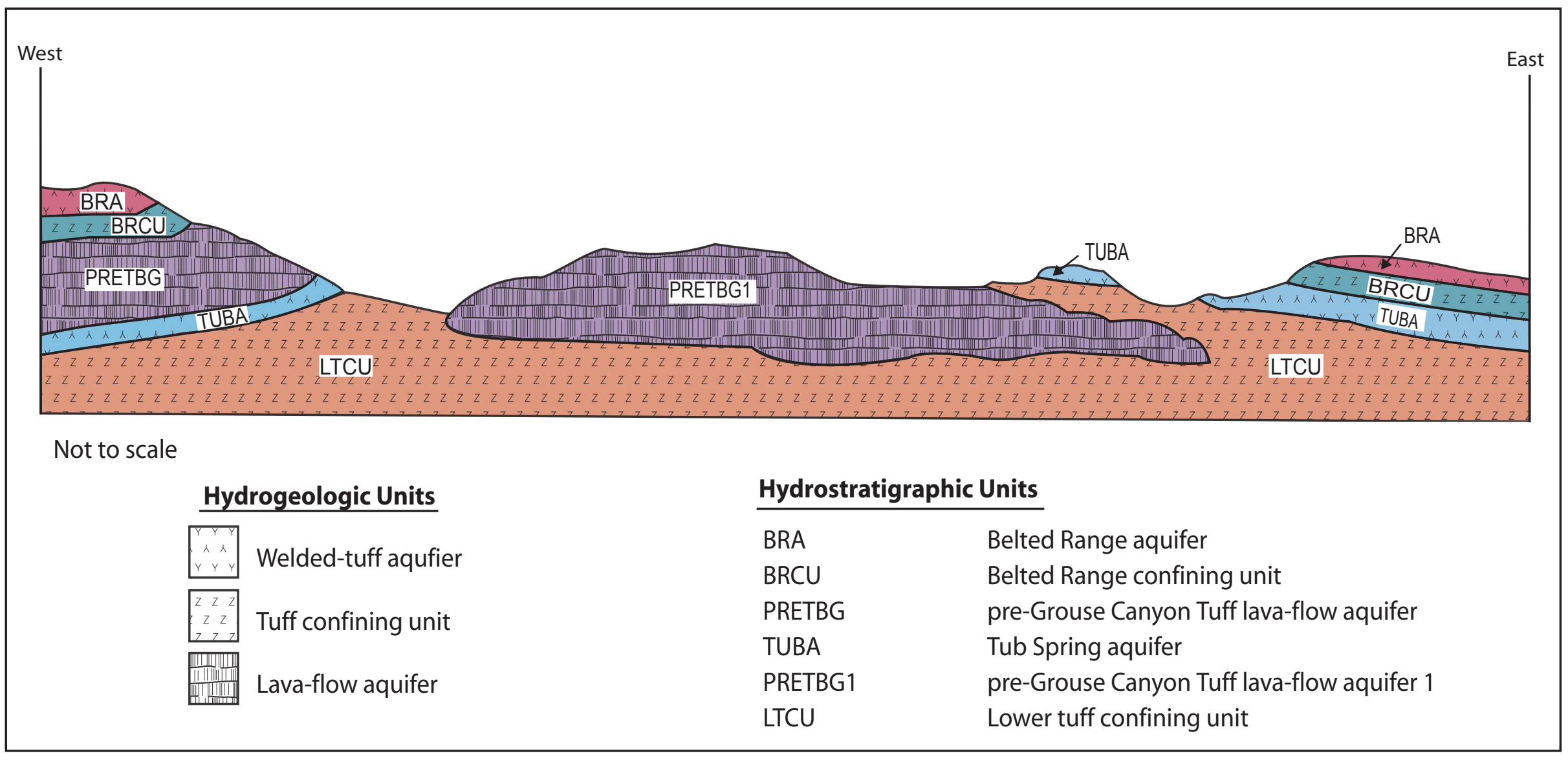

Figure 4-23

Schematic West-East Cross Section in Northern Yucca Flat Showing Relationships Among the Belted Range and Older Volcanic Hydrostratigraphic Units 


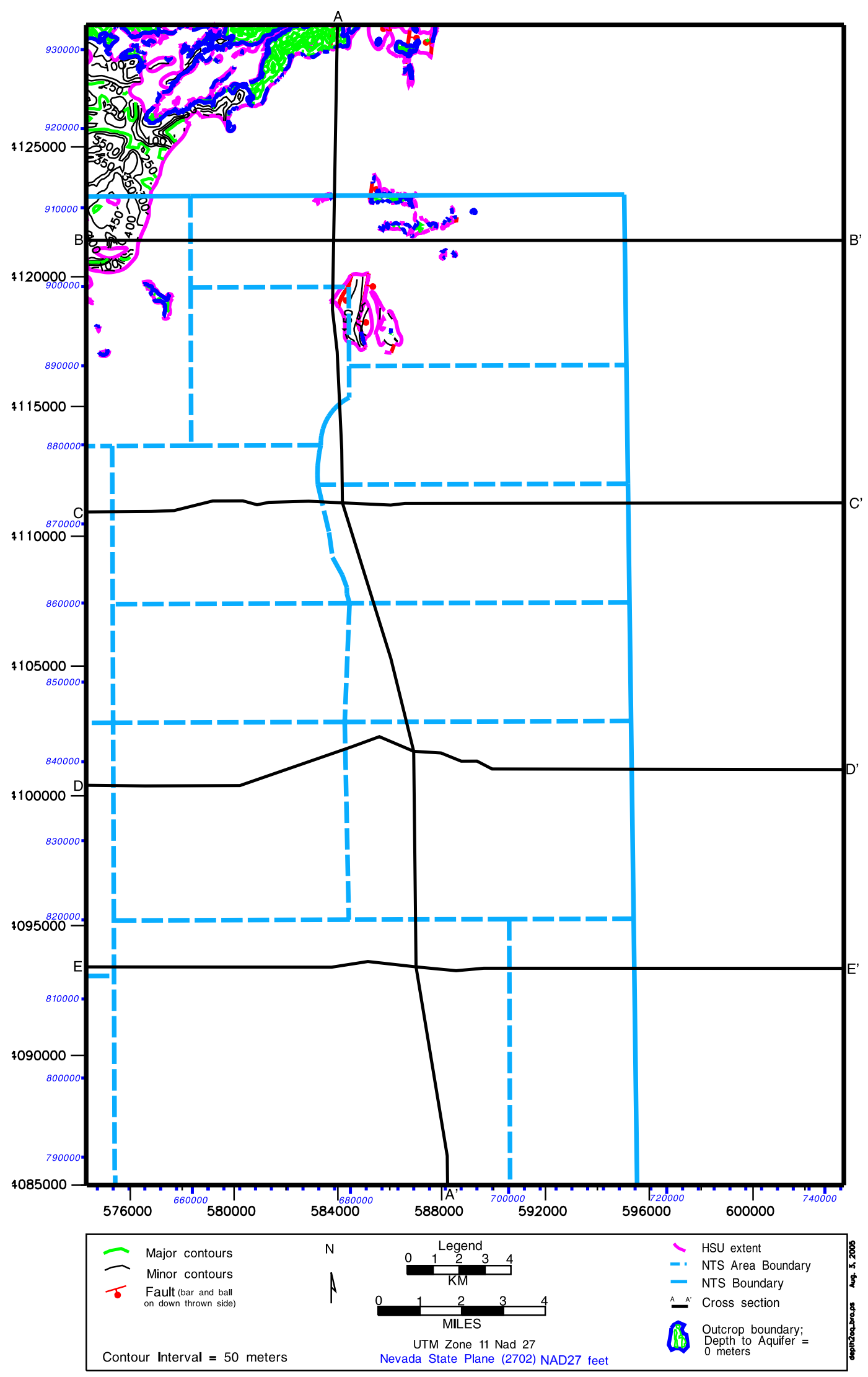

Figure 4-24

Depth to the Belted Range Aquifer (BRA) in the Yucca Flat-Climax Mine Hydrostratigrpahic Framework Model 


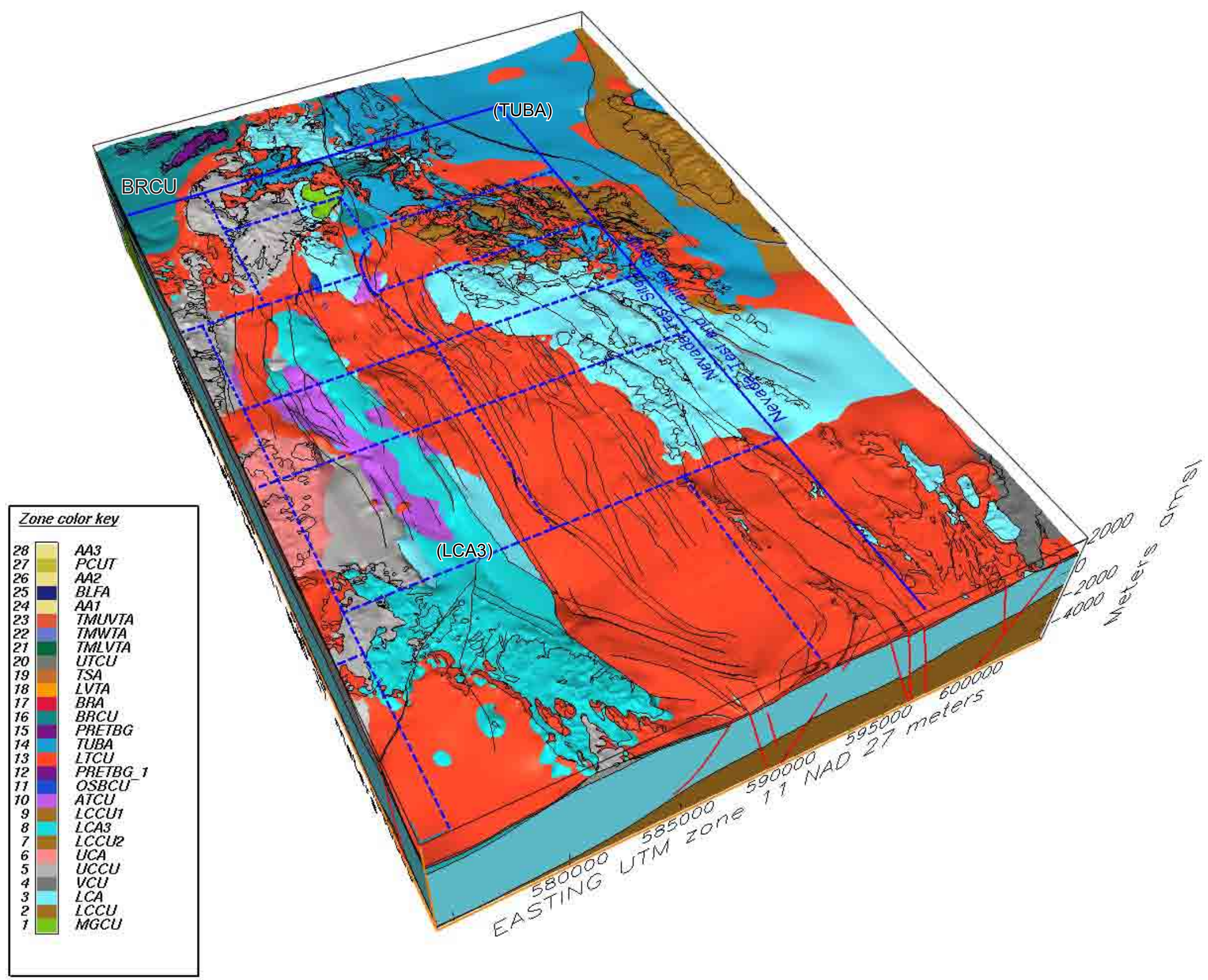

Figure 4-25

Block Model View Showing Extent of the Belted Range Confining Unit (BRCU) within the Yucca Flat-Climax Mine Model Area 


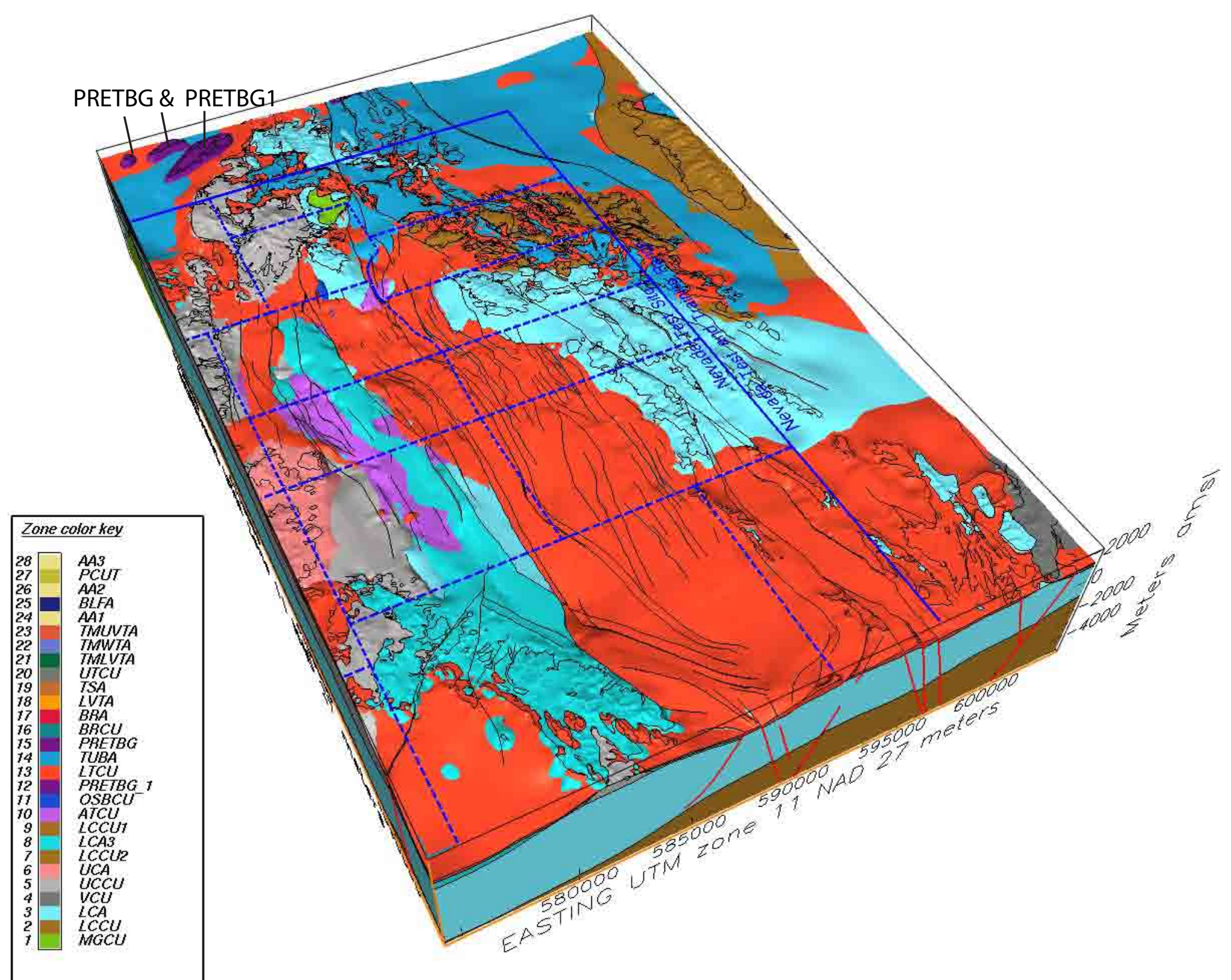

Figure 4-26

Block Model View Showing Extent of the Pre-Grouse Canyon Tuff Lava-Flow Aquifer (PRETBG\&PRETBG1) within the Yucca Flat-Climax Mine Model Area 


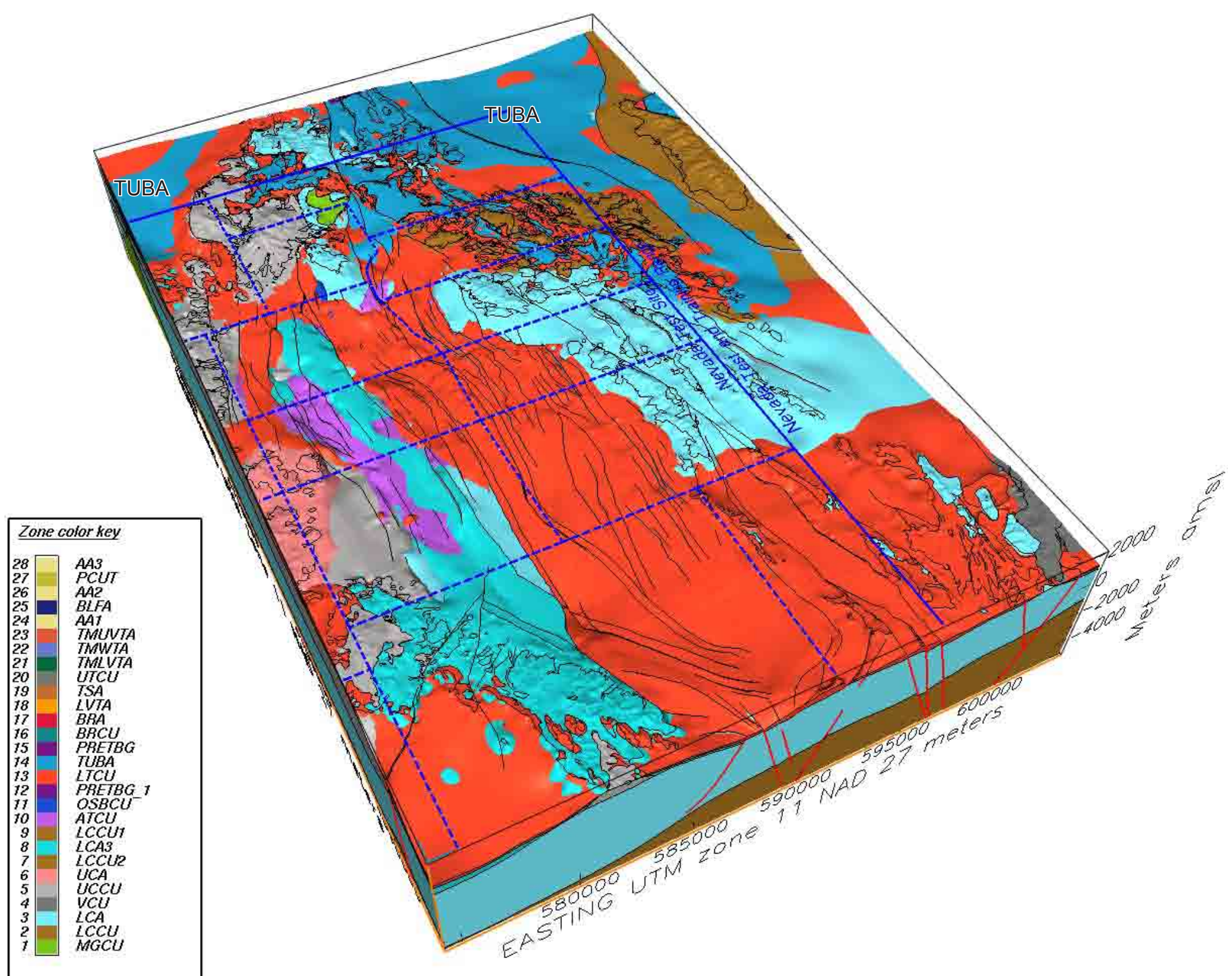

Figure 4-27

Block Model View Showing Extent of the Tub Spring Aquifer (TUBA) within the Yucca Flat-Climax Mine Model Area 


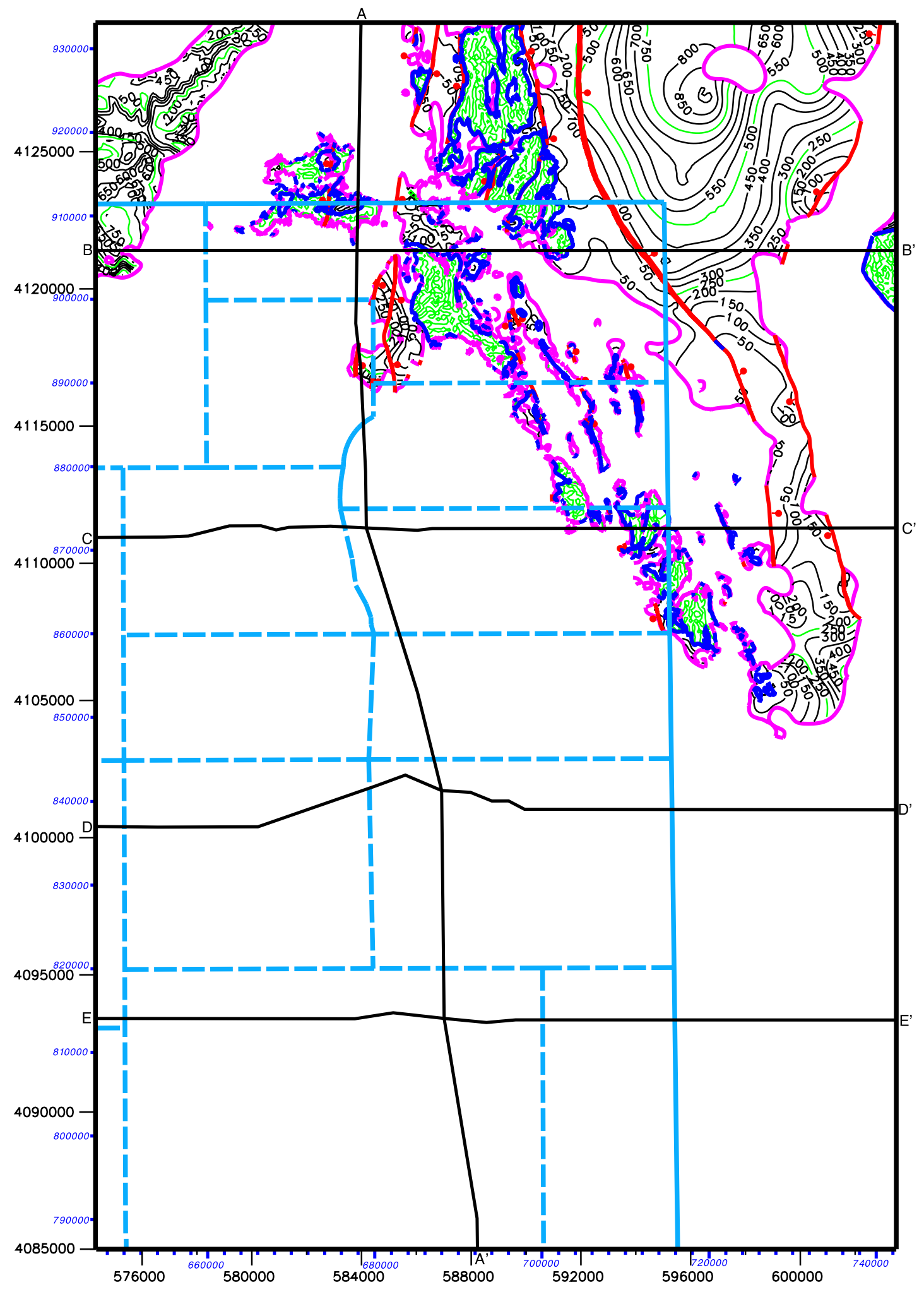

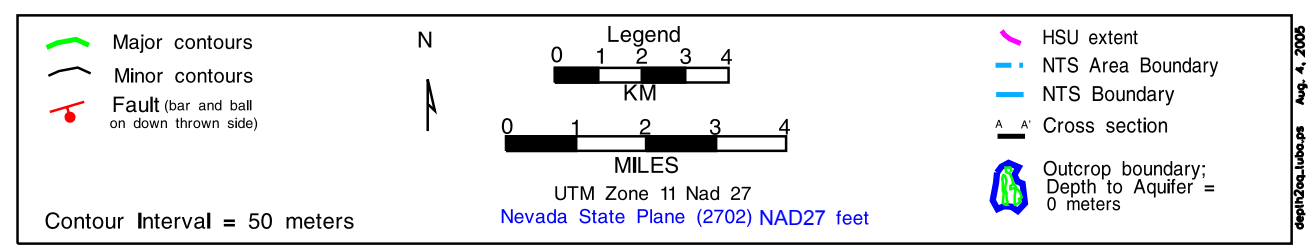

Figure 4-28

Depth to the Tub Spring Aquifer (TUBA) in the Yucca Flat-Climax Mine Hydrostratigraphic Framework Model 


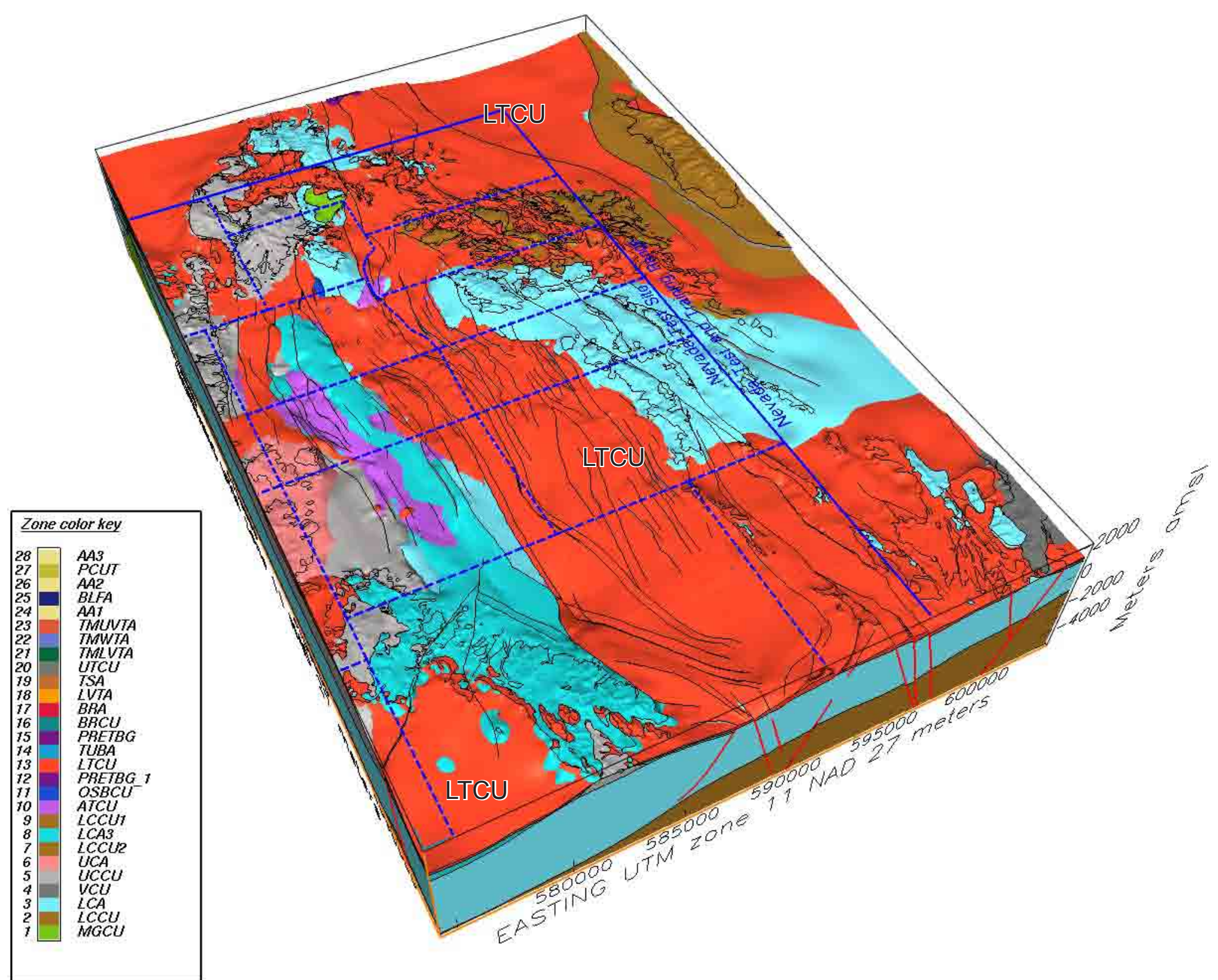

Figure 4-29

Block Model View Showing Extent of the Lower Tuff Confining Unit (LTCU) within the Yucca Flat-Climax Mine Model Area 


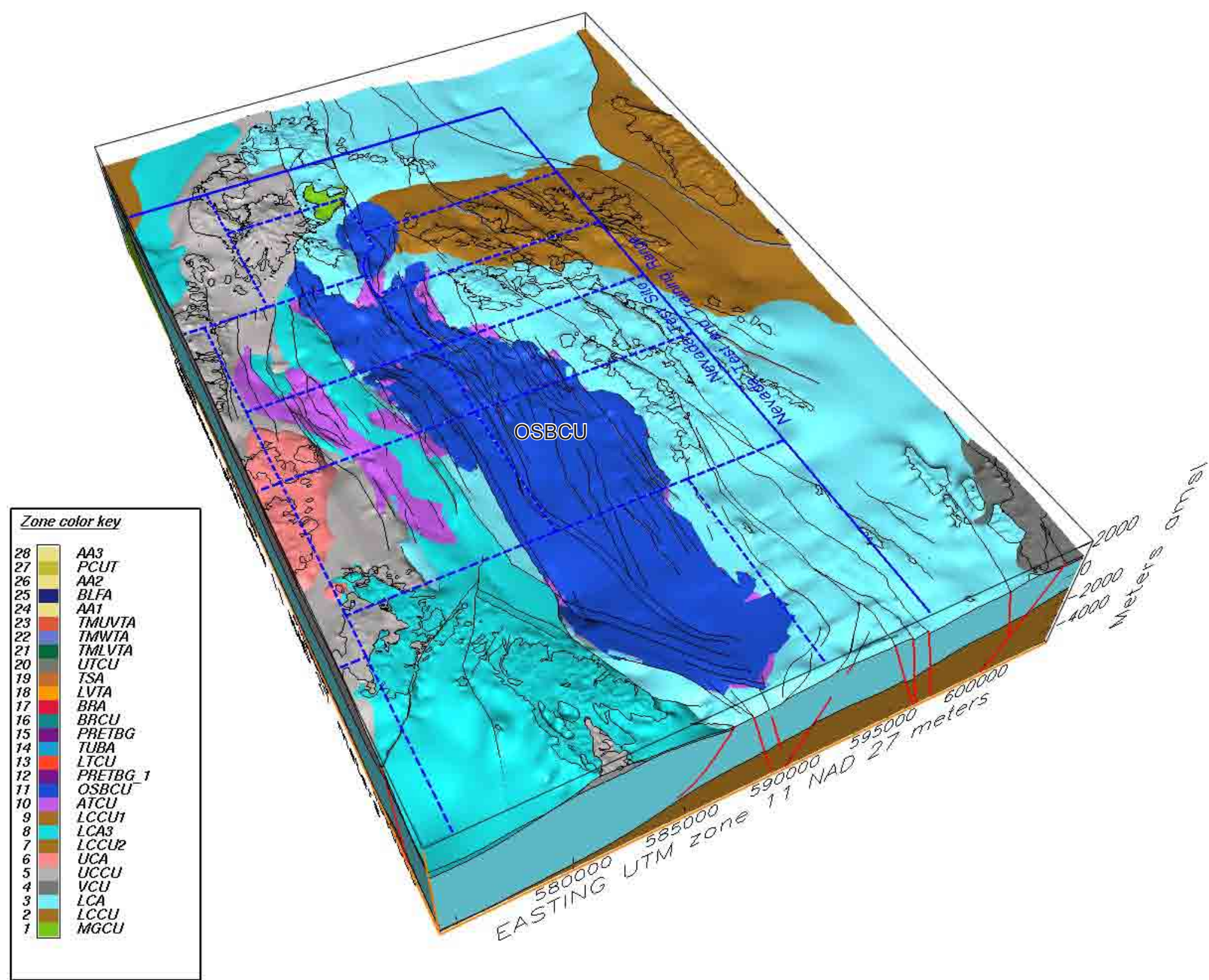

Figure 4-30

Block Model View Showing Extent of the Oak Spring Butte Confining Unit (OSBCU) within the Yucca Flat-Climax Mine Model Area 


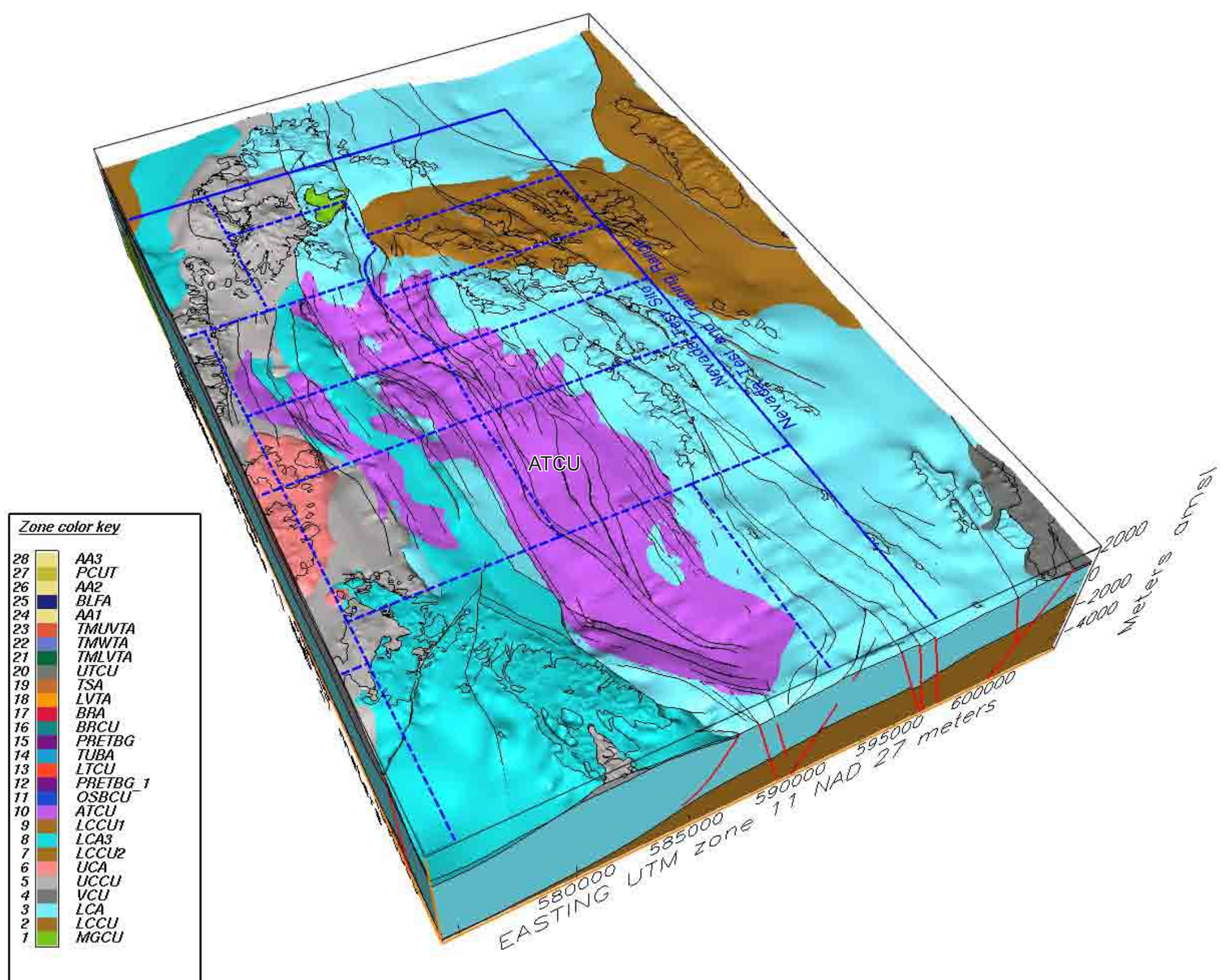

Figure 4-31

Block Model View Showing Extent of the Argillic Tuff Confining Unit (ATCU) within the Yucca Flat-Climax Mine Model Area 


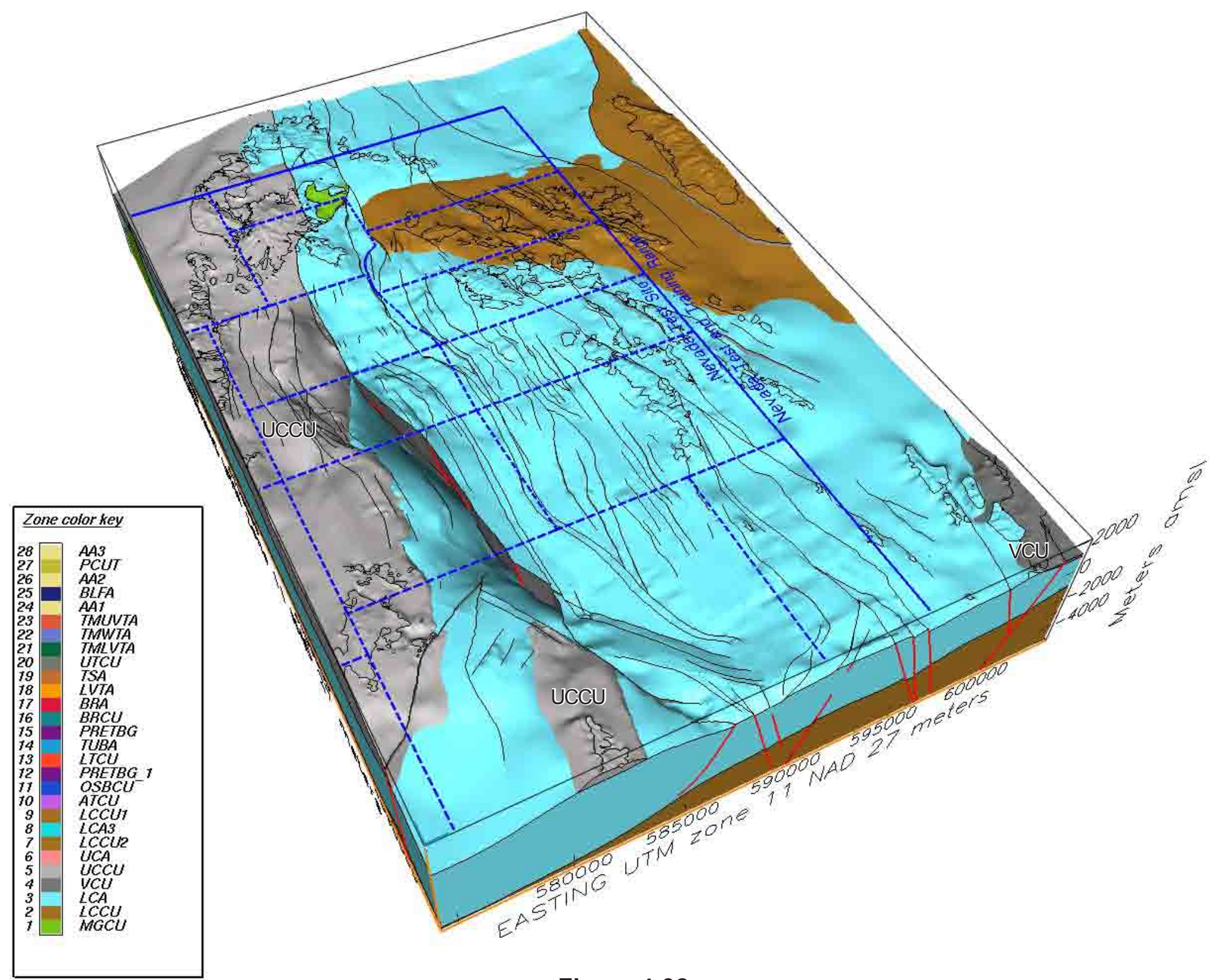

Figure 4-32

Block Model View Showing Extent of the Upper Clastic Confining Unit (UCCU) and the Volcaniclastic Confining Unit (VCU) within the Yucca Flat-Climax Mine Model Area 


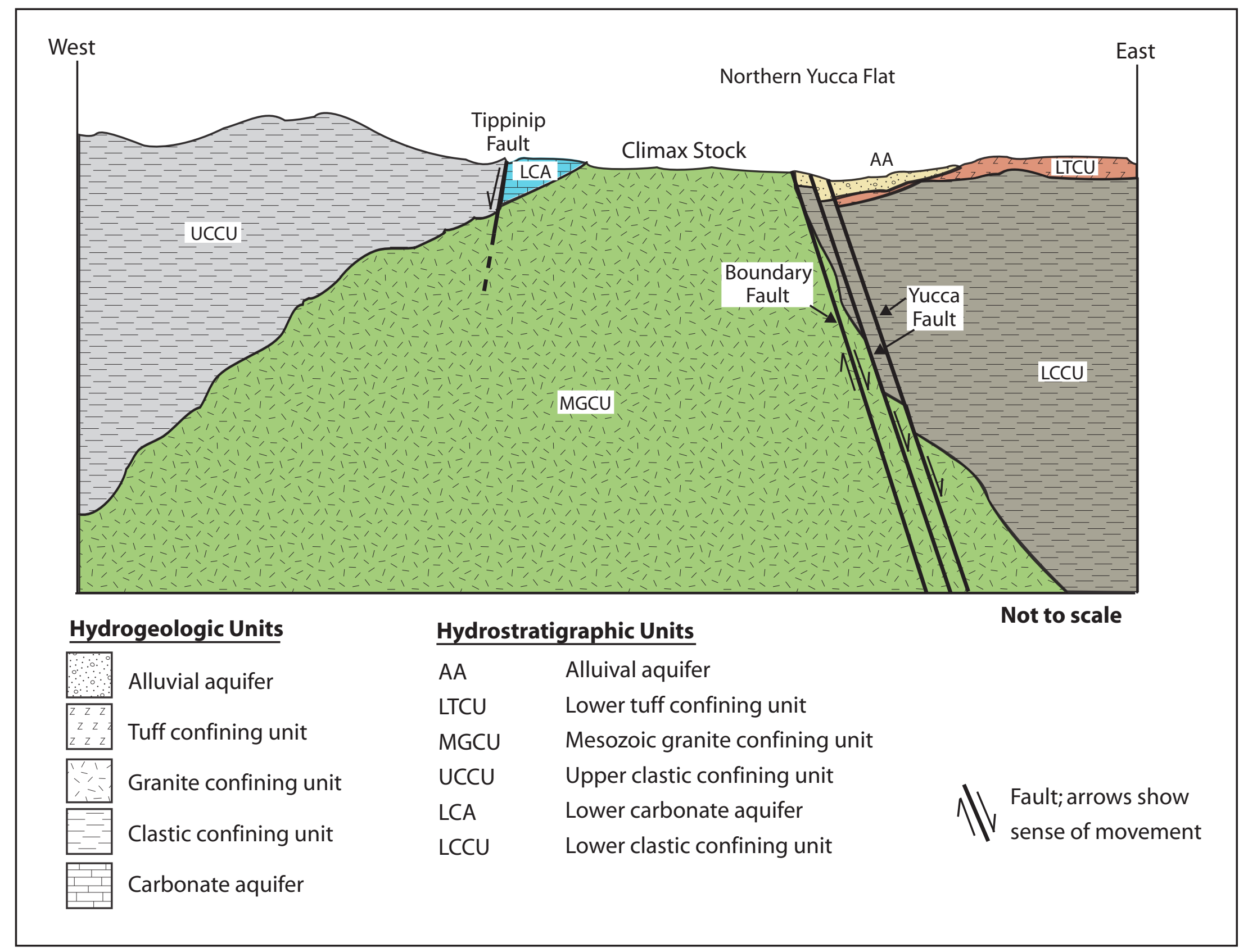

Figure 4-33

Schematic West-East Cross Section Showing the Climax Stock Granitic Instrusive 


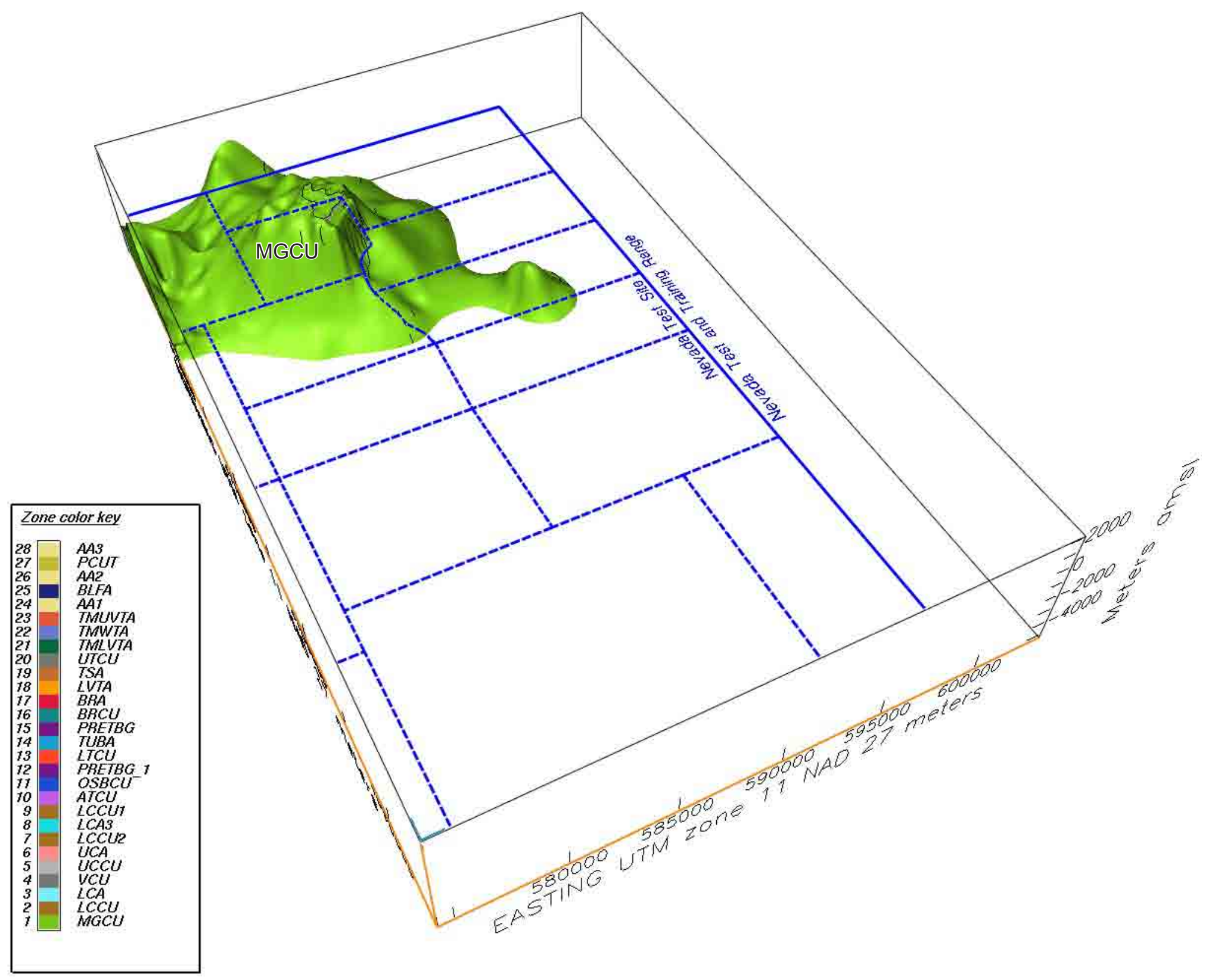

Figure 4-34

Block Model View Showing Extent of the Mesozoic Granitic Confining Unit (MGCU) within the Yucca Flat-Climax Mine Model Area 


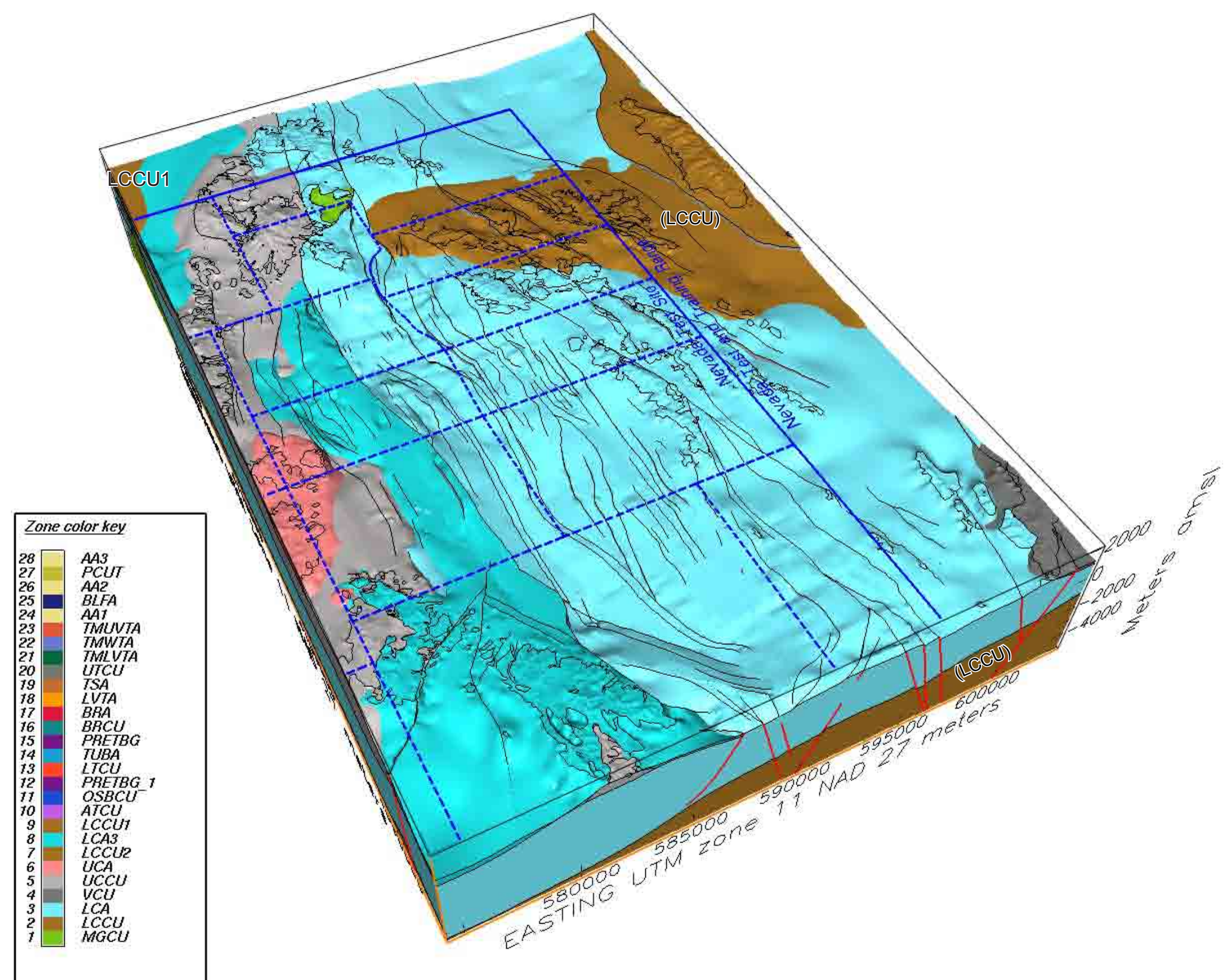

Figure 4-35

Block Model View Showing Extent of the Lower Clastic Confining Unit 1 (LCCU1) within the Yucca Flat-Climax Mine Model Area 


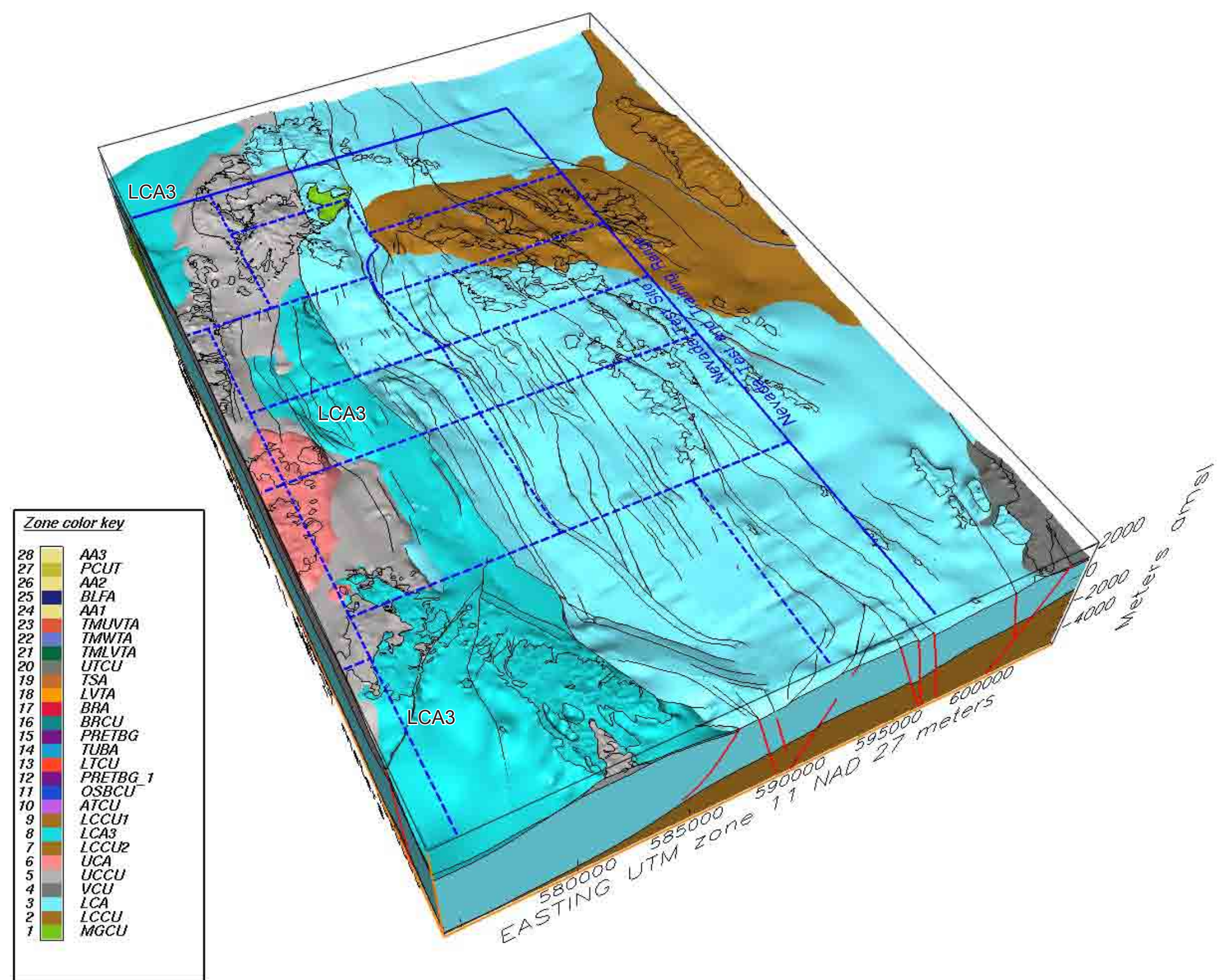

Figure 4-36

Block Model View Showing the Extent of the Lower Carbonate Aquifer-Thrust Plate (LCA3) within the Yucca Flat-Climax Mine Model Area 


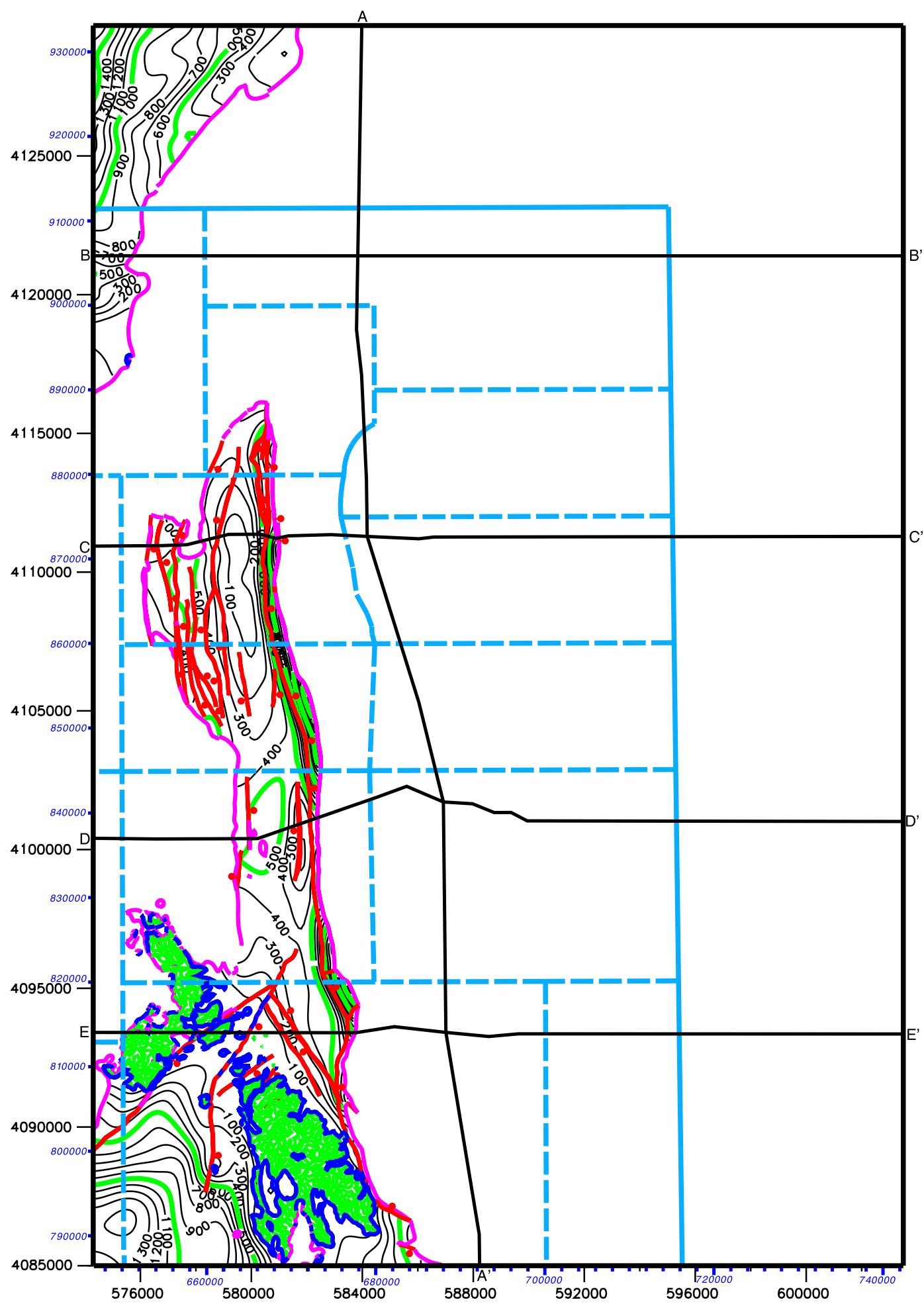

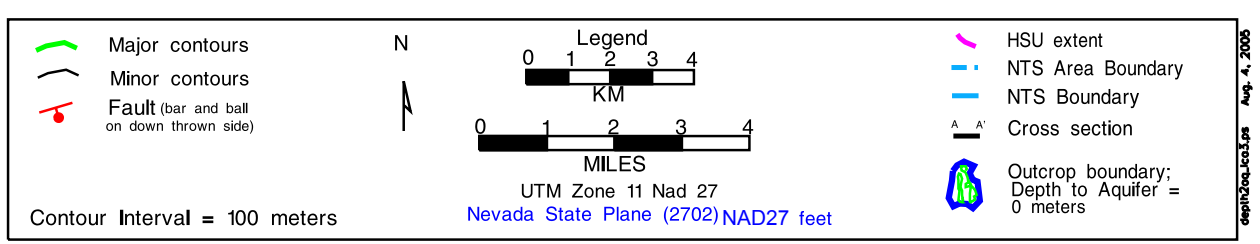

Figure 4-37

Depth to the Lower Carbonate Aquifer-Thrust Plate (LCA3) in the Yucca Flat-Climax Mine Hydrostratigraphic Framework Model 


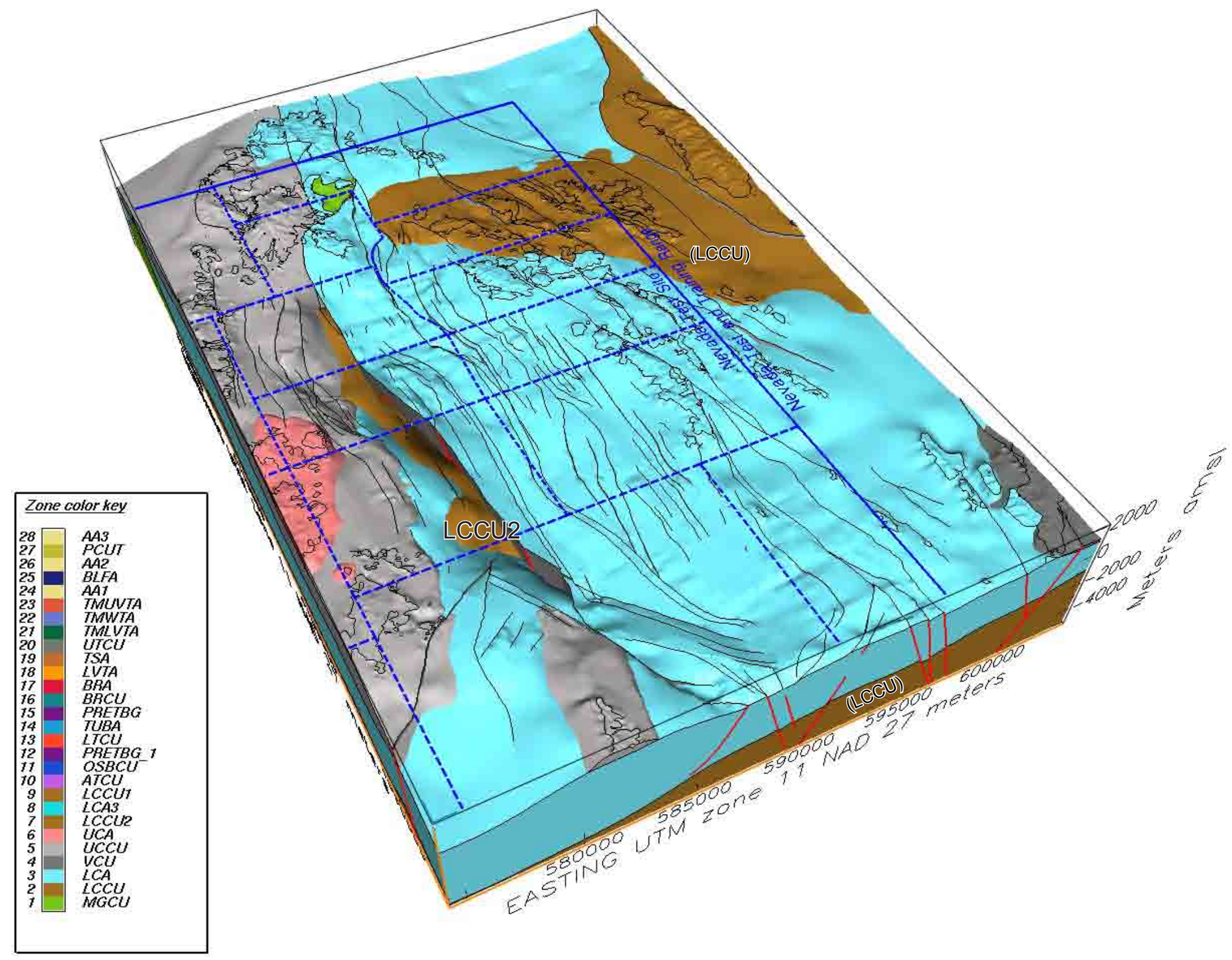

Figure 4-38

Block Model View Showing Extent of the Lower Clastic Confining Unit 2 (LCCU2) within the Yucca Flat-Climax Mine Model Area 


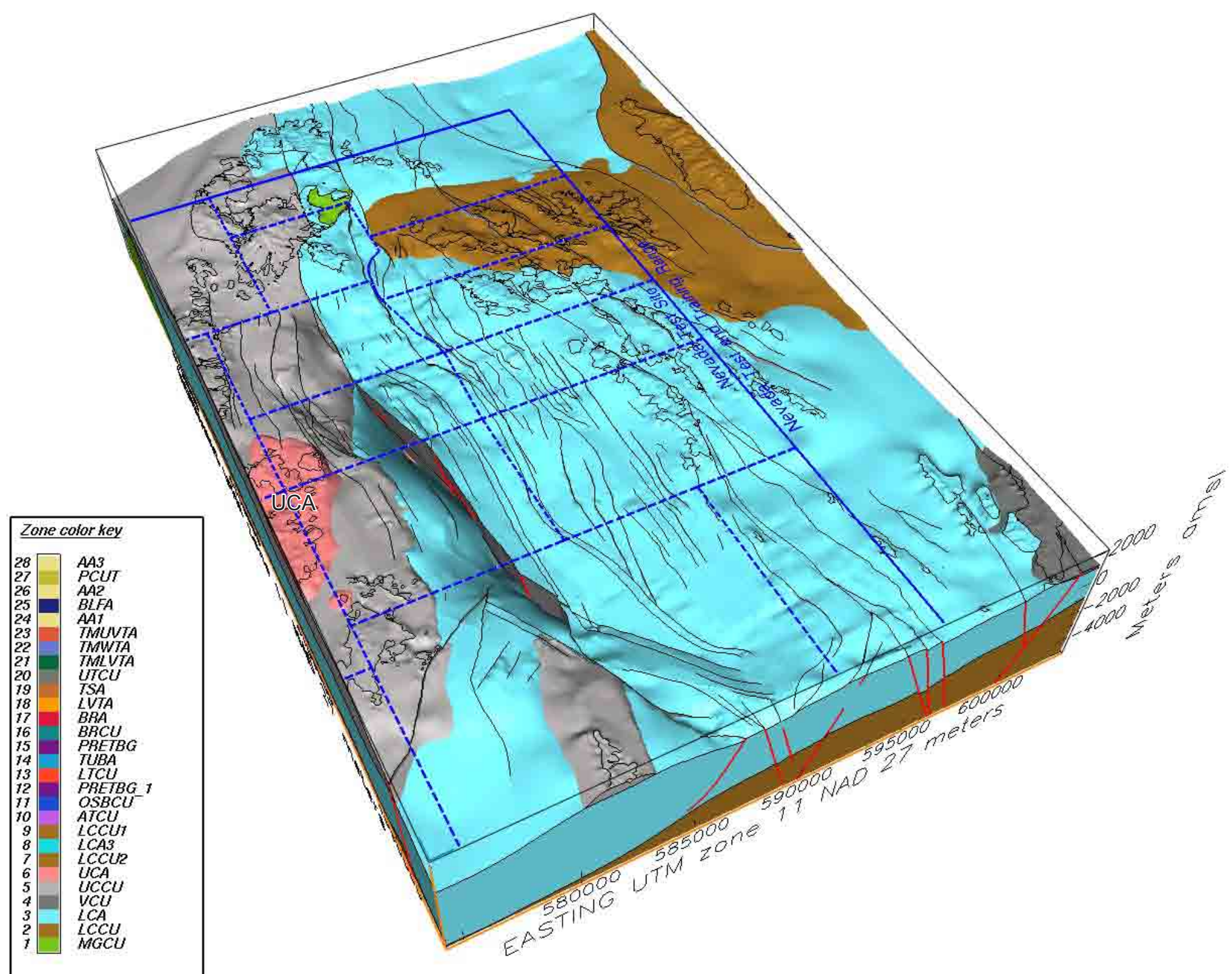

Figure 4-39

Block Model View Showing Extent of the Upper Carbonate Aquifer (UCA) within the Yucca Flat-Climax Mine Model Area 


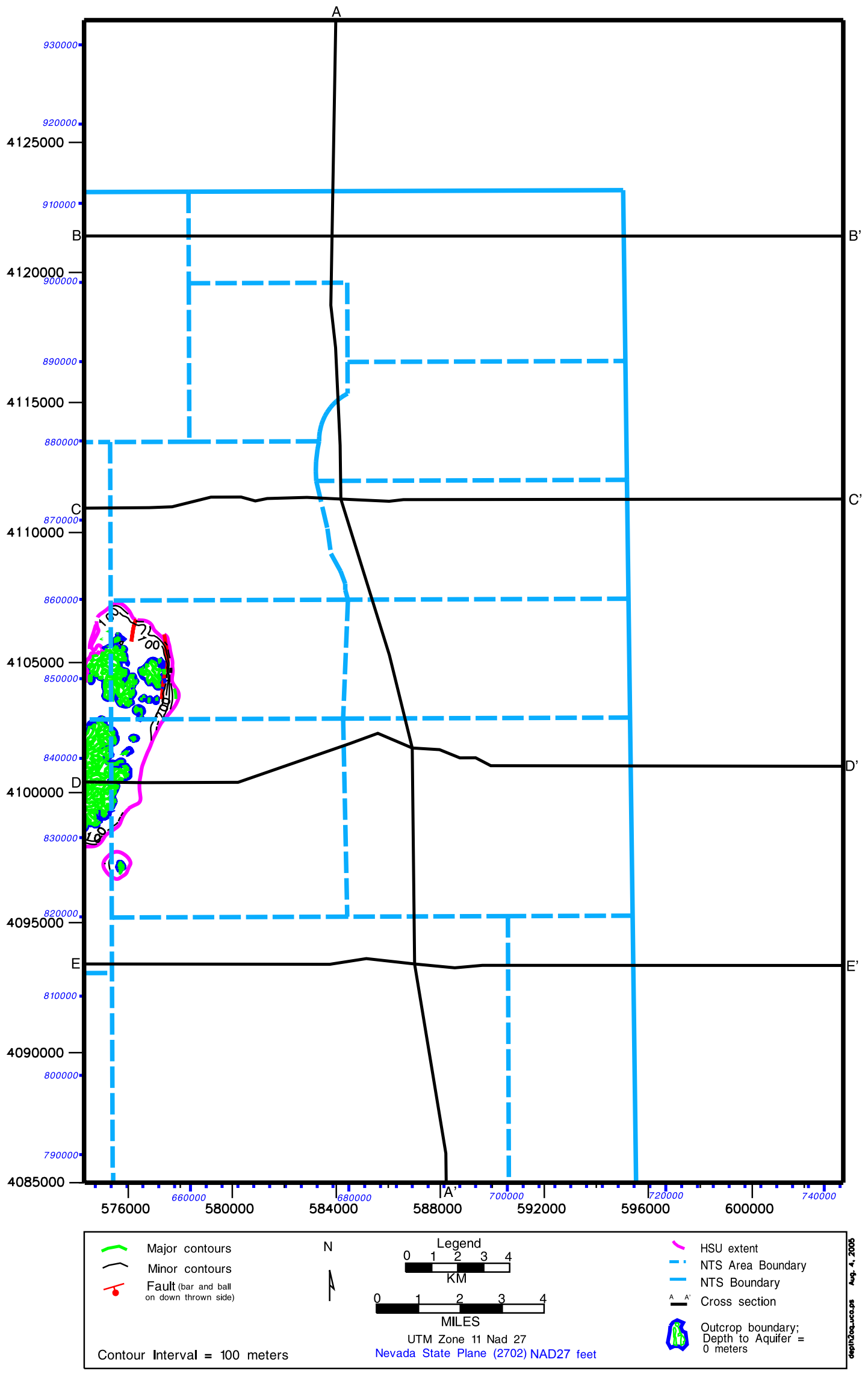

Figure 4-40

Depth to the Upper Carbonate Aquifer (UCA) in the Yucca Flat-Climax Mine Hydrostratigraphic Framework Model 


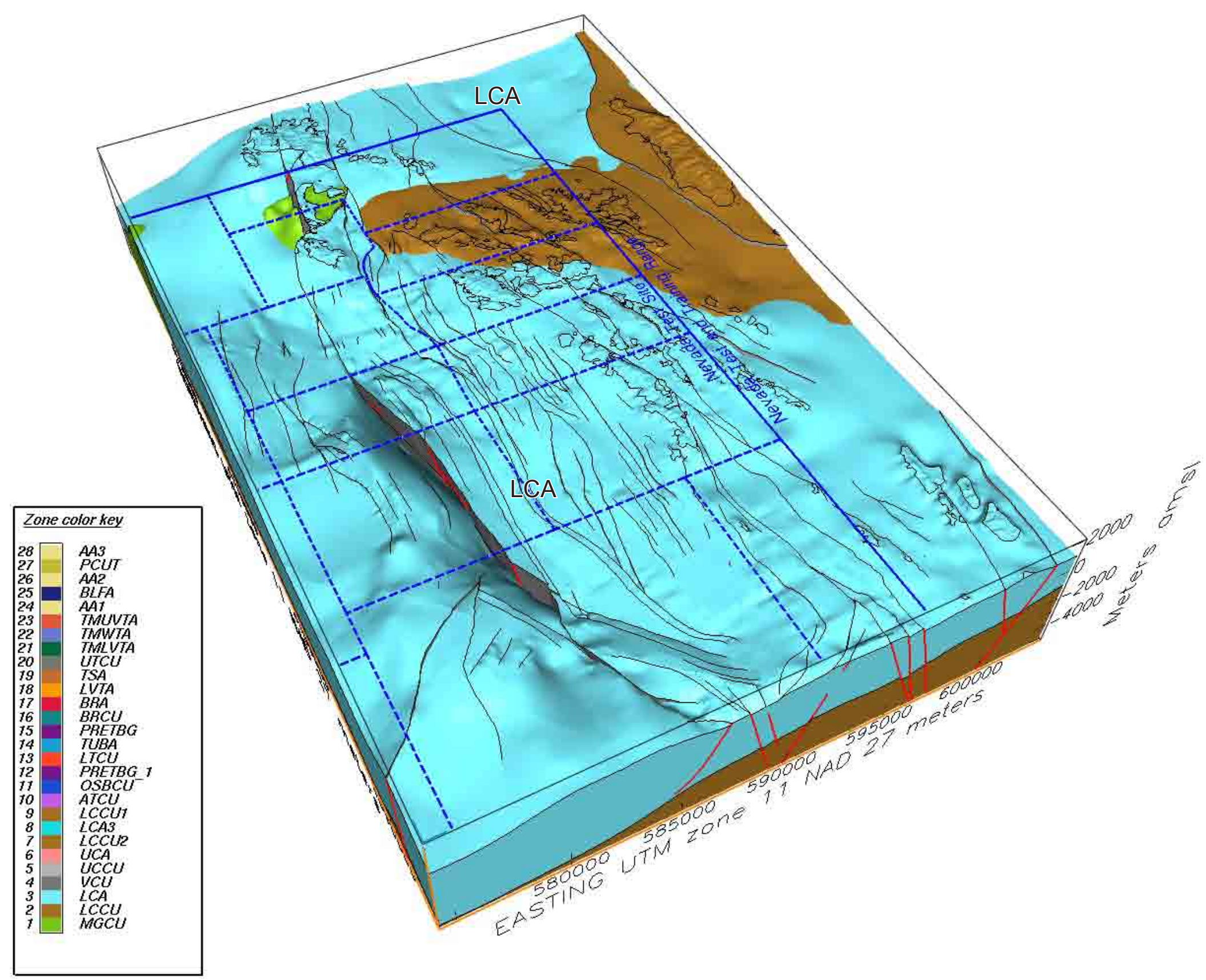

Figure 4-41

Block Model Showing the Extent of the Lower Carbonate Aquifer

(LCA) within the Yucca Flat-Climax Mine Model Area 


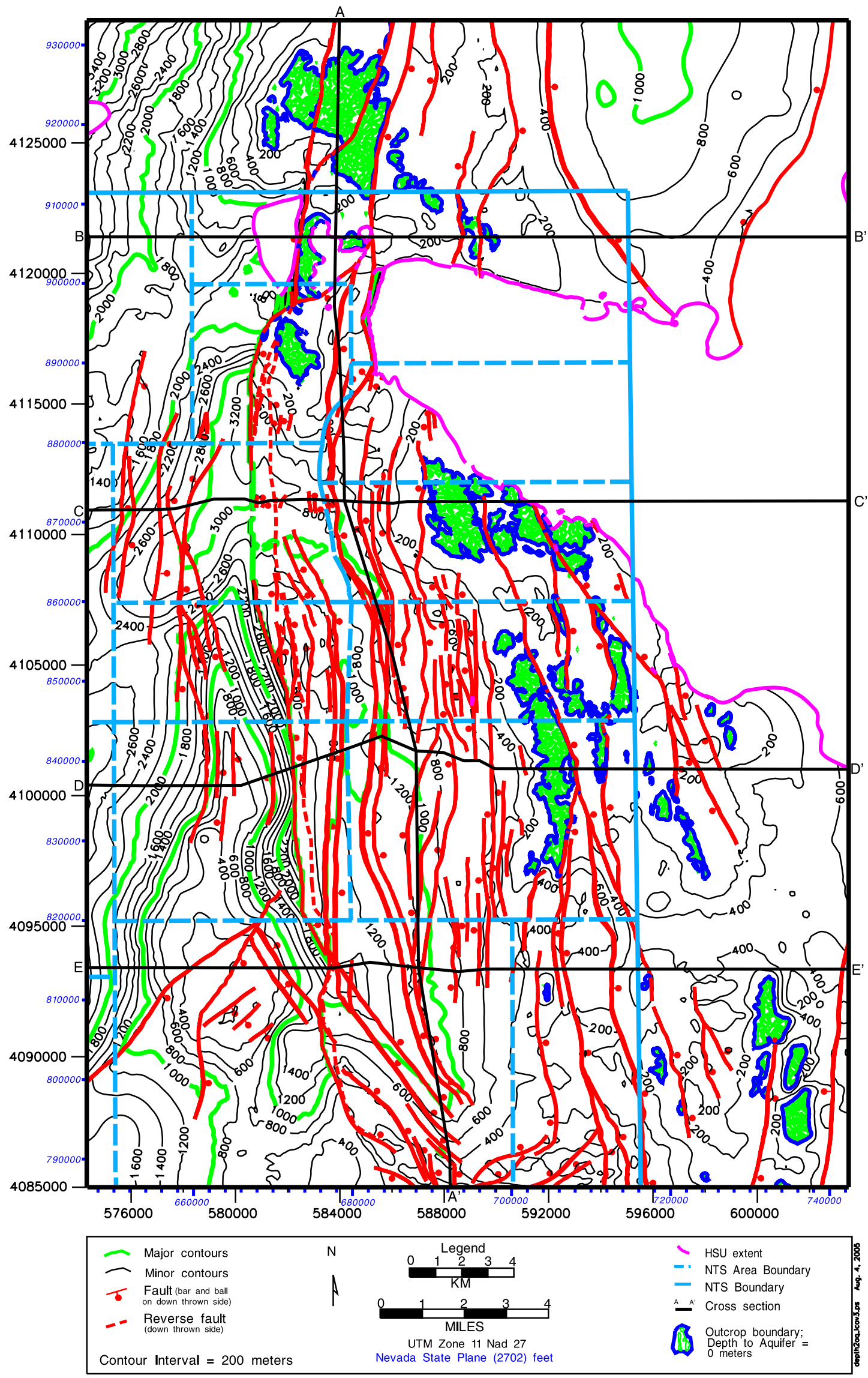

Figure 4-42

Depth to the Lower Carbonate Aquifer (LCA) in the Yucca Flat-Climax Mine Hydrostratigraphic Framework Model 


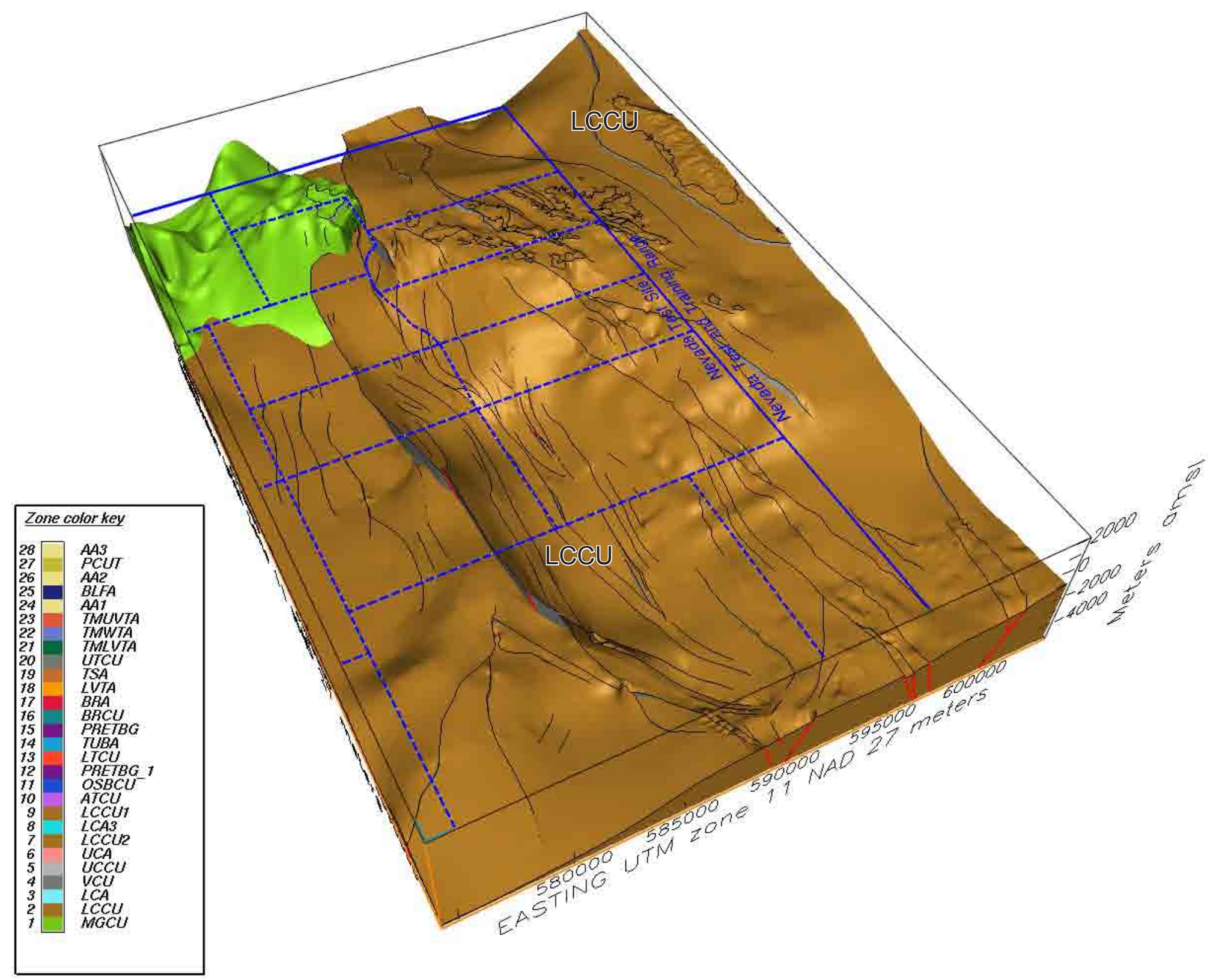

Figure 4-43

Block Model View Showing Extent of the Lower Clastic Confining Unit (LCCU) within the Yucca Flat-Climax Mine Model Area 


\subsection{Alternative Scenarios}

As mentioned in previous sections of this report, the geologic complexity of the model area and non-unique interpretations incorporated into the base model made it necessary to develop alternative interpretations. This section describes the five alternative scenarios developed into separate models, as well as the process used to identify and construct the alternatives.

\subsection{Process of Addressing Alternatives to the Base Model}

Twenty-seven ideas for alternative interpretations to the base model were identified and evaluated during construction of the Phase I base framework model (Table 5-1). These alternatives include ideas from the original draft models (Gonzales et al., 1998; Gonzales and Drellack, 1999) and alternative interpretations identified by the model builders during construction of the final Phase I model. These alternative ideas were presented to the UGTA TWG pre-emptive review committee on May 3, 2005, for their consideration and evaluation, and to solicit additional alternative ideas. Each alternative idea was evaluated and categorized. The main criterion for evaluating and categorizing alternatives was whether the proposed change or alternative interpretation had the potential to significantly affect groundwater flow and contaminant transport. The geological probability and how well constrained each alterative idea is, was also considered. Simplification of portions and specific aspects of the base model were also considered to explore ways to reduce future flow-and-transport modeling efforts without compromising the integrity of the base model.

The alternatives were grouped into four priority categories. Group A alternatives are ideas judged to be significant and viable enough to be included in the base model. Two alternatives were identified as Group A and incorporated directly into the base model. These two alternatives replaced base model interpretations that were themselves subsequently developed as alternative models (see below).

Five alternative ideas were identified as Group B alternatives. These alternatives were judged to be significant enough to develop as separate models. Each alternative was inserted into a copy of the base model, resulting in five separate alternative models. Two of these had originally been included in the draft base model, but were switched out for alternative ideas.

Group C alternatives were judged to be potentially significant, but might be further evaluated during flow modeling. If judged to be significant by the flow modelers, these alternative ideas 
Table 5-1

Abridged List of Alternative Scenarios for the Yucca Flat-Climax Mine Hydrostratigraphic Framework Model

\begin{tabular}{|c|c|c|c|}
\hline & Alternative & $\begin{array}{l}\text { Priority } \\
\text { Group a }\end{array}$ & Comment/Discussion \\
\hline \multicolumn{4}{|c|}{ 1.0 HYDROSTRATIGRAPHY-RELATED ALTERNATIVES } \\
\hline \multicolumn{4}{|c|}{ 1.1 Alternatives to Simplify Hydrostratigraphy } \\
\hline 1.1 .1 & $\begin{array}{l}\text { Simplify HSUs above the } \\
\text { water table. }\end{array}$ & D & $\begin{array}{l}\text { Can HSUs in the unsaturated zone be lumped, simplified, or ignored? } \\
\text { Reducing the detail in the unsaturated portions of the framework model will not significantly } \\
\text { reduce the flow-and-transport modeling effort. Also, most of the HSUs that occur within } \\
\text { unsaturated portions of the model also occur below the water table in other portions of the model } \\
\text { area. And finally, the UGTA project criteria, as outlined in the FFACO, address only the } \\
\text { saturated zone. }\end{array}$ \\
\hline 1.1 .2 & $\begin{array}{l}\text { Decrease the depth of the } \\
\text { model. }\end{array}$ & D & $\begin{array}{l}\text { Is there any merit in raising the bottom of the model? } \\
\text { Work on the UGTA regional model demonstrated that even after removing the lowest } 2 \mathrm{~km} \\
(1.2 \mathrm{mi}) \text { from the bottom of the model, there was no difference in the outcome compared to the } \\
\text { original model. Conductivity below about } 3,000 \mathrm{~m}(9,800 \mathrm{ft}) \text { maybe negligible. The significance } \\
\text { of changing the base of the model would, of course, be dependent upon depth decay } \\
\text { assumptions for conductivity. Also, the elevation of the bottom of the framework model is } \\
\text { consistent with the regional model. }\end{array}$ \\
\hline \multicolumn{4}{|c|}{ 1.2 Alternatives to Add Hydrostratigraphic Detail } \\
\hline & $\begin{array}{l}\text { Differentiate older ash- } \\
\text { flow tuff units of the lower } \\
\text { tuff confining unit (LTCU). }\end{array}$ & $\begin{array}{c}\text { A } \\
\text { (within } \\
\text { Yucca } \\
\text { Flat } \\
\text { basin) } \\
\\
\text { D } \\
\text { (outside } \\
\text { Yucca } \\
\text { Flat } \\
\text { basin) }\end{array}$ & $\begin{array}{l}\text { Hydraulic conductivity of the several interbedded ash-flow tuff units within the lower portion of the } \\
\text { LTCU may be worth considering. These older ash-flow tuffs include Yucca Flat Tuff (Toy), Redrock } \\
\text { Valley Tuff (Tor), and Tuff of Twin Peaks (Tot). In addition, the lower portion of the LTCU that } \\
\text { includes these older units has a more diverse mineralogy than the rest of the LTCU (Prothro, } \\
\text { 2005a). } \\
\text { Very little data exists for the 3-D distribution and hydrologic character of individual ash-flow tuffs } \\
\text { that are present within the lower portion of the LTCU beneath Yucca Flat. However, sufficient } \\
\text { data do exist within the main Yucca Flat basin for delineating the overall stratigraphic interval in } \\
\text { which these ash-flow tuffs occur. Delineation of these older ash-flow tuffs is basically addressed } \\
\text { by the recent subdivision of the TCU (Prothro, 2005a). Within the main Yucca Flat basin the } \\
\text { interval that includes the older ash-flow tuff units will be differentiated in the base model and } \\
\text { alternatives as OSBCU. There is little sub-surface control outside the main Yucca Flat basin to } \\
\text { subdivide these units which are generally unsaturated outside the main basin. }\end{array}$ \\
\hline
\end{tabular}


Table 5-1

Abridged List of Alternative Scenarios for the Yucca Flat-Climax Mine Hydrostratigraphic Framework Model

(continued)

\begin{tabular}{|c|c|c|c|}
\hline \multicolumn{2}{|r|}{ Alternative } & $\begin{array}{l}\text { Priority } \\
\text { Group a }\end{array}$ & Comment/Discussion \\
\hline 1.2 .2 & $\begin{array}{l}\text { Subdivide the alluvium } \\
\text { based on relative } \\
\text { abundance of reactive } \\
\text { minerals. }\end{array}$ & B & $\begin{array}{l}\text { Information from Warren et al. (2002) and Pawloski (1996) indicate significant differences in the } \\
\text { mineralogical and physical properties of the alluvium within Frenchman Flat that likely affect } \\
\text { significantly groundwater flow and contaminate transport within the model area. Is there enough } \\
\text { information for Yucca Flat (i.e., as in Warren et al., 2002), and are the differences significant and } \\
\text { predictable enough to warrant subdividing these units? Perhaps this should be a separate sub- } \\
\text { CAU-scale model. } \\
\text { The lowermost alluvial section is saturated only in some of the deeper sub-basins of south- } \\
\text { central Yucca Flat. It is important to model as much detail as possible only where the alluvium } \\
\text { section is saturated. The partial zeolitization alternative (1.256) addresses this concern. }\end{array}$ \\
\hline 1.2 .3 & $\begin{array}{l}\text { Maximize detail within } \\
1,000 \mathrm{~m}(3,280 \mathrm{ft}) \text { of the } \\
\text { water table. }\end{array}$ & D & $\begin{array}{l}\text { Will small differences at, or just beneath the water table make significant differences in the flow-and } \\
\text { transport modeling results (e.g., raise or lower an HSU, or, add or remove HSUs)? } \\
\text { There is already a fair amount of detail in the model (number of HSUs and structural features) } \\
\text { for the testing areas. This level of detail maybe adequate. }\end{array}$ \\
\hline 1.2 .4 & Basalt dike geometry & D & $\begin{array}{l}\text { Basalt lava flows are present in the alluvium in southwest Yucca Flat and in the Halfpint Range on } \\
\text { the east side of Yucca Flat. How would a basalt dike affect groundwater flow? What properties } \\
\text { should be assigned to this material? Can we define the hydrologic properties of such a thin tabular } \\
\text { body? } \\
\text { A basalt dike would likely have hydrologic properties similar to a basalt lava-flow aquifer. There } \\
\text { is almost no evidence that basaltic dikes occur beneath Yucca Flat except in one hole (UE-7h), } \\
\text { and thus the locations and geometries of any such features is virtually unknown. }\end{array}$ \\
\hline 1.2 .5 & $\begin{array}{l}\text { Identify areas of partial or } \\
\text { irregular zeolitic } \\
\text { alteration. }\end{array}$ & B & $\begin{array}{l}\text { For most of Yucca Flat the level of zeolitization is a relatively distinct boundary. However, in north- } \\
\text { central Yucca Flat there seems to be an area of partial zeolitization of significant thickness. Such } \\
\text { alteration could affect hydraulic properties (especially vertical conductivity) and contaminant } \\
\text { transport. This situation is likely to affect flow and transport modeling. }\end{array}$ \\
\hline
\end{tabular}


Table 5-1

Abridged List of Alternative Scenarios for the Yucca Flat-Climax Mine Hydrostratigraphic Framework Model (continued)

\begin{tabular}{|c|c|c|}
\hline Alternative & $\mid \begin{array}{l}\text { Priority } \\
\text { Group }\end{array}$ & Comment/Discussion \\
\hline \multicolumn{3}{|c|}{ 1.3 Alternatives Addressing Different Distributions for Pre-Tertiary HSUs } \\
\hline 1.3.1 Subdivide the LCA. & D & $\begin{array}{l}\text { Would occurrences of the Dunderberg Shale or Eureka Quartzite alter flow in the LCA? } \\
\text { The LCA, (approximately 4,267 m [14,000 ft] thick) consists mainly of massive carbonate. } \\
\text { However, siliciclastic units, such as the Dunderberg Shale and Eureka Quartzite, occur within } \\
\text { the LCA. These units are generally less than } 91 \mathrm{~m} \text { ( } 300 \mathrm{ft} \text { ) thick each and thus account for less } \\
\text { than } 5 \text { percent of the HSU. Few holes within the model area have penetrated a substantial } \\
\text { thickness of the LCA and none have encountered the Dunderberg Shale and only a few holes } \\
\text { have penetrated the Eureka Quartzite. Thus the 3-D distribution and hydraulic properties of } \\
\text { these minor clastic units is unknown within most of the model area. }\end{array}$ \\
\hline \multicolumn{3}{|c|}{ 2.0 STRUCTURE-RELATED ALTERNATIVES } \\
\hline $\begin{array}{l}2.1 \text { Simplify the Structural } \\
\text { Model }\end{array}$ & D & $\begin{array}{l}\text { Omit all but the most profound structures and faults. } \\
\text { The number of faults and structural detail in the model are sufficient, and any simplification of the } \\
\text { structure will not significantly reduce future modeling efforts. In addition, the level of structural } \\
\text { detail in the framework model already represents a considerable simplification of the structural } \\
\text { geology of the area. Any further simplification may detrimentally affect the integrity of the model. }\end{array}$ \\
\hline $\begin{array}{l}2.2 \text { Remove Faults Along Edge } \\
\text { of Model }\end{array}$ & D & $\begin{array}{l}\text { Remove faults in the eastern portion of the model. } \\
\text { Although removing faults might simplify flow-and-transport modeling, these faults define the } \\
\text { structural fabric of the area which is likely important with regards to groundwater flow, } \\
\text { particularly in direction. }\end{array}$ \\
\hline
\end{tabular}


Table 5-1

Abridged List of Alternative Scenarios for the Yucca Flat-Climax Mine Hydrostratigraphic Framework Model (continued)

\begin{tabular}{|c|c|c|c|}
\hline & Alternative & $\begin{array}{l}\text { Priority } \\
\text { Group }^{a}\end{array}$ & Comment/Discussion \\
\hline \multicolumn{4}{|c|}{ 2.3 Add More Structural Detail } \\
\hline 2.3 .1 & Add width to faults. & D & $\begin{array}{l}\text { Modify faults from simple 2-dimensional surfaces to 3-D features having some width. } \\
\text { The current approach to creating a model mesh explicitly assigns width to the faults. The widths } \\
\text { of faults are not known in reality, but they may exist as zones with some width. }\end{array}$ \\
\hline 2.3 .2 & $\begin{array}{l}\text { Add more Tertiary faults } \\
\text { or fault zones. }\end{array}$ & D & $\begin{array}{l}\text { Perhaps begin by adding more of the mapped faults (shown on Slate et al. [1999] or the individual } \\
\text { USGS quadrangle maps). } \\
\text { The number of faults in the model is sufficient and a good compromise between geologic reality } \\
\text { and flow and transport modeling constraints. }\end{array}$ \\
\hline 2.3 .3 & $\begin{array}{l}\text { Extend the CP thrust fault } \\
\text { east to the Yucca fault } \\
\text { and add the UCCU south } \\
\text { of Climax Stock }\end{array}$ & B & $\begin{array}{l}\text { The CP thrust is a poorly characterized, west-to-northwest-vergent thrust fault. Some uncertainty } \\
\text { exists as to the eastern extent immediately south of Climax stock. } \\
\text { The CP thrust is exposed at the surface in one place, southwest of Yucca Flat, where it places } \\
\text { carbonate rocks over siliciclastic rocks. Magnetotelluric data (MT) seem to show that the CP } \\
\text { thrust fault may be rooted within the steeply dipping Carpetbag-Topgallant fault system. } \\
\text { However, cultural features (e.g., power lines) prevented acquiring MT data between the } \\
\text { Carpetbag and Yucca faults just south of Climax stock. The eastern extent of the CP thrust in } \\
\text { this area could possibly be the Yucca fault. An alternative model will be developed to explore } \\
\text { this geometry. }\end{array}$ \\
\hline 2.3 .4 & $\begin{array}{l}\text { Change the HSU } \\
\text { designation for the } \\
\text { Paleozoic carbonate } \\
\text { rocks exposed around the } \\
\text { margins of the basin (LCA } \\
\text { or LCA3?). }\end{array}$ & D & $\begin{array}{l}\text { These outcrops are currently modeled as LCA. Could they be LCA3? } \\
\text { Published maps and reports indicate that carbonate rocks exposed around the margins of Yucca } \\
\text { Flat are part of a thick continuous carbonate sequence. Thrust faults are present southeast of } \\
\text { the model area, suggesting that the carbonate rocks around the margins of the basin may be } \\
\text { part of a thrust sheet. However, the thrust sheet would likely be very thick, based on surface } \\
\text { exposures, and the base of the thrust sheet would occur at great depths below the basin. Thus } \\
\text { it would likely have little hydrologic impact if the carbonate rocks around the margins of Yucca } \\
\text { Flat basin are designated LCA or LCA3. }\end{array}$ \\
\hline
\end{tabular}


Table 5-1

Abridged List of Alternative Scenarios for the Yucca Flat-Climax Mine Hydrostratigraphic Framework Model (continued)

\begin{tabular}{|c|c|c|c|}
\hline & Alternative & $\begin{array}{l}\text { Priority } \\
\text { Group a }^{2}\end{array}$ & Comment/Discussion \\
\hline 2.3 .5 & $\begin{array}{l}\text { Explore fault-related } \\
\text { groundwater pathways. }\end{array}$ & B & $\begin{array}{l}\text { Increase or decrease fault displacements so aquifers are juxtaposed across faults. Deliberately } \\
\text { juxtapose aquifer units across faults, but apply only in the areas formerly used for UGTs. } \\
\text { Candidates for such adjustments would include the basin-forming faults in central Yucca Flat. } \\
\text { This scenario was judged important and will be pursued as an alternative. }\end{array}$ \\
\hline 2.3 .6 & Other fault variations & $\mathbf{D}$ & $\begin{array}{l}\text { Faults are depicted in the hydrostratigraphic framework model as single planes. Can other } \\
\text { variations be represented? } \\
\text { See comment for 2.3.1. }\end{array}$ \\
\hline \multicolumn{4}{|c|}{ 2.4 Develop Different Structural Scenarios } \\
\hline 2.4 .1 & Vary fault dips. & D & $\begin{array}{l}\text { The basin-and-range normal faults are modeled using a 75-degree dip. Varying fault dips would } \\
\text { present more consequences in the source areas, where fault proximity to working points is } \\
\text { important. } \\
\text { Use of a finite element mesh does not allow arbitrary changes to fault thickness or } \\
\text { orientation. See related scenarios presented in } 2.3 .1 \text { and 2.3.6. }\end{array}$ \\
\hline 2.4 .2 & $\begin{array}{l}\text { Vary the depth to } \\
\text { basement rocks. }\end{array}$ & D & $\begin{array}{l}\text { The uncertainty in depth to basement based on geophysical data (gravity) is up to } 300 \mathrm{~m}(1,000 \mathrm{ft}) \text { in } \\
\text { places. This may not be geologically permissible in some areas. Where it is possible, what units } \\
\text { would be thinned or thickened? } \\
\text { Although some data, such as gravity, have relatively low resolution, other geologic input } \\
\text { particularly the age estimates for outcrops and stratigraphic thickness for underlying units } \\
\text { constrain the depth to basement fairly well in the hydrologically significant areas such as the } \\
\text { northern and eastern portions of the model. }\end{array}$ \\
\hline 2.4 .3 & $\begin{array}{l}\text { Thicken or thin the } \\
\text { UCCU. }\end{array}$ & D & $\begin{array}{l}\text { Thickness of the UCCU on the west side of Yucca Flat is uncertain. UCCU thickness in the model is } \\
\text { based on only a few drill holes and interpretation of MT data. } \\
\text { Discussions between geologists and hydrologic modelers concluded that thickening the UCCU } \\
\text { would have little significance to groundwater flow and contaminant transport. }\end{array}$ \\
\hline
\end{tabular}




\section{Table 5-1}

Abridged List of Alternative Scenarios for the Yucca Flat-Climax Mine Hydrostratigraphic Framework Model (continued)

\begin{tabular}{|c|c|c|c|}
\hline \multicolumn{2}{|r|}{ Alternative } & \multirow{2}{*}{$\begin{array}{c}\begin{array}{l}\text { Priority } \\
\text { Group }^{\text {a }}\end{array} \\
\\
\end{array}$} & Comment/Discussion \\
\hline 2.4 .4 & $\begin{array}{l}\text { Continuous UCCU in the } \\
\text { southwest corner of the } \\
\text { model. }\end{array}$ & & $\begin{array}{l}\text { Expand and connect the two UCCU masses in the southwestern corner of the Yucca Flat model to } \\
\text { restrict groundwater flow out of Yucca Flat towards Mid Valley. } \\
\text { This scenario was judged important because of its potential influence on groundwater flow. } \\
\text { Additional MT data in this area might resolve this uncertainty. }\end{array}$ \\
\hline \multicolumn{4}{|c|}{2.5 Other Structure-Related Alternatives } \\
\hline 2.5 .1 & $\begin{array}{l}\text { "Smooth" versus "rough" } \\
\text { HSU surface. }\end{array}$ & D & $\begin{array}{l}\text { Computer idiosyncracies have produced "hills" and "indentations" on HSU surfaces where none } \\
\text { were intended. Does it matter? A rough surface might better approximate the effect of faulting. } \\
\text { Based on discussions with modelers and the TWG pre-emptive review committee, the } \\
\text { elevations of the "hills" and "indentations" are deemed not great enough to be significant. }\end{array}$ \\
\hline 2.5 .2 & $\begin{array}{l}\text { Consider defining basin } \\
\text { slopes with faults. }\end{array}$ & $\mathbf{D}$ & $\begin{array}{l}\text { The UGTA base model portrays many of the gravity lows as syncline-type structures and not half- } \\
\text { grabens (e.g., eastern extension, Mid Valley). Are there more faults (possibly hydrologically } \\
\text { significant) that are not discernable with geophysics? } \\
\text { There are certainly more faults, however geophysical data (e.g. seismic and gravity) constrain } \\
\text { additional faults as relatively small displacement. Given the data sets for Yucca Flat proper, it's } \\
\text { unlikely that any significant unknown faults are present in the Yucca Flat underground test area. }\end{array}$ \\
\hline 2.5 .3 & $\begin{array}{l}\text { Explore variations of the } \\
\text { accommodation zone } \\
\text { between Frenchman and } \\
\text { Yucca Flat. }\end{array}$ & D & $\begin{array}{l}\text { This feature appears as a gravity high between two extensional basins. How does this area affect } \\
\text { inter-basin groundwater flow? } \\
\text { Although this area is complex, surface exposure is very good, and geophysical data are } \\
\text { available for much of the area. The base model incorporates these data, including HSU } \\
\text { contacts and faults exposed at the surface, and thus models the most important controls such as } \\
\text { HSU distribution and fault orientations fairly well in this area. }\end{array}$ \\
\hline
\end{tabular}




\section{Table 5-1}

Abridged List of Alternative Scenarios for the Yucca Flat-Climax Mine Hydrostratigraphic Framework Model (continued)

\begin{tabular}{|c|c|c|c|}
\hline \multicolumn{2}{|r|}{ Alternative } & $\begin{array}{l}\text { Priority } \\
\text { Group }^{\text {a }}\end{array}$ & Comment/Discussion \\
\hline 2.5 .4 & $\begin{array}{l}\text { Cracks on Yucca Lake } \\
\text { playa. }\end{array}$ & D & $\begin{array}{l}\text { Large arcuate cracks have appeared abruptly in the playa sediments, and large volumes of ponded } \\
\text { water drained into the newly-formed cracks. Could this intermittent focused recharge have an affect } \\
\text { on the model? } \\
\text { Based on discussions between geologists and modelers, the influence of these cracks on flow } \\
\text { and transport was deemed insignificant (silt has subsequently filled these cracks and they are no } \\
\text { longer preferential drainage conduits). Note that the UGTA project only considers the saturated } \\
\text { systems. However, this issue could be explored using the multiple recharge models, and may } \\
\text { be addressed at a later date. }\end{array}$ \\
\hline 2.5 .5 & $\begin{array}{l}\text { Extend the CP thrust fault } \\
\text { east to include the } \\
\text { Halfpint Range. }\end{array}$ & D & $\begin{array}{l}\text { Could the uppermost pre-Tertiary rocks that form the floor of Yucca Flat basin and which outcrop in } \\
\text { the Halfpint Range be a thrust sheet? These rocks would then be LCA3 and LCCU1 overlying thick } \\
\text { LCA. } \\
\text { Drilling and resistivity data from eastern Yucca Flat indicate that the pre-Tertiary surface in these } \\
\text { areas consists of carbonate rocks, and MT data indicate that the carbonate rocks extend to great } \\
\text { depths east of the Carpetbag-Topgallant fault. Thus, if the CP thrust extends beyond the Yucca } \\
\text { fault and into the eastern portion of Yucca Flat, it is either very deep or places carbonate rocks } \\
\text { over carbonate rocks, and thus will likely have minimal hydrologic effect, if present beneath } \\
\text { Yucca Flat. Geological data, including a recent MT survey, make this scenario improbable. }\end{array}$ \\
\hline 2.5 .6 & $\begin{array}{l}\text { Create groundwater } \\
\text { pathways on either side of } \\
\text { the Climax Stock. }\end{array}$ & $\mathrm{A} / \mathrm{B}$ & $\begin{array}{l}\text { The combined geometry of the Halfpint Range anticline (LCCU), the Climax stock (MGCU) and the } \\
\text { Eleana/Chainman (UCCU) is believed to collectively form a hydraulic barrier at the north end of } \\
\text { Yucca Flat. Logical breaches in this barrier would be on either side of the Climax stock. } \\
\text { Some recharge to Yucca Flat from the north is reasonable. The base model should allow some } \\
\text { flow at these complex sites while an alternative model can be developed to effectively prevent } \\
\text { (or severely limit) flow into Yucca Flat. }\end{array}$ \\
\hline
\end{tabular}




\section{Table 5-1}

Abridged List of Alternative Scenarios for the Yucca Flat-Climax Mine Hydrostratigraphic Framework Model (continued)

\begin{tabular}{|c|c|c|c|}
\hline & Alternative & $\begin{array}{l}\text { Priority } \\
\text { Group }^{a}\end{array}$ & Comment/Discussion \\
\hline 2.5 .7 & $\begin{array}{l}\text { Explore the effect of a } \\
\text { LCCU2 "ridge" along the } \\
\text { Carpetbag-Topgallant } \\
\text { fault system. }\end{array}$ & C & $\begin{array}{l}\text { The CP thrust fault ramp along the Carpetbag-Topgallant fault system may have produced a north- } \\
\text { south-trending ridge of impermeable LCCU2 (Profiles C-C' and D-D'). Could such a ridge affect } \\
\text { deep groundwater flow from the northwest? } \\
\text { Such a configuration could affect groundwater flow. However, hydraulic properties of the } \\
\text { LCCU2 ridge can be altered during modeling to explore the effect, and a separate } \\
\text { hydrostratigraphic framework alternative may not be necessary. Its presence is already } \\
\text { accounted for in the base model. Its absence could be explored by changing LCCU2 hydrologic } \\
\text { properties to LCA properties. }\end{array}$ \\
\hline
\end{tabular}

a Group A are changes to the UGTA base model recommended by the alternative scenario working group, and are already implemented.

Group B are considered viable alternative scenarios that have been developed into alternative models.

Group $\mathbf{C}$ are proposed alternatives that would be better addressed during the hydrologic modeling phase, rather than as alternatives to the base framework model.

Group $\mathbf{D}$ are proposed alternatives that were deemed to be low priority (due to perceived minimal consequences to groundwater flow and contaminant transport), not cost-effective, not practical (no data, too complex, etc.), or simply not necessary to model at this time. 
will be addressed during flow and transport modeling by manipulation of model parameters. Thus, separate alternative framework models were not developed for these ideas.

Group D alternatives were deemed not significant or viable enough to warrant development as alternative models. These alternative ideas will not be considered further.

The changes listed in Group A were implemented and are part of the base model as reported in this document.

\section{Group A - Recommended Changes to the Base Model}

(Numbers in parentheses refer to Table 5-1, where more information about these changes can be found.)

1 Create potential groundwater pathways on either side of Climax stock (2.5.6). Note that an alternative model will address the more complete barrier scenario.

2 Differentiate older ash-flow tuff units in the LTCU. (1.2.1)

The list of alternative scenarios which the working group deemed important enough to pursue (Group B) are listed below in descending order of inferred potential impact.

\section{Group B - Viable Alternative Scenarios}

(Numbers in parentheses refer to Table 5-1, where more information about these changes can be found.)

1 Extend the UCCU east to the Yucca fault, in northern Yucca Flat. (2.3.3)

2 Enhance the hydrologic barrier in northern Yucca Flat. (2.5.6)

3 Expand the UCCU in southwestern Yucca Flat into a larger, contiguous sheet. (2.4.4)

4 Explore fault-related groundwater pathways. Vary displacement of the basin-forming faults to force juxtaposition of volcanic HSUs with the LCA. (2.3.5)

5 Define the area of partial zeolitization above the level of pervasive zeolitization in central Yucca Flat. (1.2.2 and 1.2.5) 
Proposed alternatives that would be better addressed during the hydrologic modeling phase rather than as alternatives to the geologic framework model make up Group C.

\section{Group C - Proposed Alternatives to Address During the Hydrologic Modeling Phase}

(Number in parentheses refers to Table 5-1, where more information about these changes can be found.)

1 Explore the effect of a LCCU2 "ridge" along the Carpetbag-Topgallant fault system. (2.5.7)

\subsection{Alternative Models}

This section describes the five alternative models (Group B) developed for the Yucca FlatClimax Mine hydrostratigraphic framework model.

\subsubsection{CP Thrust Alternative}

Based on MT data and regional structural analysis, Mississippian siliciclastic rocks that compose the UCCU occur within the footwall of the CP thrust fault which is modeled as steepening rapidly eastward and forming a ramp structure beneath central Yucca Flat coincident with the Carpetbag-Topgallant fault system (Profiles B-B' and C-C'). As a result the base model limits the UCCU to the western portion of the model area west of the Carpetbag-Topgallant fault system (Figure 4-32). However, MT data are sparse in northern Yucca Flat east of the Carpetbag fault due to the presence of power lines that interfere with MT recordings (Figure 2-5). The eastern limit of the UCCU is therefore poorly constrained east of the Carpetbag fault in northern Yucca Flat.

The CP thrust alternative scenario models the CP thrust ramp as being coincident with the Carpetbag-Topgallant fault system in the southern and central portions of Yucca Flat, but shifting to the east in northern Yucca Flat to become coincident with the Yucca fault (Figures 5-1 and 5-2). In this scenario the UCCU within the footwall rocks of the CP thrust fault extends eastward to the Yucca fault and thus underlies northern Yucca Flat between the Carpetbag and Yucca faults (Figure 5-1). More extensive UCCU in the subsurface of northern Yucca Flat could have significant hydrologic effects, particularly with regard to influx of groundwater into Yucca Flat from the north.

\subsubsection{Hydrologic Barrier in Northern Yucca Flat}

The intent of this alternative is to limit inter-basin groundwater flow from the north, southward into Yucca Flat. The LCCU, UCCU and MGCU form a hydrologic barrier immediately north of Yucca Flat (see map of HSUs at the water table, Plate 2). If this barrier is too low, the model 
may allow too much water to flow into Yucca Flat; if it is too high, the model will not allow enough lateral flow to occur. This alternative restricts inflow, while the base model allows for some flow on the east side over the LCCU anticline (Profile B-B'). Flow on the west side of Climax is limited to deeper flow under the UCCU in both cases.

To restrict flow on the east side of the Climax stock, the "nose" of the Halfpint Range anticline (mostly LCCU at that location) is raised up to the water table (Figures 5-3 and 5-4). The west side was only slightly modified by warping the UCCU downward at the Tippinip fault. Groundwater flow on the west side of the Climax stock is forced deep under the UCCU and consequently flow is reduced due to a natural decrease in conductivity with depth.

\subsubsection{Contiguous UCCU in Southwestern Yucca Flat}

MT data (Figure 2-5) suggest that the UCCU is not continuous within the southwest portion of the model area, such as beneath the CP Hills and Mid Valley (Figure 4-32). The data seem to indicate that much of the area is underlain by thick, highly resistive carbonate, and that the more electrically conductive Mississippian siliciclastic rocks that compose the UCCU are structurally broken up in this area and thus do not form a thick continuous sheet of clastic confining unit. This interpretation was incorporated into the base model. However, interpretation of the MT data in this area is difficult due to sparse drill hole data in the area (Figure 1-2 and Plate 3) and the possible presence of abundant higher resistance quartzite-rich units within the UCCU that may make it difficult to distinguish Mississippian siliciclastic rocks (i.e., UCCU) from older carbonate rocks (i.e., LCA and LCA3). In addition, foreland imbrication related to the Belted Range thrust fault likely results in complex structural geometries in the area, further complicating interpretation of the MT data.

Because of the uncertainty with regard to the occurrence of the UCCU beneath the southwest portion of the model area and the potential significance to groundwater flow, particularly flow out of the basin to the southwest, an alternative model was created that modeled UCCU as a continuous sheet within the subsurface in the southwest portion of the model area (Figures 5-5 and 5-6).

\subsubsection{Fault Juxtaposition}

Because basin-forming faults typically have large vertical displacements, the juxtaposition of shallow aquifers against deeper aquifers could occur and may be significant with regard to flowand-transport modeling in the Yucca Flat area. In the base hydrostratigraphic framework model, aquifers maybe juxtaposed slightly in some places due to faulting along the main basin-forming faults. However, the locations, orientations and amounts of displacements associated with these 
faults are not precisely constrained. Therefore an alternative model was developed that juxtaposed shallow volcanic aquifer HSUs with the LCA along the major basin-forming faults (Figure 5-7).

For this alternative a volcanic aquifer (typically the TM-WTA or TM-LVTA) is positioned against the LCA. This is accomplished by either increasing fault displacements or thinning underlying confining units (but still conforming to any existing nearby data). The target areas for this manipulation were the testing areas in central Yucca Flat, and below the water table. Most commonly the larger basin-forming faults are involved (e.g., the Carpetbag, Topgallant, and Yucca faults). The base model does contain such geometries, but this alternative provides more such situations, particularly in the testing areas.

\subsubsection{Partial Zeolitization}

Geologists have recognized a zone of partial zeolitization above the level of pervasive zeolitization in north-central Yucca Flat (Areas 2 and 9). The zone of partial zeolitization is defined as areas of partial (less than 30 percent) zeolitization as well as areas of sporadic zeolitization (more than 30 percent) alternating with weakly to non-zeolitized rocks. This has consequences for vertical and horizontal conductivity and transport of radionuclides.

This sporadic distribution of zeolite minerals is seen in an example from the x-ray diffraction data for drill hole U-2gh, where the first zeolitic alteration starts (in alluvium) at $244 \mathrm{~m} \mathrm{(800} \mathrm{ft),}$ where the alluvium includes 22 percent zeolitic minerals. At $290 \mathrm{~m}$ (950 ft) the zeolitization

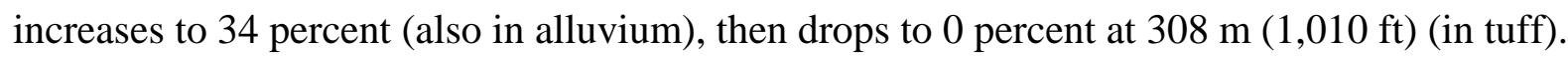
Zeolite content in the tuff rises to 36 percent at $506 \mathrm{~m}(1,660 \mathrm{ft})$ and drops again to 8 percent at $527 \mathrm{~m}(1,730 \mathrm{ft})$. Partial zeolitization is also present in drill hole $\mathrm{U}-9 \mathrm{cn}$, where the upper level of pervasive zeolitization is at $303 \mathrm{~m}$ (995 ft), but a zeolitic interval is described at 192 to $198 \mathrm{~m}$ (630 to $650 \mathrm{ft}$ ). The tuff below this section is vitric but grades from non-zeolitic to weakly zeolitic to zeolitic at $305 \mathrm{~m}(1,001 \mathrm{ft})$.

It was nearly impossible to define a clear boundary for the zone of partial zeolitization because it was not consistently identified on older lithologic logs, and because of its sporadic occurrence. This zone was defined for all strata below the water table down to the top of the LTCU in Area 2, Area 9, and the very northeast corner of Area 4 (Figure 5-8). This zone may exist above the water table, however, above the water table it will not have an effect on radionuclide transport (because the unsaturated zone will not be modeled) and therefore will not be modeled in the alternative. 
This page intentionally left blank. 

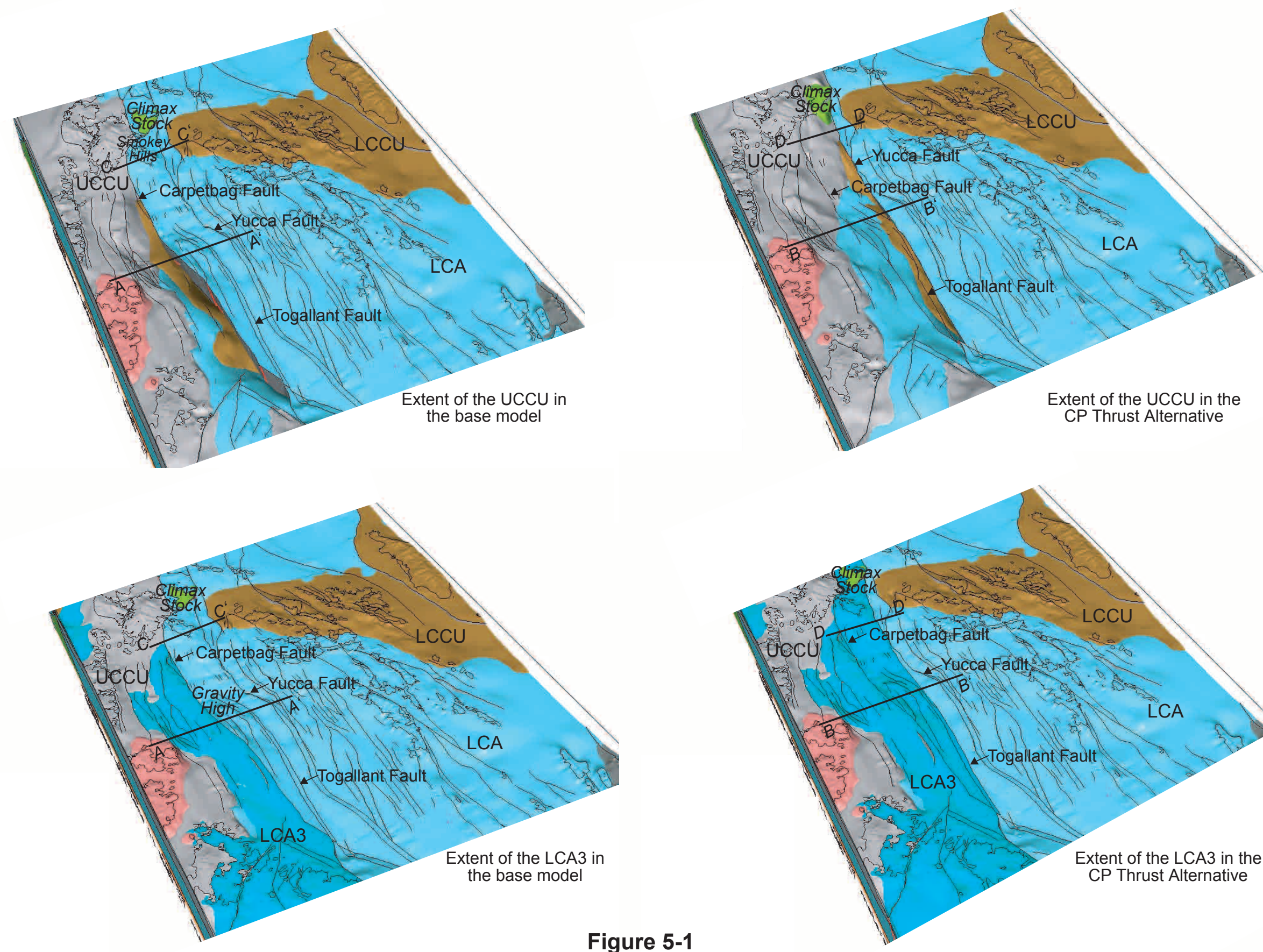

Figure 5-1

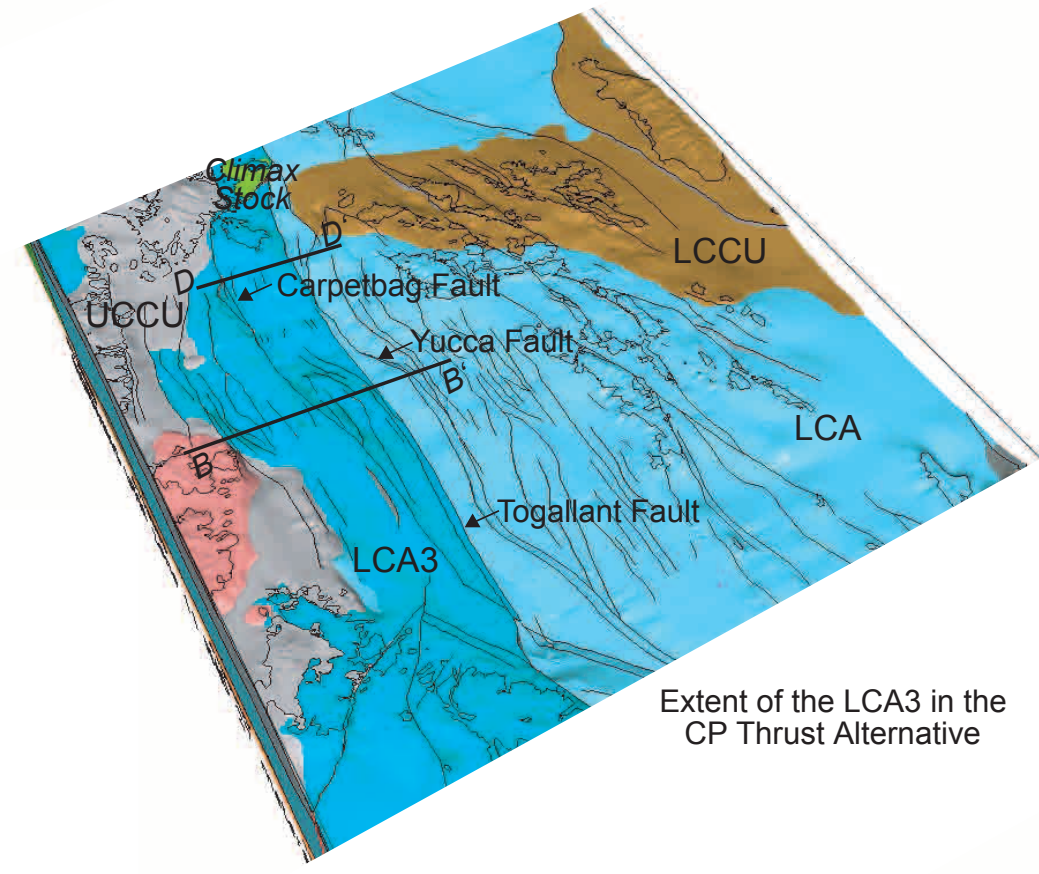

Comparison of the UCCU Extent and CP Thrust Location in the Base Model with the CP Thrust Alternative (Tertiary HSUs removed for this view) 


\section{A}

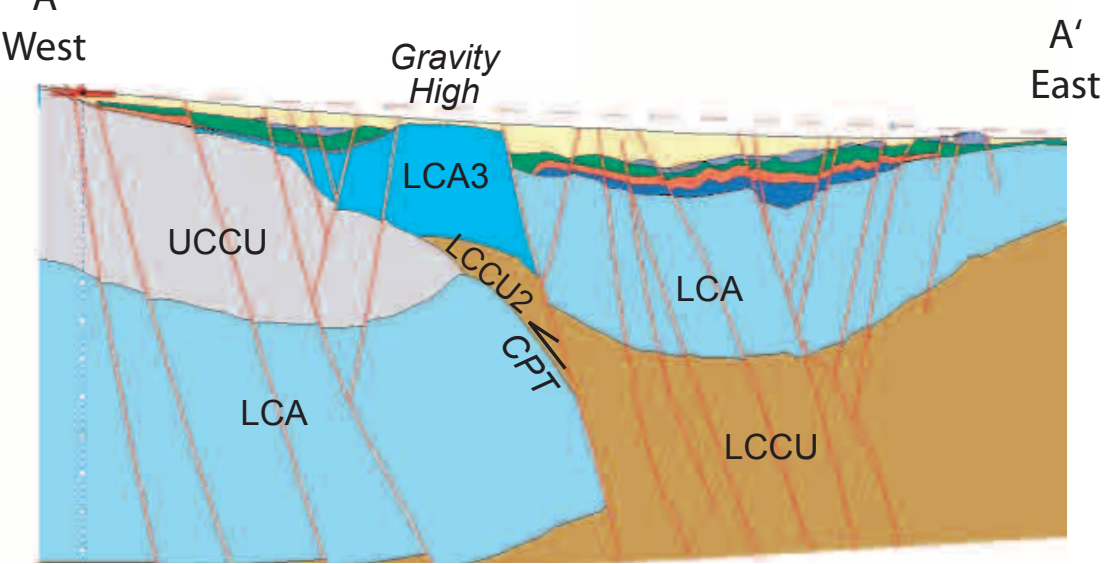

Profile through Central Yucca Flat-Base Model

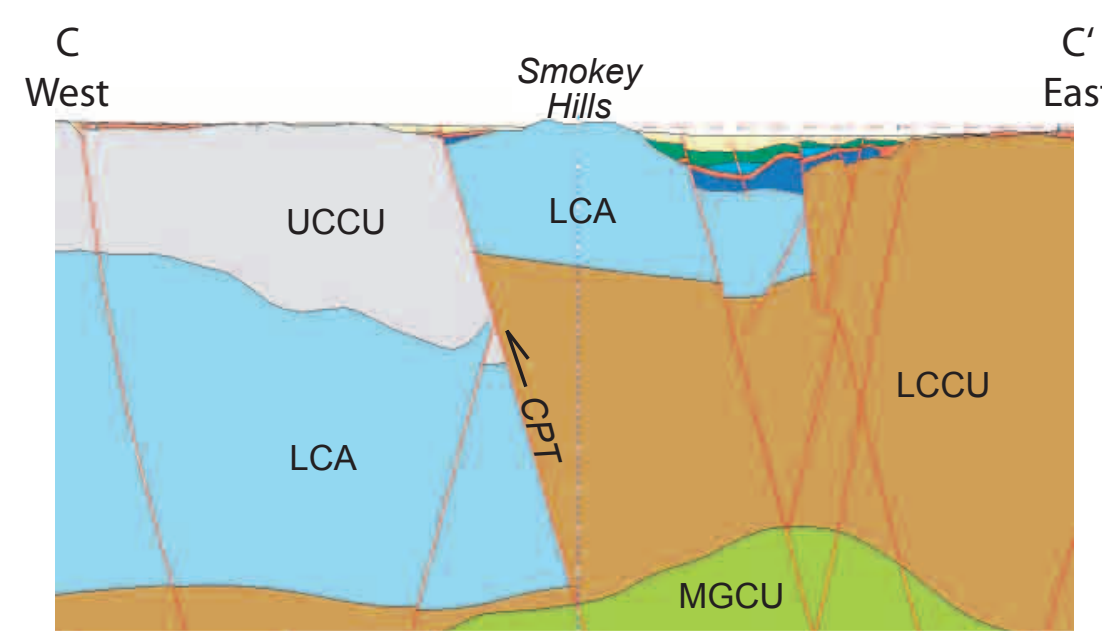

Profile through Northern Yucca Flat-Base Model
B

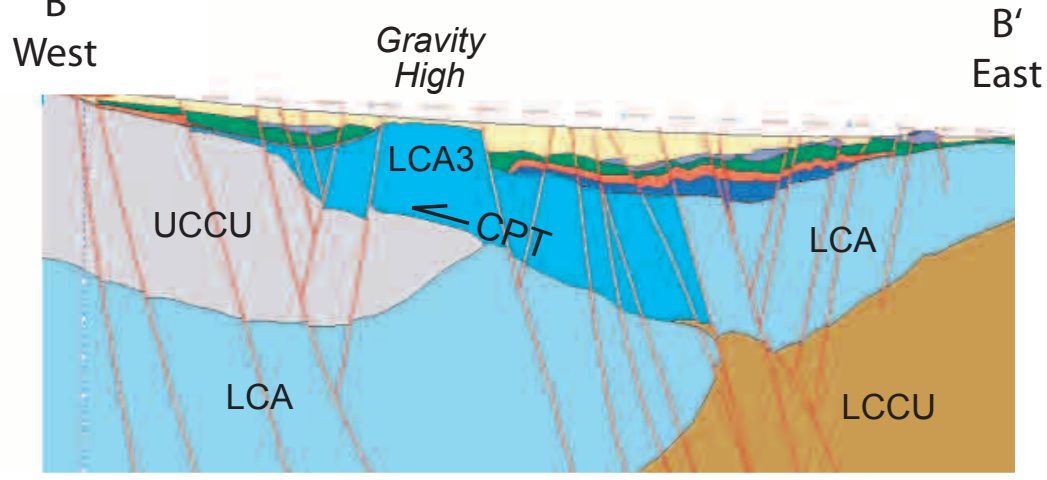

Profile through Central Yucca Flat-CP Thrust Alternative Showing a more eastern extent for the LCA3

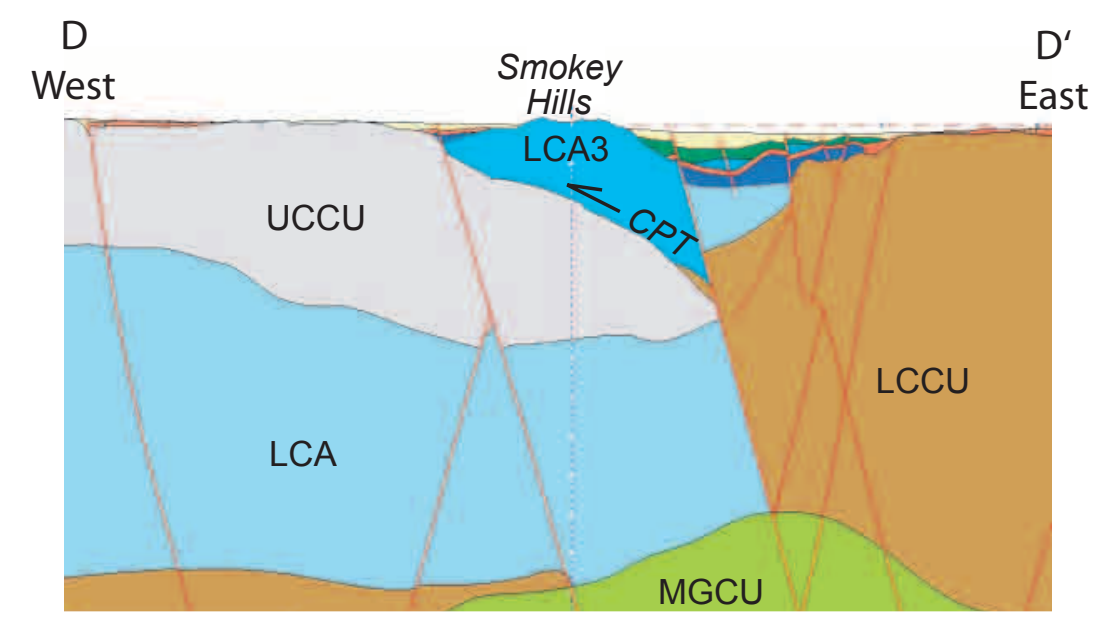

Profile through Northern Yucca Flat-CP Thrust Alternative

Figure 5-2

West-East Profiles through Central and Northern Yucca Flat Comparing the Base Model with CP Thrust Alternative 


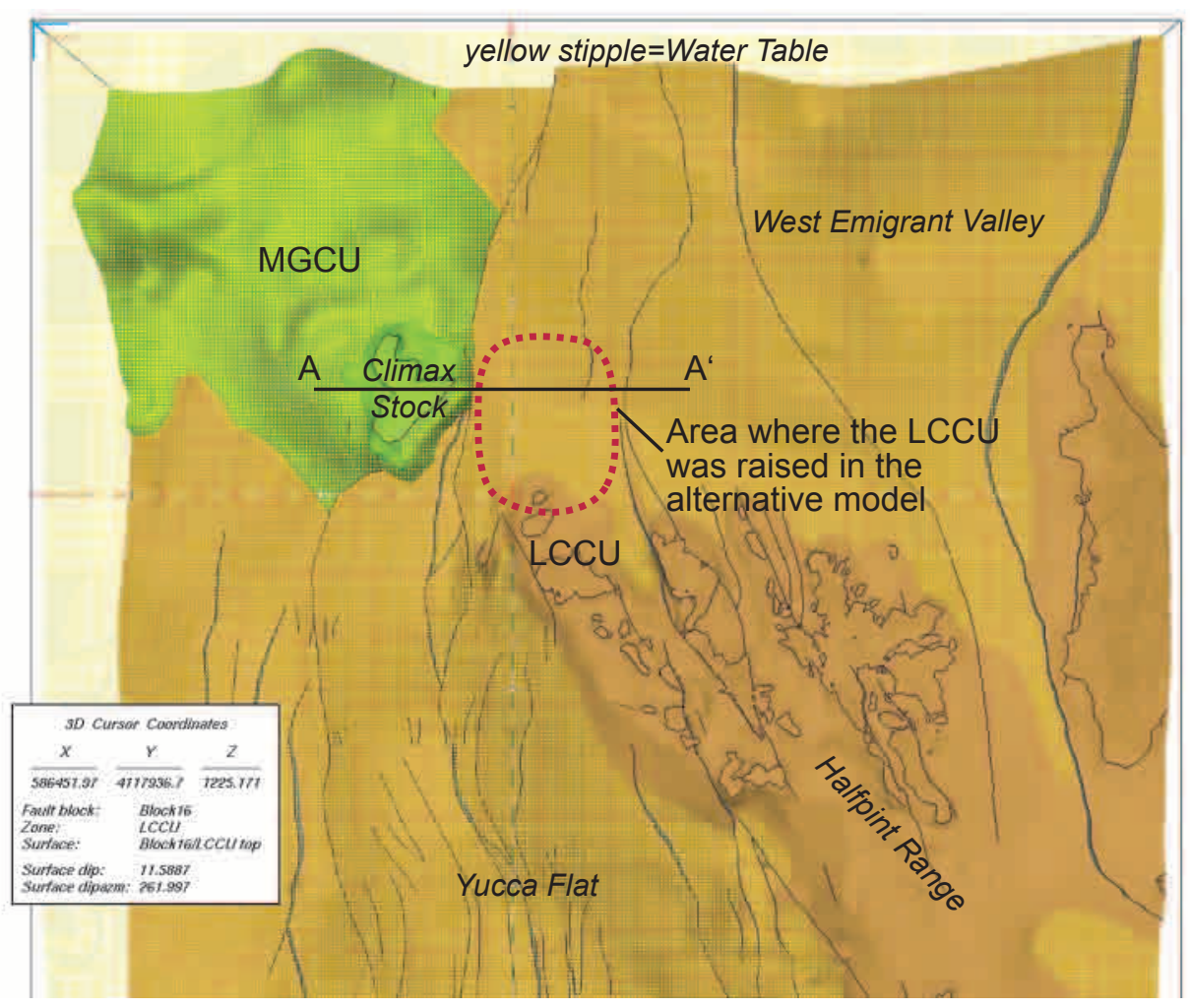

View of the LCCU and MGCU in the base model

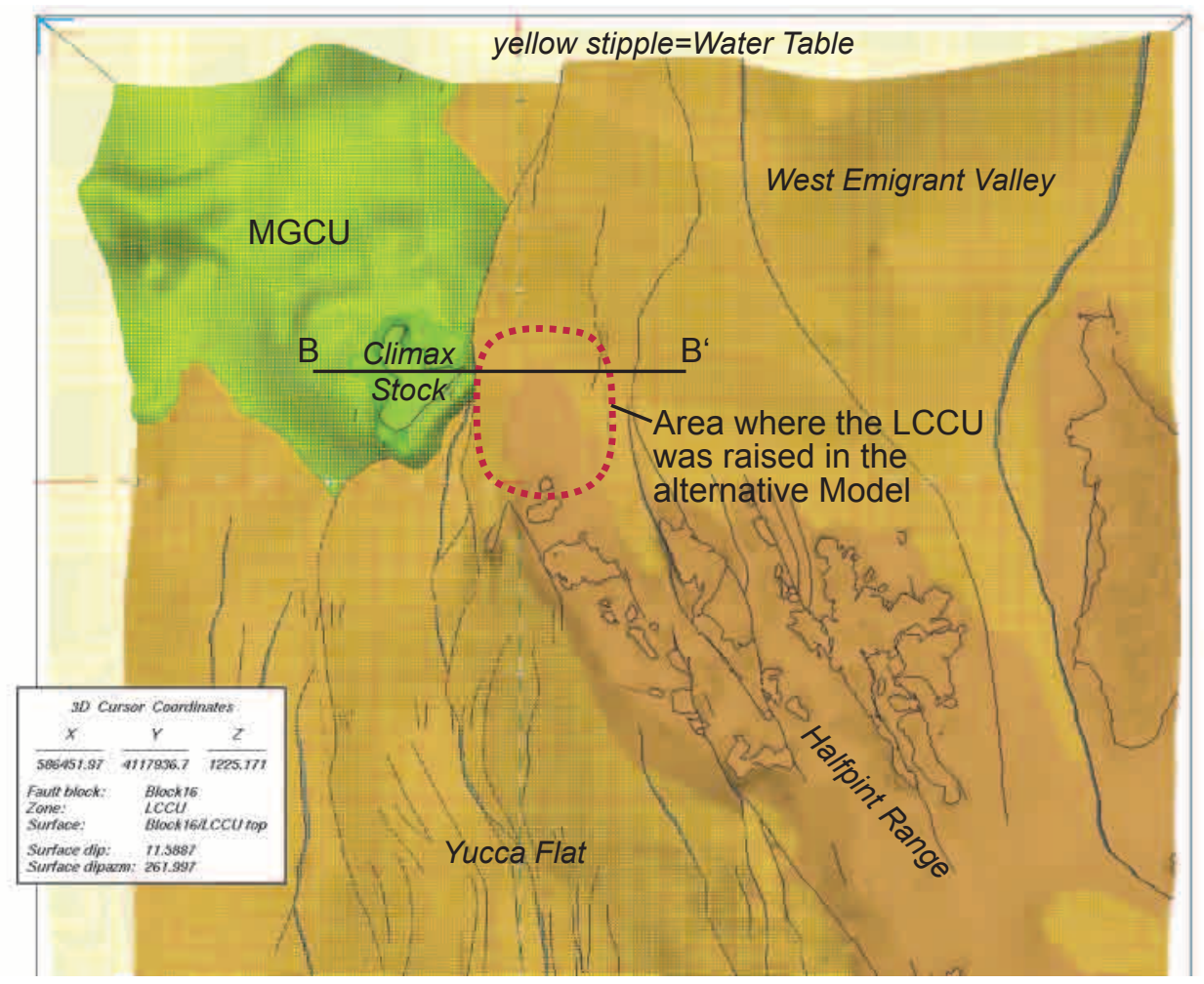

View of the LCCU and MGCU in the alternative model

Figure 5-3

Comparison of the LCCU Geometry in the Base Model with the Hydrologic Barrier Alternative 


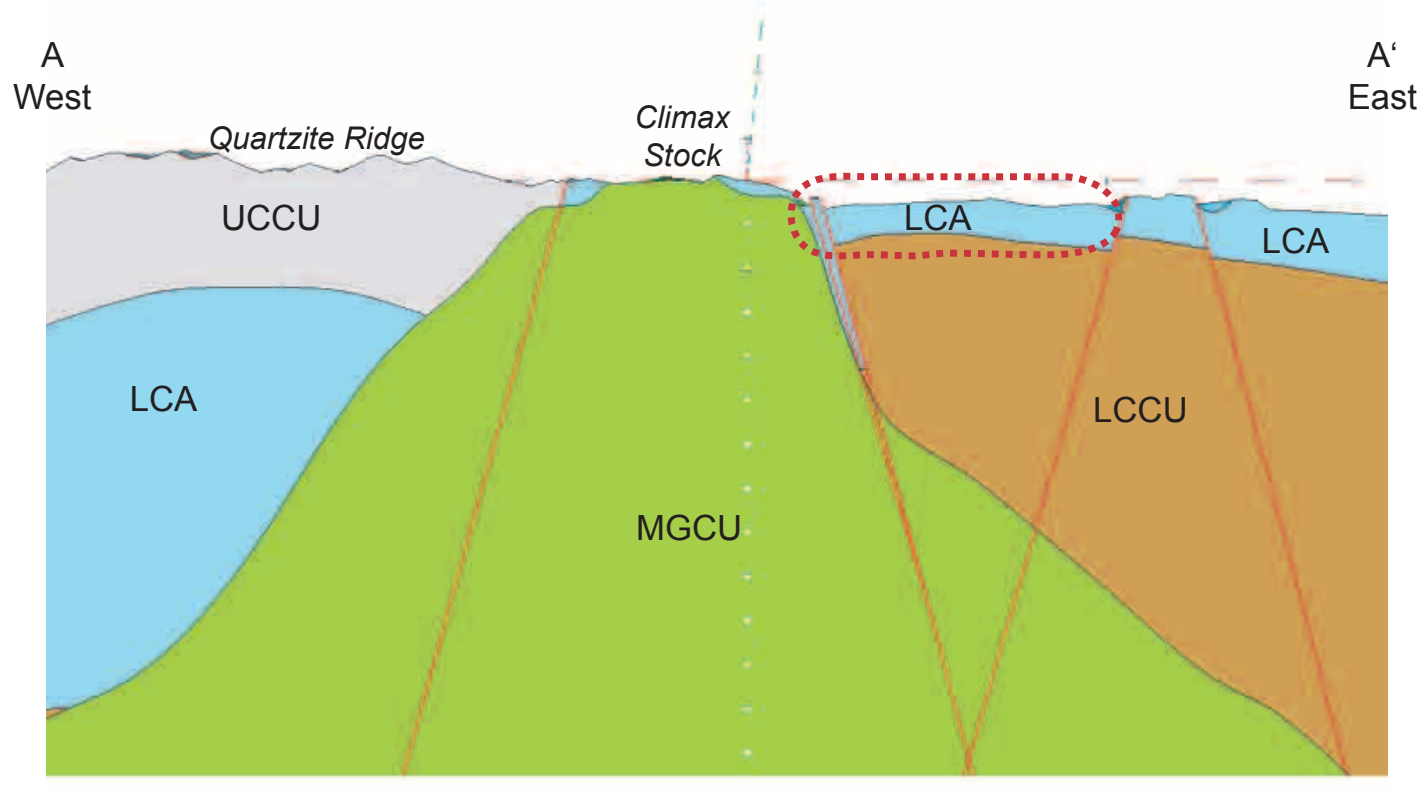

Profile through Climax Stock

Base Model

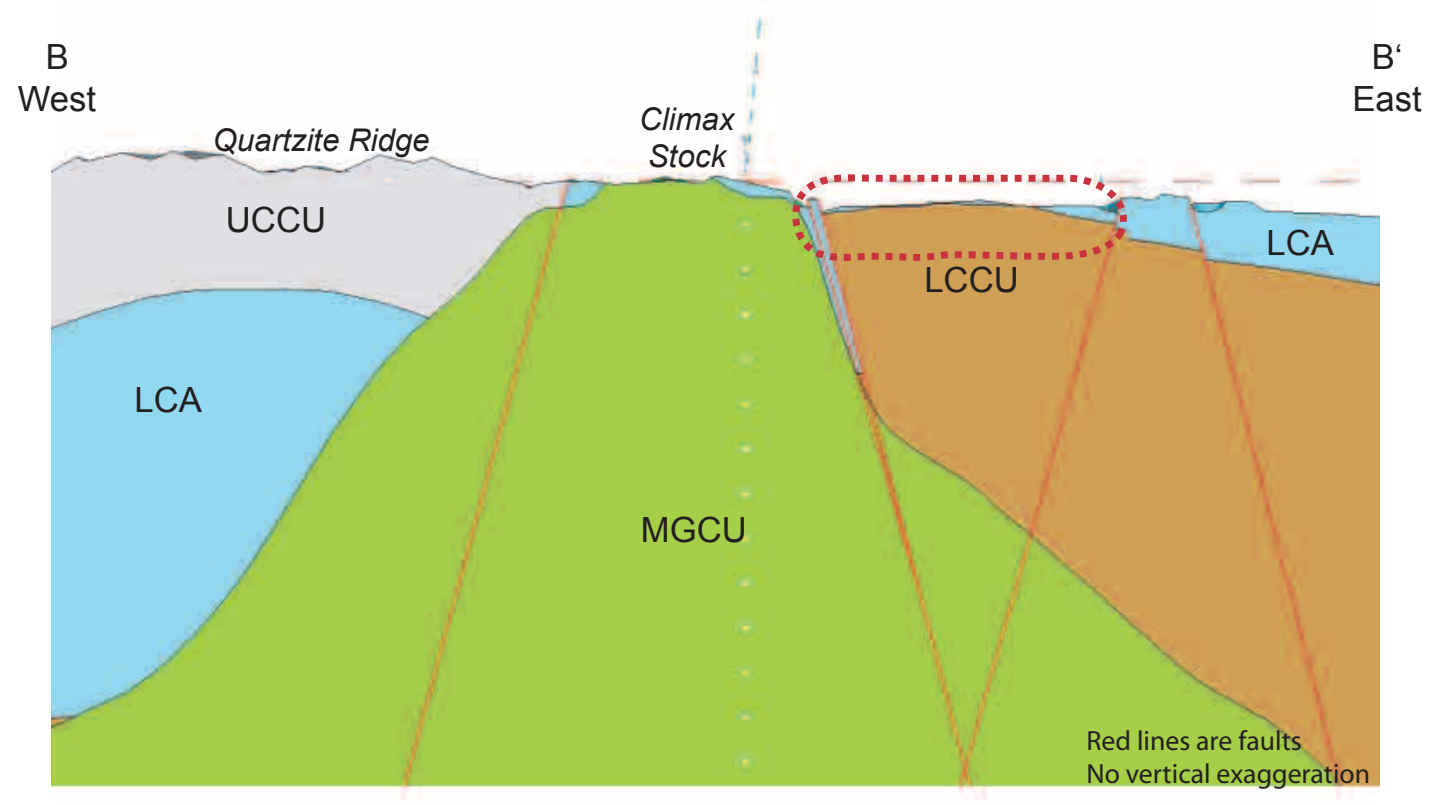

Profile through Climax Stock

Hydrologic Barrier Alternative-showing the LCCU raised to the water table

Figure 5-4

West-East Profiles through Climax Stock Comparing the Base Model with the Hydrologic Barrier Alternative 


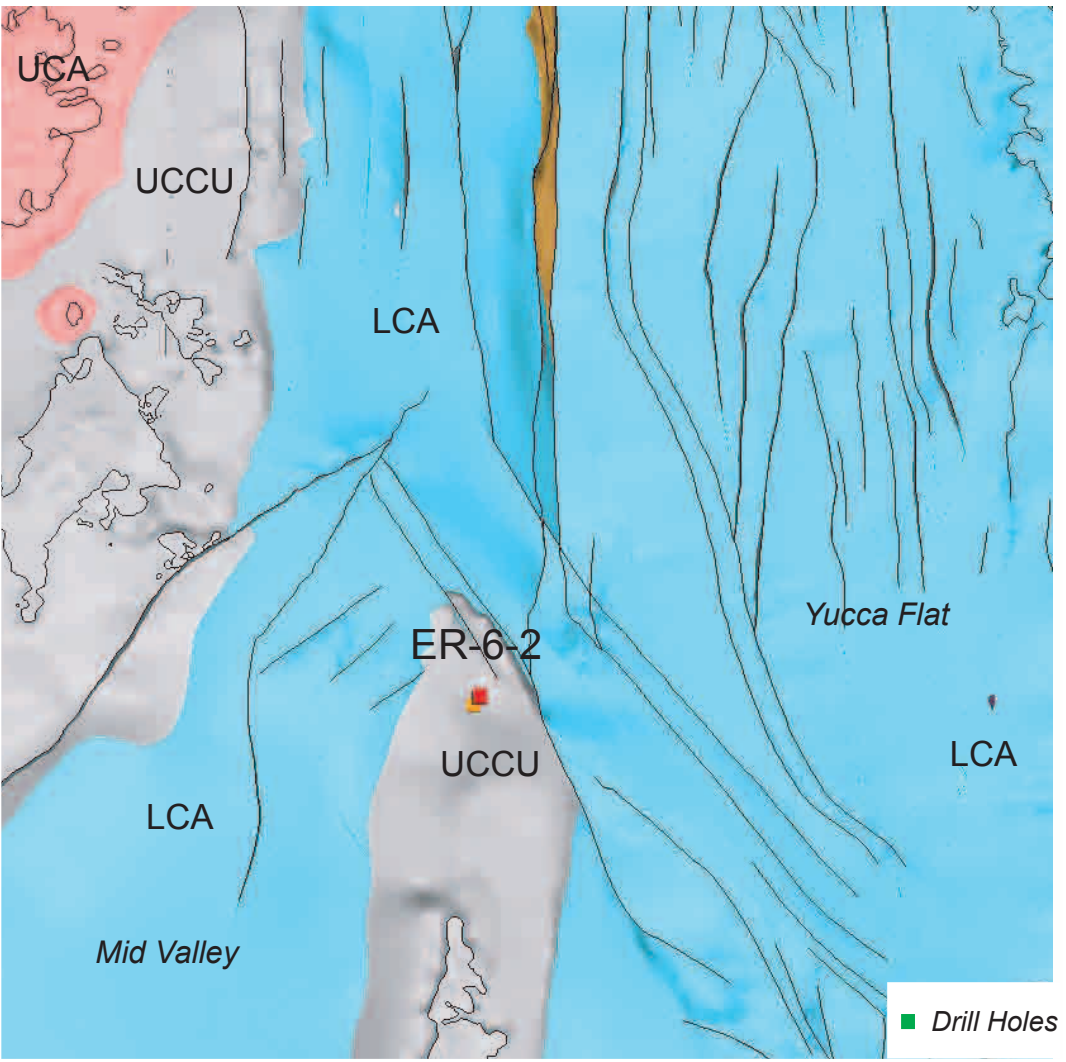

Extent of the UCCU in the Southwestern Corner of the Yucca Flat-Climax Mine Base Model

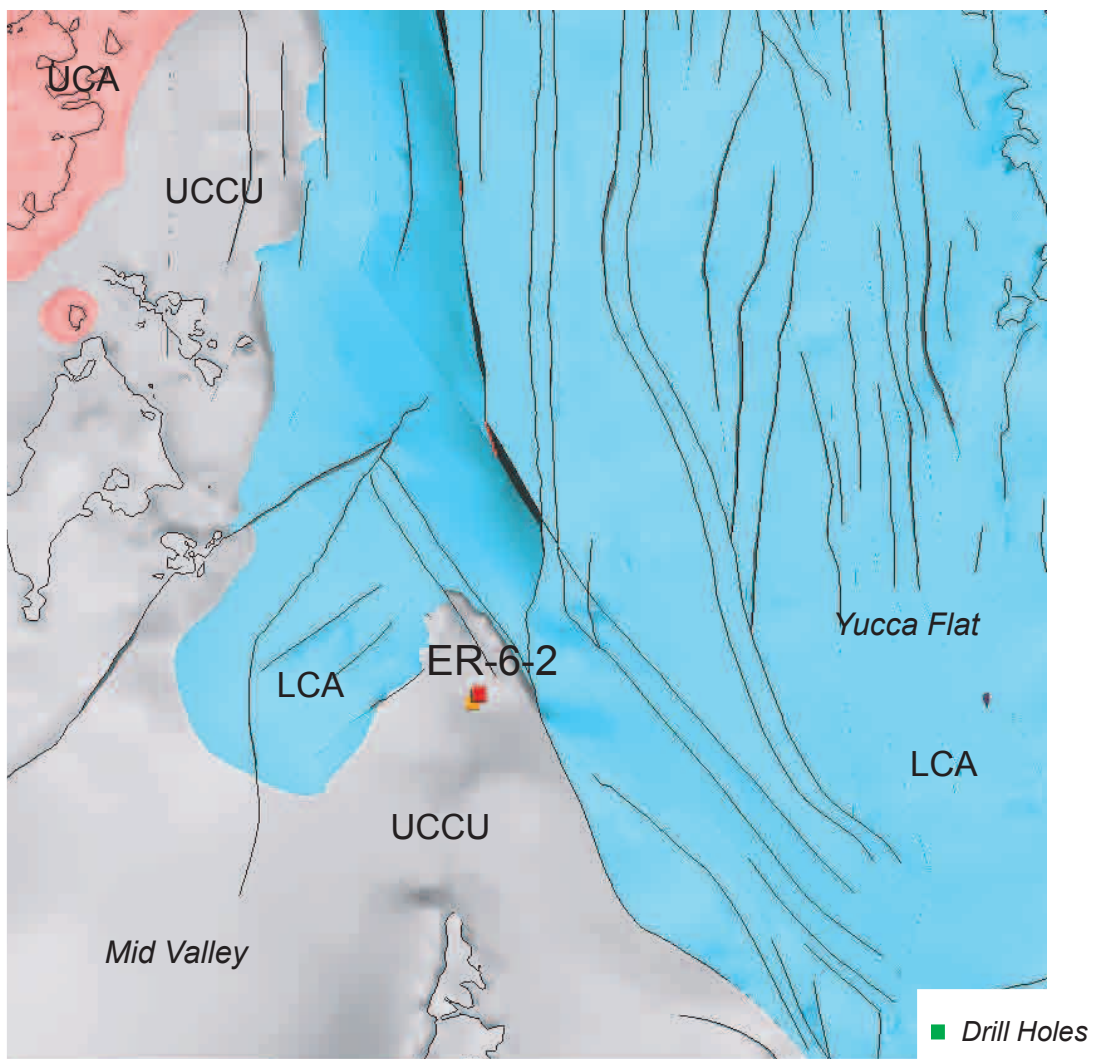

Extent of the UCCU in the Southwestern Corner of the Contiguous UCCU Alternative 


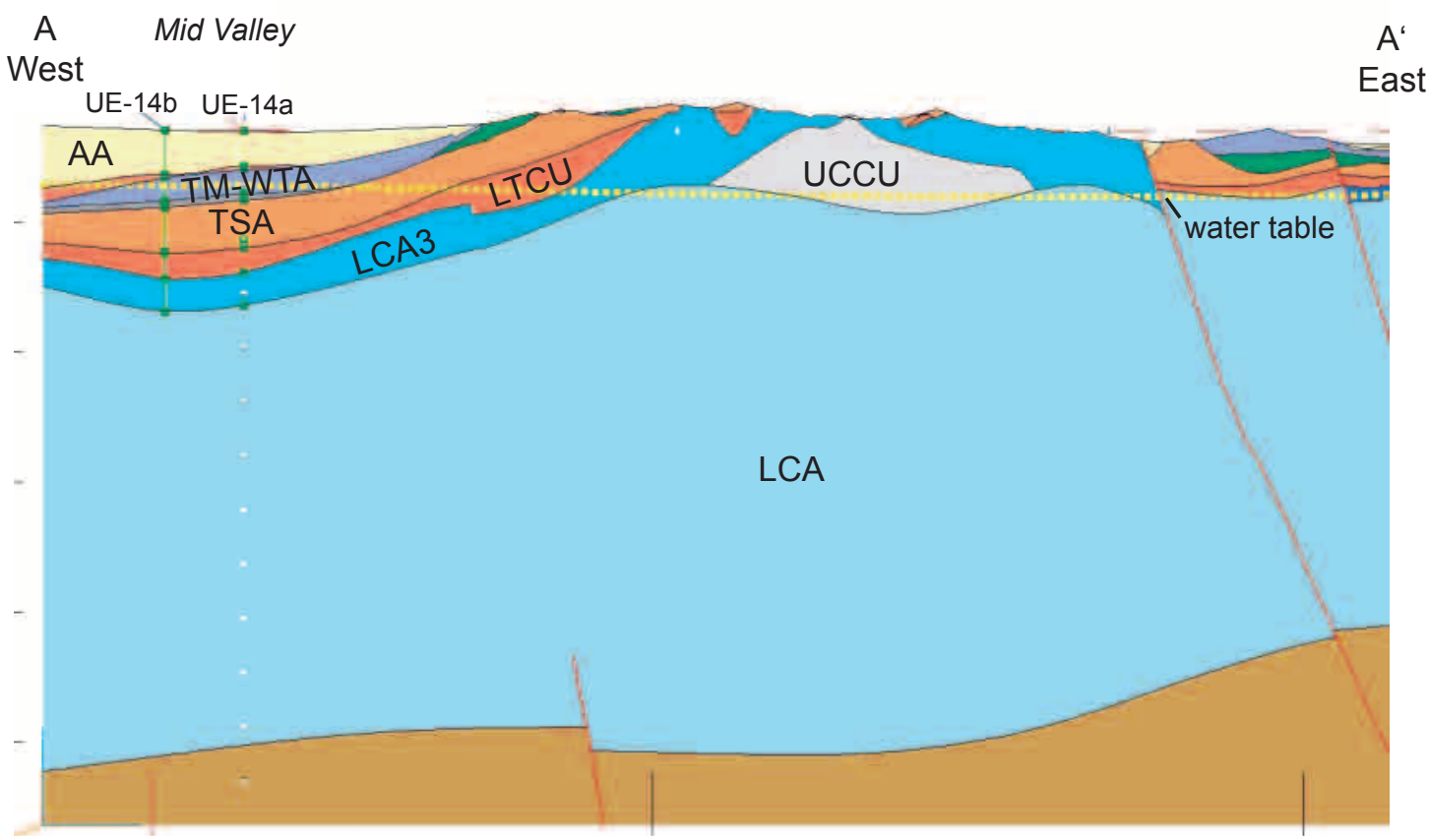

Profile through Southwest Corner of the Base Model Showing Limited Extent of the UCCU

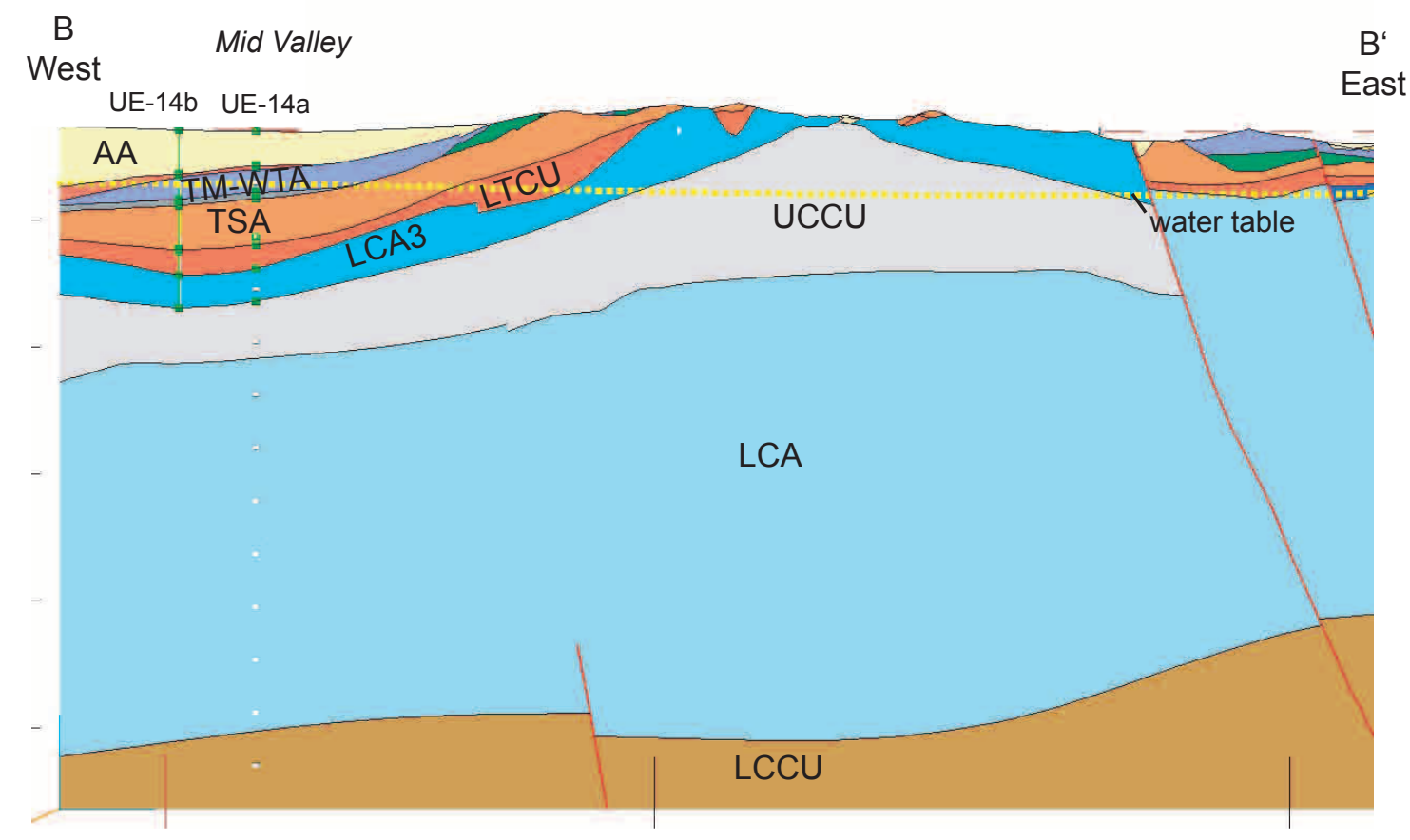

Profile through Contiguous UCCU Alternative Model Showing Extension of UCCU Beneath Mid Valley 


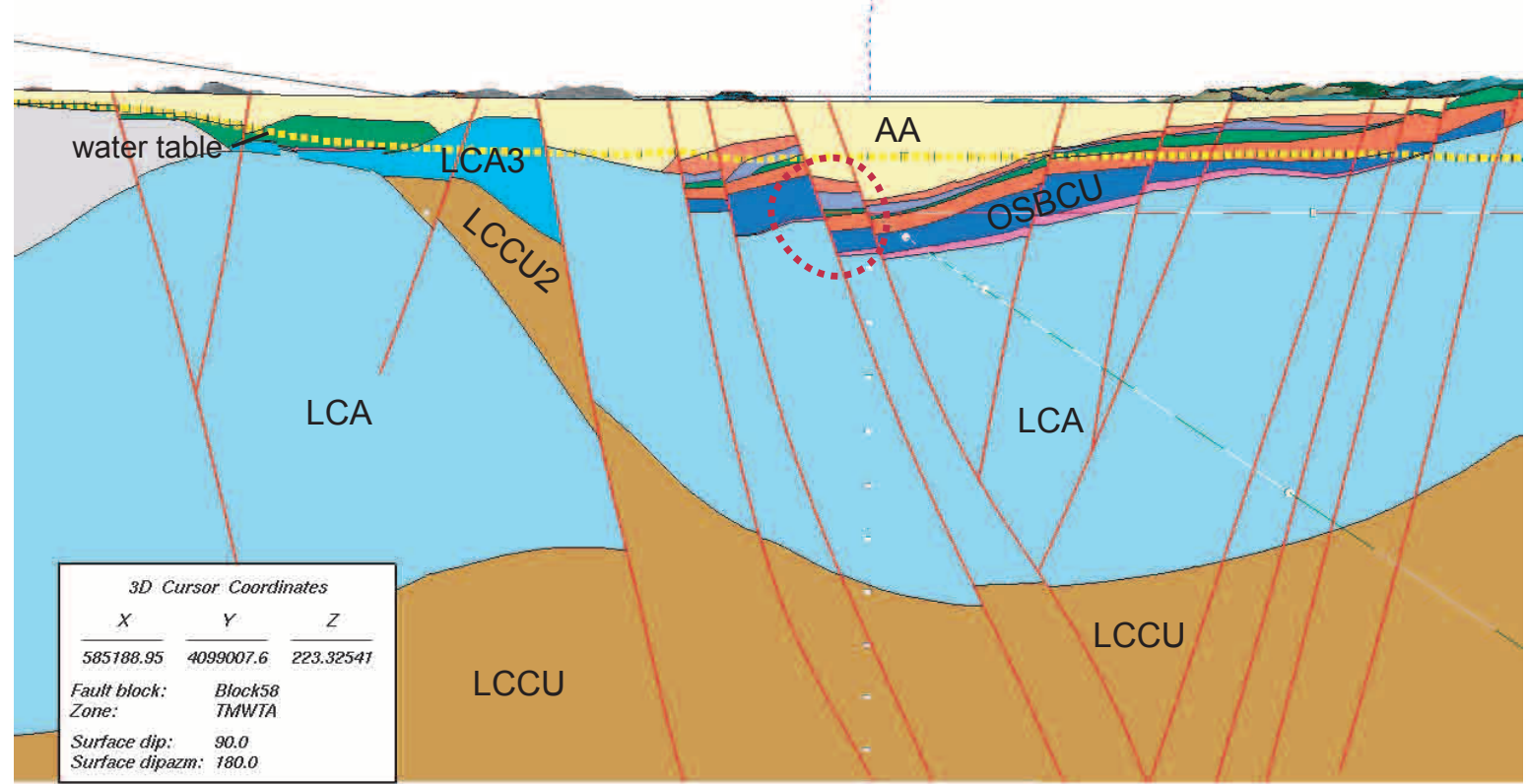

Profile through base model

West

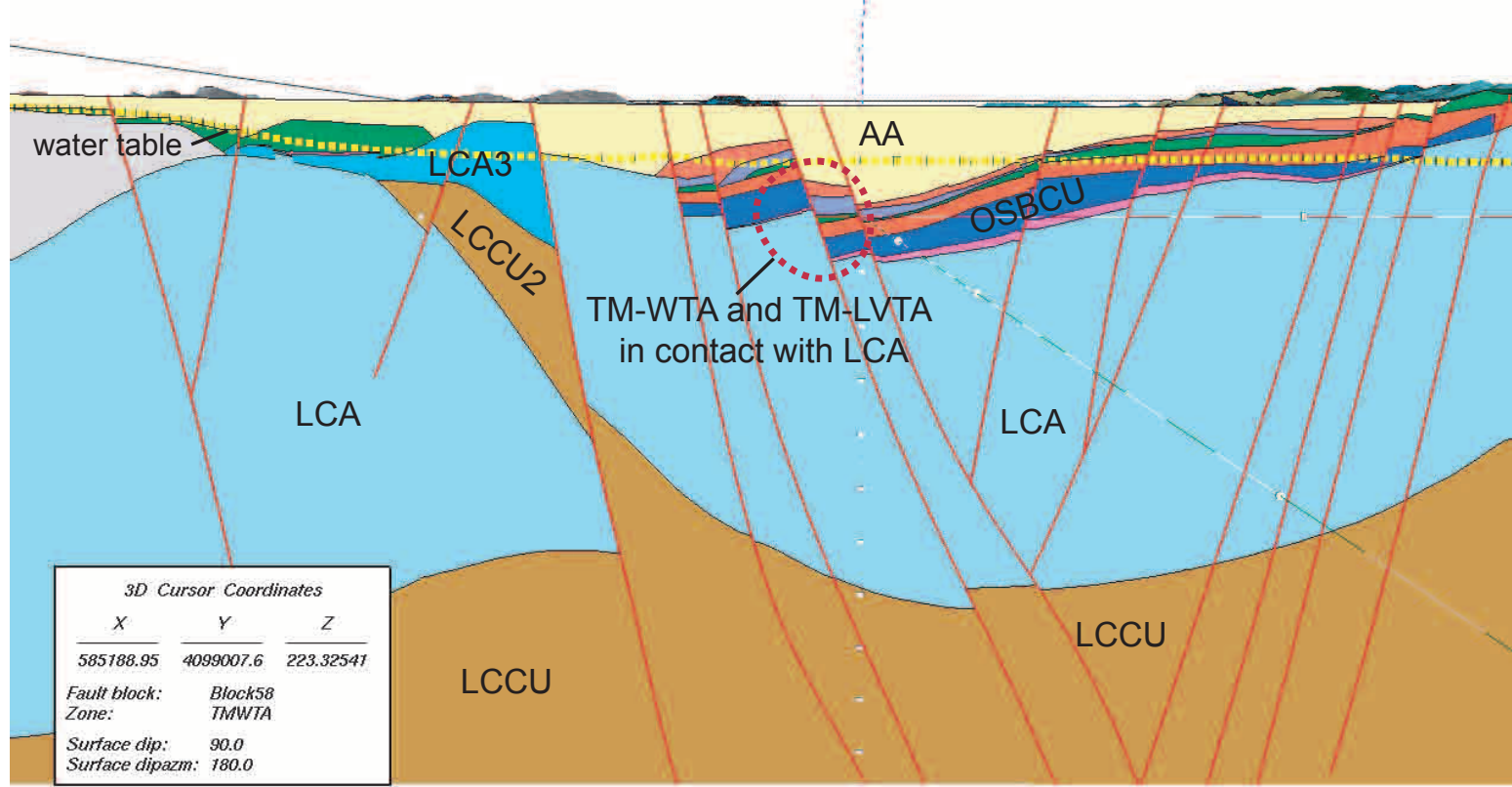

Profile through alternative model-

Showing juxtaposition of volcanic aquifers against LCA 


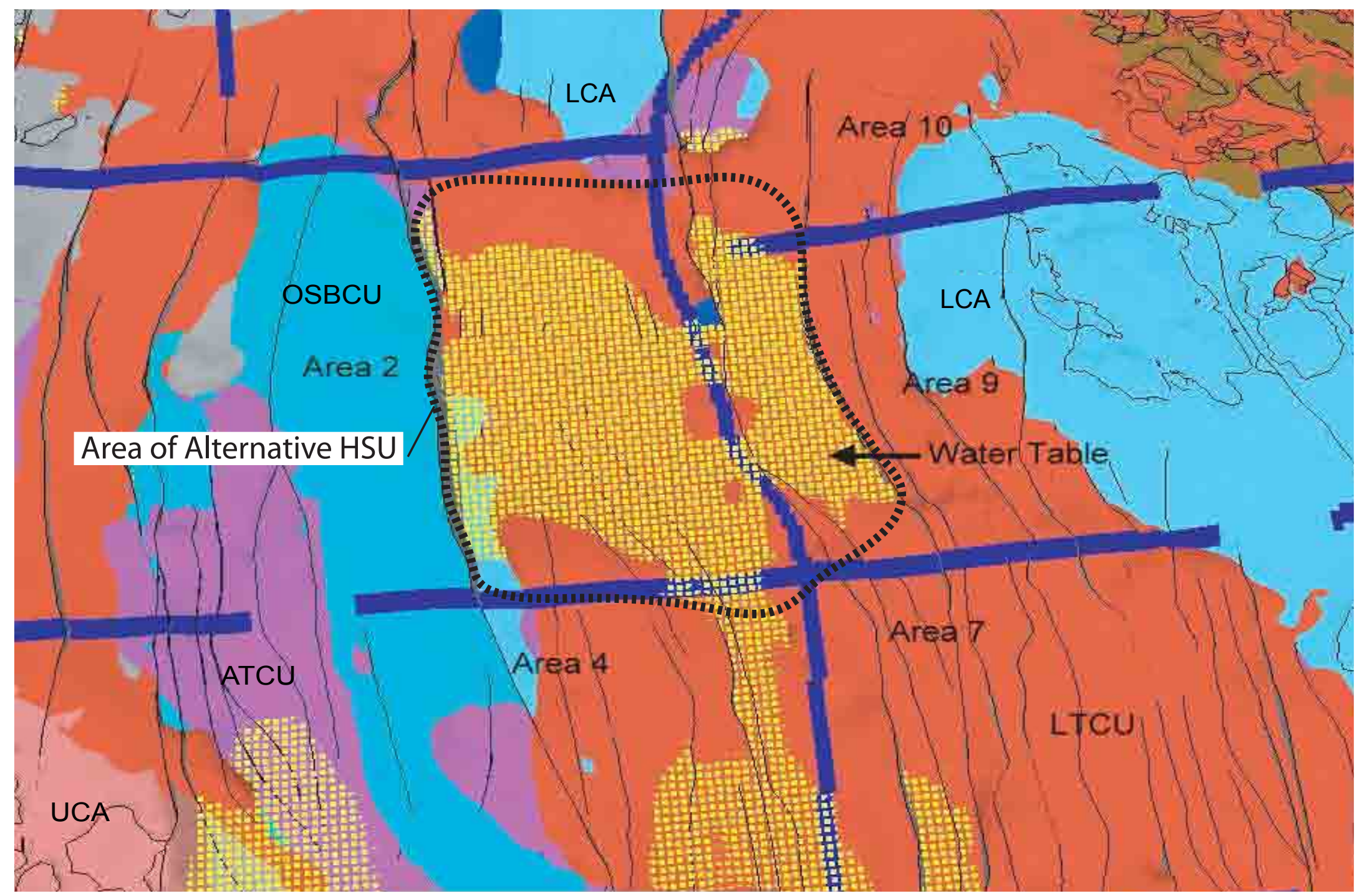

Yellow dots represent surface of water table above the HSU surfaces shown.

Blue lines are NTS operational area boundaries.

Figure 5-8

View of the Yucca Flat Base Model Showing Area Affected in the Partial Zeolitization Alternative (Alluvium and Volcanic HSUs removed for this EV view) 


\subsection{SUMMARY}

The Yucca Flat and Climax Mine areas of the NTS (CAU 97), were the site of 662 underground nuclear tests. Because many of these tests were conducted near or below the water table, testrelated contaminants are available for transport via the groundwater flow system. Models are being developed by the UGTA subroject of the NNSA/NSO Environmental Restoration Project to predict groundwater flow and contaminant transport from the source areas to groundwater discharge areas. The hydrologic and contaminant-transport modelers require a hydrostratigraphic framework that addresses the character and extent of geologic units in three dimensions. The development and description of this framework for the Yucca Flat-Climax Mine area is documented in this report.

The general hydrogeologic framework for the NTS and vicinity established by USGS geoscientists in the early 1970s, has provided the foundation for most subsequent hydrogeologic studies at the NTS, including the Yucca Flat-Climax Mine hydrostratigraphic model. The hydrostratigraphic framework for the Yucca Flat-Climax Mine area documented in this report is a product of many field and analytical studies conducted over several years, supported by the UGTA project, in which the hydrogeologic understanding of the model area has become increasingly detailed and refined as a result of the contributions of many people and organizations associated with the NTS.

The hydrogeology of the NTS, including Yucca Flat and Climax Mine, area is complex. The thick sections of alluvium and volcanic rocks comprise a wide variety of lithologies that can range in hydraulic character from aquifer to aquitard. Basin-and-range faulting has acted to further complicate the area, placing the various lithologic units in juxtaposition, and blocking or enhancing the flow of groundwater in a variety of ways.

In this study, earlier hydrogeologic framework models were integrated with drill-hole data (stratigraphic, lithologic, and alteration data), data from several geophysical, geological, and hydrological studies, and a conceptual structural model, to formulate a hydrostratigraphic system. Applying this updated understanding of Yucca Flat-Climax Mine area hydrogeology, the authors organized the geologic units in the study area into 25 HSUs that include 13 aquifers and 12 confining units. The alluvial section was subdivided into 3 HSUs, including the alluvial aquifer, a basalt lava-flow aquifer, and a playa confining unit. There are 13 Tertiary-age volcanic HSUs, including 8 aquifers and 5 confining units. The intrusive granitic rocks are classified as a confining unit. The underlying pre-Tertiary rocks were divided into 7 HSUs, including 3 aquifers and 4 confining units. The drill-hole database was then converted to a 
hydrostratigraphic database based on this hydrostratigraphic system, and, along with the enhanced conceptual structural model, provided the basis to construct cross sections, unit-extent and structure contour maps for each HSU. Three-dimensional surfaces were derived from these maps using the EarthVision ${ }^{\circledR}$ modeling software. The 3-D volumes defined by these surfaces will serve as inputs for the UGTA groundwater modeling process.

To construct this model, the raw data compiled by IT/SAIC/Geotrans (and successor contractors, Shaw and SNJV) and BN geologists, and interpretative products prepared by BN geologists (fault framework, cross sections, unit-extent maps, etc.) were input into EarthVision ${ }^{\circledR}$. Personnel of SNJV (and its predecessors, Shaw and IT/SAIC/GeoTrans) who are knowledgeable in the use of EarthVision ${ }^{\circledR}$ were responsible for building the digital 3-D model. The resultant model was reviewed and corrected as necessary by the authors in an iterative fashion, to resolve structural problems that tend to develop as a result of sparse data and the computerized model-building process. The maps and cross sections provided in this document are selected presentations from the digital model and are meant only to generally illustrate the character of the HSUs (model layers). This framework will be transmitted electronically in the form of an EarthVision ${ }^{\circledR}$ model that is directly usable by the hydrologic and transport modelers.

The geologic complexity of the model area and sparse data for much of the region resulted in the incorporation of some non-unique interpretations into the base model. This made it necessary to address alternative interpretations for some of the major features in the model. Five of these alternatives were developed so they could be modeled in the same fashion as the base model, and are expected to aid the hydrologic modelers in exploring and refining the results of the flow and transport models. 


\subsection{REFERENCES}

Allen, B. M., 1995. Preliminary Geologic Site Characterization of the LYNER Horizontal Drift Complex, Yucca Flat, NTS. Raytheon Services Nevada Report TSP:DGP:080:95, prepared for U.S. Department of Energy Nevada Operations Office, Las Vegas, NV.

Allen, B. A., S. L. Drellack, and M. J. Townsend, 1997. Surface Effects of Underground Nuclear Explosions. DOE/NV/11718--122. Bechtel Nevada, Las Vegas, NV.

App, F. N., 1981. "Progress in Seismic Exploration at Los Alamos.” In: Jones, E., ed., Proceedings, Monterey Containment Symposium. Los Alamos National Laboratory. LA-9211-C, p. 37. Los Alamos, NM.

App and Marusak, 1997. Tuff Pile I - A Justification for the Projection of Material Properties within a Portion of Los Alamos Test Areas 1, 3, 4, and 7, Nevada Test Site. LA-UR-97-1024. Los Alamos National Laboratory, Los Alamos, NM.

Asch, T. A., B. D. Rodriguez, J. A. Sampson, E. Wallin,, and J. M. Williams, 2005. Deep Resistivity Structure of Yucca Flat, Nevada Test Site, Nevada. U.S. Geological Survey Open-File Report (in press).

Baranov, V., 1957. A New Method for interpretation of Aeromagnetic Maps: Pseudogravimetric Anomalies. Geophysics, v. 2, n. 2, p. 59-383.

Barnes, H., 1962. Stratigraphic Interpretation of Rocks Penetrated by UE15d Drill Hole. U.S. Geological Survey Technical Letter Yucca 1, Supplement 5, 8 pp. Denver, CO.

Barnes, H., F. N. Houser, and F. G. Poole, 1963. "Geologic Map of the Oak Spring Quadrangle, Nye County, Nevada.” U.S. Geological Survey Map GQ-214, scale 1:24,000. Washington, DC.

Barnes, H., F. N. Houser, and F. G. Poole, 1968. Regional Thrust Fault System in Nevada Test Site and Vicinity. In: Eckel, E. B., ed., Nevada Test Site. Memoir 110, pp. 233-238. The Geological Society of America, Inc. Boulder, CO.

Barnes, H., R. L. Christiansen, and F. M. Byers, Jr., 1965. "Geologic Map of the Jangle Ridge Quadrangle, Nye and Lincoln Counties, Nevada.” U.S. Geological Survey Map GQ-363, scale 1:24,000. Washington, DC.

Barnes, Harley, E. B. Ekren, C. L. Rodgers, and D. C. Hedlund, 1982. "Geologic and Tectonic Maps of the Mercury Quadrangle, Nye and Clark Counties, Nevada.” U.S. Geological Survey Miscellaneous Investigations Series Map I-1197, scale 1:24,000.

Bath, G. D., 1968. Aeromagnetic Anomalies Related to Remnant Magnetism in Volcanic Rock, Nevada Test Site. In: Eckel, E. B., ed., Nevada Test Site. Memoir 110, pp. 135-146. The Geological Society of America, Inc. Boulder, CO. 
Bath, G. D. and C. E. Jahren, 1980. Written communication. Subject: Interpretations of Magnetic Anomalies in Northeastern Part of the Nevada Test Site, with Emphasis on the Twinridge Area. U.S. Geological Survey. Denver, CO.

Bath, G. D., C. E. Jahren, J. G. Rosenbaum, and M. J. Baldwin, 1983. "Magnetic Investigations.” In: Geologic and Geophysical Investigations of Climax Stock Intrusive, Nevada. U.S. Geological Survey Open-File Report 83-377, p. 40-57. Denver, CO.

Bechtel Nevada, 1998. Geology Report: Area 3 Radioactive Waste Management Site, Nye County, Nevada. DOE/NV/11718--195. Report to U.S. Department of Energy, Nevada Operations Office, Las Vegas, Nevada. January 1998.

Bechtel Nevada, 1999. Characterization Report for Corrective Action Unit 110: Area 3 U-3ax/bl Disposal Unit Nevada Test Site, Nevada. DOE/NV--580. Report to U.S. Department of Energy, Nevada Operations Office, Las Vegas, NV. November 1999.

Bechtel Nevada, 2002a. A Hydrostratigraphic Model and Alternatives for the Groundwater Flow and Contaminant Transport Model of Corrective Action Units 101 and 102: Central and Western Pahute Mesa, Nye County, Nevada. DOE/NV/11718--706. Las Vegas, NV.

Bechtel Nevada, 2002b. Nevada Test Site Orthophoto Site Atlas. DOE/NV/11718--604. Las Vegas, NV.

Bechtel Nevada, 2005a. A Hydrostratigraphic Model and Alternatives for the Groundwater Flow and Contaminant Transport Model of Corrective Action Unit 98: Frenchman Flat, Clark, Lincoln, and Nye County, Nevada. DOE/NV/11718--1064. Las Vegas, NV.

Bechtel Nevada, 2005b. Site Characterization Data from the U3ax/bl Exploratory Boreholes at the Nevada Test Site. DOE/NV/11718--003-REV.1. Las Vegas, NV.

Belcher, W. R., ed., 2004. Death Valley Regional Ground-Water Flow System, Nevada and California - Hydrogeologic Framework and Transient Ground-Water Flow Model. U.S. Geological Survey Scientific Investigations Report 2004-5205, 408 pages.

Blakely, R. J., and D. A. Ponce, 2001. Map Showing Depth to Pre-Cenozoic Basement in the Death Valley Ground-Water Model Area, Nevada and California. U.S. Geological Survey Miscellaneous Field Studies Map MF-2381-E.

Blankennagel, R. K. and J. E. Weir, Jr., 1973. Geohydrology of the Eastern Part of Pahute Mesa, Nevada Test Site, Nye County, Nevada. U.S. Geological Survey Professional Paper 712-B, 35 pp. Washington, DC.

Bohanon, R. G., 1984. Nonmarine Sedimentary Rocks of Tertiary Age in the Lake Mead Region, Southeastern Nevada and Northwestern Arizona. U.S. Geological Survey Professional Paper 1259.

BN, see Bechtel Nevada. 
Burchfiel, B. V., 1964. "Precambrian and Paleozoic Stratigraphy of the Specter Range Quadrangle, Nye County, Nevada.” American Association of Petroleum Geologists Bulletin, v. 48, pp. 40-56.

Burkhard, N. R., 1981. "NTS Seismic Reflection Data and the Problems Thereof.” In: Proceedings, Monterey Containment Symposium, Monterey, California, August 26-28, 1981. LA-9211-C, v. 1, pp. 339-341. Los Alamos National Laboratory, Los Alamos, NM.

Burkhard, N. R., and R. D. McArthur, 1985. "Geologic and Geophysical Investigations of Mid Valley at the NTS.” In: Olsen, C. W., ed., Proceedings, Third Symposium on the Containment of Underground Nuclear Explosions. Lawrence Livermore National Laboratory, CONF-850953, v. 2, pp. 72-84..

Byers, F. M., Jr. and H. Barnes, 1967. “Geologic Map of the Paiute Ridge Quadrangle, Nye and Lincoln Counties, Nevada.” U.S. Geological Survey Geologic Quadrangle Map GQ-577, scale 1:24,000. Washington, DC.

Byers, F. M., Jr., W. J. Carr, P. P. Orkild, W. D. Quinlivan, and K. A. Sargent, 1976. Volcanic Suites and Related Cauldrons of the Timber Mountain-Oasis Valley Caldera Complex, Southern Nevada. U.S. Geological Survey Professional Paper 919, 70 pp. Washington, DC.

Byers, F. M., Jr., W. J. Carr, and P. P. Orkild, 1989. "Volcanic Centers of Southwestern Nevada: Evolution of Understanding, 1960-1988.” Journal of Geophysical Research, v. 94, n. 5, pp. 5,908-5,924.

Cashman, P. H. and J. H. Trexler, Jr., 1991. “The Mississippian Antler Foreland and Continental Margin in Southern Nevada: The Eleana Formation Reinterpreted.” In: J.D. Cooper and C.H. Stevens, eds., Paleozoic Paleogeography of the Western United States - II: Pacific Section SEPM, v. 67, pp. 271-280.

Cashman, P. H., J. H. Trexler, and J. C. Cole, 2001. Geology of the Pre-Tertiary Rocks in the Eleana Range, Nevada Test Site, Southern Nevada. U.S. Geological Survey Open-File Report. Denver, CO.

Caskey, S. J., 1991. Mesozoic and Cenozoic Structural Geology of the CP Hills, Nevada Test Site, Nye County, Nevada; and Regional Implications. State of Nevada Agency for Nuclear Project/Nuclear Waste Project Office. Report Number NWPO-TR-018-91.

Caskey, S. J. and R. A. Schweickert, 1992. "Mesozoic Deformation in the Nevada Test Site and Vicinity: Implications for the Structural Framework of the Cordilleran Fold and Thrust Belt and Tertiary Extension North of Las Vegas.” Tectonics, v. 11, no. 6, pp. 1,314-1,331.

Chuang, F. C., E. H. McKee, and K. A. Howard, 2003. Hydrogeologic Factors that Influence Ground Water Movement in the Desert Southwest United States. U.S. Geological Survey Open-File Report 03-294.

Claassen, H. C., 1973. Water Quality and Physical Characteristics of Nevada Test Site WaterSupply Wells. U.S. Geological Survey Open-File Report USGS-474-158 (NTS-242) 
Cole, J. C., U.S. Geological Survey, 1992. Written communication to S. L. Drellack, Raytheon Services Nevada, regarding thickness of Paleozoic units at the NTS. Denver, CO.

Cole, J. C., 1997. Major Structural Controls on the Distribution of Pre-Tertiary Rocks, Nevada Test Site Vicinity, Southern Nevada. U.S. Geological Survey Open-File Report 97-533, scale 1:100,000, 19 pp. Denver, CO.

Cole, J. C. and P. H. Cashman, 1997. “Geologic Map of the Mine Mountain Area, Nevada Test Site, Southern Nevada.” U.S. Geological Survey Open-File Report 97-697, scale 1:12,000, 8 pp. Denver CO.

Cole, J. C. and P. H. Cashman, 1998. "Structural Relationships of Pre-Tertiary Rocks in the Nevada Test Site Region, Southern Nevada.” U. S. Geological Survey Professional Paper 1607.

Cole, J. C., and P. H. Cashman, 1999. Structural Relationships of Pre-Tertiary Rocks in the Nevada Test Site Region, Southern Nevada. U.S. Geological Survey Professional Paper 1607.

Cole, J. C., A. G. Harris, and R. R. Wahl, 1997. "Subcrop Geologic Map of Pre-Tertiary Rocks in the Yucca Flat and Northern Frenchman Flat Areas, Nevada Test Site, Southern Nevada." U.S. Geological Survey Open-File Report 97-678, scale 1:48,000, 24 pp. Denver, CO.

Colton, R. B. and E. J. McKay, 1966. “Geologic Map of the Yucca Flat Quadrangle, Nye and Lincoln Counties, Nevada.” U.S. Geological Survey Geologic Quadrangle Map GQ-582, scale 1:24,000. Washington, DC.

Colton, R. B. and D. C. Noble, 1967. “Geologic Map of the Groom Mine SW Quadrangle, Nye and Lincoln Counties, Nevada.” U.S. Geological Survey Map GQ-719, scale 1:24,000. Washington, DC.

D’Agnese, F. A. C. C. Faunt, A. K. Turner, and M. C. Hill, 1997. Hydrogeologic Evaluation and Numerical Simulations of the Death Valley Regional Groundwater Flow System, Nevada and California. USGS Professional Paper 1607. U.S. Geological Survey, Denver CO.

DOE, see U.S. Department of Energy.

Dixon, G. L., K. A. Sargent, and R. W. Spengler, 1973. Lithologic Logs and Stratigraphic Identification of Exploratory and Emplacement Drill Holes in Area 3, Nevada Test Site. U.S. Geological Survey Open-File Report 474-151, 138 pp. Denver, CO.

Dixon, G. L., W. D. Quinlivan, R. M. Ray, and J. P. Ohl, 1975. Supplementary Lithologic Logs and Stratigraphic Identifications for Exploratory and Emplacement Drill Holes in Areas 3, 4, and 7, Nevada Test Site. U.S. Geological Survey Open-File Report 474-211, 87 pp. Denver, CO.

Drellack, S. L., Jr., 1992. “Sloughing Sand Lens Map.” Memorandum GEO-1382 to Distribution. Raytheon Services Nevada, Las Vegas, NV. 
Drellack, S. L., Jr., 1994a. “Fault Naming Protocols.” Memorandum TSP:DGP:003:94 to Gayle Pawloski, Lawrence Livermore National Laboratory. Raytheon Services Nevada, Las Vegas, NV.

Drellack, S. L., Jr., 1994b. “Subsurface Geologic Maps of Southern Yucca Flat.” Memorandum TSP:DGP:024:95 to Distribution. Raytheon Services Nevada, Las Vegas, NV.

Drellack, S. L., Jr., 1995a. “Descriptive Narrative for Cross Sections SD1, SD2, SD3, and MS1.” Memorandum TSP:DGP:043:95 to Edwin H. Price, HSI-GeoTrans. Raytheon Services Nevada, Las Vegas, NV.

Drellack, S. L., Jr., 1995b. “Fault Inventory for Yucca Flat, NTS.” Memorandum TSP:DGP:042:95 to Edwin H. Price, HSI-GeoTrans. Raytheon Services Nevada, Las Vegas, NV.

Drellack, S. L., Jr., 1995c. "Structure Contour Map of the Pre-Tertiary Surface in Southern Yucca Flat.” Memorandum TSP:DGP:116:95 to Distribution. Raytheon Services Nevada, Las Vegas, NV.

Drellack, S. L., Jr., and P. H. Thompson, 1990. Selected Stratigraphic Data for Drill Holes in LANL Use Areas of Yucca Flat, NTS. DOE/NV/10322--39. Fenix \& Scisson, Inc., Las Vegas, NV.

Drellack, S. L., Jr., P. H. Thompson, and C. J. Rayburn, 1989. Geology of the U-1a.01 Horizontal Drift Complex, Southwestern Yucca Flat, Nevada Test Site. Fenix \& Scisson of Nevada Geologic Report DOE/NV/10322-37, 69 p. Las Vegas, NV.

Drellack, S. L., Jr., L. B. Prothro, K. E. Roberson, B. A. Schier, and E. H. Price, 1997. Analysis of Fractures in Volcanic Cores from Pahute Mesa, Nevada Test Site. DOE/NV/11718--160. Prepared by Bechtel Nevada, Las Vegas, NV.

Faulds, J. E., and J. H. Stewart, eds., 1998. Accommodation Zones and Transfer Zones: The Regional Segmentation of the Basin and Range Province. Geological Society of America Special Paper 323, Boulder, CO.

Faunt, C. C., 1998. Effects of Faulting on Groundwater Movement in the Death Valley Region, Nevada and California. U. S. Geological Survey Water Resources Investigations Report 95-4132. Denver, CO.

Faunt, C. C., W. R. Belcher, F. A. D’Agnese, 1999. “Using Geologic Data for a ThreeDimensional Hydrogeologic Framework Model of the Death Valley Region.” In: Slate, J. L., ed., Proceedings of Conference on Status of Geological Research and Mapping in Death Valley National Park, Las Vegas, Nevada, April 9-11, 1999. U.S. Geological Survey Open File Report OFR-99-153, pp. 59-60.

Federal Facility Agreement and Consent Order, 1996 as amended. Agreed to by the U.S. Department of Energy, the U.S. Department of Defense, and the State of Nevada. Las Vegas, NV. 
Fenelon, J. M., 2005. Analysis of Ground-Water Levels and Associated Trends in Yucca Flat, Nevada Test Site, Nye County, Nevada, 1951-2003. U.S. Geological Survey Scientific Investigations Report 2005-5171. Denver, CO.

Ferguson, J. J., R. N. Felch, C. L. Aiken, J. S. Oldow, and H. Dockery, 1988. Models of the Bouguer Gravity and Geologic Structure at Yucca Flat, Nevada. Geophysics, v. 53, n. 2, p. 213-244.

Ferguson, J. F., A. H. Cogbill, and R. G. Warren, 1994. “A Geophysical-Geological Transect of the Silent Canyon Caldera Complex, Pahute Mesa, Nevada.” Journal of Geophysical Research, v. 99, n. 33, pp. 4,323-4,339.

Fernald, A. T., G. S. Corchary, and W. P. Williams, 1968. "Surficial Geologic Map of Yucca Flat, Nye and Lincoln Counties, Nevada.” U.S. Geological Survey Miscellaneous Investigations Map I-550, scale 1:48,000. Washington, DC.

Fernald, A. T., F. M. Byers, and J. P. Ohl, 1975. Lithologic Logs and Stratigraphic Units of Drill Holes and Mined Shafts in Areas 1 and 6, Nevada Test Site. U.S. Geological Survey Open-File Report 474-206, 61 pp. Denver, CO.

FFACO, see Federal Facilities Agreement and Consent Order.

Frizzell, V. A. and J. Shulters, 1990. "Geologic Map of the Nevada Test Site, Southern Nevada.” U.S. Geological Survey Miscellaneous Investigation Series Map I-2046, scale 1:100,000. Washington, DC.

Gibbons, A. B., E. N. Hinrichs, W. R. Hansen, and R. W. Lemke, 1963. “Geologic Map of the Rainier Mesa Quadrangle, Nye County, Nevada.” U.S. Geological Survey Map GQ-215, scale 1:24,000. Washington, DC.

Gillespie, D., J. D. Donithon, and P. R. Seaber, 1996. NTS Water-Supply Wells. DOE/NV/10845-56 (DRI Publication No. 45138). Desert Research Institute, Las Vegas, NV.

Gonzales J. L., S. L. Drellack, and M. J. Townsend, 1998. Written communication. Subject: Descriptive Narrative for the Hydrogeologic Model at the Yucca Flat Corrective Area Unit. An interim report. Bechtel Nevada, Las Vegas NV.

Gonzales, J. L., and S. L. Drellack, 1999. Written communication. Subject: Addendum to the Descriptive Narrative for the Hydrogeologic Model of the Yucca Flat CAU: Northern Extension. Prepared for the U.S. Department of Energy by Bechtel Nevada, Las Vegas, NV.

Grasso, D. N., 2001. GIS Surface Effects Archive of Underground Nuclear Detonations Conducted at Yucca Flat and Pahute Mesa, Nevada Test Site, Nevada. U.S. Geological Survey Open-File Report OFR-2001-272. . 
Grasso, D. J., 2003. Geologic Surface Effects of Underground Nuclear Testing, Buckboard Mesa, Climax Stock, Dome Mountain, Frenchman Flat, Rainier/Aqueduct Mesa, and Shoshone Mountain, NTS, Nevada. U.S. Geological Survey Open-File Report OFR-2003-125.

Hansen, D. J., P. D. Greger, C. A. Wills, and W. K. Ostler, 1997. Nevada Test Site Wetlands Assessment. DOE/NV/11718--124. Prepared for the U.S. Department of Energy by Bechtel Nevada, Las Vegas, NV.

Harrill, J. R., J. S. Gates, and J. M. Thomas, 1988. Major Groundwater Flow Systems in the Great Basin Region of Nevada, Utah and Adjacent States. Hydrological Investigation Atlas HA-694-C, scale 1:1,000,000. U.S. Geological Survey, Denver, CO.

Hawkins, W. L., D. A. Trudeau, and T. M. Mihevc, 1989. "Hydrologic Testing in Exploratory Drill Hole UE4t, Yucca Flat, the Nevada Test Site.” In: Olsen, C. W., and J. A. Carter, eds., Proceedings, Fifth Symposium on Containment of Underground Nuclear Explosions, Santa Barbara, California, September 19-22, 1989. Lawrence Livermore National Laboratory, CONF-8909163, v. 2, pp. 141-159. Livermore, CA.

Healey, D. L., 1968. Application of Gravity Data to Geologic Problems at Nevada Test Site. In: Eckel, E. B., ed., Nevada Test Site. Memoir 110, pp. 147-156. The Geological Society of America, Inc. Boulder, CO.

Healey, D. L., 1983. “Gravity Investigations.” In: Geologic and Geophysical Investigations of Climax Stock Intrusive, Nevada. U.S. Geological Survey Open-File Report 83-377, p.25-38. Denver, CO.

Healey, D. L, R. N. Harris, D. A. Ponce, and H. W. Oliver, 1987. Complete Bouguer Gravity Map of the Nevada Test Site and Vicinity, Nevada. U.S. Geological Survey Open-File Report 87-506. Denver, CO.

Hinrichs, E. N., 1968. Geologic Structure of Yucca Flat Area, Nevada. In: Eckel, E. B., ed., Nevada Test Site. Memoir 110, pp. 239-246. The Geological Society of America, Inc. Boulder, CO.

Hinrichs, E. N. and E. J. McKay, 1965. "Geologic Map of the Plutonium Valley Quadrangle, Nye and Lincoln Counties, Nevada.” U.S. Geological Survey Geologic Quadrangle Map GQ-384, scale 1:24,000. Washington, DC.

Hoover, D. L., WC Swadley, and A. J. Gordon, 1981. Correlation Characteristics of Surficial Deposits with a Description of Surficial Stratigraphy in the Nevada Test Site Region. U.S. Geological Survey Open-File Report 81-512. Denver, CO.

Houser, F. N., 1961. Lithologic Logs of Three Exploration Core Holes, U15b Area, Climax Stock, Nevada Test Site, Nye County, Nevada. U.S. Geological Survey Technical Report TEI-792, 67 pp. Washington, DC. 
Houser, F. N. and F. G. Poole, 1960. "Preliminary Geologic Map of the Climax Stock and Vicinity, Nye County, Nevada.” U.S. Geological Survey Map I-328, scale 1:4,800. Washington, DC.

Houser, F. N., R. E. Davis, and W. L. Emerick, 1961. Geologic Reconnaissance of Granitic Intrusive Masses at Gold Meadows, Tem Piute, and Trappman's Camp, Lincoln and Nye Counties, Nevada, and Comparison with the Climax Stock at the Nevada Test Site. U.S. Geological Survey Professional Paper TEI-793, 20 pp. Washington, DC.

Hudson, M. R., 1992. "Paleomagnetic Data Bearing on the Origin of Arcuate Structures in the French Peak-Massachusetts Mountain Area of Southern Nevada.” Geological Society of America Bulletin, v. 104, pp. 581-594.

Hudson, M. R., 1997. Structural Geology of the French Peak Accommodation Zone, Nevada Test Site, Southwestern Nevada. U. S. Geological Survey Open File Report 97-56.

IT, see IT Corporation.

IT Corporation, 1992. Written communication. Subject: Drilling Criteria for Well ER-6-2, Revision 1. Prepared for the U.S. Department of Energy Nevada Operations Office. Las Vegas, NV.

IT, Corporation, 1993. Drilling/Completion Criteria for Underground Test Area Remedial Investigation and Feasibility Study Well ER-3-2. DOE/NV/10972--76. Las Vegas, NV.

IT Corporation, 1994a. Drilling/Completion Criteria for Underground Test Area Operable Unit Well ER-3-1. DOE/NV/10972--86. Las Vegas, NV.

IT Corporation, 1994b Coring, Testing, Sampling, and Completion Plan for the Underground Test Area Operable Unit Investigation Well ER-6-2. DOE/NV/10972--95. Las Vegas, NV.

IT Corporation, 1996a. Regional Geologic Model Data Documentation Package (Phase I, Data Analysis Documentation, Volume I, Parts 1 and 2). ITLV/10972--181. Las Vegas, NV.

IT Corporation, 1996b. Potentiometric Data Task Documentation Package (Phase I, Data Analysis Documentation, Vol. II). ITLV/10972--181. Las Vegas, NV.

IT Corporation, 1996c. Hydrologic Parameters Data Documentation Package (Phase I, Data Analysis Documentation, Volume IV). ITLV/10972--181. Las Vegas, NV.

IT Corporation, 1996d. Groundwater Flow Model Documentation Package (Phase 1, Data Analysis Documentation, Volume VI). ITLV/10972--181. Las Vegas, NV.

IT Corporation, 1997. Written communication prepared for the U.S. Department of Energy Nevada Operations Office. Subject: Completion Report for Well Cluster ER-6-2. Las Vegas, NV. 
IT Corporation, 2002. Yucca Flat Hydrogeologic Investigation Wells Drilling and Completion Criteria. ITLV/13052--164. Las Vegas, NV.

Jachens, R. C., U.S. Geological Survey, 1999. Written communication to S.L. Drellack, Bechtel Nevada, concerning the inferred subsurface distribution of Cretaceous granitic bodies along the north edge of Yucca Flat, Nevada Test Site. Menlo Park, CA.

Jachens, R. C., and B. C. Moring, 1990. Maps of Cenozoic Deposits and the Isostatic Residual Gravity Over Basement for Nevada. U.S. Geological Survey Open File Report 90-404, 15 p.

Kirchoff-Stein, K. S., D. A. Ponce, and B. A. Chuchel, 1989. "Preliminary Aeromagnetic Map of the Nevada Test Site and Vicinity, Nevada.” U.S. Geological Survey Open-File Report 89-446. Denver, CO.

Laczniak, R. J., J. C. Cole, D. A. Sawyer, and D. A. Trudeau, 1996. Summary of Hydrogeologic Controls on the Ground-water Flow at the Nevada Test Site, Nye County, Nevada. U.S. Geological Survey Water-Resources Investigation Report 96-4109. Carson City, NV.

Levitt, D. G., and V. Yucel, 2002. Potential Groundwater Recharge and the Effects of Soil Heterogeneity on Flow at Two Radioactive Waste Management Sites at the Nevada Test Site. DOE/NV/11718--609. Bechtel Nevada, Las Vegas, NV.

Maldonado, F. 1977. Summary of the Geology and Physical Properties of the Climax Stock, Nevada Test Site. U.S. Geological Survey Open-File Report 77-356, 25 pp. Denver, CO.

Maldonado, F., S. G. Steel, and D. R. Townsend., 1979. Supplementary Lithologic Logs of Selected Vertical Drill Holes in Area 12, Nevada Test Site. U.S. Geological Survey Report USGS-474-261, 61 pp. Denver, CO.

Marvin, R. F., H. H. Mehnert, and C. W. Naeser, 1989. U.S. Geological Survey Radiometric Ages - Compilation “C,” Part Three - California and Nevada. Isochron/West, n. 52, p. 3-11.

Maxey, G. B., 1974. Hydrostratigraphic Units. Journal of Hydrology, v. 2, p. 124-129.

McCafferty, A. E. and V. J. S. Grauch, 1997. Aeromagnetic and Gravity Anomaly Maps of the Southwestern Nevada Volcanic Field, Nevada and California. U.S. Geological Survey Geophysical Investigation Map GP-1015, scale 1:250,000.

McKeown, F. A., D. L. Healey, and C. H. Miller, 1976. “Geologic Map of the Yucca Lake Quadrangle, Nye County, Nevada.” U.S. Geological Survey, GQ-1327, scale 1:24,000. Washington, DC.

Miller, D. R., 1970. Lithologic Logs and Stratigraphic Identification for Vertical Drill Holes in Area 12, Nevada Test Site. U.S. Geological Survey Administrative Report Area 12-27, 34 pp. Denver, CO. 
Naeser, C. W., and F. Maldonado, 1981. Fission-Track Dating of the Climax and Gold Meadows Stocks, Nye County, Nevada. In: Short Contributions to Geochronology: U.S. Geological Survey Professional Paper 1199E, pp. 45-47.

Nevada Bureau of Mines and Geology, 1996. County Digital Geologic Mapping Project- Final Report. Open-File Report 97-1, scale 1:250,000.

Orkild, P. P., 1963. “Geologic Map of the Tippipah Spring Quadrangle, Nye County, Nevada.” U.S. Geological Survey, Quadrangle Map GQ-213, scale 1:24,000. Washington, DC.

Orkild, P. P., 1968. “Geologic Map of the Mine Mountain Quadrangle, Nye County, Nevada.” U.S. Geological Survey, Quadrangle Map GQ-746, scale 1:24,000. Washington, DC.

Orkild, P. P., 1983a. “Geology of the Nevada Test Site.” In: Proceedings, Monterey Containment Symposium, Monterey, California, August 26-28, 1981. LA-9211-C, v. 1, pp. 323-337. Los Alamos National Laboratory, Los Alamos, NM.

Orkild, P. P., 1983b. “Summary of Geologic and Geophysical Investigations.” In: Geologic and Geophysical Investigations of Climax Stock Intrusive, Nevada. U.S. Geological Survey Open-File Report 83-377, p. 79-82. Denver, CO.

Orkild, P. P ., M. J. Baldwin, and D. R. Townsend, 1983. “Geologic Investigations.” In: Geologic and Geophysical Investigations of Climax Stock Intrusive, Nevada. U.S. Geological Survey Open-File Report 83-377, p. 1-24. Denver, CO.

Pawloski, G. A., 1996. Written communication. Subject: Review of Data in Frenchman Flat, with Special Emphasis on Alluvium and Porosity. Lawrence Livermore National Laboratory informal report. Livermore, CA.

Pawloski, G. A., A. F. B. Tompson, C. J. Bruton, and M. Zavarin, eds., 2000. Evaluation of the Hydrologic Source Term from Underground Nuclear Tests in Frenchman Flat and the Nevada Test Site. Contributors: W. L. Bourcier, C. J. Bruton, S. F., Carle, B. K. Esser, A .B. Kersting, R. M. Maxwell, G. A. Pawloski, J. A. Rard, D. E. Shumaker, D. K. Smith, A. F. B. Tompson, and M. Zavarin. UCRL-ID-138007. Lawrence Livermore National Laboratory, Livermore, CA.

Phelps, G. A., and E. H. McKee, 1999. High-Angle Faults in the Basement of Yucca Flats, Nevada Test Site, Nevada, Based on the Analysis of a Constrained Gravity Inversion Surface. U.S. Geological Survey Open-File Report OFR-99-383.

Phelps, G. A., and S. E. Graham, 2002. Preliminary Gravity Inversion Model of Frenchman Flat Basin, Nevada Test Site, Nevada. U.S. Geological Survey Open-File Report 2002-363.

Phelps, G. A., V. E. Langenheim, R. C. Jachens, 1999. Thickness of Cenozoic Deposits of Yucca Flat Inferred from Gravity Data, Nevada Test Site, Nevada. U.S. Geological Survey OpenFile Report OFR-99-310. 
Phelps, G. A., E. H. McKee, D. S. Sweetkind, V. E. Langenheim, 2000. Preliminary Model of the Pre-Tertiary Basement Rocks Beneath Yucca Flat, Nevada Test Site, Nevada, Based on Analysis of Gravity and Magnetic Data. U.S. Geological Survey Open-File Report OFR-2000-134.

Phelps, G. A., R. C. Jachens, B. C. Moring, C. W. Roberts, 2004. Modeling of the Climax Stock and Related Plutons Based on the Inversion of Magnetic Data, Southwest Nevada. U.S. Geological Survey Open-File Report OFR-2004-1345.

Phelps, G. A., L. Justet, B. C. Moring, and C. W. Roberts, 2005. A Preliminary Investigation of the Structure of Southern Yucca Flat, Massachusetts Mountain, and CP Basin, Nevada Test Site, Nevada, Based on Geophysical Modeling. U.S. Geological Survey Open-File Report $\mathrm{xxix}-\mathrm{xxx}$ (in press).

Ponce, D. A., 1999. Digital Aeromagnetic Map of the Nevada Test Site Area, Nye, Lincoln, and Clark Counties, Nevada and Inyo County, California. U.S. Geological Survey Open File Report 99-55413, CD-ROM, scale 1:100,000.

Ponce, D. A., R. N. Harris, and H. W. Oliver, 1988. “Isostatic Gravity Map of the Nevada Test Site and Vicinity, Nevada.” U.S. Geological Survey Open-File Report 88-664. Denver, CO.

Ponce, D. A., E. A. Mankinen, J. G. Davidson, R. L. Morin, R. J. Blakely, 1999. Digital Isostatic Gravity Map of the Nevada Test Site Area, Nye, Lincoln, Clark Counties, Nevada and Inyo County, California. U.S. Geological Survey Open File Report 99-554c, CD-ROM, scale 1:100,000.

Ponce, D. A., R. J. Blakely, R. L. Morin, and E. A. Mankinen, 2001. Isostatic Gravity Map of the Death Valley Ground-Water Model Area, Nevada and California. U.S. Geological Survey Miscellaneous Field Studies Map MF-2381-C.

Poole, F. G., F. N. Houser, and P. P. Orkild, 1961. Eleana Formation of Nevada Test Site and Vicinity, Nye County, Nevada. U.S. Geological Survey Professional Paper 424-D, pp. D-104 to D-111.

Prothro, L. B. 1998. Written communication. Subject: Analysis of Fractures in Cores from the Tuff Confining Unit beneath Yucca Flat, Nevada Test Site. Prepared for U.S. Department of Energy National Nuclear Security Administration Nevada Site Office by Bechtel Nevada, Las Vegas, NV.

Prothro, L. B., 2005a. Mineralogic Zonation Within the Tuff Confining Unit, Yucca Flat, Nevada Test Site. DOE/NV/11718--995. Bechtel Nevada, Las Vegas, NV.

Prothro, L. B., 2005b. Written communication via email to P. Cashman and J. Trexler (University of Nevada, Reno [UNR]). Subject: Bechtel Nevada comments (including attached figures) on UNR report, "Interpretation of the ER-12-2 Drill Hole: Reducing Stratigraphic and Structural Uncertainty in the Yucca Flat Geologic/ Hydrostratigraphic Model,” by Patricia H. Cashman and James H. Trexler, Jr., January 5, 2005. Bechtel Nevada, February 9, 2005, Las Vegas, NV. 
Prothro, L. B. and S. L. Drellack, Jr., 1997a. Review and Reconnaissance of the Hydrogeology of Tertiary Sedimentary Rocks in the Vicinity of Frenchman Flat, Nevada Test Site. DOE/NV/11718--155. Bechtel Nevada, Las Vegas, NV.

Prothro, L. B., and S. L. Drellack, Jr., 1997b. Nature and Extent of Lava-Flow Aquifers Beneath Pahute Mesa, Nevada Test Site. Prepared for U.S. Department of Energy, National Nuclear Security Administration Nevada Site Office by Bechtel Nevada, Las Vegas, NV.

Rayburn, C. J., S. L. Drellack Jr., and P. H. Thompson, 1989. “Occurrence, Distribution, and Measurement of Carbonate in the Alluvium of Southern Yucca Flat, Nevada Test Site.” In: Olsen, C. W., and J. A. Carter, eds., Proceedings, Fifth Symposium on the Containment of Underground Nuclear Explosions, Santa Barbara, California, September 19-22, 1989. Lawrence Livermore National Laboratory, CONF-8909163, v. 2, pp. 186-205.

Raytheon Services Nevada. 1990. “Nevada Test Site Drilling and Mining Summary.” Available from Bechtel Nevada, Mercury, NV.

Reiner, S. R., 2002. Aquifer-Test Report of WW-4A, Area 6, Nevada Test Site. U.S. Geological Survey, Carson City, NV.

Reiner, S. R., G. L. Locke, and L. S. Robie. 1995. Ground-Water Data for the Nevada Test Site and Selected Other Areas in South-Central Nevada 1992-1993. U.S. Geological Survey Open-File Report 95-160.

Rodriguez, B. D., U.S. Geological Survey, 2004a. Written communication. Subject: Yucca Flat MT Model Resolution. Denver, CO.

Rodriguez, B. D., U.S. Geological Survey, 2004b. Written communication. Letter to B. K. Thompson, U.S. Geological Survey, Henderson, NV, October 13, 2004. Subject: Transmittal of Completed 2-D Profile Models Processed from the Magnetotelluric Data for the YF/CM CAU. Denver, CO.

Rogers, C. L. and D. C. Noble, 1969. “Geologic Map of the Oak Spring Butte Quadrangle, Nye County, Nevada.” U.S. Geological Survey Map GQ-822, scale 1:24,000. Washington, DC.

RSN, see Raytheon Services Nevada.

Russell, C. E., D. Gillespie, J. C. Cole, S. L. Drellack, L. B. Prothro, P. H. Thompson, R. L. McCall, G. A. Pawloski, and R. Carlson, 1996. Completion Report for Well ER-12-1. DOE/NV/10845-36. Prepared for U.S. Department of Energy Nevada Operations Office, Las Vegas, NV.

Sargent, K. A. and P. P. Orkild, 1973. "Geologic Map of the Wheelbarrow Peak-Rainier Mesa Area, Nye County, Nevada.” U.S. Geological Survey Miscellaneous Geologic Investigations Map 1-754, scale 1:48,000. Washington, DC 
Sargent, K. A., S. J. Luft, A. B. Gibbons, and D. L. Hoover, 1966. “Geologic Map of the Quartet Dome Quadrangle, Nye County, Nevada.” U.S. Geological Survey Map GQ-496, scale 1:24,000. Washington, DC.

Sawyer, D. A., R. J. Fleck, M. A. Lanphere, R. G. Warren, D. E. Broxton, and M. R. Hudson, 1994. "Episodic Caldera Volcanism in the Miocene Southwest Nevada Volcanic Field: Revised Stratigraphic Framework, ${ }^{40} \mathrm{Ar} /{ }^{39} \mathrm{Ar}$ Geochronology and Implications for Magmatism and Extension.” Geological Society of America Bulletin, v. 106, pp. 1,304-1,318.

Seaber, P. R., 1988. “Hydrostratigraphic Units.” In: Back, W., J. R., Rosenshein, and P. R. Seaber, eds., Hydrogeology. The Geology of North America, Geological Society of America, v. O-2, p. 9-14.

Slate, J. L., M. E. Berry, P. D. Rowley, C. J. Fridrich, K. S. Morgan, J. B. Workman, O. D. Young, G. L. Dixon, V. S. Williams, E. H. McKee, D. A. Ponce, T. G. Hildenbrand, WC Swadley, S. C. Lundstrom, E. B. Ekren, R. G. Warren, J. C. Cole, R. J. Fleck, M. A. Lanphere, D. A. Sawyer, S. A. Minor, D. J. Grunwald, R. J. Laczniak, C. M. Menges, J. C. Yount and A. S. Jayko, 1999. Digital Geologic Map of the Map of the Nevada Test Site and Vicinity, Nye, Lincoln, and Clark Counties, Nevada and Inyo County, California. U.S. Geological Survey Open-File Report 99B554BA, scale 1:120,000.

SNJV, see Stoller-Navarro Joint Venture.

Snyder, R. P., 1977. Geology of the Gold Meadows Stock, Nevada Test Site. U.S. Geological Survey Report 474-179, 10 pp. Denver, CO.

Stewart, J. H., and J. E. Carlson, 1978. Geologic Map of Nevada, Scale 1:500,000. U.S. Geological Survey, Reston, VA.

Stoller-Navarro Joint Venture, 2004. Written communication. Subject: Fracture.04mbd and $a$ Users' Guide to the Fracture Characterization Database for the Nevada Test Site and Vicinity. Revision 3, September. Las Vegas, NV.

Stoller-Navarro Joint Venture, 2005. Underground Test Area Fracture Analysis Report for Yucca Flat Wells ER-2-1, ER-6-2\#1, ER-7-1, and ER-12-2. S-N/99205--040. Las Vegas, NV.

Sweetkind, D., R. P. Dickerson, R. J. Blakely, and P. D. Denning, 2001. Interpretive Geologic Cross Sections for the Death Valley Regional Flow System and Surrounding Areas, Nevada and California. U.S. Geologic Survey Miscellaneous Field Studies Map MF-2370.

Thordarson, W. and E. P. Robinson, 1971. Wells and Springs in California and Nevada Within 100 Miles of the Point $37^{\circ} 15^{\prime}, 116^{\circ} 25^{\prime} W$, on Nevada Test Site. U.S. Geological Survey Report 474-85, 178 pp. Denver, CO. 
Tompson, A. F. B., C. J. Bruton, and G. A. Pawloski, 1999. Evaluation of the Hydrologic Source Term from the Underground Nuclear Tests In Frenchman Flat and the Nevada Test Site: The CAMBRIC Test. UCRL-ID-132300. Lawrence Livermore National Laboratory, Livermore, CA.

Tschanz, C. M., and E. H. Pampeyan, 1970. "Geology and Mineral Deposits of Lincoln County, Nevada, Recently Dated as Miocene.” Nevada Bureau of Mines and Geology Bulletin 73.

Trexler, J. H., Jr., J. C. Cole, and P. H. Cashman, 1996. "Middle Devonian-Mississippian Stratigraphy On and Near the Nevada Test Site: Implications for Hydrocarbon Potential." American Association of Petroleum Geologists Bulletin, v. 80, n. 11, pp. 1,736-1,762.

U.S. Department of Energy, 1995a. Completion Report for Well ER-3-1. DOE/NV--396. Prepared by IT Corporation, Las Vegas, NV.

U.S. Department of Energy, 1995b. Completion Report for Well ER-3-2. DOE/NV--408. Prepared by IT Corporation, Las Vegas, NV.

U.S. Department of Energy, 1996. Final Environmental Impact Statement for the Nevada Test Site and Off-site Locations in the State of Nevada. DOE/EIS-0243. Nevada Operations Office, Las Vegas, Nevada.

U.S. Department of Energy, 1997. Regional Groundwater Flow and Tritium Transport Modeling and Risk Assessment of the Underground Test Area, Nevada Test Site, Nevada. DOE/NV--477. Las Vegas, NV.

U.S. Department of Energy, 1998. Routine Radiological Environmental Monitoring Plan. DOE/NV/11718-244. Las Vegas, Nevada.

U.S. Department of Energy, Nevada Operations Office, 2000a. United States Nuclear Tests, July 1945 through September 1992. DOE/NV-209, Revision 15. Las Vegas, NV.

U.S. Department of Energy, Nevada Operations Office, 2000b. Corrective Action Investigation Plan for Corrective Action Unit 97: Yucca Flat/Climax Mine, Nevada Test Site, Nevada. DOE/NV--659. Las Vegas, NV.

U.S. Department of Energy, National Nuclear Security Administration Nevada Site Office, 2004a. Well Completion Report for Well Cluster ER-6-1. DOE/NV/11718--862. Prepared by Bechtel Nevada, Las Vegas, Nevada.

U.S. Department of Energy, National Nuclear Security Administration Nevada Site Office, 2004b. Well Completion Report for Well ER-2-1. DOE/NV/11718--893. Prepared by Bechtel Nevada, Las Vegas, Nevada.

U.S. Department of Energy, National Nuclear Security Administration Nevada Site Office, 2004c. Well Completion Report for Well ER-7-1. DOE/NV/11718--865. Prepared by Bechtel Nevada, Las Vegas, Nevada. 
U.S. Department of Energy, National Nuclear Security Administration Nevada Site Office, 2004d. Well Completion Report for Well ER-8-1. DOE/NV/11718--845. Prepared by Bechtel Nevada, Las Vegas, Nevada.

U.S. Department of Energy, National Nuclear Security Administration Nevada Site Office, 2004e. Well Completion Report for Well ER-12-2. DOE/NV/11718--846. Prepared by Bechtel Nevada, Las Vegas, Nevada.

U.S. Department of Energy, National Nuclear Security Administration Nevada Site Office, 2005. Well Completion Report for Well Cluster ER-5-3. DOE/NV/11718--1093. Prepared by Bechtel Nevada, Las Vegas, Nevada.

U.S. Geological Survey, 1974. Results of Exp. of Baneberry Site, Early 1971. U.S. Geological Survey Open-File Report 474-145.

USGS, see U.S. Geological Survey.

Waddell, R. K., J. H. Robison, and R. K. Blankennagel, 1984. Hydrology of Yucca Mountain and Vicinity, Nevada-California Investigative Results through Mid-1983. U.S. Geological Survey Water-Resources Investigation Report 84-4267, 72 pp. Denver, CO.

Wagoner, J. L., and H. L. McKague, 1984. Variation of Physical Properties of Alluvium in an Arid Basin. UCRL-90672. Lawrence Livermore National Laboratory, Livermore, CA

Wagoner, J. L. and W. Richardson, 1986. Stratigraphic Contacts From Drill Holes at the Nevada Test Site. UCID-20790, 39 pp. Lawrence Livermore National Laboratory, Livermore, CA.

Wahl, R. R., U.S. Geological Survey, 1995. Written communication to Ed Price, HSI-GeoTrans, “Analysis of Gravity Data Along Profile KR1, Frenchman Flat, Nevada.” November 2,1995. Golden, CO.

Wahl, R. R., D. A. Sawyer, S. A. Minor, M. D. Carr, J. C. Cole, WC Swadley, R. J. Laczniak, R. G. Warren, K. S. Green, and C. M. Engle, 1996. Digital Geologic Map Database of the Nevada Test Site Area, Nevada. U.S. Geological Survey Open-File Report 97-140. Denver, CO.

Walker, G. E., 1962. Ground Water in the Climax Stock, Nevada Test Site, Nye County, Nevada. U.S. Geological Survey Trace Elements Investigations Report TEI-813, 48 pp. Washington, DC.

Warren, R. G., F. C. Benedict Jr., T. P. Rose, D. K. Smith, S. J. Chipera, E. C. Kluk, and K. M. Raven, 2002. Alluvial Layering and Distribution of Reactive Phases within Drill Holes ER-5-4 and UE-5n of Frenchman Flat. LA-UR-02-6206. Los Alamos National Laboratory, Los Alamos, NM. 
Warren, R. G., D. A. Sawyer, F. M. Byers, Jr., and J. C. Cole, 2003. A Petrographical, Geochemical and Geophysical Database and Framework for the Southwestern Nevada Volcanic Field. LA-UR-03-1503. Los Alamos National Laboratory, Los Alamos, NM.

Winograd, I. J. and William Thordarson, 1975. Hydrogeologic and Hydrochemical Framework, South-Central Great Basin, Nevada-California, with Special Reference to the Nevada Test Site. U.S. Geological Survey Professional Paper 712-C, 126 pp. Washington, DC.

WoldeGabriel, G., S. Chipera, G. Keating, E. Kluk, S. Levy, and M. Snow, 2004. Geological Characterization of Wells ER-2-1, ER-6-1\#2, ER-7-1, ER-8-1, and ER-12-2, Yucca Flat, Nevada Test Site. Los Alamos National Laboratory Report LA-UR-04-1831. Los Alamos, NM.

Workman, J. B., C. Menges, W. R. Page, E. M. Taylor, E. B. Ekren, P. P. Rowley, G. L. Dixon, R. A. Thompson, and L. A. Wright, 2002a. Geologic Map of the Death Valley Groundwater Model Area, Nevada and California. U.S. Geological Survey Miscellaneous Map MF-2381A. Scale 1:250,000

Workman, J. B., C. Menges, W. R. Page, E. B. Ekren, P. P. Rowley, G. L. Dixon, 2002b. Tectonic Map of the Death Valley Groundwater Model Area, Nevada and California. U.S. Geologic Survey Miscellaneous Field Studies Map MF-2381-B, scale, 1:250,000.

Yount, J. C., U.S. Geological Survey, 1996. Verbal communication to L. P. Prothro, Bechtel Nevada, regarding the rocks of Winapi Wash. Las Vegas, NV.

Zavarin M., S. F. Carle, and R. M. Maxwell, 2004. Upscaling Radionuclide Retardation Linking the Surface Complexation and Ion Exchange Mechanistic Approach to a Linear Kd Approach. Report on work performed for the UGTA program, Lawrence Livermore National Laboratory Report UCRL-TR-214713, Livermore, CA.

Zohdy, A. R., and R. J. Bisdorf, 1979. Schlumberger Soundings and Geoelectric Cross Section in Yucca Lake, NTS, NV. U.S. Geological Survey Open-File Report OFR-79-220. 


\section{Distribution List}

$\underline{\text { Copies }}$

W. R. Wilborn

U.S. Department of Energy

11 (4 paper, 7 CDs)

National Nuclear Security Administration

Nevada Site Office

Environmental Restoration Division

P.O. Box 98518, M/S 505

Las Vegas, NV 89193-8518

U.S. Department of Energy

1 paper (uncontrolled)

National Nuclear Security Administration

Nevada Site Office

Technical Library

P.O. Box 98518, M/S 505

Las Vegas, NV 89193-8518

U.S. Department of Energy

National Nuclear Security Administration

2 CDs (uncontrolled)

Nevada Site Office

Public Reading Facility

c/o Nuclear Testing Archive

P.O. Box 98518, M/S 505

Las Vegas, NV 89193-8518

U.S. Department of Energy

$1 \mathrm{CD}$ (uncontrolled)

Office of Scientific and Technical Information

P.O. Box 62

Oak Ridge, Tennessee 37831-0062

Northern Nevada FFACO Public Reading Room

$1 \mathrm{CD}$ (uncontrolled)

c/o Nevada State Library and Archive

100 West Stuart Street

Carson City, NV 89701-4208

T. C. Beard

$1 \mathrm{CD}$

Stoller-Navarro Joint Venture

7710 W. Cheyenne, Bldg. 3, M/S 439

Las Vegas, NV 89129 


\section{Distribution List, continued}

$\underline{\text { Copies }}$

N. M. Becker

Los Alamos National Laboratory

2 (1 paper, $1 \mathrm{CD})$

P. O. Box 1663, EES-6, M/S F-665

Los Alamos, NM 87545-1663

N. M. DeNovio

2 (1 paper, $1 \mathrm{CD})$

Stoller-Navarro Joint Venture

7710 W. Cheyenne, Bldg. 3, M/S 439

Las Vegas, NV 89129

S. L. Drellack

2 (1 paper, $1 \mathrm{CD})$

Bechtel Nevada

P.O. Box 98521, NSF082

Las Vegas, NV 89193-8521

J. L. Gonzales

$1 \mathrm{CD}$

Bechtel Nevada

P.O. Box 98521, NSF082

Las Vegas, NV 89193-8521

J. P. McCord

2 (1 paper, $1 \mathrm{CD})$

Stoller-Navarro Joint Venture

7710 W. Cheyenne, Bldg. 3, M/S 439

Las Vegas, NV 89129

P. Montazer

2 (1 paper, 1 CD)

Stoller-Navarro Joint Venture

7710 W. Cheyenne, Bldg. 3, M/S 439

Las Vegas, NV 89129

P. K. Ortego

$1 \mathrm{CD}$

Bechtel Nevada

P.O. Box 98521, NSF082

Las Vegas, NV 89193-8521

G. A. Pawloski

2 (1 paper, 1 CD)

Lawrence Livermore National Laboratory

P. O. Box 808

Livermore, CA 94551-0808

G. A. Phelps

$1 \mathrm{CD}$

U.S. Geological Survey

345 Middlefield Road

Menlo Park, CA 94025 
Distribution List, continued

$\underline{\text { Copies }}$

L. B. Prothro

$1 \mathrm{CD}$

Bechtel Nevada

P.O. Box 98521, NSF082

Las Vegas, NV 89193-8521

S. E. Rawlinson

$1 \mathrm{CD}$

Bechtel Nevada

P.O. Box 98521, NTS416

Las Vegas, NV 89193-8521

C. E. Russell

2 (1 paper, 1 CD)

Desert Research Institute

755 East Flamingo Road

P.O. Box 19040

Las Vegas, NV 89119-7363

G. Ruskauff

$1 \mathrm{CD}$

Stoller-Navarro Joint Venture

7710 W. Cheyenne, Bldg. 3, M/S 439

Las Vegas, NV 89129

Stoller Navarro Central Files

2 (1 paper, $1 \mathrm{CD})$

Stoller-Navarro Joint Venture

7710 W. Cheyenne, Bldg. 3, M/S 439

Las Vegas, NV 89129

Environmental Management Information System

$1 \mathrm{CD}$

Stoller-Navarro Joint Venture

7710 W. Cheyenne, Bldg. 3, M/S 439

Las Vegas, NV 89129

B. K. Thompson

Water Resources, Nevada District

2 (1 paper, $1 \mathrm{CD})$

U.S. Geological Survey

160 N. Stephanie Street

Henderson, NV 89074

M. J. Townsend

2 (1 paper, $1 \mathrm{CD})$

Bechtel Nevada

P.O. Box 98521, NTS416

Las Vegas, NV 89193-8521 


\section{APPENDIX A}

Hydrostratigraphic Drill Hole Database for the Yucca Flat-Climax Mine Model Area 
Table A-1. Hydrostratigraphic Data for Selected Drill Holes in the Yucca Flat CAU Model Area.

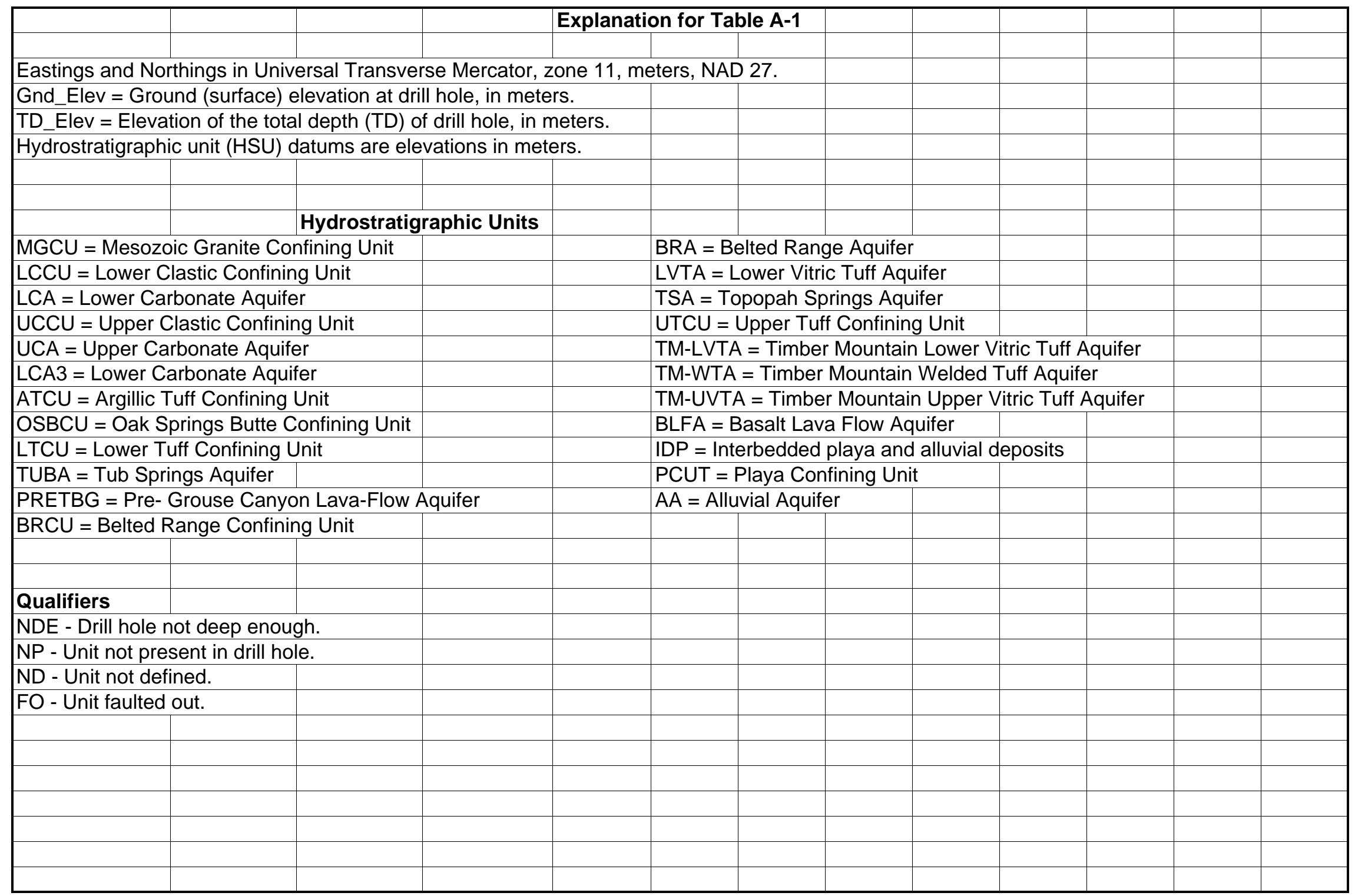




\begin{tabular}{|c|c|c|c|c|c|c|c|c|c|c|c|c|}
\hline Well_Id & EASTING & NORTHING & Gnd_Elev & TD_Elev & MGCU & LCCU & LCA & UCCU & LCA3 & ATCU & OSBCU & LTCU \\
\hline Effinger1 & 575415.5 & 4116089.0 & 1570.3 & 1515.5 & NDE & NDE & NDE & NDE & NDE & NDE & NDE & NDE \\
\hline ER_12_1 & 572411.5 & 4115492.7 & 1773.3 & 679.7 & NDE & NDE & 898.9 & 1460.6 & 1765.1 & NP & NP & $N P$ \\
\hline ER_12_2 & 577902.6 & 4114057.7 & 1434.0 & -663.9 & NDE & NDE & NDE & 1248.2 & NP & NP & NP & 1297 \\
\hline ER_2_1 & 583334.5 & 4108978.3 & 1285.0 & 492.5 & NDE & NDE & NDE & NDE & NDE & NDE & NDE & 701.4 \\
\hline ER_3_1 & 594658.3 & 4097339.0 & 1343.2 & 487.6 & NDE & NDE & 1058.9 & NP & NP & NP & NP & NP \\
\hline ER_3_2 & 585716.4 & 4099227.8 & 1222.3 & 307.9 & NDE & NDE & NDE & NDE & NDE & NDE & NDE & NDE \\
\hline ER_6_1 & 589632.7 & 4093418.7 & 1200.1 & 222.9 & NDE & NDE & 661.4 & NP & NP & 672.7 & 767.2 & 959.2 \\
\hline ER_6_1_2 & 589609.0 & 4093330.9 & 1199.5 & 224.1 & NDE & NDE & 659.9 & NP & NP & NP & NP & NP \\
\hline ER_6_2 & 582235.7 & 4090745.0 & 1289.7 & 244.2 & NDE & NDE & NDE & 411 & 1259.1 & NP & NP & NP \\
\hline ER_7_1 & 589315.1 & 4103275.3 & 1294.2 & 532.2 & NDE & NDE & 779.3 & NP & NP & NP & 913.4 & 1065.8 \\
\hline ER_8_1 & 583790.6 & 4118738.2 & 1468.6 & 596.0 & 929.9 & NP & 1134.7 & $\mathrm{NP}$ & NP & NP & 1374.3 & NP \\
\hline gravityhigh 1 & 579179.0 & 4111360.1 & 1353.3 & 1309.1 & NDE & NDE & NDE & NDE & 1309.4 & NP & NP & NP \\
\hline Stewart1 & 591781.7 & 4125878.9 & 1412.4 & 1310.0 & NDE & NDE & NDE & NDE & NDE & NDE & NDE & NDE \\
\hline TG2 & 581947.1 & 4099729.3 & 1255.8 & 1227.7 & NDE & NDE & NDE & NDE & 1233.8 & NP & NP & NP \\
\hline TH3_1 & 588752.5 & 4101334.3 & 1260.7 & 1062.5 & NDE & NDE & NDE & NDE & NDE & NDE & NDE & NDE \\
\hline TH3_4 & 589971.3 & 4101338.6 & 1281.4 & 1204.0 & NDE & NDE & NDE & NDE & NDE & NDE & NDE & NDE \\
\hline TH3_5 & 589359.8 & 4101945.9 & 1283.8 & 1130.2 & NDE & NDE & NDE & NDE & NDE & NDE & NDE & NDE \\
\hline TH3_8 & 589364.0 & 4100727.0 & 1260.0 & 1104.3 & NDE & NDE & NDE & NDE & NDE & NDE & NDE & NDE \\
\hline TH3_9 & 589941.9 & 4101033.8 & 1272.8 & 677.6 & NDE & NDE & 696.8 & NP & NP & NP & NP & NP \\
\hline TH3_E & 589361.9 & 4101336.5 & 1271.6 & 473.0 & NDE & NDE & 552.6 & NP & NP & 573.6 & NP & 918.4 \\
\hline TW_7 & 585901.0 & 4102301.1 & 1236.8 & 554.4 & NDE & NDE & NDE & NDE & NDE & NDE & NDE & 733.3 \\
\hline TW_D & 582223.9 & 4103327.0 & 1265.1 & 670.7 & NDE & NDE & 738.5 & NP & NP & 762.6 & NP & 806.8 \\
\hline TW6_B & 587779.9 & 4092815.9 & 1198.4 & 687.9 & NDE & NDE & NDE & NDE & NDE & NDE & NDE & NDE \\
\hline TW6_C & 588214.5 & 4086124.7 & 1195.1 & 676.7 & NDE & NDE & 782.1 & NP & NP & 815.3 & 826.3 & 1047.3 \\
\hline U10af & 584113.4 & 4112079.2 & 1297.5 & 764.1 & NDE & NDE & NDE & NDE & NDE & NDE & NDE & NDE \\
\hline U10ah & 584012.5 & 4112436.3 & 1298.8 & 837.0 & NDE & NDE & NDE & NDE & NDE & NDE & NDE & NDE \\
\hline U10an & 585340.2 & 4113290.2 & 1313.1 & 832.7 & NDE & NDE & NDE & NDE & NDE & NDE & NDE & 901.5 \\
\hline U10ap_3 & 585340.7 & 4113063.8 & 1312.5 & 855.3 & NDE & NDE & NDE & NDE & NDE & NDE & NDE & NDE \\
\hline U10aq & 585881.2 & 4113350.0 & 1323.4 & 987.6 & NDE & NDE & NDE & NDE & NDE & NDE & NDE & NDE \\
\hline U10aq_1 & 585881.1 & 4113365.2 & 1323.7 & 824.8 & NDE & NDE & NDE & NDE & NDE & NDE & NDE & 1049.4 \\
\hline U10as & 584266.4 & 4114406.9 & 1310.0 & 944.3 & NDE & NDE & 954.9 & NP & NP & 959.5 & NP & NP \\
\hline U10ax & 585846.5 & 4113082.3 & 1321.9 & 1017.1 & NDE & NDE & NDE & NDE & NDE & NDE & NDE & NDE \\
\hline U10b & 582825.0 & 4114420.1 & 1333.5 & 876.0 & NDE & NDE & 1153.4 & NP & NP & NP & NP & NP \\
\hline U10b_1 & 582836.6 & 4114400.4 & 1333.2 & 1052.8 & NDE & NDE & 1165.3 & NP & NP & NP & $\mathrm{NP}$ & NP \\
\hline
\end{tabular}




\begin{tabular}{|c|c|c|c|c|c|c|c|c|c|c|c|c|c|}
\hline Well_Id & TUBA & PRETBG & BRCU & BRA & TSA & UTCU & TMLVTA & TMWTA & TMUTVA & BLFA & IDP & PCUT & AA \\
\hline Effinger1 & NDE & NDE & NDE & NDE & NDE & NDE & NDE & NDE & NDE & NDE & NDE & NDE & 1570.0 \\
\hline ER_12_1 & NP & $N P$ & NP & NP & $N P$ & NP & NP & NP & NP & $N P$ & NP & NP & 1773.5 \\
\hline ER_12_2 & NP & NP & NP & $\mathrm{NP}$ & NP & NP & NP & $\mathrm{NP}$ & $\mathrm{NP}$ & NP & NP & $\mathrm{NP}$ & 1434.2 \\
\hline ER_2_1 & NP & NP & NP & NP & NP & NP & 754.7 & 798.9 & 859.9 & NP & NP & NP & 1286.0 \\
\hline ER_3_1 & NP & NP & NP & NP & NP & NP & 1104.3 & NP & NP & NP & NP & $\mathrm{NP}$ & 1343.6 \\
\hline ER_3_2 & NDE & NDE & NDE & NDE & NDE & NDE & NDE & 344.4 & 419.7 & NP & NP & NP & 1221.6 \\
\hline ER_6_1 & NP & NP & NP & NP & 1034.8 & 1048.2 & 1099.4 & NP & NP & NP & NP & NP & 1199.4 \\
\hline ER_6_1_2 & NP & NP & NP & NP & 1033.3 & 1046.7 & 1097.9 & NP & NP & NP & NP & NP & 1199.0 \\
\hline ER_6_2 & NP & $\mathrm{NP}$ & NP & $\mathrm{NP}$ & NP & NP & NP & NP & NP & NP & NP & NP & 1289.9 \\
\hline ER_7_1 & $\mathrm{NP}$ & $\mathrm{NP}$ & $\mathrm{NP}$ & $\mathrm{NP}$ & NP & NP & 1228.9 & $\mathrm{NP}$ & NP & $\mathrm{NP}$ & $\mathrm{NP}$ & $\mathrm{NP}$ & 1294.4 \\
\hline ER_8_1 & NP & NP & NP & $\mathrm{NP}$ & NP & NP & 1426.5 & NP & NP & NP & NP & $\mathrm{NP}$ & 1468.8 \\
\hline gravityhigh_1 & NP & NP & NP & NP & NP & NP & NP & NP & NP & NP & NP & NP & 1353.3 \\
\hline Stewart1 & NDE & NDE & NDE & NDE & NDE & NDE & NDE & NDE & NDE & NDE & NDE & NDE & 1412.0 \\
\hline TG2 & NP & NP & NP & NP & NP & NP & NP & NP & NP & NP & NP & NP & 1255.8 \\
\hline TH3_1 & NDE & NDE & NDE & NDE & NDE & NDE & 1083.3 & NP & NP & NP & NP & NP & 1260.7 \\
\hline TH3_4 & NDE & NDE & NDE & NDE & NDE & NDE & 1219.2 & $\mathrm{NP}$ & NP & NP & NP & NP & 1281.4 \\
\hline TH3_5 & NDE & NDE & NDE & NDE & NDE & NDE & 1147.9 & NP & NP & NP & NP & NP & 1283.8 \\
\hline TH3_8 & NDE & NDE & NDE & NDE & NDE & NDE & 1122.3 & NP & NP & $\mathrm{NP}$ & $\mathrm{NP}$ & $\mathrm{NP}$ & 1260.0 \\
\hline TH3_9 & NP & NP & NP & NP & NP & NP & 1098.2 & 1164.6 & NP & NP & NP & NP & 1272.8 \\
\hline TH3_E & NP & NP & NP & NP & NP & NP & 1073.5 & 1134.5 & NP & NP & NP & NP & 1271.6 \\
\hline TW_7 & NP & NP & NP & $\mathrm{NP}$ & NP & NP & NP & NP & NP & NP & NP & NP & 1239.3 \\
\hline TW_D & $\mathrm{NP}$ & NP & NP & NP & NP & NP & NP & $\mathrm{NP}$ & NP & NP & NP & NP & 1265.5 \\
\hline TW6_B & NDE & NDE & NDE & NDE & 767.5 & 795.2 & 832.7 & 908 & NP & NP & NP & 1029 & 1197.6 \\
\hline TW6_C & NP & NP & NP & NP & 1129.6 & NP & NP & $\mathrm{NP}$ & NP & NP & NP & 1195 & 1195.1 \\
\hline U10af & NDE & NDE & NDE & NDE & NDE & NDE & 864.4 & NP & NP & NP & NP & NP & 1297.5 \\
\hline U10ah & NDE & NDE & NDE & NDE & NDE & NDE & 841.9 & NP & NP & NP & NP & $\mathrm{NP}$ & 1298.8 \\
\hline U10an & NP & NP & NP & NP & NP & NP & 1078.4 & NP & NP & NP & NP & $\mathrm{NP}$ & 1313.1 \\
\hline U10ap_3 & NDE & NDE & NDE & NDE & NDE & NDE & 1079.3 & NP & NP & NP & NP & NP & 1312.5 \\
\hline U10aq & NDE & NDE & NDE & NDE & NDE & NDE & 1216.5 & NP & NP & NP & NP & NP & 1323.4 \\
\hline U10aq_1 & $\mathrm{NP}$ & NP & NP & NP & NP & NP & 1217.7 & NP & NP & NP & NP & $\mathrm{NP}$ & 1323.7 \\
\hline U10as & NP & NP & NP & NP & NP & NP & 1028.1 & NP & NP & NP & NP & NP & 1310.0 \\
\hline U10ax & NDE & NDE & NDE & NDE & NDE & NDE & 1194.8 & NP & NP & NP & NP & $\mathrm{NP}$ & 1321.9 \\
\hline U10b & NP & NP & NP & NP & NP & NP & 1161.5 & NP & NP & NP & NP & $N P$ & 1333.5 \\
\hline U10b_1 & $\mathrm{NP}$ & NP & NP & $\mathrm{NP}$ & NP & NP & 1175.2 & NP & NP & NP & NP & NP & 1333.2 \\
\hline
\end{tabular}




\begin{tabular}{|c|c|c|c|c|c|c|c|c|c|c|c|c|}
\hline Well_Id & EASTING & NORTHING & Gnd_Elev & TD_Elev & MGCU & LCCU & LCA & UCCU & LCA3 & ATCU & OSBCU & LTCU \\
\hline U10b_2 & 582824.5 & 4114542.0 & 1334.4 & 912.9 & $\mathrm{NDE}$ & NDE & 1126.5 & $\mathrm{NP}$ & $\mathrm{NP}$ & $\mathrm{NP}$ & $\mathrm{NP}$ & $\mathrm{NP}$ \\
\hline U10b_3 & 582832.6 & 4114420.2 & 1333.5 & 906.8 & NDE & NDE & 1165.6 & NP & NP & NP & NP & NP \\
\hline U10b_4 & 582824.2 & 4114633.4 & 1334.7 & 908.0 & NDE & NDE & 1120.7 & NP & NP & NP & NP & NP \\
\hline U10b_5 & 582823.5 & 4114846.4 & 1337.5 & 910.7 & NDE & NDE & 1131.4 & NP & NP & NP & NP & NP \\
\hline U10b_6 & 582869.6 & 4115332.9 & 1345.4 & 1151.8 & NDE & NDE & 1305.5 & NP & NP & NP & NP & NP \\
\hline U10bc & 585712.3 & 4112251.5 & 1312.2 & 1020.5 & NDE & NDE & 1035.1 & NP & NP & 1039.7 & NP & NP \\
\hline U10be & 583958.3 & 4117105.7 & 1378.3 & 1149.7 & NDE & NDE & NDE & NDE & NDE & NDE & NDE & NDE \\
\hline U10bg & 585685.2 & 4112160.0 & 1310.0 & 1089.0 & NDE & NDE & NDE & NDE & NDE & NDE & NDE & NDE \\
\hline U10bh & 584467.8 & 4115187.7 & 1317.3 & 1019.8 & NDE & NDE & NDE & NDE & NDE & NDE & NDE & 1022 \\
\hline U10c & 583885.9 & 4111681.3 & 1298.4 & 710.1 & NDE & NDE & NDE & NDE & NDE & NDE & NDE & NDE \\
\hline U10c_1 & 583894.7 & 4111689.9 & 1298.4 & 366.3 & NDE & NDE & 368.5 & NP & NP & NP & NP & NP \\
\hline U10ca & 585732.9 & 4116509.2 & 1344.5 & 1079.0 & NDE & NDE & NDE & NDE & NDE & NDE & 1110.4 & 1132.9 \\
\hline U10cb & 585704.1 & 4116403.1 & 1342.3 & 1112.2 & NDE & NDE & NDE & NDE & NDE & NDE & NDE & 1143.9 \\
\hline U10cc & 585645.9 & 4116576.5 & 1345.1 & 1115.0 & NDE & NDE & NDE & NDE & NDE & NDE & NDE & 1161 \\
\hline U10dEX1 & 585193.7 & 4112752.5 & 1308.2 & 675.4 & NDE & NDE & NDE & NDE & NDE & NDE & NDE & NDE \\
\hline U10dEX2 & 585358.9 & 4113516.7 & 1314.6 & 868.7 & NDE & NDE & NDE & NDE & NDE & NDE & NDE & NDE \\
\hline U10dS & 585375.1 & 4113516.1 & 1314.3 & 858.9 & NDE & NDE & NDE & NDE & NDE & NDE & NDE & NDE \\
\hline U10DS_1 & 585381.5 & 4113496.4 & 1314.3 & 688.5 & NDE & NDE & 756.2 & NP & NP & 776 & NP & NP \\
\hline U10e & 585241.1 & 4111838.4 & 1300.3 & 801.9 & NDE & NDE & NDE & NDE & NDE & NDE & NDE & 873.6 \\
\hline U10i & 584741.3 & 4115308.7 & 1321.3 & 789.4 & NDE & NDE & 821.4 & NP & NP & NP & NP & 992.1 \\
\hline U10its1 & 584643.9 & 4117108.1 & 1367.3 & 666.3 & NDE & NDE & 698.3 & NP & NP & NP & 873.5 & 983 \\
\hline U10its3 & 584648.8 & 4115706.7 & 1326.8 & 668.4 & NDE & NDE & 695.9 & NP & NP & NP & 761.4 & 827 \\
\hline U10its4 & 583584.2 & 4115154.1 & 1312.2 & 792.5 & NDE & NDE & 806.2 & NP & NP & NP & $\mathrm{NP}$ & 897.7 \\
\hline U10its5 & 583973.5 & 4117105.8 & 1378.3 & 662.0 & NDE & NDE & 667 & NP & NP & NP & 793.1 & 885.1 \\
\hline U10k & 584139.0 & 4113364.3 & 1302.4 & 573.6 & NDE & NDE & 587.3 & NP & $\mathrm{NP}$ & $\mathrm{NP}$ & $\mathrm{NP}$ & NP \\
\hline U10k_1 & 584148.2 & 4113350.6 & 1302.1 & 604.4 & NDE & NDE & NDE & NDE & NDE & ND & ND & 961.9 \\
\hline U10L_1 & 584922.7 & 4112269.4 & 1299.7 & 626.7 & NDE & NDE & 692.8 & NP & NP & NP & NP & 937.9 \\
\hline U10n_1 & 582824.0 & 4114709.3 & 1335.6 & 995.8 & NDE & NDE & 1115.6 & NP & NP & NP & NP & NP \\
\hline U10p & 584440.2 & 4114121.4 & 1308.2 & 846.4 & NDE & NDE & 874.2 & NP & NP & NP & NP & NP \\
\hline U10q & 584495.7 & 4111592.0 & 1291.4 & 779.4 & NDE & NDE & NDE & NDE & NDE & NDE & NDE & NDE \\
\hline U10t & 585514.7 & 4112021.9 & 1306.1 & 763.5 & NDE & NDE & 800.1 & NP & NP & NP & NP & 882.4 \\
\hline U2am & 583146.8 & 4109545.6 & 1297.8 & 519.1 & NDE & NDE & NDE & NDE & NDE & NDE & NDE & 658.4 \\
\hline U2ar & 582842.2 & 4108821.8 & 1292.0 & 591.0 & NDE & NDE & NDE & NDE & NDE & NDE & NDE & NDE \\
\hline U2as & 583612.8 & 4108400.9 & 1285.6 & 767.5 & NDE & NDE & NDE & NDE & NDE & NDE & NDE & NDE \\
\hline
\end{tabular}




\begin{tabular}{|c|c|c|c|c|c|c|c|c|c|c|c|c|c|}
\hline Well_Id & TUBA & PRETBG & BRCU & BRA & TSA & UTCU & TMLVTA & TMWTA & TMUTVA & BLFA & IDP & PCUT & AA \\
\hline U10b_2 & $\mathrm{NP}$ & NP & $\mathrm{NP}$ & $\mathrm{NP}$ & $\mathrm{NP}$ & $\mathrm{NP}$ & 1136.4 & $\mathrm{NP}$ & $\mathrm{NP}$ & $\mathrm{NP}$ & $\mathrm{NP}$ & $\mathrm{NP}$ & 1334.4 \\
\hline U10b_3 & NP & NP & NP & NP & NP & NP & 1168.5 & NP & NP & NP & NP & NP & 1333.5 \\
\hline U10b_4 & NP & NP & NP & $\mathrm{NP}$ & NP & NP & 1203.7 & NP & NP & NP & NP & $\mathrm{NP}$ & 1334.7 \\
\hline U10b_5 & NP & NP & NP & $\mathrm{NP}$ & NP & NP & 1239.5 & NP & NP & NP & NP & $\mathrm{NP}$ & 1337.5 \\
\hline U10b_6 & NP & NP & $\mathrm{NP}$ & $\mathrm{NP}$ & NP & NP & NP & NP & NP & NP & $\mathrm{NP}$ & $\mathrm{NP}$ & 1345.4 \\
\hline U10bc & $\mathrm{NP}$ & $\mathrm{NP}$ & NP & NP & $\mathrm{NP}$ & NP & 1225.3 & NP & NP & NP & NP & NP & 1312.2 \\
\hline U10be & NDE & NDE & NDE & NDE & NDE & NDE & NDE & NDE & NDE & NDE & NDE & NDE & 1378.3 \\
\hline U10bg & NDE & NDE & NDE & NDE & NDE & NDE & 1217 & NP & NP & NP & NP & NP & 1310.0 \\
\hline U10bh & $\mathrm{NP}$ & NP & NP & NP & NP & NP & 1026.3 & NP & NP & NP & NP & $\mathrm{NP}$ & 1317.3 \\
\hline U10c & NDE & NDE & NDE & NDE & NDE & NDE & 819.3 & NP & NP & NP & NP & NP & 1298.4 \\
\hline U10c_1 & $\mathrm{NP}$ & NP & NP & NP & NP & NP & 826.3 & NP & NP & NP & NP & $\mathrm{NP}$ & 1298.4 \\
\hline U10ca & $\mathrm{NP}$ & $\mathrm{NP}$ & NP & $\mathrm{NP}$ & NP & NP & 1216.5 & $\mathrm{NP}$ & NP & $\mathrm{NP}$ & $\mathrm{NP}$ & $\mathrm{NP}$ & 1344.5 \\
\hline U10cb & NP & NP & NP & $\mathrm{NP}$ & NP & NP & 1207.3 & $\mathrm{NP}$ & NP & NP & NP & $\mathrm{NP}$ & 1342.3 \\
\hline U10cc & $\mathrm{NP}$ & $\mathrm{NP}$ & NP & $\mathrm{NP}$ & NP & NP & 1214.9 & $\mathrm{NP}$ & NP & NP & NP & NP & 1345.1 \\
\hline U10dEX1 & NDE & NDE & NDE & NDE & NDE & NDE & 1095.1 & NP & NP & NP & NP & $\mathrm{NP}$ & 1308.2 \\
\hline U10dEX2 & NDE & NDE & NDE & NDE & NDE & $\mathrm{NDE}$ & 1125.6 & $\mathrm{NP}$ & NP & NP & NP & NP & 1314.6 \\
\hline U10dS & NDE & NDE & NDE & NDE & NDE & NDE & 1125.3 & NP & NP & NP & NP & NP & 1314.3 \\
\hline U10DS_1 & NP & NP & NP & NP & NP & NP & 1125.3 & $\mathrm{NP}$ & NP & $\mathrm{NP}$ & NP & NP & 1314.3 \\
\hline U10e & NP & NP & NP & $\mathrm{NP}$ & NP & NP & 1131.4 & NP & NP & NP & NP & NP & 1300.3 \\
\hline U10i & NP & $\mathrm{NP}$ & NP & $\mathrm{NP}$ & $\mathrm{NP}$ & NP & 1095.3 & $\mathrm{NP}$ & NP & $\mathrm{NP}$ & $\mathrm{NP}$ & $\mathrm{NP}$ & 1321.3 \\
\hline U10its1 & $\mathrm{NP}$ & $\mathrm{NP}$ & NP & $\mathrm{NP}$ & NP & NP & 1215.3 & NP & NP & NP & NP & $\mathrm{NP}$ & 1367.3 \\
\hline U10its3 & NP & $\mathrm{NP}$ & NP & $\mathrm{NP}$ & $\mathrm{NP}$ & NP & 1097.6 & $\mathrm{NP}$ & NP & $\mathrm{NP}$ & $\mathrm{NP}$ & $\mathrm{NP}$ & 1326.8 \\
\hline U10its4 & NP & $\mathrm{NP}$ & NP & $\mathrm{NP}$ & NP & NP & 1025.2 & NP & NP & NP & NP & NP & 1312.2 \\
\hline U10its5 & $\mathrm{NP}$ & $\mathrm{NP}$ & $\mathrm{NP}$ & $\mathrm{NP}$ & NP & NP & 1143.3 & $\mathrm{NP}$ & NP & $\mathrm{NP}$ & NP & $\mathrm{NP}$ & 1378.3 \\
\hline U10k & NP & NP & NP & $\mathrm{NP}$ & NP & NP & NP & NP & NP & NP & NP & NP & 1302.4 \\
\hline U10k_1 & NP & NP & NP & $\mathrm{NP}$ & NP & NP & NP & NP & NP & NP & NP & $\mathrm{NP}$ & 1302.1 \\
\hline U10L_1 & NP & NP & NP & NP & NP & NP & 1016.8 & NP & NP & NP & NP & NP & 1299.7 \\
\hline U10n_1 & $\mathrm{NP}$ & $\mathrm{NP}$ & NP & NP & $\mathrm{NP}$ & NP & 1190.6 & $\mathrm{NP}$ & NP & $\mathrm{NP}$ & $\mathrm{NP}$ & $\mathrm{NP}$ & 1335.6 \\
\hline U10p & $\mathrm{NP}$ & $\mathrm{NP}$ & NP & NP & $\mathrm{NP}$ & $\mathrm{NP}$ & 973.2 & $\mathrm{NP}$ & NP & NP & NP & NP & 1308.2 \\
\hline U10q & NDE & NDE & NDE & NDE & NDE & NDE & 959.5 & $\mathrm{NP}$ & NP & $\mathrm{NP}$ & $\mathrm{NP}$ & $\mathrm{NP}$ & 1291.4 \\
\hline U10t & NP & NP & NP & NP & NP & $\mathrm{NP}$ & 1172 & $\mathrm{NP}$ & NP & $\mathrm{NP}$ & $\mathrm{NP}$ & $\mathrm{NP}$ & 1306.1 \\
\hline U2am & NP & $\mathrm{NP}$ & NP & $\mathrm{NP}$ & NP & NP & 750 & 837.9 & NP & NP & NP & $\mathrm{NP}$ & 1297.8 \\
\hline U2ar & NDE & NDE & NDE & NDE & NDE & NDE & NDE & NDE & NDE & NDE & NDE & NDE & 1292.0 \\
\hline U2as & NDE & NDE & NDE & NDE & $\mathrm{NDE}$ & $\mathrm{NDE}$ & 864.7 & $\mathrm{NP}$ & $\mathrm{NP}$ & $\mathrm{NP}$ & $\mathrm{NP}$ & $\mathrm{NP}$ & 1285.6 \\
\hline
\end{tabular}




\begin{tabular}{|c|c|c|c|c|c|c|c|c|c|c|c|c|}
\hline Well_Id & EASTING & NORTHING & Gnd_Elev & TD_Elev & MGCU & LCCU & LCA & UCCU & LCA3 & ATCU & OSBCU & LTCU \\
\hline U2at & 584072.8 & 4108017.9 & 1279.9 & 610.8 & NDE & NDE & NDE & NDE & NDE & NDE & NDE & 800 \\
\hline U2au & 583943.4 & 4108335.6 & 1282.9 & 854.7 & NDE & NDE & NDE & NDE & NDE & NDE & NDE & NDE \\
\hline U2av & 583141.8 & 4110977.8 & 1310.0 & 641.6 & NDE & NDE & NDE & NDE & NDE & NDE & NDE & 711 \\
\hline U2aw & 582749.8 & 4109788.0 & 1301.8 & 641.6 & NDE & NDE & NDE & NDE & NDE & NDE & NDE & NDE \\
\hline U2az_1 & 583308.9 & 4107656.6 & 1277.7 & 723.0 & NDE & NDE & NDE & NDE & NDE & NDE & NDE & NDE \\
\hline $\mathrm{U} 2 \mathrm{br}$ & 582872.3 & 4111349.9 & 1314.3 & 757.7 & NDE & NDE & NDE & NDE & NDE & NDE & NDE & NDE \\
\hline U2bs & 583637.5 & 4108733.7 & 1288.1 & 678.5 & NDE & NDE & NDE & NDE & NDE & NDE & NDE & 761.1 \\
\hline U2bt & 584281.6 & 4107458.9 & 1274.7 & 726.0 & NDE & NDE & NDE & NDE & NDE & NDE & NDE & 872.9 \\
\hline U2bu & 584282.2 & 4107306.5 & 1273.8 & 709.9 & NDE & NDE & NDE & NDE & NDE & NDE & NDE & 874.5 \\
\hline U2bz & 582787.2 & 4112149.8 & 1320.7 & 912.3 & NDE & NDE & NDE & NDE & NDE & NDE & NDE & NDE \\
\hline U2ca_1 & 576302.4 & 4110496.1 & 1484.7 & 1035.7 & NDE & NDE & NDE & NDE & 1051.6 & 1068.6 & NP & 1234.7 \\
\hline U2ce & 576803.9 & 4110955.3 & 1452.1 & 1081.8 & NDE & NDE & NDE & NDE & 1107 & NP & NP & NP \\
\hline U2cn & 577488.7 & 4108504.9 & 1398.7 & 926.9 & NDE & NDE & NDE & NDE & 974.8 & NP & NP & NP \\
\hline U2co & 577568.2 & 4107987.2 & 1390.5 & 1033.9 & NDE & NDE & NDE & NDE & NDE & NDE & NDE & NDE \\
\hline U2cp & 577928.4 & 4107733.7 & 1374.6 & 993.6 & NDE & NDE & NDE & NDE & NDE & NDE & NDE & NDE \\
\hline U2cq & 578034.8 & 4107531.7 & 1371.3 & 929.3 & NDE & NDE & NDE & NDE & NDE & NDE & NDE & NDE \\
\hline U2cr & 577687.2 & 4110989.1 & 1403.3 & 986.6 & NDE & NDE & NDE & 1004.3 & NP & NP & NP & NP \\
\hline U2cs & 577997.8 & 4108796.2 & 1379.5 & 922.3 & NDE & NDE & NDE & NDE & NDE & NDE & NDE & NDE \\
\hline U2ct & 578020.5 & 4108039.1 & 1374.3 & 917.1 & NDE & NDE & NDE & NDE & NDE & NDE & NDE & NDE \\
\hline U2cu & 577996.1 & 4109283.8 & 1379.5 & 917.7 & NDE & NDE & NDE & NDE & NDE & NDE & NDE & NDE \\
\hline $\mathrm{U} 2 \mathrm{db}$ & 581142.7 & 4109533.4 & 1314.3 & 681.8 & NDE & NDE & NDE & NDE & NDE & NDE & NDE & NDE \\
\hline U2dd_4 & 581725.0 & 4107886.6 & 1295.1 & 830.9 & NDE & NDE & 863.2 & NP & NP & NP & NP & 898.9 \\
\hline U2df & 581050.2 & 4110535.3 & 1327.1 & 758.6 & NDE & NDE & NDE & NDE & NDE & NDE & NDE & NDE \\
\hline U2dg & 581456.2 & 4109387.3 & 1311.2 & 619.4 & NDE & NDE & NDE & NDE & NDE & NDE & NDE & NDE \\
\hline U2dj & 581421.8 & 4110588.1 & 1323.1 & 600.5 & NDE & NDE & NDE & NDE & NDE & NDE & NDE & NDE \\
\hline U2dq & 581995.9 & 4107469.5 & 1289.9 & 886.1 & NDE & NDE & NDE & NDE & NDE & NDE & NDE & NDE \\
\hline U2dr & 581340.0 & 4109927.8 & 1314.6 & 698.9 & NDE & NDE & NDE & NDE & NDE & NDE & NDE & $\mathrm{NDE}$ \\
\hline U2ds & 582208.3 & 4107805.4 & 1291.1 & 912.3 & NDE & NDE & NDE & NDE & NDE & NDE & NDE & NDE \\
\hline U2dt & 581536.8 & 4108016.4 & 1297.5 & 738.8 & NDE & NDE & 791.6 & NP & NP & NP & NP & 837.3 \\
\hline U2eh & 581499.3 & 4111689.4 & 1331.4 & 645.6 & NDE & NDE & NDE & NDE & NDE & NDE & NDE & $\mathrm{NDE}$ \\
\hline U2ei & 582803.6 & 4111845.1 & 1318.9 & 678.8 & NDE & NDE & NDE & NDE & NDE & NDE & NDE & 771.1 \\
\hline U2ek & 583361.2 & 4109241.7 & 1291.4 & 530.0 & NDE & NDE & NDE & NDE & NDE & NDE & NDE & 724.4 \\
\hline U2el & 583306.2 & 4108418.4 & 1286.3 & 554.7 & NDE & NDE & NDE & NDE & NDE & NDE & NDE & 646.2 \\
\hline U2en & 583164.7 & 4108799.1 & 1288.1 & 540.7 & NDE & NDE & NDE & NDE & NDE & NDE & NDE & 641.9 \\
\hline
\end{tabular}




\begin{tabular}{|c|c|c|c|c|c|c|c|c|c|c|c|c|c|}
\hline Well_Id & TUBA & PRETBG & BRCU & BRA & TSA & UTCU & TMLVTA & TMWTA & TMUTVA & BLFA & IDP & PCUT & AA \\
\hline U2at & NP & $\mathrm{NP}$ & $\mathrm{NP}$ & $\mathrm{NP}$ & $\mathrm{NP}$ & $\mathrm{NP}$ & 871.1 & 953.7 & $\mathrm{NP}$ & NP & NP & NP & 1279.9 \\
\hline U2au & NDE & NDE & NDE & NDE & NDE & NDE & NDE & 922.9 & NP & NP & NP & NP & 1282.9 \\
\hline U2av & NP & NP & $\mathrm{NP}$ & NP & NP & NP & 853.3 & 953.1 & NP & NP & NP & NP & 1310.0 \\
\hline U2aw & NDE & NDE & NDE & NDE & NDE & NDE & 718.4 & 800.7 & NP & $\mathrm{NP}$ & NP & NP & 1301.8 \\
\hline U2az_1 & NDE & NDE & NDE & NDE & NDE & NDE & NDE & NDE & NDE & NDE & NDE & NDE & 1277.7 \\
\hline $\mathrm{U} 2 \mathrm{br}$ & NDE & NDE & NDE & NDE & NDE & NDE & 887.6 & 924 & NP & NP & NP & NP & 1314.3 \\
\hline U2bs & NP & NP & NP & NP & NP & NP & 806.5 & 886.1 & NP & $\mathrm{NP}$ & $\mathrm{NP}$ & NP & 1288.1 \\
\hline U2bt & NP & NP & $\mathrm{NP}$ & NP & $\mathrm{NP}$ & $\mathrm{NP}$ & 903.1 & 997.6 & NP & $\mathrm{NP}$ & NP & NP & 1274.7 \\
\hline U2bu & NP & NP & NP & NP & NP & $\mathrm{NP}$ & 905 & 1026.9 & NP & NP & NP & NP & 1273.8 \\
\hline U2bz & NDE & NDE & NDE & NDE & NDE & NDE & 983.6 & NP & NP & NP & NP & NP & 1320.7 \\
\hline U2ca_1 & NP & NP & NP & NP & NP & NP & 1325.7 & NP & NP & NP & NP & NP & 1484.7 \\
\hline U2ce & $\mathrm{NP}$ & $\mathrm{NP}$ & NP & NP & NP & $\mathrm{NP}$ & 1335.1 & NP & $\mathrm{NP}$ & $\mathrm{NP}$ & $\mathrm{NP}$ & NP & 1452.1 \\
\hline U2cn & NP & NP & NP & NP & NP & $\mathrm{NP}$ & 1082 & 1151.8 & NP & NP & NP & NP & 1398.7 \\
\hline U2co & NDE & NDE & NDE & NDE & NDE & NDE & 1146.7 & 1190.5 & 1197.6 & NP & NP & NP & 1390.5 \\
\hline U2cp & NDE & NDE & NDE & NDE & NDE & NDE & 1108.3 & 1165.6 & 1178.7 & NP & NP & NP & 1374.6 \\
\hline $\mathrm{U} 2 \mathrm{cq}$ & NDE & NDE & NDE & NDE & NDE & NDE & 1130.8 & 1199.4 & 1212.2 & $\mathrm{NP}$ & NP & NP & 1371.3 \\
\hline $\mathrm{U} 2 \mathrm{cr}$ & NP & NP & NP & NP & NP & NP & 1308.3 & NP & NP & NP & NP & NP & 1403.3 \\
\hline U2cs & NDE & NDE & NDE & NDE & NDE & $\mathrm{NDE}$ & 1181.4 & NP & NP & NP & $N P$ & NP & 1379.5 \\
\hline U2ct & NDE & NDE & NDE & NDE & NDE & NDE & 1102.5 & NP & NP & NP & $\mathrm{NP}$ & NP & 1374.3 \\
\hline U2cu & NDE & $\mathrm{NDE}$ & NDE & NDE & NDE & $\mathrm{NDE}$ & 1185 & NP & $\mathrm{NP}$ & $N P$ & NP & NP & 1379.5 \\
\hline $\mathrm{U} 2 \mathrm{db}$ & NDE & NDE & NDE & NDE & NDE & NDE & 755.3 & NP & NP & NP & NP & NP & 1314.3 \\
\hline U2dd_4 & NP & NP & $\mathrm{NP}$ & NP & NP & NP & 969 & $\mathrm{NP}$ & $\mathrm{NP}$ & NP & $\mathrm{NP}$ & $\mathrm{NP}$ & 1295.1 \\
\hline U2df & NDE & NDE & NDE & NDE & NDE & NDE & NDE & NDE & NDE & NDE & NDE & NDE & 1327.1 \\
\hline U2dg & NDE & NDE & NDE & NDE & NDE & NDE & 665.4 & NP & NP & NP & $\mathrm{NP}$ & NP & 1311.2 \\
\hline U2dj & NDE & NDE & NDE & NDE & NDE & NDE & NDE & NDE & NDE & NDE & NDE & NDE & 1323.1 \\
\hline U2dq & NDE & NDE & NDE & NDE & NDE & NDE & 1018 & $\mathrm{NP}$ & NP & NP & NP & $\mathrm{NP}$ & 1289.9 \\
\hline $\mathrm{U} 2 \mathrm{dr}$ & NDE & NDE & NDE & NDE & NDE & NDE & NDE & NDE & NDE & NDE & NDE & NDE & 1314.6 \\
\hline U2ds & NDE & NDE & NDE & NDE & NDE & NDE & 992.1 & NP & NP & $\mathrm{NP}$ & NP & NP & 1291.1 \\
\hline U2dt & NP & NP & $\mathrm{NP}$ & NP & NP & NP & 910.5 & NP & NP & NP & $N P$ & NP & 1297.5 \\
\hline U2eh & NDE & NDE & NDE & $\mathrm{NDE}$ & NDE & NDE & 721.4 & $\mathrm{NP}$ & NP & $\mathrm{NP}$ & $\mathrm{NP}$ & NP & 1331.4 \\
\hline U2ei & NP & NP & NP & NP & NP & NP & 969 & NP & NP & NP & NP & NP & 1318.9 \\
\hline U2ek & NP & NP & NP & NP & NP & NP & 779.1 & 842.2 & NP & NP & NP & NP & 1291.4 \\
\hline U2el & NP & NP & NP & NP & $N P$ & $N P$ & 677.6 & 761.4 & 817.2 & NP & NP & $N P$ & 1286.3 \\
\hline U2en & NP & NP & $\mathrm{NP}$ & NP & NP & $\mathrm{NP}$ & 672.4 & 764 & 808.9 & $\mathrm{NP}$ & $\mathrm{NP}$ & $\mathrm{NP}$ & 1288.1 \\
\hline
\end{tabular}




\begin{tabular}{|c|c|c|c|c|c|c|c|c|c|c|c|c|}
\hline Well_Id & EASTING & NORTHING & Gnd_Elev & TD_Elev & MGCU & LCCU & LCA & UCCU & LCA3 & ATCU & OSBCU & LTCU \\
\hline U2eq & 583107.7 & 4107931.4 & 1281.1 & 761.1 & NDE & NDE & NDE & NDE & NDE & NDE & NDE & NDE \\
\hline U2er & 582885.3 & 4112872.3 & 1323.4 & 988.2 & NDE & NDE & NDE & NDE & NDE & NDE & NDE & NDE \\
\hline U2es & 582515.1 & 4111539.4 & 1320.4 & 802.2 & NDE & NDE & NDE & NDE & NDE & NDE & NDE & NDE \\
\hline U2et & 583164.7 & 4113141.5 & 1320.4 & 893.7 & NDE & NDE & 901.3 & NP & NP & NP & NP & NP \\
\hline U2ev & 581343.1 & 4111306.7 & 1330.8 & 901.6 & NDE & NDE & NDE & NDE & NDE & NDE & NDE & NDE \\
\hline U2ew & 583900.0 & 4108548.8 & 1282.9 & 825.7 & NDE & NDE & NDE & NDE & NDE & NDE & NDE & NDE \\
\hline U2ex & 582414.6 & 4110652.3 & 1314.0 & 701.6 & NDE & NDE & NDE & NDE & NDE & NDE & NDE & 714.1 \\
\hline U2ey & 582371.1 & 4113504.4 & 1336.2 & 1057.7 & NDE & NDE & 1063.1 & NP & NP & NP & NP & NP \\
\hline U2fa & 581179.6 & 4110132.3 & 1317.3 & 585.8 & NDE & NDE & NDE & NDE & NDE & NDE & NDE & NDE \\
\hline U2fb & 581380.9 & 4109135.7 & 1301.8 & 734.9 & NDE & NDE & NDE & NDE & NDE & NDE & NDE & NDE \\
\hline U2fd & 580969.6 & 4109096.1 & 1306.7 & 841.6 & NDE & NDE & NDE & NDE & NDE & NDE & NDE & NDE \\
\hline U2fe & 580886.0 & 4111213.7 & 1335.9 & 886.4 & NDE & NDE & NDE & NDE & NDE & NDE & NDE & NDE \\
\hline U2ff & 580942.1 & 4108258.1 & 1303.0 & 937.3 & NDE & NDE & NDE & NDE & NDE & NDE & NDE & NDE \\
\hline U2gaS & 582496.6 & 4110908.2 & 1314.3 & 766.6 & NDE & NDE & NDE & NDE & NDE & NDE & NDE & NDE \\
\hline U2gb & 583468.9 & 4108952.6 & 1286.0 & 712.9 & NDE & NDE & NDE & NDE & NDE & NDE & NDE & $\mathrm{NDE}$ \\
\hline U2ge & 581824.2 & 4110807.4 & 1321.3 & 736.1 & NDE & NDE & NDE & NDE & NDE & NDE & NDE & NDE \\
\hline U2gf & 582427.0 & 4108875.8 & 1295.1 & 743.4 & NDE & NDE & NDE & NDE & NDE & NDE & NDE & NDE \\
\hline U2gg & 582867.7 & 4110922.0 & 1307.3 & 752.2 & NDE & NDE & NDE & NDE & NDE & NDE & NDE & NDE \\
\hline U2gh & 583945.8 & 4107567.1 & 1273.1 & 724.3 & NDE & NDE & NDE & NDE & NDE & NDE & NDE & 796.1 \\
\hline U2gj & 582347.1 & 4110369.6 & 1311.6 & 740.1 & NDE & NDE & NDE & NDE & NDE & NDE & NDE & NDE \\
\hline U2n_1 & 582063.5 & 4111546.9 & 1326.8 & 634.0 & NDE & NDE & NDE & NDE & NDE & NDE & NDE & NDE \\
\hline $\mathrm{U} 2 \mathrm{q}^{-}$ & 584097.7 & 781.6 & 1278.6 & 864.1 & NDE & NDE & NDE & NDE & NDE & NDE & NDE & NDE \\
\hline U2r_1 & 582651.7 & 4109086.8 & 1299.1 & 280.4 & NDE & NDE & 282 & NP & NP & NP & NP & 553.3 \\
\hline $\mathrm{U} 2 \mathrm{t}^{-}$ & 583702.8 & 4107414.5 & 1278.6 & 582.2 & NDE & NDE & NDE & NDE & NDE & NDE & NDE & NDE \\
\hline U2v & 582934.9 & 4109148.8 & 1297.2 & 526.1 & NDE & NDE & NDE & NDE & NDE & NDE & NDE & NDE \\
\hline U2x & 583723.9 & 4107906.7 & 1282.0 & 500.2 & NDE & NDE & NDE & NDE & NDE & NDE & NDE & $\mathrm{NDE}$ \\
\hline U2z_1 & 583775.0 & 4108815.6 & 1288.7 & 249.0 & NDE & NDE & 326 & NP & NP & NP & $N P$ & NP \\
\hline U2z_2 & 582305.1 & 4110594.0 & 1315.5 & 410.3 & NDE & NDE & 437.4 & NP & NP & NP & NP & 605.5 \\
\hline U2z_3 & 581925.7 & 4110181.3 & 1315.2 & 354.5 & NDE & NDE & 372.2 & NP & NP & 384.1 & NP & 641 \\
\hline U3añ_1 & 585598.3 & 4102278.6 & 1237.5 & 469.4 & NDE & NDE & NDE & NDE & NDE & NDE & NDE & 551.7 \\
\hline U3an_3 & 585598.5 & 4102308.2 & 1237.8 & 154.2 & NDE & NDE & 253.3 & NP & NP & 261.6 & NP & NP \\
\hline U3cn_1 & 586973.5 & 4101828.2 & 1241.8 & 491.9 & NDE & NDE & NDE & NDE & NDE & NDE & NDE & $\mathrm{NDE}$ \\
\hline U3cn_5 & 586921.7 & 4101714.5 & 1222.0 & 298.5 & NDE & NDE & 363 & $N P$ & NP & 476.1 & 582.2 & 832.8 \\
\hline U3cp & 587529.6 & 4102369.5 & 1253.6 & 799.5 & NDE & NDE & NDE & NDE & NDE & NDE & NDE & 887.9 \\
\hline
\end{tabular}




\begin{tabular}{|c|c|c|c|c|c|c|c|c|c|c|c|c|c|}
\hline Well_Id & TUBA & PRETBG & BRCU & BRA & TSA & UTCU & TMLVTA & TMWTA & TMUTVA & BLFA & IDP & PCUT & AA \\
\hline U2eq & NDE & NDE & NDE & NDE & NDE & NDE & NDE & NDE & NDE & NDE & NDE & NDE & 1281.1 \\
\hline U2er & NDE & NDE & NDE & NDE & NDE & NDE & 1050.6 & NP & NP & NP & NP & NP & 1323.4 \\
\hline U2es & NDE & NDE & NDE & NDE & NDE & NDE & 890.3 & NP & NP & NP & NP & NP & 1320.4 \\
\hline U2et & NP & NP & NP & NP & NP & NP & 1113.4 & NP & NP & $\mathrm{NP}$ & NP & NP & 1320.4 \\
\hline U2ev & NDE & NDE & NDE & NDE & NDE & NDE & NDE & NDE & NDE & NDE & NDE & NDE & 1330.8 \\
\hline U2ew & NDE & NDE & NDE & NDE & NDE & NDE & 851.9 & 926.9 & NP & NP & NP & NP & 1282.9 \\
\hline U2ex & NDE & NDE & NDE & NDE & NDE & NDE & 716.6 & 794 & 813 & NP & NP & NP & 1314.0 \\
\hline U2ey & NP & NP & NP & NP & NP & NP & 1094.2 & NP & NP & NP & NP & NP & 1336.2 \\
\hline U2fa & NDE & NDE & NDE & NDE & NDE & NDE & 601.4 & NP & NP & NP & NP & NP & 1317.3 \\
\hline U2fb & NDE & NDE & NDE & NDE & NDE & NDE & 803.8 & NP & NP & NP & NP & NP & 1301.8 \\
\hline U2fd & NDE & NDE & NDE & NDE & NDE & NDE & NDE & NDE & NDE & NDE & NDE & NDE & 1306.7 \\
\hline U2fe & NDE & NDE & NDE & NDE & NDE & NDE & NDE & NDE & NDE & NDE & NDE & NDE & 1335.9 \\
\hline U2ff & NDE & NDE & NDE & NDE & NDE & NDE & NDE & NDE & NDE & NDE & NDE & NDE & 1303.0 \\
\hline U2gaS & NDE & NDE & NDE & NDE & NDE & NDE & NDE & 822.4 & 837.6 & NP & NP & NP & 1314.3 \\
\hline U2gb & NDE & NDE & NDE & NDE & NDE & NDE & 795.5 & 858 & 876 & NP & NP & NP & 1286.0 \\
\hline U2ge & NDE & NDE & NDE & NDE & NDE & NDE & 748.3 & $\mathrm{NP}$ & NP & $\mathrm{NP}$ & NP & NP & 1321.3 \\
\hline U2gf & NDE & NDE & NDE & NDE & NDE & NDE & NDE & 757 & 768 & NP & NP & NP & 1295.1 \\
\hline U2gg & NDE & NDE & NDE & NDE & NDE & $\mathrm{NDE}$ & 805.3 & 881.3 & NP & NP & NP & NP & 1307.3 \\
\hline U2gh & NP & NP & NP & NP & NP & $\mathrm{NP}$ & 813 & 895.1 & 948.2 & NP & NP & NP & 1273.1 \\
\hline U2gj & NDE & $\mathrm{NDE}$ & NDE & NDE & NDE & $\mathrm{NDE}$ & NDE & 780 & 808 & $N P$ & NP & NP & 1311.6 \\
\hline U2n_1 & NDE & NDE & NDE & NDE & NDE & NDE & 808.6 & $\mathrm{NP}$ & NP & NP & NP & NP & 1326.8 \\
\hline $\mathrm{U} 2 \mathrm{q}$ & NDE & NDE & NDE & NDE & NDE & NDE & 894.6 & 958.6 & NP & $\mathrm{NP}$ & NP & NP & 1278.6 \\
\hline U2r_1 & NP & NP & NP & NP & NP & NP & NP & 656.1 & NP & NP & NP & NP & 1299.1 \\
\hline U2t & NDE & NDE & NDE & NDE & NDE & NDE & NDE & NDE & 839.7 & $\mathrm{NP}$ & NP & NP & 1278.6 \\
\hline $\mathrm{U} 2 \mathrm{v}$ & NDE & NDE & NDE & NDE & NDE & NDE & 656.8 & 712.3 & 750.1 & NP & NP & NP & 1297.2 \\
\hline U2x & NDE & NDE & NDE & NDE & NDE & NDE & 739.7 & 858 & 876.9 & $\mathrm{NP}$ & NP & NP & 1282.0 \\
\hline U2z_1 & NP & NP & NP & NP & NP & NP & 877.8 & $\mathrm{NP}$ & NP & NP & NP & NP & 1288.7 \\
\hline U2z_2 & NP & NP & NP & NP & $\mathrm{NP}$ & $\mathrm{NP}$ & 721 & 780 & NP & $\mathrm{NP}$ & $\mathrm{NP}$ & NP & 1315.5 \\
\hline U2z_3 & NP & NP & NP & NP & NP & NP & 660 & 739.2 & 782.4 & NP & NP & NP & 1315.2 \\
\hline U3an_1 & NP & NP & $\mathrm{NP}$ & NP & $\mathrm{NP}$ & $\mathrm{NP}$ & 585.2 & 673.6 & 762 & $\mathrm{NP}$ & NP & NP & 1237.5 \\
\hline U3an_3 & NP & NP & NP & NP & NP & NP & NP & NP & NP & NP & NP & NP & 1237.8 \\
\hline U3cn_1 & NDE & NDE & NDE & NDE & NDE & NDE & 964.4 & NP & NP & NP & NP & NP & 1241.8 \\
\hline U3cn_5 & NP & NP & NP & NP & NP & NP & 940.9 & NP & NP & NP & $N P$ & NP & 1222.9 \\
\hline U3cp & NP & NP & $\mathrm{NP}$ & $\mathrm{NP}$ & NP & $\mathrm{NP}$ & 942.7 & 1000.4 & NP & $\mathrm{NP}$ & NP & $\mathrm{NP}$ & 1253.6 \\
\hline
\end{tabular}




\begin{tabular}{|c|c|c|c|c|c|c|c|c|c|c|c|c|}
\hline Well_Id & EASTING & NORTHING & Gnd_Elev & TD_Elev & MGCU & LCCU & LCA & UCCU & LCA3 & ATCU & OSBCU & LTCU \\
\hline U3cs & 587533.7 & 4101211.5 & 1239.0 & 698.0 & NDE & NDE & NDE & NDE & NDE & NDE & NDE & 903.7 \\
\hline U3daS & 587973.7 & 4101654.6 & 1249.1 & 794.9 & NDE & NDE & NDE & NDE & NDE & NDE & NDE & NDE \\
\hline U3daS4 & 587972.5 & 4101650.3 & 1249.1 & 775.4 & NDE & NDE & NDE & NDE & NDE & NDE & NDE & 886.4 \\
\hline U3dh & 586307.9 & 4103157.5 & 1250.3 & 742.8 & NDE & NDE & NDE & NDE & NDE & NDE & NDE & 841.9 \\
\hline U3dl & 586920.1 & 4102550.5 & 1248.8 & 878.4 & NDE & NDE & NDE & NDE & NDE & NDE & NDE & 910.4 \\
\hline U3do & 587526.8 & 4103161.8 & 1264.3 & 894.0 & NDE & NDE & NDE & NDE & NDE & NDE & NDE & 929 \\
\hline U3dq & 589071.8 & 4097072.6 & 1211.9 & 878.1 & NDE & NDE & NDE & NDE & NDE & NDE & NDE & NDE \\
\hline U3eh & 586950.5 & 4102397.9 & 1247.9 & 775.4 & NDE & NDE & NDE & NDE & NDE & NDE & NDE & NDE \\
\hline U3eh_1 & 586942.8 & 4102414.3 & 1246.6 & 858.0 & NDE & NDE & NDE & NDE & NDE & NDE & NDE & 888.5 \\
\hline U3ei & 587740.8 & 4102979.7 & 1264.3 & 730.9 & NDE & NDE & NDE & NDE & NDE & NDE & NDE & 895.5 \\
\hline U3ek & 589650.8 & 4097075.0 & 1222.2 & 986.0 & NDE & NDE & NDE & NDE & NDE & NDE & NDE & $\mathrm{NDE}$ \\
\hline U3ev_5 & 589935.3 & 4101195.3 & 1279.2 & 918.1 & NDE & NDE & NDE & NDE & NDE & NDE & NDE & 1072 \\
\hline U3ev3s & 589957.4 & 4100976.2 & 1274.1 & 921.7 & NDE & NDE & NDE & NDE & NDE & NDE & NDE & NDE \\
\hline U3evS & 589971.9 & 4101098.2 & 1276.8 & 941.5 & NDE & NDE & NDE & NDE & NDE & NDE & NDE & NDE \\
\hline U3ez & 588334.1 & 4098989.5 & 1222.2 & 969.2 & NDE & NDE & NDE & NDE & NDE & NDE & NDE & NDE \\
\hline U3fc & 588761.4 & 4098595.2 & 1222.2 & 815.3 & NDE & NDE & NDE & NDE & NDE & NDE & NDE & 835.2 \\
\hline U3ff & 590224.1 & 4098600.6 & 1253.9 & 970.5 & NDE & NDE & NDE & NDE & NDE & NDE & NDE & NDE \\
\hline U3fh & 588759.6 & 4099204.6 & 1230.8 & 886.4 & NDE & NDE & NDE & NDE & NDE & NDE & NDE & NDE \\
\hline U3fk & 589611.2 & 4099756.1 & 1253.0 & 841.6 & NDE & NDE & NDE & NDE & NDE & NDE & NDE & NDE \\
\hline U3fl & 588756.4 & 4100118.8 & 1240.5 & 987.6 & NDE & NDE & NDE & NDE & NDE & NDE & NDE & NDE \\
\hline U3fq & 586673.3 & 4103158.8 & 1254.6 & 843.1 & NDE & NDE & NDE & NDE & NDE & NDE & NDE & 934.5 \\
\hline U3fw & 589379.6 & 4096098.6 & 1215.2 & 962.3 & NDE & NDE & NDE & NDE & $\mathrm{NDE}$ & NDE & NDE & NDE \\
\hline U3fx & 588938.2 & 4100424.2 & 1248.8 & 995.8 & NDE & NDE & NDE & NDE & NDE & NDE & NDE & NDE \\
\hline U3gg & 584787.0 & 4102390.0 & 1243.3 & 557.5 & NDE & NDE & NDE & NDE & NDE & NDE & NDE & 802.8 \\
\hline U3gj & 590293.1 & 4096467.7 & 1234.1 & 980.2 & NDE & NDE & NDE & NDE & NDE & NDE & 996.4 & 1124.4 \\
\hline U3gk & 589468.7 & 4096860.4 & 1218.0 & 964.4 & NDE & NDE & NDE & NDE & NDE & NDE & NDE & NDE \\
\hline U3gm & 589385.8 & 4094331.2 & 1201.5 & 850.1 & NDE & NDE & NDE & NDE & NDE & NDE & NDE & 915 \\
\hline U3gr & 589681.8 & 4096496.1 & 1221.6 & 968.7 & NDE & NDE & NDE & NDE & NDE & NDE & NDE & 977.8 \\
\hline U3gs_2 & 589693.1 & 4096749.0 & 1221.9 & 932.4 & NDE & NDE & NDE & NDE & NDE & NDE & NDE & 959.8 \\
\hline U3gx & 587894.0 & 4098394.1 & 1215.2 & 808.3 & NDE & NDE & NDE & NDE & $\mathrm{NDE}$ & NDE & NDE & 819 \\
\hline U3gz & 588972.9 & 4099205.4 & 1232.9 & 810.8 & NDE & NDE & NDE & NDE & NDE & NDE & NDE & 870.2 \\
\hline U3hd_1 & 587714.3 & 4098793.8 & 1218.0 & 742.5 & NDE & NDE & NDE & NDE & NDE & NDE & NDE & NDE \\
\hline U3hg_1 & 588297.3 & 4096353.8 & 1207.3 & 759.3 & NDE & NDE & NDE & NDE & NDE & NDE & NDE & 783.6 \\
\hline U3hz & 587272.2 & 4097553.9 & 1213.1 & 816.9 & NDE & NDE & NDE & NDE & NDE & NDE & NDE & NDE \\
\hline
\end{tabular}




\begin{tabular}{|c|c|c|c|c|c|c|c|c|c|c|c|c|c|}
\hline Well_Id & TUBA & PRETBG & BRCU & BRA & TSA & UTCU & TMLVTA & TMWTA & TMUTVA & BLFA & IDP & PCUT & AA \\
\hline U3cs & $\mathrm{NP}$ & NP & $\mathrm{NP}$ & NP & NP & $\mathrm{NP}$ & 970.8 & NP & NP & $\mathrm{NP}$ & $\mathrm{NP}$ & $\mathrm{NP}$ & 1239.0 \\
\hline U3daS & NDE & NDE & NDE & NDE & NDE & NDE & 966.2 & NP & NP & NP & NP & NP & 1249.1 \\
\hline U3daS4 & NP & NP & $\mathrm{NP}$ & NP & NP & NP & 962.6 & NP & NP & NP & NP & NP & 1249.1 \\
\hline U3dh & NP & NP & NP & NP & NP & $\mathrm{NP}$ & 945.5 & 1046.1 & NP & NP & NP & NP & 1250.3 \\
\hline U3dl & NP & NP & NP & NP & NP & NP & 965.3 & NP & NP & NP & NP & NP & 1248.8 \\
\hline U3do & NP & NP & NP & NP & NP & NP & 959.5 & 1054 & NP & NP & NP & NP & 1264.3 \\
\hline U3dq & NDE & NDE & NDE & NDE & 919.3 & NP & 977.2 & NP & NP & NP & NP & NP & 1211.9 \\
\hline U3eh & NDE & NDE & NDE & NDE & NDE & NDE & 943.1 & NP & NP & NP & NP & NP & 1247.9 \\
\hline U3eh_1 & NP & NP & $\mathrm{NP}$ & NP & NP & NP & 963.8 & NP & NP & NP & NP & NP & 1246.6 \\
\hline U3ei & NP & NP & NP & NP & NP & NP & 1014.4 & 1078.4 & NP & NP & NP & NP & 1264.3 \\
\hline U3ek & NDE & NDE & NDE & NDE & NDE & NDE & 1030.2 & 1082 & NP & NP & NP & NP & 1222.2 \\
\hline U3ev_5 & $\mathrm{NP}$ & NP & $\mathrm{NP}$ & $\mathrm{NP}$ & NP & $\mathrm{NP}$ & 1132.9 & 1209.1 & NP & NP & NP & NP & 1279.2 \\
\hline U3ev3S & NDE & NDE & NDE & NDE & NDE & NDE & 1136.9 & 1194.8 & NP & NP & NP & NP & 1274.1 \\
\hline U3evS & NDE & NDE & NDE & NDE & NDE & NDE & 1135.1 & 1202.1 & NP & $\mathrm{NP}$ & $\mathrm{NP}$ & $\mathrm{NP}$ & 1276.8 \\
\hline U3ez & NDE & NDE & NDE & NDE & NDE & NDE & NDE & NDE & NDE & NDE & NDE & NDE & 1222.3 \\
\hline U3fc & NP & NP & NP & NP & NP & NP & 947.9 & 1039.4 & NP & NP & NP & NP & 1222.2 \\
\hline U3ff & NDE & NDE & NDE & NDE & NDE & NDE & 1196 & NP & NP & NP & $\mathrm{NP}$ & NP & 1253.9 \\
\hline U3fh & NDE & NDE & NDE & NDE & NDE & $\mathrm{NDE}$ & 986.9 & 1078.4 & NP & NP & NP & NP & 1230.8 \\
\hline U3fk & NDE & NDE & NDE & NDE & NDE & NDE & 970 & NP & 1064.1 & NP & $\mathrm{NP}$ & NP & 1253.0 \\
\hline U3fl & NDE & NDE & NDE & NDE & NDE & $\mathrm{NDE}$ & 1085.1 & NP & NP & $N P$ & NP & NP & 1240.5 \\
\hline U3fq & NP & NP & NP & NP & NP & NP & 986.32 & NP & 1038.2 & NP & NP & NP & 1254.6 \\
\hline U3fw & NDE & NDE & NDE & NDE & 977.5 & NP & 1020.2 & 1075 & NP & $\mathrm{NP}$ & $\mathrm{NP}$ & NP & 1215.2 \\
\hline U3fx & NDE & NDE & NDE & NDE & NDE & NDE & 1117.7 & NP & NP & NP & $\mathrm{NP}$ & NP & 1248.8 \\
\hline U3gg & NP & NP & $\mathrm{NP}$ & NP & NP & NP & 831.8 & 947.6 & 1036 & $\mathrm{NP}$ & NP & NP & 1243.3 \\
\hline U3gj & $\mathrm{NP}$ & NP & NP & NP & 1176.2 & NP & 1203.7 & NP & NP & NP & $\mathrm{NP}$ & NP & 1234.1 \\
\hline U3gk & NDE & NDE & NDE & NDE & 974.1 & $\mathrm{NP}$ & 1065.6 & NP & NP & $\mathrm{NP}$ & NP & NP & 1218.0 \\
\hline U3gm & NP & NP & NP & NP & 976 & 997.3 & 1094.8 & NP & NP & NP & NP & NP & 1201.5 \\
\hline U3gr & NP & NP & NP & NP & 1002.2 & $\mathrm{NP}$ & 1090.6 & NP & NP & $\mathrm{NP}$ & $\mathrm{NP}$ & NP & 1221.6 \\
\hline U3gs_2 & NP & NP & NP & NP & 999.4 & $N P$ & 1054.3 & 1109.2 & 1136.6 & NP & $N P$ & NP & 1221.9 \\
\hline U3gx & $\mathrm{NP}$ & NP & $\mathrm{NP}$ & NP & NP & $\mathrm{NP}$ & 867.8 & NP & NP & $\mathrm{NP}$ & $\mathrm{NP}$ & $\mathrm{NP}$ & 1215.2 \\
\hline U3gz & NP & NP & NP & NP & NP & NP & 964.7 & 1043.9 & 1089.7 & NP & NP & NP & 1232.9 \\
\hline U3hd_1 & NDE & NDE & NDE & NDE & NDE & NDE & NDE & 779.1 & NP & NP & NP & NP & 1218.0 \\
\hline U3hg_1 & NP & NP & NP & NP & 827.8 & NP & 875.1 & 933 & NP & NP & NP & NP & 1207.3 \\
\hline U3hz & NDE & $\mathrm{NDE}$ & NDE & NDE & NDE & NDE & NDE & $\mathrm{NDE}$ & $\mathrm{NDE}$ & NDE & NDE & $\mathrm{NDE}$ & 1213.1 \\
\hline
\end{tabular}




\begin{tabular}{|c|c|c|c|c|c|c|c|c|c|c|c|c|}
\hline Well_Id & EASTING & NORTHING & Gnd_Elev & TD_Elev & MGCU & LCCU & LCA & UCCU & LCA3 & ATCU & OSBCU & LTCU \\
\hline U3jh & 586841.3 & 4094444.2 & 1203.4 & 836.7 & NDE & NDE & NDE & NDE & NDE & NDE & NDE & NDE \\
\hline U3ji & 586842.2 & 4094169.9 & 1202.4 & 905.9 & NDE & NDE & NDE & NDE & NDE & NDE & NDE & NDE \\
\hline U3jk & 587114.1 & 4094413.1 & 1203.4 & 906.8 & NDE & NDE & NDE & NDE & NDE & NDE & NDE & NDE \\
\hline U3jq & 588748.7 & 4102312.8 & 1272.5 & 692.5 & NDE & NDE & NDE & NDE & NDE & NDE & 752.6 & 946.4 \\
\hline U3jq_1 & 588764.0 & 4102312.9 & 1272.5 & 594.7 & NDE & NDE & 597.4 & NP & NP & 632.4 & 752.6 & 946.4 \\
\hline U3ko & 586493.2 & 4102457.3 & 1242.7 & 815.9 & NDE & NDE & NDE & NDE & NDE & NDE & NDE & 907.4 \\
\hline U3ks & 588250.1 & 4096765.0 & 1208.8 & 716.6 & NDE & NDE & NDE & NDE & NDE & NDE & NDE & 827.8 \\
\hline U3kv & 588070.9 & 4095728.3 & 1205.8 & 718.1 & NDE & NDE & NDE & NDE & NDE & NDE & NDE & NDE \\
\hline U3kw & 587403.4 & 4094918.5 & 1204.3 & 789.8 & NDE & NDE & NDE & NDE & NDE & NDE & NDE & NDE \\
\hline U3kx & 587228.5 & 4101332.3 & 1237.5 & 795.5 & NDE & NDE & NDE & NDE & NDE & NDE & NDE & 829.1 \\
\hline U3kz & 584481.3 & 4102754.6 & 1245.1 & 559.3 & NDE & NDE & NDE & NDE & NDE & NDE & NDE & 726.9 \\
\hline U3la & 584857.3 & 4102756.2 & 1244.5 & 558.7 & NDE & NDE & NDE & NDE & NDE & NDE & NDE & 833 \\
\hline U3lh & 588082.0 & 4096993.0 & 1204.6 & 777.8 & NDE & NDE & NDE & NDE & NDE & NDE & NDE & 810 \\
\hline U3Lk & 587113.8 & 4094139.8 & 1202.1 & 805.9 & NDE & NDE & NDE & NDE & NDE & NDE & NDE & NDE \\
\hline U3lr & 584881.4 & 4101537.4 & 1238.1 & 780.9 & NDE & NDE & NDE & NDE & NDE & NDE & NDE & 785.5 \\
\hline U3lu & 588586.3 & 4094734.0 & 1202.7 & 867.8 & NDE & NDE & NDE & NDE & NDE & NDE & NDE & NDE \\
\hline U3lw & 588279.8 & 4096993.7 & 1209.1 & 782.4 & NDE & NDE & NDE & NDE & NDE & NDE & NDE & 834.2 \\
\hline U3ly & 588279.0 & 4097207.0 & 1209.8 & 767.8 & NDE & NDE & NDE & NDE & NDE & NDE & NDE & 808.9 \\
\hline U3me & 584883.3 & 4101004.2 & 1235.0 & 549.2 & NDE & NDE & NDE & NDE & NDE & NDE & NDE & 775.7 \\
\hline U3mf & 584880.3 & 4101857.7 & 1239.6 & 569.1 & NDE & NDE & NDE & NDE & NDE & NDE & NDE & 803.5 \\
\hline U3mh & 590070.9 & 4098752.1 & 1247.2 & 716.3 & NDE & NDE & 726.9 & NP & NP & 746 & 829.7 & 1098.8 \\
\hline U3mi & 589703.9 & 4095777.4 & 1221.0 & 674.1 & NDE & NDE & 678.2 & NP & NP & 719 & NP & 994.8 \\
\hline U3mk & 589600.8 & 4102651.0 & 1297.5 & 916.5 & NDE & NDE & NDE & NDE & NDE & NDE & NDE & 1015.9 \\
\hline U3ml & 590030.7 & 4097442.0 & 1234.7 & 838.5 & NDE & NDE & NDE & NDE & NDE & NDE & NDE & 992.4 \\
\hline U3ml_1 & 590023.1 & 4097441.6 & 1234.4 & 838.2 & NDE & NDE & NDE & NDE & NDE & NDE & NDE & 992.1 \\
\hline U3mr & 585119.8 & 4096456.9 & 1213.4 & 933.0 & NDE & NDE & NDE & NDE & NDE & NDE & NDE & NDE \\
\hline U3mt & 584879.0 & 4102131.9 & 1239.6 & 767.2 & NDE & NDE & NDE & NDE & NDE & NDE & NDE & 821.4 \\
\hline U3mu & 589602.2 & 4102255.5 & 1294.2 & 837.0 & NDE & NDE & NDE & NDE & NDE & NDE & 896.4 & 955.2 \\
\hline U4a & 584191.6 & 4106990.5 & 1270.7 & 310.0 & NDE & NDE & 338 & NP & NP & 361.2 & 606.2 & 840.9 \\
\hline U4ab & 580723.6 & 4105392.9 & 1290.5 & 991.8 & NDE & NDE & NDE & NDE & NDE & NDE & NDE & NDE \\
\hline U4ac & 580586.7 & 4105316.2 & 1292.7 & 1048.2 & NDE & NDE & NDE & NDE & NDE & NDE & NDE & NDE \\
\hline U4ad & 580554.3 & 4105879.8 & 1296.0 & 982.1 & NDE & NDE & NDE & NDE & 998.9 & 1004.6 & NP & NP \\
\hline U4af & 580782.8 & 4105880.6 & 1291.7 & 986.9 & NDE & NDE & NDE & NDE & 1014.7 & 1019.2 & NP & NP \\
\hline U4ah & 581625.6 & 4104512.0 & 1274.7 & 924.2 & NDE & NDE & NDE & NDE & NDE & NDE & NDE & 953 \\
\hline
\end{tabular}




\begin{tabular}{|c|c|c|c|c|c|c|c|c|c|c|c|c|c|}
\hline Well_Id & TUBA & PRETBG & BRCU & BRA & TSA & UTCU & TMLVTA & TMWTA & TMUTVA & BLFA & IDP & PCUT & AA \\
\hline U3jh & NDE & NDE & NDE & NDE & NDE & NDE & NDE & NDE & NDE & NDE & 999 & $\mathrm{NP}$ & 1203.4 \\
\hline U3ji & NDE & NDE & NDE & NDE & NDE & NDE & NDE & NDE & NDE & NDE & 1014 & NP & 1202.4 \\
\hline U3jk & NDE & NDE & NDE & NDE & NDE & NDE & NDE & NDE & NDE & NDE & 987 & NP & 1203.4 \\
\hline U3jq & NP & NP & NP & NP & NP & NP & 1023 & 1031.8 & 1072.9 & NP & NP & NP & 1272.5 \\
\hline U3jq_1 & NP & NP & NP & NP & NP & NP & 1023 & 1031.8 & 1072.9 & NP & NP & NP & 1272.5 \\
\hline U3ko & NP & NP & NP & NP & NP & NP & 1008 & NP & NP & NP & NP & NP & 1242.7 \\
\hline U3ks & NP & NP & NP & NP & 846.1 & $\mathrm{NP}$ & 899.5 & 954.3 & 977.2 & NP & NP & NP & 1208.8 \\
\hline U3kv & NDE & NDE & NDE & NDE & 730.3 & 746 & 780.6 & 849.2 & 894.9 & NP & NP & NP & 1205.8 \\
\hline U3kw & NDE & NDE & NDE & NDE & NDE & NDE & NDE & NDE & 811.1 & NP & 960 & NP & 1204.3 \\
\hline U3kx & NP & NP & NP & NP & NP & NP & 963.2 & NP & NP & NP & NP & NP & 1237.5 \\
\hline U3kz & NP & NP & NP & NP & NP & NP & 757.4 & 877.8 & 958.6 & NP & NP & NP & 1245.1 \\
\hline U3la & NP & NP & NP & NP & NP & NP & 863.5 & 985.4 & 1061.6 & NP & NP & NP & 1244.5 \\
\hline U3lh & NP & NP & NP & NP & 840.3 & $\mathrm{NP}$ & 886.1 & 937.9 & 960.1 & NP & NP & NP & 1204.6 \\
\hline U3LK & NDE & NDE & NDE & NDE & NDE & NDE & NDE & NDE & 821.4 & NP & 1010 & NP & 1202.4 \\
\hline U3Ir & NP & NP & $\mathrm{NP}$ & NP & NP & NP & 822 & 944 & 1015.6 & NP & NP & NP & 1238.1 \\
\hline U3lu & NDE & NDE & NDE & NDE & NDE & NDE & 908 & 956.8 & NP & NP & $\mathrm{NP}$ & NP & 1202.7 \\
\hline U3lw & NP & NP & NP & NP & 843.4 & 846.4 & 883 & 948.5 & 974.4 & NP & $\mathrm{NP}$ & NP & 1209.1 \\
\hline U3ly & NP & NP & NP & NP & 822.7 & 825.7 & 876 & 943.1 & 965.9 & NP & NP & NP & 1209.8 \\
\hline U3me & NP & NP & NP & NP & NP & $\mathrm{NP}$ & 806.2 & 915.9 & 992.1 & NP & $\mathrm{NP}$ & NP & 1235.0 \\
\hline U3mf & NP & NP & NP & $\mathrm{NP}$ & $\mathrm{NP}$ & $\mathrm{NP}$ & 832.4 & 948.2 & 1030.5 & $N P$ & NP & NP & 1239.6 \\
\hline U3mh & NP & NP & $\mathrm{NP}$ & NP & NP & $\mathrm{NP}$ & 1170.4 & NP & NP & NP & NP & NP & 1247.2 \\
\hline U3mi & NP & $\mathrm{NP}$ & NP & NP & 1028.7 & 1056.1 & 1112.5 & NP & NP & $\mathrm{NP}$ & $\mathrm{NP}$ & NP & 1220.4 \\
\hline U3mk & NP & NP & NP & NP & NP & NP & 1232.3 & NP & NP & NP & $\mathrm{NP}$ & NP & 1297.5 \\
\hline U3ml & $\mathrm{NP}$ & $\mathrm{NP}$ & NP & NP & $\mathrm{NP}$ & $\mathrm{NP}$ & 1022.9 & 1086.9 & 1126.5 & $\mathrm{NP}$ & NP & NP & 1234.7 \\
\hline U3ml_1 & NP & NP & NP & NP & NP & NP & 1022.6 & 1086.6 & 1126.5 & NP & $\mathrm{NP}$ & NP & 1234.4 \\
\hline U3mr & NDE & NDE & NDE & NDE & NDE & NDE & 969.9 & 1017.1 & NP & $\mathrm{NP}$ & NP & NP & 1213.4 \\
\hline U3mt & NP & NP & NP & NP & NP & NP & 851 & 962.9 & 1046.1 & NP & $\mathrm{NP}$ & NP & 1239.6 \\
\hline U3mu & NP & NP & NP & NP & $\mathrm{NP}$ & $\mathrm{NP}$ & 1185.4 & NP & NP & $\mathrm{NP}$ & $\mathrm{NP}$ & NP & 1294.2 \\
\hline U4a & NP & NP & NP & NP & NP & NP & 892.8 & 999.4 & 1033 & NP & NP & NP & 1270.7 \\
\hline U4ab & NDE & NDE & NDE & $\mathrm{NDE}$ & NDE & NDE & 1005.5 & $\mathrm{NP}$ & NP & $\mathrm{NP}$ & $\mathrm{NP}$ & NP & 1290.5 \\
\hline U4ac & NDE & NDE & NDE & NDE & NDE & NDE & 1141.8 & NP & NP & NP & NP & NP & 1292.7 \\
\hline U4ad & NP & NP & $\mathrm{NP}$ & NP & NP & NP & 1047.9 & NP & NP & NP & NP & NP & 1296.0 \\
\hline U4af & NP & NP & NP & NP & $N P$ & NP & 1076.9 & NP & NP & NP & $N P$ & $N P$ & 1291.7 \\
\hline U4ah & NP & NP & $\mathrm{NP}$ & NP & NP & $\mathrm{NP}$ & 1076.7 & $\mathrm{NP}$ & NP & $\mathrm{NP}$ & $\mathrm{NP}$ & $\mathrm{NP}$ & 1274.7 \\
\hline
\end{tabular}




\begin{tabular}{|c|c|c|c|c|c|c|c|c|c|c|c|c|}
\hline Well_Id & EASTING & NORTHING & Gnd_Elev & TD_Elev & MGCU & LCCU & LCA & UCCU & LCA3 & ATCU & OSBCU & LTCU \\
\hline U4ai & 582669.8 & 4104386.5 & 1262.5 & 773.3 & NDE & $\mathrm{NDE}$ & NDE & NDE & $\mathrm{NDE}$ & NDE & NDE & NDE \\
\hline U4aj & 582197.9 & 4106418.6 & 1280.2 & 792.5 & NDE & NDE & NDE & NDE & NDE & NDE & NDE & NDE \\
\hline U4ak & 582802.2 & 4103541.3 & 1259.1 & 762.3 & NDE & NDE & NDE & NDE & NDE & NDE & NDE & NDE \\
\hline U4am & 581416.3 & 4104858.4 & 1276.8 & 941.5 & NDE & NDE & NDE & NDE & NDE & NDE & NDE & NDE \\
\hline U4an & 582279.4 & 4106647.7 & 1281.4 & 793.7 & NDE & NDE & NDE & NDE & NDE & NDE & NDE & 887.9 \\
\hline U4ap & 581076.1 & 4107222.5 & 1294.8 & 952.8 & NDE & NDE & 973.8 & NP & NP & NP & NP & NP \\
\hline U4ar & 582552.3 & 4104689.0 & 1264.6 & 761.7 & NDE & NDE & NDE & NDE & NDE & NDE & NDE & NDE \\
\hline U4as & 578066.1 & 4107227.1 & 1367.9 & 926.0 & NDE & NDE & NDE & NDE & NDE & NDE & NDE & NDE \\
\hline U4at & 578112.7 & 4106968.3 & 1365.2 & 901.6 & NDE & NDE & NDE & NDE & NDE & NDE & NDE & NDE \\
\hline U4au & 582789.3 & 4104607.5 & 1263.4 & 730.0 & NDE & NDE & NDE & NDE & NDE & NDE & NDE & NDE \\
\hline U4av & 582680.7 & 4105777.6 & 1273.1 & 755.0 & NDE & NDE & NDE & NDE & NDE & NDE & NDE & 862.9 \\
\hline U4b & 584360.3 & 4105698.8 & 1263.4 & 763.5 & NDE & NDE & NDE & NDE & NDE & NDE & NDE & NDE \\
\hline U4c & 584134.2 & 4106044.8 & 1267.4 & 581.6 & NDE & NDE & NDE & NDE & NDE & NDE & NDE & 822.4 \\
\hline U4d & 584162.6 & 4106654.3 & 1270.1 & 583.7 & NDE & NDE & NDE & NDE & NDE & NDE & NDE & NDE \\
\hline U4d_1 & 584174.1 & 4106663.8 & 1270.1 & 497.1 & NDE & NDE & NDE & NDE & NDE & NDE & 575.2 & 829.7 \\
\hline $\mathrm{U} 4 \mathrm{e}^{-}$ & 583857.1 & 4106866.9 & 1271.9 & 249.9 & NDE & NDE & 276.7 & NP & NP & 310.9 & 541.4 & 723.3 \\
\hline U4e_1 & 583720.0 & 4106866.1 & 1273.5 & 285.9 & NDE & NDE & 288.9 & NP & NP & 308.8 & 496.3 & 729.4 \\
\hline U4f & 584199.5 & 4104826.1 & 1258.5 & 545.3 & NDE & NDE & NDE & NDE & NDE & NDE & NDE & 795.2 \\
\hline U4g & 584315.6 & 4106380.6 & 1265.5 & 521.8 & NDE & NDE & NDE & NDE & NDE & NDE & 534 & 793.1 \\
\hline U4h & 584008.0 & 4107293.7 & 1272.5 & 541.0 & NDE & NDE & NDE & NDE & NDE & NDE & 573 & 818.4 \\
\hline U4i & 583012.9 & 4104285.0 & 1260.7 & 590.1 & NDE & NDE & NDE & NDE & NDE & NDE & NDE & 763.2 \\
\hline U4j & 584319.7 & 4105223.0 & 1260.0 & 574.2 & NDE & NDE & NDE & NDE & NDE & NDE & NDE & 850.1 \\
\hline U4I & 583986.5 & 4106455.6 & 1267.7 & 557.2 & NDE & NDE & NDE & NDE & NDE & NDE & NDE & 786.1 \\
\hline U4m & 584165.1 & 4104805.8 & 1258.5 & 759.0 & NDE & NDE & NDE & NDE & NDE & NDE & NDE & NDE \\
\hline U4n & 584185.3 & 4104863.2 & 1258.8 & 588.3 & NDE & NDE & NDE & NDE & NDE & NDE & NDE & NDE \\
\hline U4o & 584466.8 & 4106807.4 & 1267.7 & 688.5 & NDE & NDE & NDE & NDE & NDE & NDE & NDE & 920.2 \\
\hline U4p & 584501.4 & 4107089.7 & 1269.8 & 705.9 & NDE & NDE & NDE & NDE & NDE & NDE & NDE & 925.4 \\
\hline$U 4 q$ & 584589.6 & 4106533.9 & 1263.7 & 626.7 & NDE & NDE & NDE & NDE & NDE & NDE & NDE & 920.8 \\
\hline$U 4 r$ & 584186.7 & 4104543.2 & 1255.5 & 569.7 & NDE & NDE & NDE & NDE & NDE & NDE & NDE & 741.9 \\
\hline U4s & 583979.3 & 4104612.0 & 1257.3 & 647.7 & NDE & NDE & NDE & NDE & NDE & NDE & NDE & 662.9 \\
\hline $\mathrm{U} 4 \mathrm{t}$ & 584590.7 & 4106233.8 & 1263.1 & 647.4 & NDE & NDE & NDE & NDE & NDE & NDE & NDE & 944.9 \\
\hline U4t_1 & 584578.5 & 4106233.7 & 1263.1 & 623.0 & NDE & NDE & NDE & NDE & NDE & NDE & NDE & 943.1 \\
\hline U4u & 584497.3 & 4104964.6 & 1255.8 & 585.2 & NDE & NDE & NDE & NDE & NDE & NDE & NDE & 862.6 \\
\hline U4u_1 & 584488.8 & 4104969.4 & 1255.5 & 753.8 & NDE & NDE & NDE & NDE & NDE & NDE & NDE & 859.3 \\
\hline
\end{tabular}




\begin{tabular}{|c|c|c|c|c|c|c|c|c|c|c|c|c|c|}
\hline Well_Id & TUBA & PRETBG & BRCU & BRA & TSA & UTCU & TMLVTA & TMWTA & TMUTVA & BLFA & IDP & PCUT & AA \\
\hline U4ai & NDE & NDE & NDE & NDE & NDE & NDE & NDE & NDE & 806.5 & $\mathrm{NP}$ & $\mathrm{NP}$ & $\mathrm{NP}$ & 1262.5 \\
\hline U4aj & NDE & NDE & NDE & NDE & NDE & NDE & 983.3 & NP & $N P$ & NP & NP & NP & 1280.2 \\
\hline U4ak & NDE & NDE & NDE & NDE & NDE & NDE & 782.1 & NP & NP & NP & NP & NP & 1259.1 \\
\hline U4am & NDE & NDE & NDE & NDE & NDE & NDE & 1043.9 & NP & NP & NP & NP & NP & 1276.8 \\
\hline U4an & NP & NP & $\mathrm{NP}$ & NP & NP & NP & 943 & 998.5 & 1016.5 & NP & NP & NP & 1281.4 \\
\hline U4ap & NP & NP & NP & NP & NP & NP & 1082.6 & NP & NP & NP & NP & NP & 1294.8 \\
\hline U4ar & NDE & NDE & NDE & NDE & NDE & NDE & NDE & NDE & 794.6 & NP & NP & NP & 1264.6 \\
\hline U4as & NDE & NDE & NDE & NDE & NDE & NDE & 1158.5 & 1230.8 & 1246 & NP & NP & NP & 1367.9 \\
\hline U4at & NDE & NDE & NDE & NDE & NDE & NDE & 1166.8 & 1241.1 & 1260 & NP & NP & NP & 1365.2 \\
\hline U4au & NDE & NDE & NDE & NDE & NDE & NDE & 764.6 & 806.4 & 886.4 & NP & NP & NP & 1263.4 \\
\hline U4av & NP & NP & $\mathrm{NP}$ & NP & NP & NP & 907.4 & 980.2 & 1005.2 & NP & NP & NP & 1273.1 \\
\hline U4b & NDE & NDE & NDE & NDE & NDE & NDE & 960 & 1030 & 1111 & NP & NP & NP & 1263.4 \\
\hline $\mathrm{U} 4 \mathrm{c}$ & NP & NP & $\mathrm{NP}$ & NP & NP & NP & 894 & 977.8 & 1029.6 & NP & $\mathrm{NP}$ & NP & 1267.4 \\
\hline U4d & NDE & NDE & NDE & NDE & NDE & NDE & 886.4 & 1006.8 & 1040.3 & $N P$ & $N P$ & NP & 1270.1 \\
\hline U4d_1 & NP & NP & $\mathrm{NP}$ & NP & NP & NP & 886.1 & 1006.4 & 1040 & NP & NP & NP & 1270.1 \\
\hline U4e & NP & NP & NP & NP & $\mathrm{NP}$ & $\mathrm{NP}$ & 793.4 & 906.2 & 961 & NP & $\mathrm{NP}$ & NP & 1271.9 \\
\hline U4e_1 & NP & NP & NP & NP & NP & NP & 754.1 & 878.7 & 926 & NP & NP & NP & 1273.5 \\
\hline U4f & NP & NP & NP & NP & NP & $N P$ & 802.8 & 914.1 & 964.4 & NP & $N P$ & NP & 1258.5 \\
\hline U4g & NP & NP & NP & NP & NP & NP & 912 & 1036.9 & 1075 & NP & $\mathrm{NP}$ & NP & 1265.5 \\
\hline $\mathrm{U} 4 \mathrm{~h}$ & NP & NP & NP & $\mathrm{NP}$ & $\mathrm{NP}$ & $\mathrm{NP}$ & 848.9 & 952.5 & 990.6 & $N P$ & NP & NP & 1272.5 \\
\hline U4i & NP & NP & NP & NP & NP & NP & 793.7 & 848.6 & 891.2 & NP & NP & NP & 1260.7 \\
\hline U4j & NP & $\mathrm{NP}$ & $\mathrm{NP}$ & NP & $\mathrm{NP}$ & $\mathrm{NP}$ & 872.9 & 976.6 & 1027.8 & $\mathrm{NP}$ & $\mathrm{NP}$ & NP & 1260.0 \\
\hline U4I & NP & NP & NP & NP & NP & $\mathrm{NP}$ & 850.1 & 953.7 & 993.3 & NP & NP & NP & 1267.7 \\
\hline $\mathrm{U} 4 \mathrm{~m}$ & NDE & NDE & NDE & NDE & NDE & NDE & 799.8 & 917.1 & 962.9 & $\mathrm{NP}$ & NP & NP & 1258.5 \\
\hline $\mathrm{U} 4 \mathrm{n}$ & NDE & NDE & NDE & NDE & NDE & NDE & 801.6 & 917.4 & 963.2 & NP & $\mathrm{NP}$ & NP & 1258.8 \\
\hline U4o & NP & NP & $\mathrm{NP}$ & NP & NP & NP & 935.4 & 1069.5 & 1097 & $\mathrm{NP}$ & NP & NP & 1267.7 \\
\hline U4p & NP & NP & NP & NP & NP & NP & 955.9 & 1058 & 1077.8 & NP & $\mathrm{NP}$ & NP & 1269.8 \\
\hline $\mathrm{U} 4 \mathrm{q}$ & NP & NP & NP & NP & $\mathrm{NP}$ & $\mathrm{NP}$ & 966.5 & 1096.1 & 1129.6 & $\mathrm{NP}$ & $\mathrm{NP}$ & NP & 1263.7 \\
\hline $\mathrm{U} 4 \mathrm{r}$ & NP & NP & NP & NP & NP & NP & 758.6 & 882.1 & 944.6 & NP & NP & NP & 1255.5 \\
\hline U4s & NP & NP & $\mathrm{NP}$ & NP & $\mathrm{NP}$ & $\mathrm{NP}$ & 682.8 & 807.7 & 890 & $\mathrm{NP}$ & $\mathrm{NP}$ & NP & 1257.3 \\
\hline U4t & NP & NP & NP & NP & NP & NP & 975.4 & 1098.8 & 1136.9 & NP & NP & NP & 1263.1 \\
\hline U4t_1 & NP & NP & NP & NP & NP & NP & 973.5 & 1093.9 & 1133.6 & NP & NP & NP & 1263.1 \\
\hline $\mathrm{U} 4 \mathrm{u}$ & NP & NP & NP & NP & NP & NP & 893.1 & 1007.4 & 1054.6 & NP & NP & NP & 1255.8 \\
\hline U4u_1 & $\mathrm{NP}$ & NP & $\mathrm{NP}$ & $\mathrm{NP}$ & $\mathrm{NP}$ & $\mathrm{NP}$ & 890 & 1004.3 & 1050 & $N P$ & $\mathrm{NP}$ & NP & 1255.5 \\
\hline
\end{tabular}




\begin{tabular}{|c|c|c|c|c|c|c|c|c|c|c|c|c|}
\hline Well_Id & EASTING & NORTHING & Gnd_Elev & TD_Elev & MGCU & LCCU & LCA & UCCU & LCA3 & ATCU & OSBCU & LTCU \\
\hline U6a & 584046.3 & 4091762.8 & 1197.9 & 1066.8 & NDE & NDE & NDE & NDE & NDE & NDE & NDE & NDE \\
\hline U6c & 585152.9 & 4093615.5 & 1201.2 & 858.6 & NDE & NDE & NDE & NDE & NDE & NDE & NDE & NDE \\
\hline U6d & 588591.5 & 4093261.8 & 1198.5 & 802.2 & NDE & NDE & NDE & NDE & NDE & NDE & NDE & NDE \\
\hline U6e & 588587.7 & 4094337.5 & 1201.5 & 744.3 & NDE & NDE & NDE & NDE & NDE & NDE & NDE & 787.9 \\
\hline U6f & 588438.5 & 4093535.9 & 1199.4 & 803.1 & NDE & NDE & NDE & NDE & NDE & NDE & NDE & $\mathrm{NDE}$ \\
\hline U6g & 587387.5 & 4094141.3 & 1202.4 & 882.4 & NDE & NDE & NDE & NDE & NDE & NDE & NDE & NDE \\
\hline U6h & 587388.8 & 4093867.1 & 1201.8 & 881.8 & NDE & NDE & NDE & NDE & NDE & NDE & NDE & NDE \\
\hline U7a & 585989.4 & 4107000.2 & 1296.9 & 474.3 & NDE & NDE & 481.3 & NP & NP & 496.5 & NP & 946.4 \\
\hline U7aa & 589600.0 & 4102864.3 & 1300.6 & 713.8 & NDE & NDE & 854 & $\mathrm{NP}$ & NP & $\mathrm{NP}$ & 910.4 & 1078.1 \\
\hline U7ab & 588743.0 & 4103928.1 & 1295.7 & 776.6 & NDE & NDE & NDE & NDE & NDE & NDE & 798.9 & 1042.7 \\
\hline U7ac & 586063.2 & 4103430.9 & 1250.3 & 575.8 & NDE & NDE & NDE & NDE & NDE & NDE & 578.2 & 880 \\
\hline U7ad & 586483.2 & 4106603.9 & 1306.1 & 707.1 & NDE & NDE & NDE & NDE & NDE & NDE & 751.3 & 949.5 \\
\hline U7ad_1 & 586470.5 & 4106595.7 & 1306.4 & 648.0 & NDE & NDE & NDE & NDE & NDE & NDE & 751.3 & 949.8 \\
\hline U7ae & 588267.9 & 4104733.7 & 1300.3 & 430.7 & NDE & NDE & 480.4 & NP & NP & NP & 745.5 & 1016.8 \\
\hline U7af & 586452.7 & 4105321.5 & 1282.3 & 676.4 & NDE & NDE & NDE & NDE & NDE & NDE & 747.4 & 956.2 \\
\hline U7ag & 586293.8 & 4107185.6 & 1306.4 & 704.4 & NDE & NDE & NDE & NDE & NDE & NDE & 750.1 & 1013.8 \\
\hline U7ah & 585660.0 & 4105623.5 & 1274.1 & 295.7 & NDE & NDE & 411.5 & NP & NP & 512.1 & 600.5 & 853.4 \\
\hline U7ai & 586217.5 & 4102791.8 & 1244.8 & 580.3 & NDE & NDE & NDE & NDE & NDE & NDE & NDE & 796.7 \\
\hline U7ajs & 585622.1 & 4106251.4 & 1281.7 & 583.7 & NDE & NDE & NDE & NDE & NDE & NDE & 655.3 & 877.8 \\
\hline U7ak & 585529.5 & 4106927.3 & 1285.0 & 599.2 & NDE & NDE & NDE & NDE & NDE & NDE & NDE & 840 \\
\hline U7al & 587130.2 & 4103312.7 & 1261.6 & 801.3 & NDE & NDE & NDE & NDE & NDE & NDE & 844 & 941.5 \\
\hline U7am & 586391.0 & 26.1 & 1286.0 & 661.1 & NDE & NDE & NDE & NDE & NDE & NDE & 697.7 & 959.8 \\
\hline U7an & 584996.6 & 4103457.6 & 1249.7 & 286.2 & NDE & NDE & NDE & NDE & NDE & NDE & 553.8 & 920.5 \\
\hline U7ao & 587154.5 & 4104958.3 & 1286.3 & 826.0 & NDE & NDE & NDE & NDE & NDE & NDE & 844.3 & 926.6 \\
\hline U7ap & 584882.5 & 4105559.8 & 1264.3 & 639.5 & NDE & NDE & NDE & NDE & NDE & NDE & 682.1 & 999.1 \\
\hline U7aq & 584449.6 & 4103090.0 & 1247.9 & 144.5 & NDE & NDE & 162.8 & NP & NP & NP & 394.4 & 687 \\
\hline U7at & 587513.1 & 4107062.2 & 1336.2 & 876.0 & NDE & NDE & 909.2 & NP & NP & NP & 970.5 & 1153.4 \\
\hline U7au & 584324.5 & 4103942.8 & 1253.0 & 509.3 & NDE & NDE & NDE & NDE & NDE & NDE & NDE & 760.8 \\
\hline U7av & 584995.6 & 4103823.6 & 1252.4 & 661.7 & NDE & NDE & NDE & NDE & NDE & NDE & NDE & 943.1 \\
\hline U7aw & 585537.2 & 4105956.7 & 1276.8 & 586.7 & NDE & NDE & NDE & NDE & NDE & NDE & NDE & 874.5 \\
\hline U7ax & 587818.7 & 4106819.5 & 1337.8 & 956.8 & NDE & NDE & NDE & NDE & NDE & NDE & 1010.1 & NP \\
\hline U7ay & 587120.4 & 4106085.7 & 1309.4 & 821.7 & NDE & NDE & NDE & NDE & NDE & NDE & 858.3 & 1060 \\
\hline U7b & 588134.1 & 4103773.3 & 1281.1 & 810.2 & NDE & NDE & NDE & NDE & NDE & NDE & NDE & 915.3 \\
\hline U7ba & 584900.6 & 4104756.9 & 1258.5 & 648.9 & NDE & NDE & NDE & NDE & NDE & NDE & 660.5 & 984.8 \\
\hline
\end{tabular}




\begin{tabular}{|c|c|c|c|c|c|c|c|c|c|c|c|c|c|}
\hline Well_Id & TUBA & PRETBG & BRCU & BRA & TSA & UTCU & TMLVTA & TMWTA & TMUTVA & BLFA & IDP & PCUT & AA \\
\hline U6a & NDE & NDE & NDE & NDE & NDE & NDE & NDE & NDE & NDE & NDE & NDE & 1183 & 1197.9 \\
\hline U6c & NDE & NDE & NDE & NDE & NDE & NDE & NDE & NDE & NDE & NDE & NDE & 1009 & 1199.4 \\
\hline U6d & NDE & NDE & NDE & NDE & 854.4 & 866.5 & 918.4 & 988.5 & $\mathrm{NP}$ & NP & NP & NP & 1198.5 \\
\hline U6e & NP & NP & NP & NP & 830.6 & 835.2 & 880.9 & 951 & 987.6 & NP & NP & NP & 1201.5 \\
\hline U6f & NDE & NDE & NDE & NDE & NDE & NDE & 851.9 & 955.5 & 967.7 & NP & $\mathrm{NP}$ & NP & 1199.4 \\
\hline U6g & NDE & NDE & NDE & NDE & NDE & NDE & NDE & NDE & NDE & NDE & 1007 & NP & 1200.6 \\
\hline U6h & NDE & NDE & NDE & NDE & NDE & NDE & NDE & NDE & NDE & NDE & 1012 & NP & 1200.9 \\
\hline U7a & $N P$ & NP & NP & $N P$ & NP & NP & 1020 & NP & NP & NP & $N P$ & NP & 1296.9 \\
\hline U7aa & NP & NP & $\mathrm{NP}$ & NP & NP & NP & 1254.9 & NP & NP & NP & $\mathrm{NP}$ & NP & 1300.6 \\
\hline U7ab & NP & NP & $\mathrm{NP}$ & NP & NP & NP & 1122 & 1201.2 & NP & NP & NP & NP & 1295.7 \\
\hline U7ac & NP & $\mathrm{NP}$ & $\mathrm{NP}$ & $\mathrm{NP}$ & NP & $\mathrm{NP}$ & 994.3 & 1078.1 & NP & NP & $\mathrm{NP}$ & NP & 1250.3 \\
\hline U7ad & $\mathrm{NP}$ & NP & $\mathrm{NP}$ & NP & NP & $\mathrm{NP}$ & 1071.4 & 1130.8 & $\mathrm{NP}$ & $\mathrm{NP}$ & $\mathrm{NP}$ & $\mathrm{NP}$ & 1306.1 \\
\hline U7ad_1 & NP & NP & $\mathrm{NP}$ & $\mathrm{NP}$ & NP & $\mathrm{NP}$ & 1071.7 & 1131.1 & NP & NP & $\mathrm{NP}$ & NP & 1306.4 \\
\hline U7ae & NP & $\mathrm{NP}$ & $\mathrm{NP}$ & $\mathrm{NP}$ & NP & $\mathrm{NP}$ & 1047.3 & 1143.3 & 1163.1 & NP & NP & NP & 1300.3 \\
\hline U7af & NP & NP & $\mathrm{NP}$ & NP & NP & NP & 992.7 & 1053.7 & 1087.2 & NP & $\mathrm{NP}$ & NP & 1282.3 \\
\hline U7ag & $\mathrm{NP}$ & $\mathrm{NP}$ & $\mathrm{NP}$ & $\mathrm{NP}$ & NP & $\mathrm{NP}$ & 1077.8 & 1138.7 & NP & NP & NP & NP & 1306.4 \\
\hline U7ah & NP & NP & $\mathrm{NP}$ & NP & NP & NP & 883 & 970.8 & 1010.4 & NP & NP & NP & 1274.1 \\
\hline U7ai & NP & NP & NP & NP & NP & NP & 982 & NP & $\mathrm{NP}$ & NP & NP & NP & 1244.8 \\
\hline U7ajs & NP & NP & $\mathrm{NP}$ & $\mathrm{NP}$ & NP & NP & 900.7 & 1013.5 & NP & NP & NP & NP & 1281.7 \\
\hline U7ak & $\mathrm{NP}$ & NP & $\mathrm{NP}$ & NP & NP & $\mathrm{NP}$ & NP & 974.1 & 995.5 & $\mathrm{NP}$ & $\mathrm{NP}$ & $\mathrm{NP}$ & 1285.0 \\
\hline U7al & NP & NP & $\mathrm{NP}$ & NP & NP & NP & 999.4 & 1063.4 & 1081.7 & NP & NP & NP & 1261.6 \\
\hline U7am & $\mathrm{NP}$ & NP & $\mathrm{NP}$ & $\mathrm{NP}$ & NP & $\mathrm{NP}$ & 990.3 & 1078.7 & $\mathrm{NP}$ & NP & $\mathrm{NP}$ & $\mathrm{NP}$ & 1286.0 \\
\hline U7an & NP & NP & $\mathrm{NP}$ & NP & NP & NP & 954 & 1079 & 1146 & NP & NP & NP & 1249.7 \\
\hline U7ao & $\mathrm{NP}$ & $\mathrm{NP}$ & $\mathrm{NP}$ & $\mathrm{NP}$ & NP & $\mathrm{NP}$ & 1059.2 & 1059.2 & 1102.8 & NP & $\mathrm{NP}$ & NP & 1286.3 \\
\hline U7ap & NP & NP & $\mathrm{NP}$ & NP & NP & NP & 1029.6 & 1150 & 1191.8 & NP & NP & NP & 1264.3 \\
\hline U7aq & NP & NP & $\mathrm{NP}$ & NP & NP & NP & 760.2 & 876 & 956.8 & NP & $\mathrm{NP}$ & NP & 1247.9 \\
\hline U7at & NP & NP & $\mathrm{NP}$ & NP & NP & NP & 1253.9 & NP & NP & NP & NP & NP & 1336.2 \\
\hline U7au & $\mathrm{NP}$ & NP & $\mathrm{NP}$ & NP & NP & $\mathrm{NP}$ & $\mathrm{NP}$ & 862.9 & 951.3 & NP & $\mathrm{NP}$ & NP & 1253.0 \\
\hline U7av & $\mathrm{NP}$ & NP & $\mathrm{NP}$ & $\mathrm{NP}$ & NP & NP & 973.5 & 1106.1 & 1162.5 & NP & NP & NP & 1252.4 \\
\hline U7aw & $\mathrm{NP}$ & NP & $\mathrm{NP}$ & $\mathrm{NP}$ & NP & $\mathrm{NP}$ & 895.8 & 975.1 & 1014.7 & NP & $\mathrm{NP}$ & $\mathrm{NP}$ & 1276.8 \\
\hline U7ax & NP & NP & NP & NP & NP & NP & 1275.3 & NP & NP & NP & NP & NP & 1337.8 \\
\hline U7ay & $\mathrm{NP}$ & NP & $\mathrm{NP}$ & NP & NP & NP & 1105.2 & 1163.1 & 1181.4 & NP & $\mathrm{NP}$ & NP & 1309.4 \\
\hline U7b & NP & NP & $\mathrm{NP}$ & NP & NP & NP & 976.3 & 1067.7 & 1107.3 & NP & $\mathrm{NP}$ & NP & 1281.1 \\
\hline U7ba & $\mathrm{NP}$ & NP & NP & $\mathrm{NP}$ & $\mathrm{NP}$ & $\mathrm{NP}$ & 1015.3 & 1129 & 1167.1 & $\mathrm{NP}$ & $\mathrm{NP}$ & $\mathrm{NP}$ & 1258.5 \\
\hline
\end{tabular}




\begin{tabular}{|c|c|c|c|c|c|c|c|c|c|c|c|c|}
\hline Well_Id & EASTING & NORTHING & Gnd_Elev & TD_Elev & MGCU & LCCU & LCA & UCCU & LCA3 & ATCU & OSBCU & LTCU \\
\hline U7bc & 588432.0 & 4103893.8 & 1289.0 & 603.2 & NDE & NDE & NDE & NDE & NDE & NDE & 798.3 & 1031.4 \\
\hline U7bd & 588106.2 & 4104182.8 & 1287.5 & 677.9 & NDE & NDE & NDE & NDE & NDE & NDE & 799.8 & 953.7 \\
\hline U7be & 586148.4 & 4106326.1 & 1292.7 & 683.1 & NDE & NDE & NDE & NDE & NDE & NDE & 748.6 & 966.5 \\
\hline U7bf & 586113.2 & 4106630.4 & 1296.3 & 848.6 & NDE & NDE & NDE & NDE & NDE & NDE & NDE & 924.5 \\
\hline U7bg & 588499.6 & 4106431.8 & 1337.5 & 941.2 & NDE & NDE & NDE & NDE & NDE & NDE & 1001.3 & 1169.8 \\
\hline U7bh & 588352.9 & 4106547.1 & 1338.7 & 942.4 & NDE & NDE & NDE & NDE & NDE & NDE & 986.6 & 1181.7 \\
\hline U7bi & 588930.9 & 4105098.7 & 1318.0 & 860.8 & NDE & NDE & NDE & NDE & NDE & NDE & 911 & 1069.8 \\
\hline U7bk & 587666.5 & 4106940.6 & 1338.4 & 957.1 & NDE & NDE & 960.1 & NP & NP & 968.4 & 998.5 & 1135.4 \\
\hline U7bl & 587486.3 & 4106026.0 & 1315.8 & 764.1 & NDE & NDE & NDE & NDE & NDE & NDE & 779.4 & 1053.7 \\
\hline U7bm & 588957.9 & 4103410.3 & 1291.7 & 819.3 & NDE & NDE & NDE & NDE & NDE & NDE & NDE & 1047.9 \\
\hline U7bo & 586866.8 & 4106899.7 & 1319.2 & 709.6 & NDE & NDE & NDE & NDE & NDE & NDE & 819.3 & 1057 \\
\hline U7bp & 588299.3 & 4104471.7 & 1294.8 & 609.0 & NDE & NDE & NDE & NDE & NDE & NDE & 683.7 & 1032.7 \\
\hline U7br & 584883.7 & 4105224.3 & 1261.0 & 651.4 & NDE & NDE & NDE & NDE & NDE & NDE & 678.8 & 994.3 \\
\hline U7bs & 585994.6 & 4105624.7 & 1277.7 & 600.8 & NDE & NDE & NDE & NDE & NDE & NDE & NDE & 851 \\
\hline U7bs_1 & 585979.6 & 4105624.0 & 1277.7 & 571.5 & NDE & NDE & NDE & NDE & NDE & NDE & NDE & 847.3 \\
\hline U7bu & 584809.2 & 4103174.8 & 1246.0 & 636.4 & NDE & NDE & NDE & NDE & NDE & NDE & NDE & 836.1 \\
\hline U7bv & 588717.6 & 4105097.9 & 1310.6 & 914.4 & NDE & NDE & NDE & NDE & NDE & NDE & NDE & 1106.4 \\
\hline U7bw & 588486.1 & 4103332.7 & 1282.0 & 672.4 & NDE & NDE & NDE & NDE & NDE & NDE & 776 & 900.7 \\
\hline U7by & 586783.4 & 4106602.6 & 1310.6 & 762.0 & NDE & NDE & NDE & NDE & NDE & NDE & 853.4 & 1053.1 \\
\hline U7bz & 586041.4 & 4105290.2 & 1272.8 & 575.5 & NDE & NDE & 614.2 & NP & NP & 631.2 & 673.9 & 877.8 \\
\hline U7c & 587220.0 & 4103770.4 & 1269.5 & 878.1 & NDE & NDE & NDE & NDE & NDE & NDE & NDE & 934.2 \\
\hline U7ca & 588835.4 & 4103653.9 & 1293.6 & 744.9 & NDE & NDE & NDE & NDE & NDE & NDE & 813.5 & 1065 \\
\hline U7cb & 588718.6 & 4104823.3 & 1306.7 & 742.8 & NDE & NDE & NDE & NDE & NDE & NDE & 819 & 1065.9 \\
\hline U7cc & 586784.0 & 4106359.1 & 1306.4 & 818.7 & NDE & NDE & NDE & NDE & NDE & NDE & 843.1 & 1061 \\
\hline U7cd & 584903.0 & 4104066.7 & 1254.3 & 759.0 & NDE & NDE & NDE & NDE & NDE & NDE & NDE & 937.3 \\
\hline U7cd_1 & 584912.4 & 4104067.4 & 1253.9 & 735.8 & NDE & NDE & NDE & NDE & NDE & NDE & NDE & 940.3 \\
\hline U7e & 585905.9 & 4104740.6 & 1263.7 & 676.4 & NDE & NDE & NDE & NDE & NDE & NDE & NDE & 821.7 \\
\hline U7f & 585932.4 & 4105959.3 & 1284.1 & 708.1 & NDE & NDE & NDE & NDE & NDE & NDE & NDE & 872.6 \\
\hline U7g & 587402.8 & 4103770.5 & 1271.6 & 800.7 & NDE & NDE & NDE & NDE & NDE & NDE & NDE & 921.1 \\
\hline U7h & 586153.4 & 4103766.4 & 1255.2 & 785.5 & NDE & NDE & NDE & NDE & $\mathrm{NDE}$ & NDE & NDE & 916.8 \\
\hline U7i & 587212.2 & 4105292.2 & 1294.2 & 715.1 & NDE & NDE & NDE & NDE & NDE & NDE & NDE & 1012.2 \\
\hline U7j & 587088.1 & 4106511.9 & 1318.6 & 741.0 & NDE & NDE & NDE & NDE & NDE & NDE & NDE & 1044.2 \\
\hline U7k & 585761.0 & 4102698.5 & 1240.5 & 661.4 & NDE & NDE & NDE & NDE & NDE & NDE & NDE & NDE \\
\hline $\mathrm{U} 7 \mathrm{~m}$ & 589307.3 & 4103777.5 & 1304.5 & 786.4 & NDE & NDE & NDE & NDE & NDE & NDE & NDE & 1036.3 \\
\hline
\end{tabular}




\begin{tabular}{|c|c|c|c|c|c|c|c|c|c|c|c|c|c|}
\hline Well_Id & TUBA & PRETBG & BRCU & BRA & TSA & UTCU & TMLVTA & TMWTA & TMUTVA & BLFA & IDP & PCUT & AA \\
\hline $\mathrm{U} 7 \mathrm{bc}$ & $\mathrm{NP}$ & NP & $\mathrm{NP}$ & NP & NP & $\mathrm{NP}$ & 1105.5 & 1162.5 & NP & $\mathrm{NP}$ & $\mathrm{NP}$ & $\mathrm{NP}$ & 1289.0 \\
\hline U7bd & NP & NP & NP & NP & NP & NP & 985 & 998 & 1075.6 & NP & NP & NP & 1287.5 \\
\hline U7be & NP & NP & NP & NP & NP & NP & 1000 & 1064.1 & NP & NP & NP & NP & 1292.7 \\
\hline U7bf & NP & NP & NP & NP & NP & NP & 991.5 & 1067.7 & 1092.1 & NP & NP & NP & 1296.3 \\
\hline U7bg & NP & NP & NP & NP & NP & $\mathrm{NP}$ & 1288.7 & NP & NP & NP & NP & NP & 1337.5 \\
\hline U7bh & NP & NP & NP & NP & NP & NP & 1242.8 & 1262.5 & 1283.4 & NP & NP & NP & 1338.7 \\
\hline U7bi & NP & NP & NP & NP & NP & NP & 1188.4 & 1248.2 & 1255.8 & NP & NP & NP & 1318.0 \\
\hline U7bk & NP & NP & NP & NP & NP & NP & 1292.4 & NP & NP & NP & NP & NP & 1338.4 \\
\hline U7bl & NP & NP & NP & NP & NP & NP & 1084.2 & 1174.4 & 1200 & NP & NP & NP & 1315.8 \\
\hline U7bm & NP & NP & NP & NP & NP & NP & 1134.8 & 1199.4 & NP & NP & NP & NP & 1291.7 \\
\hline U7bo & NP & NP & NP & NP & NP & NP & 1130 & 1180.4 & NP & NP & NP & NP & 1319.2 \\
\hline U7bp & NP & NP & NP & NP & NP & NP & 1063.1 & 1156.1 & NP & NP & NP & NP & 1294.8 \\
\hline $\mathrm{U} 7 \mathrm{br}$ & NP & NP & NP & NP & NP & NP & 1024.7 & 1143.6 & 1190.9 & NP & $\mathrm{NP}$ & NP & 1261.0 \\
\hline U7bs & NP & NP & NP & NP & NP & NP & 873.9 & 976 & 1024.7 & $N P$ & $N P$ & NP & 1277.7 \\
\hline U7bs_1 & NP & NP & NP & NP & NP & NP & 877.8 & 976.9 & 1025.7 & NP & NP & NP & 1277.7 \\
\hline U7bu & NP & NP & $\mathrm{NP}$ & NP & $\mathrm{NP}$ & $\mathrm{NP}$ & 866.5 & 990 & 1066.2 & $\mathrm{NP}$ & NP & NP & 1246.0 \\
\hline U7bv & NP & NP & $\mathrm{NP}$ & NP & NP & NP & 1199.4 & 1252.7 & NP & NP & $\mathrm{NP}$ & NP & 1310.6 \\
\hline U7bw & NP & NP & NP & NP & NP & NP & 946.4 & 1057.7 & 1101.9 & NP & NP & NP & 1282.0 \\
\hline U7by & NP & NP & $\mathrm{NP}$ & NP & NP & NP & 1137 & 1141.5 & 1175 & NP & $\mathrm{NP}$ & NP & 1310.6 \\
\hline $\mathrm{U} 7 \mathrm{bz}$ & NP & NP & NP & $\mathrm{NP}$ & $\mathrm{NP}$ & $\mathrm{NP}$ & 896.1 & 1008.9 & 1036.3 & $N P$ & NP & NP & 1272.8 \\
\hline U7c & NP & NP & $\mathrm{NP}$ & NP & NP & NP & NP & 1004.3 & 1034.8 & NP & NP & NP & 1269.5 \\
\hline U7ca & NP & $\mathrm{NP}$ & $\mathrm{NP}$ & NP & $\mathrm{NP}$ & $\mathrm{NP}$ & 1129 & 1208.2 & 1226.5 & $\mathrm{NP}$ & $\mathrm{NP}$ & NP & 1293.6 \\
\hline U7cb & NP & NP & $\mathrm{NP}$ & NP & NP & NP & 1225.9 & $\mathrm{NP}$ & NP & NP & $\mathrm{NP}$ & NP & 1306.7 \\
\hline U7cc & NP & $\mathrm{NP}$ & $\mathrm{NP}$ & NP & $\mathrm{NP}$ & $\mathrm{NP}$ & 1091 & 1101 & 1154 & $\mathrm{NP}$ & NP & NP & 1306.4 \\
\hline U7cd & NP & NP & $\mathrm{NP}$ & NP & NP & NP & 956.2 & 1078.7 & 1138.6 & NP & $\mathrm{NP}$ & NP & 1254.3 \\
\hline U7cd_1 & $\mathrm{NP}$ & $\mathrm{NP}$ & $\mathrm{NP}$ & NP & NP & NP & 957.1 & 1082.3 & 1143.5 & $\mathrm{NP}$ & NP & NP & 1253.9 \\
\hline $\mathrm{U} 7 \mathrm{e}$ & NP & NP & $\mathrm{NP}$ & NP & NP & NP & NP & 943.7 & 995.5 & NP & $\mathrm{NP}$ & NP & 1263.7 \\
\hline U7f & NP & $\mathrm{NP}$ & NP & NP & $\mathrm{NP}$ & $\mathrm{NP}$ & $\mathrm{NP}$ & 991.5 & 1028.1 & $\mathrm{NP}$ & $\mathrm{NP}$ & NP & 1284.1 \\
\hline U7g & $\mathrm{NP}$ & $\mathrm{NP}$ & $\mathrm{NP}$ & NP & $\mathrm{NP}$ & $N P$ & 951 & 980 & 1033.9 & NP & $N P$ & NP & 1271.6 \\
\hline U7h & NP & NP & $\mathrm{NP}$ & NP & $\mathrm{NP}$ & $\mathrm{NP}$ & NP & 1014.4 & 1024.1 & $\mathrm{NP}$ & $\mathrm{NP}$ & NP & 1255.2 \\
\hline U7i & NP & NP & NP & NP & NP & NP & NP & NP & 1105.2 & NP & NP & NP & 1294.2 \\
\hline U7j & NP & NP & NP & NP & NP & NP & 1120.4 & 1181.4 & NP & NP & NP & NP & 1318.6 \\
\hline U7k & NDE & NDE & NDE & NDE & NDE & NDE & 716.3 & 804.7 & 911.4 & NP & NP & NP & 1240.5 \\
\hline $\mathrm{U} 7 \mathrm{~m}$ & NP & $\mathrm{NP}$ & $\mathrm{NP}$ & $\mathrm{NP}$ & NP & $\mathrm{NP}$ & 1234.4 & $\mathrm{NP}$ & $\mathrm{NP}$ & NP & $\mathrm{NP}$ & NP & 1304.5 \\
\hline
\end{tabular}




\begin{tabular}{|c|c|c|c|c|c|c|c|c|c|c|c|c|}
\hline Well_Id & EASTING & NORTHING & Gnd_Elev & TD_Elev & MGCU & LCCU & LCA & UCCU & LCA3 & ATCU & OSBCU & LTCU \\
\hline U7n & 588521.7 & 4106212.5 & 1333.2 & 755.6 & NDE & NDE & 790.7 & $\mathrm{NP}$ & $\mathrm{NP}$ & 804.1 & 808.9 & 1144.2 \\
\hline U7n_1 & 588506.7 & 4106227.4 & 1333.2 & 750.1 & NDE & NDE & 785.2 & NP & NP & NP & 808.9 & 1138.7 \\
\hline U7o & 585686.5 & 4106568.5 & 1287.2 & 708.1 & NDE & NDE & NDE & NDE & NDE & NDE & NDE & 863.5 \\
\hline$U 7 p$ & 587645.2 & 4104167.5 & 1281.7 & 702.6 & NDE & NDE & NDE & NDE & NDE & NDE & NDE & 940.3 \\
\hline$U 7 r$ & 587003.8 & 4104683.3 & 1278.6 & 699.5 & NDE & NDE & $\mathrm{NDE}$ & NDE & NDE & NDE & NDE & NDE \\
\hline U7s & 588741.4 & 4104384.9 & 1300.9 & 721.8 & NDE & NDE & NDE & NDE & NDE & NDE & 743.1 & 1011.3 \\
\hline U7t & 588372.8 & 4105145.1 & 1307.9 & 728.8 & NDE & NDE & NDE & NDE & NDE & NDE & NDE & 1018.3 \\
\hline U7u & 585690.7 & 4105288.4 & 1269.2 & 583.4 & NDE & NDE & NDE & NDE & NDE & NDE & NDE & 799.8 \\
\hline U7v & 586511.3 & 4105992.2 & 1296.3 & 717.2 & NDE & NDE & NDE & NDE & NDE & NDE & 735.5 & 942.7 \\
\hline U7w & 589308.4 & 4103472.4 & 1297.2 & 763.8 & NDE & NDE & NDE & NDE & NDE & NDE & NDE & 1035.1 \\
\hline U7x & 588155.6 & 4106241.4 & 1328.9 & 795.5 & NDE & NDE & NDE & NDE & NDE & NDE & NDE & 1106.4 \\
\hline U7y & 588441.4 & 4102969.9 & 1276.2 & 697.1 & NDE & NDE & NDE & NDE & NDE & NDE & 718.4 & 940.9 \\
\hline U7z & 585633.6 & 4104206.1 & 1252.1 & 671.2 & NDE & NDE & NDE & NDE & NDE & NDE & NDE & 730 \\
\hline U7z_1 & 585622.9 & 4104195.1 & 1252.1 & 601.4 & NDE & NDE & NDE & NDE & NDE & NDE & NDE & 730 \\
\hline U8a & 580092.9 & 4114839.3 & 1406.7 & 1047.0 & NDE & NDE & NDE & NDE & NDE & NDE & NDE & 1048.6 \\
\hline U8a_1 & 580095.5 & 4114866.7 & 1406.0 & 1028.7 & NDE & NDE & NDE & NDE & 1047.9 & NP & NP & NP \\
\hline U8a_10 & 580032.5 & 4114233.3 & 1392.6 & 808.0 & NDE & NDE & NDE & NDE & 950.7 & NP & NP & NP \\
\hline U8a_11 & 580017.2 & 4114078.4 & 1391.1 & 798.3 & NDE & NDE & NDE & NDE & 943.1 & NP & NP & NP \\
\hline U8a_12 & 579960.4 & 4113506.5 & 1383.5 & 875.1 & NDE & NDE & NDE & NDE & 1000.4 & 1009.2 & NP & 1051.3 \\
\hline U8a_13 & 580083.0 & 4114855.7 & 1406.3 & 1235.7 & NDE & NDE & NDE & NDE & NDE & NDE & NDE & NDE \\
\hline U8a_3 & 580089.6 & 4114803.0 & 1405.1 & 1002.2 & NDE & NDE & NDE & NDE & 1024.1 & $\mathrm{NP}$ & NP & NP \\
\hline U8a_4 & 580091.4 & 4114824.3 & 1406.3 & 819.6 & NDE & NDE & NDE & NDE & 1036.3 & NP & NP & 1061.9 \\
\hline U8a_5 & 580080.8 & 4114718.3 & 1403.3 & 819.6 & NDE & NDE & NDE & NDE & 1016.2 & 1092.4 & NP & NP \\
\hline U8a_6 & 580074.6 & 4114657.3 & 1401.5 & 881.2 & NDE & NDE & NDE & NDE & 1018.5 & NP & NP & 1115 \\
\hline U8a_7 & 580068.4 & 4114596.9 & 1399.9 & 871.1 & NDE & NDE & NDE & NDE & 1010.9 & NP & NP & NP \\
\hline U8a_8 & 580062.5 & 4114536.3 & 1398.4 & 868.1 & NDE & NDE & NDE & NDE & 1011.4 & NP & NP & NP \\
\hline U8a_9 & 580044.3 & 4114354.3 & 1394.5 & 827.5 & NDE & NDE & NDE & NDE & 973.5 & NP & NP & NP \\
\hline U8b & 580631.5 & 4114259.8 & 1379.8 & 1065.9 & NDE & NDE & NDE & NDE & NDE & NDE & NDE & $\mathrm{NDE}$ \\
\hline U8d & 580000.4 & 4114255.1 & 1394.2 & 1094.8 & NDE & NDE & NDE & NDE & NDE & NDE & NDE & NDE \\
\hline U8e & 581041.3 & 4114029.9 & 1367.9 & 758.3 & NDE & NDE & NDE & NDE & NDE & NDE & 810 & NP \\
\hline U8e_1 & 581132.7 & 4114037.8 & 1367.9 & 573.9 & NDE & NDE & 649.5 & NP & NP & 669 & 839.1 & NP \\
\hline U8j & 580872.6 & 4115022.7 & 1388.7 & 779.1 & NDE & NDE & 788.7 & NP & NP & 812 & 977.2 & NP \\
\hline U8k & 581247.8 & 4114733.3 & 1373.4 & 1006.1 & NDE & NDE & NDE & NDE & NDE & NDE & 1058 & NP \\
\hline U8I & 581288.4 & 4115240.2 & 1383.2 & 1150.0 & NDE & $\mathrm{NDE}$ & $\mathrm{NDE}$ & NDE & NDE & NDE & $\mathrm{NDE}$ & NDE \\
\hline
\end{tabular}




\begin{tabular}{|c|c|c|c|c|c|c|c|c|c|c|c|c|c|}
\hline Well_Id & TUBA & PRETBG & BRCU & BRA & TSA & UTCU & TMLVTA & TMWTA & TMUTVA & BLFA & IDP & PCUT & AA \\
\hline U7n & $\mathrm{NP}$ & NP & $\mathrm{NP}$ & $\mathrm{NP}$ & $\mathrm{NP}$ & $\mathrm{NP}$ & 1199.1 & 1253.9 & 1260 & $\mathrm{NP}$ & NP & $\mathrm{NP}$ & 1333.2 \\
\hline U7n_1 & NP & NP & NP & NP & NP & NP & 1193.6 & 1248.5 & 1254.6 & NP & NP & NP & 1333.2 \\
\hline U7o & NP & NP & NP & $\mathrm{NP}$ & NP & NP & 894 & 964.1 & NP & NP & NP & $\mathrm{NP}$ & 1287.2 \\
\hline U7p & NP & NP & NP & NP & NP & NP & 964.7 & 1004.3 & 1037.8 & NP & NP & NP & 1281.7 \\
\hline U7r & NDE & NDE & NDE & NDE & NDE & NDE & 1065.3 & $\mathrm{NP}$ & NP & NP & $\mathrm{NP}$ & $\mathrm{NP}$ & 1278.6 \\
\hline U7s & NP & NP & $\mathrm{NP}$ & NP & NP & NP & 1215.5 & NP & NP & NP & NP & NP & 1300.9 \\
\hline $\mathrm{U} 7 \mathrm{t}$ & NP & NP & NP & NP & NP & NP & NP & NP & NP & NP & NP & NP & 1307.9 \\
\hline U7u & NP & $\mathrm{NP}$ & $\mathrm{NP}$ & $\mathrm{NP}$ & NP & NP & 876 & 946.1 & 1007.1 & $\mathrm{NP}$ & $\mathrm{NP}$ & NP & 1269.2 \\
\hline U7v & NP & NP & NP & $\mathrm{NP}$ & NP & NP & 1025 & 1086 & NP & NP & NP & NP & 1296.3 \\
\hline U7w & NP & NP & NP & NP & NP & NP & 1227.1 & NP & NP & NP & NP & NP & 1297.2 \\
\hline U7x & NP & NP & NP & $\mathrm{NP}$ & NP & NP & 1261.9 & $\mathrm{NP}$ & NP & NP & NP & $\mathrm{NP}$ & 1328.9 \\
\hline U7y & $\mathrm{NP}$ & $\mathrm{NP}$ & NP & $\mathrm{NP}$ & NP & NP & 1011 & 1078.1 & NP & $\mathrm{NP}$ & $\mathrm{NP}$ & $\mathrm{NP}$ & 1276.2 \\
\hline U7z & NP & NP & NP & $\mathrm{NP}$ & NP & NP & 822.4 & 913.8 & 956.5 & NP & $\mathrm{NP}$ & $\mathrm{NP}$ & 1252.1 \\
\hline U7z_1 & NP & $\mathrm{NP}$ & NP & $\mathrm{NP}$ & NP & NP & 823 & 914.4 & 957.1 & NP & NP & $\mathrm{NP}$ & 1252.1 \\
\hline U8a & NP & NP & NP & $\mathrm{NP}$ & NP & NP & 1217.7 & $\mathrm{NP}$ & NP & NP & NP & $\mathrm{NP}$ & 1406.7 \\
\hline U8a_1 & NP & $\mathrm{NP}$ & NP & $\mathrm{NP}$ & $\mathrm{NP}$ & $\mathrm{NP}$ & 1200.3 & $\mathrm{NP}$ & NP & $\mathrm{NP}$ & $\mathrm{NP}$ & $\mathrm{NP}$ & 1406.0 \\
\hline U8a_10 & NP & NP & NP & $\mathrm{NP}$ & NP & $\mathrm{NO}$ & 1116.5 & NP & NP & NP & NP & $\mathrm{NP}$ & 1392.6 \\
\hline U8a_11 & NP & $\mathrm{NP}$ & NP & $\mathrm{NP}$ & $\mathrm{NP}$ & $\mathrm{NP}$ & 1135.1 & $\mathrm{NP}$ & NP & $\mathrm{NP}$ & NP & $\mathrm{NP}$ & 1391.1 \\
\hline U8a_12 & $\mathrm{NP}$ & NP & $\mathrm{NP}$ & NP & NP & NP & 1154.5 & NP & NP & NP & NP & NP & 1383.5 \\
\hline U8a_13 & NDE & NDE & NDE & NDE & NDE & NDE & NDE & NDE & NDE & NDE & NDE & NDE & 1406.3 \\
\hline U8a_3 & NP & NP & $\mathrm{NP}$ & NP & NP & NP & 1198.17 & NP & NP & NP & NP & NP & 1405.1 \\
\hline U8a_4 & NP & $\mathrm{NP}$ & NP & $\mathrm{NP}$ & $\mathrm{NP}$ & NP & 1202.44 & $\mathrm{NP}$ & NP & $\mathrm{NP}$ & NP & $\mathrm{NP}$ & 1406.3 \\
\hline U8a_5 & NP & $\mathrm{NP}$ & NP & $\mathrm{NP}$ & NP & NP & 1223.47 & NP & NP & NP & NP & NP & 1403.3 \\
\hline U8a_6 & $\mathrm{NP}$ & $\mathrm{NP}$ & $\mathrm{NP}$ & $\mathrm{NP}$ & NP & NP & NP & $\mathrm{NP}$ & NP & $\mathrm{NP}$ & NP & $\mathrm{NP}$ & 1401.5 \\
\hline U8a_7 & NP & NP & NP & $\mathrm{NP}$ & NP & NP & 1160 & NP & NP & NP & NP & NP & 1399.9 \\
\hline U8a_8 & NP & NP & NP & NP & NP & NP & 1142.4 & NP & NP & NP & NP & $\mathrm{NP}$ & 1398.4 \\
\hline U8a_9 & $\mathrm{NP}$ & NP & NP & NP & NP & NP & 1114.3 & NP & NP & NP & NP & NP & 1394.5 \\
\hline U8b & NDE & NDE & NDE & NDE & NDE & NDE & 1202.7 & $\mathrm{NP}$ & $\mathrm{NP}$ & $\mathrm{NP}$ & $\mathrm{NP}$ & NP & 1379.8 \\
\hline U8d & NDE & NDE & NDE & NDE & NDE & NDE & 1132 & $\mathrm{NP}$ & NP & NP & NP & $\mathrm{NP}$ & 1394.2 \\
\hline U8e & NP & NP & NP & NP & NP & NP & 1098.2 & $\mathrm{NP}$ & $\mathrm{NP}$ & $\mathrm{NP}$ & $\mathrm{NP}$ & $\mathrm{NP}$ & 1367.9 \\
\hline U8e_1 & $\mathrm{NP}$ & $\mathrm{NP}$ & $\mathrm{NP}$ & $\mathrm{NP}$ & $\mathrm{NP}$ & NP & 990 & $\mathrm{NP}$ & $\mathrm{NP}$ & $\mathrm{NP}$ & $\mathrm{NP}$ & NP & 1367.9 \\
\hline U8j & NP & $\mathrm{NP}$ & NP & $\mathrm{NP}$ & NP & NP & 1265.7 & $\mathrm{NP}$ & NP & $\mathrm{NP}$ & NP & $\mathrm{NP}$ & 1388.7 \\
\hline U8k & NP & NP & NP & NP & NP & NP & 1250.4 & NP & NP & NP & NP & NP & 1373.4 \\
\hline U8I & NDE & NDE & NDE & NDE & NDE & NDE & 1297.4 & NP & NP & $\mathrm{NP}$ & NP & $\mathrm{NP}$ & 1383.2 \\
\hline
\end{tabular}




\begin{tabular}{|c|c|c|c|c|c|c|c|c|c|c|c|c|}
\hline Well_Id & EASTING & NORTHING & Gnd_Elev & TD_Elev & MGCU & LCCU & LCA & UCCU & LCA3 & ATCU & OSBCU & LTCU \\
\hline U8m & 580981.3 & 4114444.1 & 1373.7 & 855.6 & NDE & NDE & NDE & NDE & NDE & NDE & 969 & $N P$ \\
\hline U8n & 580630.7 & 4114503.8 & 1384.4 & 807.4 & NDE & NDE & NDE & NDE & NDE & NDE & 1015.3 & 1064.1 \\
\hline U9_AA27 & 586159.5 & 4110714.2 & 1306.4 & 1098.5 & NDE & NDE & 1117.4 & NP & NP & NP & NP & NP \\
\hline U9ad & 584347.0 & 4110555.5 & 1290.5 & 737.9 & NDE & NDE & NDE & NDE & NDE & NDE & NDE & NDE \\
\hline U9ae & 585378.8 & 4107420.1 & 1284.1 & 880.9 & NDE & NDE & NDE & NDE & NDE & NDE & NDE & NDE \\
\hline U9aj & 586075.5 & 4108091.1 & 1301.2 & 1142.7 & NDE & NDE & NDE & NDE & NDE & NDE & NDE & NDE \\
\hline U9ao & 584452.2 & 4110875.8 & 1289.6 & 785.2 & NDE & NDE & NDE & NDE & NDE & NDE & NDE & NDE \\
\hline U9aw & 585382.4 & 4108119.5 & 1284.1 & 1048.8 & NDE & NDE & NDE & NDE & NDE & NDE & NDE & NDE \\
\hline U9ax & 584827.1 & 4108332.3 & 1274.7 & 947.0 & NDE & NDE & NDE & NDE & NDE & NDE & NDE & NDE \\
\hline U9ay & 585607.7 & 4109127.7 & 1286.6 & 1009.5 & NDE & NDE & NDE & NDE & NDE & NDE & NDE & NDE \\
\hline U9az & 585062.8 & 4110618.9 & 1287.8 & 815.3 & NDE & NDE & NDE & NDE & NDE & NDE & NDE & NDE \\
\hline U9ba & 585600.0 & 4109517.7 & 1287.8 & 1098.8 & NDE & NDE & NDE & NDE & NDE & NDE & NDE & NDE \\
\hline U9bb & 585952.6 & 4109752.0 & 1296.6 & 1059.5 & NDE & NDE & NDE & NDE & NDE & NDE & NDE & NDE \\
\hline U9bd & 586581.4 & 4107729.0 & 1315.5 & 1126.5 & NDE & NDE & NDE & NDE & NDE & NDE & NDE & NDE \\
\hline U9be & 586292.9 & 4107438.8 & 1307.0 & 1072.3 & NDE & NDE & NDE & NDE & NDE & NDE & NDE & $\mathrm{NDE}$ \\
\hline U9bg & 586140.4 & 4107469.1 & 1303.3 & 1074.7 & NDE & NDE & NDE & NDE & NDE & NDE & NDE & $\mathrm{NDE}$ \\
\hline U9bh & 586640.0 & 4108317.7 & 1313.7 & 1009.8 & NDE & NDE & NDE & NDE & NDE & NDE & NDE & 1054.7 \\
\hline U9bi_1 & 585749.6 & 4108470.0 & 1290.8 & 810.8 & NDE & NDE & NDE & NDE & NDE & NDE & NDE & NDE \\
\hline U9bi_2 & 586297.1 & 4108498.7 & 1303.9 & 862.0 & NDE & NDE & NDE & NDE & NDE & NDE & NDE & $\mathrm{NDE}$ \\
\hline U9bj & 586536.1 & 4107607.3 & 1314.9 & 1078.7 & NDE & NDE & NDE & NDE & NDE & NDE & NDE & $\mathrm{NDE}$ \\
\hline U9bj_1 & 586542.2 & 4107607.3 & 1314.9 & 1071.1 & NDE & NDE & NDE & NDE & NDE & NDE & NDE & $\mathrm{NDE}$ \\
\hline U9bk & 586490.8 & 4107916.7 & 1312.8 & 1160.4 & NDE & NDE & NDE & NDE & NDE & NDE & NDE & NDE \\
\hline U9bm & 586089.7 & 4108118.3 & 1301.2 & 1148.8 & NDE & NDE & NDE & NDE & NDE & NDE & NDE & $\mathrm{NDE}$ \\
\hline U9bn & 586381.4 & 4108261.9 & 1308.2 & 986.6 & NDE & NDE & NDE & NDE & NDE & NDE & NDE & $\mathrm{NDE}$ \\
\hline U9bo & 586778.3 & 4107958.6 & 1320.4 & 1129.9 & NDE & NDE & NDE & NDE & NDE & NDE & NDE & NDE \\
\hline U9bp & 585682.0 & 4107863.3 & 1299.7 & 1060.4 & NDE & NDE & NDE & NDE & NDE & NDE & NDE & NDE \\
\hline U9br & 586397.6 & 4108003.3 & 1310.0 & 1002.2 & NDE & NDE & NDE & NDE & NDE & NDE & NDE & $\mathrm{NDE}$ \\
\hline U9bs & 585774.9 & 4107421.8 & 1293.9 & 954.0 & NDE & NDE & NDE & NDE & NDE & NDE & NDE & NDE \\
\hline U9bt & 586061.7 & 4107680.9 & 1301.8 & 1068.6 & NDE & NDE & NDE & NDE & NDE & NDE & NDE & NDE \\
\hline U9bu & 585210.3 & 4107663.6 & 1280.8 & 905.9 & NDE & NDE & NDE & NDE & NDE & NDE & NDE & $\mathrm{NDE}$ \\
\hline U9bx & 584631.9 & 4110188.0 & 1286.3 & 646.2 & NDE & NDE & NDE & NDE & NDE & NDE & NDE & NDE \\
\hline U9bz & 585248.2 & 4109887.9 & 1283.8 & 1032.4 & NDE & NDE & NDE & NDE & NDE & NDE & NDE & NDE \\
\hline U9ca_1 & 584176.2 & 4111286.2 & 1293.6 & 315.2 & NDE & NDE & 354.5 & NP & NP & 403 & NP & 708.2 \\
\hline U9cb & 584998.0 & 4111471.6 & 1293.9 & 735.5 & NDE & NDE & NDE & NDE & NDE & NDE & NDE & 815.4 \\
\hline
\end{tabular}




\begin{tabular}{|c|c|c|c|c|c|c|c|c|c|c|c|c|c|}
\hline Well_Id & TUBA & PRETBG & BRCU & BRA & TSA & UTCU & TMLVTA & TMWTA & TMUTVA & BLFA & IDP & PCUT & AA \\
\hline U8m & NP & $\mathrm{NP}$ & $\mathrm{NP}$ & $\mathrm{NP}$ & $\mathrm{NP}$ & $\mathrm{NP}$ & 1226.8 & $\mathrm{NP}$ & $\mathrm{NP}$ & NP & $\mathrm{NP}$ & NP & 1373.7 \\
\hline U8n & NP & NP & NP & NP & NP & NP & 1222.2 & NP & NP & NP & NP & NP & 1384.4 \\
\hline U9_AA27 & $\mathrm{NP}$ & NP & $\mathrm{NP}$ & NP & $\mathrm{NP}$ & $\mathrm{NP}$ & 1268.4 & NP & NP & NP & NP & NP & 1306.4 \\
\hline U9ad & NDE & NDE & NDE & NDE & NDE & NDE & 845.5 & NP & NP & NP & NP & NP & 1290.5 \\
\hline U9ae & NDE & NDE & NDE & NDE & NDE & NDE & 945.5 & 1010.1 & NP & NP & NP & NP & 1284.1 \\
\hline U9aj & NDE & NDE & NDE & NDE & NDE & NDE & 1167.1 & NP & NP & NP & NP & NP & 1301.2 \\
\hline U9ao & NDE & NDE & NDE & NDE & NDE & NDE & 848 & 895.5 & NP & NP & NP & NP & 1289.6 \\
\hline U9aw & NDE & NDE & NDE & NDE & NDE & NDE & 1055.2 & NP & NP & NP & NP & NP & 1284.1 \\
\hline U9ax & NDE & NDE & NDE & NDE & NDE & NDE & 948.5 & NP & NP & NP & NP & NP & 1274.7 \\
\hline U9ay & NDE & NDE & NDE & NDE & NDE & NDE & 1061 & 1118.6 & NP & NP & NP & NP & 1286.6 \\
\hline U9az & NDE & NDE & NDE & NDE & NDE & NDE & 1055.5 & NP & NP & NP & $\mathrm{NP}$ & $\mathrm{NP}$ & 1287.8 \\
\hline U9ba & NDE & NDE & NDE & NDE & NDE & NDE & NDE & NDE & NDE & NDE & NDE & NDE & 1287.8 \\
\hline U9bb & NDE & NDE & NDE & NDE & NDE & NDE & 1177.6 & $\mathrm{NP}$ & NP & NP & NP & NP & 1296.6 \\
\hline U9bd & NDE & NDE & NDE & NDE & NDE & NDE & 1163.7 & NP & NP & $N P$ & $N P$ & NP & 1315.5 \\
\hline U9be & NDE & NDE & NDE & NDE & NDE & NDE & NDE & 1161 & NP & NP & NP & NP & 1307.0 \\
\hline U9bg & NDE & NDE & NDE & NDE & NDE & NDE & 1117.4 & NP & NP & NP & NP & NP & 1303.3 \\
\hline U9bh & NP & NP & NP & NP & NP & NP & 1141.2 & 1247.5 & NP & NP & $\mathrm{NP}$ & NP & 1313.7 \\
\hline U9bi_1 & NDE & NDE & NDE & NDE & NDE & $\mathrm{NDE}$ & 1089.8 & 1090 & NP & NP & NP & NP & 1290.8 \\
\hline U9bi_2 & NDE & NDE & NDE & NDE & NDE & NDE & 1181.8 & NP & NP & NP & NP & $\mathrm{NP}$ & 1303.9 \\
\hline U9bj & NDE & $\mathrm{NDE}$ & NDE & NDE & NDE & $\mathrm{NDE}$ & NDE & NDE & NDE & $\mathrm{NDE}$ & NDE & NDE & 1314.9 \\
\hline U9bj_1 & NDE & NDE & NDE & NDE & NDE & NDE & 1155.8 & NP & NP & NP & NP & NP & 1314.9 \\
\hline U9bk & NDE & NDE & NDE & NDE & NDE & NDE & 1227.7 & $\mathrm{NP}$ & NP & $\mathrm{NP}$ & $\mathrm{NP}$ & NP & 1312.8 \\
\hline U9bm & NDE & NDE & NDE & NDE & NDE & NDE & 1194.2 & NP & NP & NP & $\mathrm{NP}$ & NP & 1301.2 \\
\hline U9bn & NDE & NDE & NDE & NDE & NDE & NDE & 1170 & 1215 & NP & $\mathrm{NP}$ & NP & NP & 1308.2 \\
\hline U9bo & NDE & NDE & NDE & NDE & NDE & NDE & 1253.3 & NP & NP & NP & $\mathrm{NP}$ & NP & 1320.4 \\
\hline U9bp & NDE & NDE & NDE & NDE & NDE & NDE & NDE & 1092.7 & NP & $\mathrm{NP}$ & NP & NP & 1299.7 \\
\hline U9br & NDE & NDE & NDE & NDE & NDE & NDE & 1196 & NP & NP & NP & NP & NP & 1310.0 \\
\hline U9bs & NDE & NDE & NDE & NDE & NDE & NDE & 1016.2 & 1080.8 & NP & $\mathrm{NP}$ & NP & NP & 1293.9 \\
\hline U9bt & NDE & NDE & NDE & NDE & NDE & NDE & 1099.4 & 1207.9 & NP & NP & $N P$ & NP & 1301.8 \\
\hline U9bu & NDE & NDE & NDE & $\mathrm{NDE}$ & NDE & NDE & 960.7 & NP & NP & $\mathrm{NP}$ & $\mathrm{NP}$ & NP & 1280.8 \\
\hline U9bx & NDE & NDE & NDE & NDE & NDE & NDE & 829 & 881 & NP & NP & NP & NP & 1286.3 \\
\hline U9bz & NDE & NDE & NDE & NDE & NDE & NDE & 1042.7 & $\mathrm{NP}$ & NP & NP & NP & NP & 1283.8 \\
\hline U9ca_1 & $\mathrm{NP}$ & NP & NP & NP & NP & NP & 866.6 & NP & NP & NP & NP & $N P$ & 1293.6 \\
\hline $\mathrm{U} 9 \mathrm{cb}$ & $\mathrm{NP}$ & $\mathrm{NP}$ & $\mathrm{NP}$ & $\mathrm{NP}$ & $\mathrm{NP}$ & $\mathrm{NP}$ & 1050.3 & 1095.8 & NP & $N P$ & $\mathrm{NP}$ & NP & 1293.9 \\
\hline
\end{tabular}




\begin{tabular}{|c|c|c|c|c|c|c|c|c|c|c|c|c|}
\hline Well_Id & EASTING & NORTHING & Gnd_Elev & TD_Elev & MGCU & LCCU & LCA & UCCU & LCA3 & ATCU & OSBCU & LTCU \\
\hline U9ce & 584147.2 & 4111027.4 & 1293.0 & 608.7 & NDE & NDE & NDE & NDE & NDE & NDE & NDE & 640.7 \\
\hline U9cg & 584451.4 & 4111195.7 & 1289.9 & 954.6 & NDE & NDE & NDE & NDE & NDE & NDE & NDE & NDE \\
\hline U9ch & 585530.1 & 4107725.7 & 1288.1 & 867.5 & NDE & NDE & NDE & NDE & NDE & NDE & NDE & NDE \\
\hline U9ci & 585965.9 & 4108579.5 & 1295.1 & 1036.0 & NDE & NDE & NDE & NDE & NDE & NDE & NDE & NDE \\
\hline U9ci_1 & 585973.8 & 4108578.9 & 1295.1 & 917.4 & NDE & NDE & NDE & NDE & NDE & NDE & NDE & 993.3 \\
\hline U9ck̄ & 585209.7 & 4107846.4 & 1280.8 & 944.9 & NDE & NDE & NDE & NDE & NDE & NDE & NDE & NDE \\
\hline U9cl & 586977.4 & 4107776.4 & 1327.1 & 972.0 & NDE & NDE & NDE & NDE & NDE & NDE & NDE & 1068 \\
\hline U9cn & 587373.1 & 4107793.1 & 1338.4 & 1002.5 & NDE & NDE & NDE & NDE & NDE & NDE & NDE & 1102.2 \\
\hline U9co & 584517.9 & 4109611.4 & 1283.2 & 551.7 & NDE & NDE & NDE & NDE & NDE & NDE & NDE & 589.8 \\
\hline U9cq & 587191.7 & 4107487.7 & 1332.6 & 997.0 & NDE & NDE & NDE & NDE & NDE & NDE & NDE & 1103.1 \\
\hline U9cr & 585829.0 & 4109372.2 & 1293.0 & 924.2 & NDE & NDE & NDE & NDE & NDE & NDE & NDE & 990 \\
\hline U9cs & 586856.5 & 4107486.5 & 1322.5 & 956.2 & NDE & NDE & NDE & NDE & NDE & NDE & NDE & 1117.1 \\
\hline U9ct & 583707.8 & 4110340.2 & 1300.0 & 781.2 & NDE & NDE & NDE & NDE & NDE & NDE & NDE & NDE \\
\hline U9cv & 586059.4 & 4108855.0 & 1295.7 & 838.5 & NDE & NDE & NDE & NDE & NDE & NDE & NDE & 1026 \\
\hline U9cw & 587572.4 & 4107446.1 & 1342.6 & 1129.3 & NDE & NDE & NDE & NDE & NDE & NDE & NDE & 1146 \\
\hline U9d & 584494.4 & 4108644.4 & 1280.5 & 940.6 & NDE & NDE & NDE & NDE & NDE & NDE & NDE & NDE \\
\hline U9IZ21 & 586040.2 & 4109982.7 & 1300.0 & 1088.7 & NDE & NDE & 1093 & NP & NP & NP & NP & NP \\
\hline U9IZ24 & 586038.9 & 4110344.7 & 1301.8 & 1095.2 & NDE & NDE & 1152.8 & NP & NP & NP & NP & NP \\
\hline U9IZ27 & 586037.6 & 4110713.8 & 1303.0 & 1039.0 & NDE & NDE & 1040.9 & NP & $N P$ & NP & NP & NP \\
\hline U9S25 & 585185.3 & 4110467.0 & 1286.9 & 782.7 & NDE & NDE & NDE & NDE & NDE & NDE & NDE & 851 \\
\hline U9T28 & 585305.9 & 4110833.1 & 1291.1 & 896.4 & NDE & NDE & NDE & NDE & NDE & NDE & NDE & NDE \\
\hline U9U29 & 585427.3 & 4110955.4 & 1293.3 & 947.3 & NDE & NDE & NDE & NDE & NDE & NDE & NDE & NDE \\
\hline U9W21 & 585674.2 & 4109981.4 & 1290.5 & 971.4 & NDE & NDE & NDE & NDE & NDE & NDE & NDE & 1046.7 \\
\hline U9x & 585931.2 & 4108050.1 & 1297.8 & 1034.2 & NDE & NDE & NDE & NDE & NDE & NDE & NDE & NDE \\
\hline U9X20 & 585797.2 & 4109859.7 & 1293.0 & 1012.5 & NDE & NDE & NDE & NDE & NDE & NDE & NDE & NDE \\
\hline UE10aa & 585438.6 & 4116410.0 & 1341.4 & 917.7 & NDE & 996.4 & NP & NP & NP & NP & 1042.1 & 1086.9 \\
\hline UE10bd & 585425.7 & 4112296.2 & 1307.3 & 790.7 & NDE & NDE & 802.9 & NP & NP & 824.2 & NP & NP \\
\hline UE10bf & 584510.1 & 4116147.8 & 1337.2 & 646.5 & NDE & NDE & 659.3 & NP & NP & $\mathrm{NP}$ & 758 & 780.9 \\
\hline UE10bg & 585730.9 & 4112160.1 & 1310.3 & 1009.5 & NDE & NDE & 1017.4 & NP & NP & NP & NP & NP \\
\hline UE10j & 581526.6 & 4115644.9 & 1394.1 & 597.6 & NDE & NDE & 1078.1 & $\mathrm{NP}$ & $\mathrm{NP}$ & $\mathrm{NP}$ & 1166.2 & NP \\
\hline UE12p & 574350.7 & 4121402.4 & 1931.5 & 1368.3 & NDE & NDE & NDE & NDE & 1378 & ND & ND & NP \\
\hline UE12p_1 & 573696.9 & 4121528.3 & 1974.2 & 1314.3 & 1371.6 & NP & NP & NP & NP & ND & ND & 1416.4 \\
\hline UE12p_3 & 575401.4 & 4121926.5 & 1930.0 & 1137.2 & NDE & NDE & NDE & NDE & NDE & NDE & NDE & 1157.3 \\
\hline UE12p_4 & 574224.1 & 4121017.0 & 1951.0 & 1408.2 & NDE & NDE & NDE & NDE & 1408.8 & ND & ND & 1425.6 \\
\hline
\end{tabular}




\begin{tabular}{|c|c|c|c|c|c|c|c|c|c|c|c|c|c|}
\hline Well_Id & TUBA & PRETBG & BRCU & BRA & TSA & UTCU & TMLVTA & TMWTA & TMUTVA & BLFA & IDP & PCUT & AA \\
\hline U9ce & $\mathrm{NP}$ & $\mathrm{NP}$ & $\mathrm{NP}$ & NP & NP & $\mathrm{NP}$ & 747.4 & 848 & $\mathrm{NP}$ & $\mathrm{NP}$ & NP & $\mathrm{NP}$ & 1293.0 \\
\hline U9cg & NDE & NDE & NDE & NDE & NDE & NDE & NDE & NDE & NDE & NDE & NDE & NDE & 1290.2 \\
\hline U9ch & NDE & NDE & NDE & NDE & NDE & NDE & 1001.6 & 1052.2 & NP & NP & NP & NP & 1288.1 \\
\hline U9ci & NDE & NDE & NDE & NDE & NDE & NDE & NDE & 1144 & NP & NP & NP & NP & 1295.1 \\
\hline U9ci_1 & $\mathrm{NP}$ & $\mathrm{NP}$ & NP & $\mathrm{NP}$ & $\mathrm{NP}$ & NP & 1099.1 & 1142.7 & NP & NP & NP & NP & 1295.1 \\
\hline U9ck & NDE & NDE & NDE & NDE & NDE & NDE & NDE & 979 & NP & NP & NP & NP & 1280.8 \\
\hline U9cl & NP & NP & NP & NP & NP & NP & 1251.2 & NP & $N P$ & NP & NP & NP & 1327.1 \\
\hline U9cn & NP & NP & $N P$ & NP & NP & $N P$ & 1276.4 & NP & NP & NP & NP & NP & 1338.4 \\
\hline U9co & NP & NP & NP & NP & NP & NP & 823.3 & 823 & NP & NP & NP & NP & 1283.2 \\
\hline U9cq & NP & NP & NP & NP & NP & NP & 1223.8 & NP & NP & NP & NP & NP & 1332.6 \\
\hline U9cr & $N P$ & NP & NP & NP & $N P$ & $N P$ & 1187.2 & NP & NP & NP & NP & NP & 1293.0 \\
\hline U9cs & NP & NP & NP & NP & NP & NP & 1149.1 & 1195.4 & NP & NP & NP & NP & 1322.5 \\
\hline U9ct & NDE & NDE & NDE & NDE & NDE & NDE & 940.3 & 1003.1 & NP & NP & NP & NP & 1300.0 \\
\hline U9cv & NP & NP & NP & NP & NP & NP & 1174.1 & NP & NP & NP & NP & NP & 1295.7 \\
\hline U9cw & NP & NP & $\mathrm{NP}$ & NP & NP & NP & 1322.5 & $\mathrm{NP}$ & $\mathrm{NP}$ & $\mathrm{NP}$ & NP & $\mathrm{NP}$ & 1342.6 \\
\hline U9d & NDE & NDE & NDE & NDE & NDE & NDE & NDE & NDE & NDE & NDE & NDE & NDE & 1280.5 \\
\hline U9IZ21 & NP & NP & NP & NP & NP & NP & 1254 & NP & NP & NP & NP & NP & 1300.0 \\
\hline U9IZ24 & NP & NP & NP & NP & NP & NP & 1231.8 & NP & NP & NP & NP & NP & 1301.8 \\
\hline U9IZ27 & NP & NP & $\mathrm{NP}$ & NP & NP & NP & 1260 & NP & NP & NP & NP & NP & 1303.0 \\
\hline U9S25 & NP & $\mathrm{NP}$ & NP & NP & NP & NP & 1083.9 & NP & $\mathrm{NP}$ & $N P$ & NP & NP & 1288.1 \\
\hline U9T28 & NDE & NDE & NDE & NDE & NDE & NDE & 1163.1 & NP & NP & NP & NP & NP & 1291.1 \\
\hline U9U29 & NDE & NDE & NDE & NDE & NDE & NDE & 1188.1 & NP & NP & NP & NP & NP & 1293.3 \\
\hline U9W21 & NP & NP & NP & NP & NP & NP & 1192.4 & NP & NP & NP & NP & NP & 1290.5 \\
\hline U9x & NDE & NDE & NDE & NDE & NDE & NDE & 1066.2 & 1129.9 & NP & $\mathrm{NP}$ & NP & NP & 1297.8 \\
\hline U9X20 & NDE & NDE & NDE & NDE & NDE & NDE & 1221.3 & NP & NP & NP & NP & NP & 1293.0 \\
\hline UE10aa & NP & NP & NP & NP & NP & NP & 1198.4 & NP & NP & NP & NP & NP & 1341.4 \\
\hline UE10bd & NP & NP & $\mathrm{NP}$ & NP & NP & NP & 1146.3 & NP & NP & NP & NP & NP & 1307.3 \\
\hline UE10bf & NP & NP & NP & NP & $\mathrm{NP}$ & $\mathrm{NP}$ & 1092.2 & NP & NP & $\mathrm{NP}$ & NP & NP & 1337.2 \\
\hline UE10bg & NP & NP & NP & NP & NP & NP & 1230 & NP & NP & NP & NP & NP & 1310.3 \\
\hline UE10j & $\mathrm{NP}$ & NP & NP & NP & NP & NP & 1362.2 & NP & NP & NP & NP & NP & 1394.2 \\
\hline UE12p & 1394.2 & NP & 1542 & 1550.8 & NP & NP & 1809.9 & 1901.3 & 1931.8 & NP & NP & NP & NP \\
\hline UE12p_1 & NP & NP & 1532.5 & 1603.9 & NP & 1710.8 & 1890.4 & 1951 & 1974.2 & NP & NP & NP & NP \\
\hline UE12p_3 & 1181.4 & NP & 1396.6 & 1471.3 & NP & NP & 1790.3 & 1930 & NP & NP & NP & NP & NP \\
\hline UE12p_4 & NP & NP & 1529.5 & 1571.6 & NP & $\mathrm{NP}$ & 1829.1 & $\mathrm{NP}$ & 1949.5 & $N P$ & NP & NP & $\mathrm{NP}$ \\
\hline
\end{tabular}




\begin{tabular}{|c|c|c|c|c|c|c|c|c|c|c|c|c|}
\hline Well_Id & EASTING & NORTHING & Gnd_Elev & TD_Elev & MGCU & LCCU & LCA & UCCU & LCA3 & ATCU & OSBCU & LTCU \\
\hline UE12t_1 & 573002.3 & 4119245.6 & 2127.5 & 1438.0 & NDE & NDE & NDE & NDE & 1390.9 & ND & ND & 1606.1 \\
\hline UE12t_2 & 572461.2 & 4118773.5 & 2136.0 & 1622.8 & NDE & NDE & NDE & NDE & 1567.9 & ND & ND & 1897.9 \\
\hline UE12t_3 & 572804.1 & 4119514.3 & 2065.6 & 1402.4 & NDE & NDE & NDE & NDE & NDE & NDE & NDE & 1611.5 \\
\hline UE12t_5 & 572294.6 & 4118655.3 & 2151.6 & 1660.6 & NDE & NDE & NDE & NDE & 1691 & ND & ND & 1985.5 \\
\hline UE12t_8 & 573084.6 & 4120793.6 & 2049.8 & 1727.3 & NDE & NDE & NDE & NDE & NDE & NDE & NDE & 1801.6 \\
\hline UE13ā & 586981.4 & 4129563.2 & 1466.4 & 1240.5 & NDE & NDE & NDE & NDE & NDE & NDE & NDE & 1366 \\
\hline UE14a & 576155.1 & 4087306.7 & 1322.5 & 316.7 & NDE & NDE & NDE & NDE & NDE & NDE & NDE & NDE \\
\hline UE14b & 575427.1 & 4087304.1 & 1326.8 & 205.1 & NDE & NDE & NDE & NDE & NDE & NDE & NDE & NDE \\
\hline UE15d & 585061.4 & 4118300.8 & 1397.8 & -431.3 & NDE & 857 & NP & NP & NP & NP & 1087.1 & 1155.4 \\
\hline UE15j & 592299.1 & 4117406.6 & 1451.5 & 1071.1 & NDE & 1420 & NP & NP & NP & NP & NP & NP \\
\hline UE1a & 578394.6 & 4100387.8 & 1311.7 & 1020.0 & NDE & NDE & NDE & 1037.2 & NP & NP & NP & NP \\
\hline UE1b & 579004.2 & 4100390.1 & 1302.5 & 920.3 & NDE & NDE & NDE & 1070.5 & $\mathrm{NP}$ & NP & NP & NP \\
\hline UE1c & 580223.0 & 4100394.2 & 1282.2 & 709.2 & NDE & NDE & NDE & NDE & 742 & 746.2 & NP & NP \\
\hline UE1d & 578714.0 & 4100601.6 & 1309.4 & 1048.2 & NDE & NDE & NDE & 1074.7 & NP & 1080.8 & NP & 1147.9 \\
\hline UE1e & 579492.3 & 4100238.7 & 1293.9 & 771.4 & NDE & NDE & NDE & 780 & 824.2 & 836.7 & NP & 903.4 \\
\hline UE1f & 578814.0 & 4100148.5 & 1303.6 & 1089.4 & NDE & NDE & NDE & 1132.9 & NP & NP & NP & NP \\
\hline UE1g & 579276.9 & 4100847.4 & 1299.4 & 859.8 & NDE & NDE & NDE & 880.3 & NP & NP & NP & NP \\
\hline UE1h & 582983.1 & 4095223.5 & 1217.7 & 194.1 & NDE & NDE & 699.5 & $N P$ & NP & NP & NP & NP \\
\hline UE1j & 582445.7 & 4096592.3 & 1219.2 & 721.8 & NDE & NDE & NDE & NDE & 781.8 & NP & NP & NP \\
\hline UE1k & 583731.1 & 4099339.4 & 1234.7 & 522.1 & NDE & NDE & NDE & NDE & NDE & NDE & NDE & NDE \\
\hline UE1I & 576566.8 & 4100381.8 & 1358.5 & -268.8 & NDE & NDE & NDE & 1296.6 & NP & NP & NP & NP \\
\hline UE1q & 583722.7 & 4101777.7 & 1244.0 & 451.5 & NDE & NDE & 527.9 & NP & NP & 534 & $\mathrm{NP}$ & 695.6 \\
\hline UE1r & 583674.1 & 4098227.8 & 1232.0 & -42.7 & NDE & NDE & 116.4 & NP & NP & 118.9 & NP & 431.9 \\
\hline UE2a & 580637.7 & 4109718.1 & 1317.6 & 1126.8 & NDE & NDE & NDE & NDE & NDE & NDE & NDE & NDE \\
\hline UE2a_1 & 580864.0 & 4108806.6 & 1319.8 & 570.0 & NDE & NDE & 585.4 & NP & NP & NP & NP & NP \\
\hline UE2aa & 582406.9 & 4111980.9 & 1325.3 & 619.0 & NDE & NDE & 624.2 & NP & NP & NP & NP & 666.8 \\
\hline UE2ab & 580337.0 & 4111364.1 & 1345.1 & 958.0 & NDE & NDE & NDE & NDE & 982.1 & NP & NP & NP \\
\hline UE2ac & 580099.1 & 4109687.3 & 1325.9 & 1083.0 & NDE & NDE & $\mathrm{NDE}$ & NDE & 1100 & NP & NP & NP \\
\hline UE2ad & 578667.7 & 4109529.9 & 1355.8 & 1091.8 & NDE & NDE & NDE & NDE & 1117.7 & 1120.5 & NP & NP \\
\hline UE2arIns & 582831.3 & 4108811.1 & 1292.7 & 576.1 & NDE & NDE & NDE & NDE & NDE & NDE & NDE & NDE \\
\hline UE2aw & 582743.7 & 4109794.4 & 1302.1 & 592.5 & NDE & NDE & NDE & NDE & NDE & NDE & NDE & 641.9 \\
\hline UE2ax & 581409.0 & 4112043.8 & 1340.5 & 450.5 & NDE & NDE & 480.4 & NP & NP & NP & NP & 625 \\
\hline UE2ax_2 & 581425.7 & 4111995.4 & 1339.9 & 593.1 & NDE & NDE & NDE & NDE & NDE & NDE & NDE & 627 \\
\hline UE2b & 581137.7 & 4109485.3 & 1313.7 & 243.2 & NDE & NDE & 286.8 & NP & NP & 309.4 & NP & NP \\
\hline
\end{tabular}




\begin{tabular}{|c|c|c|c|c|c|c|c|c|c|c|c|c|c|}
\hline Well_Id & TUBA & PRETBG & BRCU & BRA & TSA & UTCU & TMLVTA & TMWTA & TMUTVA & BLFA & IDP & PCUT & $\mathrm{AA}$ \\
\hline UE12t_1 & 1677.1 & NP & 1793 & 1841.7 & NP & $\mathrm{NP}$ & 1966.7 & 2161.2 & NP & $\mathrm{NP}$ & $\mathrm{NP}$ & $\mathrm{NP}$ & $\mathrm{NP}$ \\
\hline UE12t_2 & NP & NP & NP & NP & NP & NP & 2095.7 & 2136 & NP & NP & NP & NP & NP \\
\hline UE12t_3 & 1621.5 & NP & 1785.8 & 1836.4 & NP & NP & 1968.1 & 2065.6 & NP & NP & NP & NP & NP \\
\hline UE12t_5 & NP & NP & NP & NP & NP & NP & 2105.9 & 2152.6 & NP & NP & NP & NP & NP \\
\hline UE12t_8 & $\mathrm{NP}$ & NP & $\mathrm{NP}$ & $\mathrm{NP}$ & NP & NP & 2004 & 2049.7 & NP & NP & NP & NP & NP \\
\hline UE13a & 1402 & NP & 1451 & 1466 & NP & NP & NP & NP & NP & NP & NP & NP & 1466.4 \\
\hline UE14a & NDE & NDE & NDE & NDE & 681.5 & 747.6 & NP & 969.6 & 998.5 & NP & NP & NP & 1322.5 \\
\hline UE14b & NDE & NDE & NDE & NDE & 611.7 & 674.5 & NP & 893.7 & 918.7 & NP & NP & NP & 1326.8 \\
\hline UE15d & 1149 & NP & 1270 & 1309 & NP & $\mathrm{NP}$ & NP & NP & NP & NP & NP & NP & 1398.0 \\
\hline UE15j & NP & NP & NP & NP & NP & NP & NP & NP & NP & NP & NP & NP & 1452.0 \\
\hline UE1a & NP & NP & NP & NP & NP & $\mathrm{Np}$ & NP & NP & NP & NP & NP & NP & 1311.6 \\
\hline UE1b & NP & NP & NP & NP & NP & $\mathrm{NP}$ & $\mathrm{NP}$ & NP & NP & NP & NP & NP & 1302.4 \\
\hline UE1c & NP & NP & NP & NP & NP & NP & 1093 & NP & NP & NP & NP & NP & 1282.0 \\
\hline UE1d & NP & $\mathrm{NP}$ & $\mathrm{NP}$ & NP & $\mathrm{NP}$ & $\mathrm{NP}$ & $\mathrm{NP}$ & $\mathrm{NP}$ & NP & $\mathrm{NP}$ & $\mathrm{NP}$ & $\mathrm{NP}$ & 1309.4 \\
\hline UE1e & NP & NP & NP & NP & NP & NP & 1132 & NP & NP & NP & NP & NP & 1293.9 \\
\hline UE1f & NP & NP & NP & NP & $\mathrm{NP}$ & $\mathrm{NP}$ & 1221.2 & NP & $\mathrm{NP}$ & NP & $\mathrm{NP}$ & NP & 1303.6 \\
\hline UE1g & NP & NP & NP & NP & NP & NP & 1140 & NP & NP & NP & NP & NP & 1299.4 \\
\hline UE1h & $\mathrm{NP}$ & $\mathrm{NP}$ & NP & NP & $\mathrm{NP}$ & $\mathrm{NP}$ & NP & NP & NP & 992 & NP & NP & 1217.7 \\
\hline UE1j & NP & NP & NP & NP & NP & $\mathrm{NP}$ & NP & $\mathrm{NP}$ & NP & 816 & NP & NP & 1230.0 \\
\hline UE1k & NDE & NDE & NDE & NDE & NDE & $\mathrm{NDE}$ & NDE & 570.2 & $\mathrm{NP}$ & $\mathrm{NP}$ & NP & NP & 1234.7 \\
\hline UE1I & NP & NP & NP & NP & NP & NP & NP & NP & NP & NP & NP & NP & 1357.6 \\
\hline UE1q & NP & $\mathrm{NP}$ & NP & NP & $\mathrm{NP}$ & $\mathrm{NP}$ & 739.7 & 833.6 & 855.6 & $\mathrm{NP}$ & $\mathrm{NP}$ & NP & 1244.2 \\
\hline UE1r & NP & NP & NP & NP & NP & NP & 459.3 & 549.2 & NP & NP & NP & NP & 1231.4 \\
\hline UE2a & NDE & NDE & NDE & NDE & NDE & NDE & NDE & NDE & NDE & NDE & NDE & NDE & 1316.7 \\
\hline UE2a_1 & NP & NP & NP & NP & NP & NP & 743.4 & NP & NP & NP & NP & NP & 1319.7 \\
\hline UE2aa & NP & NP & NP & NP & NP & $\mathrm{np}$ & 914.1 & NP & NP & $\mathrm{NP}$ & NP & NP & 1325.3 \\
\hline UE2ab & NP & NP & NP & NP & NP & NP & NP & NP & NP & NP & $\mathrm{NP}$ & NP & 1345.1 \\
\hline UE2ac & NP & NP & NP & NP & $\mathrm{NP}$ & $\mathrm{NP}$ & NP & $\mathrm{NP}$ & NP & $\mathrm{NP}$ & $\mathrm{NP}$ & NP & 1325.9 \\
\hline UE2ad & NP & NP & NP & NP & NP & NP & 1213 & NP & NP & NP & NP & NP & 1355.8 \\
\hline UE2arlns & NDE & NDE & NDE & NDE & NDE & NDE & 577 & 649.7 & 673.6 & NP & NP & NP & 1292.7 \\
\hline UE2aw & NP & NP & NP & NP & NP & NP & 718 & 801 & NP & NP & NP & NP & 1302.1 \\
\hline UE2ax & NP & NP & NP & NP & NP & NP & 712.6 & $\mathrm{NP}$ & NP & NP & NP & NP & 1340.5 \\
\hline UE2ax_2 & NP & NP & NP & NP & $N P$ & $N P$ & 709.5 & NP & NP & NP & $N P$ & NP & 1339.9 \\
\hline UE2b & NP & NP & $\mathrm{NP}$ & NP & NP & $\mathrm{NP}$ & 754.7 & $\mathrm{NP}$ & NP & $\mathrm{NP}$ & $\mathrm{NP}$ & $\mathrm{NP}$ & 1313.7 \\
\hline
\end{tabular}




\begin{tabular}{|c|c|c|c|c|c|c|c|c|c|c|c|c|}
\hline Well_Id & EASTING & NORTHING & Gnd_Elev & TD_Elev & MGCU & LCCU & LCA & UCCU & LCA3 & ATCU & OSBCU & LTCU \\
\hline UE2ce & 576804.2 & 4110772.7 & 1452.1 & 949.2 & $\mathrm{NDE}$ & NDE & NDE & NDE & 1115 & $\mathrm{NP}$ & $\mathrm{NP}$ & $\mathrm{NP}$ \\
\hline UE2co & 577575.9 & 4107972.0 & 1390.5 & 805.0 & NDE & NDE & NDE & NDE & 847 & 852.9 & NP & NP \\
\hline UE2djIns & 581406.3 & 4110575.6 & 1323.1 & 606.8 & NDE & NDE & NDE & NDE & NDE & NDE & NDE & NDE \\
\hline UE2dy & 581080.1 & 4107907.5 & 1299.4 & 731.9 & NDE & NDE & 744.3 & NP & NP & NP & NP & NP \\
\hline UE2dz & 581581.3 & 4108898.7 & 1302.4 & 570.9 & NDE & NDE & NDE & NDE & NDE & NDE & NDE & NDE \\
\hline UE2en & 583119.0 & 4108799.0 & 1288.7 & 671.8 & NDE & NDE & NDE & NDE & NDE & NDE & NDE & NDE \\
\hline UE2en_1 & 583118.9 & 4108814.2 & 1288.1 & 526.1 & NDE & NDE & NDE & NDE & NDE & NDE & NDE & NDE \\
\hline UE2ep & 582922.0 & 4108493.5 & 1288.1 & 465.1 & NDE & NDE & NDE & NDE & NDE & NDE & NDE & NDE \\
\hline UE2eu & 580818.6 & 4112542.1 & 1353.6 & 509.3 & NDE & NDE & 550.5 & NP & NP & NP & NP & NP \\
\hline UE2fa & 581148.8 & 4110132.8 & 1317.3 & 463.9 & NDE & NDE & NDE & NDE & NDE & NDE & NDE & NDE \\
\hline UE2fa_1 & 580978.5 & 4110131.6 & 1319.8 & 445.6 & NDE & NDE & 487.7 & NP & NP & 488.9 & NP & NP \\
\hline UE2fb & 581365.7 & 4109112.8 & 1302.7 & 452.3 & NDE & NDE & 510.8 & NP & NP & $\mathrm{NP}$ & NP & 522.7 \\
\hline UE2sInst & 577504.3 & 4108322.2 & 1396.9 & 796.4 & NDE & NDE & NDE & NDE & 867.8 & NP & NP & NP \\
\hline UE3a & 589986.0 & 4097075.8 & 1219.2 & 709.9 & NDE & NDE & NDE & NDE & NDE & NDE & NDE & 906.8 \\
\hline UE3c & 586569.7 & 4098115.5 & 1215.5 & 131.6 & NDE & NDE & NDE & NDE & NDE & NDE & NDE & 630.9 \\
\hline UE3e & 584475.9 & 4102815.2 & 1244.5 & 479.5 & NDE & NDE & NDE & NDE & NDE & NDE & NDE & 730.9 \\
\hline UE3e_2 & 584475.6 & 4102827.4 & 1244.5 & 521.5 & NDE & NDE & NDE & NDE & NDE & NDE & NDE & 730.3 \\
\hline UE3e_3 & 584678.9 & 4102876.6 & 1244.2 & 567.2 & NDE & NDE & NDE & NDE & NDE & NDE & NDE & NDE \\
\hline UE3e_4 & 584481.0 & 4102812.6 & 1244.0 & 543.0 & NDE & NDE & NDE & NDE & NDE & NDE & NDE & 747.7 \\
\hline UE3eh_1 & 586935.6 & 4102402.1 & 1247.5 & 714.1 & NDE & NDE & NDE & NDE & NDE & NDE & NDE & NDE \\
\hline UE3lj & 584527.0 & 4101886.0 & 1239.9 & 301.1 & NDE & NDE & 338.3 & NP & NP & 359.1 & 409.3 & 715.1 \\
\hline UE3mf & 584886.1 & 1847.0 & 1239.3 & 509.3 & NDE & NDE & NDE & NDE & NDE & NDE & NDE & 809.5 \\
\hline UE3mo_1 & 590050.2 & 4095704.8 & 1228.0 & 1178.4 & NDE & NDE & NDE & NDE & NDE & NDE & NDE & NDE \\
\hline UE3mo_2 & 590140.5 & 4096466.9 & 1230.2 & 1107.3 & NDE & NDE & NDE & NDE & NDE & NDE & NDE & NDE \\
\hline UE4a & 584389.9 & 4106210.5 & 1266.4 & 343.5 & NDE & NDE & NDE & NDE & NDE & 375.8 & 585.8 & 915.9 \\
\hline UE4aa & 580446.7 & 4105618.9 & 1296.6 & 924.8 & NDE & NDE & NDE & NDE & 930.6 & 951.9 & NP & NP \\
\hline UE4abIns & 582167.4 & 4106418.8 & 1280.5 & 472.7 & NDE & NDE & 505.7 & NP & NP & NP & 640.4 & 854 \\
\hline UE4ac & 578146.0 & 4106160.9 & 1301.8 & 790.7 & NDE & NDE & NDE & NDE & 824.8 & 868.4 & NP & NP \\
\hline UE4ad & 581640.6 & 4104512.1 & 1274.4 & 831.5 & NDE & NDE & NDE & NDE & 832.4 & 882.1 & NP & NP \\
\hline UE4aelns & 582802.3 & 4103510.9 & 1258.8 & 509.9 & NDE & NDE & 539.8 & NP & NP & 552.3 & NP & 710.29 \\
\hline UE4af & 579268.5 & 4103224.2 & 1312.2 & 857.7 & NDE & NDE & NDE & 882.1 & NP & 1083.6 & NP & NP \\
\hline UE4ahIns & 582647.0 & 4104363.5 & 1262.5 & 393.5 & NDE & NDE & 413.6 & NP & NP & NP & NP & 660.8 \\
\hline UE4ai & 581834.1 & 4105192.0 & 1273.1 & 916.5 & NDE & NDE & 941.2 & NP & NP & NP & NP & NP \\
\hline UE4al & 582212.6 & 4103965.9 & 1266.4 & 599.8 & NDE & NDE & 757.4 & NP & NP & NP & $\mathrm{NP}$ & 786.3 \\
\hline
\end{tabular}




\begin{tabular}{|c|c|c|c|c|c|c|c|c|c|c|c|c|c|}
\hline Well_Id & TUBA & PRETBG & BRCU & BRA & TSA & UTCU & TMLVTA & TMWTA & TMUTVA & BLFA & IDP & PCUT & AA \\
\hline UE2ce & $\mathrm{NP}$ & NP & $\mathrm{NP}$ & $\mathrm{NP}$ & $\mathrm{NP}$ & $\mathrm{NP}$ & 1335.1 & $\mathrm{NP}$ & $\mathrm{NP}$ & $\mathrm{NP}$ & $\mathrm{NP}$ & $\mathrm{NP}$ & 1452.1 \\
\hline UE2co & NP & NP & NP & NP & NP & NP & 1178.5 & NP & NP & NP & NP & NP & 1390.5 \\
\hline UE2djIns & NDE & NDE & NDE & NDE & NDE & NDE & 665.1 & NP & NP & NP & NP & $\mathrm{NP}$ & 1323.1 \\
\hline UE2dy & NP & NP & NP & NP & NP & NP & 976 & NP & NP & NP & NP & $\mathrm{NP}$ & 1299.4 \\
\hline UE2dz & NDE & NDE & NDE & NDE & NDE & NDE & 683.4 & $\mathrm{NP}$ & NP & NP & $\mathrm{NP}$ & $\mathrm{NP}$ & 1302.4 \\
\hline UE2en & NDE & NDE & NDE & NDE & NDE & NDE & NDE & 749 & 797 & NP & NP & NP & 1288.7 \\
\hline UE2en_1 & NDE & NDE & NDE & NDE & NDE & NDE & 663 & 749 & 797 & NP & NP & $\mathrm{NP}$ & 1288.1 \\
\hline UE2ep & NDE & NDE & NDE & NDE & NDE & NDE & 576 & 697 & 696.8 & $\mathrm{NP}$ & $\mathrm{NP}$ & NP & 1288.1 \\
\hline UE2eu & $\mathrm{NP}$ & NP & NP & NP & NP & NP & NP & NP & NP & NP & NP & $\mathrm{NP}$ & 1353.6 \\
\hline UE2fa & NDE & NDE & NDE & NDE & NDE & NDE & 619.4 & NP & NP & NP & NP & NP & 1317.3 \\
\hline UE2fa_1 & $\mathrm{NP}$ & NP & NP & NP & NP & NP & 711.8 & NP & NP & NP & NP & $\mathrm{NP}$ & 1319.8 \\
\hline UE2fb & $\mathrm{NP}$ & $\mathrm{NP}$ & $\mathrm{NP}$ & $\mathrm{NP}$ & NP & NP & 803.5 & $\mathrm{NP}$ & NP & $\mathrm{NP}$ & $\mathrm{NP}$ & $\mathrm{NP}$ & 1302.7 \\
\hline UE2sInst & NP & NP & NP & $\mathrm{NP}$ & NP & NP & 1140.9 & $\mathrm{NP}$ & NP & NP & $\mathrm{NP}$ & $\mathrm{NP}$ & 1396.9 \\
\hline UE3a & NP & NP & $\mathrm{NP}$ & $\mathrm{NP}$ & 983 & NP & 1050 & 1172 & $\mathrm{NP}$ & $\mathrm{NP}$ & NP & NP & 1229.9 \\
\hline UE3c & NP & NP & $\mathrm{NP}$ & $\mathrm{NP}$ & NP & NP & 661 & 692 & 746.8 & NP & NP & $\mathrm{NP}$ & 1215.5 \\
\hline UE3e & NP & $\mathrm{NP}$ & $\mathrm{NP}$ & $\mathrm{NP}$ & $\mathrm{NP}$ & NP & 761.4 & 878.7 & 961 & $\mathrm{NP}$ & $\mathrm{NP}$ & $\mathrm{NP}$ & 1244.5 \\
\hline UE3e_2 & $\mathrm{NP}$ & NP & NP & NP & NP & NP & 757.7 & 875.1 & 957.4 & NP & NP & $\mathrm{NP}$ & 1243.9 \\
\hline UE3e_3 & NDE & NDE & NDE & NDE & NDE & $\mathrm{NDE}$ & 776.3 & 912 & 1000.7 & $\mathrm{NP}$ & NP & NP & 1244.2 \\
\hline UE3e_4 & NP & NP & NP & NP & NP & NP & 761.4 & 878.7 & 960 & NP & NP & NP & 1244.2 \\
\hline UE3eh_1 & NDE & NDE & NDE & NDE & NDE & NDE & 964.7 & NP & NP & $\mathrm{NP}$ & $\mathrm{NP}$ & $\mathrm{NP}$ & 1247.5 \\
\hline UE3lj & NP & NP & $\mathrm{NP}$ & NP & NP & $\mathrm{NP}$ & 745.5 & 863.5 & 930.6 & NP & NP & NP & 1239.9 \\
\hline UE3mf & $\mathrm{NP}$ & $\mathrm{NP}$ & NP & NP & $\mathrm{NP}$ & NP & 832.4 & 949.8 & 1030.5 & $\mathrm{NP}$ & NP & $\mathrm{NP}$ & 1239.3 \\
\hline UE3mo_1 & NDE & NDE & NDE & NDE & NDE & NDE & 1181.1 & $\mathrm{NP}$ & NP & NP & NP & $\mathrm{NP}$ & 1228.0 \\
\hline UE3mo_2 & NDE & NDE & NDE & NDE & NDE & NDE & 1139.3 & NP & $\mathrm{NP}$ & $\mathrm{NP}$ & NP & $\mathrm{NP}$ & 1230.2 \\
\hline UE4a & NP & NP & NP & NP & NP & NP & 940 & 1030 & 1101.9 & NP & NP & $\mathrm{NP}$ & 1266.4 \\
\hline UE4aa & NP & NP & NP & NP & NP & NP & 1057.6 & NP & NP & NP & NP & $\mathrm{NP}$ & 1296.6 \\
\hline UE4abIns & NP & NP & NP & $\mathrm{NP}$ & NP & NP & 978.4 & NP & NP & NP & NP & NP & 1280.5 \\
\hline UE4ac & NP & $\mathrm{NP}$ & NP & $\mathrm{NP}$ & $\mathrm{NP}$ & NP & 1141.8 & $\mathrm{NP}$ & NP & $\mathrm{NP}$ & $\mathrm{NP}$ & $\mathrm{NP}$ & 1301.8 \\
\hline UE4ad & NP & $\mathrm{NP}$ & NP & $\mathrm{NP}$ & NP & NP & 1045.5 & NP & NP & NP & NP & $\mathrm{NP}$ & 1274.4 \\
\hline UE4aelns & NP & $\mathrm{NP}$ & $\mathrm{NP}$ & $\mathrm{NP}$ & NP & NP & 783.9 & $\mathrm{NP}$ & NP & $\mathrm{NP}$ & $\mathrm{NP}$ & $\mathrm{NP}$ & 1258.8 \\
\hline UE4af & NP & $\mathrm{NP}$ & $\mathrm{NP}$ & $\mathrm{NP}$ & $\mathrm{NP}$ & NP & NP & $\mathrm{NP}$ & NP & $\mathrm{NP}$ & $\mathrm{NP}$ & $\mathrm{NP}$ & 1312.2 \\
\hline UE4ahIns & NP & $\mathrm{NP}$ & NP & $\mathrm{NP}$ & NP & NP & 674.2 & 732.5 & 801.6 & NP & NP & $\mathrm{NP}$ & 1262.5 \\
\hline UE4ai & $N P$ & NP & NP & NP & NP & NP & 1088.1 & NP & NP & NP & NP & NP & 1273.1 \\
\hline UE4al & NP & $\mathrm{NP}$ & NP & $\mathrm{NP}$ & $\mathrm{NP}$ & $\mathrm{NP}$ & NP & NP & NP & $\mathrm{NP}$ & NP & $\mathrm{NP}$ & 1266.4 \\
\hline
\end{tabular}




\begin{tabular}{|c|c|c|c|c|c|c|c|c|c|c|c|c|}
\hline Well_Id & EASTING & NORTHING & Gnd_Elev & TD_Elev & MGCU & LCCU & LCA & UCCU & LCA3 & ATCU & OSBCU & LTCU \\
\hline UE4av & 582665.5 & 4105777.5 & 1273.1 & 415.1 & NDE & NDE & 461.5 & NP & NP & 496.2 & 679.1 & 872.9 \\
\hline UE4b & 583436.2 & 4104286.5 & 1259.1 & 298.1 & NDE & NDE & 352.6 & NP & NP & 415.1 & NP & NP \\
\hline UE4c & 583426.6 & 4105813.4 & 1268.6 & 646.8 & NDE & NDE & 670 & NP & NP & 705.7 & 729.1 & 826.6 \\
\hline UE4f & 584207.3 & 4104853.8 & 1258.5 & 163.4 & NDE & NDE & 187.1 & NP & $\mathrm{NP}$ & 252.1 & 342.6 & 783 \\
\hline UE4g_2 & 584330.8 & 4106380.6 & 1265.5 & 518.2 & NDE & NDE & NDE & NDE & NDE & NDE & 541.3 & 793.1 \\
\hline UE4p & 584547.1 & 4107086.8 & 1269.2 & 469.4 & NDE & NDE & 490.4 & NP & NP & 511.5 & 623 & 937 \\
\hline UE4t & 584576.0 & 4106066.1 & 1263.1 & 527.6 & NDE & NDE & NDE & NDE & NDE & NDE & 616.9 & 955.2 \\
\hline UE6d & 583751.3 & 4093397.3 & 1203.0 & 15.5 & NDE & NDE & NDE & NDE & NDE & NDE & NDE & NDE \\
\hline UE6d_2 & 588629.6 & 4093262.0 & 1198.5 & 745.2 & NDE & NDE & NDE & NDE & NDE & NDE & NDE & 773.9 \\
\hline UE6d_3 & 588553.4 & 4093261.7 & 1198.5 & 317.9 & NDE & NDE & 378.9 & NP & NP & NP & 529.4 & 753.5 \\
\hline UE6e & 587012.5 & 4093408.8 & 1200.3 & -82.6 & NDE & NDE & -14.9 & NP & NP & -3.6 & 309.7 & 526.1 \\
\hline UE7aa & 589492.9 & 4102909.3 & 1298.1 & 641.6 & NDE & NDE & 822.7 & NP & NP & 853.1 & 892.8 & 1060.4 \\
\hline UE7ax & 587826.2 & 4106845.1 & 1338.1 & 923.8 & NDE & NDE & 928.7 & NP & NP & NP & 1012.9 & 1140 \\
\hline UE7az & 587766.3 & 4104381.5 & 1285.6 & 541.6 & NDE & NDE & 544.4 & NP & NP & 631.5 & 729.4 & 957.4 \\
\hline UE7ba & 584885.3 & 4104756.6 & 1258.8 & 518.7 & NDE & NDE & 528.5 & NP & NP & 566.6 & 656.8 & 981.8 \\
\hline UE7bc & 588485.8 & 4103774.6 & 1287.8 & 462.7 & NDE & NDE & 465.1 & NP & NP & 495.3 & 773 & 1059.2 \\
\hline UE7be & 586150.7 & 4106356.6 & 1292.7 & 499.0 & NDE & NDE & 509.3 & NP & NP & NP & 731.8 & 965 \\
\hline UE7bh & 589420.7 & 4105240.8 & 1331.7 & 994.9 & NDE & NDE & 1007 & NP & NP & 1017.7 & NP & 1200.6 \\
\hline UE7bi & 588860.7 & 4105147.2 & 1316.4 & 662.9 & NDE & NDE & 664.2 & NP & NP & 676.3 & 917.1 & NP \\
\hline UE7f & 584527.5 & 4105135.0 & 1257.0 & 396.2 & NDE & NDE & 402.3 & NP & NP & 438 & 574.5 & 891.5 \\
\hline UE7h & 588370.3 & 4106564.6 & 1338.7 & 558.1 & NDE & NDE & 738.2 & NP & NP & 774.8 & 985.1 & 1186 \\
\hline UE7i & 586950.3 & 4106801.2 & 1319.8 & 426.7 & NDE & NDE & 597.4 & NP & NP & 613.6 & 815.3 & 1043.9 \\
\hline UE7j & 587516.7 & 4106056.6 & 1315.5 & 454.2 & NDE & NDE & 613.9 & NP & NP & 630.9 & 769.9 & 1045.5 \\
\hline UE7k & 586121.7 & 4104132.0 & 1257.6 & 481.0 & NDE & NDE & 519.4 & $\mathrm{NP}$ & NP & 533.1 & 689.2 & NP \\
\hline UE7I & 585229.1 & 4106658.1 & 1275.9 & 447.4 & NDE & NDE & 634.3 & NP & NP & 655.3 & NP & 849.2 \\
\hline UE7m & 589008.9 & 4105112.6 & 1317.7 & 730.6 & NDE & NDE & 766.6 & NP & NP & 784 & 941.2 & 1074.4 \\
\hline UE7nS & 588643.5 & 4106091.4 & 1331.0 & 658.9 & NDE & NDE & 831.2 & NP & NP & NP & 913.5 & 1177.1 \\
\hline UE8c & 581414.1 & 4115024.3 & 1376.2 & 922.6 & NDE & NDE & 974.1 & NP & NP & NP & 1114.1 & NP \\
\hline UE8d & 581783.6 & 4114197.1 & 1352.7 & 972.9 & NDE & NDE & 994.6 & NP & NP & NP & 1047.6 & NP \\
\hline UE8e_1 & 580914.2 & 4114017.3 & 1370.4 & 576.4 & NDE & NDE & 623.6 & NP & NP & 671.5 & 782.1 & NP \\
\hline UE8e_2 & 580693.8 & 4113864.1 & 1374.0 & 685.2 & NDE & NDE & 703.4 & NP & NP & 733.9 & NP & NP \\
\hline UE8elnst & 580998.1 & 4113987.1 & 1368.2 & 615.3 & NDE & NDE & 631.8 & $\mathrm{NP}$ & NP & 664.1 & 804.3 & 811.9 \\
\hline UE8f & 580180.3 & 4114223.7 & 1389.9 & 704.7 & NDE & NDE & NDE & NDE & 737.9 & 744.2 & NP & NP \\
\hline UE8h & 579792.0 & 4114335.1 & 1400.3 & 909.5 & NDE & NDE & NDE & NDE & 1025.3 & 1078.7 & $\mathrm{NP}$ & NP \\
\hline
\end{tabular}




\begin{tabular}{|c|c|c|c|c|c|c|c|c|c|c|c|c|c|}
\hline Well_Id & TUBA & PRETBG & BRCU & BRA & TSA & UTCU & TMLVTA & TMWTA & TMUTVA & BLFA & IDP & PCUT & AA \\
\hline UE4av & $N P$ & NP & $\mathrm{NP}$ & $\mathrm{NP}$ & $\mathrm{NP}$ & $\mathrm{NP}$ & 918 & 980.2 & 1004.6 & $\mathrm{NP}$ & NP & $\mathrm{NP}$ & 1273.1 \\
\hline UE4b & NP & NP & NP & NP & NP & NP & 832 & 856.2 & NP & NP & NP & NP & 1259.1 \\
\hline UE4c & NP & NP & NP & $\mathrm{NP}$ & NP & NP & 850 & 884.6 & 904.3 & NP & NP & $\mathrm{NP}$ & 1268.6 \\
\hline UE4f & NP & NP & NP & $\mathrm{NP}$ & NP & NP & 801.3 & 909.5 & 969 & NP & NP & NP & 1258.5 \\
\hline UE4g_2 & NP & NP & $\mathrm{NP}$ & $\mathrm{NP}$ & NP & NP & 927.2 & 1027.8 & 1081.1 & NP & $\mathrm{NP}$ & $\mathrm{NP}$ & 1265.5 \\
\hline UE4p & NP & $\mathrm{NP}$ & NP & $\mathrm{NP}$ & NP & NP & 967.4 & 1068 & 1083.3 & NP & NP & NP & 1269.2 \\
\hline UE4t & $\mathrm{NP}$ & NP & $\mathrm{NP}$ & $\mathrm{NP}$ & NP & $\mathrm{NP}$ & 976.6 & 1093.9 & 1132 & NP & NP & $\mathrm{np}$ & 1263.1 \\
\hline UE6d & NDE & NDE & NDE & NDE & $\mathrm{NDE}$ & NDE & 41.8 & NP & NP & $\mathrm{NP}$ & $\mathrm{NP}$ & 1115 & 1203.0 \\
\hline UE6d_2 & $\mathrm{NP}$ & NP & $\mathrm{NP}$ & NP & 867.5 & 878.4 & 927.2 & 991.2 & NP & NP & NP & NP & 1198.5 \\
\hline UE6d_3 & NP & NP & NP & NP & 842.2 & 857.4 & 909.2 & 979.3 & NP & NP & NP & NP & 1198.5 \\
\hline UE6e & NP & NP & NP & $\mathrm{NP}$ & 627.3 & 651.1 & 705.9 & 773.6 & NP & NP & NP & 1002 & 1199.7 \\
\hline UE7aa & $\mathrm{NP}$ & $\mathrm{NP}$ & $\mathrm{NP}$ & $\mathrm{NP}$ & NP & NP & 1237.2 & NP & NP & $\mathrm{NP}$ & $\mathrm{NP}$ & $\mathrm{NP}$ & 1298.1 \\
\hline UE7ax & NP & NP & NP & $\mathrm{NP}$ & NP & NP & 1257.6 & $\mathrm{NP}$ & NP & NP & $\mathrm{NP}$ & $\mathrm{NP}$ & 1338.1 \\
\hline UE7az & NP & NP & NP & $\mathrm{NP}$ & NP & NP & 984 & NP & 1060.1 & NP & NP & NP & 1285.6 \\
\hline UE7ba & NP & NP & NP & $\mathrm{NP}$ & NP & NP & 1011.3 & 1124.7 & 1163.1 & NP & NP & $\mathrm{NP}$ & 1258.8 \\
\hline UE7bc & $\mathrm{NP}$ & $\mathrm{NP}$ & $\mathrm{NP}$ & $\mathrm{NP}$ & $\mathrm{NP}$ & NP & 1120 & 1162.8 & NP & $\mathrm{NP}$ & $\mathrm{NP}$ & $\mathrm{NP}$ & 1287.8 \\
\hline UE7be & NP & NP & NP & $\mathrm{NP}$ & NP & NP & 992.4 & 1064.1 & 1102.2 & NP & NP & $\mathrm{NP}$ & 1292.7 \\
\hline UE7bh & $\mathrm{NP}$ & $\mathrm{NP}$ & NP & $\mathrm{NP}$ & $\mathrm{NP}$ & NP & 1328.6 & NP & NP & $\mathrm{NP}$ & NP & NP & 1331.7 \\
\hline UE7bi & NP & NP & NP & $\mathrm{NP}$ & NP & NP & 1196 & 1244.8 & 1266.1 & NP & NP & NP & 1316.4 \\
\hline UE7f & $\mathrm{NP}$ & $\mathrm{NP}$ & NP & $\mathrm{NP}$ & $\mathrm{NP}$ & NP & 914.4 & 1028.4 & 1086.3 & $\mathrm{NP}$ & $\mathrm{NP}$ & $\mathrm{NP}$ & 1257.0 \\
\hline UE7h & $\mathrm{NP}$ & $\mathrm{NP}$ & NP & $\mathrm{NP}$ & $\mathrm{NP}$ & NP & 1245.7 & 1268.6 & 1286.9 & NP & NP & NP & 1338.7 \\
\hline UE7i & $\mathrm{NP}$ & $\mathrm{NP}$ & NP & $\mathrm{NP}$ & $\mathrm{NP}$ & $\mathrm{NP}$ & 1135.4 & 1182.6 & NP & $\mathrm{NP}$ & $\mathrm{NP}$ & NP & 1319.8 \\
\hline UE7j & NP & $\mathrm{NP}$ & NP & $\mathrm{NP}$ & NP & NP & 1075.9 & 1168 & 1197.9 & NP & NP & NP & 1315.5 \\
\hline UE7k & $\mathrm{NP}$ & $\mathrm{NP}$ & $\mathrm{NP}$ & $\mathrm{NP}$ & NP & NP & 995 & 1014 & 1065.6 & $\mathrm{NP}$ & NP & NP & 1257.6 \\
\hline UE7I & NP & NP & NP & $\mathrm{NP}$ & NP & NP & 870.8 & 959.8 & 978.1 & NP & NP & NP & 1275.9 \\
\hline UE7m & NP & NP & NP & $\mathrm{NP}$ & NP & NP & 1190.2 & 1254.3 & NP & NP & NP & $\mathrm{NP}$ & 1317.7 \\
\hline UE7nS & NP & NP & NP & $\mathrm{NP}$ & NP & NP & 1275.3 & $\mathrm{NP}$ & NP & NP & NP & NP & 1331.1 \\
\hline UE8c & $\mathrm{NP}$ & $\mathrm{NP}$ & NP & $\mathrm{NP}$ & $\mathrm{NP}$ & NP & 1250.2 & NP & NP & $\mathrm{NP}$ & $\mathrm{NP}$ & $\mathrm{NP}$ & 1376.2 \\
\hline UE8d & $\mathrm{NP}$ & $\mathrm{NP}$ & NP & $\mathrm{NP}$ & $\mathrm{NP}$ & NP & 1218.7 & $\mathrm{NP}$ & NP & NP & NP & $\mathrm{NP}$ & 1352.7 \\
\hline UE8e_1 & $\mathrm{NP}$ & $\mathrm{NP}$ & NP & $\mathrm{NP}$ & $\mathrm{NP}$ & NP & 990 & $\mathrm{NP}$ & $\mathrm{NP}$ & $\mathrm{NP}$ & $\mathrm{NP}$ & $\mathrm{NP}$ & 1370.4 \\
\hline UE8e_2 & NP & $\mathrm{NP}$ & $\mathrm{NP}$ & $\mathrm{NP}$ & $\mathrm{NP}$ & $\mathrm{NP}$ & 1038.7 & $\mathrm{NP}$ & NP & $\mathrm{NP}$ & $\mathrm{NP}$ & $\mathrm{NP}$ & 1374.0 \\
\hline UE8elnst & NP & $\mathrm{NP}$ & NP & $\mathrm{NP}$ & NP & NP & 1098.5 & $\mathrm{NP}$ & NP & NP & NP & $\mathrm{NP}$ & 1368.2 \\
\hline UE8f & NP & $\mathrm{NP}$ & NP & NP & $\mathrm{NP}$ & NP & 1054.9 & NP & NP & $\mathrm{NP}$ & NP & $\mathrm{NP}$ & 1389.9 \\
\hline UE8h & NP & $\mathrm{NP}$ & NP & NP & $\mathrm{NP}$ & $\mathrm{NP}$ & 1238.1 & NP & NP & $\mathrm{NP}$ & NP & $\mathrm{NP}$ & 1400.3 \\
\hline
\end{tabular}


Table A-1. Hydrostratigraphic Data for Selected Drill Holes in the Yucca Flat CAU Model Area.

\begin{tabular}{|c|c|c|c|c|c|c|c|c|c|c|c|c|}
\hline Well_Id & EASTING & NORTHING & Gnd_Elev & TD_Elev & MGCU & LCCU & LCA & UCCU & LCA3 & ATCU & OSBCU & LTCU \\
\hline UE8i & 579988.3 & 4114147.8 & 1391.7 & 1026.0 & $\mathrm{NDE}$ & NDE & NDE & $\mathrm{NDE}$ & NDE & NDE & NDE & NDE \\
\hline UE8n & 580478.5 & 4114442.4 & 1386.5 & 663.5 & NDE & NDE & NDE & NDE & 685.5 & 705.6 & 1017.4 & 1061.9 \\
\hline UE80 & 580852.9 & 4115418.5 & 1399.0 & 1304.5 & NDE & NDE & NDE & NDE & NDE & NDE & NDE & NDE \\
\hline UE9_29_1 & 585556.5 & 4110961.3 & 1294.8 & 914.4 & NDE & NDE & 947.9 & NP & NP & $N P$ & NP & $N P$ \\
\hline UE9_30_5 & 585824.6 & 4111146.6 & 1299.7 & 933.9 & NDE & NDE & 958.6 & NP & NP & 976 & NP & 1043.7 \\
\hline UE9cg & 584466.6 & 4111195.8 & 1290.2 & 913.2 & NDE & NDE & NDE & NDE & NDE & NDE & NDE & NDE \\
\hline UE9cn & 587385.1 & 4107782.4 & 1338.4 & 893.4 & NDE & NDE & 914.4 & NP & NP & 933 & NP & NP \\
\hline UE9cp & 586012.8 & 4109113.9 & 1296.3 & 736.7 & NDE & NDE & 753.8 & NP & NP & 759.9 & 848.2 & 936.6 \\
\hline UE9IS25 & 585153.6 & 4110463.8 & 1286.9 & 668.7 & NDE & NDE & 689.8 & NP & NP & NP & NP & 878.5 \\
\hline UE9ITS_1 & 586696.2 & 4109741.6 & 1321.9 & 1119.8 & NDE & NDE & 1132.9 & NP & NP & NP & NP & 1172.5 \\
\hline UE9ITS_2 & 586583.9 & 4111264.2 & 1319.8 & 1142.1 & NDE & NDE & 1154.9 & NP & NP & NP & NP & NP \\
\hline UE9ITS_3 & 585795.1 & 4110347.2 & 1296.0 & 946.4 & NDE & NDE & 985.1 & NP & NP & 994.2 & NP & 1024.7 \\
\hline UE9ITS_4 & 586041.1 & 4109738.6 & 1298.8 & 1012.2 & NDE & NDE & 1021.7 & NP & NP & NP & NP & NP \\
\hline UE9ITS_5 & 586036.5 & 4111201.3 & 1303.3 & 1036.0 & NDE & NDE & 1047.3 & NP & NP & NP & NP & NP \\
\hline UENB & 596393.2 & 4116535.9 & 1417.9 & 1128.3 & $\mathrm{NDE}$ & 1418 & NP & NP & NP & NP & NP & NP \\
\hline UEU22 & 585430.3 & 4110114.4 & 1287.2 & 733.3 & NDE & NDE & NDE & NDE & NDE & NDE & NDE & NDE \\
\hline UEU29_2 & 585398.5 & 4110926.3 & 1293.0 & 813.8 & $\mathrm{NDE}$ & NDE & 859.8 & NP & NP & $\mathrm{NP}$ & NP & 945 \\
\hline WW2 - & 581005.7 & 4113499.5 & 1362.3 & 479.6 & NDE & NDE & 582.2 & NP & NP & 609.7 & NP & NP \\
\hline
\end{tabular}


Table A-1. Hydrostratigraphic Data for Selected Drill Holes in the Yucca Flat CAU Model Area.

\begin{tabular}{|c|c|c|c|c|c|c|c|c|c|c|c|c|c|}
\hline Well_Id & TUBA & PRETBG & BRCU & BRA & TSA & UTCU & TMLVTA & TMWTA & TMUTVA & BLFA & IDP & PCUT & AA \\
\hline UE8i & NDE & NDE & NDE & NDE & NDE & NDE & 1091.8 & $\mathrm{NP}$ & $\mathrm{NP}$ & $\mathrm{NP}$ & $\mathrm{NP}$ & $\mathrm{NP}$ & 1391.7 \\
\hline UE8n & NP & NP & NP & NP & NP & NP & 1184.5 & NP & NP & NP & NP & NP & 1386.5 \\
\hline UE8o & NDE & NDE & NDE & NDE & NDE & NDE & 1307.9 & NP & NP & NP & NP & NP & 1399.0 \\
\hline UE9_29_1 & NP & NP & NP & NP & NP & NP & 1201.8 & NP & NP & NP & NP & NP & 1294.8 \\
\hline UE9_30_5 & NP & NP & NP & NP & NP & NP & 1244.8 & NP & NP & NP & NP & NP & 1299.7 \\
\hline UE9cg & NDE & NDE & NDE & NDE & NDE & NDE & NDE & 930.2 & 940.3 & NP & NP & NP & 1290.2 \\
\hline UE9cn & NP & NP & NP & NP & NP & NP & 1276.4 & NP & NP & NP & NP & NP & 1338.4 \\
\hline UE9cp & NP & NP & NP & NP & NP & NP & 1175.3 & NP & NP & NP & NP & NP & 1296.3 \\
\hline UE9IS25 & NP & NP & NP & NP & NP & NP & 1070.9 & NP & NP & NP & NP & NP & 1286.9 \\
\hline UE9ITS_1 & NP & NP & NP & NP & NP & NP & 1184.9 & NP & NP & NP & NP & NP & 1321.9 \\
\hline UE9ITS_2 & NP & NP & NP & NP & NP & NP & 1261.8 & NP & NP & NP & NP & NP & 1319.8 \\
\hline UE9ITS_3 & NP & NP & NP & NP & NP & NP & 1204 & NP & NP & NP & NP & NP & 1296.0 \\
\hline UE9ITS_4 & NP & NP & NP & NP & NP & NP & 1216.8 & NP & NP & NP & NP & NP & 1298.8 \\
\hline UE9ITS_5 & NP & NP & NP & NP & NP & NP & 1230.3 & NP & NP & NP & NP & NP & 1303.3 \\
\hline UENB & NP & NP & NP & NP & NP & NP & NP & NP & NP & NP & NP & NP & 1417.9 \\
\hline UEU22 & NDE & NDE & NDE & NDE & NDE & NDE & 1120.7 & NP & NP & NP & NP & NP & 1287.2 \\
\hline UEU29_2 & NP & NP & NP & NP & NP & NP & 1179 & NP & NP & NP & NP & NP & 1293.0 \\
\hline WW2 & NP & NP & NP & NP & NP & NP & 981.5 & NP & NP & NP & NP & NP & 1362.5 \\
\hline
\end{tabular}


This page intentionally left blank. 


\title{
APPENDIX B
}

Graphical Presentations for Selected UGTA Wells in the Yucca Flat - Climax Mine Model Area Showing Stratigraphy, Lithology, Alteration, and Hydrogeologic Units

\author{
B-1 Well ER-2-1 (DOE, 2004b) \\ B-2 Well Cluster ER-6-1 (DOE, 2004a) \\ B-3 Well ER-7-1 (DOE, 2004c) \\ B-4 Well ER-8-1 (DOE, 2004d) \\ B-5 Well ER-12-2 (DOE, 2004e)
}




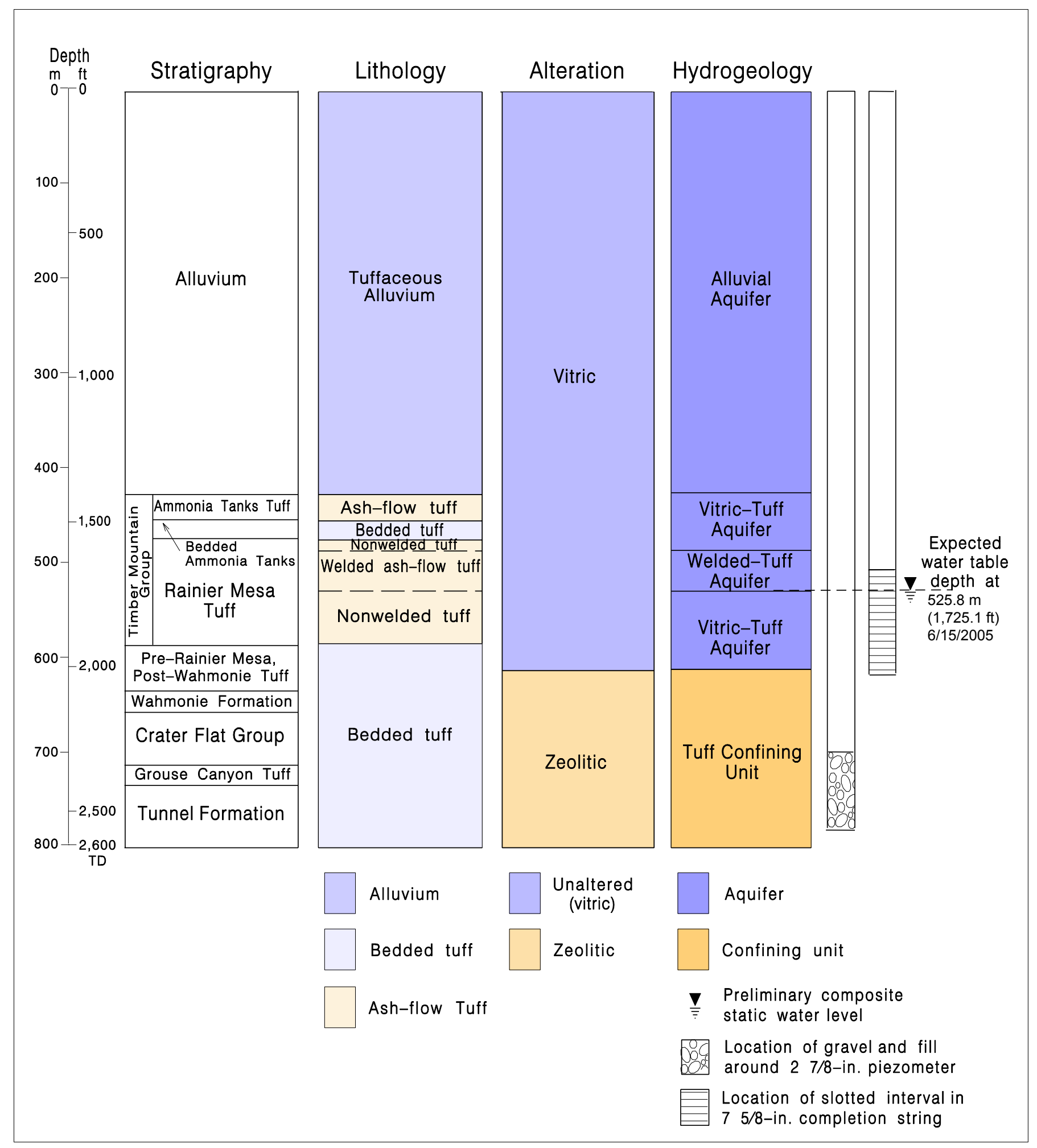

Figure B-1

Graphical Presentation Showing Stratigraphy, Lithology, Alteration, and Hydrogeolgic Units for UGTA Well ER-2-1 


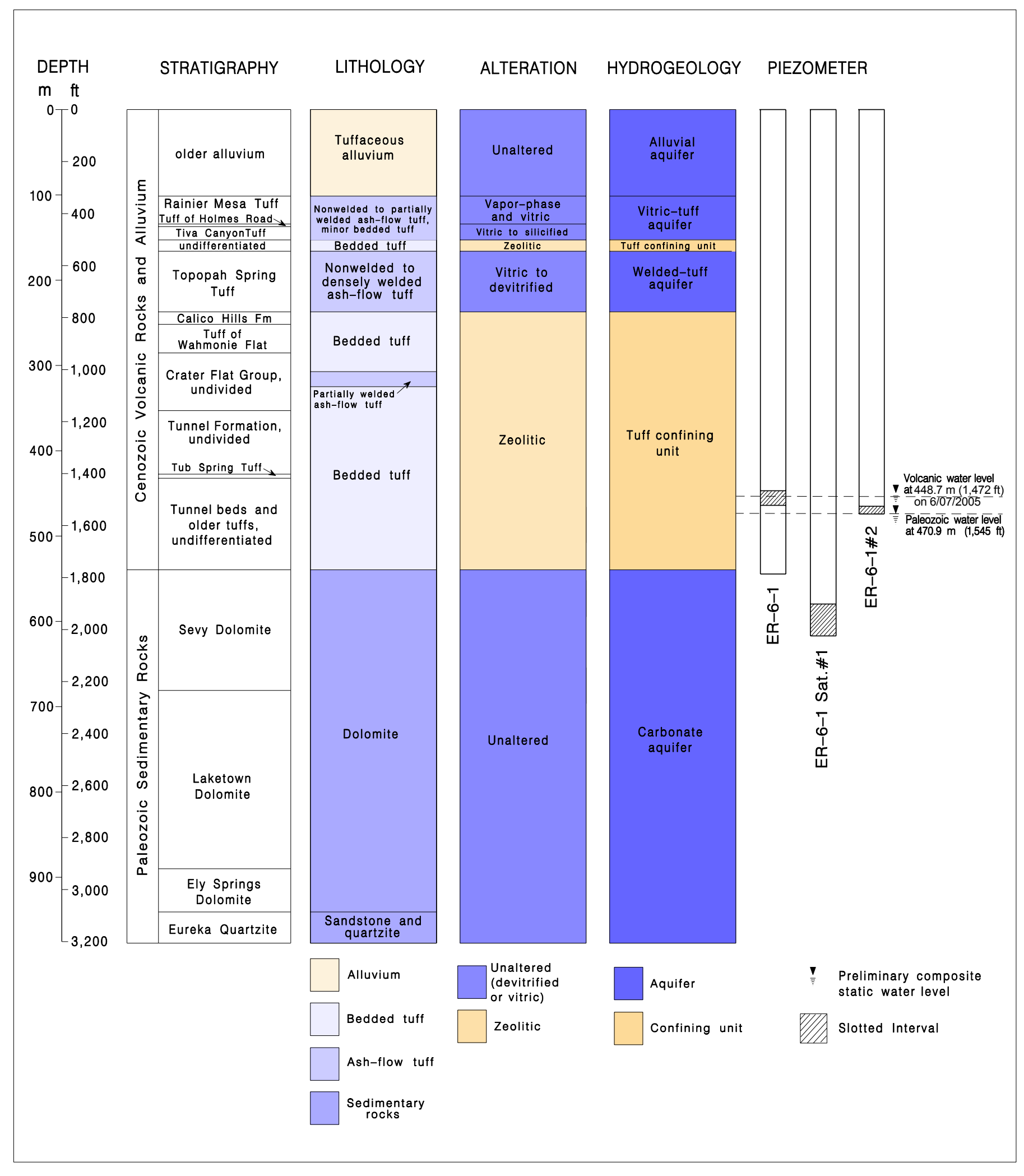

Figure B-2

Graphical Presentation Showing Stratigraphy, Lithology, Alteration, and Hydrogeolgic Units for UGTA Well Cluster ER-6-1 


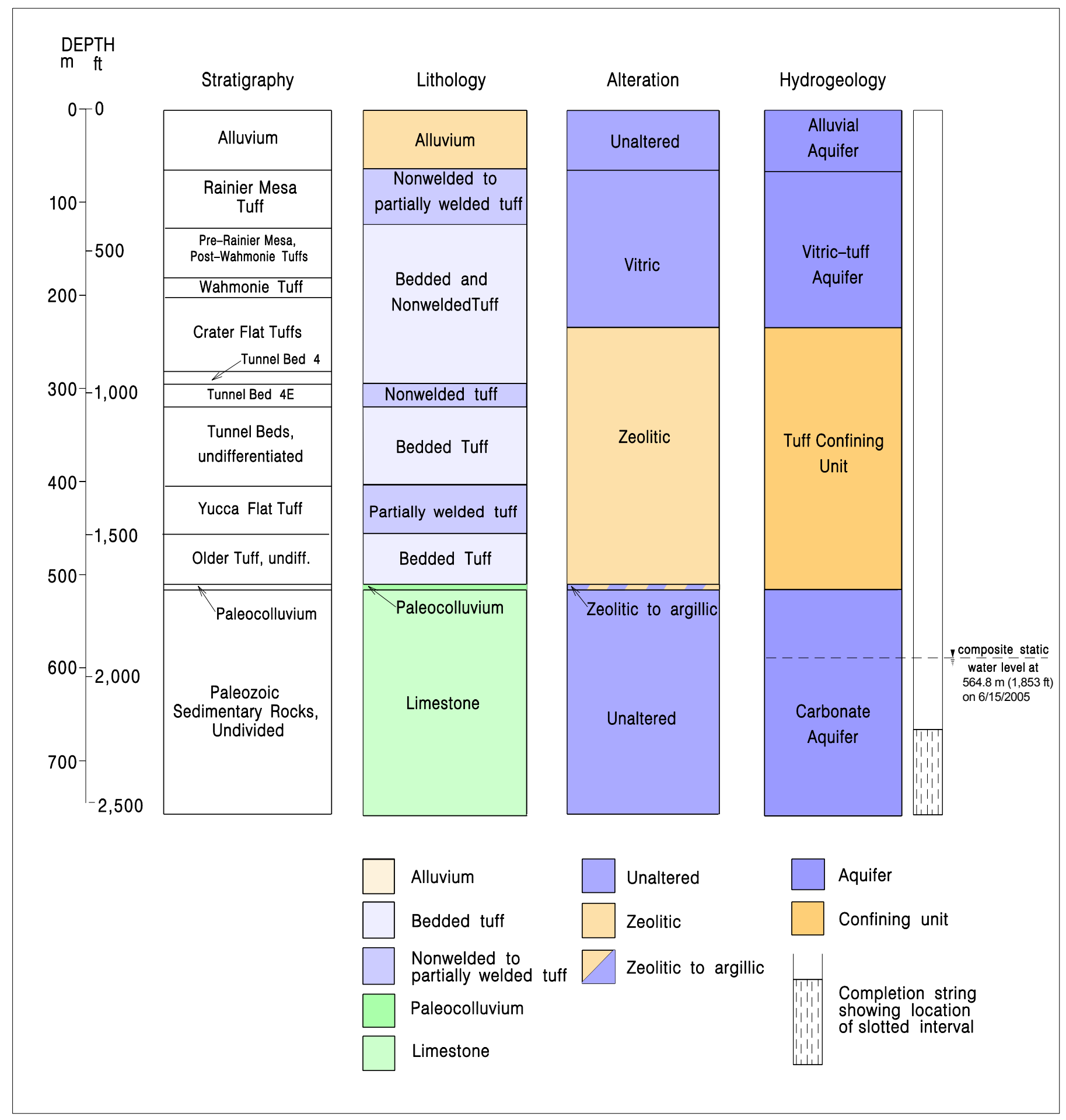

Figure B-3

Graphical Presentation Showing Stratigraphy, Lithology, Alteration, and Hydrogeolgic Units for UGTA Well ER-7-1 


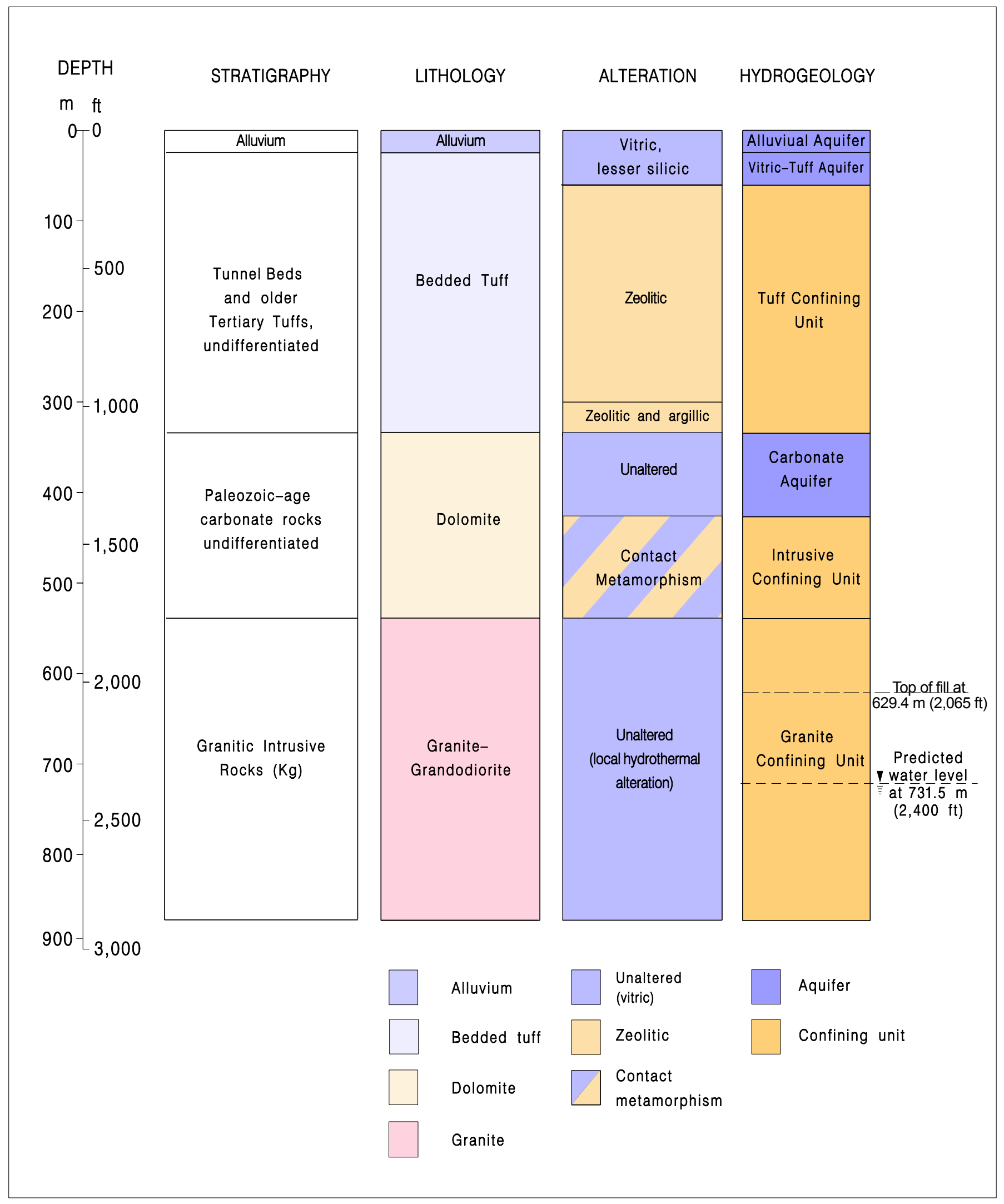

Figure B-4

Graphical Presentation Showing Stratigraphy, Lithology, Alteration, and Hydrogeolgic Units for UGTA Well ER-8-1 


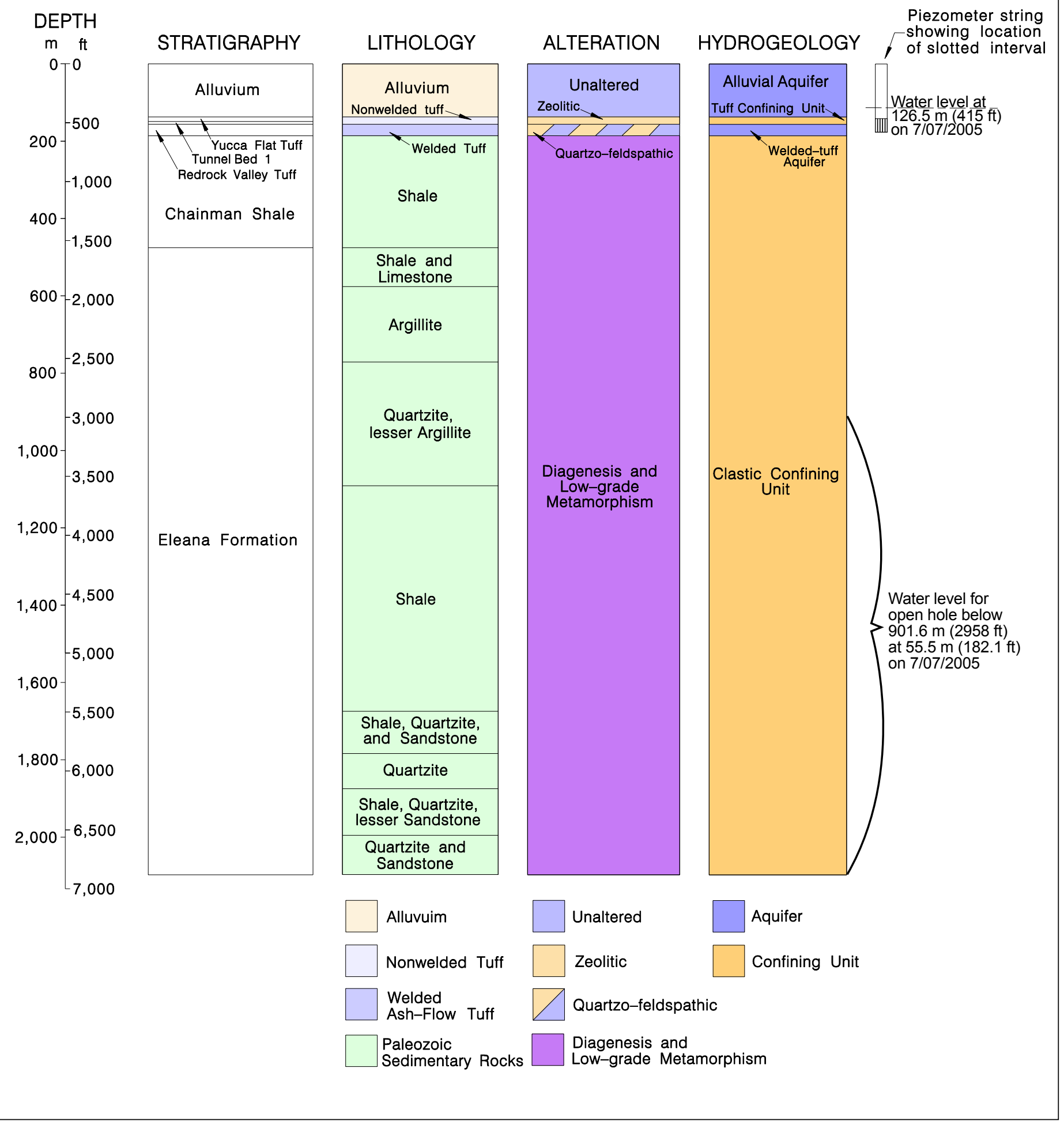

Figure B-5

Graphical Presentation Showing Stratigraphy, Lithology, Alteration, and Hydrogeolgic Units for UGTA Well ER-12-2 


\section{APPENDIX C}

Hydrostratigraphic Profiles through the Yucca Flat - Climax Mine Model Area 
North-South Model Profile $\left(A-A^{\prime}\right)$ through Western Yucca Flat

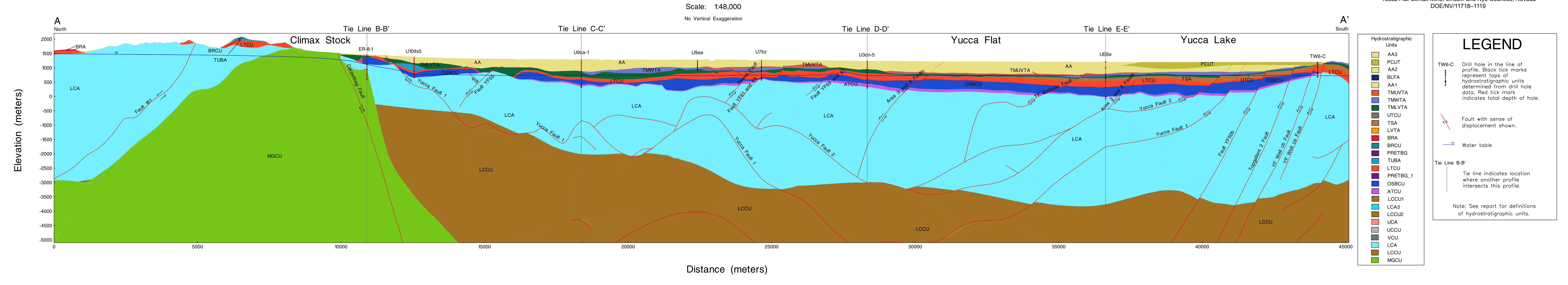




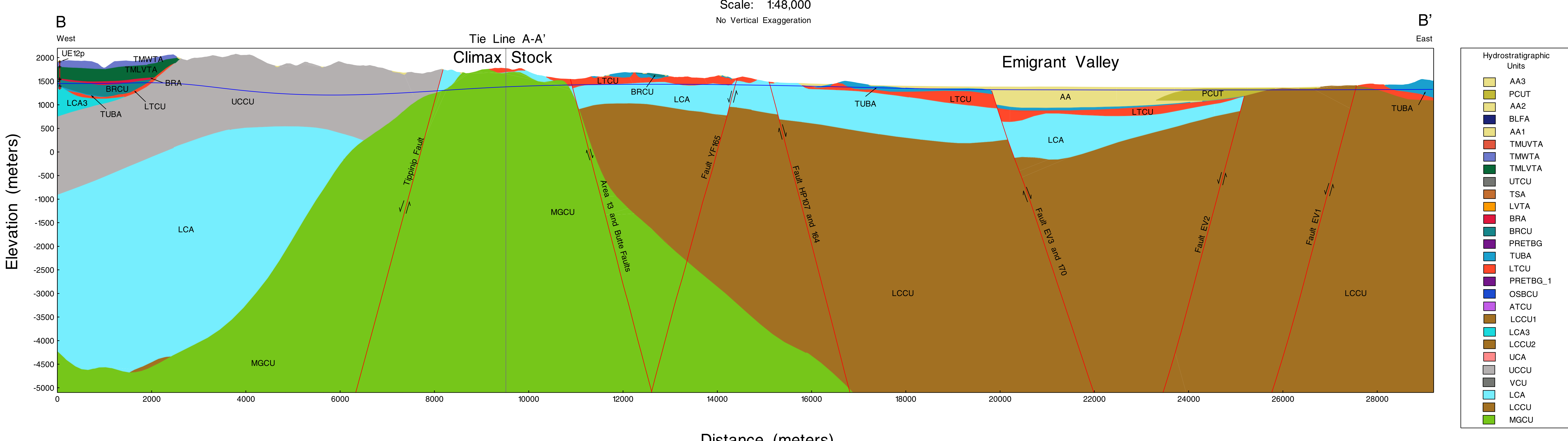

LEGEND

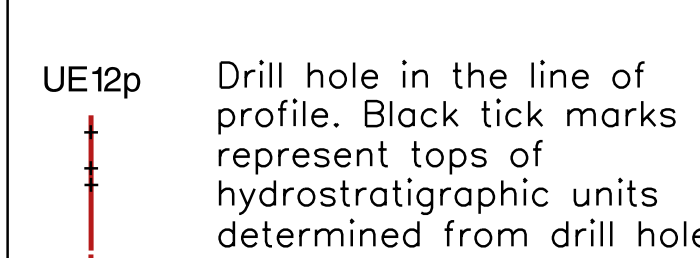

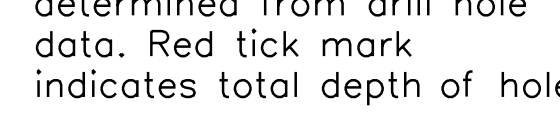

woter toble

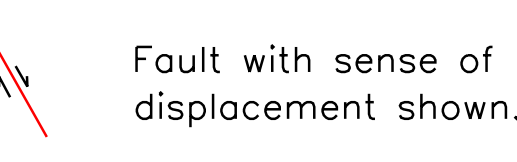

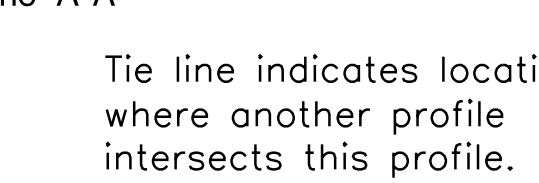

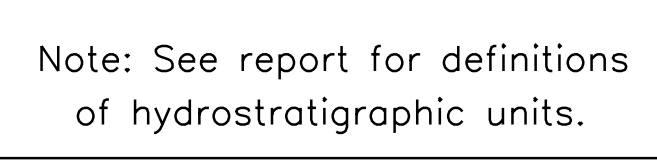


West - East Model Profile (C-C') through Well Gravity High 1

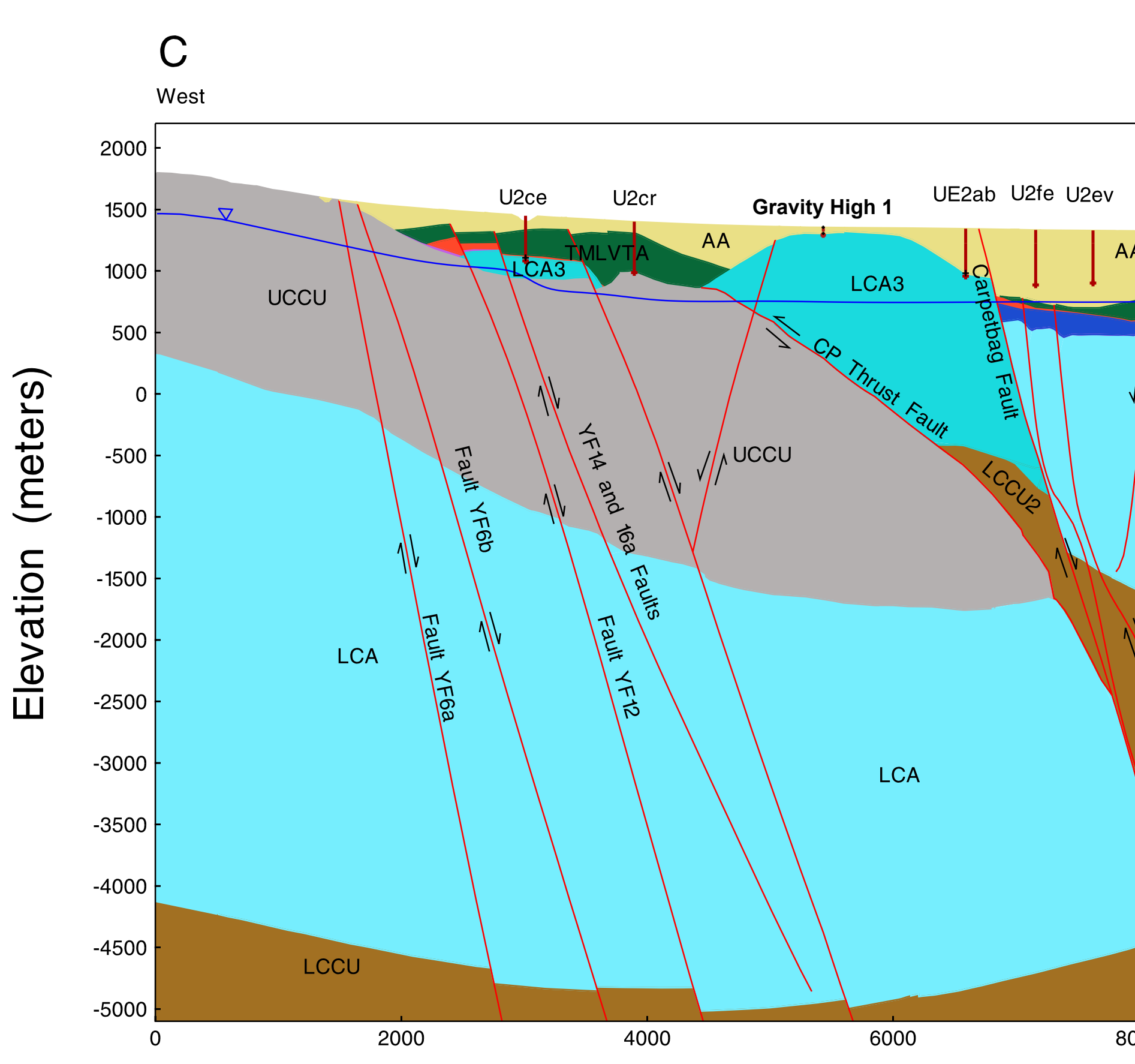

Scale: $1: 48,000$
No verical 4 xagageration

$$
\begin{aligned}
& \text { Tie Line }\left(A-A^{\prime}\right) \\
& \text { Yucca Flat }
\end{aligned}
$$

Halfpint Range

$\underset{\text { LTCU }}{\text { Halfpint Range }}$

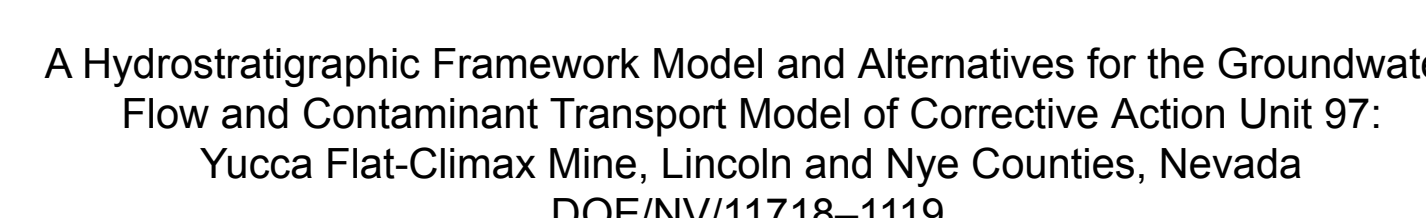

$C^{\prime}$

$[+$


West - East Model Profile (D-D') through Central Yucca Flat at Well U-3cn-5

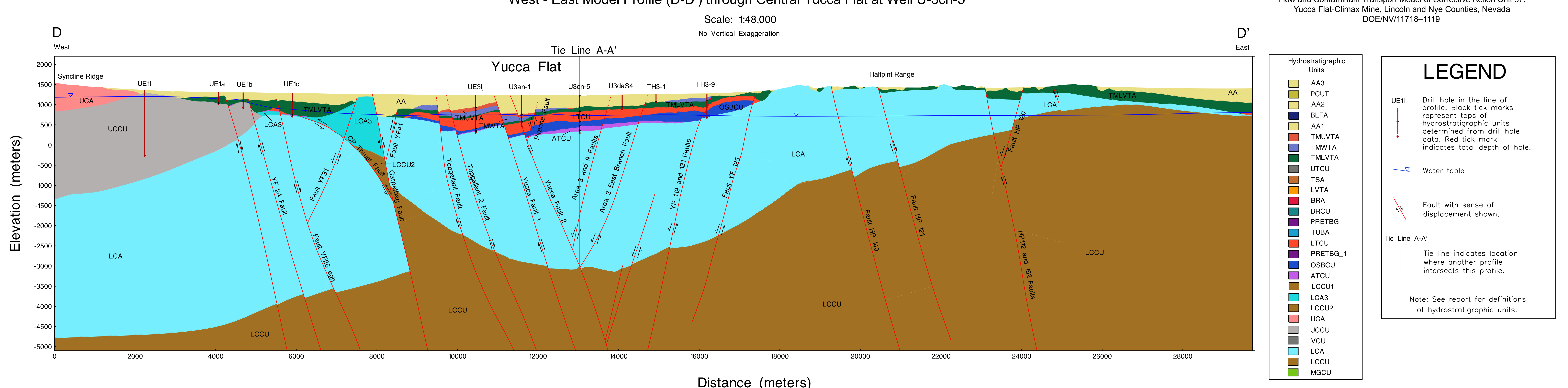

Distance (meters) 
West - East Model Profile (E-E') through Southern Yucca Flat at Well ER-6-1\#2

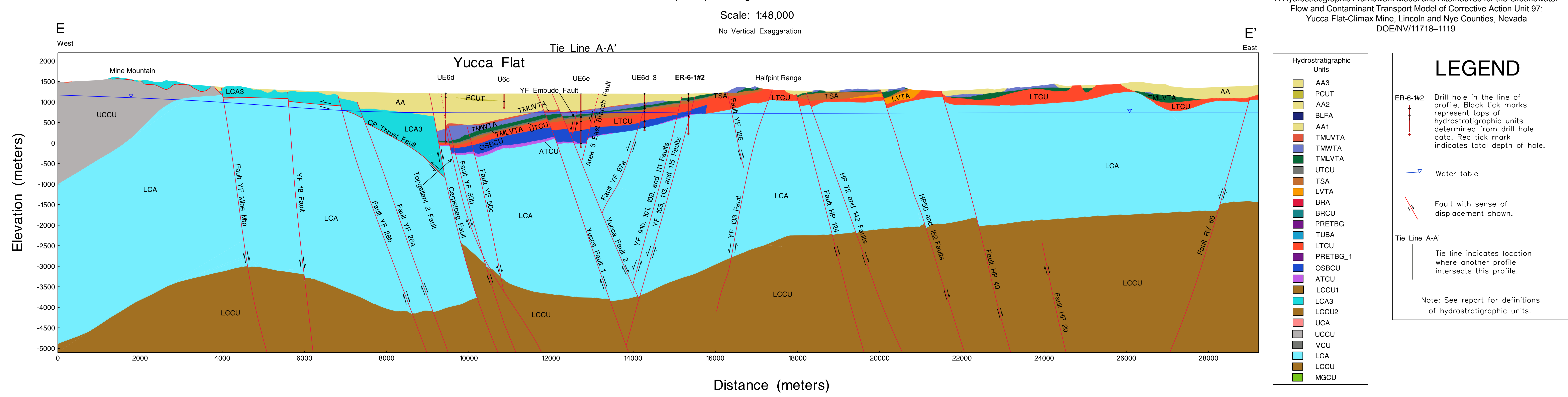




\section{APPENDIX D}

\section{Magnetotelluric Survey Conducted in the Yucca Flat - Climax Mine Model Area}




\title{
Yucca Flat Magnetotelluric Survey Interpreted Profiles
}

\author{
by \\ Lance Prothro \\ Bechtel Nevada Geotechnical Sciences \\ September 2005
}

\begin{abstract}
Summary
The magnetotelluric method proved very successful in providing important constraints on the general thickness and lateral extent of the upper clastic confining unit beneath Yucca Flat. The data indicate that this thick, electrically conductive siliciclastic sequence is confined to the western portions of the basin, and is not present beneath the central and eastern portions of Yucca Flat. The data also indicate that this unit has a maximum thickness of 2,000 to 3,000 meters (6,600 to 9,800 feet ) beneath the western portion of the basin.
\end{abstract}

\subsection{Background Information}

A natural-source magnetotelluric (MT) survey was conducted in the Yucca Flat area in 2003 to better constrain the three-dimensional distribution of the upper clastic confining unit (UCCU) beneath the basin. The UCCU consists of Mississippian siliciclastic rocks assigned to the Eleana Formation and Chainman Shale. The survey was conducted by personnel from the U.S. Geological Survey (USGS), and consisted of 51 stations established along 7 generally eastwest oriented lines across the basin (Figure D-1). Stations were typically spaced 2 to 3 kilometers $(\mathrm{km})$ (1.2 to 1.9 miles [mi]) apart. Data were collected with both high and low frequency MT systems (Asch et.al., 2005). USGS personnel processed the MT data, and provided two-dimensional (2-D) inverted resistivity models along each profile to Bechtel Nevada geologists for interpretation and integration into the Yucca Flat hydrostratigraphic framework model (Rodriguez 2004a). USGS personnel also performed 2-D forward modeling of the data to address questions presented by Bechtel Nevada geologists (Rodriguez, 2004b). Forward modeling mostly involved determining the resolution of the MT data with regards to the thickness and lateral extent of the UCCU.

The MT method was chosen over other geophysical methods because 1) the MT method could exploit the geology of the upper Paleozoic section that includes thick, electrically conductive UCCU overlying very thick high resitivity carbonate rocks, and 2) other geophysical methods such as gravity, magnetics, and seismic conducted previously in Yucca Flat had been unsuccessful in adequately characterizing pre-Tertiary structure and stratigraphy beneath the basin. 
This page intentionally left blank. 


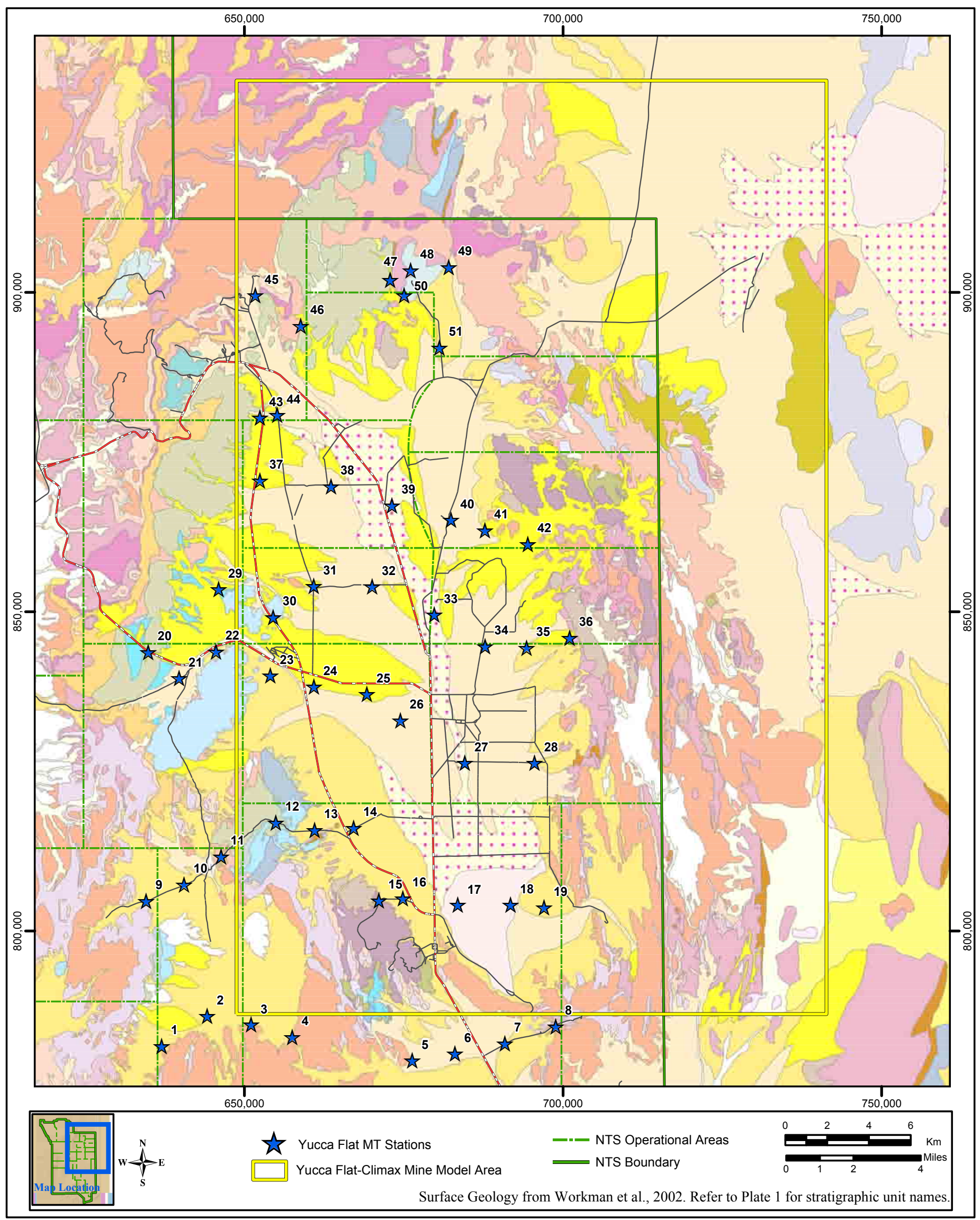

Figure D-1

Magnetotelluric (MT) Stations in the Yucca Flat-Climax Mine Model Area 


\subsection{Interpreted Profiles}

This section describes the interpretation of each of the 2-D inverted profile models. For reference, an interpreted 2-D profile is provided after each discussion. These profiles extend from the surface to 3,000 $\mathrm{m}$ (9,800 ft). A geologic map with MT station locations and nearby drill holes is provided for each profile. Figure D-2 provides the legend applicable to each of the geologic maps.

Results of 2-D forward modeling are also discussed. Forward modeling was performed to a depth of 10,000 m (32,800 ft) to investigate whether UCCU occurs below 3,000 m (9,800 ft), particularly beneath eastern Yucca Flat.

Certain limitations regarding the resolution of MT data should be considered when interpreting the profiles, particularly with respect to the distribution of the UCCU. In order for zones of resistivity contrast such as the UCCU to be resolved using MT data, they must be of sufficient thickness. A general "rule of thumb" is that the thickness of a zone must be at least one tenth of the depth to be resolved. For example, a zone at 1,000-m (3,280-ft) depth must be at least $100 \mathrm{~m}$ (328 ft) thick to be resolved by the MT data. Likewise, a zone $200 \mathrm{~m}$ (656 ft) thick at 3,000-m (9,800-ft) depth will probably not be seen in the data. This must be considered when determining the presence or absence of a unit such as the UCCU using MT data.

With regards to the UCCU and its hydrologic significance, extensive thin (less than $300 \mathrm{~m}$ [984 ft] thick) slivers of UCCU are probably not geologically likely in the Yucca Flat vicinity. However, the thinner and deeper the UCCU is, the less effect it probably has on groundwater flow beneath Yucca Flat. Also, thick higher resistivity zones, such as quartzite facies, within the UCCU will appear similar in resistivity to carbonate. If such units are present in sufficient thickness at the top or base of the UCCU, then the UCCU maybe thicker than indicated by the MT data. 
This page intentionally left blank. 
Quaternary and Tertiary Alluvial and Basin-filling Deposits

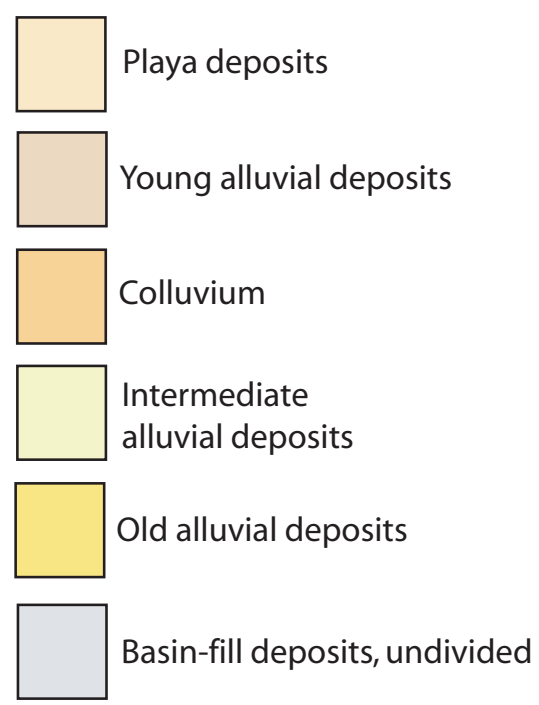

\section{Mesozoic Intrusive Rocks}

Granitic rocks

\section{Tertiary Volcanic Rocks}

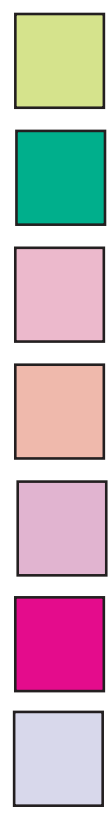

Ammonia Tanks Tuff

Rainier Mesa Tuff

Tiva Canyon Tuff

Topopah Spring Tuff

Calico Hills Formation

Intrusive rocks

of Wahmonie

Wahmonie Formation

Sayler Formation

Bullfrog Tuff

Grouse Canyon Tuff
Lithic Ridge Tuff

Comendite of Quartet Dome Tub Spring Tuff

Tunnel Formation

Older tunnel beds

Redrock Valley Tuff

Monotony Tuff

Intermediate-age basalt

Basalt

\section{Paleozoic and Precambrian Sedimentary Rocks}

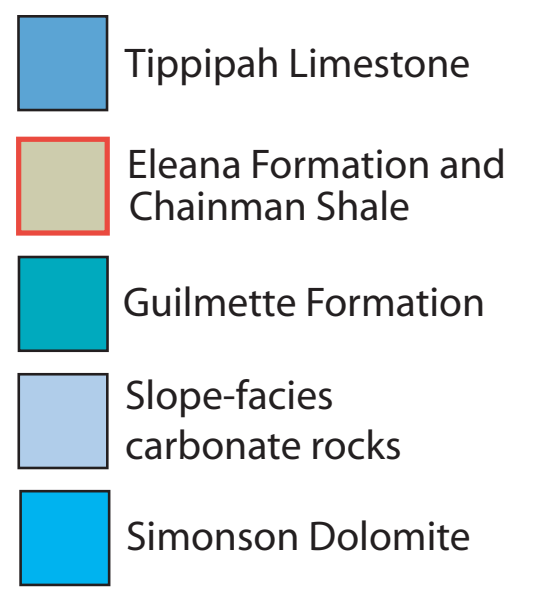

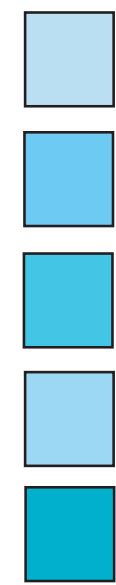

Sevy Dolomite and

Laketown Dolomite

Eureka Quartzite

Pogonip Group

Nopah Formation

Banded Mountain Member, Bonanza King Formation
Papoose Lake Member, Bonanza King Formation

Carrara Formation and Zabriski Quartzite

Wood Canyon Formation

Stirling Quartzite Johnnie Formation

Figure D-2 
Profile \#1 consists of 9 MT stations oriented in a west-northwest line that extends across the central portion of Yucca Flat. The east end of the profile line is at station 28 located approximately $1,500 \mathrm{~m}$ (5,000 ft) west of Tertiary volcanic and pre-Tertiary sedimentary rock outcrops that compose the highlands east of Yucca Flat. The line crosses the Yucca and Carpetbag-Topgallant faults near the boundary between NTS Areas 1 and 3. The line continues to the west-northwest, crossing Syncline Ridge before ending at Station 20 located within the Eleana Range. Pre-Tertiary outcrops along the western portion of the profile line provide excellent control for the Mississippian siliciclastic rocks (i.e., UCCU) and Pennsylvanian carbonate rocks (i.e., upper carbonate aquifer [UCA]). Drill hole control along and near the profile line is good, particularly above a depth of 1,000 $\mathrm{m}(3,300 \mathrm{ft})$. Along the eastern portion of the line, drill holes provide excellent control on the Cenozoic stratigraphy, top of pre-Tertiary rocks, and locations of major normal faults such as the Carpetbag-Topgallant and Yucca faults. Drill holes along the western portion of the line, such as UE-1L and UE-16d, provide good constraints on the thicknesses of the UCA and UCCU.

MT data along the eastern end of Profile \#1 (stations 26, 27, and 28) define the main Yucca Flat basin very well. Volcanic and alluvial deposits within the basin are represented on Profile \#1 as a westward-thickening wedge of 20- to 50-ohm-meter (ohm-m) material. The CarpetbagTopgallant and Yucca faults, the main basin-forming faults, are also visible in the MT data as abrupt lateral changes in resistivity between stations 26 and 27. Pre-Tertiary rocks below the eastern portion of the line show higher resistivity values of 100 - $200 \mathrm{ohm}-\mathrm{m}$, which is representative of carbonate, and is consistent with information from nearby drill holes UE-1r and U-3mi, both of which bottomed in carbonate rocks.

Data from stations 25 and 26 clearly show the high buried structural ridge that runs the length of Yucca Flat, and separates the main Yucca Flat structural basin from the smaller western subbasin. This structural ridge is well defined with gravity and drill hole data. The high resistivity values (up to $500 \mathrm{ohm}-\mathrm{m}$ ) observed below stations 25 and 26 indicate that carbonate rocks compose the ridge at this location, which is consistent with information from drill hole TG2 which encountered pre-Tertiary carbonate rocks at $21.9 \mathrm{~m}(72 \mathrm{ft})$ depth.

MT data from stations 20, 21, 22, 23, and 24 along the western portion of the line show rather well the pre-Tertiary structure and the thickness and extent of the UCCU, and are consistent with nearby outcrop and drill hole data. The syncline observed at the surface at Syncline Ridge is well defined by the MT data. The UCCU is represented in the MT data as a thick sequence of 
10- to 20-ohm-m rock underlying more resistive carbonate of the UCA. Deep drill holes UE-16d and UE-1L, as well as geologic exposure in the area, provide important controls on the MT interpretations in this area. The MT data show that the eastern limit of the UCCU is likely between stations 24 and 25. The data also show the western limit of the UCCU is between stations 20 and 21. However, station 20 is located within the Eleana Range which is composed of the UCCU. This seems to indicate that either the base of the UCCU is shallow beneath station 20, or that the UCCU west of station 21 is much more resistive, and possibly consisting of high resistivity quartzite and argillite.

Based on forward modeling of the MT data along Profile \#1, the UCCU beneath the western portion of Profile \#1 has a minimum thickness of approximately 1,500 m (4,900 ft) and a maximum thickness of approximately 2,000 m (6,600 ft). Forward modeling to $10,000 \mathrm{~m}$ $(33,000 \mathrm{ft})$ depth also indicates that the UCCU is not present below or east of station 25. 


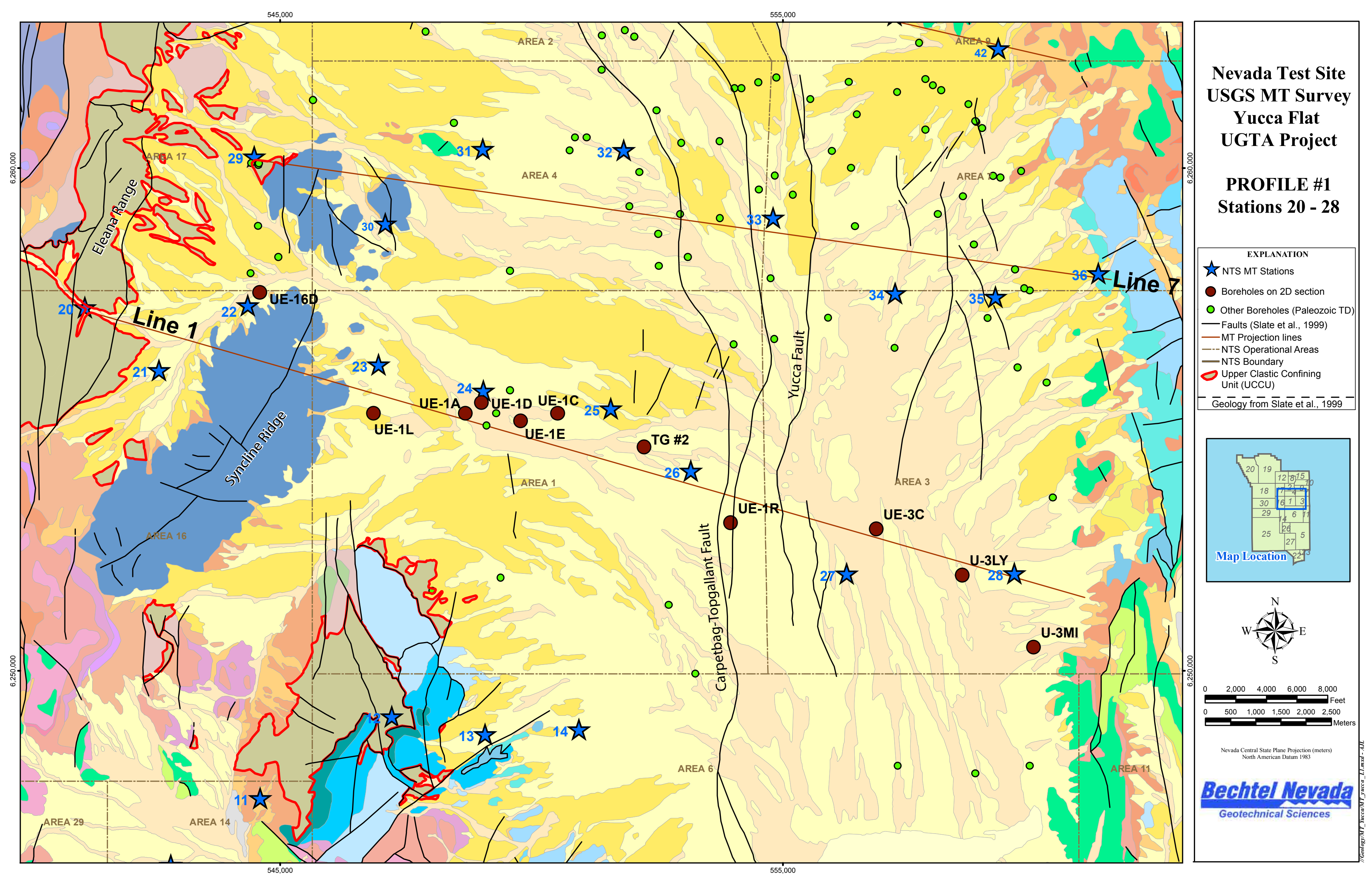




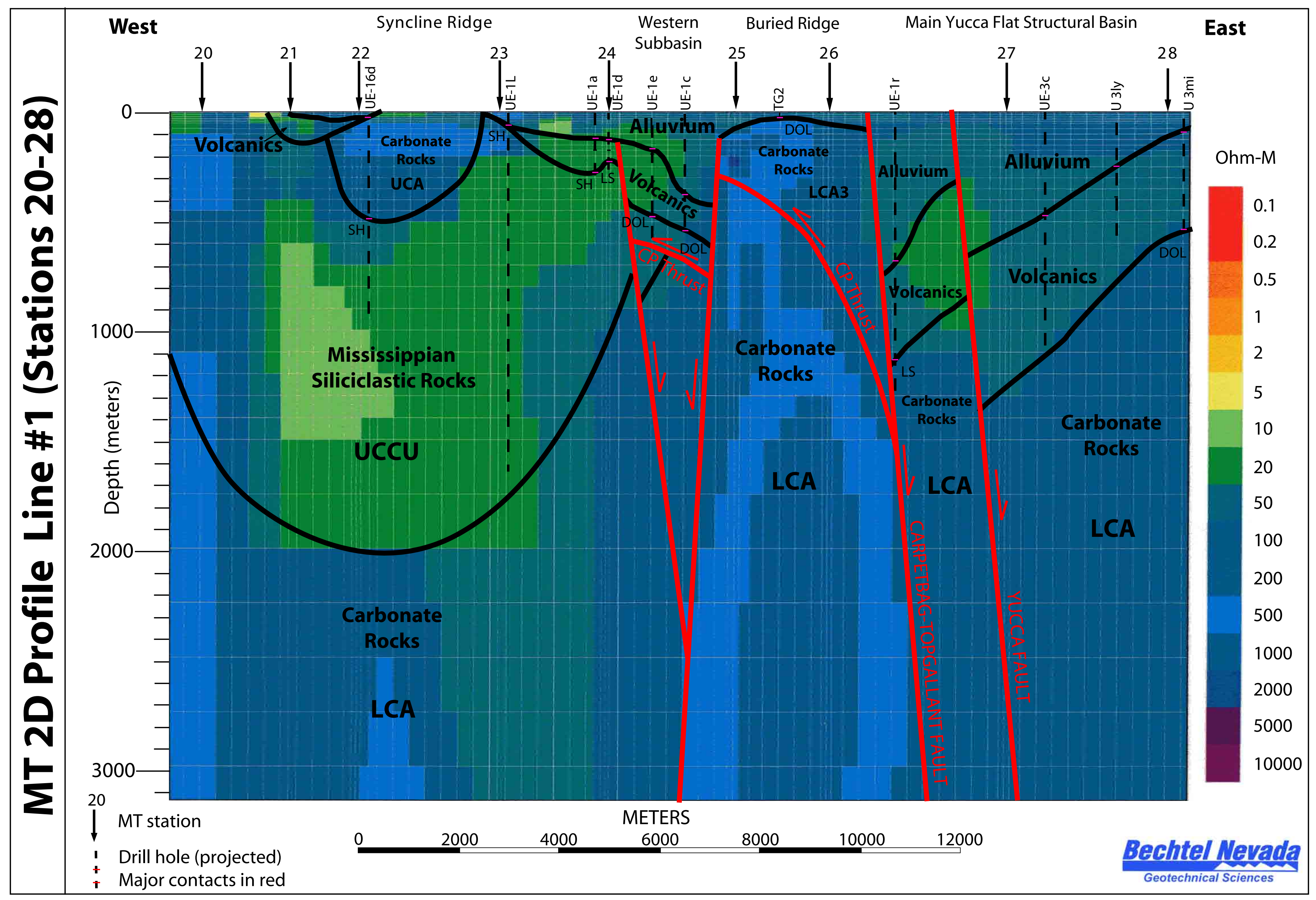


Profile \#2 consists of 6 MT stations oriented along a west-northwest line that extends across central Yucca Flat. The east end of the profile line is at station 42 located just west of Tertiary volcanic rock outcrops that partly compose the highlands east of Yucca Flat. The line crosses the Yucca fault near the boundary between NTS Areas 9 and 2, and the Carpetbag-Topgallant fault in central Area 9. The line continues to the west-northwest and ends at station 37, located approximately $600 \mathrm{~m}$ (2,000 ft) from UCCU exposures along the eastern flank of the Eleana Range.

Surface exposures of volcanic rocks near stations 41 and 42 provide control on the interpretation of the shallow MT data along the eastern end of Profile \#2. Exposures of pre-Tertiary rocks near the eastern and western ends of the profile provide some control on the interpretation of the preTertiary sedimentary rocks in these areas. Drill hole control is very good along the full length of the profile, with 10 holes providing important information on the depth and lithology of the preTertiary rocks along the profile.

Like Profile \#1, the MT data along Profile \#2 show the main Yucca Flat structural basin very well. The basin is visible in the MT data as a westward-thickening wedge of 10 - to $100-\mathrm{ohm}-\mathrm{m}$ values beneath stations $39,40,41$, and 42 . The main basin-forming faults are also visible in the data. High resistivity values (200 to $500 \mathrm{ohm}-\mathrm{m}$ ) below the main basin indicate carbonate rocks are the dominant pre-Tertiary rock type above 3,000 $\mathrm{m}(9,800 \mathrm{ft})$.

The buried structural ridge is observed beneath station 38 as very high resistivity (up to 5,000 ohm-m) rocks within $300 \mathrm{~m}$ (984 ft) of the surface. The high resistivity indicates that carbonate rocks compose the ridge at this location, and this is consistent with data from drill holes UE-2ad and UE-2ac, which both encountered dolomite relatively shallow in the area. At a depth of approximately 1,200 $\mathrm{m}$ (3,940 ft) below station 38 the resistivity of the rocks decreases substantially to approximately $20 \mathrm{ohm}-\mathrm{m}$, more typical of the UCCU. To the west at station 37 , the MT data indicate that no high resistivity rocks (e.g., carbonate) are present above 3,000 m $(9,800 \mathrm{ft})$ depth. This suggests that thick UCCU is present beneath the western end of the profile, which ends just east of UCCU exposures in the Eleana Range.

Lithologic information from drill holes UE-2ad and UE-2ac, as well as biostratigraphic data from other drill holes in the area (Cole et. al., 1997) indicate that the carbonate rocks that overlie the UCCU below station 38 are older than the UCCU. This is consistent with structural interpretations of the Yucca Flat area that include the west-vergent CP thrust fault placing rocks 
as old as Cambrian over rocks as young as Mississippian along the western margin of Yucca Flat (McKeown et al., 1976; Caskey, 1991; Cole and Cashman, 1999). The CP thrust fault is clearly visible in the MT data between stations 37 and 38 as a moderately east-dipping resistivity contrast that appears to steepen eastward as it approaches the Carpetbag fault. Carbonate rocks that occur within the hanging wall of the CP thrust fault are designated hydrostratigraphically as the lower carbonate aquifer - thrust plate (LCA3).

Forward modeling of the MT data along Profile \#2 indicates a wide range of possible thicknesses for the UCCU beneath stations 37 and 38. The minimum thickness is approximately $600 \mathrm{~m}$ $(1,970 \mathrm{ft})$, and the maximum thickness is approximately 3,000 $\mathrm{m}(9,800 \mathrm{ft})$. Forward modeling also indicates that UCCU is not present beneath or east of station 39. 


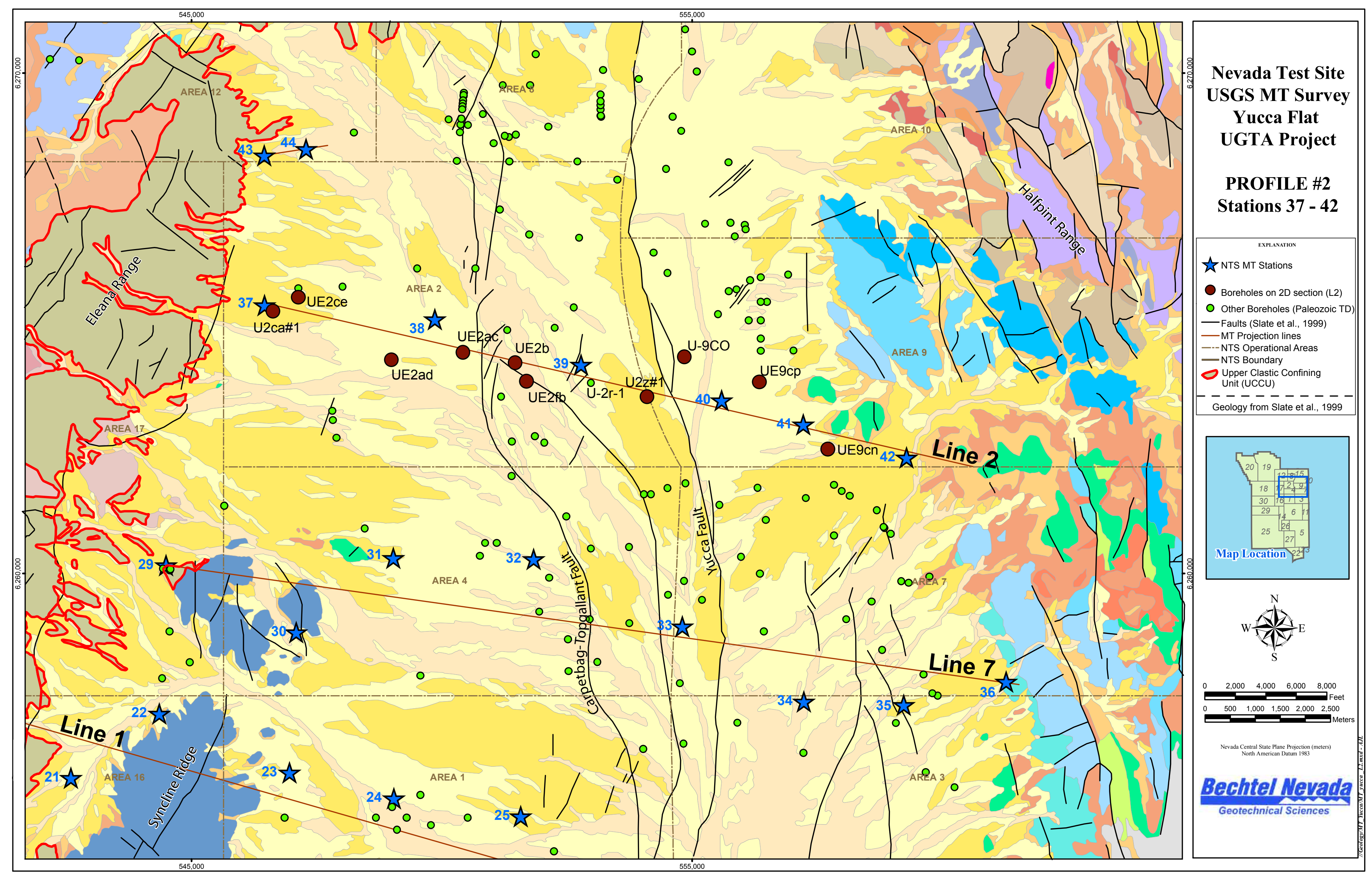




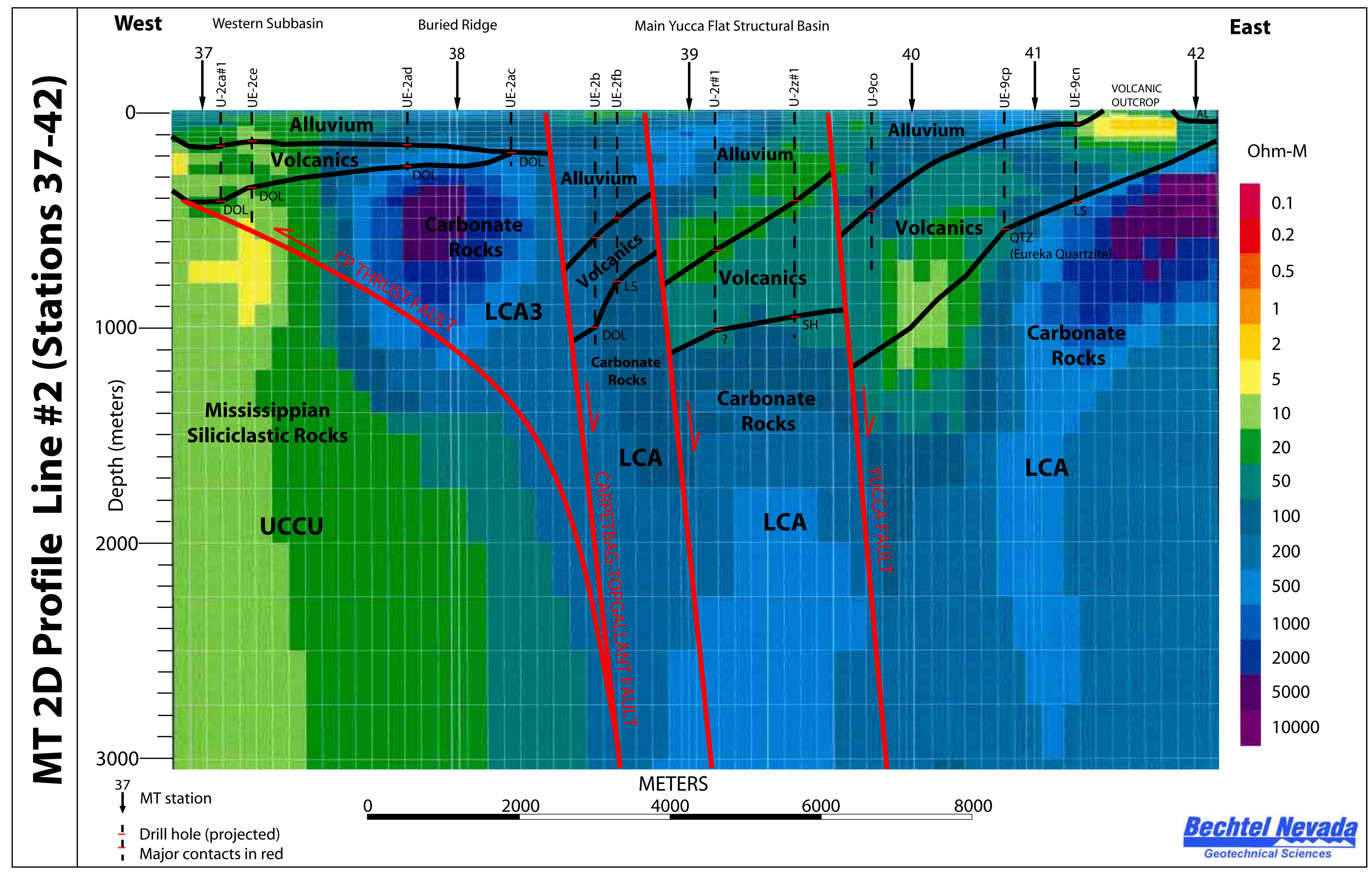


Profile \#3 consists of 8 stations oriented along a general east-west line. Most stations are spaced 2 to $3 \mathrm{~km}$ (1.2 to $1.9 \mathrm{mi}$ ) apart except for stations 4 and 5 which are spaced approximately $6 \mathrm{~km}$ (3.7 mi) apart due to inaccessible terrain between the two stations. This results in a data gap along the profile between these two stations. The eastern end of Profile \#3 is at station 8 located in the volcanic hills that border CP Basin on the northeast. The profile runs west across CP Basin where stations 5, 6, and 7 are located. The western end of the line runs along the southern edge of Mid Valley and includes stations 1, 2, 3 and 4.

Exposures of volcanic rocks at the eastern end of the profile line and along the western twothirds of the line provide good control on near-surface volcanic rocks. Drill hole control along and near the line is sparse. Water Wells 4 and 4a and drill hole UE-5j in CP Basin provide geologic information to a depth of approximately $450 \mathrm{~m}$ (1,480 ft). Drill holes UE-14a and UE-14b in Mid Valley are located approximately $2.5 \mathrm{~km}$ (1.6 mi) north of station 3, but provide geologic information to a depth of approximately $1,150 \mathrm{~m}(3,770 \mathrm{ft})$.

Lateral resistivity changes just east of station 7 define the eastern margin of CP Basin, and appear to be coincident with the northeast projection of the Cane Spring fault. Resistivity values in the 10- to 50-ohm-m range above 400-m (1,310-ft) depth beneath station 8 are likely zeolitic

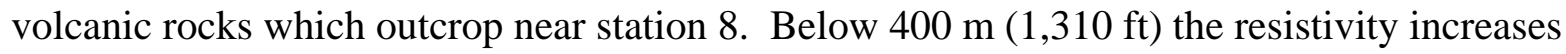
considerably, to $500 \mathrm{ohm}-\mathrm{m}$, suggesting that volcanic rocks overlie carbonate rocks east of the Cane Spring fault.

To the west, beneath stations 5, 6, and 7 in CP Basin, an eastward-thickening wedge of higher resistivity material that occurs from the surface to a depth of 1,000 m (3,280 ft) is likely alluvium and welded volcanic rocks, based on information from nearby drill holes. These higher resistivity rocks overlie an eastward-thickening wedge of 50 -ohm-m material that is probably zeolitic volcanic rock.

MT data are consistent with outcrop, drill hole, and other geophysical data that together indicate CP Basin is an east- to southeast-tilted half-graben style basin bounded on the east by the Cane Spring fault. Cenozoic rocks beneath the basin dip and thicken eastward against the Cane Spring fault. MT data indicate that the Cane Spring fault has approximately $500 \mathrm{~m}(1,640 \mathrm{ft})$ of downto-the-west displacement between stations 7 and 8. 
MT data suggest that volcanic rocks in CP Basin overlie thick UCCU beneath the eastern portion of the basin (east of station 6) and carbonate rocks beneath the western portion, beneath stations 5 and 6. The 10- to 20 -ohm-m signature below $1,100 \mathrm{~m}(3,610 \mathrm{ft})$ beneath the eastern portion of the basin is interpreted to be UCCU that appears to be rather thick but limited in lateral extent.

The western portion of Profile \#3, including stations 1, 2, 3, and 4, traverses the southern edge of Mid Valley. Incorporating information from nearby outcrops and drill holes UE-14a and UE-14b, the MT data above 1,000 m (3,280 ft) are interpreted as showing higher resistivity alluvium and welded volcanic rock overlying lower resistivity zeolitic volcanic rock beneath stations 2 and 3. A down-on-the-west fault is indicated between stations 3 and 4 . Resistivity values of 100 to 1,000 ohm-m occur below 1,000 m (3,280 ft) indicating that the volcanic rocks along the southern edge of Mid Valley likely overlie carbonate rocks. MT data indicate that UCCU is not present beneath the southern portion of Mid Valley.

Forward modeling of the MT data along Profile \#3 indicates that the minimum thickness of the UCCU under station 7 is approximately $2,000 \mathrm{~m}(6,560 \mathrm{ft})$, and the maximum thickness is approximately 3,000 $\mathrm{m}(9,840 \mathrm{ft})$. It also indicates that in the upper 3,000 $\mathrm{m}(9,840 \mathrm{ft})$ the western extent of thick UCCU (more than $300 \mathrm{~m}$ [980 ft]) is east of station 6. 


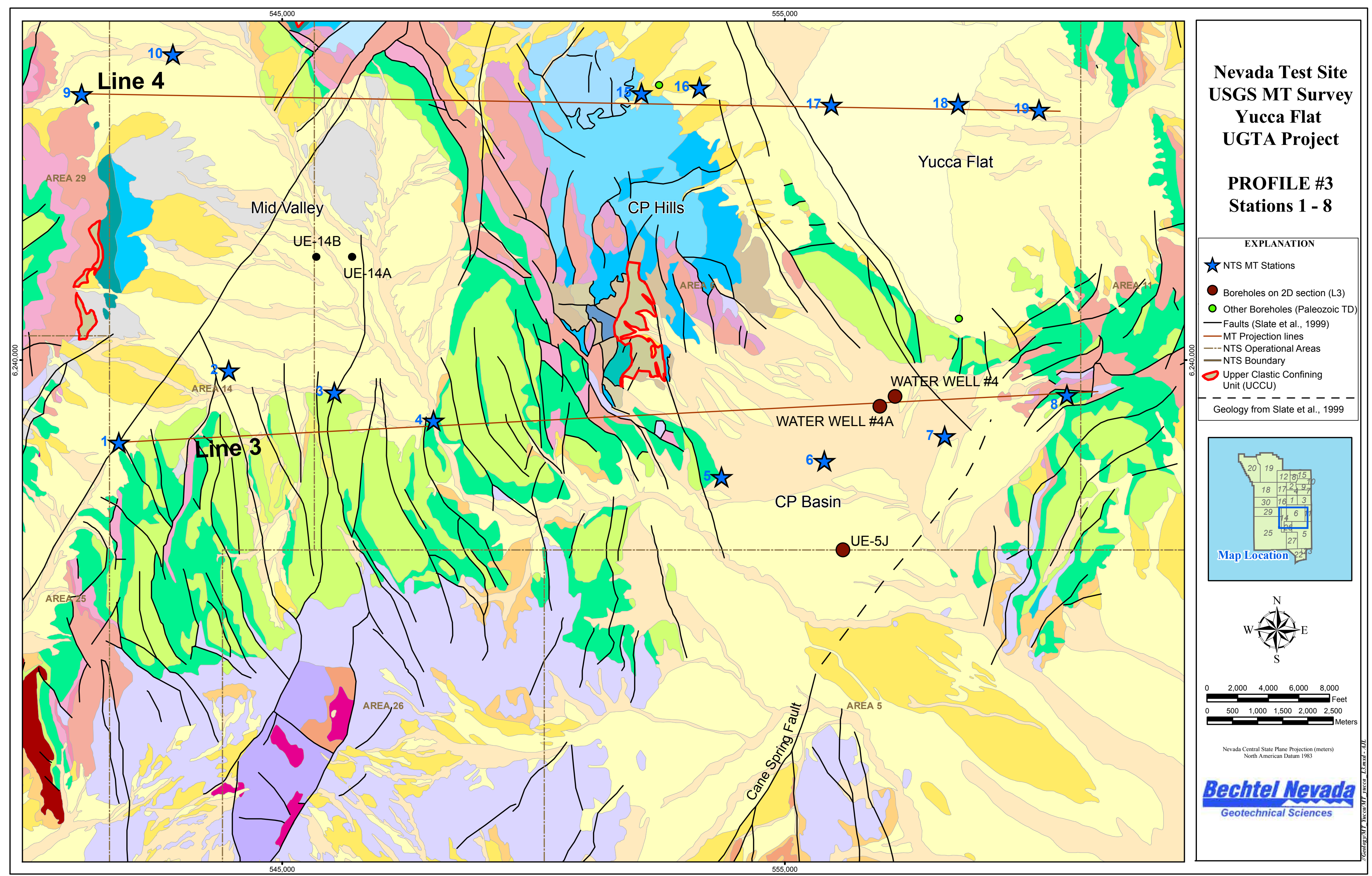




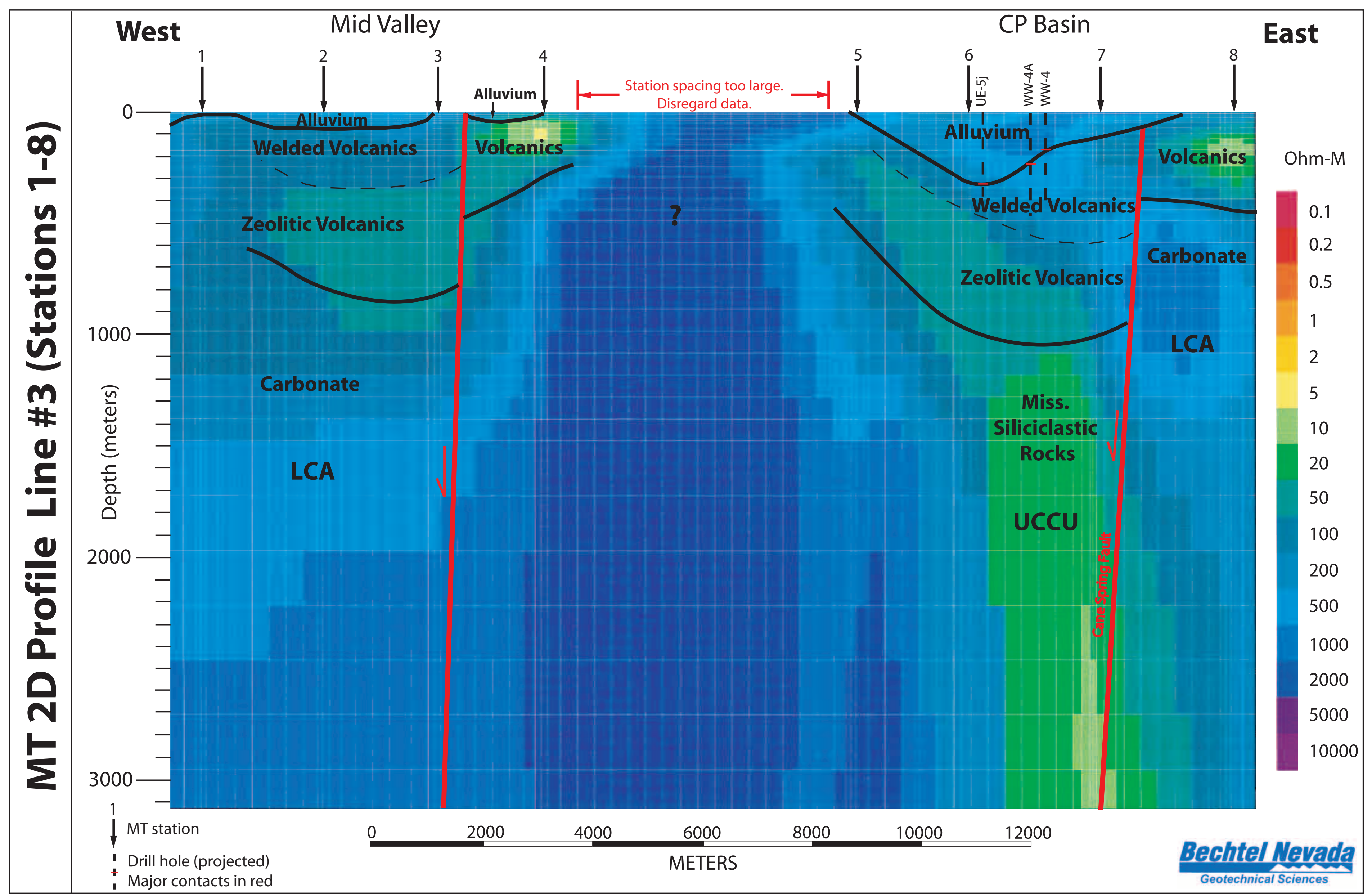


MT Profile \#4 consists of 11 stations spaced 2 to $3 \mathrm{~km}$ (1.2 to $1.9 \mathrm{mi}$ ) apart and oriented in a general east-west line. However, stations 11 through 14 are located up to $3.5 \mathrm{~km}$ (2.8 mi) north of the profile line, creating a significant separation between the eastern half of the profile line (stations 15 through 19) and the western half (stations 9 through 14). Thus, the eastern and western portions of the profile have been interpreted somewhat independently from each other. Consequently, the following discussions will refer to the eastern half of Profile \#4 as Profile \#4a and the western half as Profile \#4b.

\subsubsection{Profile \#4a}

The 5 stations that compose Profile \#4a are oriented in an east-west line across southern Yucca Flat. The eastern end of the line is at station 19 located in eastern Area 6 east of the Yucca Flat dry lake bed. The western portion of the line ends at station 15 located in the CP Hills. Stations 17 and 18 are located on the dry lake bed.

Surface exposures of pre-Tertiary carbonate near station 15 provide good control on interpretations at the western end of Profile \#4a. The occurrence of playa deposits associated with the dry lake bed at stations 17 and 18 provide excellent control on the interpretation of the shallow MT data in this area. Nearby drill hole data along Profile \#4a are sparse. Well ER-6-2 near stations 15 and 16 provides excellent control on MT interpretations at the west end of the line. Although located approximately $3 \mathrm{~km}$ (1.9 mi) north of the profile line, drill holes UE-6e, UE-6d\#3 and Well ER-6-1 provide useful constraints on the interpretation of the MT data at stations 17,18 , and 19.

Unlike profile lines that cross Yucca Flat to the north (e.g., Profiles \#1, \#2, and \#7), MT data along Profile \#4a do not define the Yucca Flat basin very well, and the interpretations depicted in the profile are based mainly on information from drill holes located north of the line. The MT data do show the playa deposits quite well, indicating that the deposits are on the order of several hundred meters thick. The resistivity contrast between the volcanic rocks and pre-Tertiary sedimentary rocks is not observed on the MT data. The reason for this is unknown, but information from drill holes to the north indicates a thick section of volcanic rocks is likely present below stations 17 and 18, and that the pre-Tertiary surface is probably composed of carbonate and is probably below $1,000 \mathrm{~m}(3,280 \mathrm{ft})$ depth. This is consistent with gravity data that indicate that the top of pre-Tertiary rocks is well below 1,000 $\mathrm{m}(3,280 \mathrm{ft})$ depth in the southern portion of Yucca Flat. 
The MT data for stations 15 and 16 depict the geology beneath these stations very well as interpreted from surface exposures and information from well ER-6-2. The high resistivity observed above $800 \mathrm{~m}(2,620 \mathrm{ft})$ is consistent with carbonate rocks, which are exposed at the surface and penetrated at Well ER-6-2. These rocks are Cambrian in age and form the hanging wall of the CP thrust fault in the area. Well ER-6-2 penetrated the CP thrust fault at a depth of $730 \mathrm{~m}$ (2,400 ft), encountering $149 \mathrm{~m}$ (489 ft) of overturned Devonian carbonate below the fault before entering Mississippian shale (i.e., UCCU) at a depth of $879 \mathrm{~m}$ (2,880 ft). The well bottomed in shale at a depth of 1,046 m (3,430 ft). Below $800 \mathrm{~m}(2,620 \mathrm{ft})$, and extending to a depth of 1,100 m (3,610 ft), MT data show a zone of low resistivity (i.e., 20 ohm-m) characteristic of UCCU and consistent with information from Well ER-6-2. The MT data indicate that the UCCU is relatively thin (about $300 \mathrm{~m}$ [980 ft], which is also the minimum thickness based on forward modeling) below stations 15 and 16, and that the UCCU does not extend very far east of station 16. Because of the break in the profile line between stations 15 and 14, it is unknown how far west of station 15 the UCCU extends. High resistivity observed below 1,100 m (3,610 ft) indicates the UCCU overlies carbonate (i.e., LCA).

Forward modeling indicates a minimum thickness of $300 \mathrm{~m}$ (984 ft) for the UCCU under stations 15 and 16 . The maximum thickness is $1,400 \mathrm{~m}(4,590 \mathrm{ft})$.

\subsubsection{Profile \#4b}

Profile \#4b is a northeast-southwest oriented line consisting of 6 stations. The eastern-most station is station 14, located in the southwestern portion of Yucca Flat. The profile line crosses Mine Mountain (stations 11, 12, and 13) and the northern portion of Mid Valley (Stations 9 and 10). Surface exposures of Tertiary volcanic rocks and pre-Tertiary sedimentary rocks in the Mine Mountain vicinity provide some control along this portion of the profile line. No drill holes are located near the profile line.

Although good surface exposures of Tertiary and pre-Tertiary rocks are present along much of the profile, the lack of drill hole control makes interpreting the MT data difficult. The resistivity signature of rocks above 1,500-m (4,920-ft) depth has a mottled appearance that may be reflecting the diverse lithologic composition of the Mississippian rocks in the Mine Mountain vicinity. This section may include coarser, more resistive deposits such as quartzite, interbedded with more conductive rocks such as shale and argillite. Below 1,500 m (4,920 ft) resistivity values are lower (10 to $20 \mathrm{ohm}-\mathrm{m}$ ), and more typical of the UCCU below the western portion of Yucca Flat where it is known to consist of thick conductive shale. One interpretation is that coarser Mississippian-age siliciclastic rocks that either represent a western facies (Cashman and Texler, 1991) or the lower portion (Poole et al., 1961) of the Mississippian section have been 
thrust over the shale facies. This would result in the UCCU being structurally thickened on the order of 3,000 m (9,840 ft) beneath Mine Mountain.

Several prominent lateral resistivity changes are observed below 1,300 m (4,270 ft). This may indicate that significant structural deformation of these rocks has occurred along high angle faults.

The mottled resistivity signature of the rocks above approximately 1,500 m (4,920 ft) does not show up on forward modeling profiles (Rodriquez, 2004b), which indicates that these rocks have relatively high resistivity values (e.g., 100 to $500 \mathrm{ohm}-\mathrm{m}$ ). Likewise, forward modeling indicates the 20-ohm-m signature below 1,300-m (4,270-ft) depth beneath station 13 is also probably more resistive (i.e., $500 \mathrm{ohm}-\mathrm{m}$ ) than indicated in Profile \#4b. The deep 10- to 20-ohm-m zone beneath stations 10 and 11 has a minimum thickness of approximately $500 \mathrm{~m}$ $(1,640 \mathrm{ft})$ and a maximum thickness of 2,300 $\mathrm{m}(7,550 \mathrm{ft})$. 
This page intentionally left blank. 


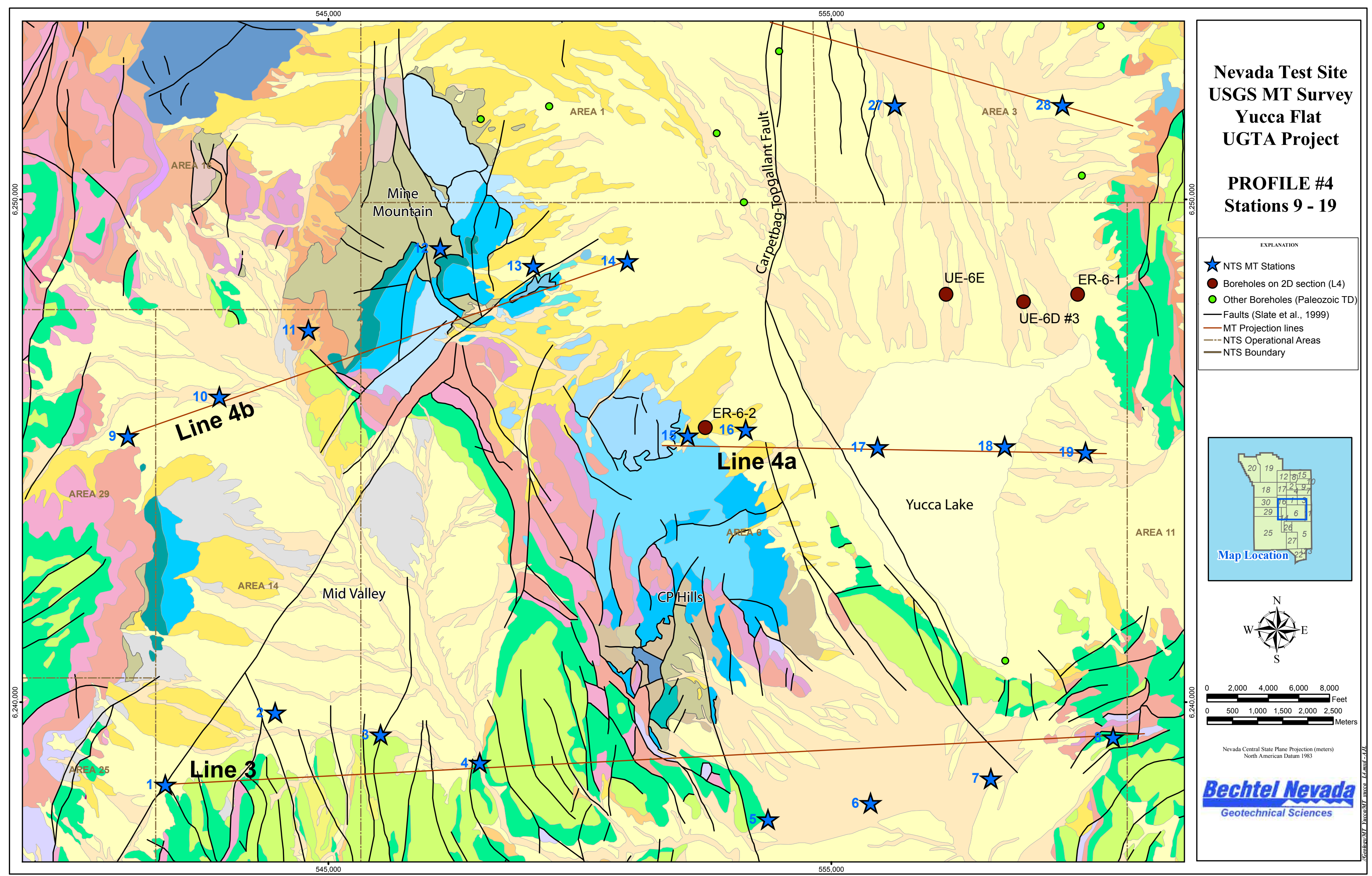




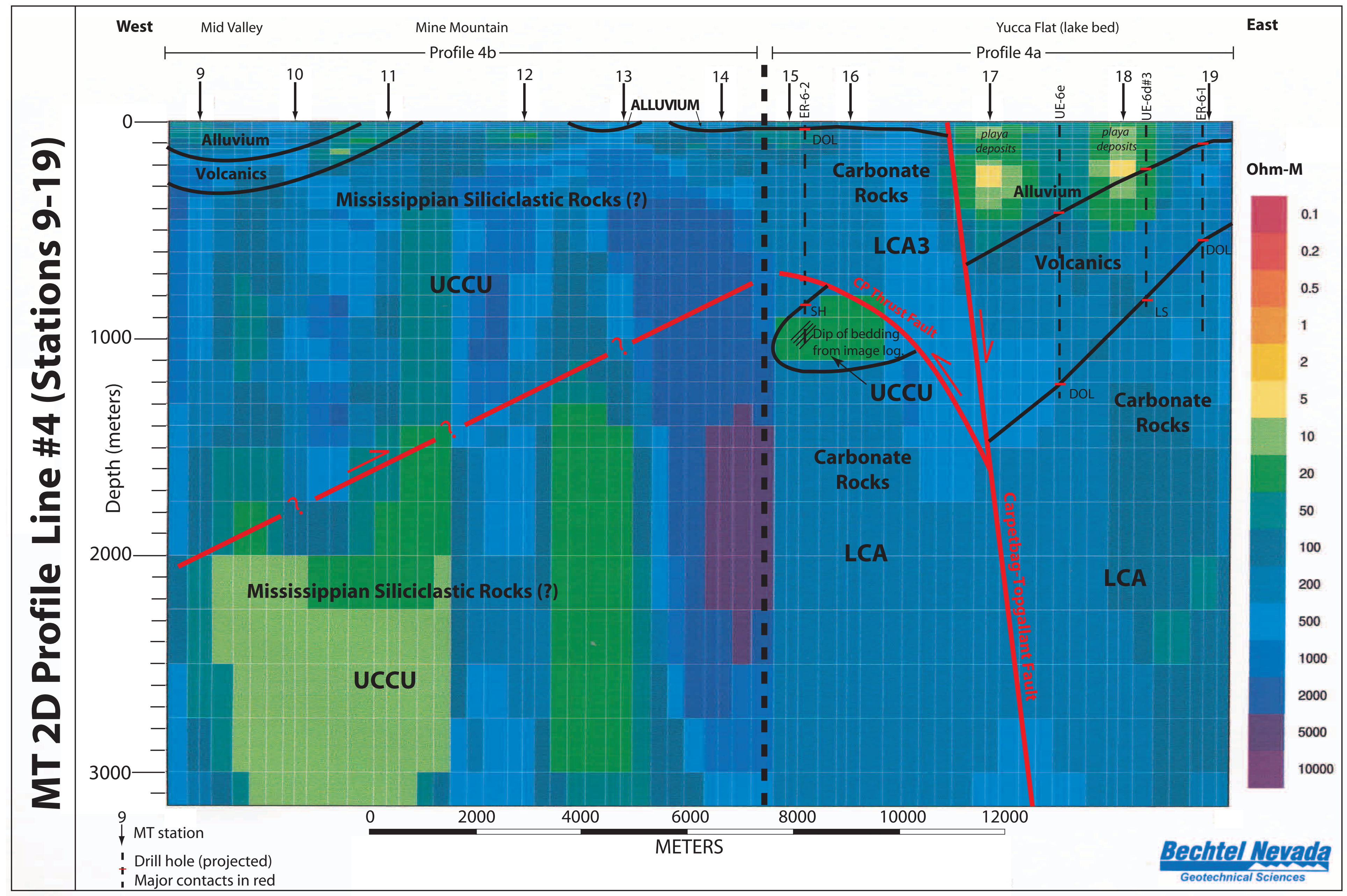


Profile \#5 is located in the northwest portion of Yucca Flat between the Eleana Range and Well ER-12-2. Because Profile \#5 consists of only 2 stations, it was not possible to construct a 2-D inverted resistivity model along the profile. Consequently, Profile \#5 only shows the independent resistivity signatures for each station side by side for comparison. The stations were sited to aid in extrapolating the geology encountered in Well ER-12-2 to the west towards UCCU exposures in the Eleana Range. Due to power lines in the vicinity of the well, no stations could be located to the east of the well.

Stations 43 and 44 both show low resistivity values (10 to $50 \mathrm{ohm}-\mathrm{m}$ ) to a depth of 3,000 m $(9,840 \mathrm{ft})$. This is consistent with the geology penetrated at Well ER-12-2, which bottomed in UCCU at a true vertical depth of 1,896 m (6,220 ft). However, the resistivity values of the UCCU penetrated at Well ER-12-2 are generally higher than those recorded at stations 43 and 44. Still, the MT data do seem to indicate that thick UCCU extends west from Well ER-12-2 to the base of the Eleana Range.

Forward modeling indicates a minimum thickness for UCCU beneath stations 43 and 44 of approximately 2,500 m (8,200 ft) and maximum thickness of approximately 4,000 m (13,120 ft). 
This page intentionally left blank. 


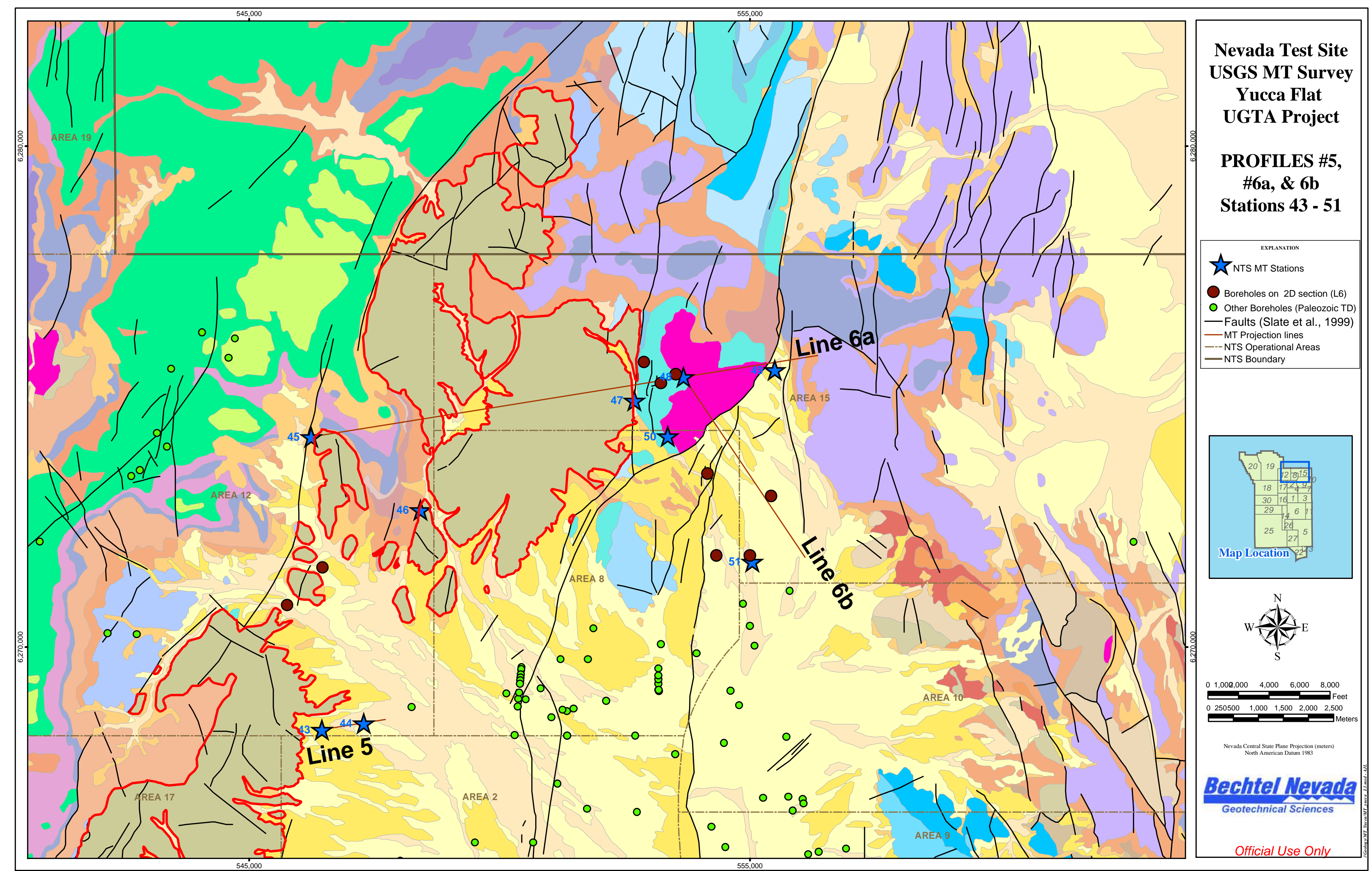




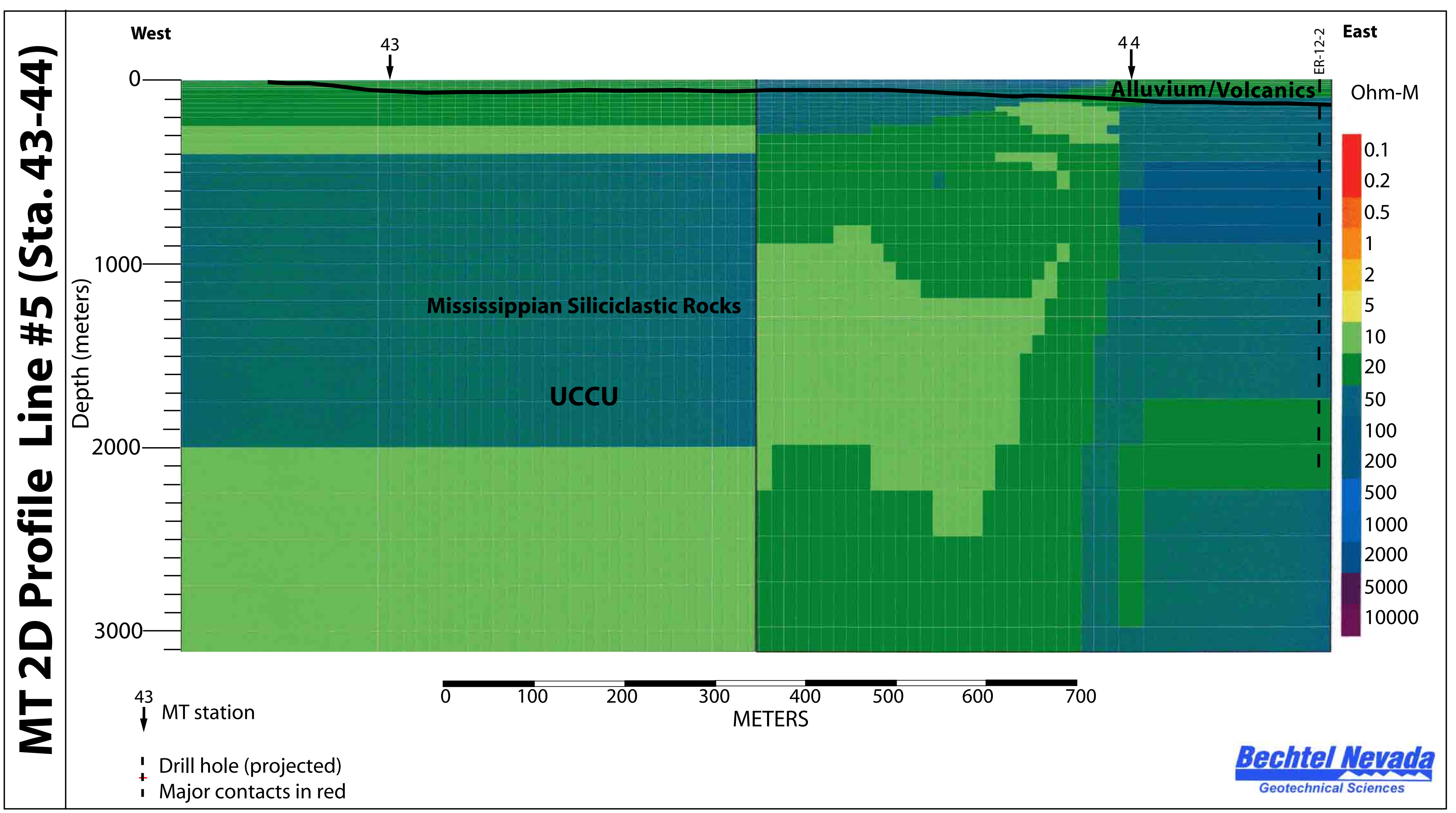


Profile \#6a consists of 5 MT stations oriented in an east-northeast line that runs from eastern Area 12, across Quartzite Ridge, and ends just east of the Climax stock. The spacing between stations 46 and 47 is approximately $4.5 \mathrm{~km}$ ( $2.8 \mathrm{mi})$ due to inaccessible terrain on Quartzite Ridge which is located between the two stations. This results in a data gap along the profile between these two stations. Surface exposures are extensive along the profile, but drill hole control, particularly deep control, is sparse.

Along the eastern portion of the profile line, a conductive zone from surface to $1,500 \mathrm{~m}$ (4,920 ft) depth between stations 48 and 49 is granitic rock of the Climax stock, based on surface exposures and drill hole information. Beneath station 47 the rock shows very high resistivity to the base of the profile, indicating that a thick carbonate section borders the stock at depth on the west.

At stations 45 and 46 along the western end of the profile, resistivity values vary from 50 to 1,000 ohm-m above 1,300 m (4,270 ft). This may be indicative of complex structure or lithologic variation in the area. Because of the lack of drill hole control and the presence of only two MT stations, the MT data in this area are somewhat inconclusive. A zone of consistent

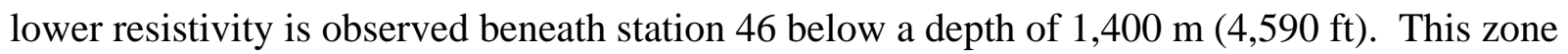
shows resistivity values of approximately $20 \mathrm{ohm}-\mathrm{m}$, which is similar to UCCU to the south, beneath Yucca Flat. Lower resistivity values of approximately $50 \mathrm{ohm}-\mathrm{m}$ extend downward from the $20-\mathrm{ohm}-\mathrm{m}$ zone to the base of the profile, and to the west beneath station 45 . Forward modeling indicates that the combined minimum thickness of the 20 - to $50-\mathrm{ohm}-\mathrm{m}$ zone is approximately $700 \mathrm{~m}(2,300 \mathrm{ft})$, and the maximum thickness is $2,000 \mathrm{~m}(6,560 \mathrm{ft})$. 
This page intentionally left blank. 


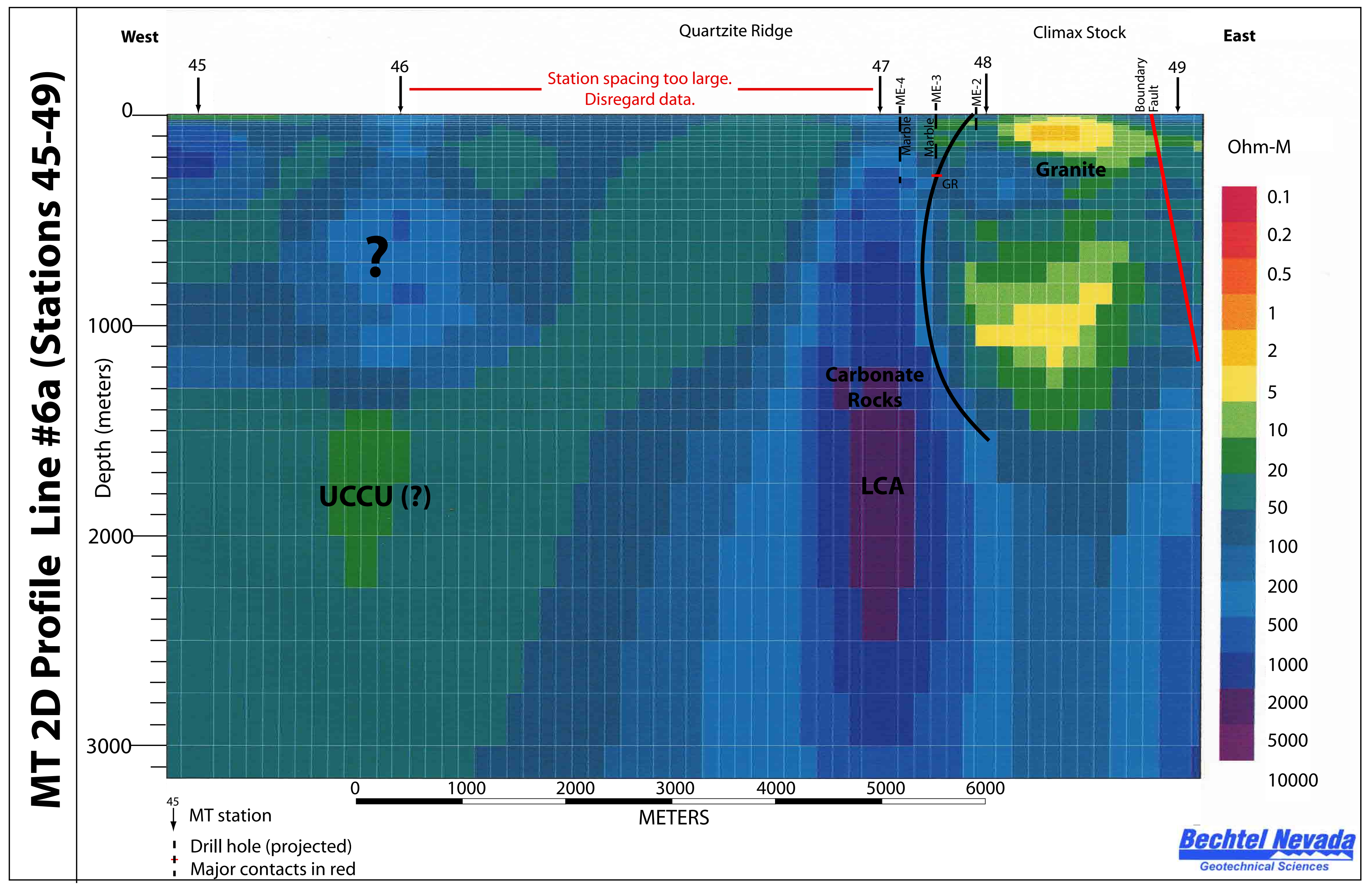


Profile \#6b consists of 3 stations oriented in a generally northwest-southeast line that runs from the Climax stock on the northwest across the Boundary and Yucca faults, and ends near drill hole UE-ITS \#1 at the north end of Yucca Flat. Outcrop control is good at the northwest portion of the line and several drill holes provide subsurface control along the southeastern portion of the line. The locations of the faults and the southern edge of the Climax granite body marked on Profile \#6b were determined from drill hole, outcrop, and magnetic data, rather than from MT data.

Except for near-surface deposits such as weathered granite and zeolitic volcanic rock, Profile \#6b indicates that the north end of Yucca Flat is underlain to a depth of 3,000 m ( $9,840 \mathrm{ft}$ ) by high resistivity rocks. Resistivity values of 10 to $20 \mathrm{ohm}-\mathrm{m}$, typical of the UCCU, are not observed, indicating that UCCU is not present beneath this portion of Yucca Flat. 
This page intentionally left blank. 


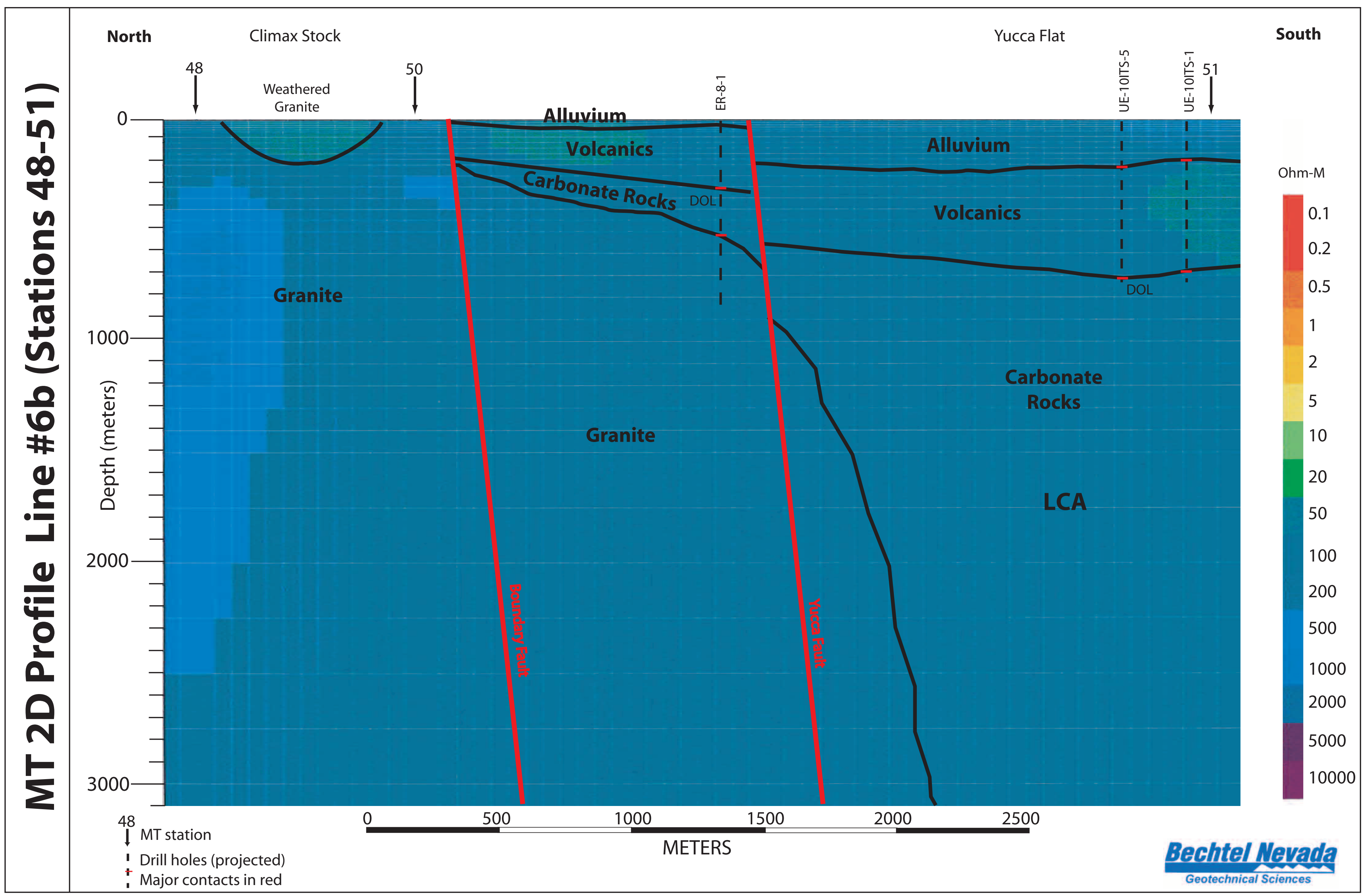


Profile \#7 consists of 8 MT stations oriented in a west-northwest line that extends across central Yucca Flat. The eastern end of the line is at station 36, located at the very eastern edge of Yucca Flat adjacent to pre-Tertiary outcrops that partly compose the highlands east of Yucca Flat. The line crosses the Yucca fault in western Area 7, and the Carpetbag-Topgallant fault system in eastern Area 4. The line extends to the west-northwest, crossing the northern end of Syncline Ridge and ending at station 29, located between Syncline Ridge and the Eleana Range.

Outcrops of pre-Tertiary rocks along the western portion of the profile line provide excellent control for the Mississippian-age siliciclastic rocks (i.e., UCCU) and Pennsylvanian carbonate rocks (i.e., UCA). Drill hole control along and near the profile line is very good above a depth of 1,000 m (3,300 ft). Along the eastern portion of the line, drill holes provide excellent control on the Cenozoic stratigraphy, top of pre-Tertiary rocks, and locations of major normal faults such as the Carpetbag-Topgallant and Yucca faults.

MT data along the eastern half of Profile \#7 (stations 32, 33, 34, 35, and 36) define the main Yucca Flat basin very well. Volcanic and alluvial deposits within the basin are represented on Profile \#7 as a westward-thickening wedge of 20- to $100-\mathrm{ohm}-\mathrm{m}$ values. The CarpetbagTopgallant fault is visible in the MT data as an abrupt lateral change in resistivity between stations 32 and 33. Pre-Tertiary rocks below the eastern portion of the line show higher resistivity values of 100 to $1000 \mathrm{ohm}-\mathrm{m}$, which is characteristic of carbonate rocks, and is consistent with information from nearby drill holes which bottomed in limestone and dolomite.

MT data along the western portion of the profile show several lateral and vertical resistivity changes that define important structures. A lateral resistivity change between stations 31 and 32 below $1,000-\mathrm{m}$ (3,280-ft) depth is interpreted to represent the moderately west-dipping stratigraphic contact between the UCCU (i.e., Mississippian-age siliciclastic rocks) and the LCA (i.e. Devonian-age carbonate rocks). This is the eastern limb of the Syncline Ridge syncline. The vertical resistivity change beneath station 31 at approximately $1,000-\mathrm{m}$ (3,280-ft) depth is interpreted to represent the $\mathrm{CP}$ thrust fault that has placed higher resistivity carbonate rocks (LCA3) over UCCU. The lateral resistivity change observed between stations 30 and 31 above $1,000 \mathrm{~m}$ (3,280 ft) represents the western boundary of the western sub-basin. Higher resistivity values more typical of carbonate rock are observed above 1,000 m (3,280 ft) at station 29 and between stations 29 and 30. However, information from drill hole UE-17e, located very near station 29, confirms that Mississippian-age siliciclastic rocks are present beneath station 29 to a depth of $900 \mathrm{~m}$ (2,950 ft), and indicates that in places the UCCU may be quite resistive. 
Forward modeling of the MT data along Profile \#7 indicates a minimum thickness of the UCCU beneath stations 29 to 31 of approximately 1,000 m (3,280 ft). Forward modeling provides a maximum thickness of approximately $2,500 \mathrm{~m}(8,200 \mathrm{ft})$. Forward modeling also indicates that the eastern extent of the UCCU is west of station 32, and thus is not present beneath the eastern portion of Yucca Flat. 


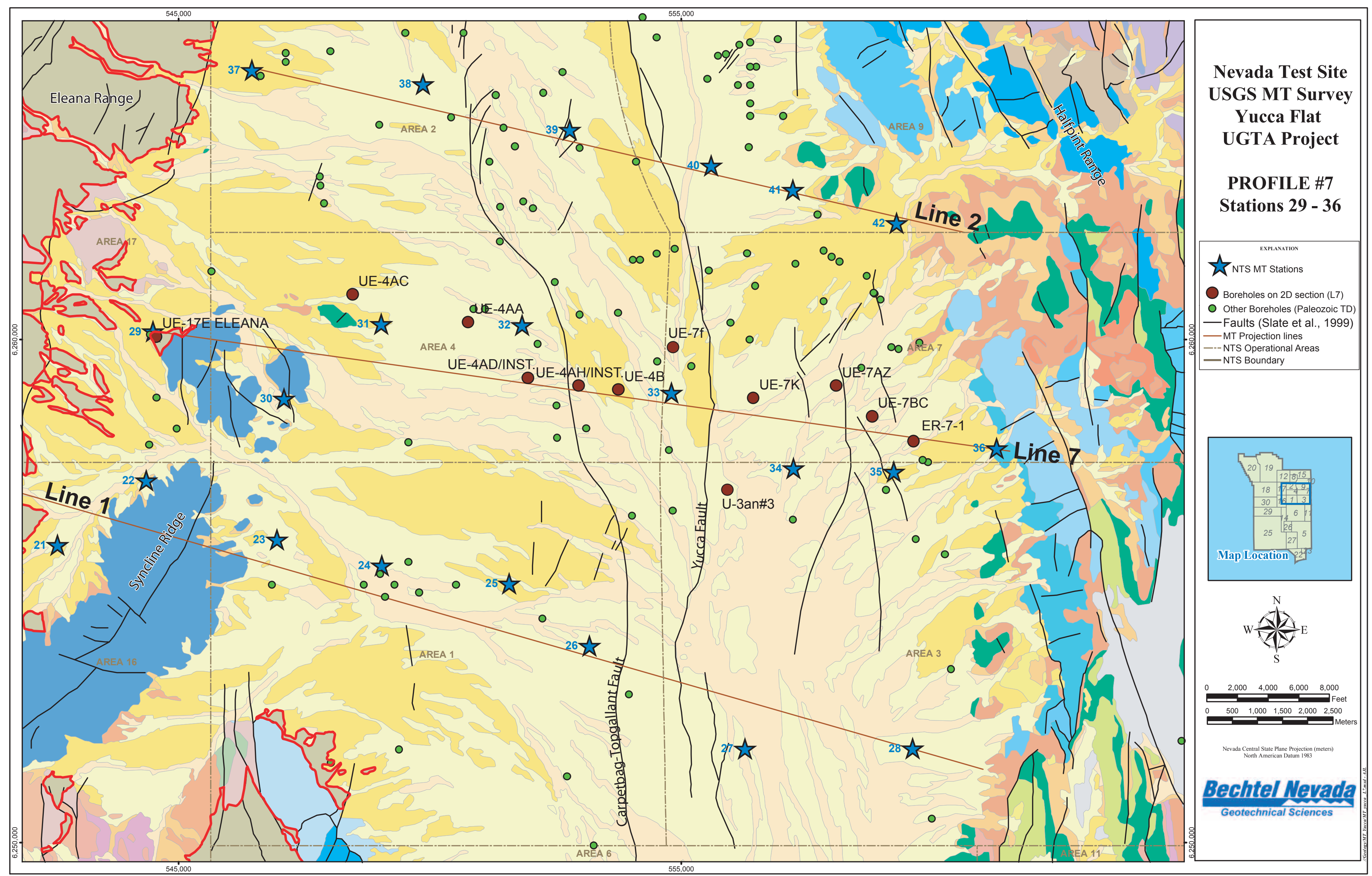




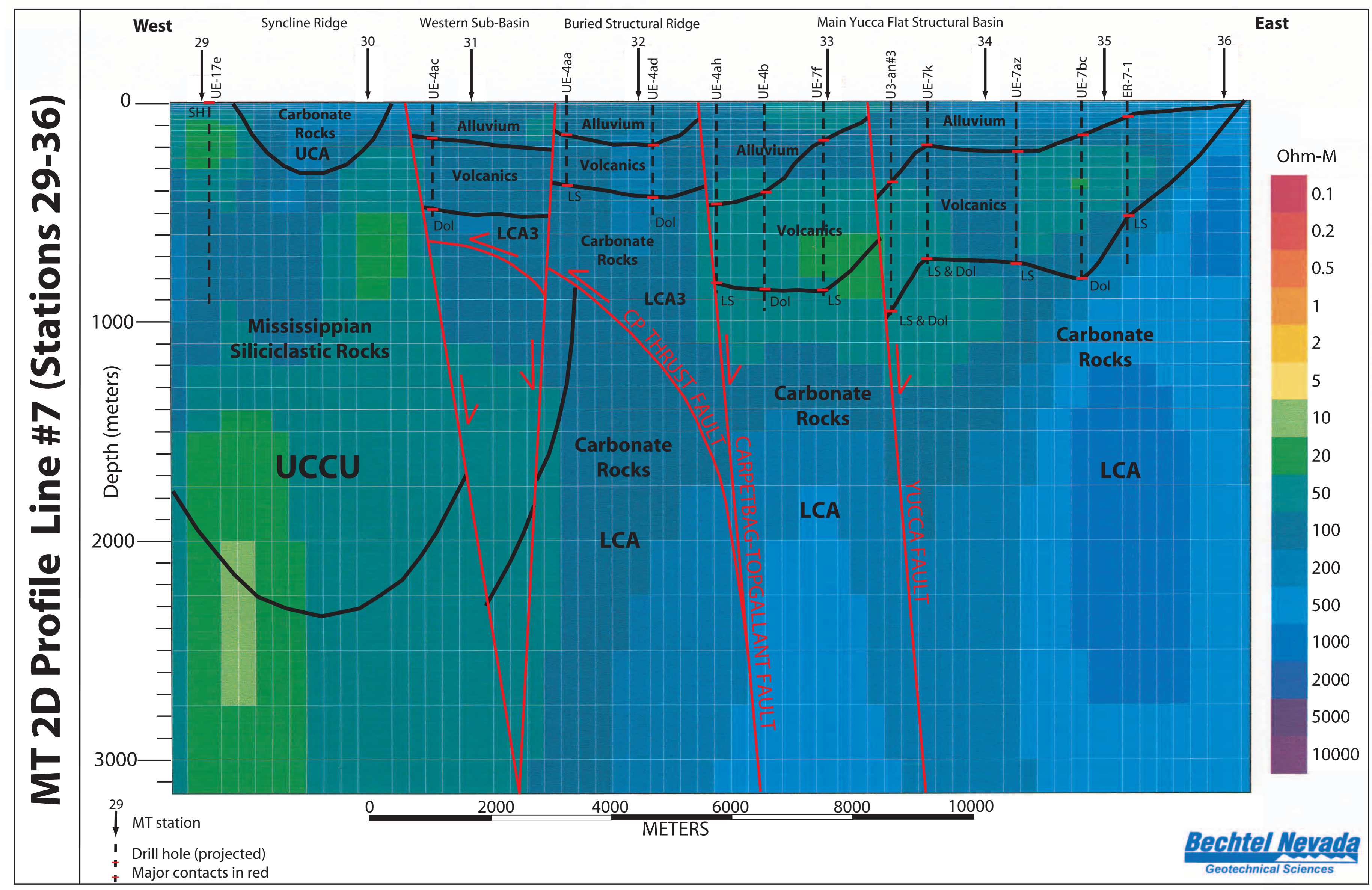




\subsection{References Cited}

Asch, T. A., B. D. Rodriguez, J. A. Sampson, E. Wallin,, and J. M. Williams, 2005. Deep Resistivity Structure of Yucca Flat, Nevada Test Site, Nevada. U.S. Geological Survey Open-File Report (in press).

Cashman, P. H. and J. H. Trexler, Jr., 1991. "The Mississippian Antler Foreland and Continental Margin in Southern Nevada: The Eleana Formation Reinterpreted.” In: J.D. Cooper and C.H. Stevens, eds., Paleozoic Paleogeography of the Western United States - II: Pacific Section SEPM, v. 67, pp. 271-280.

Caskey, S. J., 1991. Mesozoic and Cenozoic Structural Geology of the CP Hills, Nevada Test Site, Nye County, Nevada; and Regional Implications. State of Nevada Agency for Nuclear Project/Nuclear Waste Project Office. Report Number NWPO-TR-018-91.

Cole, J. C., and P. H. Cashman, 1999. Structural Relationships of Pre-Tertiary Rocks in the Nevada Test Site Region, Southern Nevada. U.S. Geological Survey Professional Paper 1607.

Cole, J. C., A. G. Harris, and R. R. Wahl, 1997. "Subcrop Geologic Map of Pre-Tertiary Rocks in the Yucca Flat and Northern Frenchman Flat Areas, Nevada Test Site, Southern Nevada." U.S. Geological Survey Open-File Report 97-678, scale 1:48,000, 24 pp. Denver, CO.

McKeown, F. A., D. L. Healey, and C. H. Miller, 1976. "Geologic Map of the Yucca Lake Quadrangle, Nye County, Nevada.” U.S. Geological Survey, GQ-1327, scale 1:24,000. Washington, DC.

Poole, F. G., F. N. Houser, and P. P. Orkild, 1961. Eleana Formation of Nevada Test Site and Vicinity, Nye County, Nevada. U.S. Geological Survey Professional Paper 424-D, pp. D-104 to D-111.

Rodriguez, B. D., U.S. Geological Survey, 2004a. Written communication. Subject: Yucca Flat MT Model Resolution. Denver, CO.

Rodriguez, B. D., U.S. Geological Survey, 2004b. Written communication. Letter to B. K. Thompson, U.S. Geological Survey, Henderson, NV, October 13, 2004. Subject: Transmittal of Completed 2-D Profile Models Processed from the Magnetotelluric Data for the YF/CM CAU. Denver, CO. 
This page intentionally left blank. 


\section{Plate 1}

Surface Geologic Map of the Yucca Flat - Climax Mine Model Area 


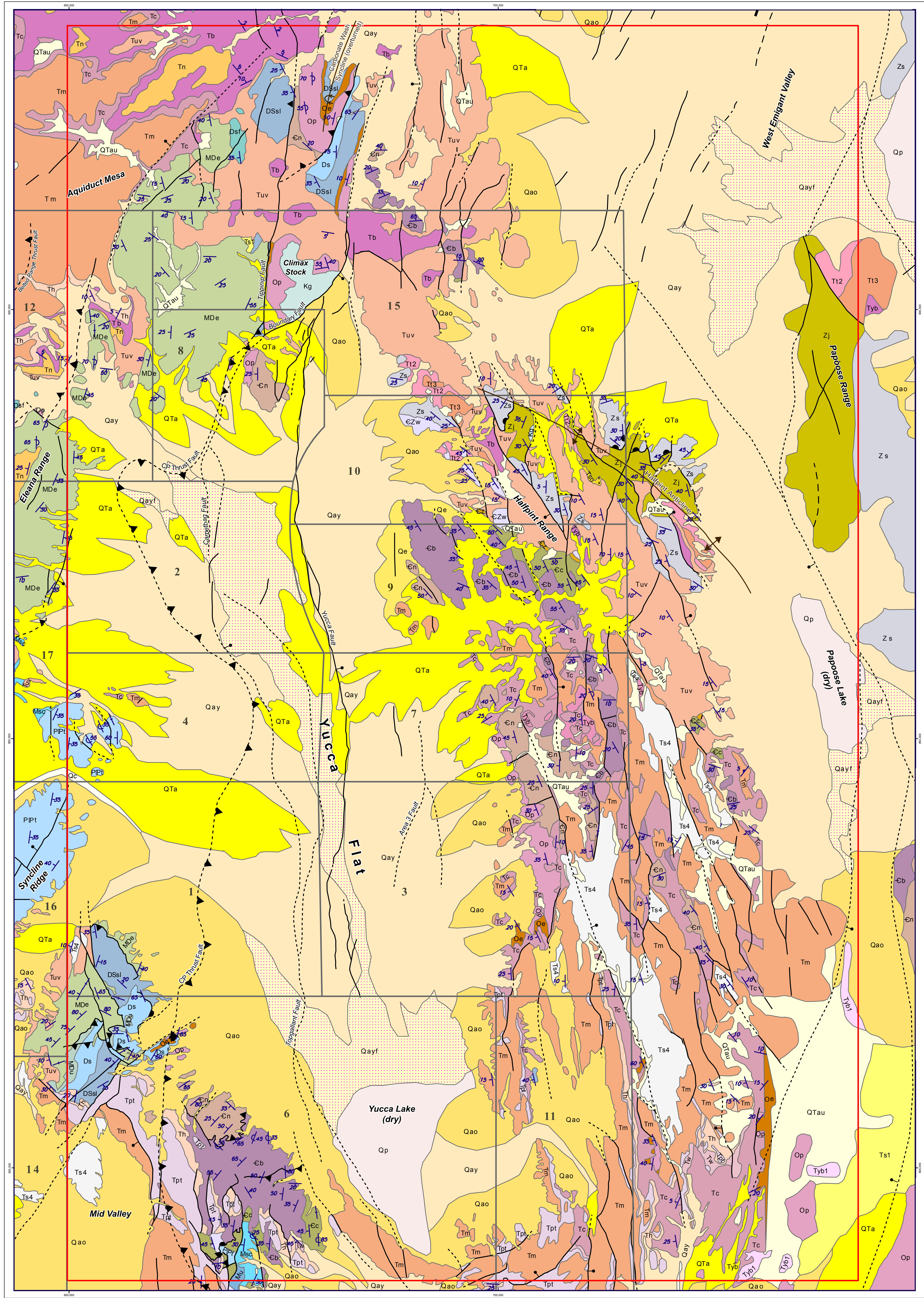

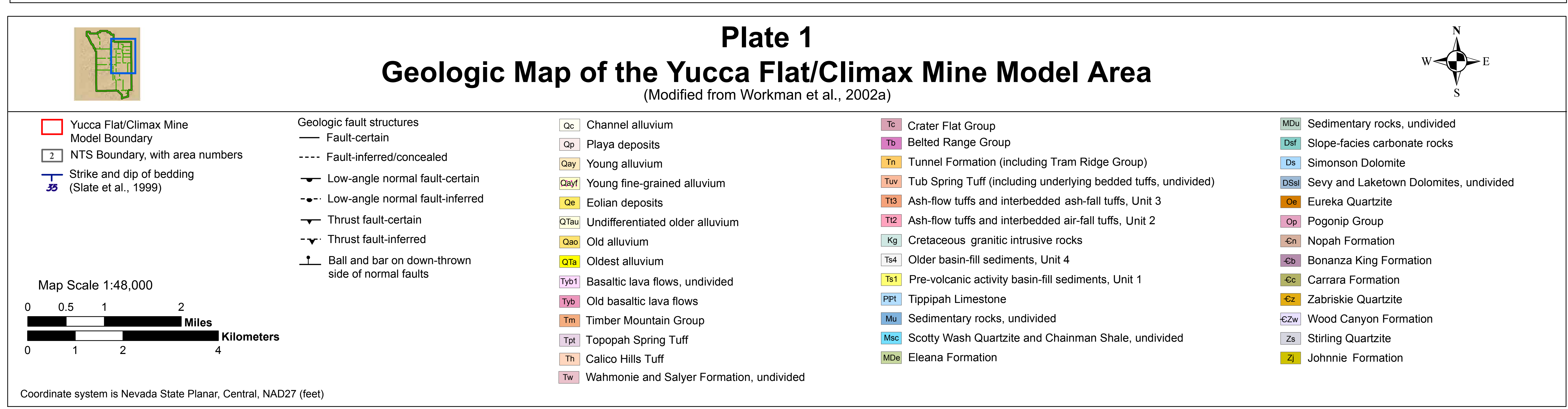




\section{Plate 2}

\section{Hydrostratigraphic Units at the Water Table in the Yucca Flat - Climax Mine Hydrostratigraphic Framework Model}




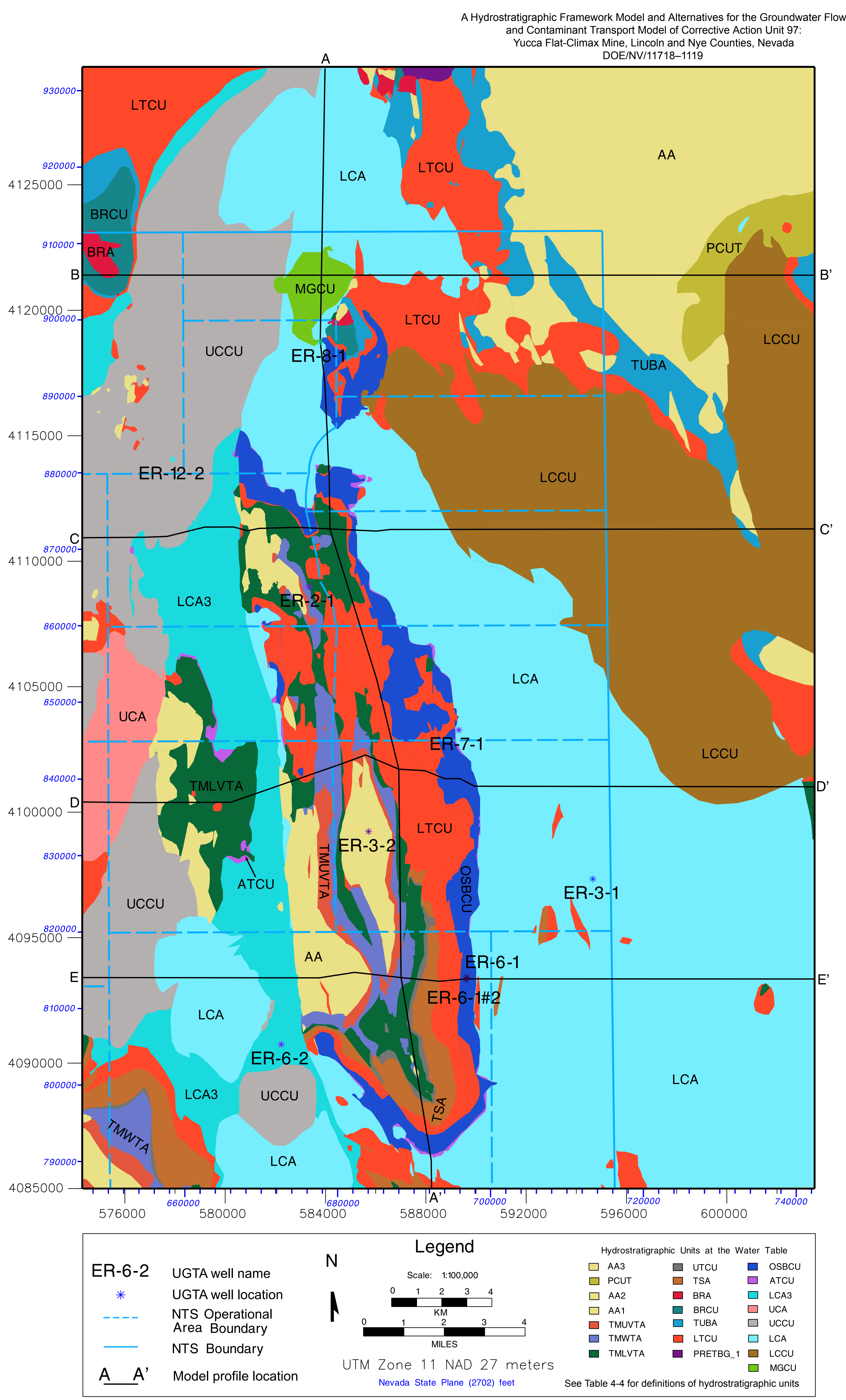

Plate 2

Hydrostratigraphic Units at the Water Table in the Yucca Flat-Climax Mine Hydrostratigraphic Framework Model 


\section{Plate 3}

Figure Showing All Drill Holes Used in the Yucca Flat Climax Mine Hydrostratigraphic Model 

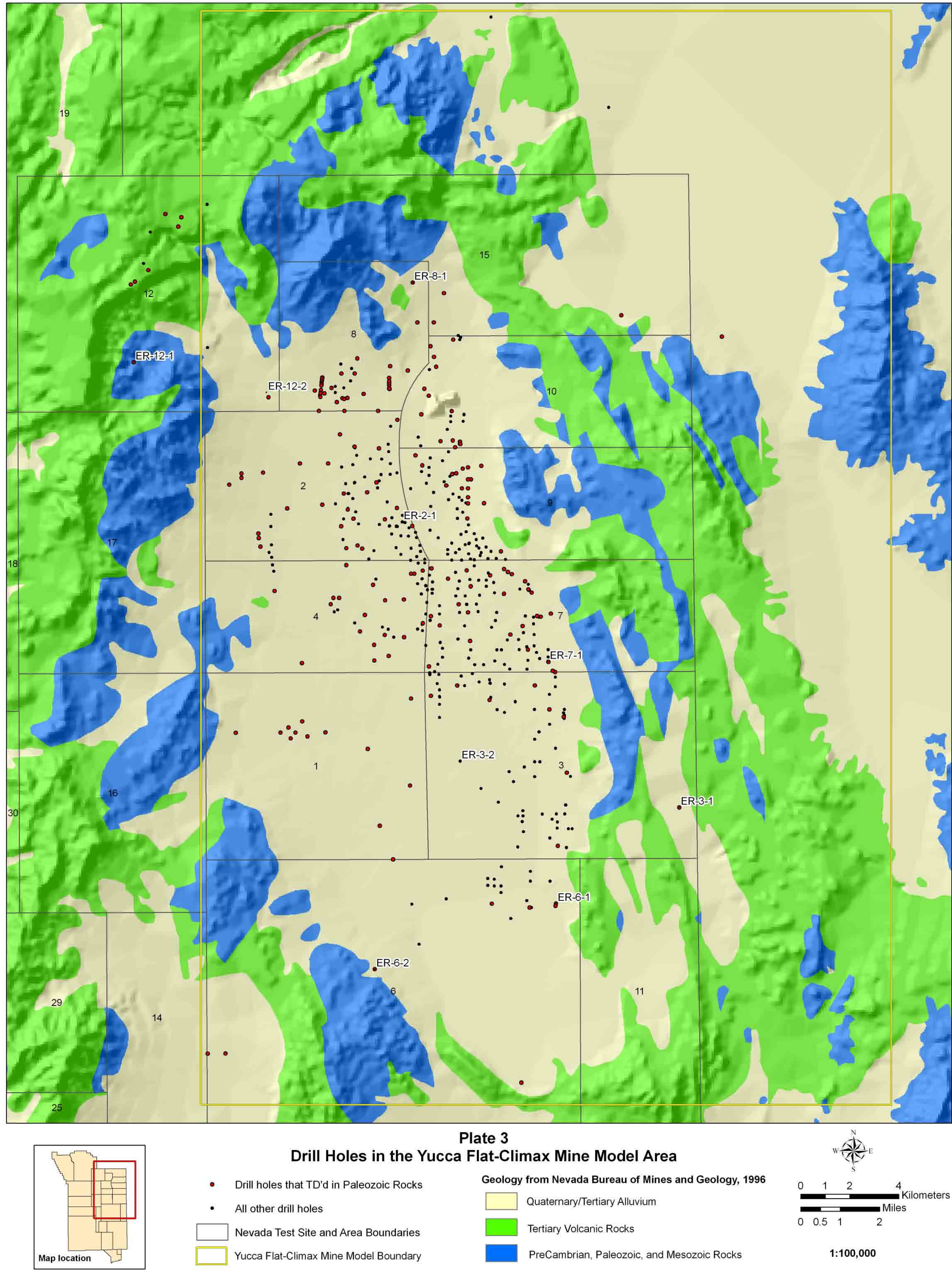

Drill Holes in the Yucca Flat-Climax Mine Model Area

Geology from Nevada Bureau of Mines and Geology, 1996

- Drill holes that TD'd in Paleozoic Rocks

- $\quad$ All other drill holes

Nevada Test Site and Area Boundaries Yucca Flat-Climax Mine Model Boundary $\square$ Quaternary/Tertiary Alluvium

Tertiary Volcanic Rocks

PreCambrian, Paleozoic, and Mesozoic Rocks
霆的

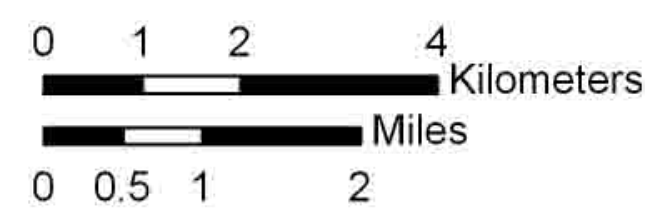

$1: 100,000$ 